Matteo Valleriani

Editor

De sphaera

of Johannes

de Sacrobosco

in the Early

Modern Period

The Authors of the Commentaries

Springer Open 
De sphaera of Johannes de Sacrobosco in the Early Modern Period 
Matteo Valleriani

Editor

De sphaera of Johannes

de Sacrobosco in the Early

Modern Period

The Authors of the Commentaries

Springer Open 


\author{
Editor \\ Matteo Valleriani \\ Max Planck Institute for the History of Science \\ Berlin, Germany \\ Technische Universität Berlin \\ Berlin, Germany \\ University of Tel Aviv \\ Tel Aviv, Israel
}

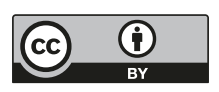

ISBN 978-3-030-30832-2

ISBN 978-3-030-30833-9 (eBook)

https://doi.org/10.1007/978-3-030-30833-9

(C) The Editor(s) (if applicable) and The Author(s) 2020. This book is an open access publication.

Open Access This book is licensed under the terms of the Creative Commons Attribution 4.0 International License (http://creativecommons.org/licenses/by/4.0/), which permits use, sharing, adaptation, distribution and reproduction in any medium or format, as long as you give appropriate credit to the original author(s) and the source, provide a link to the Creative Commons license and indicate if changes were made.

The images or other third party material in this book are included in the book's Creative Commons license, unless indicated otherwise in a credit line to the material. If material is not included in the book's Creative Commons license and your intended use is not permitted by statutory regulation or exceeds the permitted use, you will need to obtain permission directly from the copyright holder.

The use of general descriptive names, registered names, trademarks, service marks, etc. in this publication does not imply, even in the absence of a specific statement, that such names are exempt from the relevant protective laws and regulations and therefore free for general use.

The publisher, the authors, and the editors are safe to assume that the advice and information in this book are believed to be true and accurate at the date of publication. Neither the publisher nor the authors or the editors give a warranty, expressed or implied, with respect to the material contained herein or for any errors or omissions that may have been made. The publisher remains neutral with regard to jurisdictional claims in published maps and institutional affiliations.

This Springer imprint is published by the registered company Springer Nature Switzerland AG. The registered company address is: Gewerbestrasse 11, 6330 Cham, Switzerland 


\section{Preface}

This volume presents the results achieved by a working group established in the framework of the research project "The Sphere: Knowledge System Evolution and the Shared Scientific Identity of Europe" (https://sphaera.mpiwg-berlin.mpg.de). The project's general aim is to reconstruct the long transformation process of cosmological knowledge that took place from the second half of the fifteenth century to 1650. Its focus lies on a specific corpus of historical sources, namely, textbooks that were used above all for introductory studies at the liberal arts faculties of early modern European universities.

In order to collect a meaningful corpus of historical sources, the selection of treatises was limited by one condition: they had to contain or have a strong connection to a treatise by Johannes de Sacrobosco, Tractatus de sphaera, which was already established as a standard textbook in the late Middle Ages. Because of the enduring teaching tradition associated with this text, the corpus of historical sources that was built up around it is considered to be historically representative of the teaching of this discipline and of the period covered by the corpus itself.

Because the corpus consists of treatises that were conceived of, designed, and printed throughout Europe for students, a reconstruction of the transformation process of cosmological knowledge during this period parallels the process by which scientific knowledge came to be shared by university students in Europe. A common scientific identity can be seen to have developed during the early modern period.

On the basis of a census of all early modern printed editions of such treatises, it is possible to state with certainty the number and the identity of the early modern commentators. As shown in the introduction to this volume, this number is surprisingly small when compared with the impressive number of different editions 
produced. The scope of this volume is to investigate the intellectual, institutional, confessional, and geographic context of the actors involved in the process of this transformation. The working group was therefore tasked with writing the intellectual profiles of the authors of early modern commentaries on Sacrobosco's Sphaera. Additional questions concerning the profiles and identities of the publishers and printers of such commentaries or of the buyers of such books will hopefully be answered in future endeavors.

Each contribution highlights one or more of the early modern commentators from different perspectives; the commentators were chosen by the authors of the contributions themselves. Their order of appearance is based on a simple chronology referring to the first commentary work mentioned in each contribution. Not all of the commentators are investigated in this volume. Notably, specific works dedicated to Élie Vinet and Christophorus Clavius as commentators of De sphaera remain a desideratum.

All early modern editions of Sacrobosco's Sphaera are collected in a database that is accessible via the project's main website: https://sphaera.mpiwg-berlin.mpg. de. Because this database was one of the research tools used by the members of the working group, the references to the editions are enriched with the corresponding PID numbers from the database. This gives the reader rapid access to the mentioned sources.

For the initial preparation of the volume, the members of the working group prepared precirculating papers and then met to discuss these at the Max Planck Institute for the History of Science in Berlin on $14^{\text {th }}$ and $15^{\text {th }}$ of February 2018. This intensive but very pleasant two-day meeting also involved other colleagues as discussants (Fig. 1). 


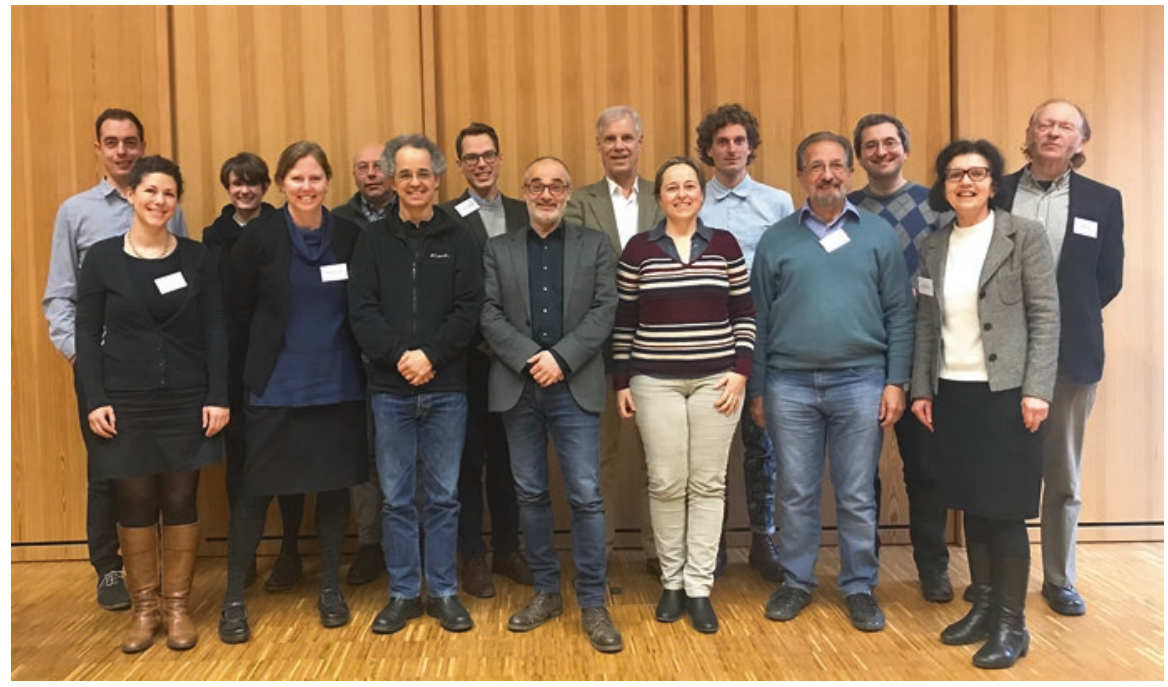

Fig. 1 Back (left to right): Marius Buning, Charlotte Girout, Elio Nenci, Richard Oosterhoff, James Brannon, Christoph Sander, Thomas Horst, Peter Barker. Front (left to right): Angela Axworthy, Kathleen M. Crowther, Leo Corry, Matteo Valleriani, Tayra M.C. Lanuza Navarro, Roberto de Andrade Martins, Isabelle Pantin

Max Planck Institute for the History of Science

Berlin, Germany

Technische Universität Berlin Berlin, Germany

University of Tel Aviv

Tel Aviv, Israel
Matteo Valleriani valleriani@mpiwg-berlin.mpg.de 


\section{Acknowledgments}

While discussing a previous publication of mine, it was Ursula Klein who in 2016 first suggested that I undertake the investigation which led to this volume. For this reason, a special acknowledgment goes to her. The creation of this volume by the working group is just one of the many activities undertaken in the frame of the project "The Sphere: Knowledge System Evolution and the Shared Scientific Identity in Europe." I would like to thank the core group of scholars at the Max Planck Institute for the History of Science who took an active role in this working group: Florian Kräutli, Christoph Sander, Sabine Bertram, Gesa Funke, Victoria Beyer, Chantal Wahbi, and Olga Potschernina. A special acknowledgment goes to Nana Citron, also a member of the core group of the project but, in addition, organizer and coordinator of the activities of the working group members and a coauthor of one of the contributions. Nana Citron and Victoria Beyer also supported the publication process in all of its phases. The work on the index was also supported by Razieh Mousavi. The organization of the Berlin meeting was further supported by Petra Schröter, Carina Panther, and Tilman Kemeny. The permissions to publish the images were obtained by Nana Citron and Urte Brauckmann. A special acknowledgment also goes to Charlie Zaharoff for his excellent copyediting work. Many thanks to my friend and colleague Lindy Divarci for her continuous support, too. On the publishing side, I would like to thank Corina van der Giessen and Christopher Wilby for providing support for the design and production process of the cover. The working group and the related publication project was supported by the Department I of the Max Planck Institute for the History of Science, whose director, Jürgen Renn, I would like to thank deeply for his generosity.

In memory of Iliana Capisani (August 14, 1944-September 19, 2018)

Tel Aviv

Matteo Valleriani

May 26, 2019 


\section{Contents}

1 Prolegomena to the Study of Early Modern Commentators on Johannes de Sacrobosco's Tractatus de sphaera .............................. Matteo Valleriani

2 A Lathe and the Material Sphaera: Astronomical Technique at the Origins of the Cosmographical Handbook

Richard J. Oosterhoff

3 Pedro Sánchez Ciruelo. A Commentary on Sacrobosco's Tractatus de sphaera with a Defense of Astrology

Tayra M. C. Lanuza Navarro

4 Francesco Capuano di Manfredonia

Elio Nenci

5 Conrad Tockler's Research Agenda Matteo Valleriani and Nana Citron

6 John of Glogów Peter Barker

7 Sacrobosco's Sphaera in Spain and Portugal Kathleen M. Crowther

8 Oronce Fine and Sacrobosco: From the Edition of the Tractatus de sphaera (1516) to the Cosmographia (1532) Angela Axworthy

9 Borrowers and Innovators in the History of Printing Sacrobosco: The Case of the In-Octavo Tradition Isabelle Pantin 
10 André do Avelar and the Teaching of Sacrobosco's Sphaera at the University of Coimbra.

Roberto de Andrade Martins

11 Fashioning Cosmology: Franco Burgersdijk as the Author of the Dutch Tractatus de sphaera

Marius Buning

Index

391 


\section{About the Authors}

Roberto de Andrade Martins is a Brazilian historian and philosopher of science. His main research interests are history of physics and history of astronomy. He has been the president of the Brazilian Association for History of Science (SBHC) and of the South Cone Association of Philosophy and History of Science (AFHIC). His published books include the following: $O$ Universo: Teorias sobre sua Origem $e$ Evolução; Becquerel e a Descoberta da Radioatividade: uma Análise Crítica; A Origem Histórica da Relatividade Especial; and História da Teoria Quântica: a Dualidade Onda-Partícula, de Einstein a De Broglie. He was a professor at the Physics Institute of the State University of Campinas (UNICAMP) up to his retirement. Nowadays, he is a researcher of the Brazilian National Council for Scientific and Technological Development (CNPq) and collaborates with São Paulo Federal University (UNIFESP), Municipal Higher Education Bragança Paulista Foundation (FESB), and University of São Paulo (GHTC-USP).

Angela Axworthy has a $\mathrm{PhD}$ in philosophy (2011, CESR, Tours, France) and is a postdoctoral research fellow at the Technische Universität (Berlin) in the framework of the Berlin Center for the History of Knowledge. She was previously research fellow at the Max Planck Institute for the History of Science in Berlin (2012-2016). Her research focuses on Renaissance epistemology of mathematics. Her current themes of investigation are the medieval and Renaissance geocentric cosmology, the sixteenth-century treatises of practical geometry, and the epistemology of geometry in the Renaissance Euclidean tradition. She is the author of Le Mathématicien renaissant et son savoir: Le statut des mathématiques selon Oronce Fine (Paris, Classiques Garnier, 2016). 
Peter Barker is professor of the History of Science at the University of Oklahoma since 1995. He is the author or editor of four books and over 60 journal articles, mainly on the history and philosophy of science in the period from Copernicus to Kepler. His current research interests include knowledge flows between the Ottoman, Safavid, and Mughal empires in the early modern period and the rise and decline of orb models in astronomy.

Marius Buning received his PhD from the European University Institute (2013) with a dissertation on the making of a patent system in the Dutch Republic. He is currently a DRS fellow at the Dahlem Humanities Center of the Freie Universität Berlin. Previously, Marius has held fellowships at Harvard University, the Netherlands Institute for Advanced Study, and the Max Planck Institute for the History of Science. His research interests focus on the origins of intellectual property, the relationship between science and technology, how experiment bears upon theory, and the part played by the early modern state in defining these respective fields.

Nana Citron studies History of Science and Technology at the Technische Universität Berlin. She currently is project assistant for the project "The Sphere: Knowledge System Evolution and the Shared Scientific Identity of Europe" (https:// sphaera.mpiwg-berlin.mpg.de) at the Max Planck Institute for the History of Science.

Kathleen M. Crowther received her PhD from the Department of the History of Science, Medicine, and Technology at Johns Hopkins University. She is currently an associate professor in the History of Science Department at the University of Oklahoma. She has published articles in Isis, Renaissance Quarterly, and the Journal for the History of Astronomy. Her first book, Adam and Eve in the Protestant Reformation (Cambridge, 2010), won the Gerald Strauss Prize for best new book in Reformation studies. She is currently working on a book about Sacrobosco's Sphere.

Tayra M. C. Lanuza Navarro is currently a visiting researcher at the El Instituto de Historia de la Medicina y de la Ciencia "López Piñero," Universitat de València. She obtained her PhD in History of Science at the University of Valencia and has been a research fellow at several institutions in Europe and the USA, as well as a teacher in the Department of History of Science at the University of Valencia. Her main lines of research are focused on the study of the ideas, practices, and works of early modern astronomers, cosmographers, and physicians, with a focus on astronomy and astrology, on the censorship of astrology and related disciplines by the Spanish Inquisition, and on the representation of science and medicine in early modern literature. She has published several articles and book chapters on astrology, science, and society in early modern Spain. 
Elio Nenci is professor of History of Science at the Università degli Studi in Milan. He completed his PhD in Philosophy in Milan in 1987 and his PhD in History of Science from the University of Bari in 1996. His research focuses on the recovery of science and ancient techniques in the Renaissance and on the relationship between the knowledge of the technicians and that of philosophers and scientists in the sixteenth and seventeenth centuries. He published the critical edition of Bernardino Baldi's Vite de' matematici (Milan, 1998), Girolamo Cardano's De subtilitate (Milan, 2004), and Baldi's In mechanica Aristotelis problemata exercitationes (Milan, 2010).

Richard J. Oosterhoff is a lecturer in early modern history at the University of Edinburgh. He completed his PhD in Notre Dame in 2013. He has previously held fellowships at Cambridge, Harvard, Notre Dame, and the Huntington Library. He has written Making Mathematical Culture: University and Print in the Circle of Lefèvre d'Étaples (Oxford, 2018) and with colleagues on the ERC project "Genius Before Romanticism" is coauthor of Logodaedalus: Word Histories of Ingenuity in Early Modern Europe (Pittsburgh, 2018).

Isabelle Pantin is professor of Renaissance Literature at the École Normale Supérieure in Paris (PSL University). She participates in the research programs of the Institut d'Histoire Moderne et Contemporaine (IHMC) in the sections dedicated to the history of the book and the history of astronomy and related fields.

Her research interests are in early modern scientific literature and culture. She has published on the history of the scientific book and on cosmological poetry as viewed from both cultural and literary perspectives and prepared critical editions (with French translations) of Galileo's and Kepler's works.

Matteo Valleriani is research group leader at the Department I at the Max Planck Institute for the History of Science in Berlin, honorary professor at the Technische Universität of Berlin, and professor by Special Appointments at the University of Tel Aviv. He investigates the relation between diffusion processes of scientific, practical, and technological knowledge and their economic and political preconditions. His research focuses on the Hellenistic period, the late Middle Ages, and the early modern period. Among his principal research endeavors, he leads the project "The Sphere: Knowledge System Evolution and the Shared Scientific Identity of Europe" (https://sphaera.mpiwg-berlin.mpg.de), which investigates the formation and evolution of a shared scientific identity in Europe between the thirteenth and seventeenth centuries.

Among his publications, he has authored the book Galileo Engineer (Springer Dordrecht 2010) and is editor of The Structures of Practical Knowledge (Springer Dordrecht 2017). 


\title{
Chapter 1 \\ Prolegomena to the Study of Early Modern \\ Commentators on Johannes de Sacrobosco's Tractatus de sphaera
}

\author{
Matteo Valleriani
}

\begin{abstract}
By way of introduction to the present volume, a corpus of 359 treatises is described that was used in early modern educational institutions for introductory classes on cosmology and that is referenced by the following contributions. Following a taxonomy of early modern commentaries, central characteristics are analyzed in detail such as the rate of production of the treatises, the places where they were produced, and their various languages and formats. The focus then turns to the balance between the temporal dynamics of production of the treatises and the lifespans of their commentators. This reveals how the early modern textbooks first amplified medieval scientific knowledge and only slowly began to support and spread the echoes of scientific debate among contemporary scholars. The institutional and intellectual profiles of the commentary authors are then described on the basis of the results presented in the contributions to this volume. The commentators are described by referring on one hand to their relations to the universities, religious orders, and commercial institutions, and on the other to their engagement with disciplines both inside and outside the conceptual framework of the quadrivium. Finally, a quantitative summary of the results achieved by this volume is presented along with outlines for future research endeavors that will focus, consequently, on the role of the printers and publishers of the same commentaries.
\end{abstract}

Commentaries on the Sphaera of Johannes de Sacrobosco (died ca. 1256) constitute a peculiar genre in the mare magnum of medieval and early modern scientific commentaries. They are peculiar for a number of reasons. First and foremost, they do not comment on an ancient text but rather on a late medieval textbook, compiled for coursework at the University of Paris (Thorndike 1949, 76-142). Sacrobosco's

\footnotetext{
M. Valleriani $(\triangle)$

Max Planck Institute for the History of Science, Berlin, Germany

Technische Universität Berlin, Berlin, Germany

University of Tel Aviv, Tel Aviv, Israel

e-mail: valleriani@mpiwg-berlin.mpg.de
} 
work, a short qualitative introduction to geocentric cosmology, was not ambitious in its treatment of mathematical astronomy. It is actually best defined as a manual for using a scientific instrument, namely, the armillary sphere. It is a piece of deictic writing and it was probably used for deictic teaching-its main purpose was to make students familiar with this specific instrument. A second peculiarity of these commentaries is the fact that their history of publication, the precise run of editions between the thirteenth and the mid-seventeenth century, ${ }^{1}$ exhibits such exceptional continuity that the usual historical periodization that divides the Middle Ages from the early modern period does not seem significant in the least.

The original text does not introduce any relevant innovation from the point of view of cosmological knowledge. It is clearly based on the geocentric conception of the universe found in Ptolemy's Almagest, but it is also influenced by later works, especially from the Islamic scientific tradition, as Lynn Thorndike has clearly shown (Thorndike 1949, 1-75). Nevertheless, the textbook cannot be considered a simple paraphrase or abridgment, first of all because it contains a short but significant passage at the end to contextualize it in the general frame of Christian theology, and secondly because it has an original textual structure-it was designed to function in a particular context: the newly conceived university, built around the scheme of the quadrivium.

Retracing the history of the treatise over four centuries is a fascinating project that can only be accomplished by splitting it up into specific aspects and time windows. The exceptional continuity of this commentary tradition is due to the central role of cosmology in the general scientific and cultural framework that emerged in the late medieval time. The cosmological worldview was the nucleus around which the European knowledge system — with its constellation of scientific subjects — was organized. This central role remained unchanged until the mid-seventeenth century, when it mutated not only because of the emergence of alternative worldviews but also because of the progressive specialization of subjects previously attached to cosmology, which in turn achieved the status of new, independent disciplines. The matter of which scientific subjects were seen as kindred to cosmology had in fact been evolving throughout the centuries in question. In the thirteenth and fourteenth centuries, for instance, the study of cosmology at the universities was certainly instrumental to the study of computus ecclesiasticus. The association between these two subjects - cosmology and calendric_-is readily apparent to even a cursory analysis of the many Sphaera manuscripts deposited in archives of medieval sources. They very often appear in collections of university textbooks that contain treatises on both subjects. Yet this association can scarcely be found in later periods. Meanwhile, the text of Sacrobosco in the early modern period was often written or printed together with texts whose subjects were previously either non-existent, such as cosmography, or not associated with cosmology.

\footnotetext{
${ }^{1}$ After 1650, some further editions of the commentaries on Sacrobosco's Sphaera were published. However, the role of this text, for instance in the context of university teaching, declined to such an extent that those late editions can no longer be considered representative of the scientific debate in Europe in that period.
} 
If the tradition of commentaries on the Sphaera of Sacrobosco is seen in light of the role of cosmology within the entire scientific knowledge system, what appears are four centuries characterized by a profound continuity. If, however, the same tradition is analyzed with the aim of determining which scientific subjects pivoted on cosmology in the same knowledge system, this continuity also seems to accommodate a more dynamic development, one which might allow us to reconstruct how scientific knowledge, as it was imparted at European universities, fundamentally changed over time. ${ }^{2}$

This characteristic opens up the possibility for a temporal segmentation of this long commentary tradition, a segmentation which is further supported-and perhaps made necessary-by three important contextual factors and changes that took place in the first phase of the early modern period.

Firstly, commentaries on the Sphaera got on board the exciting new medium of the printed book in 1472. Two 1472 editions, one printed in Ferrara and the other in Venice (de Sacrobosco [1472a]; 1472b), opened a long, spectacular series of 359 different editions of treatises on the Sphaera up to $1650 .^{3}$ As book historians (recently, Angela Nuovo in particular) have well demonstrated, the market for printed books became a transnational European market very quickly. Large printer's workshops set up a selling network able to cover large geographic areas, which smaller workshops could also tap into. The European book market was already well established before the turn of the fifteenth century, and great central nodes such as book fairs supported the continuous development of this market during the whole early modern period. An elaborate texture of printers, publishers, and booksellers emerged all over Europe and continuously expanded. These central nodes-the book fairs, and centers such as Paris, Venice, and Basel-attracted a myriad of printer's workshops, either because they were appropriately situated on the lines of distribution or because of the presence of authorities and institutions relevant and necessary to their economic activity (Nuovo 2013).

The second factor relates to the history of the universities. From the same period of the expansion of book printing activity toward the end of the fifteenth century, the so-called third phase of university foundation took place. Especially the sixteenth century is marked by an impressive increase in the number of universities in Europe. Because of the high mobility of lecturers and students, the universities as such can be seen as another network of interconnected nodes sharing similar aims, structures, and, most importantly, knowledge (Rüegg 1994-2011, Vol. 2; Grendler 2002).

The increasing homogenization of scientific knowledge over the continent, also detectable in the corpus of the early modern commentaries on the Sphaera, might be

\footnotetext{
${ }^{2}$ The reconstruction of a shared scientific identity in Europe between the late medieval and early modern periods, based on an analysis of the evolution of its underlying knowledge system, is the overarching goal of the project in whose context the present study was conducted. For more information, see https://sphaera.mpiwg-berlin.mpg.de. Accessed June 2019.

${ }^{3}$ The number of known books constituting the corpus of the printed commentaries on the Sphaera of Sacrobosco can obviously increase if new texts are found. The database displaying the current status of research is available through the website of the Sphaera research project (see footnote 2).
} 
explained by the combination of these first two factors. However, homogenization does not mean stagnation or lack of innovation. In fact, homogenization was a process that could only take place through the continuous input of innovations by the actors of networks-innovations such as additional scholia, new images for the same textual content, or a description of a new solar clock. Innovations were the motor that justified exchange and connectivity in the network, and the higher the level of exchange, the more homogenous the knowledge became-the shared scientific knowledge of Europe that manifested itself in the teaching of young students in their first years at the faculties of liberal arts.

The third factor is represented by great epochal processes and events in general. Although their consequences are often difficult to grasp by looking directly at the Sphaera commentaries, the journeys of exploration and events such as the Reformation in 1517 clearly determined "waves of knowledge" that are detectable in the content of these treatises-for instance, they had bearing on the appearance of new subjects and the disappearance of others.

Because of these factors, it appears justifiable to segment the analysis of the commentary tradition into at least two great temporal phases, the first dating from the authorship of the treatise by Sacrobosco's own hand until the first appearance of the treatise as an incunable in 1472; the second from this same year until 1650, when the commentary tradition of this specific text and its scientific relevance came to an end. What follows will refer to the second phase of this editorial history.

This segmentation into two epochs, however, does not yet fully consider the medium through which the knowledge was disseminated. The diffusion of print technology did not suddenly nullify the habit of using handwritten material for study purposes. It is well known that, at least during the first phase of the history of printed books, manuscripts remained predominant as a medium. Therefore, when an editorial history of this temporal length is investigated, one has to deal with two different time scales, each associated with a specific medium. This would imply that the investigation of the corpus of early modern commentaries on the Sphaera of Sacrobosco should not be limited to the printed books only, but needs to take into consideration the manuscript tradition as well. ${ }^{4}$ Unfortunately, however, no census of the manuscripts of this era containing the text of Sacrobosco with or without commentary has ever been compiled. This means, first, that research can only be carried out based on the exclusive analysis of printed sources, which in contrast to handwritten manuscripts have been systematically and completely identified and collected; and second, that research results, especially concerning the phase during which the printed book established itself as the academic standard, have to be considered temporary until further source analyses can complete the picture.

\footnotetext{
${ }^{4}$ Research that systematically combines the analysis of printed sources with the handwritten ones for a long period during the fifteenth and sixteenth centuries would require additional temporal scaling because of regionally different speeds of decline for the manuscript and emergence for the printed book as the principal medium for scientific and teaching purposes.
} 


\section{The Corpus of the Printed Commentaries}

The 359 printed treatises, which cover a time span of 178 years, offer the possibility to investigate multiple aspects of this editorial history. On one hand, there are basic changes to the knowledge system (even as it remained grounded in cosmology), and on the other there is the way these changes came to be "represented" through the evolution of printed books. These two points of focus can be investigated on the basis of their mutual relationship. In this respect, it is useful to sub-divide the corpus into a taxonomy that reflects the book or edition typology. In particular, five categories can be identified by following a bottom-up approach, that is, by analyzing the corpus in its entirety and focusing only on textual elements (Fig. 1.1).

The first type of book that can be easily identified contains the short original tract of Sacrobosco, and nothing more. This is the smallest group of books in the corpus and it mostly appears in the first phase of the history of production. A close look at the texts nevertheless shows that they cannot be considered truly identical. In these books as well as in all the others that contain a reproduction of the original text, deviations of all sorts can be detected. Indeed, a census of all these variations is still a desideratum. Often, such changes concern linguistic or syntactic aspects. Sometimes they are made explicit-for instance, on title pages or colophons (sphaera revisa, sphaera emendata, etc.)—particularly under the influence of the humanistic requirement for a more elegant Latin, but many times they were just applied by the correctors employed in the printer's or publisher's workshops, who mostly remained anonymous. Thorndike indeed noticed that different variants of the text were circulating already during the first phase of its history in the thirteenth and

105

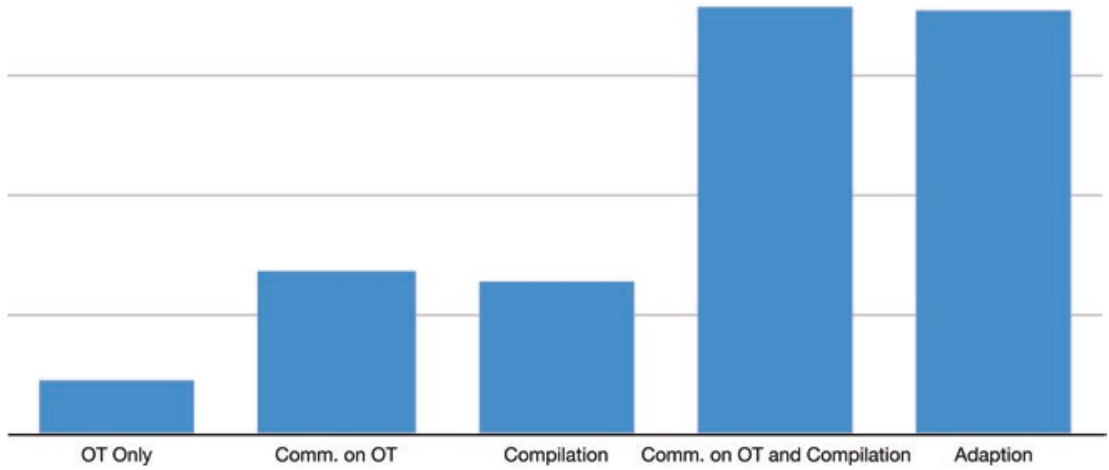

Fig. 1.1 A typology for the editions constituting the corpus of early modern printed commentaries on the Sphaera of Johannes de Sacrobosco: editions that contain the original medieval tract (OT) only; those that contain the original treatise with commentary; those that contain the original treatise and other treatises (compilations); those that contain the original treatise, commentary, and other texts; and adaptions 
fourteenth centuries (Thorndike 1949, 1-76). Other differences are more content related. They can concern the citation of sources and even aspects of cosmology. Finally, new variants were created through the process of translation into local tongues, as will be shown later. Generally speaking, it can be said that the reproduction of the original text certainly was faithful, but not made with the historical and philological sensitivity that would be expected nowadays. In the spirit of the time, the continuous variations compiled until the very end of this series of editions did not encounter any scientific objection, as the main goal was scientific and not philological.

The second type of book displays the original treatise plus a commentary on it. This is not, however, the most relevant of the sub-groups of treatises, as one might expect. It also appears quite early in the history of this corpus, but in total only accounts for 48 editions. The identity of the corpus is characterized by a combination between the second and the third type of edition, namely, compilations.

Compilations are volumes that contain the original tract (without comments) alongside other texts. The most studied example of this is the compilation of Sacrobosco's text with Georg von Peuerbach's (1423-1461) Theorica planetarum (Chap. 6). In this case, the compilation of the two texts clearly aimed to enlarge the spectrum of subjects the volume dealt with: from the description of the machina mundi to a method for determining the positions of the planets. Often, however, commentaries on the Sphaera were added that might or might not refer to specific passages of the original text-though they were never directly integrated into its textual flux. A classic example of this kind of commentary addition is represented by the compilation of Sacrobosco's text with the Questions of Pierre d'Ailly (1340-1520). The latter text itself is not a commentary on the Sphaera, but placing the two texts together nevertheless creates a commentary, a way to deepen certain aspects of the original text.

Identifying compilations, which account for 45 editions in the corpus, is made particularly difficult and "risky" for source analysis because of a series of issues related to the characteristics of the early modern book market. In particular, the practice of producing bound books developed very slowly and did not become a market standard until after the period in question. ${ }^{5}$ Quaternions were printed, stored in the bookshops as piles of sheets, and bound in the shops themselves, together with other books, selected by the customer at the moment of purchase. However, this does not imply that printers and publishers were producing only single texts and avoiding the design and manufacture of more elaborate books like compilations. For a researcher with some knowledge of the quadrivium tradition-the teaching

\footnotetext{
${ }^{5}$ During the second half of the sixteenth century, some publishers and printers introduced the corezze, a sort of light binding whose main function was to facilitate the transportation to, and storage at bookshops. They did not represent normative guidelines concerning the content of a final volume, which was bound at the shop by the seller according to the selection of books made by the customer (Nuovo 2013, 136).
} 
framework to which these books mostly belong-recognizing the printer's intention is often quite simple indeed. ${ }^{6}$

As mentioned, a combination of the second and third book types gives us the most essential representation of the corpus of editions. These are volumes that contain at least one commented edition of the Sphaera of Sacrobosco and further content-related texts as well. The great Venetian anthologies of 1508 and 1531, published by Giuntino Giunta (1477-1521) and Lucantonio Giunta (1457-1538), respectively, are among the most impressive examples of this mixed typology. They contain commentaries and texts of authors such as Bartolomeo Vespucci, Francesco Capuano (died ca. 1490), Jacques Lefèvre d'Étaples (ca. 1455-1536), Johannes Regiomontanus (1436-1476), Pierre d'Ailly, and Robert Grosseteste (ca. 1175-1253) (de Sacrobosco et al. 1508, 1531), and they were produced with the clear intent to give an up-to-date survey of the relevant subjects. This group amounts to 125 editions and is therefore the most significant for understanding both the role of cosmology and the way knowledge was systematized over time.

The last type of treatise can be called 'adaption.' Identifying the books in this category requires the most background knowledge. These books, together a considerable group of 124 editions, do not actually contain Sacrobosco's text. They are seen as related to it, above all because they share a similar design, that is, they discuss the same subjects and in the same order. They also often make use of the same illustrative apparatus, at least partially. Finally, adaptions also include the so-called Quaestiones, books written in the form of questions and answers and intended for the students as an auxiliary means to prepare for an examination. While the identification of adaptions is very simple in certain cases, such as in the case of the works of Alessandro Piccolomini (1508-1578), ${ }^{7}$ in many others the application of this category requires a close reading and a final decision on each individual source at hand. This type of edition serves as a limit category to distinguish the corpus from other works produced in the frame of early modern cosmology. It is necessary for the corpus to maintain a well-defined identity, and at the same time to keep the number of sources under examination at a manageable level.

Apart from the first type (a simple reproduction of Sacrobosco's treatise), all the Sphaera editions can be considered forms of commentaries. Beginning from the kind of comment that is created by breaking the original text into sections for the insertion of additional text, or "atomizing" the text, as Anthony Grafton calls it

\footnotetext{
${ }^{6}$ Besides a content-related analysis of the texts, there are several further ways to distinguish between compilations of texts as conceived by the printers and those created by individual customers in the bookshops. The principal ones are: (a) if it exists, an analysis of the table of contents, (b) the position of the colophon, (c) an examination of binding, paper, types, and ink, and (d) a comparison with other copies of the same volume. Nevertheless, a certain degree of uncertainty remains sometimes in reference to some editions, in particular to those which were produced in the early phase of the diffusion of printing technology, during which the design and conception of 'book' as a final product was still under development.

${ }^{7}$ Alessandro Piccolomini authored fourteen editions that belong to the corpus of the printed commentaries on the Sphaera of Sacrobosco. For more information about these editions, see http://hdl. handle.net/21.11103/sphaera.100964
} 
(Grafton 2010), these typologies can be used to understand the historical developments that slowly brought the practice of commentary in science to an end, giving way to the emergence of a new genre, which in turn became a forerunner to the scientific monograph. Moreover, the compilation of texts, despite being a practice that always existed on an individual level (any medieval manuscript is testament to this), almost became a new genre of its own when it entered the world of the printed book-namely, when it exited the realm of individual research and interests to become an object of public scientific discourse, a process motivated in large part by the printer's will to conquer or maintain sectors of the academic book market.

If other elements aside from the textual aspects of the treatises are considered, such as the visual apparatus, the panorama becomes even more sophisticated. Ongoing research is showing that the books constituting this corpus contain roughly 16,000 content-related scientific illustrations, most of them astronomic and cosmological diagrams. Together with other sorts of images-frontispiece, illustrations from title pages, printer marks, decorations, and initials - they amount to about 20,000 . Scientific visual material does not simply display knowledge that is otherwise written. It conveys it in a different way and can even display different scientific content. The development of the visual material used in this corpus (Chap. 9) attests to the increasing relevance of this medium for the transmission and transformation of knowledge. In other words, the insertion of images into the texts can be seen as an additional way of commenting on it.

Textual typology and visual apparatus are aspects of the book whose materiality calls for the analysis of further aspects, including those related to the printing process and those concerned with selling the book as a product. Although not all this data is available, some further considerations pertaining to the internal dynamics of the corpus and especially to the role of the commentators within the framework of this corpus can be easily added at this stage, namely those concerned with the places of production, the formats of the books, and the languages in which they were published.

In Europe, the production of these commentaries took place in forty-one different cities whose geographical distribution basically covers the entire continent, from Krakow to Lisbon and from London to Rome. Nevertheless, the production was not equally distributed and if only those centers of production are considered where at least ten different editions were printed, only nine cities remain (Fig. 1.2). As one might expect, the two most relevant centers are Venice and Paris, both hubs of the transnational European market for printed books. The third position of Wittenberg is all the more relevant if one considers that it entered this market as late as 1531, forty-one years after the first printed edition. As the intellectual center of the Reformation, its political and pedagogical influence over Europe is reflected by this position. ${ }^{8}$ The fourth position of Leipzig, on the contrary, is based on the production of books that took place before 1520, at which point its role as the main producer of university textbooks was completely taken over in the course of only a

\footnotetext{
${ }^{8}$ For a study that shows how Wittenberg's treatises shaped the content of the textbooks on cosmology in Europe, see (Valleriani et al. 2019).
} 


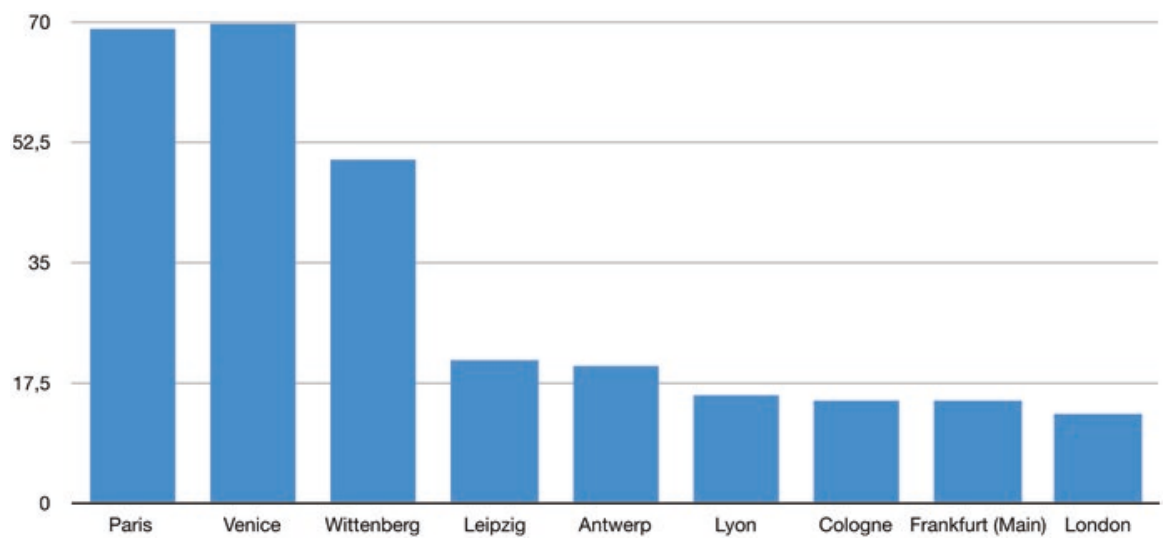

Fig. 1.2 The top nine places where early modern printed commentaries on the Sphaera of Johannes de Sacrobosco were produced

few years by Wittenberg after the onset of the Reformation. Antwerp deserves a special mention, too; its position at number five is due to production that, though beginning in 1543, was prolific only between 1560 and 1585, when the intensity of production of this commentary was at its peak across the continent. If the bookproducing cities are considered nodes of a network, what results is a wide circulation of knowledge that is mostly determined by a few centers. In other terms, the centers of production of the treatises collected in the corpus analyzed here are the same major centers of production of printed books in general, except perhaps for the low relevance of Basel. ${ }^{9}$

That these books were mostly destined for the student market can be easily shown by considering their prevalent formats (Fig. 1.3). Among the three major format categories - in order of decreasing size and price: folio, quarto, and octavo $-{ }^{10}$ the in-octavo books are the models that shape the material identity of the corpus most. Moreover, the folio format was mostly produced during the first 50 years of the history of Sphaera editions, that is, in the period for which the data at our disposal are less representative (because reading material still regularly came in manuscript form).

\footnotetext{
${ }^{9}$ For an interesting study concerned with the diffusion of the commentary on Sacrobosco's $D e$ sphaera in the region culturally influenced by Prague, see (Hadravovi and Hadravovi 2019).

${ }^{10}$ The editions of the corpus were printed twice in sextodecimo format otherwise always either folio, quarto, or octavo. We disregard the folding of the sheets. The precise dimensions of the books, moreover, are more differentiated, and certain editions would more accurately be defined as small folios or small quartos. Furthermore, the three categories do not denote any universally accepted book dimension, as libraries tend to follow slightly different organizing principles. Nevertheless, the use of the categories (disregarding those small differences) still accounts for how printers and publishers made investments, and therefore represents an indication of the final price of the books.
} 


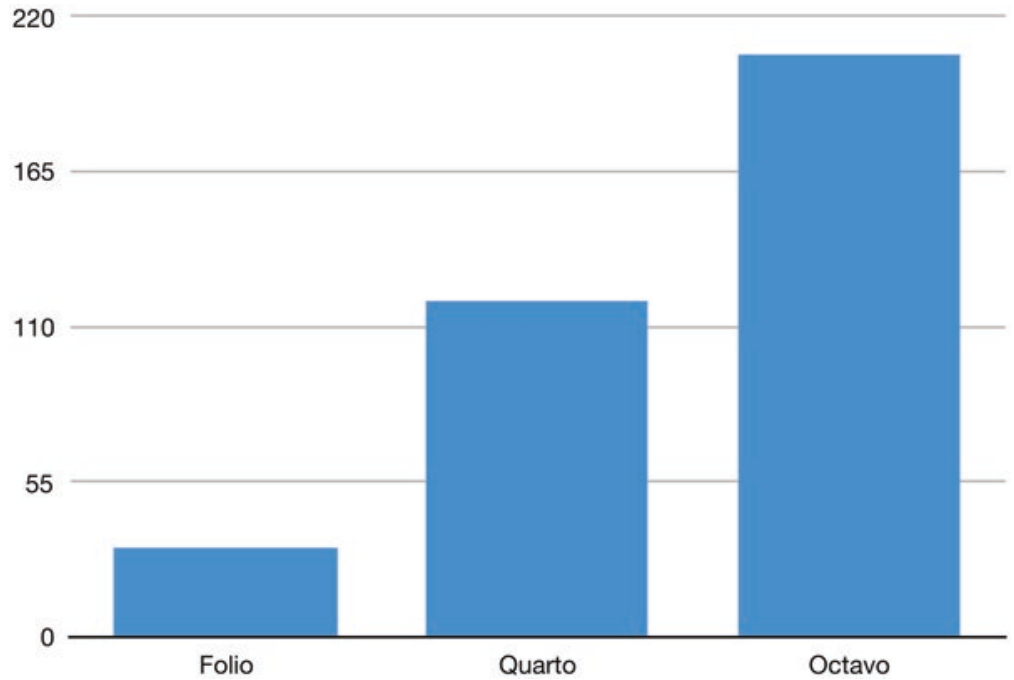

Fig. 1.3 Book formats of the early modern printed commentaries on the Sphaera of Johannes de Sacrobosco

300

225

150

75
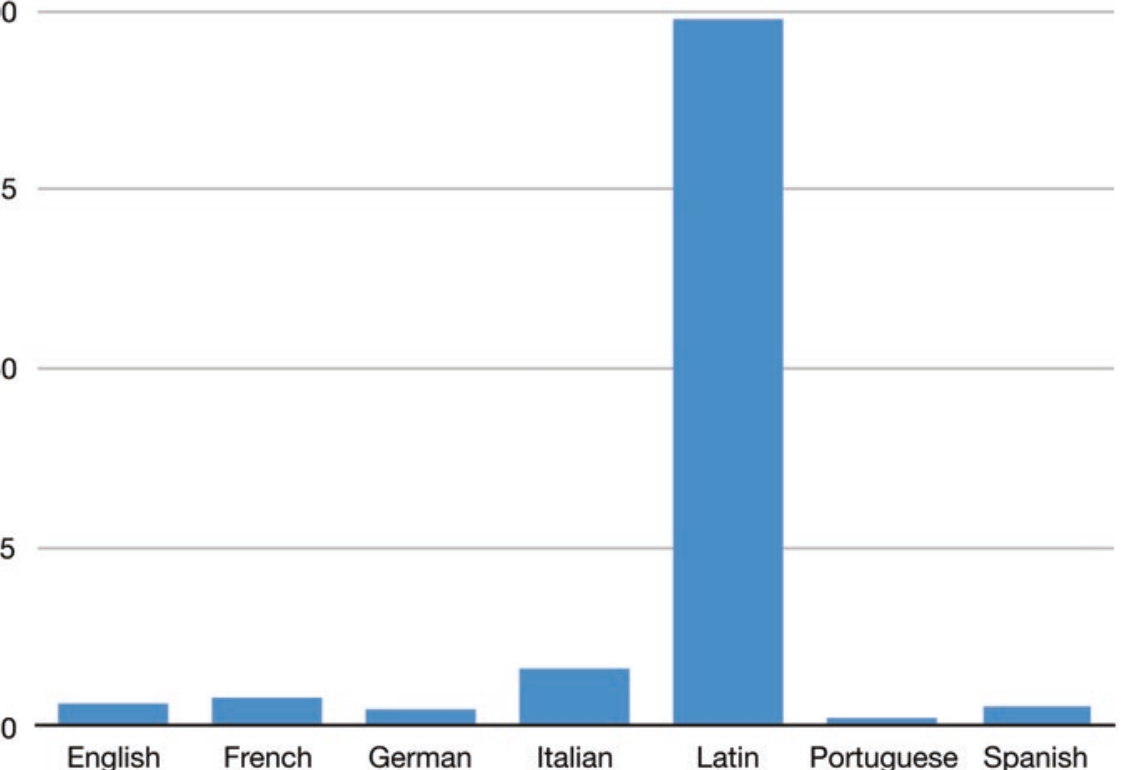

Fig. 1.4 Languages in which the early modern commentaries on the Sphaera of Johannes de Sacrobosco were published 


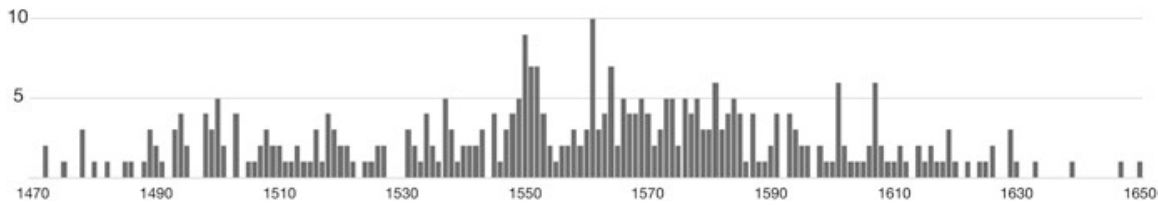

Fig. 1.5 Temporal distribution of the production of the early modern commentaries on the Sphaera of Johannes de Sacrobosco

Finally, the dominance of Latin over other languages is the clearest indicator of the function of these books within the university teaching context (Fig. 1.4). This does not necessarily imply that treatises compiled in different languages, in many cases one-to-one translations of books published in Latin, were not used for teaching, but probably not at the universities. Other kinds of educational institutions, for instance in Portugal, used both manuscripts and printed books that were not written in Latin, as Henrique Leitão has shown (Leitão 2008). It is interesting to notice that, in spite of the fact that the majority of books produced in local tongues are in Italian, the first Italian book did not appear on the market before 1537, at which point books had already been produced in Portuguese (first edition: 1509), German (first edition: 1516), and French (first edition: between 1525 and 1529), with a printed version of the medieval commentary of Nicole Oresme (1320-1382).

Finally, concerning the dynamics of production, this is not constant over time but it relevantly increases around 1550 and keeps this peak until about 1580 (Fig. 1.5). In this specific interval, while Paris and Venice remain dominant centers of production, their relevance strongly decreases in favor of other centers, especially Wittenberg - almost as productive as Venice but by means of only a few publishers and printers - and Antwerp.

\section{The Authors of the Commentaries as a Social Network}

The corpus of Sphaera commentaries lends itself to being analyzed as a series of at least two overlapping networks: an economic one, whose protagonists are the printers, publishers, and booksellers (supported by a network of distribution all over the continent), and a "semantic" one, wherein the circulation and transformation of knowledge are dynamically interlinked. The role of authors in this context appears to be fairly aleatory at first sight. Yet some external (to the corpus) information from historical sources can be found that testifies to direct relationships between different authors of Sphaera commentaries, and the outlines of a social network can be partially reconstructed from this information. For instance, it is known that Élie Vinet (1509-1587) and Pedro Nuñes (1502-1578) were in contact with each other. ${ }^{11}$

\footnotetext{
${ }^{11}$ For the connection between Élie Vinet and Pedro Nuñes, identified as a weak tie, see (Valleriani 2017).
} 
However, it is neither realistic nor methodologically possible to reconstruct all the relevant social relationships by following this procedure. It is possible, however, to approach the subject by applying limitations to the research field as well as taking steps to identifying where the author of a given commentary is positioned within the social network and then trying to profile who they were.

Authors in the network are people who must have had a connection with a particular publisher to publish their text. The publisher or printer is conceived of here as a point of convergence in the network; his workshop represents a sort of social micro-region populated by employees-press-men, correctors, and engravers - in addition to many relevant external figures, such as creditors, book-sellers, representatives, and, in the case of the academic book market, representatives of educational institutions. ${ }^{12}$ The advantage of taking the printer's workshop or the publisher's office as a starting point is that one can systematically approach the question of whether a social network indeed exists amongst the authors by looking at a set of bibliographic metadata for the editions constituting the corpus.

A first limitation to the study is represented by the fact that only the so-called 'credited authors' can initially be considered. Credited authors are those whose names are detectable on the title pages, frontispieces, colophons, or in the long incipit that characterizes the fifteenth-century incunables. This means that some authors will be left out. A cursory analysis of the treatises that have been defined as compilations reveals namely that those editions contain more texts (by more authors) than what the title pages or even the tables of contents declare. The anthological work mentioned above published in Venice in 1531 by Lucantonio Giunta, for instance, mentions 13 authors in the table of contents but contains texts authored by fifteen scholarsamong them Campanus of Novara (1220-1296), who is not mentioned.

The case of Campanus, moreover, points to a second vital limitation, namely, in linking the dates of birth and death of the authors to the date of publication of the specific edition bearing their names. Obviously, if the credited authors are dead, no social relationship can be assumed between them and the publisher. This research is therefore executed in reference to all editions of the corpus and not in reference to the publishers themselves - that is, their lifetimes or periods of activity.

A search for pairs of authors who were both mentioned in one edition and both alive at the time of its publication results in 120 relationships, which appear in the impressively small number of 36 editions. In other words, the publication process of only 36 out of 359 editions could have involved some sort of exchange between more than one scholar and a publisher, and therefore between the scholars by way of the publishers. One way to explain this astonishing result is through a phenomenon well known to (especially economically-oriented) historians of the early modern book, although systematic studies have not yet been completed. It seems that the first generations of printers and publishers were particularly reluctant to publish

\footnotetext{
${ }^{12}$ Isabelle Pantin has been able to demonstrate how early modern publishers of academic textbooks were producing their books in accordance with or by means of an exchange with the scholars and representatives of educational institutions that were within their market. For more information, see (Pantin 1986, 1998) and (Chap. 9).
} 


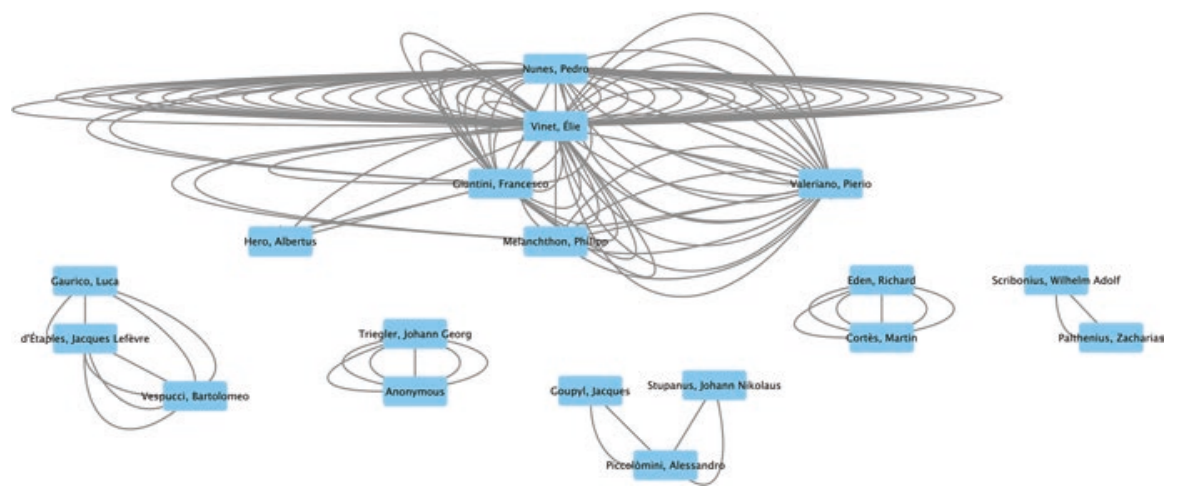

Fig. 1.6 Potential social relationships among the authors of the commentaries on the Sphaera of Johannes de Sacrobosco reconstructed by choosing authors who were alive when the editions containing their texts were published and when more than one author simultaneously contributed to the same edition. The humanist Élie Vinet comes out as the most central figure

texts by contemporary authors and scholars. ${ }^{13}$ This tendency, which makes sense if one assumes that there was no demand for contemporary authors, can be recognized in the editorial history of the commentaries on Sacrobosco's Sphaera, too. Indeed, until 1550, only two works appeared in which more than one living scholar appeared as a credited author, and these were in fact the two peculiar anthologies printed in Venice in 1508 and 1531 mentioned above. The living authors involved were Bartolomeo Vespucci, Jacques Lefèvre d'Étaples, and Luca Guarico (1475-1558). This tendency suddenly changed thanks to the almost herculean efforts of basically one man, whom Isabelle Pantin calls the first publisher specialized in scientific books in Western history (Pantin 1998): Guillaume Cavellat (ca. 1500-1576), active in Paris. The first followers of Cavellat's style arrived 11 years later in London (Richard Jugge, ca. 1514-1577) and twelve years later in Venice (Girolamo Scoto, 1505-1572).

The resulting social network inferred in this way is made up of six components (Fig. 1.6). Three are pairs of authors, two are between three authors, and the final one involves six scholars: Élie Vinet, Francesco Giuntini (1523-1590), Albertus Hero (1549-1589), Pierio Valeriano (1477-1560), Pedro Nuñes, and finally Philipp Melanchthon (1497-1560), whose social contacts with the rest of those mentioned through the Catholic publisher Cavellat should be considered improbable. If the

\footnotetext{
${ }^{13}$ The number of publications of texts of contemporary authors quickly increased, beginning in the 30 s of the sixteenth century. The change of tendency was due to the new legal protections means for printed books that favored new books and did not consider the so-called 'common books,' a category of books to which academic works such as Sacrobosco's belonged. In order to obtain the legal protection, the books had to display substantial novelties which finally resulted in the publication of a quickly increasing number of commentaries written by contemporary scholars. For more information on such normative aspects, see (Nuovo 2013, Chap. 6, esp. 212-14).
} 
parameter of centrality of this network of eighteen actors is then calculated, it turns out that Élie Vinet is positioned at the center of all potential exchanges. ${ }^{14}$

If the analysis is expanded to consider all those authors who were alive at the time of publication of their texts but who appear to be mentioned only together with Johannes de Sacrobosco (with whom there is no possible relationship) or just alone, the numbers suddenly acquire a different quality. The first case (author mentioned with Sacrobosco) involves another twenty-four scholars whose texts were published and re-published a total of 76 times. Within these new parameters, one sees that the intensity of publication enters its peak in the 1540s, although the number of publications of the previous period is much more significant. The major publisher until 1520 is Martin Landsberg (died ca. 1523) in Leipzig. In the second case, which mostly concerns the authors of adaptions for which the name of Sacrobosco is no longer mentioned on the title page but rather in the proemium (if at all), there are fourteen scholars appearing in a total of twenty-eight editions. ${ }^{15}$

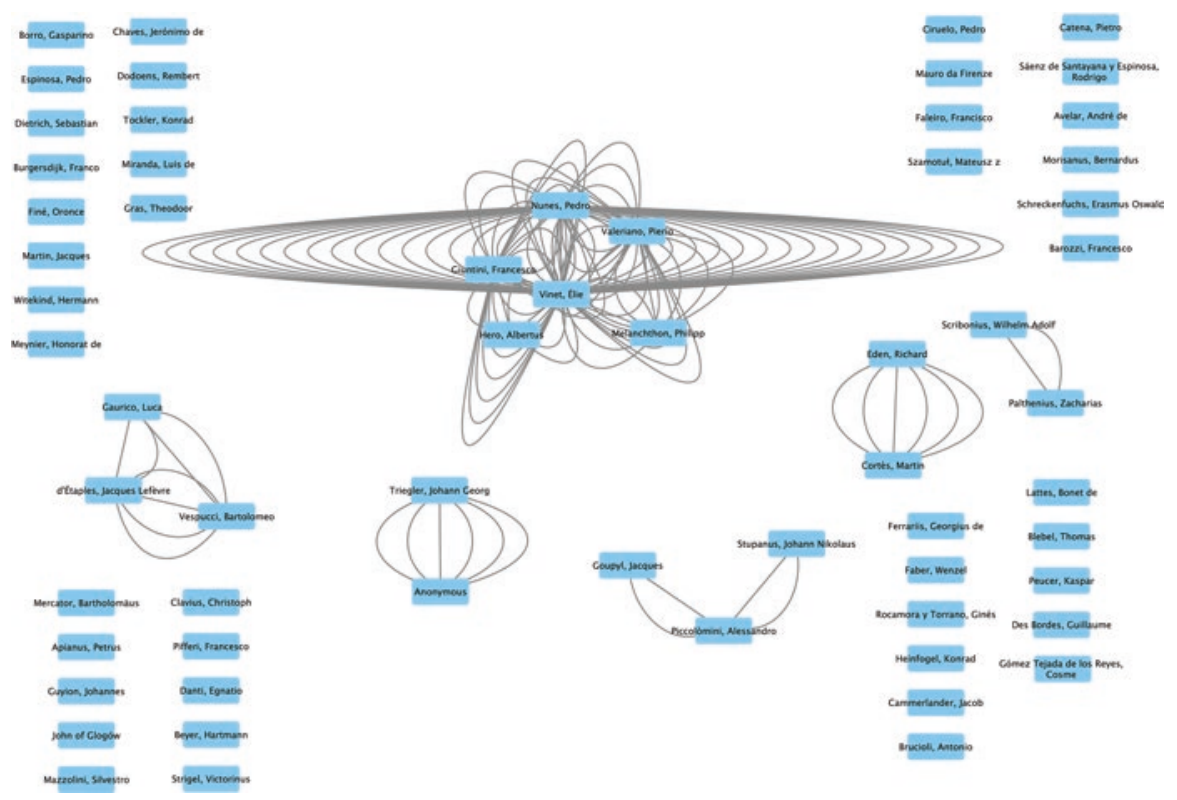

Fig. 1.7 Representation of all authors of commentaries on the Sphaera of Johannes de Sacrobosco who were alive when the editions containing their texts were published (fifty-eight authors) and potential relationships among them (involving only eighteen of them)

\footnotetext{
${ }^{14} \mathrm{~A}$ more precise reconstruction of the possible social network among the authors of the commentaries could be achieved by segmenting the editorial history into time windows of 40 or 50 years in order to be more sensitive to generational changes. This step, which would be necessary if the amount of resulting data had been significantly bigger, is not strictly necessary at this stage, as the few authors discussed here can be temporally situated very easily.

${ }^{15}$ If one looks at the data from another angle, it appears that the three groups of publishers- - those who acted as social intermediaries between scholars, those who worked one-to-one with a single
} 
To sum up, only fifty-eight of 164 credited authors were (at least potentially) in active contact with their respective publishers over the course of the 178-year editorial history of commentaries on the Sphaera, and a very small portion of these authors might have been in contact with each other through the common engagement with the same publishers (Fig. 1.7).

Such social segmentation, in spite of the basic similarity of their work in terms of content and intention, can now be further investigated by trying to reconstruct these authors' intellectual profiles. The following relies on the papers in this book.

\section{Profiling the Authors}

A quick overview of the authors of scientific commentaries in the early modern period makes clear that their profiles cannot be placed in simple and well-defined categories. Even against the background of a smaller field, as the only scientific commentaries under consideration here were written in the same framework (cosmology) and in reference to the same original text (Sacrobosco's Sphaera), the variety that emerges certainly cannot be circumscribed by simple-perhaps even anachronistic-dichotomies such as natural philosophers versus astronomers, as Edward Grant has suggested (Grant 2009, 46-59).

Starting with their educational backgrounds, the spectrum immediately enlarges to encompass mathematics, logic, and astrology, as well as medicine, theology, and natural philosophy. Thus, all possible subjects of the academic curriculum are represented, with the notable exception of juridical studies. This aspect displays once more the vitality of Sacrobosco's text from an intellectual point of view, as this text came to be considered the test bench for entering the scientific discourse during this long period. As a matter of fact, the centrality of the Sphaera was imparted to the future authors of the commentaries when they were still students at the universities. The full integration of this text into the leading pedagogical model in Europe at that time, the quadrivium, ${ }^{16}$ made it a kind of crossroads in the pursuit of all fields - and fittingly so, because cosmology was the pivot of the entire knowledge system (Valleriani 2017). While it is true that contemporary disputes such as disagreement over the reality of the planetary orbs (Chap. 6) can only be explained by the fact that

scholar and remained close to Sacrobosco's text, and those who worked one-to-one with a single scholar but published adaptions-do not significantly overlap, though they were involved in the same book market.

${ }^{16}$ The quadrivium, as conceived by Boethius, was followed in the European universities of the early modern period with a degree of flexibility (Moyer 2012). Especially the subject of music (in its original form, which included the musica sphaerarum) had quickly declined and perhaps disappeared altogether by the beginning of the sixteenth century. Nevertheless, the classic Boethian division was still considered an efficient taxonomy even as the nature of the content of the individual disciplines went through profound transformations. 
both astronomers (i.e., mathematicians) and natural philosophers were involved, this still does not exhaust the potential reach of the commentaries, which contained knowledge ranging from technological innovations on clocks and observational instruments to theological disquisitions.

Against such an educational background, it is easy to imagine that the institutional activities in which the authors of the commentaries were involved over the course of their lives were at least as heterogeneous as the educational background itself, if not even more so, albeit with some common denominators. Among the common denominators, the most relevant is the institutional engagement of the authors: As it turns out, they were all university lecturers. However, they were not only lecturers in astronomy and/or cosmology. Clearly, most of the authors of the commentaries were active in the frame of the quadrivium, and as such they were often employed to teach subjects related to mathematics. Many of them, however, were teaching different subjects, too. Pedro Ciruelo (1470-1554), for instance, also taught dialectics and theology after having been professor of astrology; Francesco Capuano was also lecturer in philosophy; John of Glógow (1445-1507) taught logic and philosophy, as did Franco Burgersdijk (1590-1635), who additionally gave classes in ethics. Turning our attention to the more practical undertakings related to geocentric cosmology, for instance, cosmography, geography, cartography, and nautical astronomy, plenty of Sphaera commentators, especially from the Iberian Peninsula (Chap. 7), can be identified who used both their publications and their classrooms as forums to discuss the latest geographic discoveries, which unfolded continuously. Working with the Sphaera was therefore also a means to reflect upon the most groundbreaking of early modern activities, namely, the exploration of the earth's surface.

Moreover, as active academicians, it is not rare to find the same figures involved in the process of reforming the curriculum of studies. Famous in this respect are the French scholars Jacques Lefevre d'Étaples and Oronce Fine (1494-1555) (Chaps. 2 and 8). Both of them insisted on a mathematical turn in the pedagogical framework of their time. However, it was not only about more or better mathematics; increasingly, it concerned more practical applications of mathematics, forging in this way a common spirit, or a shared scientific identity, between them and many of the Iberian authors of Sphaera commentaries. Also involved in a process of re-shaping curricula was Burgersdijk, who did not, however, act in favor of any particular subject but rather worked to create a textbook that accorded with the political and religious conditions of a Calvinist society (Chap. 11).

While some of them, such as Francisco Faleiro and Jerónimo de Chaves (1523-1574), were working with agencies like the Spanish House of Trades, and others, such as Capuano and Pedro Avelar, entered religious orders, another significant activity of the authors of the commentaries outside the universities seems to has been their involvement with printing workshops. As Isabelle Pantin has shown, printers were fundamentally connected to these university lecturers and authors of commentaries because they received from them the information and content necessary to design whatever editions they planned to put on the market next (Chap. 9). 
But from another perspective, for instance, by looking at the activities of Lefèvre d'Étaples and Fine, it becomes evident that such a connection was so close that these roles sometimes overlapped. Looking at the census of treatises on the Sphaera, there are several people who appear to be both the printers or publishers and, at the same time, authors of the textbooks. The most relevant among them is certainly Petrus Apianus (ca. 1501-1552).

The intellectual profiles of the authors of the commentaries are best investigated if the content of their commentaries is also scrutinized. True, the scientific content was influenced by a series of external factors, such as the economic interest of the printers, as already mentioned, as well as by the kind of institution in which the authors were teaching. The example of the two editions of the commentary on the Sphaera by Capuano, for instance, shows that the content of his texts changed according to his audience: first the students of the faculty of arts, and later the clerics of the religious order of St. Augustine (Chap. 4).

In spite of this difficulty, however, an overview of the commentaries reveals that the variety of the topics they cover perfectly matches the heterogeneity of the educational backgrounds of the scholars and of their teaching subjects.

The commentaries here examined delve into astronomy, cosmography, geography, geometry and arithmetic, medicine, astrology, theology, logic, philosophy, as well as technological applications of these knowledge domains, especially the design of mathematical instruments. It is not easy to say which of these subjects were prevalent, if any. The content of individual commentaries depended very much on their particular authors and on the context (time and space) in which they were active.

Certainly, many commentaries facilitated better connections between the standard disciplines of the quadrivium (Chap. 5). The most relevant examples to this effect are given by commentaries that dealt with geometry. Specific and different classes were dedicated to the study of Euclidean geometry, but it was nevertheless a subject to which the commentators on the Sphaera of Sacrobosco dedicated increasing space in their editions. As exemplified by the case of John of Glogów, authors of the commentaries also devoted themselves to the establishment of a new planetary astronomy based on the Theorica planetarum of Georg von Peuerbach. The same question of the philosophical and scientific status of astronomy-that is, where it stood in the scientific context of the early modern period-was discussed by Capuano and Fine, for instance. Philosophical questions of this sort, associated with the ongoing process of mathematization, resulted in frequent discussions concerning the reality of the orbs and of the cosmological system delineated in these treatises (Chaps. 6, 8 and 9): The lathe depicted in Lefèvre d'Étaples's 1495 commentary is a symbol for the ontological interpretation of mathematics in general, as pointed out by Richard Oosterhoff (Chap. 2).

The discussion surrounding the reality of the orbs and the general development in favor of an ontological interpretation of mathematics was accompanied and perhaps supported by the increasing connection of cosmology and geography, a link 
that implied the practical reality of the inhabited zones, and therefore the necessity to grasp them mathematically. In this vein, cosmography emerged as a mathematically codified discipline, whose fundamental task was to map the great celestial spheres onto the earth's surface. The treatises on the Sphaera were objects that absorbed and furthered this tendency, beginning in 1495 (Chap. 2). An entire new genre emerged specifically dedicated to cosmography, whose texts also belong in part to the corpus of the treatises on the Sphaera, though they increasingly freed themselves from such a traditional background, quickly moving toward the more practically and technologically-oriented frameworks of nautical astronomy and the design of mathematical instruments (Chap. 7). Finally, the increasing relevance of cosmography (Chap. 8) might have worked to re-shape the identity of the commentary tradition of Sacrobosco's Sphaera to emphasize practical knowledge. Such a long transformative process thus began with an appeal for a realistic interpretation of mathematically-defined planetary orbs and resulted in diminishing the centrality of ontological lines of questioning: it became useful knowledge-it worked well, and that sufficed.

In fact, the practical turn had already been realized in the late medieval period, but at that stage it was confined to another field: medicine. The authors of the early modern Sphaera commentaries still associated cosmology with medicine, but their commentaries only rarely become explicit in this respect. The same authors dealt with proper medical knowledge in other works, and the Sphaera commentaries of this period simply refer the reader to them, if the subject is mentioned at all. Much more relevant as a subject of the commentaries is astrology, the discipline that bridged cosmology and medicine. It was astrology that allowed cosmology to be the conceptual and scientific nucleus of the whole knowledge system. Astronomy, astrology, and medicine together constituted a circle around cosmology, and all possible connections between them and with the center were exploited. Because of the 1494 prohibition of judicial astrology, which was enacted at the University of Paris, the debate about the epistemic fundament of the discipline, its scientific character, and its usefulness became very vivid at least during the first phase of the sixteenth century (Chap. 3). The availability of increasingly precise tables, useful for the mathematical workflow required to locate heavenly objects, only supported the refinement of the discipline in mathematical terms. During the first phase of the sixteenth century, this process combined perfectly with the simultaneous practical turn toward cosmography. Both frameworks made similar ontological assumptions and applied similar criteria of truth while using mathematical models and workflows, and both had the goal of asserting something useful about the real world-the earth and its inhabitants. It is conceivable that the process of mathematization that necessarily accompanied the cosmographic turn is the final explanation for this great expansion of the medieval knowledge system. In the early modern period, the circle of knowledge pivoted on cosmology expanded to involve geography, nautical astronomy, and technological developments, all harmoniously connected to each other and elegantly expressed by the tradition of commentaries on the Sphaera.

As is well known, however, this system later came undone. While cosmology, mathematical and nautical astronomy, and technology increasingly joined together 
and became the knowledge of specialized personnel such as pilots, astrological medicine was increasingly marginalized (Thomas 1971, chap. 3). Both these knowledge clusters eventually exited the universities. The first one entered new schools for the education of specific professions ${ }^{17}$ while astrological knowledge became increasingly insignificant in the curriculum of most universities over the course of the seventeenth century.

Most of the commentaries printed between 1472 and 1650 were destined for the academic book market, that is, they were conceived as textbooks for students. From the perspective of the authors of those commentaries, however, the function of these texts was much broader. In line with the practical turn mentioned above, the treatises also played an important political role: they offered the authors of the commentaries an opportunity to make a confessional statement (MacLean 2012), an aspect that becomes evident when the corpus is investigated in its entirety.

Writing a commentary on cosmology was a convenient occasion to profess adherence to Christianity. Authors such as Francesco Capuano and Pedro Ciruelo, for instance, mentioned explicitly that knowing the structure of the cosmos is a way to admire God's creation. For this reason, the treatise was also an occasion for dissimulation in matters of confessional belonging. The case of Pedro Avelar, who was an active member of a secret Jewish confessional group and as such brutally persecuted by the Catholic Inquisition in Portugal, is exemplary in this regard.

For him, publication was an opportunity not only to teach, but also to keep up a front of religious conformism (Chap. 10). The Sphaera was never under serious attack by the Congregation or the Inquisition, though several editions were indeed controlled and some of their content censored (Sander 2018). Nevertheless, the text was definitely an object of political control. Several perspectives show that this was the case. The first example chronologically is the case of the production of textbooks in Wittenberg. When Philipp Melanchthon designed the curriculum, he chose books and commentaries for confessional reasons and their function was made explicit (Chap. 9). The famous Letter to Grynaeus moreover, published 64 times in the corpus of the printed commentaries on Sacrobosco's Sphaera, shows that Melanchthon's commitment to astrology was appreciated well beyond the geographic boundaries of the Reformation. The second famous example is the commentary on the Sphaera by Christophorus Clavius (1538-1612). The book, first published in 1570 and later re-published seventeen times, was intended as part of a curriculum conceived in the frame of the Jesuit Ratio studiorum - that is, against a confessional background (Lattis 1994, 1-29). Thirdly, there is the example of Franco Burgersdijk, who, in recompiling the treatise in the wake of Clavius's commentary, dressed it up to suit the Calvinist School Order (Chap. 11). Finally, the process of integrating knowledge that helped make sense of the great journeys of exploration—and on occasion helped facilitate the journeys themselves (Valleriani

\footnotetext{
${ }^{17}$ The Portuguese Aula de esfera, a school dedicated to the education of pilots, was indeed operative much earlier, during the sixteenth century. However, this was an exception, as all the other political and geographic entities of Europe entered the planetary nautical market later; they systematized the necessary knowledge in the seventeenth century.
} 
2017; Crowther et al. 2015) (Chaps. 7 and 10) —not only lent credence to the claim that the treatise was useful but also represented an opportunity to celebrate "Christian knowledge." In the rhetoric of the time, this furthermore served as a justification for Christian navigators to brutally conquer the planet.

\section{The Publishers and Future Research}

The great changes and developments that can be detected in the corpus of the early modern printed commentaries on the Sphaera of Sacrobosco are clearly related to the regional, temporal, and intellectual context in which these commentaries were conceived and written. The profiles of the authors are therefore indispensable for understanding this evolution of knowledge. Against the background of the entire corpus of historical sources, the present volume considers about $43 \%$ of them (Fig. 1.8). By means of an interactive map (https://sphaera.mpiwg-berlin.mpg.de/ doi-visualisation-authors-volume), moreover, it is possible to explore the way the contributions of this volume deepen the investigation of the sources. The entire period covered by the corpus is considered, and the number of sources investigated at given time intervals is indeed proportional to the dynamic of production of these treatises which increases around the half of the sixteenth century. Nevertheless, as book historians have recently disclosed (Nuovo 2013; MacLean 2009) and as historians of science are increasingly becoming aware (Valleriani 2017) (Chap. 9), the final decisions on the content of these treatises did not simply emerge from the milieu of scholars. It was in fact the publishers who had the last word on all aspects of the books' publication - their form and content. Indeed, these publishers engaged in intellectual, institutional, and economic negotiations with authors, professors, and other institutional representatives for each edition within the corpus - generally speaking, the same applies for every book they published. By laying more emphasis on the booksellers and printers-on the shifting commercial, material, and intellectual landscapes on which the corpus of printed Sphaera commentaries came into existence-it might be possible to enrich the investigation undertaken in this chapter. Future research will be undertaken to investigate the social network of the publishers as a way to account for the similarities among these editions! 


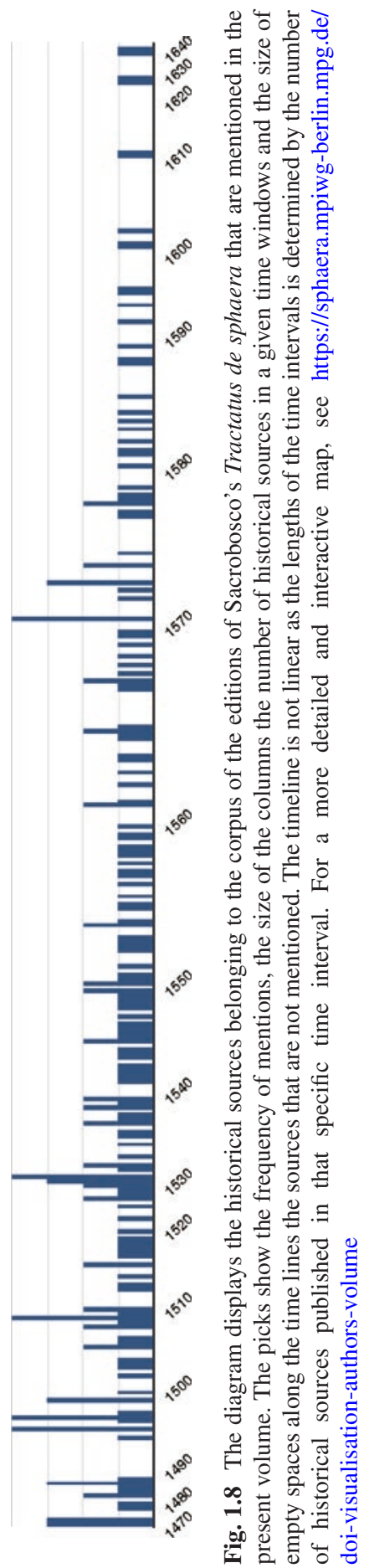




\section{References}

Crowther, Kathleen M., Ashley Nicole McCray, Leila McNeill, Amy Rodgers, and Blair Stein. 2015. The book everybody read: Vernacular translations of Sacrobosco's Sphere in the sixteenth century. Journal for the History of Astronomy 46 (1): 4-28.

de Sacrobosco, Johannes. [1472a]. Tractatum de Spera. Venice: Florentinus de Argentina. http:// hdl.handle.net/21.11103/sphaera.100685.

1472b. Ioannis de Sacrobosco anglici v[iri] c[larissimi] spaera mondi feliciter incipit. Ferrara: Andrea Bellifortis. http://hdl.handle.net/21.11103/sphaera.101122.

de Sacrobosco, Johannes, Jacques Lefèvre d'Étaples, Johannes Regiomontanus, Robert Grosseteste, Pierre d'Ailly, Bartolomeo Vespucci, and Francesco Capuano di Manfredonia. 1508. Nota eorum qua in hoc libro continentur. Oratio de laudibus astrologiae habita a Bartholomeo Vespucio florentino in almo Patavio Gymnasio anno.M.d.vi. TEXTUS SPHAERAE IOANNIS DE SACRO BUSTO. Expositio sphaerae Eximii artium \& medicinae doctoris Domini Francisci Capuani de manfredonia. Annotationes nonnullae eiusdem Bartholomei Vespucii hic ide itersertae. Iacobi frabri stapulensis Commentarii in eandem sphaeram. Reverendissimi Domini Petri de aliaco Cardinalis \& episcopi Cameracensis in eandem quaestiones subtilissimae numero xiiii. Reverendissimi episcopi Domini Roberti linconiensis sphaerae compendium. Disputationes Ioannis de regio monte contra cremonensia deliramenta. Theoricarum novarum textus cum expositione eiusdem Francisci Capuani omnia nuper diligentia summa emendata. Venice: Giuntino Giunta. Printed by Giovanni and Bernardino Rosso. http://hdl. handle.net/21.11103/sphaera.100915.

de Sacrobosco, Johannes, Bartolomeo Vespucci, Francesco Capuano di Manfredonia, Georg von Peuerbach, Jacques Lefèvre d'Étaples, Johannes Regiomontanus, Luca Guarico, Michael Scot, Nūr al-Dīn Abū Isḥāq al-Bitrūği, Pierre d'Ailly, Prodoscimo Beldomandi, Robert Grosseteste, and Gerard of Cremona. 1531. Spherae tractatus Ioannis de Sacro Busto Anglici viri clarissimi. Gerardi Cremonensis theoricae planetarum veteres. Georgii Purbachii theoricae planetarum novae. Prosdocimi de beldomando patavini super tractatu sphaerico commentaria, nuper in lucem diducta per. L. GA. nunque amplius impressa. Ioannis baptistae capuani sipontini expositio in sphaera \& theoricis. Ioannis de monteregio disputationes contra theoricas gerardi. Michaelis scoti expositio brevis \& quaestiones in sphaera. Iacobi fabri stapulensis paraphrases \& annotationes. Campani compendium super tractatu de sphera. Eiusdem tractatulus de modo fabricandi spheram solidam. Petri cardin. de aliaco epi cameracensis. 14. Quaestiones. Roberti linconiensis epi tractatulus de sphaera. Bartholomei vesputii glossulae in plerisque locis sphaerae. Eiusdem oratio. De laudibus astrologiae. Lucae Gaurici castigationes \& figurae toto opere diligentissime reformatae. Eiusdem quaestio Nunquid sub aequatore sit habitatio. Eiusdem Oratio de inventoribus \& laudibus Astrologiae. Reverendissimo cardin. epo. D. Bernardo Tridentinor principi dicata. Alpetragii Arabi theorica planetarum nuperrime Latinis mandata literis a calo calonymos hebreo neapolitano, ubi nititur salvare apparentias in motibus Planetarum absque eccentricis \& epicyclis. Venice: Lucantonio Giunta. http://hdl. handle.net/21.11103/sphaera.100999.

Grafton, Anthony. 2010. Commentary. In The classical tradition, ed. Anthony Grafton, Glenn W. Most, and Salvatore Settis, 225-233. Cambridge: Harvard University Press.

Grant, Edward. 2009. Planets, stars, \& orbs. The Medieval cosmos, 1200-1687. Cambridge: Cambridge University Press.

Grendler, Paul F. 2002. The universities of the Italian Renaissance. Baltimore/London: The Johns Hopkins University Press.

Hadravovi, Alena, and Petr Hadravovi. 2019. Traktát o sfére. Iohannes de Sacrobosco: Tractatus de spera materiali s komentárem Václava Fabera z Budějovic. Praha: Akropolis.

Lattis, James. 1994. Between Copernicus and Galileo. Christoph Clavius and the collapse of Ptolemaic cosmology. Chicago: University of Chicago Press.

Leitão, Henrique. 2008. Sphaera Mundi: A Ciência na Aula de Esfera. Manuscriptos científicos do Colégio de Santo Antão nas colecções da BNP. Lisboa: Biblioteca Nacional de Portugal. 
MacLean, Ian. 2009. Learning and the market place: Essays in the history of the early modern book. Leiden: Brill.

2012. Scholarship, commerce, religion. The learned book in the age of confessions, 1560 1630. Cambridge: Harvard University Press.

Moyer, Ann E. 2012. The Quadrivium and the decline of Boethian influence. In A companion to Boethius in the Middle Ages, ed. Noel Harold Kaylor and Philip Edward Phillips, 479-517. Leiden: Brill.

Nuovo, Angela. 2013. The book trade in the Italian Renaissance. Leiden: Brill.

Pantin, Isabelle. 1986. Imprimeurs et libraires parisiens du XVIe siècle: Cavellat - Marnef et Cavellat. Paris: Bibliothèque nationale.

1998. Les problèmes de l'édition des livres scientifiques: l'exemple de Guillaume Cavellat. In Le livre dans l'Europe de la Renaissance: Actes du XXVIIIe Colloque international d'Etudes humanistes de Tours, ed. Bibliothèque Nationale, 240-252. Paris: Promodis, Editions du Circle de la Librairie.

Rüegg, Walter. 1994-2011. A history of the university in Europe, 4 vols. Cambridge: Cambridge University Press.

Sander, Christoph. 2018. Johannes de Sacrobosco und die Sphaera-Tradition in der katholischen Zensur der Frühen Neuzeit. NTM Zeitschrift für Geschichte der Wissenschaften, Technik und Medizin 26 (4): 437-474. https://doi.org/10.1007/s00048-018-0199-6.

Thomas, Keith. 1971. Religion and the decline of magic: Studies in popular beliefs in sixteenth and seventeenth century England. London: Weidenfeld and Nicolson.

Thorndike, Lynn. 1949. The Sphere of Sacrobosco and its commentators. Chicago: The University of Chicago Press.

Valleriani, Matteo. 2017. The tracts on the Sphere. Knowledge restructured over a network. In The structures of practical knowledge, ed. Matteo Valleriani, 421-473. Dordrecht: Springer Nature.

Valleriani, M., F. Kräutli, M. Zamani, A. Tejedor, C. Sander, M. Vogl, S. Bertram, G. Funke, and H. Kantz. 2019. The emergence of epistemic communities in the Sphaera corpus. Journal of Historical Network Research 3(1): 50-91. https://doi.org/10.25517/jhnr.v3i1.63.

Open Access This chapter is licensed under the terms of the Creative Commons Attribution 4.0 International License (http://creativecommons.org/licenses/by/4.0/), which permits use, sharing, adaptation, distribution and reproduction in any medium or format, as long as you give appropriate credit to the original author(s) and the source, provide a link to the Creative Commons license and indicate if changes were made.

The images or other third party material in this chapter are included in the chapter's Creative Commons license, unless indicated otherwise in a credit line to the material. If material is not included in the chapter's Creative Commons license and your intended use is not permitted by statutory regulation or exceeds the permitted use, you will need to obtain permission directly from the copyright holder.

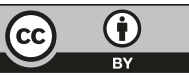




\title{
Chapter 2
}

\section{A Lathe and the Material Sphaera: Astronomical Technique at the Origins of the Cosmographical Handbook}

\author{
Richard J. Oosterhoff
}

\begin{abstract}
Even though cosmographers loved to drape their discipline in the ancient dignity of Ptolemy, actual manuals of cosmography often depended on Johannes de Sacrobosco's medieval introduction to spherical astronomy. In fact, certain strains of cosmography shared organization, principles, and even visual apparatus with Sacrobosco's Sphaera and its growing commentary tradition, to the extent that these cosmographies can be seen as themselves commenting on the Sphaera. This paper traces the origins of certain Renaissance cosmographical handbooks to the commentary on the Sphaera by Lefèvre d'Étaples and his colleagues at Paris around 1495. By focusing on the visual elements of this commentary, its instructions for calculating techniques, and the emergence of the "lathe" model of the "material sphere," this chapter argues that one of the mixed mathematical genres now seen as most characteristic of the Renaissance-cosmography-in fact was based on a medieval textbook.
\end{abstract}

\section{Introduction ${ }^{1}$}

The first printed commentary on the Sphaera of Johannes de Sacrobosco (died ca. 1256) was published at Paris in February of 1495. Early in the book the Paris arts master Jacques Lefèvre d'Étaples (ca. 1455-1536) turns to the artisan's workshop to explain the sphere. There one would find a "description of wonderful efficacy,"

\footnotetext{
${ }^{1}$ I wish to thank Matteo Valleriani for helpful comments, the other contributors to this volume for stimulating conversation, and an anonymous reviewer for a useful suggestion. This research has been supported in part by the European Research Council under the European Union's Seventh Framework Programme (FP7/2007-2013)/ERC grant agreement no 617391.
}

\author{
R. J. Oosterhoff $(\square)$ \\ University of Edinburgh, Edinburgh, UK \\ e-mail: richard.oosterhoff@ed.ac.uk
}


which clearly teaches (insofar as sensible matter can take it) how to make an artificial sphere. Artisans in our time who wish to fashion figures with a lathe in metal or another material should find its use worth its weight in gold. So, having taken a compass of thin steel or iron, a semicircle is inscribed on some line which is then cut out from the arc to the diameter, and moreover the diameter in between as well; then it is fit for cutting and dividing, and you have a tool very much suited for turning a sphere, just as a compass is for turning circles. ${ }^{2}$

The example of turning a sphere on a lathe makes a point about the status of astronomy, a classic example of a mixed science. The compass, a paradigmatic instrument of geometry, embeds the description firmly within the objects of mathematical study: lines and curves. At the same time, Lefèvre sets before his readers a concrete example, a lathe with a semi-circular blade (Fig. 2.1). A compass inscribes the edge of a tool, cutting the curve into the surface of a metallic chunk.

As we shall see, the lathe is a visual analogy that pervades later versions of the Sphaera; but this tradition originates in Lefèvre's commentary. As the first printed commentary within the genre, the Textus de sphera shows the changes the printed medium and new modes of commentary could bring to the Sphaera. ${ }^{3}$ Lefèvre's version was widely available in the first part of the sixteenth century, through the two great exporting centers of print, Paris and Venice. In 1499 it was republished in Venice, together with commentaries by Cecco d'Ascoli (ca. 1269-1327) and Capuano de Manfredonia (died ca. 1490) ${ }^{4}$; Lefèvre's Textus de sphera thereafter formed the core of omnibus editions $(1508,1518,1519,1531)$, which included cosmographical writing such as travel narratives of Amerigo Vespucci (1454-1512) and medieval alternatives to Sacrobosco such as the textbook of spherical astronomy by Robert Grosseteste (ca. 1175-1253) (Barker 2011). On its own, the Textus de sphera remained a venerable standard in the printing repertoire of Henri Estienne the Elder (1460-1520) (printed in 1500, 1503, 1507, 1511, 1516) and his successor Simon de Colines (ca. 1480-1546) (1521, 1527, 1532, 1534, 1538). Colines framed the work with new frontispieces and marginal notes by the next generation's most eminent mathematical practitioner, Oronce Fine (1494-1555), ${ }^{6}$ but retained the diagram woodblocks and layout of the commentary's original edition of 1495 .

\footnotetext{
${ }^{2}$ (Lefèvre 1495, a iiiir): "Et hec profecto mire efficacie descriptio est, que aperte docet (quantum sensibilis materia recipere valet) artificialem constituere spheram, cuius utilem commodamque intelligentiam nostre tempestatis artifices multi auri pondo comparare deberent, qui metalo, ligno, aut alia materia figuras torno exprimere volunt. Si itaque in levi calybe aut ferro, sumpto circino supra quancunque lineam semicirculus educatur qui ab arcu ad diametrum usque excavetur, quin immo et medium diametri interstitium, et mox ad arcum circumferentiamque excavatur ut ea. ex parte ad scindendum secandumque fiat aptus, exurget instrumentum tornandis spheris (haud secus quam circinus circulis) aptissimum."

${ }^{3}$ The scholarly framework here includes (Johnson 1953; Gingerich 1988, 1999; Hamel 2004, 2006, 2014; Pantin 2001, 2012; Crowther and Barker 2013; Oosterhoff 2015; Valleriani 2017).

${ }^{4}$ On Francesco Capuano de Manfredonia's work concerning Sacrobosco's Sphaera see (Chap. 4).

${ }^{5}$ The relationship of Lefèvre to these printers is addressed by (Armstrong 1952; Veyrin-Forrer 1995). (Rice 1972) edited Lefèvre's prefatory letters to these works. For further context, see also (Bedouelle 1976).

${ }^{6}$ On Oronce Fine's work concerning Sacrobosco's Sphaera see (Chap. 8).
} 


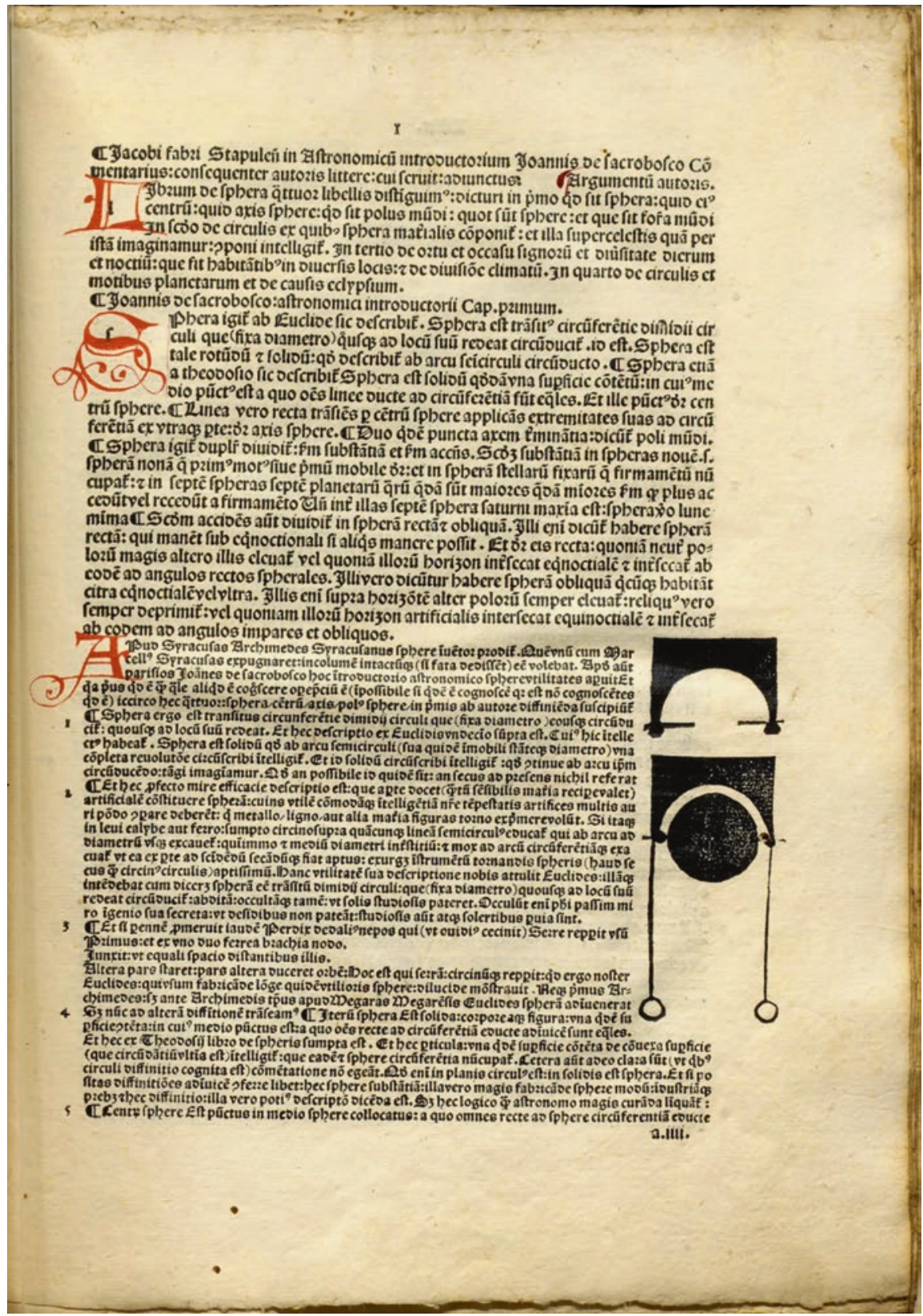

Fig. 2.1 Lefèvre opens his commentary on Sacrobosco's Sphaera with the illustration of a semicircular blade cutting a sphere on a lathe. (From (Lefèvre 1495, a iiiir). University Library Basel, CC II 7:3, https://doi.org/10.3931/e-rara-49305/ Public Domain Mark 
The case of the lathe evokes a central problem of early modern mathematical learning: how does one learn to manipulate mathematical tools with integrity, while mapping them onto the physical world? To meet this challenge, I shall show that Lefèvre made use of a resource new in the fifteenth century, Ptolemy's rediscovered Geographia. ${ }^{7}$ The result was that the first printed commentary on Sacrobosco's Sphaera inaugurated a particular tradition of cosmographical handbooks. I will suggest that the merger of astronomy with new handbooks for making maps had two implications for the ramifying genres of the Sphaera. The first is a higher emphasis on competent practice within astronomy, raising the epistemic value of technique even among beginners. Second, later versions of Sacrobosco's Sphaera refocused attention on the metaphorical nature of astronomical reasoning - the transfer from model to reality — a shift embodied in Lefèvre's material metaphor of the lathe.

\section{Mathematical Reform}

Lefèvre's Textus de sphera of 1495 was the first public result of a turn to mathematics at Paris. ${ }^{8}$ The goal was to renovate the University of Paris, Lefèvre explained in his prefatory letter to a bureaucrat in the Paris Parliament. After all, he reported, Plato had said that mathematics "is of the greatest importance not only for the republic of letters, but also for the civil republic_-Plato thinks those with the best natures especially should be taught in it."9 Lefèvre named George of Trebizond (1395-1486) — an arch-Aristotelian in Florence and Rome who had written a lengthy controversial commentary on Ptolemy's Almagest - as an example of how mathematics might benefit learning (Monfasani 1976, 105-8; Shank 2002, 2007a). Lefèvre himself was already deep into his project, having prepared an extensive revision of the Elementa arithmetica of Jordanus (fl. thirteenth century). The following year, he would have this edition printed together with his own introductory study of arithmetic, an innovative study of Pythagorean music theory, and the arithmetical game Rithmimachia (Lefèvre 1496).

Lefèvre carried out this project during a 17-year tenure as regent master of the Collège du Cardinal Lemoine, one of the older and smaller colleges of the University of Paris, with the help of an expanding circle of students. His right hand man was Josse Clichtove (1472-1543), who eventually became a leading theologian in the powerful Paris faculty of theology, but apprenticed in print as Lefèvre's corrector and editor in his Paraphrases on Natural Philosophy of 1492 (Lefèvre 1492; Massaut 1968). In the summer of 1495, after the Textus de sphera was already published, Lefèvre met Charles de Bovelles (ca. 1475-ca. 1566), who immediately

\footnotetext{
${ }^{7}$ For the subject of the rediscovery of Ptolemy's Geographia, I build on an argument sketched in (Oosterhoff 2018, 133-50).

${ }^{8}$ On this mathematical turn more generally, see (Oosterhoff 2018) and (Chap. 3).

${ }^{9}$ (Lefèvre 1495, a iv; Rice 1972, 27): "Mathemata, inquit, que (si Platoni septimo de republica credimus) non modo reipublice litterarie, sed et civili momentum habent maximum, et in his (ut sentit Plato) precipue erudiendi sunt qui naturis sunt optimis."
} 
joined him at Cardinal Lemoine. Bovelles later identified this moment as the origin point of his life-long preoccupation with mathematical figures and numbers in philosophy, responding to Ramon Lull (1232-1316) and Nicholas of Cusa (1401-1464). ${ }^{10}$ The extent to which Lefèvre depended on such close students in making his books, especially his mathematical books, can be seen in the Textus de sphera, where in the prefatory note Lefèvre recorded a debt to his familiaris Jean Grietan for doing many calculations; the colophon also thanked three correctors besides Grietan. Lefèvre often worked with students: Clichtove and Bovelles published a suite of textbooks on number theory, practical arithmetic, geometry, optics in 1503, which took its starting point in an extended commentary on Lefèvre's epitome of arithmetic, and closed with Lefèvre's Astronomicon, a contribution to the genre of theorics that was usually read after the Sphaera. ${ }^{11}$ This mathematical project was marked by intensive habits of collaboration (Oosterhoff 2019b).

These habits matched a language of friendship and harmony. The preface to the Textus de sphera closed on the benevolentia or goodwill Lefèvre shared with his patron. The idiom of shared goodwill as a bond between two people built on Aristotle's (384-322 BCE) account of friendship. ${ }^{12}$ It also echoed the intuition that the world's deep, hidden structures include patterns of sympathy and repulsion, friendship and repulsion. Lefèvre hinted as much in his manuscript treatise De magia naturali of the mid-1490s- just when he published the Textus de spherawhich offered a learned astrology organised around these forces and included a book on "Pythagorean magic."13 Lefèvre's interest in arithmetic and its subaltern science of music revolved around the Pythagorean notion of concord. Mathematically, the idea addresses the relation of quantities, ratios, or proportions: number theory or arithmetic offers a classification scheme for understanding different ratios, while music theory offers a way to use ratios of small numbers to divide the scale. This could have much larger implications. Lefèvre's edition of Euclid's (fifth century to fourth century BCE) Elements set a new humanist translation alongside the classic medieval translation of Campanus of Novara (1220-1296), who introduced Book 6 with a long excursus on proportion as the habitudo or relation of any one thing to another, citing Aristotle's Categories as support (Lefèvre 1517, 57r). Although the immediate question was how to relate arithmetical numbers to geometrical points and lines, the discussion opened larger questions. Campanus cited Boethius (early sixth century) on music, noting that the question related to sound. He also cited Plato's (ca. 428-ca. 348 BCE) Timaeus, which suggested that weights and powers relate in mathematical proportion. The fact that arithmetic theory seemed to get at

\footnotetext{
${ }^{10}$ (Bovelles 1511, 168v): "Parhisiis, quod anno 1495 peste affecti sunt...te ruri illustrem disciplinarum solem ostenderi. Tu nempe per introductiones numerorum, per arithmetice discipline preludia, Pythagorico more, totius mei philosophici profectus ac litterarii studii extitisti causa." On Bovelles more generally, see (Cassirer 1927; Faye 1998; Klinger-Dollé 2016).

${ }^{11}$ The Astronomicon was republished under the editorship of Oronce Fine in 1515, and again in a deluxe edition with Clichtove's commentary in 1517.

${ }^{12}$ This culture of friendship and its relation to mathematics is described in (Oosterhoff 2016).

${ }^{13}$ Book 2 is titled "de Pythagorica philosophia que ad Magiam introducit" (Olomouc, University Library, MS M.I.119, 198r). See (Mandosio 2013 and 2018).
} 
the forces governing the physical experience of sound, weight, and natural powers offered a suggestive hint that mathematics could explain and even control physical causes too.

These intuitions sparkle under the surface of Lefèvre's commentary on the Sphaera. At the beginning of Book 2, he added to his explanation of the great circles (equator, zodiac, colures, etc.) a report from the magi. Magicians, he said, divide the heavens into four points: the eastern one is that of God; the midday point is that of "the intelligences;" the western point belongs to the fallen dead (caducorum), while the midnight point to "evil powers" (Lefèvre 1538, 9r-v). Elsewhere, on the topic of "crespuscular risings" he alerted readers that those who concern themselves with such matters are not the good sort of mathematicus, engaged as they ought to be with arithmetical, musical, geometrical, or astronomical profit. Rather, the mathematici who indulge in such topics are "those we call vain and poisonous, such as we read poisonous wise-women were, especially that notorious Thessalian, or Circe, or Medea...."14

Despite evident familiarity with operative magic, Lefèvre quickly steered readers clear of such dangerous waters. The account of the four points of heaven turns into an anodyne analogy for contemplative theology; the movement of the heavens from first light, to midday sun, shadow, and then darkness "unfolds the movement of contemplation" (contemplationis motus explicatur). Lefèvre urged readers to read this in light of Romans 1:20, which proclaimed that "through those visible things that were made, we sense an understanding of the invisible things of God." 15 Although he recognised that "the magicians foretell great and hidden things through these four points," Lefèvre offered a deflationist reading: readers should learn to use such insights into the movements of the heavens in order to gain an understanding (idea cognita) of everything, to feed a cycle of higher intellectual insight, not to manipulate the occult forces of the natural world.

In hindsight, we can distinguish both Platonist and Aristotelian sources on mathematics flowing into Lefèvre's approach to the Sphaera. The broadly Platonist assumption that ideas are the most powerful objects that exist also nourished the Pythagorean preoccupation with numbers as the most fundamental category of being, stretching even to the possibility that numbers might underly magic. These ideas were filtered through a Christian modulation of Plato, especially through late antique authorities such as Pseudo-Dionysius (early sixth century) and Boethius, both reimagined by the fifteenth-century cardinal Nicholas of Cusa (1401-1464) whose Opera omnia Lefèvre and colleagues edited in 1514. Using such resources, Lefèvre offered a middle way between realism and nominalism: number exists out there in the world, but is only accessed mentally through human creative conjectures. In fact, the human mind makes up number and so, in the act of measuring, imitates God's creation of number in the world. Since Lefèvre thought that late

\footnotetext{
${ }^{14}$ (Lefèvre 1538, 16r): "Eo enim tempore quod a crepusculo vespertino principium sumit, mathematici utuntur, non qui Arithmeticen, Musicen, Geometricam, Astronomicamque dignitatem profitentur, sed quos vanos veneficosque nuncupamus, qualibus veneficis sagisque mulieribus, maxime infamis Thessalia fuisse legitur, qualem fuisse Circen, qualemque Medeam...."

${ }^{15}$ (Lefèvre $1538,9 v$ ): "ex iis quae visibilia facta sunt, invisibilia dei comprehensa cernamus."
} 
antique Platonists had actually stolen the insights of New Testament thinkers, he believed this roughly Platonist framework to be distinctively Christian. But like the ancient Platonists themselves, within this general framework, he had no trouble using Aristotle as a reliable guide in specific domains of scholarly study such as natural philosophy, meteorology, or astronomy. ${ }^{16}$

By making mathematics foundational for inculcating Aristotelian intellectual virtue, Lefèvre emphasised an educational program of soul-craft slightly different from Platonist mentors such as Marsilio Ficino (1433-1499) (Chap. 5). This can be seen clearly in Lefèvre's account of the "fatal number" that Plato gave in the Republic as the enigmatic number that encoded the shifts between political regimes. Aristotle had commented on the passage in his Politics, in a passage that elicited Lefèvre's longest scholium in his entire study of the work. Ficino had offered a magical explanation of the passage: souls were constructed as a geometrical set of relations, so to change political systems or groups of souls was at root a matter of manipulating mathematics. ${ }^{17}$ For Ficino, contemplation was valuable because it had pragmatic uses. Lefèvre reversed this approach. He agreed with Ficino that the number was 1728 , and the bulk of his comments coached the reader through the mathematical theory and techniques necessary to arrive at this conclusion. But he constantly warned his reader to treat this solely as a matter of mathematical exegesis, not vatic soothsaying. ${ }^{18}$ The point of moving one's mind along the paths of a mathematical problem was just the exercise of the soul, not for technological power, but for the pedagogical acquisition of habitus. Although the goal was theoretical, motivated by a contemplative vision of exercising the soul's virtues, this metaphysical end was only achieved through an operative emphasis on practical technique.

\section{Vision and Technique}

What techniques then did a reader exercise in the Sphaera? Since nearly every university student in Renaissance Europe encountered Sacrobosco's Sphaera at some point in their studies, its opening pages give an especially good snapshot of what standard mathematical knowledge could look like. After all, astronomy was a classic example of a "mixed" science, taking the pure principles of geometry and applying them to the moving heavens. ${ }^{19}$ Therefore a student opening the Sphaera needed

\footnotetext{
${ }^{16}$ On Lefèvre's theory of numbers, see (Oosterhoff 2018, 199-204); on his self-positioning vis-àvis Plato and Aristotle, see (Oosterhoff 2019a).

${ }^{17}$ The relevant passages are Plato, Republic, 8.546a1-d3; Aristotle, Politics, 5.1316a1b26. See (Ficino 1491, 225r; 1496, unnumbered final quire). On Ficino's metaphysics here, see (Allen 1994, 1999).

${ }^{18}$ (Lefèvre 1506, 87r): "verum vaticinari ex illis querere, et futili coniectura divinum scrutari velle secretum, vanum."

${ }^{19}$ Most students could have traced this classic account to the quadrivium of Boethius: e.g. De arithmetica I.1.
} 
to recall the language of geometry (the exotic vocabulary of points, lines, surfaces, and solids) in order to reimagine the heavens as an orderly machina mundi, which was what Sacrobosco named the cosmos early in Book 1. With these tools in hand, the risings of stars, the conjunctions of planets, and the shadows of eclipses might be measured, explained, and — with the help of Lefèvre's commentary-calculated.

Before 1495, a student gained mostly qualitative and general geometrical knowledge from the Sphaera. As other chapters in this book reveal, the genre expanded and diversified in many ways between the first printed editions of 1472 and the late sixteenth century. The first editions were slim octavos, visually sparce, with no prefatory material, and although they left space for diagrams, it appears that readers were expected to pen them in (de Sacrobosco 1472a, b). ${ }^{20}$ Erhard Ratdolt (ca. 1447ca. 1527) introduced only three woodcuts in 1478 and 1482; these grew to 24 in his edition of $1485 .{ }^{21}$ Many of these appear to be available in the manuscript tradition. The next major change occurred in a Venetian edition of 1488, which added a lengthy prefatory note as well as a "definition of the sphere and of certain presupposed geometrical principles." 22 These five pages gave the terminology of circumferences, poles, lines, curves, and surfaces, etc., accompanying a regime of diagrams; this can be seen as the first step towards including commentaries with the printed Sphaera.

This expansion of the Sphaera's visual apparatus between 1485 and 1495 suggests an important function for Sacrobosco in this period. Certainly, the competition of printers partly explains the proliferation of diagrams. But those printers seem to have spotted a need in late medieval learning of astronomical phenomena. Students needed to develop their capacity to image mentally - to imagine - the mathematical structure of heavenly movements. Imagination could be unreliable, of course, and since Pierre Duhem a classic strand in the history of science has focused on this language of imaginatio as a problem in "saving the phenomena." ${ }^{23}$ Recent scholarship has noticed that this language was ambivalent-the faculty of imagination also mediated trustworthy knowledge (Crowther and Barker 2013) (Chap. 9). ${ }^{24}$ For example, mental imaging allowed one to identify the mathematical shape of physical bodies. A culminating proposition in Sacrobosco observes how "Euclid imagined that a sphere is caused by the revolution of a semicircle firmly set on a chord, returned around to the place it started from." ${ }^{25}$ The geometrical rudiments added to fifteenth-century manuscript and printed editions of the Sphaera suggest the effort

\footnotetext{
${ }^{20}$ For a more detailed overview of the developments described in this paragraph, see (Baldasso 2007), and especially (Crowther and Barker 2013).

${ }^{21}$ This edition, and many others from Venice and Paris up to 1500 also included the Theorica of Georg Peuerbach and the Contra Cremonensem of Johannes Regiomontanus.

${ }^{22}$ (de Sacrobosco 1488, a4r): "Diffinitio sphaerae et de quibusdam principiis geometricis supponendis."

${ }^{23}$ For an overview of this historiography, see (Shank 2002; Barker 2011).

${ }^{24} \mathrm{~A}$ wideranging study of vision's ambiguous place in early modern culture is (Clark 2007).

${ }^{25}$ (de Sacrobosco 1490, a6r): "Imaginatus est Euclides quod sphaera causetur ex revolutione semicirculi super chordam suam firmiter permanentis donec revertitur ad locum a quo caepit circumduci."
} 
to foster a certain kind of spatial imagination as part of the everyday cultural and mental furniture of Renaissance intellectual life.

The same observation might be made of many diagrams throughout these early printed editions: the concentric orbs of the planets; the images of small stick figures walking around the globe as they observe the stars rising over the horizon (an argument for the sphericity of the world and heavens); the ubiquitous ship with observers at its mast and on its deck, in which the lower sailor's line of sight is blocked by the earth's bulge; the smiling sun as the moon eclipses it for a viewer from earth. ${ }^{26}$ These figures supply the toolkit needed to reframe the heavenly bodies as mathematical objects within the mind. This diagrammatic tradition performs an important function-but it is sharply limited. It does help the mind gain certain geometrical intuitions and abstractly apply them to a heavenly model. But these diagrams do little to help one calculate anything. Before 1495, Sacrobosco did little to teach students the specialist skills of quantification.

This is by no means a presentist observation. Contemporaries would have recognised this point. The main purpose of early modern astronomy, Robert Westman has shown in abundant detail, was prognostication (Westman 2011). Even those interested primarily in the theoretical description of heavenly models-as Lefèvre claimed to be-were acutely aware of their utility for medicine or courtly advice. Physicians and courtly astrologers therefore depended on techniques of calculation to cast a horoscope: they had to understand the locations of the heavens in the past, and to decipher where they would be in the future. A would-be prognosticator required several things beyond some geometrical intuitions about how the heavens move. ${ }^{27}$ First, a set of tables locating heavenly bodies, usually based on the thirteenth-century tables associated with King Alphonse of Spain, or (increasingly) the newly calculated tables of Johannes Regiomontanus (1436-1476). Second, a set of canons, which supplied the protocols for calculating from those tables. Third, skill in sexagesimal arithmetic, since all calculations were in degrees, minutes, and seconds. Fourth, and optionally, a prognosticator might take a shortcut with a calculation device, such as an equatorium or an astrolabe- these allowed one to read values off the instrument, rather than perform laborious calculations. None of these elements were part of Sacrobosco's introduction to the sphere.

All of these, however, were integrated into Lefèvre's commentary on the Sphaera, to one degree or another. The edition of 1500 even added Bonet de Lattes's (fifteenth century to sixteenth century) short treatise on a miniature astrolabe, which Lefèvre had found in his travels to Italy. ${ }^{28}$ In the shape of a ring intended to fit a finger, it was too small for meaningful observations or for precise calculations-but it gestured towards the company Lefèvre expected his treatise to keep.

\footnotetext{
${ }^{26}$ (Crowther and Barker 2013, 442-63) have categorized these into three kinds of images: abstract geometrical diagrams; hybrid images that are diagrammatic with naturalistic features (such as the ship); and cosmic section, i.e. the cross-sections of the planetary orbs.

${ }^{27}$ An overview of recent work in this area can be found in (Chabás and Goldstein 2014; Kremer and Husson 2012).

${ }^{28}$ The first edition is (de Lattes 1493).
} 
Throughout the commentary itself, Lefèvre took his reader by the hand, explaining the techniques needed to perform calculations. This starts with the opening Introductoria additio, which offers a brief overview of the same definitions of points, lines, and circles that we have already seen in versions of Sacrobosco from the previous decade. Lefèvre concluded this note with a telling primer on sexagesimal arithmetic. Although it is clear from annotated copies that readers did in fact sharpen their skills on the two specimen calculations he included, nevertheless Lefèvre sent readers to other sources if they wished to become proficient: "these things are added about the physical mode of calculation, not because this is enough for abacus or astronomical calculation, but so that those educated in this astronomical instruction might consult calculations and experts in calculation." 29

Beyond his introduction to sexagesimal arithmetic, Lefèvre offered a series of tables for astronomy and cosmography. Elsewhere I have discussed in some detail the series of astronomical tables, but a few words about their function will be significant here (Oosterhoff 2020). In Book 3, Sacrobosco sets the topic of "risings," namely the times when the stars in the various signs of the zodiac rise over the eastern horizon. This is a fundamental task for spherical astronomy: it allows one to determine the speed of the heavenly sphere's movement. Therefore not only are these tables the basis for calculating the location of any other star at a given time, but they also set the starry backdrop against which to calculate the movement of the lower planets. The task is fairly straightforward when an observer stands at the equator ("right sphere"), so that is where Lefèvre begins. His commentary constructs six rules based on Sacrobosco's text, and joins them to worked up specimen examples. Using short, simplified tables, he connects the movement of the heavens with the passing of time: a quarter of the zodiac has passed when a quarter of a day has passed, and so on. The matter is simplified since, even though the zodiac wobbles with the sun's annual movement through the ecliptic, this wobble is symmetrical at the equator. The basics set, Lefèvre complicates the picture, moving the observer north from the equator, to the latitude of Paris. From this perspective ("oblique sphere"), the zodiac speeds up and slows down irregularly from the observer's perspective. Here Lefèvre's rules help the reader to respond and recalculate from a realistic point.

By this point in the text, the reader has worked through enough techniques to read a table of risings or ascensions. Lefèvre includes, therefore, two full tables of ascensions that synthesize the information taught in the earlier rules: one for the equator and one for the latitude of Paris. These are not intended to replace the much fuller tables used by professionals. In fact, Lefèvre offered recommendations to readers who wished to work with actual tables. They should avoid the older Alphonsine tables, "for they are not precise. Instead, it is from the tables of ascensions of Johannes Regiomontanus...that they should compute." ${ }^{30}$ Lefèvre

\footnotetext{
${ }^{29}$ (Lefèvre 1538, 3r): "Haec de abaci physica ratione adiecta sunt, non quia ad abacum astronomicumque calculum sufficienter introducant, sed ut calculum calculique peritos consulant, qui hoc astronomico instituto sunt informandi."

${ }^{30}$ (Lefèvre 1538, 20r): "Caveant tamen abacistae...per ascensiones tabulis Alphonsinis adiectas numerando perquirere, nam praecisae non sunt; sed potius per tabulas ascensionum Ioannis Nurembergi ubilibet...computent."
} 
did not claim that his commentary on Sacrobosco was everything needed for the competent astrologer. Nevertheless, the student who had mastered it could approach the canons and tables of professionals with some degree of confidence, now able to visualise the movements of the heavens and also to relate those movements to tables of measurements.

\section{Introducing Cosmographical Practice}

The other set of tables in Lefèvre's commentary on the Sphaera addressed cosmography. The word "cosmography" was a moving target throughout the period. The discipline itself was new to the Renaissance. Medieval authors had provided narrative accounts of cities, rivers, and lands, but the word gained new associations after ca. 1410, when one of Manuel Chrysoloras's (1353-1415) students Jacopo d'Angelo (ca. 1360-1411) finished the translation of a text his master had brought from Greece, Ptolemy's Geographia. ${ }^{31}$ By titling his Latin version Cosmographia, d'Angelo linked the term to Ptolemy's practice of mapping: projecting the grid of stars on the celestial sphere onto the terrestrial globe- then projecting this globe, in turn, onto the flat surface of a map. Using this insight, the bulk of the book comprised lists of longitudes and latitudes for around 8000 cities, along with three modes of projection that would allow users to construct maps from these coordinates. By 1533, when Erasmus of Rotterdam (1466-1536) wrote a preface for the Basel editio princeps of the Greek text, the book had been published in dozens of editions and had spawned a whole subgenre of introductory handbooks. ${ }^{32}$

We have often identified the earliest cosmographical handbooks as those by Matthias Ringmann (1482-1511) (1507) and Heinrich Glarean (1488-1563) (1513). ${ }^{33}$ Some have loosely linked these handbooks to Sacrobosco. Benjamin Weiss suggested that the reading patterns of Sacrobosco's Sphaera-heavily annotated witnesses to underlying manuscript notes and circles of readers - are analogous to the ways readers of Ptolemy's work labored over practices of recalculating and remapping the longitudes and latitudes in his Cosmographia. Such specialist readers existed, as we know from their noisy complaints that Ptolemy's data was incorrect, and by the 1530s Ptolemaic techniques of mapmaking were common across Europe. I would claim this connection between the reading practices of Ptolemy and Sacrobosco is more than an analogy; in fact, beginning in 1495 with Lefèvre's publication of the Textus de sphera, commentaries on the Sphaera actually introduced students to the techniques of Ptolemaic cartography.

\footnotetext{
${ }^{31}$ A range of useful recent studies includes (Tessicini 2011; Mosley 2009; Dalché 2009; Hankins 2003).

${ }^{32}$ On expansion of Ptolemaic handbooks and cartography, see (Buisseret 2003, 49-70; Weiss 2011). Erasmus's involvement in the edition of Ptolemy was minimal, as convincingly argued by (Reedijk 1989).

${ }^{33}$ Glarean's work is in manuscript (Glarean 1513) and was first printed in 1527.
} 
We can see this in Lefèvre's commentary on Book 2 of the Sphaera, which introduces the major and minor circles of spherical geometry. Major circles are fundamental reference points for cartography, as they divide the sphere's surface into equal halves or hemispheres: e.g. the equator, the meridian, and the horizon. The equator runs east-west, while a meridian evenly splits the earth by running northsouth. When projected up onto the heavenly sphere of the stars, these circles define the celestial equator, meridians, and celestial horizons - the latter is the major circle that defines the hemisphere of stars visible to any observer on earth. Minor circles are smaller circles on the surface of the globe, which divide the sphere unequally: e.g. the colures such as the lines of Cancer and Capricorn that lie above and below the equator; the smallest of these minor circles are the arctic and antarctic circles. Taken together, these various circles slice the sphere into five zones.

Lefèvre's commentary draws out the key assumption necessary for Ptolemaic cartography, namely that "the sphere" is both the earth and the heavenly system of concentric orbs. The zodiac is therefore the belt of stars embedded on the inner surface of the outer starry sphere, a belt that follows the celestial equator; but the zodiac also includes the space below it, projected ever more narrowly onto the earthly sphere. "And in this sense we may properly say that the planets are in signs" (Thorndike 1949, 125). To illustrate this point, previous versions of the Sphaera included an image of what Sacrobosco called a "pyramid" based on the zodiac, with its apex at the center of the earth (Fig. 2.2 left). Lefèvre's version of the pyramid is clearer; but his biggest change is to present a sphere in which the major circles of longitude are assembled, hinting at the gores of a globe (Fig. 2.2 right). Around the sphere's middle is the belt of the zodiac giving a physical sense of the pyramid bases linked together as a cross section of the celestial globe. To clarify the arrangement, a third diagram presents this cross section from above, like an orange sliced in half,

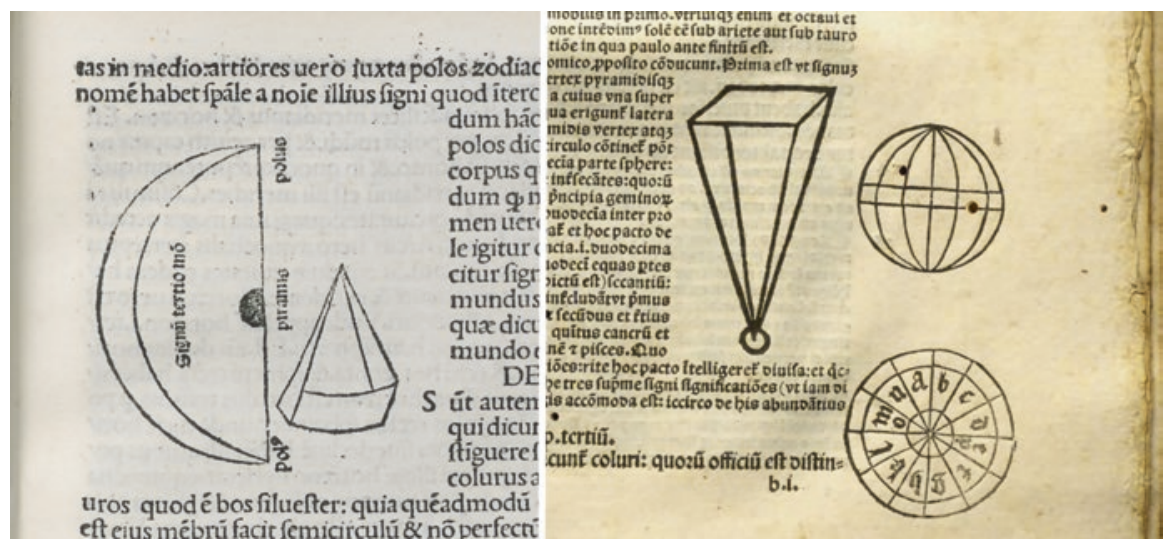

Fig. 2.2 Two illustrations of the spherical portion shared by earth and heaven, where the zodiac is the base of a pyramid with an apex at earth's center. Left: From (de Sacrobosco 1490 (Venice), b ii r). Bavarian State Library, Ink I-507, http://mdz-nbn-resolving.de/urn:nbn:de:bvb:12-bsb00020990-0. (http://hdl.handle.net/21.11103/sphaera.100885) Right: From (Lefèvre 1516, b i r). University Library Basel, CC II 7:3, https://doi.org/10.3931/e-rara-49305/ Public Domain Mark 
revealing the pyramids fanning out from the center of the earth where their points meet. The image crystallises the assumption that the geometry of the heavenly spheres maps directly onto earth.

From this point, Lefèvre offers tools for deploying spherical astronomy to map locations on earth. In passing, Sacrobosco mentions that the meridian line is known as the longitude of a city. Lefèvre specifies precisely how to calculate the difference in degrees and minutes of two cities, and how to convert a difference of coordinates into a difference of time (useful for calculating horoscopes). A specimen example compared the time in Paris and Jerusalem, where the sun rises 2 hours and 47 minutes earlier. This gave the reader a simple task in order to begin using the central exhibit of the text: a four-page table of longitudes and latitudes, "taken from Ptolemy." 34

Longitude-physically measured by travellers and shared in such tableswould have posed students no great challenge, since there was little to be done but read it off the table. ${ }^{35}$ The more interesting technical challenge was to measure latitude, based on the altitude of the sun. Of course, this required additional information. The sun's altitude changes over the course of the year, between its maximum height at the summer solstice, and maximum depth in winter. As Sacrobosco pointed out, these solstitial points determine the place of the minor circles at the tropics of Cancer and Capricorn (since the sun would be in those signs during June and December). But if one can account for the sun's elevation, the geometry of greater and minor circles will allow a novice astronomer to calculate the latitude of a given location. More generally, the same techniques allow one to set a given location in relation to the various circles drawn on a map. Lefèvre presented these techniques as a set of seven rules, adding a small table of worked examples for the reader's benefit (Fig. 2.3).

Is this astronomy or cosmography? Lefèvre's specimen examples emphasised that the techniques were useful for both disciplines: they allow one to calculate distances on a star map or a on terrestrial map. ${ }^{36}$ But both the tables and the techniques were explicitly taken from Ptolemy's Cosmographia, and Lefèvre clearly had in mind that his reader would be prepared to read geographical works. He concluded his list of seven techniques with the claim that "quickness in thinking through these intervals and distances will have great value for the Cosmography of Ptolemy and the Geography of Strabo." 37 The goal was cosmographical literacy.

The overlap of genre between the Sphaera and the new handbooks of cosmography has been noted several times before. ${ }^{38}$ I would emphasise that this overlap

\footnotetext{
${ }^{34}$ (Lefèvre 1495, b iir): “...ex Ptolemaeo deprompta.”

${ }^{35}$ Determination of longitude from astronomical principles required time-keeping devices sufficiently reliable over long distances to give a time measurement independent from the sun-a practical impossibility before the eighteenth century.

${ }^{36}$ (Lefèvre 1538, 14r): "Ex his quoque et determinatis in praecedente commento, distantias tum in caelo, tum in terra cognoscere promptum est."

${ }^{37}$ (Lefèvre 1538, 14v): "Et horum intervallorum distantiarumque cognoscendarum promptitudo non parvum ad Cosmographiam Ptolemaei et Geographiam Strabonis habet momentum."

${ }^{38}$ (Johnson 1953, 296-99) already offered some suggestive comments; see now (Weiss 2011; Mosley 2009).
} 


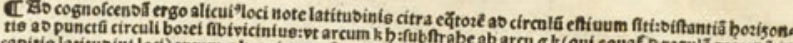

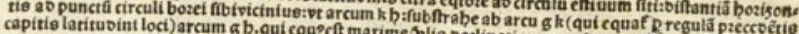

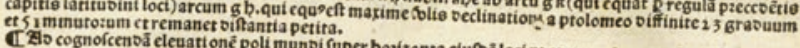

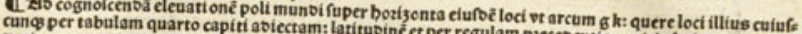

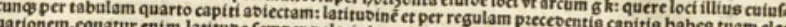
uationem.equatur enim latitubo femper polari cleuationt.

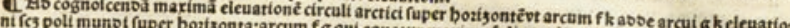

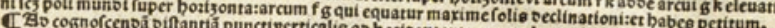
Lecosnofcen ba biffantia punctiverticalio a b bozizontavt arcum e k:partire 360 ctrculi numerus.

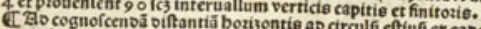

(qui eft quarta circuli $\tau$ 9 o grabuí) arcum a circulfi eftiufi ez easem parte que eft arcue o k:abijce arcui o b qui eft quarta ctrculi $\tau 9$ o grabufi) arcum b $\mathrm{k}$ paiue cognitum:ct babes interuallum inter bozice arcui o b Ti

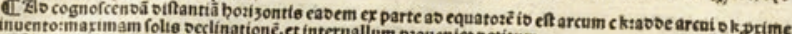

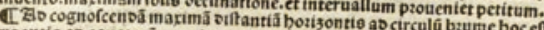

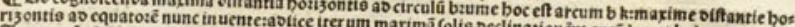

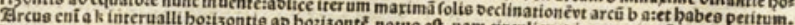

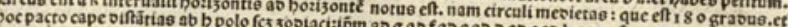

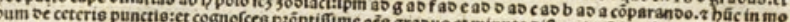

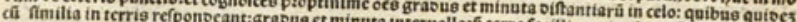

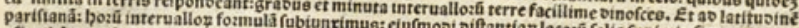
vif.ve $k$ b pto eleuatione poli ectyptice fuper bosis ciufmosi oiftantiap locozí folio fugiozie figure lifterio

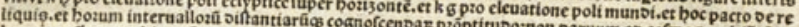

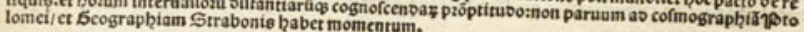

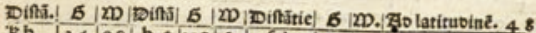

$\mathrm { kb } \longdiv { 2 4 1 0 9 \mathrm { bc } / 1 1 3 \mathrm { si } \mathrm { fb } / 8 9 1 5 }$

$\mathrm{kg}|48 / 00| \mathrm{b} b|37|_{42}|\mathrm{fa}| 108|09|$

Rf $|7 r| 5 r|b a| r 5 s|5 r| c t|24| 09 \mid$

ke $12000|\mathrm{ff}| 23|51| \mathrm{ec}|48 / 00|$

$\mathrm{Ko}|114| 09 \mid \mathrm{g} \mathrm{e} / 42$ loo e e $\mid 71 / 51$

Kc $|138100| 50|66| 09 \mid$ ea $|90|$ I

$\mathrm{kb}|\mathrm{roris}| \mathrm{aclo0100|}$ oc $23|53|$

Ka $180000 \mid 5$ b $|115| 51 \mid$ ob $|47|^{142}$

IDg $\mid 23 i 5 \mathrm{ilg}$ a $\{132 i 00\}$ o a $|65| 5 \mathrm{I} \mid$

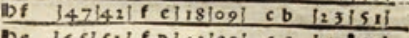

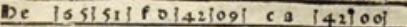

Do 19 ol oo|fe $66 \mid$ | ba 18 | 09 !

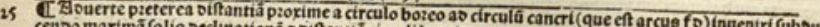

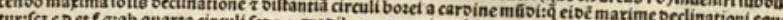

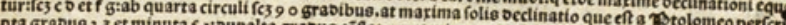

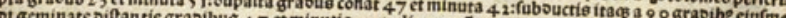

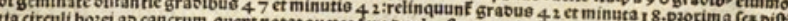
tha circuir bozet as cancrum.quevt notat auctoz fere oupla eft av maximá folis oeclinationem. fere re aolectit cit : qzea minoz eft ouplo maxime occlinationis: quanto 4.7 grabue ect 42 minuta fuenon a Grabus et 18 minuta: (c) 5 grasibus et 24 minutie. neqs autoz eractí pzo introouctionis officio cont 42 ponere muncrationcm,

(1)

minuta 51 couftanter feruare p:opter motum inclinationis octaui circuli: quem motum fol infeguitu 25 inbefintenoa vererminanbag maxime oeclinationtis quantitate:fecutus eft alpbraganfol infeguitur. fes cui nonts an ocs quober theosicis fioelius requirere licebit.

\section{CDe quincs 30nis. Lap.feptimum.}

C. Equmoctialis cum quattıoz curculis muozbus oicuntur quincs paraldli quafi cque olfantcs: quit:feo quia quilibet ouo circuli fimul iuncti:fccioum quâtı partcm eque olftant abinuicen $z$ oicûtur paralcllus equinectioli ualı/paralellus folftitu biemalis/paralellus arcticus/ct paralellus antarcticus.

Fig. 2.3 Seven rules, with a specimen table, for calculating various problems of latitude. (From (Lefèvre 1516, b iiiiv ). University Library Basel, CC II 7:3, https://doi.org/10.3931/e-rara-49305/ Public Domain Mark) 
begins quite deeply already within the Fabrist commentary on the Sphaera, well before the cosmography manuals just mentioned (see Appendix). It would be simplistic to claim a linear influence from Lefèvre's Textus de sphera to those early manuals, but there exist some suggestive links. Prosopographically, three of the earliest writers on the topic were connected to Lefèvre and his circle. The first is Matthias Ringmann, who wrote his Cosmographiae introducto (1507) to accompany the gores for a Ptolemaic map by Martin Waldseemüller (ca. 1472-1520). ${ }^{39}$ Ringmann quite likely had been Lefèvre's student in Paris; by most accounts he had gone to the grammar school at Sélestat. Certainly he was close to the circle of Alsatian students who first studied in Sélestat and then went to Paris to study for the MA with Lefèvre, before returning to participate in the Rhineland community of humanists that would attract Erasmus to Basel: the sons of Johann Amerbach (1440-1513), Johann Sapidus (1490-1561), Michael Hummelberg (1487-1527), and Beatus Rhenanus (1485-1547). ${ }^{40}$ All of these were Lefèvre's students; it is not surprising then that Ringmann identified Lefèvre's own textbooks as a model for his Grammatica figurata (1509) (Ringmann 1509, 2r). ${ }^{41}$

The second case is Henricus Glarean, whose manuscript handbook from 1513 is also among the earliest examples of the genre. The book seems to have been composed near the end of Glarean's stay at the University of Cologne, probably as part of his teaching at the Bursa Montis just before he moved to teach at Basel in 1514. Although it was not until 1517 that Glarean spent time in Paris with Lefèvre, there are suggestions that he was already familiar with the older humanist's commentary on Sacrobosco. Glarean's own teaching copy of the Sphaera from this period is a 1493 edition of Sacrobosco. Glarean had transformed the book into a compendium of annotations from a wide range of other texts, including other versions of the Sphaera. Two sets of annotations are enough to make the point. One is a table of the various climates, together with a diagram that is directly copied from Ringmann's Cosmographiae introductio (Fig. 2.4 right). The second telling note is the pyramids we have already seen from Lefèvre's 1495 commentary on the Sphaera, complete with a cross-section of the heavenly sphere showing the circle of pyramids fanning from earth to zodiac (Fig. 2.4 left). Evidently, already during his teaching at Cologne from 1507 to 1513 Glarean had set Ringmann's cosmography alongside Lefèvre's Textus de sphera, even as he was compiling his own Geography (with its own set of maps expanding on Waldseemüller's charts). ${ }^{42}$ In this trend-setting early stage-Glarean's handbook would inform Peter Apian's (ca. 1495-1552) cosmographical handbooks (Chap. 9)Ptolemaic cartography is impossible to separate from the genre of the Sphaera.

\footnotetext{
${ }^{39}$ The relation between Waldseemüller and Ringmann is discussed in (Laubenberger 1982; Johnson 2006).

${ }^{40}$ On this circle, see (Bietenholz 1971; Oosterhoff 2014).

${ }^{41}$ More generally on the relationship between Ringmann and Lefèvre, see (Schmidt 1879, 90-91, 121-23; Margolin 1972).

${ }^{42}$ Glarean's associated maps are extant. See the book list of (Fenlon and Groote 2013, nos. 57, 119). A description can be found in (Heawood 1905). More generally, on Glarean's geographical teaching, see (Johnson 2013), who presents Glarean's astronomy as part of his geography; the argument could equally go the other way.
} 


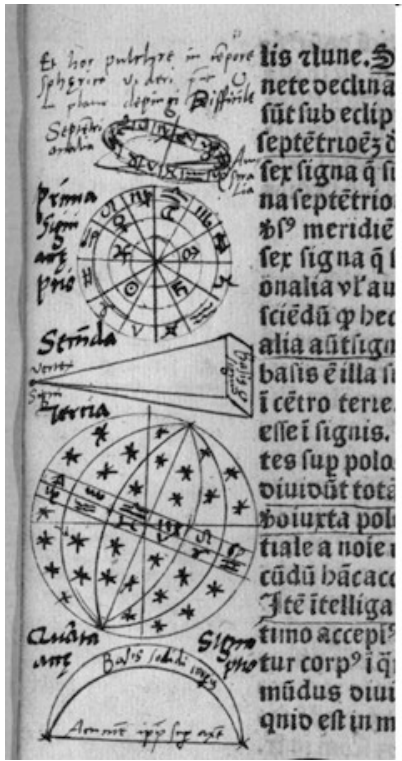

quantí tncupit oies idé fenfibuliter variari oicit dima.łec eीt idẽ̃ borologú cú puncipioet fine buius fpacii obferuatú

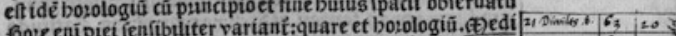

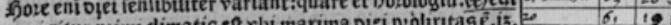
um igítur psimi dimatis en vot maxuna otei p:oltxtas e. 15 . bosau:et eleuatio poli múdi fupta circulú bemíperii gradt bus

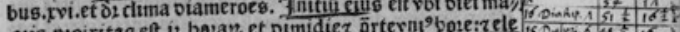

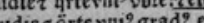

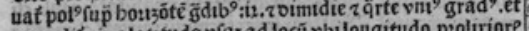
ertendit́ eius latıtudo viqs ad locú vbilongitudo prolixiore

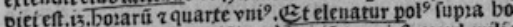

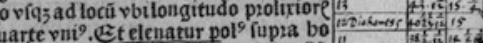

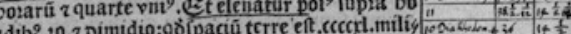
risonte gradib if foudiclimatigeft vbi mato: oies eft. is.bo

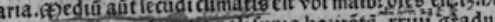

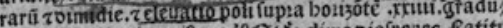

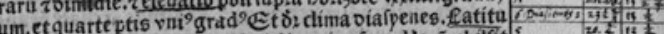

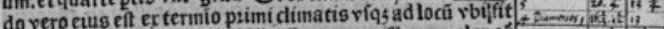
do vero euts ent exter $z$ oumidic $z$ ärte pte vni bose. $z$ eleuat

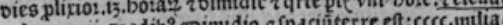

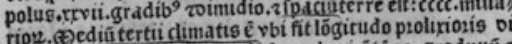

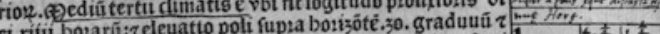
ei.jilu.

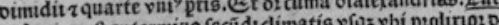
tudo cius eft er termino iecudidititu poli:3: graduum et

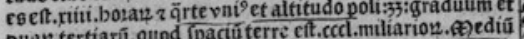

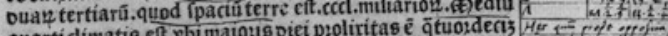
quarticimatis elt ve botarum 20 imidie. $z$ arislatitudo. tarum. Etó: oiarbodos. fatitudo vo et é ex termio tertii climate vfqз vbi plixitas mato:e oiei é. xíii.bo:a» zoimidie

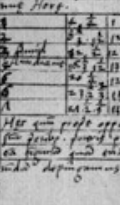

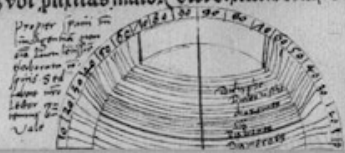

Fig. 2.4 On the left, the diagrams closely follow those given in Lefèvre's Textus de sphera (see also Fig. 2.2 right). On the right, the bottom figure has been hand-copied directly from (Ringmann 1507). From (Sacrobosco 1493, fol. 5v, 12r). University Library Munich, 4 Inc.lat.310 no. 6 https:// nbn-resolving.org/urn:nbn:de:bvb:19-epub-11720-8

A third example is taken up by Angela Axworthy in much closer detail: Oronce Fine's De mundi sphaera, sive Cosmographia (first edition 1532) (Chap. 8). Here I simply wish to highlight the book's debt to Lefèvre. While it is not clear how closely Fine and Lefèvre associated in Paris, their intellectual filiation is not in doubt: Fine's first significant contribution to the mathematical writing and illustration that made him famous was his frontispiece for Simon de Colines' 1521 edition of Lefèvre's Textus de sphera. ${ }^{43}$ The title of Fine's own De mundi sphaera, sive Cosmographia already betrayed its origins in Sacrobosco, and a glance at the contents confirms that its first five books quite closely follow the Sphaera (see Appendix). Moreover, the text itself depends considerably on Lefèvre's commentary, even augmenting Lefèvre's use of tables. Book 2 adds star charts, giving not only the locations of cities on the earthly grid, but the longitudes and latitudes of stars on the heavenly grid. Book 3 has at its core the same task as Lefèvre's Textus de sphera, using a selection of small charts to prime the reader for interpreting larger tables of right and oblique ascensions. Building on Lefèvre's work, Fine's Cosmographia binds astronomy and cosmography even closer together by underscoring the fact that the astronomer and cosmographer share the same techniques (Besse 2009).

\footnotetext{
${ }^{43}$ On this relationship, see (Axworthy 2016, 28; Pantin 2009a, b).
} 
As Henrique Leitão has argued, Fine's work was open to critique from many angles; but this was precisely because Fine, as the prestigious royal professor of mathematics in Francis I's Collège Royal, was the pre-eminent mathematical practitioner of mid-sixteenth-century Europe (Leitão 2009). The cosmographies of Ringmann, Glarean, and especially Fine defined the shape of cosmography in the Renaissance_-and they cemented Lefèvre's version of the Sphaera into the foundations of cosmography.

\section{The Material Sphaera}

The techniques of actual measurement and calculation discussed above bring us back to lathes and the question of how manipulation and models relate to the physical world. By the seventeenth century, the art of turning stood in for the manual use of mathematics to rival and control nature's untiring motions. Princes from Maximilian I (1459-1519) and Rudolf II (ca. 1401-1495) to Peter the Great sought recreation in the art of turning. Courtly collections of wonders from Dresden to the Palazzo Vecchio of Florence included fine pieces of ornamental turnery (Klaus 1985, 2004; Connors 1990). In 1565 Samuel Quiccheberg (1529-1567) recommended that such collections devote an entire room to such tools and their artefacts. ${ }^{44}$ Turned ivories among surviving examples in the Kunstkammer of the Electors of Saxony, in Dresden, are material ruminations on the five platonic solids, examples of how turning became a metaphor for mechanical control of nature, or what Horst Bredekamp has called the "cult of the machine" (Korey 2007; Dupré and Korey 2009, 417; Bredekamp 1995). ${ }^{45}$ Such lathework quoted in matter the Timaeus, where Plato set gave his analogy of the cosmos as spinning bowls formed by a divine Craftsman, setting up his account of the five solids as the building blocks of the universe. Over the course of the sixteenth century, the image of a lathe permeated versions of the Sphaera, part of the construction of turning as a material topos.

In 1495, the lathe was not yet a commonplace depiction of the heavenly sphere. When he introduced it in his Textus de sphera, Lefèvre likely had in mind the Platonic image of God as artifex; in his Astronomicon (1503) he offered planetary astronomy as a way for human souls to imitate the circular, productive motions of the first Artisan (Lefèvre et al. 1503, xcviir). With the lathe, Lefèvre set readers the problem of reasoning about how mathematical forms regulate matter, and especially the movement of that matter. Although axial motion was a common question in late medieval physics, the metaphor of the lathe was problematic for other reasons. ${ }^{46}$

\footnotetext{
${ }^{44}$ (Quiccheberg 2013, 72): “A workshop of turner's equipment and turning and joining tools, such as those considered among most princes and patricians to belong to the domain of the more congenial arts." More generally, see (Maurice 1985, 2004).

${ }^{45}$ On the metaphor machina mundi in this period, see (Popplow 2007).

${ }^{46}$ Late medieval reflections on revolving objects include Gaetano da Thiene, commenting on the Merton calculators: see (Wallace 1981, 55-56; Shank 2007b, 2009).
} 
Even Plato had observed that mathematics was only fitted to matter by means of "bastard kind of reasoning" (Plato, Timaeus, 52b2).

How much could the metaphor describe what the Sphaera called the material sphere? Not all of Lefèvre's own readers were happy with the lathe. In 1498, Pedro Ciruelo's (1470-1554) own commentary on the Sphaera provides evidence that Lefèvre's commentary was already being read more widely at the University of Paris (Chap. 3). His ambivalence, however, shows that the lathe example touched on unresolved issues within the philosophy of mathematics. First he paraphrased Lefèvre's example at length, anonymously as the "account of others." Then he noted that "although this seems to be a beautiful and ingenious case, nevertheless this was not what Euclid had in mind." ${ }^{47}$ The primary reason explicitly draws on Aristotle's misgivings about mathematical abstraction in On the Soul and the Metaphysics: "since sensible matter cannot take those forms or shapes that mathematicians think up." ${ }^{48}$ Ciruelo was a talented mathematician, who regularly expressed his appreciation of Lefèvre, Clichtove, and Bovelles, yet he was worried that Lefèvre's lathe example was overoptimistic about how well mathematics can define a physical object.

Still, the visual echoes of Lefèvre's lathe suggest that the example was too powerful to let go. Readers of early books often, like Glarean, took images that they found useful from other versions of the Sphaera and copied them into the margins of their own copies. One 1508 version from Cologne reveals just this: at the top of the page the reader has drawn in the metal blade, defined as the "curve of the circumference;" a little ways down the page is drawn the lathe, which "is an example of the first definition [i.e. of Euclid's definition]" (Fig. 2.5). To someone whose mathematical literacy is set by twentieth- or twenty-first-century visual culture, the series of geometrical "principles" that introduced most editions of the Sphaeraand also cosmography manuals_-may seem somewhat superfluous. But such visual cues required cultivation in the sixteenth century.

An important turning point in this visual topos comes in the 1530s, in the stripped-down versions of the Sphaera published at Wittemberg, often with Philip Melanchthon's oration on astronomy. The first chapter addresses the definitio sphaerae, and for the first several editions, the only commentary added to Sacrobosco's words is the diagram of a lathe, before moving on to the next chapter on the division of the sphere (Fig. 2.6 left). After 1538, a further brief scholium was added, citing the Greek edition of Euclid. This note did not eclipse the old lathe, however, but complemented it with a new image of a pseudo-lathe (Fig. 2.6 right). Where the first lathe shows how to create a solid sphere from a semi-circular hollow, the second image does something slightly less intuitive. It takes a semicircular surface, and asks the viewer to imagine it spun around an axis - the space it sweeps out exemplifies a hollow sphere. The place of this example between physical object and

\footnotetext{
${ }^{47}$ (Ciruelo 1498, b ir): "Sed quamvis hec pulchra et ingeniosa videantur, hanc tamen non fuisse Euclydis mentem."

${ }^{48}$ (Ciruelo 1498, b ir): "Cum materia sensibilis non tales formas seu figuras recipere possit quales mathematici concipiunt ut satis probatur in primo de anima et in tertio methaphysice."
} 


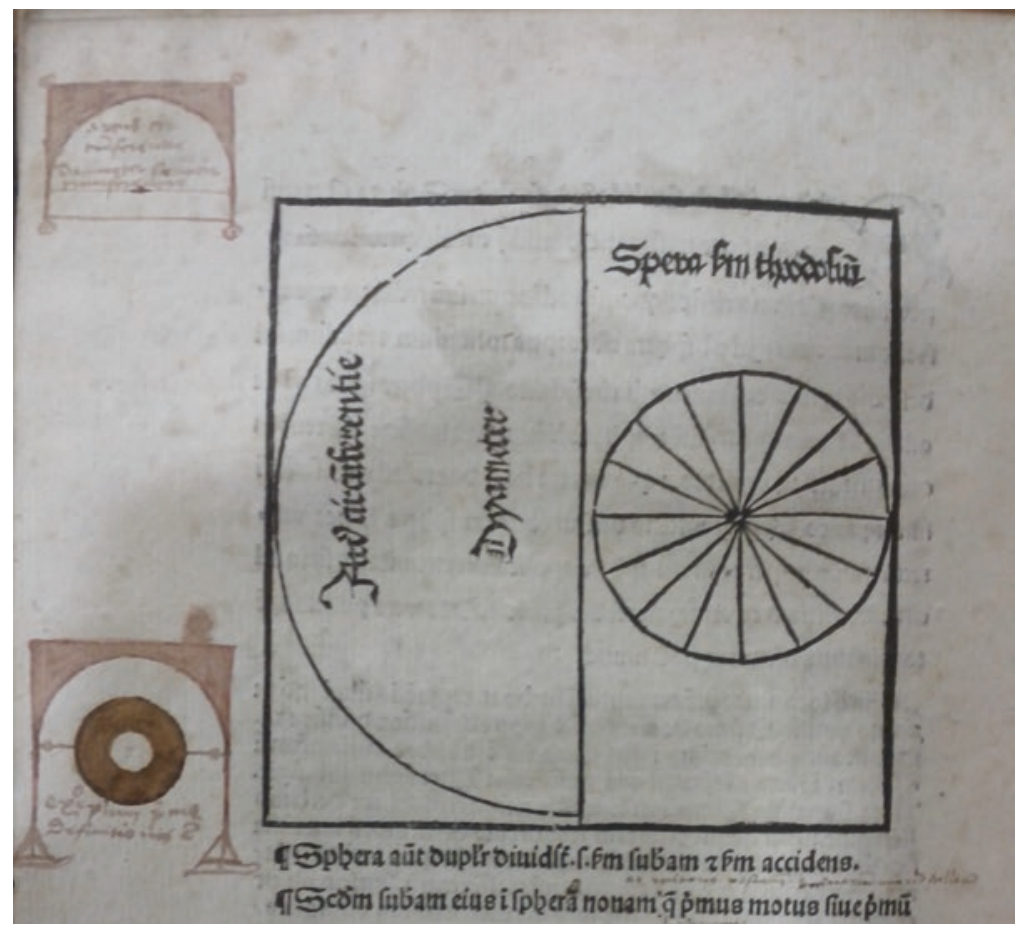

Fig. 2.5 A reader adds diagrams of the material lathe, inscribing above "arcus circumferentie," and below, "exemplum prime definitionis est." (From (de Budweys 1508, A iiii v). Newberry Library, Ayer oQB 41.S12, (image by Author/Public Domain)

imagined concept is underscored by two tiny figures standing on the ground below the sphere, allowing the reader to imagine themselves standing below an enormous space. By the second half of the sixteenth century, this second, inverted lathe was widely common in the genre of the Sphaera, including versions by Giuntino Giunta 1477-1521, Elie Vinet (1509-1587), and Franco Burgersdijk (1590-1635). ${ }^{49}$

To what extent was this object on a lathe identified with the physical cosmos? Typically, the figure introduced a discussion of the "material sphere." One might suppose this meant the actual nested orbs that were the subject of Sacrobosco's planetary astronomy (Barker 2011). This seems to have been the case for Lefèvre, who took no trouble to distinguish the "machina mundi materialis" from the actual cosmos. But over the course of the sixteenth century, the material metaphor seems to have become more troubling. One example is the Epitome astronomiae of Michael Maestlin (1550-1631), which gives the inverse, Wittenberg version of the lathe to exemplify the Euclidean definition of the sphere (Maestlin 1597, 10). Maestlin qualified the "material sphere" differently than Lefèvre had done: "We give the name 'material sphere' to the instrument that represents the outermost, convex sur-

${ }^{49}$ See also the versions of the Sphaera by Vinet and Burgersdijk (Chap. 11). 

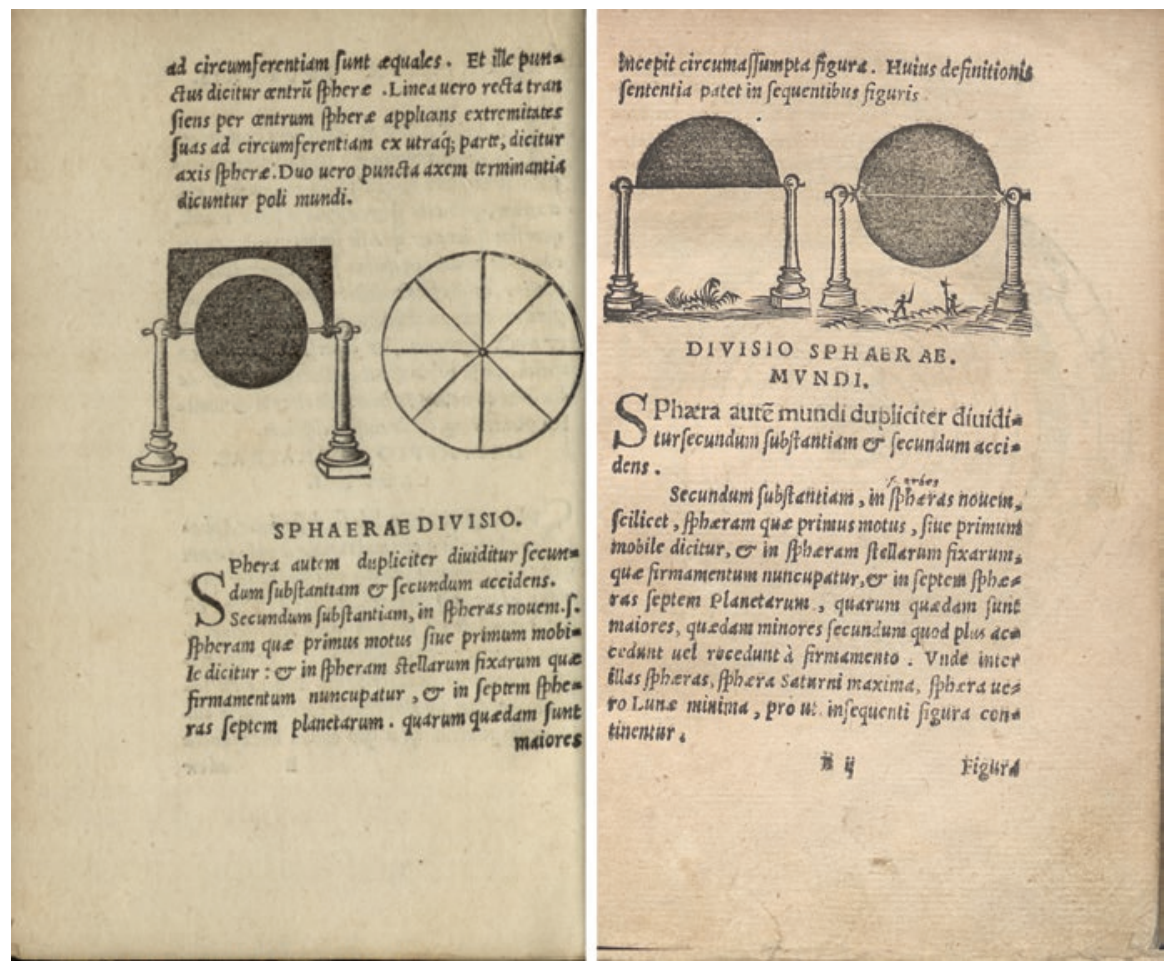

Fig. 2.6 Lefèvre's lathe example became mainstream in the enormously popular Wittenberg edition of 1531 (left), which was then augmented in 1538 with an additional outsized example of a revolving semi-circle (right). Left: From (de Sacrobosco 1531, B i v). Bavarian State Library, H.g.hum. 18 1, http://mdz-nbn-resolving.de/urn:nbn:de:bvb:12-bsb00039827-2. Right: From (de Sacrobosco 1538, B ii r). Bavarian State Library, Astr.u. 154, http://mdz-nbn-resolving.de/ urn:nbn:de:bvb:12-bsb00020992-1, http://hdl.handle.net/21.11103/sphaera.101106

face, or the circles that define it, of the highest heaven (which we call the "natural sphere')." ${ }^{50}$ In other words, Maestlin applied the term "material sphere" to the instrument or model (perhaps thinking of an armillary sphere) rather than to the heavens themselves.

The lathe had become a commonplace, within the genre of the Sphaera as well as at courts. Moreover, the function of that commonplace seems to have shifted ever so slightly. Only a much larger study could adequately consider the range of concerns implicit in such a commonplace. ${ }^{51}$ But this brief sketch suggests that the lathe

\footnotetext{
${ }^{50}$ (Maestlin 1597, 13): "Ut sphaeram Materialem appellamus illud instrumentum, quod ultimi coeli extremam seu convexam superficiem (quam vocamus, Sphaeram Naturalem) vel Circulos in ea. conceptos, repraesentat."

${ }^{51} \mathrm{~A}$ study considering the range of concerns implicit in the lathe as a commonplace would include reflection on movement within mathematical argument, e.g. (Axworthy 2017, 2018). On the epistemic status of armillary spheres and globes, see (Mosley 2006a, b).
} 
pushed to the foreground the question of what constitutes an adequate model. To what extent, that is, can a tool serve as a metaphor for the universe; to what extent do the qualities of one object or domain transfer over to another? Maestlin (and others who implicitly agreed by reusing the image) seems to have shifted away from accounts that seamlessly elided the lathe model with the materiality of the heavenly referent, opening a space for alternative theories of the heavenly sphere's composition. At the same time, he paid closer attention to the visual work of such machines as machines, suggesting that the model helped to think about physics. ${ }^{52}$ Perhaps this is reading too closely-but, if not, then the paradigmatically Ptolemaic Sphaera helped to stage some of problems that a new mathematization of motion would set. At all events, for Maestlin as well as for Ciruelo, the example of the lathe prompted reflection on the relationship of model to original, of mathematics to matter.

\section{Conclusion}

Taken together with the tables and cosmographical tools discussed earlier in this chapter, the example of the lathe suggests the multiple trajectories that could meet within a capacious and growing genre such as the Sphaera. First, the Textus de sphera, first printed in 1495, presented techniques for calculation that became more widespread in books on the Sphaera during the course of the sixteenth century. Lefèvre offered commentary on literary and terminological questions, offering the kind of qualitative mastery of the science of the stars that any university educated man was expected to have in the Renaissance. As I show elsewhere, this skill set can be traced through later versions of the Sphaera, and constitutes an important shift in the wider cultural expectation of early modern Europe that educated people should be literate in the arts of number as well as the alphabet (Oosterhoff 2020).

Second, I have argued that Lefèvre's Textus de sphera, first published in 1495, brought together the techniques of Ptolemy's Geography with the genre of the Sphaera. Therefore, Lefèvre's book could be read as a cosmographical handbook; and I have suggested that it did set a precedent for Ringmann, Glarean, and Fine. Lefèvre's expectation that readers of the Sphaera should be interested and able to calculate for themselves locations on a map fed the new genre of cosmography.

A third trajectory is particularly clear with the lathe, a visual topos that originates in Lefèvre's commentary. The reformulation of this topos offers a chance to consider the accruing visual culture of the Sphaera in print, and the way that a visual topos that could travel independently of verbal commentary. While Lefèvre's verbal account was eventually made redundant by new versions of the Sphaera that incorporated new tables and rules for their use, the visual power of the lathe seems to have helped it outlast Lefèvre's own text. As a material metaphor it reprised the

\footnotetext{
${ }^{52}$ E.g. (Lefèvre 2004). These twin shifts would produce a paradox: mathematics is separated from the heavens, while at the same time the machine's motion is conceived of more mathematically. For one discussion of the tensions at play, see (Gal and Chen-Morris 2013, 117-160).
} 
Timaean account of the universe as a crafted mathematical object; as a visual object, particularly in the Wittenberg tradition where it came to represent a hollow or absence, it kept the viewer in mind of the difference between model and reality-a crucial cognitive habit in the later sixteenth century as alternative world models became public.

\section{Appendix. Contents of the Early Handbooks of Cosmography}

\begin{tabular}{|c|c|c|c|c|}
\hline $\begin{array}{l}\text { Sacrobosco, } \\
\text { Sphaera }\end{array}$ & $\begin{array}{l}\text { Matthias } \\
\text { Ringmann, } \\
\text { Cosmographiae } \\
(1507) .\end{array}$ & $\begin{array}{l}\text { Heinrich Glarean, } \\
\text { De geographia liber } \\
\text { unus (Basel: Jo. } \\
\text { Faber. Emmeus, } \\
\text { 1527) [MS c. 1513] }\end{array}$ & $\begin{array}{l}\text { Peter Apian, } \\
\text { Cosmographia } \\
(1529) .\end{array}$ & $\begin{array}{l}\text { Oronce Fine, } \\
\text { Cosmographia } \\
(1 \text { st ed. 1532) }\end{array}$ \\
\hline Lib. I & & & & Lib. I \\
\hline $\begin{array}{l}\text { - Definition of } \\
\text { the sphere } \\
\text { - Four elements } \\
\text { - Revolutions } \\
\text { of the heavens } \\
\text { - Rotundity of } \\
\text { the earth } \\
\text { - Diameter of } \\
\text { the earth }\end{array}$ & $\begin{array}{l}\text { 1. Basics of } \\
\text { geometry } \\
\text { 2. Sphere, axis, } \\
\text { poles }\end{array}$ & $\begin{array}{l}\text { 1. Principles of } \\
\text { geometry and } \\
\text { spherical astronomy } \\
\text { 2. Celestial and } \\
\text { planetary spheres } \\
\text { 3. Motions of the } \\
\text { spheres }\end{array}$ & $\begin{array}{l}\text { 1. Definition of } \\
\text { cosmographia } \\
\text { 2. Motion of the } \\
\text { sphere }\end{array}$ & $\begin{array}{l}\text { - The world, its } \\
\text { parts and } \\
\text { motions }\end{array}$ \\
\hline - Lib. II & & & & Lib. II \\
\hline $\begin{array}{l}\text { - Celestial } \\
\text { circles } \\
\text { - North, south } \\
\text { poles } \\
\text { - Division of } \\
\text { the zodiac } \\
\text { - Ecliptic } \\
\text { - Colures, } \\
\text { meridian, } \\
\text { horizon, } \\
\text { - Tropics } \\
\text { - Five zones } \\
\text { [parallels] }\end{array}$ & $\begin{array}{l}\text { 3. Celestial circles } \\
\text { 4. Various degrees } \\
\text { of the sphere } \\
\text { 5. The five } \\
\text { heavenly zones } \\
\text { 6. Parallels }\end{array}$ & $\begin{array}{l}\text { 4. Axis, poles } \\
\text { 5. Right, oblique } \\
\text { spheres } \\
\text { 6. Greater and } \\
\text { smaller circles } \\
\text { (ecliptic, colures, } \\
\text { meridian, etc.) } \\
\text { 7. Composition of } \\
\text { the material sphere } \\
\text { 8. Elevation of the } \\
\text { poles } \\
\text { 9. The five zones } \\
\text { 10. Parallels }\end{array}$ & $\begin{array}{l}\text { 3. Definition of } \\
\text { a sphere, its } \\
\text { circles, signs of } \\
\text { zodiac } \\
\text { 4. The five } \\
\text { zones } \\
\text { 5. The parallels }\end{array}$ & $\begin{array}{l}\text { - Equator, poles, } \\
\text { zodiac } \\
\text { - Longitude and } \\
\text { latitude } \\
\text { - Meridian } \\
\text { - Minor circles } \\
\text { - Five zones }\end{array}$ \\
\hline
\end{tabular}




\begin{tabular}{|c|c|c|c|c|}
\hline $\begin{array}{l}\text { Sacrobosco, } \\
\text { Sphaera }\end{array}$ & $\begin{array}{l}\text { Matthias } \\
\text { Ringmann, } \\
\text { Cosmographiae } \\
\text { (1507). }\end{array}$ & $\begin{array}{l}\text { Heinrich Glarean, } \\
\text { De geographia liber } \\
\text { unus (Basel: Jo. } \\
\text { Faber. Emmeus, } \\
\text { 1527) [MS c. 1513] }\end{array}$ & $\begin{array}{l}\text { Peter Apian, } \\
\text { Cosmographia } \\
(1529) \text {. }\end{array}$ & $\begin{array}{l}\text { Oronce Fine, } \\
\text { Cosmographia } \\
(1 \text { st ed. 1532) }\end{array}$ \\
\hline Lib. III & & & & Lib. III \\
\hline $\begin{array}{l}\text { - Rising and } \\
\text { setting of } \\
\text { signs } \\
\text { - Chronic, solar } \\
\text { risings } \\
\text { - Right } \\
\text { ascensions } \\
\text { - Inequality of } \\
\text { days } \\
\text { - Oblique } \\
\text { ascensions } \\
\text { - Living at } \\
\text { equator } \\
\text { - Arctic circle } \\
\text { - Seven climes }\end{array}$ & 7. The climes & $\begin{array}{l}\text { 11. The climes } \\
\text { 12. Technique for } \\
\text { measuring the earth } \\
\text { 13. Breatdth of the } \\
\text { earth } \\
\text { 14. Longitudes of } \\
\text { cities } \\
\text { 15. Units of } \\
\text { measurement }\end{array}$ & $\begin{array}{l}\text { 6. The climes } \\
\text { 7. Longitude } \\
\text { 8. Latitude } \\
\text { 9. Calculating } \\
\text { solar altitude } \\
\text { 10. Longitudes } \\
\text { of places } \\
\text { 11. Units of } \\
\text { measurement } \\
\ldots\end{array}$ & $\begin{array}{l}\text { - Rising and } \\
\text { setting of stars } \\
\text { - Right and } \\
\text { oblique } \\
\text { ascensions }\end{array}$ \\
\hline Lib. IV & & & & Lib. IV \\
\hline $\begin{array}{l}\text { - Movement of } \\
\text { the sun } \\
\text { - Equant, } \\
\text { deferent, } \\
\text { epicycle } \\
\text { - Lunar eclipse }\end{array}$ & $\begin{array}{l}\text { 8. Winds } \\
\text { 9. Division of the } \\
\text { earth, the ends of } \\
\text { the sea, and } \\
\text { distances of } \\
\text { various islands } \\
\text { [10.] A quadrant } \\
\text { useful to the } \\
\text { cosmographer }\end{array}$ & $\begin{array}{l}\text { 16. Winds } \\
\text { 17. Ptolemy's } \\
\text { method for } \\
\text { depicting the world } \\
\text { 18. The image of the } \\
\text { world } \\
\text { 19. Putting paper on } \\
\text { a globe (i.e. gores) } \\
\text { 20. Geographical } \\
\text { names } \\
21 . \text { Division of the } \\
\text { earth } \\
22-40 . \text { Europe... } \\
\text { Africa...Asia....and } \\
\text { regions beyond } \\
\text { Ptolemy }\end{array}$ & & $\begin{array}{l}\text { - Inequality of } \\
\text { days } \\
\text { - Calculating } \\
\text { equal/inequal } \\
\text { times } \\
\text { - Calculating } \\
\text { solar altitude } \\
\\
\text { Lib. V } \\
\text { - Parallels } \\
\text { - Longitude and } \\
\text { latitude } \\
\text { - Calculating } \\
\text { distances } \\
\text { - Winds } \\
\text { - Sines and } \\
\text { chords } \\
\ldots\end{array}$ \\
\hline
\end{tabular}

\section{References}

\section{Manuscripts}

Glarean, Heinrich. ca. 1513. De gaeometriae principiis ad sphaerae astronomicae noticiam necessariis. Brown University, John Carter Brown Library, MS Cod.Lat.1.

Lefèvre d'Étaples, Jacques. ca. 1495. De magia naturali. Olomouc, University Library, MS M.I.119. Sacrobosco, Joannes. 1493. Tractatus de Sphera. Paris: Georg Mittelhus. Munich, Universitätsbibliothek der Ludwig-Maximilians-Universität, 4 Inc.lat.310 no. 6. A copy heavily annotated by Heinrich Glarean. 


\section{Primary Sources}

Apian, Peter. 1529. In Cosmographia...Additis de eadem re ipsius Gemmae Phyr. libellis, ed. Gemma Frisius. Antwerp: Arnold Berckmann.

Ciruelo, Pedro. 1498. Uberrimum sphere mundi commentum intersertis etiam questionibus domini Petri de Aliaco. Paris: Jehan Petit. http://hdl.handle.net/21.11103/sphaera.100038.

de Bovelles, Charles. 1511. Que hoc volumine continentur: Liber de intellectu; Liber de sensu; Liber de nichilo; Ars oppositorum; Liber de generatione; Liber de sapiente; Liber de duodecim numeris; Epistole complures. Insuper mathematicum opus quadripartitum: De numeris perfectis; De mathematicis rosis; De geometricis corporibus; De geometricis supplementis. Paris: Henri Estienne.

de Budweys, Wenceslaus Faber. 1508. Opus sphericum Ioannis de Sacro Busto figuris et perutili commento illustratum. Cologne: Heinrich Quentell. http://hdl.handle.net/21.11103/ sphaera.100183.

de Lattes, Bonetus. 1493. Anuli per eum compositi super astrologiam utilitates. Rome: Per A. Fritag de Argentina.

de Sacrobosco, Johannes. 1472a. Spaera mondi. Ferrara. Gallus: Andreas Belfortis. http://hdl. handle.net/21.11103/sphaera.101122.

—. 1472b. Tractatum de spera. Venice: Florentius de Argentina. http://hdl.handle. net/21.11103/sphaera.100685.

—. 1488. Sphaera mundi. Venice: J. L. Santritter and H. de Sanctis. http://hdl.handle. net/21.11103/sphaera.100822.

- 1490. Spaerae mundi compendium foeliciter inchoat. Venice: Ottaviano Scotto. http://hdl. handle.net/21.11103/sphaera.100885.

—. 1531. Liber de sphaera. Wittenberg: Joseph Clug. http://hdl.handle.net/21.11103/ sphaera.100138.

- 1538. Libellus de sphaera. Wittenberg: Joseph Klug. http://hdl.handle.net/21.11103/ sphaera.101106.

Ficino, Marsilio. 1491. Opera omnia Platonis. Venice: Andrea Toresani de Asula.

- 1496. Commentaria in Platonem. Florence: Lorenzo di Alopa.

Fine, Oronce (ed.). 1515. Theoricarum novarum Textus Georgii Purbachii, cum expositione Capuani, Item de Prierio; Insuper Jacobi Fabri Stapulensis astronomicon: Omnia nuper summa diligentia emendata cum figuris ac commodatisssimis longe castigatius insculptis quam prius suis in locis adiectis. Paris: Jean Petit.

- 1532. De mundi sphaera, sive Cosmographia, part 3 of Protomathesis. Paris: Morhii. http://hdl.handle.net/21.11103/sphaera.101190.

Lefèvre d'Étaples, Jacques. 1492. Totius Aristotelis philosophiae naturalis paraphrases. Paris: Johann Higman.

1495. Textus de sphera Johannis de Sacrobosco, cum additione (quantum necessarium est) adiecta: novo commentario nuper edito ad utilitatem studentium philosophice parisiensis academie: illustratus. Paris: Wolfgang Hopyl. http://hdl.handle.net/21.11103/sphaera.101126.

. 1496. Arithmetica elementa; Musica elementa; Epitome in libros arithmeticos divi Severini Boetii; Rithmimachie ludus que et pugna numerorum appellatur. Paris: Johannes Higman and Wolfgang Hopyl.

— (ed. and comm.). 1506. Contenta. Politicorum libro octo. Commentarii. Economicorum duo. Commentarii. Hecatonomiarum septem. Economiarum publ. unus. Explanationis Leonardi in Oeconomica duo [trans. Leonardo Bruni]. Paris: Henri Estienne.

- 1516. Textus de Sphaera Ioannis de Sacrobosco...Introductoria additione...illustratus. Paris: Henri Estienne. http://hdl.handle.net/21.11103/sphaera.100990.

- (ed.). 1517. Euclidis Megarensis mathematici clarissimi Elementorum geometricorum libri xv, Campani Galli transalpini in eosdem commentariorum libri xv, Theonis Alexandrini Bartholamaeo Zamberto Veneto interprete, in tredecim priores, commentariorum libri xiii, Hypsiclis Alexandrini in duos posteriores, eodem Bartholomaeo Zamberto Veneto interprete, commentariorum libri ii. Paris: Henri Estienne. 
1538. Textus de Sphaera Ioannis de Sacrobosco...Introductoria additione...illustratus. Cum compositione Annuli astronomici Boneti Latensis et geometria Euclidis Megarensis (a latinum a Boetio translata). Paris: Simon de Colines. http://hdl.handle.net/21.11103/ sphaera.101011.

Lefèvre d'Étaples, Jacques and Josse Clichtove, comm. 1517. Introductorium astronomicum theorias corporum coelestium duobus libris complectens, adiecto commentario declaratum. Paris: Henri Estienne.

Lefèvre d'Étaples, Jacques, Josse Clichtove, and Charles Bovelles. 1503. Epitome compendiosaque introductio in libros arithmeticos divi Severini Boetii, adiecto familiari [Clichtovei] commentario dilucidata. Praxis numerandi certis quibusdam regulis (auctore Clichtoveo). Introductio in geometriam Caroli Bovilli. Astronomicon Stapulensis. Paris: Wolfgang Hopyl and Henri Esienne.

Maestlin, Michael. 1597. Epitome astronomiae: qua brevi explicatione omnia, tam ad sphaericam quàm theoricam eius partem pertinentia, ex ipsius scientiae fontibus deducta. Tübingen: Gruppenbachius.

Quiccheberg. 1565 [2013]. The first treatise on museums: Samuel Quiccheberg's Inscriptiones, 1565. Trans. Mark A. Meadow, and B. Robertson. Los Angeles: Getty Publications.

Ringmann, Matthias. 1507. Cosmographiae introductio cum quisbusdam geometriae ac astronomiae principiis ad eam rem necessariis insuper quatuor Americi Vespucii navigationes universalis Chosmographiae descriptio. St. Dié: Vautrin Lud, Nicolas Lud.

-1509. Grammatica figurata. Strassburg: Gauthier Lud and the Author.

\section{Secondary Literature}

Allen, Michael J.B. 1994. Nuptial arithmetic: Marsilio Ficino's commentary on the fatal number in book VIII of Plato's Republic. Berkeley: University of California Press.

- 1999. Ficino, daemonic mathematics, and the spirit. In Natural particulars: Nature and the disciplines in Renaissance Europe, ed. Anthony Grafton and Nancy G. Siraisi, 121-137. Cambridge, MA: MIT Press.

Armstrong Tyler, Elizabeth. 1952. Jacques Lefèvre d'Etaples and Henri Estienne the Elder, 15021520. In The French mind: Studies in honour of Gustave Rudler, ed. W. Grayburn Moore, 17-33. Oxford: Sutherland and Starkis.

Axworthy, Angela. 2016. Le Mathématicien renaissant et son savoir. Le statut des mathématiques selon Oronce Fine. Paris: Classiques Garnier.

- 2017. La notion géométrique de flux du point à la Renaissance et dans le commentaire des Éléments de Jacques Peletier du Mans. In Miroir de l'amitié. Mélanges offerts à Joël Biard à l'occasion de ses 65 ans, ed. Christophe Grellard, 17-33. Paris: Vrin.

- 2018. The debate between Peletier and Clavius on superposition. Historia Mathematica 45: 1-38.

Baldasso, Renzo. 2007. Illustrating the Book of Nature in the Renaissance: Drawing, painting, and printing geometric diagrams and scientific figures. Ph.D. diss., Columbia University.

Barker, Peter. 2011. The reality of Peurbach's orbs: Cosmological continuity in fifteenth and sixteenth century astronomy. In Change and continuity in early modern cosmology, ed. Patrick J. Boner, 7-32. Berlin/New York: Springer.

Bedouelle, Guy. 1976. Lefèvre d'Étaples at l'intelligence des Écritures. Geneva: Droz.

Besse, Jean-Marc. 2009. Cosmography and geography in the sixteenth century, the position of Oronce Fine between mathematics and history. In The worlds of Oronce Fine. Mathematics, instruments and print in Renaissance France, ed. Alexander Marr, 100-113. Donington: Shaun Tyas.

Bietenholz, Peter G. 1971. Basle and France in the sixteenth century. Geneva: Droz.

Bredekamp, Horst. 1995. The lure of Antiquity and the cult of the machine. The Kunstkammer and the evolution of nature, art and technology. Trans. A. Brown. Princeton: Markus Wiener.

Buisseret, D. 2003. The mapmaker's quest: Depicting new worlds in Renaissance Europe. Oxford: Oxford University Press. 
Cassirer, Ernst. 1927. Individuum und Kosmos in der Philosophie der Renaissance. Leipzig/ Berlin: Springer.

Chabás, José, and Bernard R. Goldstein. 2014. Essays on medieval computational astronomy. Leiden: Brill.

Clark, Stuart. 2007. Vanities of the eye: Vision in early modern European culture. New York: Oxford University Press.

Connors, Joseph. 1990. Ars Tornandi: Baroque architecture and the lathe. Journal of the Warburg and Courtauld Institutes 53: 217-236.

Crowther, Kathleen M., and Peter Barker. 2013. Training the intelligent eye: Understanding illustrations in early modern astronomy texts. Isis 104 (3): 429-470.

Dalché, Patrick Gautier. 2009. La géographie de Ptolémée en Occident (IVe-XVIe siècle). Turnhout: Brepols.

Dupré, Sven, and Michael Korey. 2009. Inside the Kunstkammer: The circulation of optical knowledge and instruments at the Dresden court. Studies in History and Philosophy of Science 40: 405-520.

Faye, Emmanuel. 1998. Philosophie et perfection de l'homme: De la Renaissance à Descartes. Paris: Vrin.

Fenlon, Iain, and Inga Mai Groote. 2013. Heinrich Glarean's books. In Heinrich Glarean's books: The intellectual world of a sixteenth-century musical humanist, ed. Iain Fenlon and Inga Mai Groote, 303-383. Cambridge: Cambridge University Press.

Gal, Ofer, and Raz Chen-Morris. 2013. Baroque science. Chicago: University of Chicago Press.

Gingerich, Owen. 1988. Sacrobosco as a textbook. Journal for the History of Astronomy 19: 269-273.

- 1999. Sacrobosco illustrated. In Between demonstration and imagination: Essays in the history of science and philosophy presented to John D. North, ed. Lodi Nauta and Arie Johan Vanderjagt, 211-224. Leiden: Brill.

Hamel, Jürgen. 2004. Johannes Sacrobosco: Handbuch der Astronomie, Kommentierte Bibliographie der Drucke der Sphaera 1472 bis 1656. In Wege der Erkenntnis: Festschrift für Dieter B. Herrmann zum 65. Geburtstag, ed. Dietmar Fürst, Dieter B. Herrmann, and Eckehard Rothenberg, 115-170. Frankfurt am Main: Harri Deutsch Verlag. 2006. Johannes de Sacroboscos Sphaera. Gutenberg-Jahrbuch 81: 113-136.

2014. Studien zur Sphaera des Johannes de Sacrobosco. Leipzig: Akademische Verlagsanstalt.

Hankins, James. 2003. Ptolemy's geography in the Renaissance. In Humanism and Platonism in the Italian Renaissance, 2 vols., 1, 457-468. Rome: Edizioni di storia e letteratura.

Heawood, Edward. 1905. Glareanus: His geography and maps. The Geographical Journal 25 (6): 647-654.

Johnson, Francis R. 1953. Astronomical textbooks in the sixteenth century. In Science, medicine, and history: Essays on the evolution of scientific thought and medical practice written in honour of Charles Singer, ed. E. Ashworth Underwood, vol. 1, 285-302. Oxford: Oxford University Press.

Johnson, Christine R. 2006. Renaissance German cosmographers and the naming of America. Past \& Present 191 (1): 3-43.

2013. Between the human and the divine: Glarean's De Geographia and the span of Renaissance geography. In Heinrich Glarean's books: The intellectual world of a sixteenthcentury musical humanist, ed. Iain Fenlon and Inga Mai Groote, 139-158. Cambridge: Cambridge University Press.

Klinger-Dollé, Anne-Hélène. 2016. Le De sensu de Charles de Bovelles (1511): conception philosophique des sens et figuration de la pensée. Geneva: Droz.

Korey, Michael. 2007. The geometry of power: Mathematical instruments and princely mechanics around 1600. Berlin: Deutscher Kunstverlag.

Kremer, Richard L., and Matthieu Husson. 2012. Introduction: Astronomical tables in late Medieval Europe. Journal for the History of Astronomy 43: 267-268.

Laubenberger, Franz. 1982. The naming of America. Trans. Steven Rowan. The Sixteenth Century Journal 13 (4):91-113.

Lefèvre, Wolfgang, ed. 2004. Picturing machines 1400-1700. Boston: MIT Press. 
Leitão, Henrique. 2009. Pedro Nunes against Oronce Fine: Content and context of a refutation. In The worlds of Oronce Fine. Mathematics, instruments and print in Renaissance France, ed. Alexander Marr, 156-171. Donington: Shaun Tyas.

Mandosio, Jean-Marc. 2013. Le De magia naturali de Jacques Lefèvre d'Étaples: Magie, alchimie et cabale. In Les Muses secrètes: kabbale, alchimie et littérature à la Renaissance, ed. Rosanna Camos Gorris, 37-79. Geneva: Droz.

— I. L'Influence des astres. Paris: Les Belles Lettres.

Margolin, Jean-Claude. 1972. Mathias Ringmann's Grammatica Figurata, or, grammar as a card game. Yale French Studies 47: 33-46.

Massaut, Jean-Pierre. 1968. Josse Clichtove, l'humanisme et la réforme du clergé, 2 vols. Paris: Société d'Edition "Les Belles Lettres."

Maurice, Klaus. 1985. Der drechselnde Souverän: Materialien zu einer fürstlichen Maschinenkunst. Zürich: Ineichen.

- 2004. The princely art of turning: On the aesthetic significance of the natural sciences and technology. In Turned treasuries, ed. George Laue, 17-24. Munich.

Monfasani, John. 1976. George of Trebizond: A biography and a study of his rhetoric and logic. Leiden: Brill.

Mosley, Adam. 2006a. Objects of knowledge: Mathematics and models in sixteenth-century cosmology and astronomy. In Transmitting knowledge: Words, images, and instruments in early modern Europe, ed. Sachiko Kusukawa and Ian Maclean, 193-216. Oxford: Oxford University Press.

- 2006b. Spheres and texts on spheres: The book-instrument relationship and an armillary sphere in the Whipple Museum of the History of Science. In The Whipple Museum of the history of science: Instruments and interpretations, ed. Liba Taub and Frances Willmoth, 301-318. Cambridge: Whipple Museum of the History of Science.

- 2009. The cosmographer's role in the sixteenth century: A preliminary study. Archives Internationales d'Histoire des Sciences 59 (2): 423-439.

Oosterhoff, Richard J. 2014. The fabrist origins of Erasmian science: Mathematical erudition in Erasmus' Basle. Journal of Interdisciplinary History of Ideas 3 (6): 3-37.

. 2015. A Book, a Pen, and the Sphere: Reading Sacrobosco in the Renaissance. History of Universities 28 (2): 1-54.

- 2016. Lovers in paratexts: Oronce Fine's republic of mathematics. Nuncius 31 (3): $549-583$.

-2018. Making mathematical culture: University and print in the circle of Lefèvre d'Étaples. Oxford: Oxford University Press.

- 2019a. Jacques Lefèvre d'Étaples and Charles de Bovelles on platonism, theurgy, and intellectual difficulty. In Plotinus' legacy: The transformation of Platonism from the Renaissance to the Modern Era, ed. Stephen Gersh, 73-95. Cambridge: Cambridge University Press.

. 2019b. Apprenticeship in the Renaissance university: Student authorship and craft knowledge. Science in Context 32 (2): 119-136.

- 2020. Visualising observation: Data management in astronomy before Galileo. In Coping with Copia: Epistemological excess in early modern Europe, ed. Fabian Krämer and Itay Sapir. Amsterdam: Amsterdam University Press.

Pantin, Isabelle. 2001. L'illustration des livres d'astronomie à la renaissance: l'évolution d'une discipline à travers ses images. In Immagini per conoscere: Dal Rinascimento alla Rivoluzione scientifica, ed. Fabrizio Meroi and Claudio Pogliano, 3-42. Firenze: Leo S. Olschki.

—.2009a. Altior incubuit animus sub imagine mundi. L'inspiration du cosmographe d'après un gravure d'Oronce Finé. In Les méditations cosmographiques à la Renaissance, 69-90. Paris: Presses de l'Université Paris-Sorbonne.

2009b. Oronce Fine's role as royal lecturer. In The worlds of Oronce Fine. Mathematics, instruments and print in Renaissance France, ed. Alexander Marr, 13-30. Donington: Shaun Tyas.

. 2012. The first phases of the Theoricae planetarum printed tradition (1474-1535): The evolution of a genre observed through its images. Journal for the History of Astronomy 43: $3-26$. 
Popplow, Marcus. 2007. Setting the world machine in motion: The meaning of Machina Mundi in the Middle Ages and the early modern period. In Mechanics and cosmology in the Medieval and early modern period, ed. Massimo Bucciantini, Michele Camerota, and Sophie Roux, 45-70. Florence: Leo S. Olschki.

Reedijk, Cornelis. 1989. The story of a fallacy: Erasmus's share in the first printed edition in Greek of Ptolemy's geography (Basel, 1533). In Theatrum orbis librorum: Liber amicorum presented to Nico Israel on the occasion of his seventieth birthday, ed. A.R.A. Croiset van Uchelen, K. van der Horst, and G. Schilder, 250-276. Utrecht: HES Publishers.

Rice, Eugene F. 1972. The prefatory epistles of Jacques Lefèvre d'Étaples and related texts. New York: Columbia University Press.

Schmidt, Charles. 1879. Histoire littéraire de l'Alsace à la fin du XVe et au commencement du XVIe siècle. Vol. 2. Paris: Sandoz et Fischbacher.

Shank, Michael H. 2002. Regiomontanus on Ptolemy, physical orbs, and astronomical fictionalism: Goldsteinian themes in the "defense of Theon against George of Trebizond". Perspectives on Science 10 (2): 179-207.

- 2007a. Regiomontanus as a physical astronomer: Samplings from the defence of Theon against George of Trebizond. Journal for the History of Astronomy 38: 325-349.

2007b. Mechanical thinking in European astronomy (13th-15th centuries). In Mechanics and cosmology in the Medieval and early modern period, ed. Massimo Bucciantini, Michele Camerota, and Sophie Roux, 3-27. Florence: Leo S. Olschki.

- 2009. Setting up Copernicus? Astronomy and natural philosophy in Giambattista Capuano da Manfredonia's Expositio on the Sphere. Early Science and Medicine 14: 290-315.

Tessicini, Dario. 2011. Definitions of "cosmography" and "geography" in the wake of fifteenthand sixteenth-century translations and editions of Ptolemy's geography. In Ptolemy's geography in the Renaissance, ed. Zur Shalev and Charles Burnett, 31-49. London: Warburg Institute.

Thorndike, Lynn, ed. 1949. The sphere of Sacrobosco and its commentators. Chicago: University of Chicago Press.

Valleriani, Matteo. 2017. The tracts on the Sphere: Knowledge restructured over a network. In The structures of practical knowledge, ed. Matteo Valleriani, 421-473. Dordrecht: Springer.

Veyrin-Forrer, Jeanne. 1995. Simon de Colines, imprimeur de Lefèvre d'Etaples. In Jacques Lefèvre d'Etaples (1450?-1536), ed. Jean-François Pernot, 97-117. Paris: Honoré Champion Éditeur.

Wallace, William A. 1981. Prelude to Galileo: Essays on Medieval and sixteenth-century sources of Galileo's thought. Dordrecht: Reidel.

Weiss, Benjamin. 2011. The geography in print: 1475-1530. In Ptolemy's geography in the Renaissance, ed. Zur Shalev and Charles Burnett, 91-120. London: Warburg Institute.

Westman, Robert S. 2011. The Copernican question: Prognostication, skepticism, and celestial order. Berkeley: University of California Press.

Open Access This chapter is licensed under the terms of the Creative Commons Attribution 4.0 International License (http://creativecommons.org/licenses/by/4.0/), which permits use, sharing, adaptation, distribution and reproduction in any medium or format, as long as you give appropriate credit to the original author(s) and the source, provide a link to the Creative Commons license and indicate if changes were made.

The images or other third party material in this chapter are included in the chapter's Creative Commons license, unless indicated otherwise in a credit line to the material. If material is not included in the chapter's Creative Commons license and your intended use is not permitted by statutory regulation or exceeds the permitted use, you will need to obtain permission directly from the copyright holder. 


\title{
Chapter 3 \\ Pedro Sánchez Ciruelo. A Commentary \\ on Sacrobosco's Tractatus de sphaera with a Defense of Astrology
}

\author{
Tayra M. C. Lanuza Navarro
}

\begin{abstract}
This paper focuses on the figure of the Spanish scholar Pedro Sánchez Ciruelo (ca. 1470-1548), who published a commentary on Johannes de Sacrobosco's Sphaera in 1498. The aim of this study is to analyze the defense of astrology that Ciruelo prepared for the preface of his commentary in order to show that this praise of astrology represents a significant part of the scholar's intellectual interests, which remained constant throughout his career. It is possible to get a richer understanding of Ciruelo's defenses of astrology in several of his works by placing them in their own specific context: the first one in the context of the prohibition of Simon de Phares's activities in Paris in 1494, and the second one in Europe in the first decades of the sixteenth century, during which those interested in astrology were mainly concerned with Pico della Mirandola's Disputationes and its consequences for the discipline.
\end{abstract}

\section{Introduction ${ }^{1}$}

The Spanish scholar Pedro Sánchez Ciruelo (ca. 1470-1548) published his commentary on Johannes de Sacrobosco's (died ca. 1256) Tractatus de sphaera, Uberrimum Sphere mundi commentum, in 1498 (Ciruelo 1498). At that time, he was in Paris, teaching mathematics and studying theology at the University of Paris. Ciruelo had arrived in Paris in 1492, after having spent 10 years at the University of Salamanca. There he was trained at the faculty of arts in the quadrivium, particularly in astrology, as well as in moral and natural philosophy and metaphysics, while teaching disciplines of the trivium simultaneously.

\footnotetext{
${ }^{1}$ The research for this article was funded by the 2016-1017 Fellowship Programme of the Herzog August Bibliothek (Wolfenbüttel) and by the Mellon Fellowship (2014-2015) at Villa I Tatti, The Harvard University Center for Italian Renaissance Studies.

T. M. C. Lanuza Navarro $(\bowtie)$

Instituto de Historia de la Medicina y de la Ciencia "López Piñero.” Universitat de València,

Valencia, Spain

e-mail: tayra.lanuza@uv.es
} 
Many aspects of Ciruelo's commentary on the Sphaera are of interest. First, his insertion of the fourteen Questions on the Sphere of Pierre d'Ailly (1351-1420) to complement his own comments and his additions to some of the subjects treated in the text, such as the definitions of the sphere, the number of celestial spheres, or the rise and setting of the signs. Also, the dialogue at the end of the work, where he discussed the role of authorities in a discipline, and his decisions when writing the commentary. And his defense of the certainty of mathematics, and of astrology within the mathematical sciences.

In this paper, I am going to focus particularly on this last aspect, Ciruelo's defense of astrology in the preface of his commentary on Sacrobosco. However, I will also refer to his inclusion of Pierre d'Ailly's Questions, to some of the issues he discussed in the comments in addition to what was originally in the Tractatus de sphaera, and to some of his explanations in the dialogue, which are related to his interest in astrology. One of the objectives of this paper is to show that Ciruelo defended this discipline from the beginning of his career, while in Paris. Another aim is showing that the preface of the Sphaera is not an isolated piece. The text of the preface in praise of astrology represents a significant part of this scholar's intellectual interests, which remained constant throughout his career. The arguments he introduced in the Sphaera are present in several of his later works. In 1521, Ciruelo published a complete treatise titled Apotelesmata astrologiae Christianae, in which he reflected on his previous assertions and extended his arguments in defense of astrology (Ciruelo 1521).

Despite several historians' emphasis on Ciruelo's relevance as a scholar, the studies considering his figure and works have passed over his astrological ideasmentioning this part of his intellectual endeavors as an afterthought, if not completely dismissing or ignoring it (Albares 1996; Ayala 1993; Rodríguez Vidal 1981; Lorente Pérez 1921; Flórez et al. 1989, 1990). ${ }^{2}$ Theology and becoming a respected theologian were the main focuses of his career. ${ }^{3}$ However, astrology and the mathematical sciences in general were indeed some of Ciruelo's scholarly interests.

This paper concentrates on his astrological interests for two reasons. On the one hand, ignoring the influence that the mathematical sciences and astrology had on his career-as is the trend to date-misrepresents his intellectual ventures. On the other hand, I argue, his theological interests were not separated from his astrological ideas. His aim of establishing a clear definition of what constituted a Christian astrology and of differentiating it from non-orthodox practices and superstition, following the Thomistic tradition, was strongly linked to his theological ideals. Both aspects need to be taken into account to understand Ciruelo's writings, and specifically the preface to Sacrobosco as he wrote it in the Paris edition of 1498.

\footnotetext{
${ }^{2} \mathrm{An}$ exception to the attitude of passing over Ciruelo's astrological ideas is Lou Ann Homza's study, which is focused on Ciruelo's religious attitudes and theological works, and therefore does not delve into his astrological interests. See (Homza 1992, 2000).

${ }^{3}$ (Ciruelo 1521, f. A2r): "divinam theologorum facultatem..., ad quam totis praecordiis aspirabat."
} 


\section{Social and Intellectual Background}

Pedro Sánchez Ciruelo was born in the town of Daroca, in the kingdom of Aragon, between 1460 and 1470. Daroca was not a small village in a remote area, as it has been represented in previous studies related to this scholar. It was a city of political, military, and administrative significance for the kingdom, albeit one of small size (Rodrigo Esteban 1999, 11). Daroca was one of the ten biggest towns in Aragon, which ruled a community of villages around it, and by 1495 the census listed 482 fuegos, or ca. 2.410 inhabitants (Serrano Montalvo 1995-1997). It had a weekly market and three prosperous annual trade fairs (Rodrigo Esteban 1999, 14, 27; Mateos Royo 1997). It had a collegial cathedral and an arts study particularly relevant to Ciruelo's career.

Both his family and the Darocense Study of Arts played a significant role in Ciruelo's later ambitions. In the biographical information he provided in the prologue to the astrological work Apotelesmata, Ciruelo stated that he was an early orphan, and that he was poor and alone in the world. ${ }^{4}$ This was hardly the case, not only because a good number of relatives were alive and living in the city of Daroca or the neighboring town of Molina during the 1460s and 1470s (Homza 1992, 24), but also because of the cost of education. ${ }^{5}$ Each student had to pay an annual tax to be admitted to the Study (which was twenty-eight sueldos in 1525), and although students from Daroca were exempt from paying the five sueldos due to the director, and probably also from paying the monthly payment of thirteen more for food and lodging if they did not use it, Ciruelo would hardly have been able to go through the years of schooling without family help or patronage. ${ }^{6}$

Daroca's Studium Artibus had been assigned a master to teach "Arts, Logic, and Nature" from 1381 on, as well as a teacher of theology from the local Franciscan convent (Rodrigo Esteban 2004, 144). Even if it was referred to as Estudio General in the royal approval of 1381, it is difficult to know to what extent education there went beyond that of a regular grammar school. It was, in any case, the place where the members of the city oligarchy received their education. Sons of merchants and liberal professionals made up most of the student body, but members of more modest social groups were not unheard of. Ciruelo's family does not seem to have been wealthy, as the professions mentioned in the Inquisitorial files are the likes of

\footnotetext{
${ }^{4}$ (Ciruelo 1521, f. A2r): "mihi humili solo nato, omni etiam humano auxilio parentum et patriae destituto."

${ }^{5}$ Even if Ciruelo's paternal grandparents (Francisco Sánchez Ciruelo and his wife) and his parents (Hernán Ciruelo and his wife) had died when he was a child, he could count with his two paternal uncles (Bartolomé and Alonso Ciruelo) and also an aunt (Francisca) to take him in, as well as his brothers Bartolomé and Jorge, and maybe a sister. He had also, or would later have, several cousins and nephews.

${ }^{6}$ On the cost of education in Daroca, see (Mateos Royo 2002).
} 
shoe-maker (his uncle Bartolomé) and "meat cutter" (his cousin Francisco). ${ }^{7}$ So, it would seem he was not really alone in the world, but was probably more or less poor. It is true, however, that he was not the only member of the family to attend university. Whether his studies and those of his brother Bartolomé, who ended up as "maestre" in Alcalá, were paid by his relatives, by the ecclesiastical authorities, or by the city council, which had an effective influence over the Arts Study, is unknown.

Ciruelo's preface to the Apotelesmata was of course an exercise in self-promotion, in self-fashioning, as were many dedicatory letters, introductions, prefaces, and prologues in the period. ${ }^{8} \mathrm{He}$ was creating an image of himself in a piece addressed to the professors of his alma mater, the University of Salamanca. In that image, he presented himself as a successful mathematician and theologian who had overcome hard beginnings for the sake of knowledge. ${ }^{9} \mathrm{He}$ also made a point of explaining that he had funded his university studies by teaching a discipline while studying another one: he used his knowledge of the trivium to teach dialectics in Salamanca while he took the courses to become a Master of Arts, and then used his knowledge of mathematics and astrology to teach in Paris while he studied theology.

In promoting himself as a self-made scholar, as an expert in orthodox doctrine, and as the right person to consult when it came to deciding about astrological practices, Ciruelo was also avoiding mentioning his relatives, maybe because of their converso origins. ${ }^{10}$ He was a descendent of Jews and of judaizers, according to the Inquisitorial files. His grandfather, Francisco Sánchez Ciruelo, had been condemned by the Inquisition for apostasy. His uncle Bartolomé was a confeso, that is, he was a Catholic who had confessed reverting to Jewish practices or beliefs. ${ }^{11}$ The sons of Bartolomé, Ciruelo's four cousins Benito, Cristóbal, Francisco and Pero, had been forbidden to work in public positions for this reason, making it clear that the family had Jewish ancestors. In 1553, after Ciruelo's death, the Inquisition prosecuted his cousin Benito for heretical blasphemy, and also his nephew Juan Ciruelo, son of his cousin Cristóbal (via his other uncle Alonso), for insulting the labor of the Inquisitors. ${ }^{12}$

\footnotetext{
${ }^{7}$ The genealogy of the family has been preserved because of the trials of the Inquisition of his nephew Juan and his cousin Benito in 1553, both of whom mentioned Ciruelo during the lawsuit. Albares presented Ciruelo's family as wealthy, but the Inquisitorial files do not seem to support such an assessment (Albares 1996, 181).

${ }^{8}$ For recent considerations of self-fashioning in the Early Modern University, see the articles in (Kirwan 2016).

${ }^{9}$ The whole sentence was written to present his 'avid search' for knowledge and early struggles: "ut litteras a me quasi fugientes toto pene orbe avidissime persequerer, mihi humili solo nato, omni etiam humano auxilio parentum et patriae destituto foret nimium difficile" (Ciruelo 1521, f. A2r).

10 "He seems to have tried deliberately to mislead his audience about his family," as put by Lou Ann Homza (1992, 24).

${ }^{11}$ The files of the trials of the grandfather, Francisco Sánchez Ciruelo, and of his wife, whose name does not appear but is also mentioned as a judaizer, as well as the file of the trial of Bartolomé Ciruelo, confeso, have not been found to date.

${ }^{12}$ The files are at the Archivo Diocesano de Cuenca, Inquisición, leg. 193, exp. 2175 and 2181. The records of these two trials were summarily described by (Homza 1992, 24-27).
} 
There is no way to know if this family history was one of the motivations behind Ciruelo's insistence in Catholic orthodoxy, or his determination to become a respected theologian and to obtain ecclesiastical positions, which was not unusual among members of converso families (Homza 1992, 101-02). What is certain, however, is that he kept ties with his family and with Daroca throughout most of his life.

After his years in Paris, he returned to Daroca on several occasions to stay for months or years. The significance of the Darocense Study of Arts for him is attested to by his acceptance of the study's director position, as well as the way he managed to coordinate this position with his chair at the University of Alcalá for nearly 20 years.

The first time he accepted the position seems to have been at the end of 1499, when he was still supposed to be in Paris, but after only a few months he renounced and left Daroca (Rodrigo Esteban 2004, 146). He might have gone back to Paris, as it is unknown where he was up until his appointment as professor of philosophy at the College of San Antonio de Portaceli-which also made him canon at the cathedral of Sigüenza-from 1502 to 1505 (Lorente Pérez 1921, 276). Then the city council of Daroca, in agreement with the archbishop of Zaragoza, in whose power lay the appointment of the director of the Study of Arts, offered him the position again. Ciruelo accepted it, as well as the later offer to become the teacher of theology, which improved his salary. His presence as a teacher in Daroca is supposed to have caused the huge increase in the number of students in 1505, which spiked to 150 from around 30 in 1496 and 1499 (Mateos Royo 2002, 131).

He remained as maestro mayor of the Study for four academic courses, during which he worked to obtain from the city council funding to make reforms and improvements to the buildings of the school, and wrote new statutes for the institution (Rodrigo Esteban 2004; Mateos Royo 2002). After his appointment as professor of Thomistic theology at the University of Alcalá de Henares in 1510, he did not quit his teaching position in Daroca.

Ciruelo managed to remain linked to the Study of Arts of his hometown for many more years. He continued to teach at least part-time in Daroca between 1508 and 1516. By dividing his salary with two assistants and often asking the city council for permissions and leaves, he combined these positions with the chair in Alcalá, with the administration of the vicariate in one of the villages of Daroca (Cuencabuena), and with preaching occasionally in Zaragoza (Rodrigo Esteban 2004, 152). He was also involved in the church of Santo Domingo in Daroca, where his brother Bartolomé was the vicar, after they both had been racioneros (canons with right to portion) there for some years.

He definitely left his positions at the Study of Daroca, from which he had been mostly absent for some years already, in 1523, but his links with Daroca and the Study were never forgotten. He went back there in 1524 when his brother died, and in his own testament he donated to the city 400 sueldos for works and maintenance of the Study of Arts (Rodrigo Esteban 2004, 153). 


\section{University Training and Works}

Ciruelo's studies at the University of Salamanca, where he arrived around 1482, seem to have inclined him towards logic and the mathematical sciences, and initiated his interest in astrology. He found in Salamanca an intellectual environment with a concentration on astronomy and astrology, strongly influenced by the figure of Abraham Zacut (1452-ca. 1515) and his astronomical tables, even after Zacut left the city in 1485 (and the country in 1492, forced by the expulsion of the Jews). Zacut wrote two of his astrological works, the Tratado breve de las influencias del cielo (Brief treatise on the influences of heavens) and De los eclipses del sol y la luna (On the eclipses of the sun and the moon), in 1486, not long after leaving Salamanca. These were also well known among professors and students at Salamanca, as Zacut always stayed in contact with his colleagues, who were professors at the university. The first translator of Zacut's Great Composition, later known as the Almanach perpetuum, including the tables and the canons to use them, was Juan the Salaya (ca. 1450-ca. 1524). Salaya was teaching logic while Ciruelo studied at Salamanca, meaning he taught Ciruelo one of the disciplines on which he later focused. Before taking the chair of logic, which he obtained in 1469, Salaya had been the professor of astrology since 1464.

The professors of the chair of mathematics and astrology who taught in the last two decades of the century followed Zacut's and Salaya's path. Besides Salaya's lectures on logic, Ciruelo attended the lectures on astrology by one of them, Diego de Torres (ca. 1435-1496), who was the professor from 1482 to 1496 . He also met and admired the subsequent professor, Rodrigo Vasurto (ca. 1470-1507), who had the chair of astrology from 1496 to 1504, and who might have previously been the professor of natural philosophy. He wrote a work on the calendar, and also a Praxis pronosticandi in 1497 (Flórez et al. 1989, 233-38; Thorndike and Kibre 1963, 504). Diego de Torres wrote an astrological commentary, which remained manuscript, and he seems to have been one of the translators of Sacrobosco's Sphaera, writing a version in Spanish around 1484 (Flórez et al. 1988, 22, 1989, 66-75; Burgueño 2009, 8; Gómez Martínez 2006). ${ }^{13}$ Ciruelo's appreciation of Zacut's and Vasurto's knowledge is mentioned in several of his texts. In the prefatory letter of his 1521 work Apotelesmata, he referred to Zacut among those who had studied the sphere and created astronomical tables, praising the Almanach, which gave easy access to the information on the course, place, and aspects of the fixed stars and the planets. ${ }^{14}$

\footnotetext{
${ }^{13}$ The Spanish translation by Torres of the Sphaera is found in manuscript 3385 at the Biblioteca Nacional de Madrid, ff. 189r-199v, and the commentary as well. For other translations of Sacrobosco's Sphaera, see (Crowther et al. 2015). For translations into Spanish, and also into Portuguese (Chap. 7), and for the Latin version of André de Avelar and the genre of the Reportorios de los tiempos in Spain and Portugal, see (Chap. 10).

${ }^{14}$ (Ciruelo 1521, a2v): "Si eruditioni sphericae a nobis accepte Almanach cum perpetua tum et temporalia superaddant, quae omnes cursus, situs, aspectus, siderum sive fixorum sive errantium brevissime diurneque ostendunt sine ambagibus ac laboribus excessivis. Haec eum Zacutus vester Salmanticensis, Jonannes Nurembergensis et quidam alii recentiores divino quodam ingenio elaborata posteris reliquerunt."
} 
In the Dialogue at the end of the commentary to the Sphaera, he expressed his admiration for Vasurto, "an Alphonse of our own times."15

With this mathematical and astrological background, Ciruelo moved to Paris in 1492 with the aim of studying theology. The intellectual circle he joined there has been studied with an emphasis on those known as the Spanish calculatores, a group of mathematicians who later tried to integrate mathematical knowledge into physical science in Spanish universities. They were also students of theology in Paris. This group included Juan Martínez Silíceo (1477-1557) and Fernando de Encinas (died 1523), and later Gaspar Lax (1487-1560) and Fernán Pérez de Oliva (ca. 1494-1531). ${ }^{16}$

Ciruelo also found in Paris a scholarly milieu marked by Jacques Lefèvre d'Étaples's (ca. 1455-1536) vindication of mathematics in his fight against Scotism at the University of Paris, and by his influence on the studies of mathematics and on the printing of mathematical works (Pantin 2013, 23). ${ }^{17}$ Ciruelo was following Lefèvre d'Étaples's example when he printed his commentary to the Tractatus de sphaera only 3 years after the Parisian professor had published his own in 1495. Ciruelo seems to confirm that this was the case in his own words in the new version of the preface to the Sphaera of Sacrobosco that he prepared for publication in Alcalá de Henares in 1526 (Ciruelo 1526). It has been pointed out that Ciruelo seems to have shared some of the ideas expressed by Lefèvre concerning, for instance, the reality of the celestial orbs (in this case, an idea also held by Pierre d'Ailly) (Barker 2011, 15-16) (Chap. 6). The extent to which both shared mathematical notions and natural philosophical ideas on the heavens is a subject still waiting to be explored in depth.

During this period in Paris, Ciruelo published most of his mathematical works: an Arithmeticae practicae in 1495, the Arithmetica Speculativa in the same year, and the Geometria Speculativa by Thomas Bradwardine (ca. 1300-1349) (Ciruelo 1495a, b, c). In 1498, Ciruelo published the commentary on Sacrobosco, which was reprinted in Paris in 1508 and 1515, and in Alcalá in $1526 .{ }^{18}$ His interest in preparing materials for teaching the mathematical liberal arts did not end after he left Paris. His course on them (Cursus quattuor mathematicarum artium liberalium) was published in 1516, when he was back in Spain (Ciruelo 1516).

\footnotetext{
${ }^{15}$ (Ciruelo, 1498, n7r.): "Placeret utique si prius hec Rodericus noster Vasurtus rescivisset, qui ita profunde ut nosti mathematica hec callet ut alter nostris temporibus Alphonsus appareat, adde etiam quod nostri amantissimus est et nisi quod verum cognovisse consuluisset nichil."

${ }^{16}$ On the Spanish calculatores in Paris, see (Wallace 1969, 1981, 79-90; Rey Pastor 1926, 72-81; Villoslada 1938; Calderón 1991, 247-48; Navarro Brotons 2014, 26-28, 58-72). See also (Elie 1950-1951). On a few of Ciruelo's mathematical notions, see (Cajori 1928; Lorente Pérez 1921). On the interest of these Spaniards in logic, see also (Noreña 1975).

${ }^{17}$ On the mathematical context in Paris at the moment, and on Lefèvre's plans for mathematical reform, see (Chap. 2).

${ }^{18}$ Different editions are sometimes mentioned but it does not seem possible to find them. For the editions of the commentaries on Sacrobosco's Sphaera, see the database accessible through the website of the project The Sphere. Knowledge System Evolution and the Shared Scientific Identity of Europe (https://sphaera.mpiwg-berlin.mpg.de).
} 
Later in his life, after his ten years of theological studies in Paris, Ciruelo went back to Spain and in 1510 became professor of theology, in the chair called "of Saint Thomas," at the newly created University of Alcalá de Henares. There, while teaching Thomas Aquinas's (1225-1274) theology and philosophy, Ciruelo published most of his works on logic. These included an edition of Aristotle's (384-322 BCE) logic in 1519 and two commentaries on the Posteriora Analytica in 1528 and 1529 (Ciruelo 1519, 1528). While in Alcalá, he also published his major work on astrology, the above mentioned Apotelesmata, in 1521, as well as an Introductio astrologica in 1523.

Ciruelo would leave the university in 1533 to hold ecclesiastical positions, first in Segovia, and then in Salamanca, where he became the canon preacher of the cathedral. There are no data about him teaching at the university there; however, he certainly continued publishing. This period was focused on religious texts, with sermons, reflections on theological mysticism, and translations of the Bible (Flórez et al. 1990, 18-19; Homza 1992, 175-208). ${ }^{19}$ It was in 1537, while living in Salamanca, that he also published what has been labeled his most mature work on logic, his Summule Petri Hispani (Muñoz Delgado 1967, 197).

The Cursus mathematicarum of 1516 included Bradwardine's Arithmetic and Geometry with some comments extracted from Jordanus Nemorarius (active ca. 1222) and Campanus of Novara (ca. 1220-1296) (Lorente Pérez 1921, 314), as well as John Peckham's (ca. 1230-1292) and Alhacen's (Ibn-al-Haytam, ca. 965ca.1040) Perspective, and the music of Lefèvre d'Étaples, with Boethius's (active ca. 525) theory. ${ }^{20}$ In the prologue of this Cursus, which he dedicated to the rector and scholars of the University of Alcalá de Henares, Ciruelo explained that his intention was to serve the university by providing it with an introduction to the four mathematical doctrines mentioned. To these he seemed to intend to add a fifth piece, an astrological introduction. He referred to this work as already written, explaining that it was a small work on the Sphaera based on Ptolemy's (ca. 100-ca. 160) Almagest, on Zacut's Almanach, "and on our own judicial Quadripartitum and Centiloquium." ${ }^{21}$ Ciruelo's "own Quadripartitum and Centiloquium" are the components of the Apotelesmata Astrologiae Christianae, which he printed in 1521. This seems to suggest that the work, or a shorter earlier version of it for students, was already written in 1516. It could also mean that the 1523 Introductio astrologica listed among his works — of which no copies are left—was this fifth part of the mathematical course, and that it could have been a summary of the Apotelesmata. ${ }^{22}$

\footnotetext{
${ }^{19}$ On Ciruelo's translations, see also (Valle 1999).

${ }^{20}$ On how the Cursus was based on Lefèvre d'Étaples's works, see (Oosterhoff 2018, 108-11).

${ }^{21}$ (Ciruelo 1516, a3r.): "Quinta quoque erit introductio astrologica, quam in sphericum opusculum olim condideram correspondentem Almagesto Claudii Ptholomei clarissimi, et Almanach perpetuum Zacuti Salmanticensis, cum nostro judiciario Quadripartito ac Centilegio."

${ }^{22}$ The work was recorded by (Picatoste Rodríguez 1891, 46-52; Latassa Ortiz 1798, 182-91). See the catalogues of Ciruelo's works in (Navarro Brotons et al. 1999, 94-96; Wilkinson 2010, 128-30).
} 
If this was his intention - to create a fifth book with the basics of astronomy and astrology-it would explain why he did not include such knowledge in the Cursus. ${ }^{23}$

The kind of defense of astrology which Ciruelo decided to include in his commentary on Sacrobosco's Sphaera is different from that of the Apotelesmata. This, I argue, is due to the context in which he wrote each text, not in the sense implied by Thorndike, who asserted that the prohibitions of judicial astrology by the Paris faculty would have prevented him from openly standing in defense of the discipline in 1498 (Thorndike 1941, 275-79), but precisely the opposite. It gave him a reason to place his arguments for astrology in the Sphaera, and these arguments were later the base for the expanded defense constituted by the Apotelesmata. Before discussing this issue, I will describe the actual contents of the preface to the Sphaera, and their relationship to the other elements of the commentary mentioned above.

\section{The Commentary on Sacrobosco's Tractatus de sphaera, the Preface, and It's Context}

Ciruelo's edition of Sacrobosco was composed of three parts. It started with the preface containing the defense of astrology, and it ended with a dialogue discussing what would be a crucial theme in sixteenth century works on natural philosophy: the authority of ancient and highly-esteemed medieval scholars versus new ideas and information.

The central part of the work is composed, as expected, by Sacrobosco's text and Ciruelo's glosses. This is where Ciruelo inserted the fourteen Questions on the Sphere of Pierre d'Ailly. The text of the Questions is placed after Ciruelo's own comments to Sacrobosco. Thus he could introduce issues which were not found originally in the Sphaera, or add later opinions on a subject. Many of them were issues which had been regularly discussed by natural philosophers between the thirteenth and the fifteenth centuries, such as the existence of void, the movement of the primum mobile, the physical existence of the planetary spheres, the necessity of epicycles and eccentrics, the habitability of all zones of Earth, etc. (Grant 1996). Concerning this last issue, Ciruelo introduced in the commentary news on the travels of Columbus, pointing out that the experience of Spanish and Portuguese sailors had shown that there were territories near the equinox which were inhabited. ${ }^{24}$ From the first trip "they brought back with them men of that region," he explained. Ciruelo's description here of the inhabitants of those tropical regions, men who were "not tall but... agreeable... smiling...friendly.... with a dark color" (ceruleo colore) might

\footnotetext{
${ }^{23}$ On the teaching of mathematics in Spanish universities during the sixteenth century, see (Navarro Brotons 1995, 1998, 2006).

${ }^{24}$ (Ciruelo 1498, h2r-h2v): "Cum enim anno Christi domini 1491 illustrissimus hyspaniarum rex Fernandus expertissimos nautas versus occidentem equinoctialem ad insulae quererendas miserit; tandem post quattuor fere menses idem nautae reversi insulas multas sub equinoctiali vel prope dicunt se reperisse. In cuius rei testimonium multa genera avium exquisitissima multasque species aromaticas preciosissimas aurumque et homines illius regionis secum advexerunt."
} 
Fig. 3.1 Illustration of a black man. The printer, Guy Marchand, had previously used this image in the widespread almanac Calendrier des bergers and other works, so its association with the contents of Ciruelo's Sphera is not clear. From (Ciruelo 1498). Biblioteca de Catalunya, Barcelona

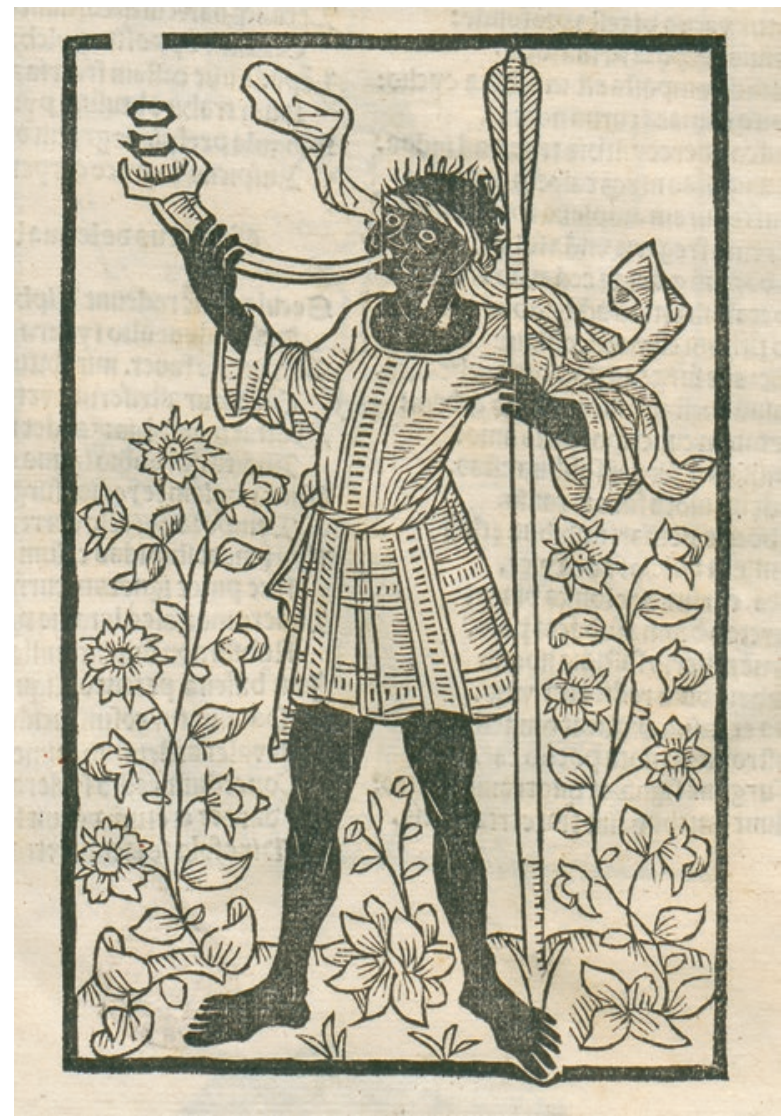

have been the inspiration for the inclusion of the illustration of a black man, placed at the beginning of the work, before his preface (Fig. 3.1). ${ }^{25}$ The decision must have been taken at the printer's workshop. Guy Marchand, who was printing it on behalf of Jean Petit, had previously used the same image in his printed version of the Calendrier des bergers in 1493, and in his edition of Savonarola (1452-1498)'s Revelatio de tribulationibus of $1496 .{ }^{26}$ Whether Marchand decided to reuse the image because he associated Ciruelo's work with the astrological contents of the Calendrier des bergers, or as a call for repentance-as the image seems to be interpreted in Savonarola's work where the image includes the legend "Le maure de sales"-or in relation to the mentioned description, it is difficult to say. In Ciruelo's Sphera, the image was present only in the 1498 edition, not to be found in those of

\footnotetext{
${ }^{25}$ (Ciruelo1498, h2v): "Homines quidem illi non magne stature, sed periocundi, saepius ridentes et bone indolis facile omnibus credentes et aquiescentes, satis ingeniosi, ceruleo colore et capite quadrangulari hyspanis mirabiles apparverunt." The illustration is in fol. a2v.

${ }^{26}$ (Savonarola 1496, a1v). On the role of publishers in the iconographical program of the different editions of the Sphaera in the sixteenth century, see (Chap. 9). On the Calendrier des Bergers, see (Engammare 2008).
} 
1508 and 1515 which were printed by Jean Petit (fl. 1493-1530) in Paris, and it was absent also from the 1526 edition of Miguel de Eguía (1495-1544) in Alcalá.

Initiating his Sphaera with a praise of mathematics was following the tradition of the Boethian claims about their nature and value, and certainly working in the mold of Lefèvre d'Étaples. Actually, Ciruelo started the preface by using the same biblical quotation used sometimes by Lefèvre d'Étaples: Romans, 1:20. ${ }^{27}$ All human sciences provided men with knowledge of God, and a science had to be considered worthier if it did so with more certitude than others, he wrote. ${ }^{28}$ Thus, he explained, mathematical doctrines had to be preferred to all other sciences after theology, because they fulfilled this role, and therefore had superior dignity (Fig. 3.2). ${ }^{29}$ In this first part of the preface, Ciruelo was careful to quote only the Bible and Aristotle, mainly the Metaphysics, through Averroes's (Abū 1-Walīd'Ahmad ibn Muhammad ibn Rušd, 1126-1198) words in some cases. Later natural philosophers and mathematicians, some also editing Sacrobosco's work, would include this same ideathat the study of mathematics and specifically of astronomy led to knowledge of God-among them Oronce Finé (1494-1555) and most famously Philipp Melanchton (1497-1560), who also used this idea to support the legitimacy of astrology (Almási 2014, 10-11). ${ }^{30}$

Other authors, like Nicholas Cusanus (1401-1464), had preceded Ciruelo in insisting on the Aristotelian (Averroistic) idea of the certitude of mathematics and the value of mathematical demonstration (Albertson 2014). These, combined with the also oft-repeated argument that mathematics was superior to other sciences in that it allowed no diversity of opinions, constituted the main ways to praise mathematics in this period, that is, before the 1540s and the burst of debate on the Quaestio de certitudine mathematicarum. ${ }^{31}$ Ciruelo's work illustrate this previous stage of the question, as all three reprints of his commentary to Sacrobosco were published before the onset of that debate. Ciruelo chose this path to later substantiate the nobility and excellence of astrology not only as one of the mathematical sciences, but as superior to all others.

\footnotetext{
${ }^{27}$ Ciruelo's version was: "Invisibilia inquit dei per ea quae facta sunt a creatura mundi intellecta conspiciuntur sempiterna quoque virtus eius et divinitas." (Ciruelo 1498, a3v). On the quote and its meaning in Lefèvre d'Étaples, see (Oosterhoff 2018, 127).

${ }^{28}$ (Ciruelo 1498, a3v): "Ideo sciencia omnis a sapientibus huius seculi humanis parta laboribus viribusque omnipotentis et veri dei aliqualem agnitionem hominibus affert...et tanto scienciam aliquam digniorem existimare oportet quanto altius certiusque deum nobis insinuat."

${ }^{29}$ (Ciruelo 1498, a3v): "Cum igitur in mathematicis doctrinis horum utrumque manifeste appareat: merito post primam philosophiam ceteris humanis scienciis preferende sunt easque dignitate antecedent."

${ }^{30}$ On Finé's edition of the Sphaera see (Chap. 8). On Finé, see (Pantin 2013), and the articles in (Marr 2009). Specifically on the status of mathematics in Finé, see (Axworthy 2009, 2016), and on Melanchton's letter, see (Pantin 1987). On the theological significance of nature in the sixteenth century, see (Crowther-Heyck 2003).

${ }^{31}$ Ciruelo phrased it thus: "In aliis item scienciis propter earum minorem certitudinem doctorum diversitas et opinionum controversia locum habet; in mathematicis vero nequaquam." (Ciruelo 1498, a3v). On the Questio, debated later in the sixteenth century, see (Jardine 1984, 1988, 1998; De Pace 1993; Mancosu 1992, 1996, 8-24; Dear 1995, 34-42; Cozzoli 2007).
} 


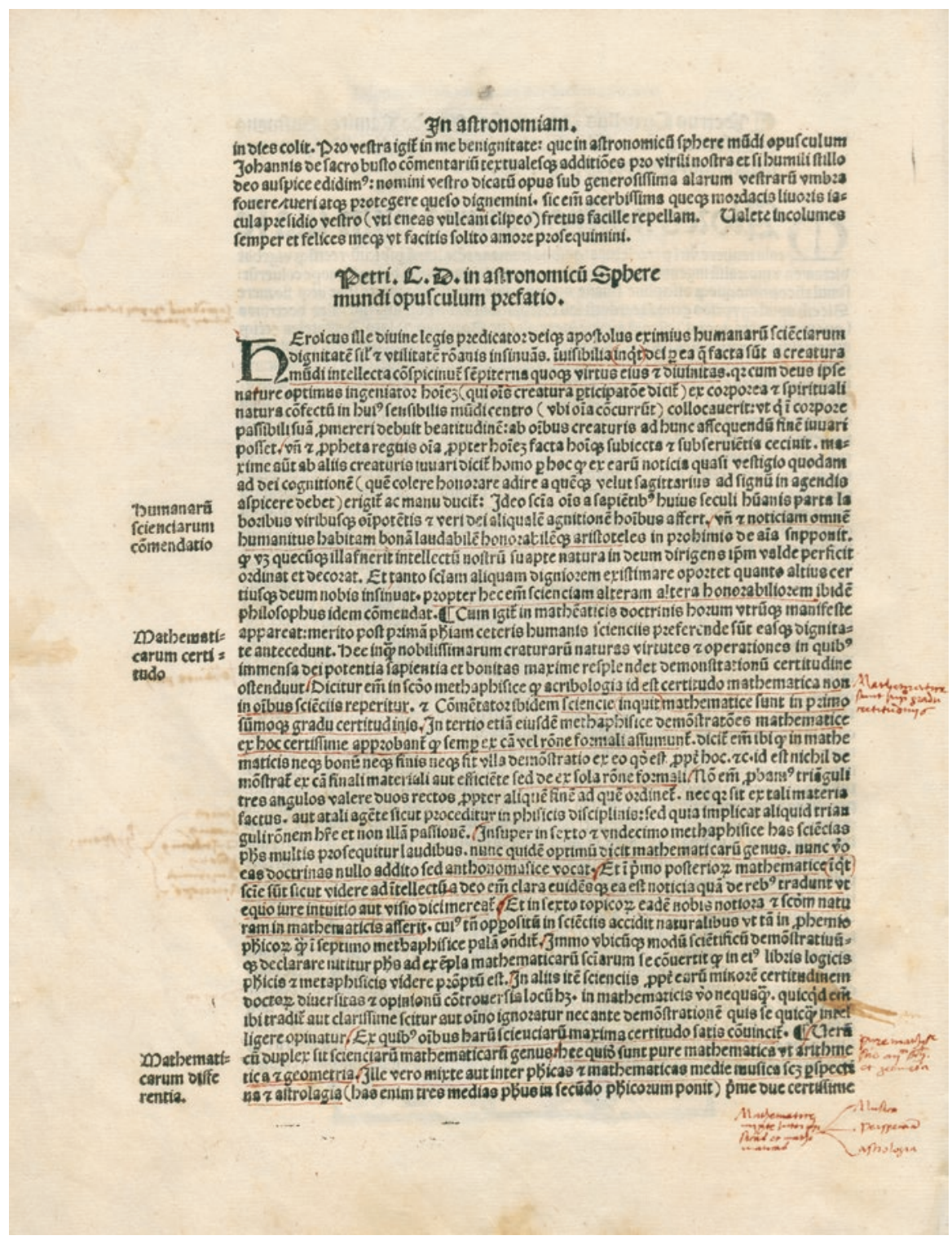

Fig. 3.2 Preface. This first page contains Ciruelo's praise of mathematics as a superior discipline and his discussion on the issue of certitude regarding mathematical doctrines. From (Ciruelo 1498). Biblioteca de Catalunya, Barcelona

This part of the preface closed with Aristotle's categorization of the mathematical disciplines. Those dealing with abstract magnitude (number and quantity) were pure mathematical sciences: arithmetic and geometry. Those concerned with magnitude together with some specific natural matter were subordinate to them: mainly astronomy, astrology, and music, but also perspective and optics in general. These did not 
follow the Aristotelian rule that demonstrations could not jump from one kind of subject matter to another, belonging to what in the medieval period were often called middle (medie), intermediate, or, later on, mixed mathematical disciplines. ${ }^{32}$ Aristotle's classification of the sciences and his discussion about the scientific status of the mathematical disciplines in the Posteriora Analytica and the Methaphysics, both of which Ciruelo cites, were the guides for the differentiation developed by medieval authors. ${ }^{33}$

The distinction between purely mathematical sciences and mathematical disciplines which applied mathematics to physical phenomena was common in scholastic philosophy (Galle 2003, 126-27) and provoked later debates on demonstration within the latter sort (Dear 1995; Laird 2016). Thomas Aquinas had explained that there were purely natural sciences, purely mathematical sciences, and scientiae mediae. The last received abstract principles from purely mathematical sciences and applied them to sensible matter. ${ }^{34}$ On this basis, the Spanish scholar could insist on one of the ideas that appears crucial to his consideration of astrology: that it was demonstrative, like other mathematical sciences, but it also provided information on physical reality. He would reemphasize the importance of this Aristotelian classification again in the dialogue that closed the Sphaera, and in some of his other works. To further support this part of the preface, Ciruelo had included Pierre d'Ailly's Questio Prima at the beginning of the commentary. Ailly's commentary on the first part of Sacrobosco's first chapter (on the shape of the world) was partly focused on the nature of mathematics and how astrology was part of the mathematical sciences. The bishop's explanation of the two kinds of mathematical disciplines and the nature of perspective, music, and astronomy was summed up in the margin with the words "mathematice medie vel mixte" (Ciruelo 1498, b3v). In this part d'Ailly also explained the different branches of astrology, and what astrologia iudiciaria was. ${ }^{35}$

Because astrology and the other two mixed mathematical sciences were also physical disciplines, they were nobler, as they transmitted knowledge about natural things with the certitude of mathematical demonstration. ${ }^{36}$ In the dialogue at the end

\footnotetext{
${ }^{32}$ Astronomy, astrology, music, perspective, and optics would be the disciplines which during the seventeenth century debates, at least from the publication of Francis Bacon's Advancement of learning (if not earlier), were called "mixed mathematics." See (Brown 1991; Dear 1995, 38-39).

${ }^{33}$ Aristotle, Posterior analytics I and II, particularly I.7; Aristotle, Metaphysics XI and XIII, particularly XIII.3. Also, Aristotle, Physics, I.1 and II.2. See (McKirahan 1978, Mandosio 1994).

${ }^{34}$ In the commentary on the Physics. See (Gagné 1969; Ribeiro do Nascimento 1974; Laird 2016).

${ }^{35}$ (Ciruelo 1498, b3v): "Quinta parts considerat de effectibus consequentibus coniunctiones vel oppositiones vel aspectus corporum celestium. Et ista vocatur astrologia iudiciaria, et etiam potest proprie vocari astrologia...."

${ }^{36}$ (Ciruelo 1498, a4r): "Hec igitur tres omnium particularium scienciarum nobilissime sunt, quia in eis simul phisice et mathematice pericie pulchritudo reperitur, qua enim phisice sunt obiecti pollent nobilitate, qua vero mathematice demonstrationis gaudent certitudine. Unde rerum naturalium non inductive et debiliter (ut alie sciencie permulte) sed demonstrative et scientifice cognitionem servata materie qualitate tradunt." The idea that among the branches of natural philosophy, astronomy was superior because of the perfection of its subject matter and because of the certainty of its mathematical nature, was a conclusion authors extracted from Aristotle's Metaphysics, XII, 8 (Jardine 1988, 145).
} 
of the work, he repeated that astrologia, in this case meaning astronomy, was "physical more than mathematical," as it studied the movements of the celestial bodies. ${ }^{37}$ The question of categorizing astronomy and astrology this way appeared in other prefaces to Sacrobosco's Sphaera (Almási 2014, 11). It was this mixed nature between physics and mathematics that made the science of the stars superior to other disciplines, a notion not unfamiliar to the context of sixteenth century astronomy, nor to later debates about the status of the discipline and the identity of the astronomer (Biagioli 1989, 1993, 211-44; Westman 1980, 2011, 202-9, 353-55).

The core of the preface focused on four arguments to support the assertion of the perfection of astrology among mathematical disciplines. These arguments would be reused by astrologers during the sixteenth and seventeenth centuries in defense of their art. The same questions about the dignity and nobility of astronomy and the value of astrology, although with different views concerning the last, were discussed later, for instance, by Francesco Capuano da Manfredonia (active fifteenth century) (Chap. 4).

Ciruelo's piece proceeded from the Aristotelian idea that the dignity of astrology/astronomy was elevated because its object of study, the celestial bodies, was superior. ${ }^{38}$ This was the first place Ciruelo cited Ptolemy, and he was careful not to quote only the Almagest, but to mention the Quadripartitum as well. This delivered the message that his praise was not only for mathematical astronomy and the study of the movements of the heavens, but for the whole science of the stars, including the study of the influences of the heavens, i.e., astrology. Ciruelo had started using the term astrologia for the science of the stars in general. But he made sure to keep readers from interpreting his defense as strictly applying to astronomy, the study of the movements, and not necessarily to astrology, the discipline focused on influences. He used a good number of quotes from Aristotle's works on celestial bodies as causes of natural events on earth, on the hierarchical classification of bodies in nature, and on the inferior world as being ruled by the superior bodies of the heavens. Astrology, he insisted — and he had made clear he meant the study of influences as much as any other aspect of the science of the stars-exceeded all other disciplines, because the other disciplines studied only corruptible bodies; they were not focused on the study of the heavens and the whole universe. ${ }^{39}$

Ciruelo continued by stressing that astrology also had to be praised because of the method it used, the way it established knowledge. This was where he discussed the key issue of the study of causes. According to the Aristotelian principles, a discipline only qualified as scientia if it concerned the study of causes. The debate of

\footnotetext{
${ }^{37}$ (Ciruelo 1498, n5v): "Astrologiam, o amice, Aristoteles phisicam magis quam mathematicam ostendit, quod scilicet supremorum corporum motus potissimum perscrutatur."

${ }^{38}$ (Ciruelo 1498, a4r): "Quod enim rei digeste dignitate astrologia omnes alias particulares sciencias excedat hec res indicio erit, quia ut Ptholemeus in primo et Almagesti et Quadripartiti habet hec sciencia celorum et ornatissimorum astrorum naturas virtues motus et effectus speculator."

${ }^{39}$ (Ciruelo 1498, a4r): "Cum igitur alie omnes discipline aut nullam aut non ita propriam celorum et totius universi faciant theoriam sed earum precipua intentio circa corruptibilia versetur corpora palam est astrologiam eas omnes hac ex parte antecellere."
} 
the quaestio de certitudine mathematicarum, very much focused on this issue as it pertained to mathematics, had not started yet-it developed later, in the sixteenth century. However, scholars were aware that a defense of a discipline had to deal with this question, particularly in the case of a mathematical discipline. Here, the assertion that it was a mixed mathematical discipline played the central role. As a partly physical science, it departed from the effects to get to know the causes. Ciruelo linked this to the previous argument by stressing that astrology investigated the highest causes. ${ }^{40}$ The argument was rounded off with the assertion that astrology comprehended the infallible demonstrations of the other four mathematical disciplines. It used geometry to understand the dimensions of the heavens and arithmetic to know the ratio and rules of the celestial movements. The courses of the heavens, Ciruelo stated, were connected with a musical harmonic proportion, and astrology also made use of perspective to understand the influential rays and the aspects of the stars (which had effects on earth and on men). ${ }^{41}$ Thus "the procedure of this science is more certain than the ways of all the other [sciences]," he concluded. ${ }^{42}$ The fact that the first part of the preface was a praise of the disciplines of the quadrivium gave strength to this part of Ciruelo's defense of astrology.

The next argument was a traditional one: there had been great scholars who studied astrology in the past, and their intellectual relevance and their piety was proof of astrology's nobility. Using a history of mathematics, astronomy, or any scientific discipline was a strategy developed to justify its study and give legitimacy to it, which both humanist and scholastic writers used (Grafton 1997; Goulding 2006). The authors used such narratives to distinguish the acceptable from the unacceptable parts of their discipline, the licit from the illicit (Popper 2006), which was particularly fitting for a defense of astrology designed in the context of a prohibition such as existed in Paris after the Simon de Phares (1444-ca. 1499) affair (see below). Highlighting ancient authorities for mathematics - and astrology-the authors tried to contribute to the process of legitimizing such knowledge (Popper 2006, 106). This was actually the path chosen by Simon de Phares to defend astrology when some of his practices and books on astrology were condemned by the Parliament and by the University of Paris's faculty of theology. He had intended to radically distinguish magical, divinatory, and superstitious arts from astrology, an objective he shared with Ciruelo. He decided to describe the historical precedents,

\footnotetext{
${ }^{40}$ (Ciruelo 1498, a4r): "Ex suo etiam procedendi modo certissimo astrologia super omnes humanas sciencias laudatur, siquidem enim vigoris modus habet procedendi phisicus ex effectibus scilicet ad causas perveniendo hoc in astrologia que partim phisica est tanto excellentiori modo reperitur quanto altiores causas suo processu investigat."

${ }^{41}$ On musical harmony in nature, and the spheres, see (Voss 1998).

${ }^{42}$ (Ciruelo 1498, a4r-a4v): "Infallibilem etiam demonstrandi modum aliarum quattuor mathematicarum hec sola comprehendit. Ibi enim geometricis theorematibus...celorum et stellarum...comprehenduntur et mesurantur, motuum quoque celestium norme arithmeticis numerorum rationibus cognoscuntur. Tot etiam tamque differentes celorum cursus armonica musicave proportionalitate connectuntur...Non desunt etiam perspective demonstrationes han scienciam condecorantes, irradiationum enim et aspectum stellarum...perspective sunt....Huius igtur sciencie processus omnium aliarum modis certior est."
} 
with an inventory of previous practitioners, which would prove the utility of the discipline and its respectability by way of those previous authorities (Boudet 1994, 10-11). Simon the Phares's Élucidaire, which became the Recueil des plus célebres astrologues, was still in the making when Ciruelo's Sphera went to print. Ciruelo used Josephus's (37-ca. 100) Antiquities to mention the tradition that attributed knowledge of astrology to Noah and Abraham, proceeding then to Hermes and Ptolemy, then medieval authors, citing among others Tebit (Thābit ibn Qurra, 826-901) and Alfarganus (Ahmad ibn Muhammad ibn Kathir al-Farghani, ca. 805-870) before getting to Sacrobosco himself and king Alphonse X of Castile, followed by Pierre d'Ailly, whom he couldn't fail to cite, and ending with the two most relevant scholars of fifteenth century astronomy, Peuerbach (1426-1461) and Regiomontanus (1536-1476). ${ }^{43}$ "Enjoy the regal and imperial astrology, which is commended by the piety, dignity and sublimity of its authors," Ciruelo concluded. ${ }^{44}$

His last argument appealed to the kind of piety he had just mentioned in association with those authors. Astrology was a discipline which aimed at raising men to the knowledge of the work of God, he said. ${ }^{45}$ Establishing the general notion of nature as a divine epiphany allowed for a justification of the sciences in general, and in this case of astrology in particular, as it fit coherently into such a view of nature. This was one of the most important ways to defend astrology when it was confronted with the principles of Christianity. It was obviously necessary to hold up astrology's pietas, meaning both its morality and its respect for divinity (Ernst 1991a, 251-53, 1991b). This argument was connected in the preface to the one insisting on the utility of astrological predictions, which was also a traditional defense of astrological knowledge.

Ciruelo had constructed a solid defense of astrology in this preface to the Sphaera, with some of the same arguments that would be repeatedly used by astrologers of the sixteenth and seventeenth centuries. His intention was not, however, to turn Sacrobosco's treatise into an introduction to astrology. The work was an introduction to astronomy, and, unlike Cecco d'Ascoli (1257-1327) and Robertus Anglicus (active ca. 1326), Ciruelo did not add the basics of astrology to his commentary. ${ }^{46}$ There was Alcabitius for that (Abu al-Saqr Abd al-Aziz al-Qabisi, active ca. 950), namely his Introduction to the Art of Judgments of the Stars. In deciding to place Pierre d'Ailly's questions on the Sphaera after the chapters to which they applied, Ciruelo gave himself the chance to introduce some astrological content, such as a piece on the nature of the planets and their influences on men (Chapter one of the Sphaera, Questio quinta by d'Ailly). But Ciruelo's aim when choosing to include d'Ailly's ideas could also be related to the defense of astrology as a discipline. D'Ailly's writings demonstrated a fundamental interplay and essential

\footnotetext{
${ }^{43}$ On the literary sources of the Sphaera, see (Martins 2003).

${ }^{44}$ (Ciruelo 1498, a5r): "Gaudeat igitur regia et imperialis astrologia que tanta inventorum auctorumque suorum santitate, maiestate et sublimitate commendatur."

${ }^{45}$ (Ciruelo 1498, a5r): "Finis quoque huius sciencie pius strenuus et divinus est per creaturas scilicet sensibiles ad dei cognitionem homines elevare."

${ }^{46}$ On Cecco d'Ascoli's and Robertus Anglicus's commentaries, see (Thorndike 1949, 48-54).
} 
harmony between his astrological and his theological beliefs (Smoller 1994, 22). His work Concordantia astronomie cum theologia (1414), which had been printed by Erhard Ratdolt (1442-1528) only a few years before in 1490, was one of the main references when authors attempted to resolve possible conflicts between the practice of astrology and the Christian religion (Smoller 1994, 122-30). The constant presence of d'Ailly's ideas in the commentary could be taken as a subtle reminder of the "concordance" of astrology and theology. Inserting d'Ailly's questions into the core of the text gave Ciruelo the chance to insist, after his first gloss on Sacrobosco, on the initial subject he had introduced in the preface, the place of astrology among the mathematical sciences (Chapter one, Questio prima).

The last part of the preface contained not only further arguments in defense of astrology, but specifically those which were needed due to what happened in Paris in 1494. While Ciruelo was there teaching the mathematical disciplines and studying theology, he witnessed the condemnation of astrological prognostications of a judicial nature by the University of Paris in 1494. The theology faculty was acting against the activity of Simon de Phares, condemning his astrological activities and part of his astrological library (Boudet 1994, 1999; Thorndike 1934, 544-61).

Simon de Phares was an astrologer who also claimed to be a physician. ${ }^{47} \mathrm{He}$ had established an astrological practice in Lyon, where he consulted clients and seems to have mainly exercised the branch of astrology known as interrogations. After a royal visit in 1490 and the subsequent fame, he was accused of using a "familiar demon" for his divinatory practice and arrested. This charge was later cancelled, but he was ordered to stop his practice of astrology, and his library was confiscated. He appealed to the Parliament of Paris in 1491. The Parliament asked the faculty of theology at the University of Paris to examine de Phares's library, at least his works on astrology. In 1494, the theologians of the university censored the content of eleven of his astrological works and published a notice condemning judicial astrology. This document was quite a wide condemnation of the discipline, or more specifically of nativities, interrogations, and elections. Knowledge of all the secrets of the future, said the Parisian theologians, as the Papal Bull of 1586 would say a century later, was reserved to God ${ }^{48}$ The theologians were actually focusing on the condemnation of interrogations and elections, and in that, Ciruelo agreed with them. He pointed out the same idea, that those two branches of astrology were to be forbidden, both in the commentary to Sacrobosco and in the Apotelesmata. However, despite how radical the notice of the faculty of theology seemed to early modern

\footnotetext{
${ }^{47}$ Boudet pointed out that there is no evidence of Phares receiving a medical education. For all the details on Simon de Phares's biography, activity, arrest, and condemnation, and for a transcription of the sources related to them, see (Boudet 1988, 1994, 1999). The document of the Parliament was published by (Plessis d'Argentré 1724, I: 324-30).

${ }^{48}$ (Plessis d'Argentré 1724, 325): “...eam nos mathematicam artem seu astrologiam divinatoriam appellamus, quae ex horarum natalium consideratione futuros hominum mores et qua item ex quarumcumque rerum vel operationum horis initialibus futuros eorum successus et casus, fortunas determinative et particulariter praedicere quae etiam cuiusvis interrogationis hora notata et veritatem respondere et omne prorsus cum praesens, tum praeteritum ac futurum secretum revelare ac manifestare se posse, quod divinitas proprium est."
} 
Europeans in 1494, it specified that it was not condemning "true astronomy," which besides the movements of the celestial bodies "conjectured about some of their natural effects." 49 Again, Ciruelo agreed that there was a part of astrology which studied natural influences, and that it was a licit and true liberal art- this he established at length in the preface to Sacrobosco. He did not seem to agree completely with the wide prohibition the document implied, as he defended certain predictions using genethlialogy in his later work, as well as revolutions. Jean-Patrice Boudet explained that the trial of Simon de Phares developed in a repressive context in which any deviation from orthodox faith was addressed with severity, and that divination, including astrology, was associated with blasphemy, as can be seen in royal orders published during the period (Boudet 1999, 108-10). The University-and following its instructions, the Parliament — of Paris prohibited divinatory astrology (astrologia divinatoria), but Ciruelo thought that it was necessary to discuss which aspects of astrology were divinatory and which were natural. And those were the issues he addressed in the preface to Sacrobosco, after he made clear that not all astrology was to be considered judicial or divinatory, and that it was a valid, licit, and worthy discipline.

Pedro Ciruelo's main work in defense of astrology, Apotelesmata astrologiae Christianae, was not published until much later, in 1521, while he was back in Spain as professor of Thomistic philosophy in the very nominalist environment of the University of Alcalá de Henares. Thorndike assumed that Ciruelo published his work in defense of astrology after he had returned to Spain because he then felt on safer ground, due to the theological opposition found in Paris during the last years of the fifteenth century. ${ }^{50}$ This idea is not consistent with the analysis of Ciruelo's strong defense of the discipline in the preface of his commentary to the Sphaera given above. Actually, I argue, it was precisely because of the situation in Paris that he decided to defend astrology so vehemently in his preface to Sacrobosco. He was not hiding his opinion on astrology, as his defense was very explicit, nor did he pretend that his words were unrelated to the condemnation of astrology resulting from the De Phares affair. He was addressing the problems created for the discipline because of the decision of the University of Paris about that case. He stated it both in the same preface and later again in the Apotelesmata. He explained that the same discipline he was praising had been the object of a recent decision by the theology faculty. The watchers of the Catholic truth wanted to keep all disciplines clean of falsity, so they had to condemn "certain writers, liars and corruptors of truth, who

\footnotetext{
${ }^{49}$ (Plessis d'Argentré 1724, 325): "Ne quis autem veram astronomiam, quae corporum coelestium magnitudinem, oppositiones, motusque considerat, quae Solis et lunae aliorumque planetarum conjunctiones vel oppositiones caeteras vel habitudines praedicit, quae item effectus quosdam eorum naturales probabiliter ac prudener in universali conjiciit, quam ut liberalem, nobilem, utilemque artem veneramur." On the distinction in this case, see (North 2009, 292).

${ }^{50}$ Thorndike expressed this theory as follows: "Whether Ciruelo expressed such favorable views towards astrology during his residence at Paris before 1502 may be doubted. At any rate he did not print them until 1521 in Spain, and one suspects that he felt somewhat freer to express himself on the subject there and surer of a sympathetic audience." (Thorndike 1941, 275-79).
} 
had tried to mix the chaste astrology with courtesan sciences." 51 This was one of the main defenses on which astrologers relied: it was the specific practitioner who mixed false ideas and superstitions with his astrology who had to be condemned. Ciruelo made a point of this in the preface when making the reference to the condemnation of Paris of 1494. In the Epistola proemialis of the Apotelesmata, Ciruelo mentioned again the situation in Paris as he introduced his discussion on who was entitled to decide about the nature of astrology and its legitimacy, and on the training of theologians and their lack of knowledge of astrology. ${ }^{52}$

Further evidence that the notice condemning the books and practices of Simon de Phares in Paris in 1494 had a role in the way Ciruelo defended astrology in the preface of his commentary to Sacrobosco's Sphaera is the new version of it he prepared for the 1526 edition (Fig. 3.3). The prohemium to this edition was a shortened version of the original one. In it, Ciruelo praised Lefèvre d'Étaples and mentioned his experience in Paris making his living as professor of mathematics. ${ }^{53} \mathrm{He}$ explained that he wanted to make the new version easier to read for the students of the University of Alcalá, and to eliminate his mistakes and youthful verbosity (Fig. 3.4).$^{54}$ The context had changed completely in terms of his own status and that of astrology as a discipline. He would not have worried about the 1494 decision against Simon de Phares anymore, because it was by then a past event without much effect. After the publication of Pico della Mirandola's (1463-1494) work against astrology, hardly anything else would have rivaled its importance. In the decade of the 1520s, Ciruelo addressed this issue with the Apotelesmata and the Reprobación. The preface to Ciruelo's commentary to the Sphaera of 1526 did not mention De Phares. However, Ciruelo had not abandoned his objective of placing a defense of

\footnotetext{
${ }^{51}$ (Ciruelo 1498, a5r): "Nec tamen qui divinam astrologiam tot tantisque laudibus efferre conor determinationi cuidam alme facultatis theologie doctorum parisiensium super quibusdam mathematicis libris nuper edite inficior....Ideo predicti doctores et veritatis catholice zelatores volentes tam dominam quam eius ancillas omni falsitate purgatas inmunesque custodire: falsarios quosdam scriptores et veritatis corruptores (qui castissimam astrologiam cum scienciis meretriculis nixi sunt collocare eamque apud dominam suam de magno superstitionis crimine falsa quedam immiscentes diffamare tentarum) a generosissima astrologorum schola perpetuo eiiciendos et dampnandos iamque dampnatos pronunciarunt."

${ }^{52}$ (Ciruelo 1521, a2v): "Verum de iudiciis astrologicis tunc temporis nihil egimus Parisii, eo quod vulgaribus theologis essent invisa atque ludibrio exposita. Nam tota eorum facultas plures iudiciorum astronomicorum libros anno Christi domini 1494 examinans, quesdam illorum manifeste erroneos infide et moribus alios valde suspectos aut dubios damnavit." On Ciruelo presenting himself as the perfect judge for what was orthodox in astrology, see (Lanuza 2017, 9-14).

${ }^{53}$ (Ciruelo 1526, a2v): "Cum in adolescentia mea Parisiensium theologorum scholas famigeratissimas perlustrarem, atque ex professione matheseos mihi necessaria ad victum et indumenta compararem, accidit tunc Iacobum Stapulensem praeclarum certe nostra tempestate philosophum, egregium quendam edere in opusculum sphaericum Ioannis de Sacro Busto commentarium et mox ipsum excussoribus imprimendum trader."

${ }^{54}$ (Ciruelo 1526, a2v): “...hanc sphaericam meam elucubrationem revidere, corrigere, emmendare breviorem facere, atque in melius permutare, eliminata prorsus ab ea. omni prolixitate, omni barbarie omnique iuvenili loquacitate, sicque renovatam eisdem complutensibus calcographis et quidem artificiosissimis formanda tradere, ad usum nostrorum adolescentum hic et alibi philosophantium.”
} 


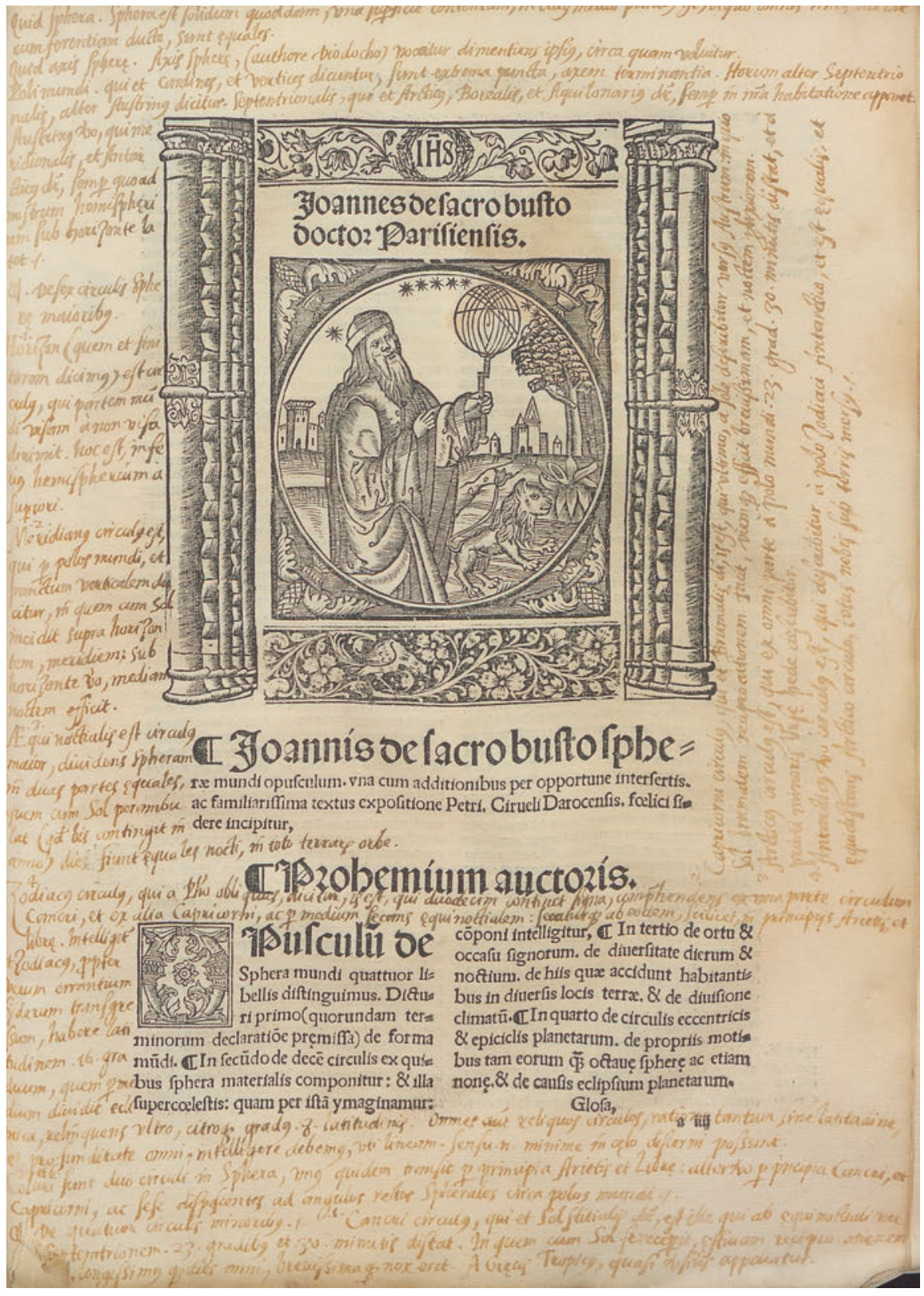

Fig. 3.3 Cover page. This copy at Seville is one of the many with marginal notes denoting the intense use of this commentary of Sacrobosco's Sphere. From (Ciruelo 1526). Courtesy of the Biblioteca Universidad de Sevilla 


\section{Rzobernium. I Tiníuerfísliberalium artíum}

fudiofis in praclariflimogymnafio complutēfi Petrus Ciruelus Daro: cenfis falutem : \& fui commentaril in fphrericum opufculum feriofam recognitionem.

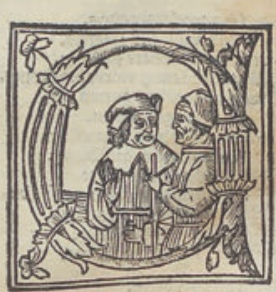

Zim in adolefeêtia mea Parifien fium theologorum fcholas famigeratiffimas perluftrarem: atçex pfeffōo mathefeos mihi neceffaria ad viçü \& indu menta cōpararé:accidit tunc Iacobū Stapulêfem præclarū certe noftra tēpeftate philofophū: egregium quendã edere inopufculū fphrericū Ioannis de facro bufto cōmētartū: $\&$ mox ipfum excufforibs imprimendum tradere, Q vo per manus fcholafticorū circū acto: clamor eorum ad me vfö peruenit dicentium $q$ nimis effet breuis $\alpha$ valde obfcurns: atơs textu ipfo captu difficilior:ob exquifitâ fcilicet eius la: tinitatē Parifienfibus tūc infuetã. Quare plurimorū importuna efflagitatione deuítus: qui fphrericūi illud opufcult̄i ibidē publice legerâ:allam familiariorem extenfiorēó̧ eiưdēē libri commentationê: $\&$ fi humili ac pedeftrif fribèdi ftilo:præmaturâ coactus fum edere. Qux tamen eorū iudicio vifa eft illis accōmoda \& perutilis perpenfa : adeo vt oés ibidé phificorum regètes eam gratifime duobus complecterētur brachiis, at đ̧ fubinde in cōs muniliberaliū artiū curfì ipfam anummerare decreuerunt, Hinc etiam actum eft $\psi$ impée fis Ioannis parui bibliopolx notiflimi in viginti annorū fpacio iam tertio Impreffa fit:

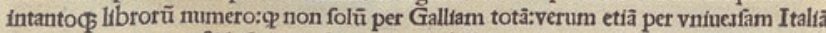
(taceo germaniam) \& hifpaniam longe lateç diffeminata plurimorum præceptorū fue rit ore laudata. At ego fam fenior ímperfectū menm videns: $\alpha$ in operibusmeis plaraç tuuentutis errata recognofcēs:poft introductioné quadrifidx mathefis nuperrime clima:

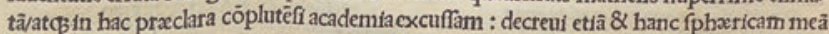
elucubrationê reuidere/corrigere/emēdare/breuiorē facere/atos in melip pnutare, eliminas ta prorfus ab ea oñi plixitate/oñī barbarie/ omniq̧̧ inuenili loquacitate, fieç̧ renonatã eifdem cöplutenfibus calcographis \& quidem artificiofffimis formâdâ tradere:ad vfum noftrorum adulefcentū hic $\mathcal{Q}$ alibi philofophantium. Et in eius recognitione illico fefe mihi obtulit prohomiorū eius immoderataextenfio:quare rcicța inde phomfali epifto la:q̄ directa erat ad duos nobiles hifpanos tūc mihi cömilitones in paleftra illa theologis ca:agebat ф̧̧ fere tota de litterarū nobilitate : q̄ ea erat olim vt non nifi a nobilib’ genere poffideretur:a quibus etiam primum innenta fuerat, quãuis in hac noftra ferrea tēpeftate ab eifdem videretur effé quã alieniflìma. Mox fubfequenté prefationé $\&$ quidé latifilimä de aftrologix comendatione:hicadeo breutorem efficere curaui: vt eã per folas fere mars ginales annotationes colleçà recéfeam. In ea fiquidè imprimis humanarū féetiarū:ab ho minibufós lumine naturalis ingenil inuētarū: cōmēdatio proponebatur:maxime ex fine: $q$ per hxc vifibilia ad noftri creatoris inuifibilia cognofcenda (qux eft magna hominū beatitudo)nos erigebant ac perducebant. Deinde aliis fcientiis protermiffis: mathematic carum artium liberalium excellens dignitas:tum ex obiecti nobilitate : tum vel maxime ex demonftrandi certitudine declarabatur. Pofita infuper earum inconfueta:fed ex ariftc $=$ tele habita diuifiöe:per puras mathematicas:qux funt Arithmetica \& Gẹometria: \& mix

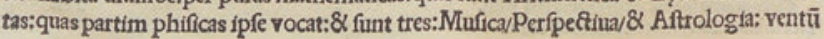

Fig. 3.4 Preface. This first page of the 1526 edition can be compared to Fig. 3.2. It contains the same initial arguments and praise of mathematics, discussing the dignity of mathematical sciences, in a briefer and more concise structure. From (Ciruelo 1526). Courtesy of the Biblioteca Universidad de Sevilla 
astrology in his commentary. He did it by including the same arguments he had put in the original, only in a shortened version. Some of them were reduced to a single sentence: the nobility of mathematical disciplines, the division between pure and mixed disciplines, the higher status of astrology due to its object and its mixed physico-mathematical nature. The genealogy of the discipline was only slightly abridged. The last part maintained that the science of the stars had two parts, one focusing on the movements of celestial bodies, the other on their (strictly natural) effects. ${ }^{55} \mathrm{He}$ did not leave out citing the Almagest and the Quadripartitum together. He finished this new version by insisting on the excellence of astrology, and on the utility of the Tractatus de sphaera of Sacrobosco to learn basic astronomical knowledge. The shortened preface of 1526 , less prolix indeed, seems to transmit less urgency, which is consistent with its publication in a dissimilar context.

When Pedro Ciruelo published the Apotelesmata astrologiae Christianae, it was due to a different situation. He felt the need to answer Pico della Mirandola's Disputationes adversus astrologiam divinatricem and his attack on astrology. When he printed the commentary to the Sphaera he already knew some of Pico's works. He referred to him as a man who had arrived at the top of all human and divine sciences, and who shone as a new star. "What he ignores, nobody knows," said Ciruelo about Pico. ${ }^{56}$ But when he made a first defense of the discipline in the Sphaera, it does not seem to have been due to the Disputationes, although they had been published already in 1496. He did it because of the condemnation of Simon de Phares.

The differences between the kind of defense that Ciruelo created in these two works (the commentary and the Apotelesmata) are due to the context of the moment and the kind of attack against astrology to which he was responding. But the commentary to the Sphaera, with its solid combination of arguments defending astrology by associating it with mathematics, and the Apotelesmata, where the aim was to answer Pico's work while renovating astrology, constitute a unity in which the first one functions like an introduction to the second. In the Apotelesmata, the same simple arguments are mentioned-developed in different ways, but not literally repeated.

\footnotetext{
${ }^{55}$ (Ciruelo 1526, a3r): “...pars theorica seu contemplativa de magnitudinibus, mensuris, numeris et motibus coelorum et stellarum.... Altera vero est quasi practica, quia iudiativa effectuum naturalium ex actione corporum coelestium in terra et mari in hominibus et brutibus animalibus atque in terrae vegetabilibus contingentium, voacturque ab eodem proprie astrologia."

${ }^{56}$ (Ciruelo 1498, a3r): “...qui....et virtutes et scientias licito amore prosequuntur unde et Johannes Picus italorum principum gloria nitidissimumque ornamentum diebus hiis velut novum sidus emicuit. Qui omnium tam humanarum quam divinarum scientiarum fastigium adeo celeriter optinuit ut omne genus scibile antequam adolescentiam excederet calluerit et quod is ignoraverit sapiat nemo."
} 


\section{The Structure of the Apotelesmata and the Renovation of Astrology}

Between the first printing of the Disputationes in Bologna in 1496 and the publication of the response to it by the Pedro Sánchez Ciruelo in 1521, several other answers to Pico della Mirandola's work had been already published, mainly in Italy. Before Ciruelo wrote his Apotelesmata astrologiae Christianae, Lucio Bellanti (died ca. 1499) had already printed his Defensio astrologiae twice (in 1498 and 1502) and Giovanni Pontano (1426-1503) had published his answer in De rebus coelestibus in 1512 (Bellanti, 1498; Pontano, 1512). Agostino Nifo (ca. 1473-ca. 1540) had printed his commentary on the Tetrabiblos in 1513, and according to the studies of Paola Zambelli, Tiberio Russiliano (1490-ca. 1570) had also mentioned his intention to "destroy the disputations" around 1519 (Zambelli 1986, 1994; Nifo 1513).

The Apotelesmata was in a certain way a combination of Bellanti's choice to respond to Pico's work with that of Pontano-if we see Bellanti as a model in which each and every argument in the Disputationes is summed up and responded to in the same order-and Pontano's De rebus coelestibus, written with the objective of answering Pico by constructing a complete treatise on astrology. In his work, Ciruelo did both.

When he decided to structure his work in four books after Ptolemy's Tetrabiblos, it was an exercise inspired by Renaissance imitatio and by the general principle of going back to the authority of antiquity for the renovatio of the discipline. In the context of the debates about astrology in sixteenth century Europe, this meant a clear position, that of those who based their defense of astrology on the idea that the valid discipline, "pristine" as it was contained in Ptolemy's work, had been corrupted by later medieval—particularly Arab_additions, from which it had to be cleaned to restore a "truer" astrology. Ciruelo was one of the scholars with an interest in astrology who proposed such a view. The condemnation in Paris and Pico's work made him aware of the need for a renovation of the discipline. At that time, other scholars were also defending a return to Ptolemaic astrology. In this respect Ciruelo was not different from Pontano, from Nifo, from Albert Pigghe (1490-1542), and others, before Girolamo Cardano (1501-1576) famously advocated for such a way to recreate the discipline in his commentary to the Tetrabiblos in $1547 .{ }^{57}$ The argument of the "return to Ptolemy" was also to be found in Melanchton (Pantin 1987). Cardano's role in this debate was crucial during the second half of the sixteenth century. His commentary on Ptolemy's astrological work is the best-known example of the larger theme-found in many authors of the period-of the need to reform astrology by a systematic program of study. Ciruelo would have concurred with this idea. Cardano's opinion, like Ciruelo's, was that the best way to reestablish his art was through the study of Ptolemy (Grafton 1999, 134). He claimed that he

\footnotetext{
${ }^{57}$ On Bellanti and Pontano, see (Faracovi 2008a, b, a, b; Akopyan 2017). On Pontano, see also (Desantis 1986; Rinaldi 2002). On Pigghe, see (Vanden Broecke 2003, 85-99). On Cardano, see (Grafton 1999, 134-53; Ernst 2001). See also (Rabin 1997).
} 
had clarified the validity of astrological principles to be found in Ptolemy's Tetrabiblos, but he also highlighted the limits of the discipline, its imperfection, and he criticized other practitioners in the frame of distinguishing good from bad astrology (Grafton 1999, 91-108, 127-55).

This was one of the ways in which Ciruelo connected the arguments he had introduced in the commentary on the Sphaera with those he developed in the Apotelesmata. He had already stated in the preface to Sacrobosco that Ptolemy's astrology was the "pure" and legitimate one, and that later-medieval-additions had mixed with it false ideas and practices. He particularly cited as erroneous the astrological ideas of Albumasar (Abū Ma'shar Ja'far ibn Muḥammad ibn 'Umar al-Balkhī, 787-886), Abenragel (Abū l-Ḥasan 'Alī ibn Abī l-Rijāl, active late tenthearly eleventh century), and Guido Bonatti (1210-1296). To reform astrology, it was necessary to return to Ptolemaic astrology, creating a new discipline by eliminating certain theories from the intervening period..$^{58}$ What had constituted a few paragraphs in the prefaces to the Sphaera became the basis for Ciruelo's main work in defense of astrology. The idea of the renovation of astrology was often structured upon the distinction between a true and a false astrology. The first would be learned and legitimate; the second would be superstitious and incompatible with Christian doctrine (Walker 1958; Ernst 2001, 39-68). Medieval authors had already attempted to establish criteria to guide the efforts to distinguish between natural and judicial astrology. Natural astrology would interpret the effects that the properties and movements of celestial bodies caused naturally on earthly bodies and events, neither requiring supernatural intervention nor denying human free will. Judicial astrology predicted human activities which depended on the decisions of men, but its deterministic interpretation presupposed the annulment of free will, of the possibility of unpredictable events, and of divine intervention. These theoretical descriptions of the two kinds of astrology were the subject of many works during the early modern period. They insisted on the existence of a good astrology which was true and licit from the point of view of the Church, and a false, superstitious, illicit one. But opinions on which theories and practices must be classified as one or the other were varied and contradictory. Medieval antecedents were to be found in the works of Roger Bacon and Albertus Magnus (Crombie and North 1970, 377-85; Molland 1997, 68-71, Zambelli 1986, 1992). Ciruelo discussed the issue in the Apotelesmata for a learned audience, and later, in his Reprobacion de supersticiones y hechicerias (Reprobation of superstitions and sorceries), first published in 1537, he tried to explain the difference between the two kinds of astrology in the vernacular to reach a wider audience. True astrology, he explained, was based on the natural effects of the stars on air and water, thus affecting the weather and human health, complexions, and inclinations. False astrology predicted things related to human free will

\footnotetext{
${ }^{58}$ (Ciruelo 1498, a5v-a6r): "Hanc tamen astrologiam multi ut dictum est plura falsa immiscentes late ampliarunt, nam Albumazar, Hali Abenragel, Guydo Bonati, Abraham Avenezre et multi alii...."
} 
and chance. ${ }^{59}$ While brief in form, this was an argument that had also been present in Ciruelo's commentary on Sacrobosco. When discussing the contents of the third chapter on the risings and settings of the signs, and on climates and the habitability of the diverse zones of the earth, he repeated the differences among the mathematical disciplines explained in the preface. He then explained that several of them were "artes mathematice prohibite ab ecclesia que sunt divinatorie" (Ciruelo 1498, h4v). The list of the prohibited arts is reminiscent of those he criticized in the Reprobación. His efforts to establish a distinction between licit and illicit astrology, and to distinguish the former from any divinatory art, was quite constant throughout his career. He was successful in spreading these distinctions. The three reprints of the Sphaera and the Apotelesmata were received only by scholarly audiences, but his vernacular Reprobación, containing the same distinction, had a huge impact. It was printed at least ten times during the sixteenth century since its first edition in 1537 (Mateo Ripoll 2002). ${ }^{60} \mathrm{He}$ was repeatedly cited as an authority on the subject during the seventeenth century debates on astrology at the core of the Inquisition (Lanuza Navarro 2017).

The determination of which astrological doctrines had to be considered unacceptable from the point of view of Catholic orthodoxy was associated in the Apotelesmata with the explanation of all aspects that constituted a 'true' Ptolemaic astrology. Both were directly linked, which was also the reason why Ciruelo presented himself as a perfect judge for astrological issues. His knowledge of astrology, which other theologians lacked, was the reason he considered himself better qualified (Lanuza Navarro 2017).

Ciruelo devoted a great portion of the Apotelesmata to forming an answer to each and every argument contained in Pico's attack. ${ }^{61}$ His response to the Disputationes was organized in two parts. The first part responded to Pico's books I and II, and was placed before the astrological treatise. Then Ciruelo's work became a manual

\footnotetext{
${ }^{59}$ (Ciruelo 1551, 16r-17r): "La verdadera astrología habla de cosas que se causan por las virtudes de los cielos, que con sus movimientos y luces alteran el ayre y la mar, y la tierra, y assí causan diversos effetos de tiempos..., y porque los cielos y las estrellas alterando el ayre y la tierra también alteran a los hombres..., assí los cielos causan a nuestros cuerpos diversas calidades, complexiones, passiones y enfermedades, diversas inclinaciones y abilidades.... Y en estos juicios no hay vanidad ni superstición alguna, porque aplica a los effectos sus causas que tienen virtud natural para los hazer..., y esta astrología es lícita y verdadera sciencia como filosofía natural, o la medicina.... La falsa astrología no es arte ni sciencia verdadera, antes es una superstición, porque de los cielos y estrellas presumen de juzgar de cosas que ellas no pueden ser causas dellas..., las cosas de acaescimientos por diversos casos de fortuna...y los secretos del coraçón y voluntad del hombre... [que es] libre."

${ }^{60}$ On the Reprobación, see (Ebersole 1962; Zamora Calvo 2008; Tausiet Carles 1992).

${ }^{61}$ (Ciruelo 1521, a4r): "In secundo prologo ponuntur argumenta et responsiones circa primos duos libros operis Mirandulani Contra astrólogos;" (Ciruelo 1521, C4r): "Restat etiam pro nostri operis complemento ad argumenta que contra veritates astrologicas fieri consueverunt respondere. Et que nobilis quidam Joannes Picus Mirandula insignis orator et sumus in arte dicendi, putavit se recollegisse omnia argumenta que contra haec facultatem apparentiam aliquam habent in suo opere dicto contra astrologos...."
} 
explaining astrological theories, followed by his glosses on the pseudo-Ptolemaic Centiloquium. At the end of the work he placed the second part of his answer to Pico. In this, he responded more briefly to the rest of the books (III to XII) of the Disputationes.

The internal structure of the texts of these 'Responsiones' is, like Bellanti's work, that of the scholastic tradition. Ciruelo summed up the content of each of the chapters of the Disputationes, following its order, and then answered Pico's arguments with his own opinions.

The arguments with which he rebuked Pico's criticisms in the second book were not innovative, which is unsurprising as Pico also drew his attacks from the critical tradition. The re-elaboration of medieval and classical arguments which were previously pointed out in the Disputationes happens thus in both the condemnation and the responses, sometimes lending a kind of circularity to the two in tandem, as Pico had considered in advance the usual answers of astrologers to his objections and created his work by responding to them preemptively. ${ }^{62}$

Claims for and against astrology had classical origins and passed through medieval recreations. According to Bouché-Leclerc, after the first attacks had been issued, nothing new followed; they had already presented every argument and the ensuing criticisms only repeated themselves without innovations (Bouché-Leclercq 1899, 571). This is not as straightforward as he claims. Even if the participants in the early modern polemics against astrology made use of the same arguments, this does not mean they were mere repetitions. In the first place, Pico's Disputationes is much more than a list of the same arguments, and, as put by Cesare Vasoli, it is not a work reducible to the traditional argumentations of the anti-astrological polemics of an Augustinian nature and origin. ${ }^{63}$ In the second place, more generally, even if the arguments are the same, the context—socially speaking, politically speaking, scholarly speaking - was seriously different in each moment, and that altered not just the way they were presented, but probably also their meaning. ${ }^{64}$ It would be wise to follow the arguments through time and see how they were reproduced in different contexts to understand how they changed and the roles they played at different points in this long-lasting debate.

\section{Conclusion}

Pedro Sánchez Ciruelo was a scholar of scholastic training, educated in the nominalist tradition. He has repeatedly been described as a humanist (Flórez et al. 1990, 50-53; Albares 1996). It is difficult to agree with applying such a label to him, due as much to the nature of his writings and activities as to the problematic definition

\footnotetext{
${ }^{62}$ On the re-elaboration of arguments, see (Caroti 2008, 72-78).

${ }^{63}$ Arguments which according to Boll and Bouché-Leclercq were traceable to Carneades through Cicero (Bouché-Leclercq 1899, 571, citing Boll 1894, 182). See, against that idea, (Vasoli 2008, $5)$.

${ }^{64}$ On the difference that social and political context made in arguments concerning astrology, see (Vanden Broecke 2016).
} 
of the term "humanism." Created as a historian's category in the nineteenth century after the Renaissance term "humanist," humanism has been the subject of much controversy and of varied and often contradictory views. Even after leaving behind nineteenth and twentieth century debates over the meaning of humanism and over its main traits, scholars currently working on several aspects of Renaissance culture and society still disagree about how best to categorize it. ${ }^{65}$ Assuming certain points of agreement, I will try to briefly expose why applying them to Ciruelo's works is problematic. Some characteristics described as typical of humanism can be found in his writings; however, the weight of medieval scholasticism in them cannot be denied either.

According to the traditional definition of humanism, humanists promoted the disciplines concerning language-grammar, rhetoric, and poetics-the studia humanitatis, as opposed to the predominant scholastic Aristotelian philosophy. One of the points of discussion about it is, of course, to what extent it really opposed scholastic philosophy, as the borders between them cannot be taken as so neat and clear as the historical actors, and many historians, affirmed. ${ }^{66}$ The not-sostraightforward definition of what medieval Scholasticism was has been another point of discussion, as well as the role of many medieval legacies in humanist attitudes (Fubini 2006). It is reasonable to agree with Paul Oskar Kristeller that reducing fifteenth century culture to a confrontation between these two cultural movements is a misrepresentation of it, that the culture of this period was more varied, and that humanism and Scholasticism coexisted during the fifteenth and sixteenth centuries (Mazzoco 2006a, 17). Seeing Ciruelo's life and works in a context of coexistence seems quite reasonable as well. If his writings can be said to share some of the traits of humanist works, it is also certain that he cultivated literary genres usually associated with scholastic activity. He wrote commentaries on Aristotle's Posteriora analytica, he used pedagogical dialogues, disputations, and disputations in the form of quaestio ${ }^{67}$ His dedication to logic and his role as the professor of Thomistic theology for three decades can hardly be ignored either. ${ }^{68}$

The values of the humanists pervaded scholarship as a whole, including scholastic commentaries of the sixteenth century (Dear 2001, 32). Humanists put emphasis on the value of education to create better citizens, on the relevance of discarding medieval Latin in favor of classical Latin because they saw it as inseparably related to the wisdom of the content, and on the idea of a rebirth of classical culture,

\footnotetext{
${ }^{65}$ For a summary of the nineteenth and twentieth century debates over humanism, and the relevant roles played by different scholars, including the significant works of Burckhardt and Haskins, and of Baron, Garin, and Kristeller, see (Mazzoco 2006a). For several current views of humanism and the most relevant aspects of it, some of them contradictory, see the varied essays in this edited volume. See also (Grendler 2002; Fubini 2001, 25-27; Celenza 2004, 16-57).

${ }^{66}$ Kristeller insisted that humanism evolved out of the grammatical and rhetorical medieval traditions. Discussion on the real meaning of Kristeller's thesis and influence, in (Mazzoco 2006b, 176-77).

${ }^{67}$ See an analysis of the Dialogue at the end of the Sphaera, and of the genres in the works of Ciruelo, in (Gómez Sierra 1999, 2000).

${ }^{68}$ On Ciruelo’s logic, see (Ayala 1993; Muñoz Delgado 1964, 1966, 1967).
} 
of renewing culture by a return to the language and knowledge of antiquity, which in their opinion were linked. Language or the recovery of ancient texts for better translations seems not to have been one of Ciruelo's concerns, at least not concerning scientific works. He did, however, embark on a translation from Hebrew of parts of the Old Testament, though late in his life. This must be analyzed in the context of another debate concerning humanism, this one from the point of view of religious studies and focused specifically on Spain. Marcel Bataillon's immeasurably influential Erasme et l'Espagne defended the idea that humanism in Spain arose exclusively from the supporters of Erasmus and his doctrines, spiritual ideals, and philological criticism (Bataillon 1966) ${ }^{69}$ Bataillon presented Ciruelo as the epitome of conventional Catholicism and an enemy of Erasmus, and therefore as the absolute opposite of a humanist. ${ }^{70}$ Lou Ann Homza demonstrated how biased this view of humanism, and of this scholar, was, by analyzing Ciruelo's theology and his religious works. She concluded that although Ciruelo's early works displayed no respect for the integrity of the text or interest in exegetical issues, he evolved, became a Hebrew scholar and showed philological interests, embraced the humanist historicist approach and developed a new exegetical awareness (Homza 1992, 60-101, 175-209). His "altered approach to biblical hermeneutics qualifies him as a Renaissance humanist" (Homza 1992, 11, 284).

From the point of view of the historian of science there is also a long debate on the relationship of humanism and science to be taken into account. Scholarship discarded long ago the traditional view of an opposition between Renaissance humanism and scientific thought, once defended by Thorndike (Blair and Grafton 1992, 535). In the last decades, several scholars have made a 'reassessment' of humanism and its interaction with science, pointing out, among other issues, the impact of ancient texts of a scientific nature made available by humanist scholarship and the press, and the spread of scientific ideas through humanist works (Blair and Grafton 1992; Grafton 1991).

Regiomontanus has been held up as an example of a humanist specialist in Latin literature who was simultaneously a mathematician and astronomer-an example of how the ideal of renewing culture by a return to antiquity was applied to the mathematical sciences. In Peter Dear's words, he transferred the language of the humanists regarding decline and renewal to the specific arena of mathematics, and his humanist rhetoric of 'restoration' in the Epitome found a receptive audience (Dear 2001, 33-34). It is not difficult to relate Regiomontanus's defense of mathematics as well as his regard of astronomy as the highest of the mathematical sciences to Ciruelo's words in the preface to Sacrobosco. Ciruelo's insistence on returning to Ptolemaic astrology could be read as participation in the humanist revival of ancient sources and practices. In this he would be following Regiomontanus's, as well as

\footnotetext{
${ }^{69}$ For a description of the scholarship concerning humanism in Spain as presented by Bataillon, and a criticism of what it erroneously entailed, see (Homza 1992).

${ }^{70} \mathrm{~A}$ transcription of Ciruelo's opinions on Erasmus in the Assembly of Valladolid in 1527, can be found in (Beltran de Heredia 1972, 50-53). See an analysis of it in (Homza 1992, 209-81, 1997, 2000, 49-76).
} 
Lefèvre d'Étaples's, humanist way of addressing the issue. The same could be said about basing his argument for the value and nobility of astrology on an appeal to ancient authorities: the strategy of creating a genealogy of a discipline that extends as far back into antiquity as possible and ties in the most famous individuals to legitimize it and justify its practice was also a humanist move (Grafton 1992). In this sense, it must be pointed out that in the dialogue at the end of the commentary Ciruelo also discusses the function of authoritas. The use of historical narrative to work through problems of the legitimacy and nature of disciplines, as used by Regiomontanus and others, has been termed "the most humanist of activities" (Goulding 2006; Popper 2006). Still, one should not lose sight of how Ciruelo, like Lefèvre d'Étaples, also built his defense on Boethius's claims for the value of mathematics, and that this medieval tradition dovetailed with the humanist interest in mathematics (Moyer 2014). Nor should one lose sight of the fact that as much as a mathematician and astrologer, Ciruelo wrote as a theologian, and that his main concern was to establish the parts of astrology acceptable from the point of view of orthodox Catholic doctrine.

Ciruelo's preface is strikingly similar to Regiomontanus's inaugural oration on the history and utility of the mathematical arts at the University of Padua in $1464 .^{71}$ The main features were shared: praise of the mathematical arts and its practitioners, a history of mathematics, the utility of the discipline and its supremacy based on certainty, and among the mathematical sciences, the superiority of astrology because of the knowledge it provided of the secrets of God. Another idea used by Ciruelo in the commentary on Sacrobosco, that astrology encompassed all other branches of mathematics (arithmetic, geometry, etc.), could also be found in the letter contained in some copies of Regiomontanus' Epitome, as Robert Westman has recently pointed out. This letter, written by Giovanni Battista Abiosi (active in the last decades of the fifteenth century), was also an encomium to astrology (Westman 2016, 17).

Regiomontanus's oratio is considered an example of a humanist rhetorical text on the revival of ancient mathematics. James Byrne has shown, however, that even if it is stylistically consistent with humanist norms, its vision is grounded in the medieval university's mathematical curriculum and does not reject medieval authorities (Byrne 2006). Stylistically speaking, Ciruelo's preface would probably not be considered humanist, as he shares the vision of the scholastic mathematical university training and the respect for medieval authorities.

In this paper I did not intend to place Ciruelo into one or another category or to discuss his humanist versus his scholastic traits. The aim was to analyze his defense of astrology, and to show that we get a richer understanding of Ciruelo's works involved in that defense, by placing them in their own specific context.

In the case of the preface to Sacrobosco, he wrote it while trying to establish his relevance as a professor of the mathematical disciplines, including astrology, in Paris. When Simon de Phares and his astrology of elections and interrogations, two

\footnotetext{
${ }^{71}$ For a study and description of Regiomontanus's oratio at the University of Padua in 1464, see (Byrne 2006).
} 
astrological practices very much in conflict with Christian doctrine, were condemned by the faculty of theology in 1494 in a decree that was critical of all branches of astrology, Ciruelo had to defend the legitimacy and importance of the discipline he was teaching. He placed this defense in his commentary on the Sphaera of Sacrobosco, the traditional work for teaching astronomy, and used the arguments that aimed to praise the virtues of astrology and the mathematical disciplines and to differentiate the "good" from the "bad" astrology. Those were the arguments that would help him vindicate his place at the university and reinforce his status there. Placing the defense in the most widely read of all works on astronomy in academic circles, in a commentary addressed to an audience of students and professors, was a wise strategy. ${ }^{72}$

When he published the Apotelesmata two decades later, in the middle of the debates about the discipline renewed at the end of the fifteenth century by the publication of Pico de la Mirandola's Disputationes, the arguments Ciruelo highlighted were different. He focused then on the creation of a whole corpus of astrological knowledge not in conflict with Christian doctrine. One of his objectives was to set up guidelines that would make himself seem a valid authority in decisions about astrology. To this end, he emphasized his training as a theologian at the University of Paris, one of the reference colleges for theology. This, combined with his knowledge of astrology resulting from his earlier training in mathematics and astrology at the University of Salamanca-knowledge well exposed in the work-would make him the perfect judge.

The works aiming to defend astrology before and after Pico della Mirandola's attack followed different strategies according to the concrete ideas of their authors. They shared many arguments, as is obvious from the overlap between Ciruelo's arguments and Regiomontanus's and Bellanti's, for instance. Those arguments were inherited from the medieval tradition, but their particular context determined what was highlighted in each case and in what way the arguments were presented. The case of Ciruelo shows that his way of presenting the defense was immersed in the specific context in which he was living, and that it grew in part from the perceived need to vindicate his own status and that of the discipline within two different scholar communities at two points in time.

\section{References}

\section{Manuscripts}

Torres, Diego de. Sphaera de Sacrobosco. In Tratados de astronomía. mss/3385, fols. 189r-99v. Biblioteca Nacional de Madrid, Spain.

\footnotetext{
${ }^{72}$ On the diffusion of diverse commentaries to Sacrobosco's Tractatus de Sphaera and the general relevance of it, see (Valleriani 2017; Crowther et al. 2015).
} 


\section{Primary Sources}

Bellanti, Lucio. 1498. Liber de astrologica veritate et In disputationes Ioannis Pici aduersus astrologos responsiones. Florence: Gherardus de Haerlem.

Ciruelo, Pedro. 1495a. Arithmetica speculativa Thome Bravardini bene revisa et correcta a Petro Sánchez Ciruelo Aragonensi mathematicas legente. Paris: Guy Marchand. (reprinted Paris, 1502).

1495b. Geometría speculativa Thome Bravardini. Paris: Jean Petit. (reprinted 1502, 1508, $1511,1530)$.

. 1495c. Tractatus Arithmeticae Practice qui dicitur algorismus. Paris: Guy Marchand. (reprinted 1502, 1505, 1509, 1513, 1514).

. 1498. Uberrimum sphere mundi comentum intersertis etiam questionibus domini Petri de Aliaco. Paris: Jean Petit. http://hdl.handle.net/21.11103/sphaera.100038 and http://hdl.handle. net/21.11103/sphaera.100274.

. 1508. Uberrimum Sphere mundi commentum. Johannis de sacro busto anglici, una cum textualibus optimisque additionibus ac uberrimo commentario Petri Ciruelli; intersertis etiam questionibus domini Petri de Aliaco. Paris: Jean Petit. http://hdl.handle.net/21.11103/ sphaera.100642.

- 1515. Habes lector Iohannis de sacro busto sphere textum una cum additionibus non aspernandis Petri Ciruelli. D. Paris: Jean Petit. http://hdl.handle.net/21.11103/sphaera.100988.

— 1516. Cursus quattuor mathematicarum artium liberalium. Alcalá: Arnaldo Guillén Brocar. This work was reprinted in Alcalá in 1526 and 1528.

- 1519. Prima pars logices ad veriores sensus textus Aristotelis. Alcalá: Arnaldo Guillén Brocar.

1521. Apotelesmata astrologiae Christianae. Alcalá de Henares: Juan de Eguía.

1526. Opusculum de sphera mundi Joannis de sacro busto: cum additionibus: et familiarissimo commentario Petri Ciruelli Darocensis: nunc recenter correctis a suo autore: intersertis etiam egregijs questionibus domini Petri de Aliaco. Alcalá de Henares: Miguel de Eguía. http:// hdl.handle.net/21.11103/sphaera.100884.

- 1528. In Posteriora analytica commentarius. Alcalá: Miguel de Eguía. (two new editions in 1529).

- 1551. Reprobación de supersticiones y hechicerías. Medina del Campo: Guillermo de Millis.

Le Kalendrier des bergers. 1493. Paris: Guy Marchant.

Nifo, Agostino. 1513. Ad Apotelesmata Ptolomaei eruditiones. Naples: P.M. De Richis.

Pontano, Giovanni. 1512. De rebus coelestibus. Naples: Sigismundus Mayr.

Savonarola, Girolamo. 1496. Revelatio de tribulationibus nostrorum temporum. Paris: Guy Marchant.

\section{Secondary Literature}

Akopyan, Ovanes. 2017. Controversies on astrology in Renaissance Italy (late 15th-early 16th centuries). PhD Thesis. University of Warwick.

Albares Albares, Roberto. 1996. El humanismo científico de Pedro Ciruelo. In La Universidad Complutense Cisneriana. Impulso filosófico, científico y literario, ed. Luis Jiménez Moreno, 177-205. Madrid: Editorial Complutense.

Albertson, David. 2014. Mathematical theologies: Nicholas of Cusa and the legacy of Thierry of Chartres. Oxford: Oxford University Press.

Almási, Gábor. (2014). Rethinking Sixteenth-Century 'Lutheran Astronomy'. Intellectual History Review 24 (1): 5-20. 
Axworthy, Angela. 2009. The epistemological foundations of the propaedeutic status of mathematics according to the epistolary and prefatory writings of Oronce Finé. In The worlds of Oronce Fine. Mathematics, instruments and print in Renaissance France, ed. A. Marr, 31-51. Donington: S. Tyas.

- 2016. Le Mathématicien renaissant et son savoir. Le statut des mathématiques selon Oronce Fine. Classiques Garnier.

Ayala, Jorge M. 1993. El Maestro Darocense Pedro Sánchez Ciruelo. Aragón en la Edad Media 10-11:85-99. Zaragoza: Universidad de Zaragoza.

Barker, Peter. 2011. The reality of Peurbach's orbs: Cosmological continuity in fifteenth and sixteenth century astronomy. In Change and continuity in early modern cosmology, ed. Patrick J. Boner, 7-32. Heidelberg/London/New York: Springer.

Bataillon, Marcel. 1966. Erasmo y España. Madrid: Fondo de Cultura Económica. (French original: Erasme et l'Espagne. Recherches sur l'histoire spirituelle du XVIe siècle, first ed. 1937).

Beltrán de Heredia, Vicente. 1972. Cartulario de la Universidad de Salamanca. Salamanca: Universidad de Salamanca.

Biagioli, Mario. 1989. The social status of Italian mathematicians, 1450-1600. History of Science 27: 41-95.

-1993. Galileo courtier. The practice of science in the culture of absolutism. Chicago: The University of Chicago Press.

Blair, Ann, and Anthony Grafton. 1992. Reassessing humanism and science. Journal of the History of Ideas 53 (4): 535-540.

Boll, Franz. 1894. Studien über Claudius Ptolemaeus. Ein Beitrag zur Geschichte der griechischen Philosophie und Astrologie. Leipzig: Teubner.

Bouché-Leclercq, Auguste. 1899. L'astrologie grecque. Paris: E. Lerous.

Boudet, Jean-Patrice. 1988. Simon de Phares et l'astrologie a Lyon a la fin du XV siècle. In Lyon, cité de savants. Paris: Éditions du C.T.H.S.

—. 1994. Lire dans le ciel: la bibliothèque de Simon de Phares. Bruxelles: Centre d'Étude des Manuscrits.

. 1999. Le Recueil des plus célèbres astrologues de Simon de Phares. Paris: Champion.

Brown, Gary I. 1991. The evolution of the term 'mixed mathematics'. Journal of the History of ideas 52: 81-102.

Burgueño, Susana. 2009. Astronomia, filosofia y humanismo cientifico en Diego de Torres (14821496). Duererías, Analecta Philosophiae. Revista de Filosofía 1: 1-11.

Byrne, James S. 2006. A humanist history of mathematics? Regiomontanus's Padua oration in context. Journal of the History of Ideas 67 (1): 41-61.

Cajori, Florian. 1928. Ciruelo on the names arithmetical and geometrical proportions and progressions. ISIS 10: 363-366.

Calderon, Calixto. 1991. The 16th century Iberian Calculatores. Revista de la Unión Matemática Argentina 35: 245-258.

Caroti, Stefano. 2008. Le fonti medievali delle Disputationes adversus astrologiam divinatricem. In Nello specchio del cielo. Giovanni Pico della Mirandola e le Disputationes contro l'astrologia divinatoria, ed. Marco Bertozzi, 67-93. Florence: Leo S. Olschki.

Celenza, Christopher S. 2004. The lost Italian Renaissance: Humanists, historians, and Latin's legacy. Baltimore: Johns Hopkins University Press.

Cozzoli, Daniele. 2007. Alessandro Piccolomini and the certitude of mathematics. History and Philosophy of Logic 28: 151-171.

Crombie, A.C., and J.D. North. 1970. Roger Bacon. In Dictionary of scientific biography, ed. Ch. Gillispie, vol. I, 377-385. New York: Charles Scribner's Sons.

Crowther, Kathleen, Ashley Nicole McCray, Leila McNeill, Amy Rodgers, and Blair Stein. 2015. The book everybody read: Vernacular translations of Sacrobosco's Sphere in the sixteenth century. Journal for the History of Astronomy 46 (1): 4-28.

Crowther-Heyck, Kathleen. 2003. Wonderful secrets of nature. Natural knowledge and religious piety in reformation Germany. ISIS 94: 253-273. 
De Pace, Anna. 1993. Le matematiche e il mondo: ricerche su un dibattito in Italia nella seconda metà del cinquecento. Milan: Franco Angeli.

Dear, Peter. 1995. Discipline and experience: The mathematical way in the scientific revolution. Chicago: The University of Chicago Press.

- 2001. Revolutionizing the sciences: European knowledge and its ambitions, 1500-1700. Basingstoke: Palgrave.

Desantis, G. 1986. Pico, Pontano e la polemica astrologica. Annali Della Facoltà di Lettere e Filosofia 29: 155-192.

Ebersole, A.V. 1962. Pedro Ciruelo y su Reprobación de hechicerías. Nueva Revista de Filología Hispánica 3/4: 430-437.

Elie, Hubert. 1950-1951. Quelques Maitres de l'université de Paris vers l'an 1500. Archives d'histoire doctrinale et littéraire du Moyen Âge 18: 193-243.

Engammare, Max. 2008. Calendrier des bergers, préface de Max Engammare. Paris: PUF, collection Sources, Fondation Martin Bodmer.

Ernst, Germana. 1991a. Astrology, religion and politics in counter-reformation Rome. In Science, culture and popular belief in Renaissance Europe, ed. S. Pumfrey, P. Rossi, and M. Slawinski, 249-273. Manchester/New York: Manchester University Press.

- 1991b. Religione, ragione e natura. Ricerche su Tommaso Campanella nel tardo Rinascimento. Milan: Franco Angeli.

2001. Veritatis amor dulcissimus: Aspects of Cardano's astrology. In Secrets of nature. Astrology and alchemy in early modern Europe, ed. W. Newman and A. Grafton, 39-68. Cambridge, MA/London: MIT Press.

Faracovi, Ornella Pompeo. 2008a. In difesa dell'astrologia: risposte a Pico in Bellanti e Pontano. In Nello specchio del cielo. Giovanni Pico della Mirandola e le Disputationes contro l'astrologia divinatoria, ed. Marco Bertozzi, 47-66. Firenze: Olschki.

- 2008b. La riforma dell'astrologia, in Il Rinascimento italiano e l'Europa, eds. G.L. Fontana and L. Molà, vol. V, Le scienze, eds. A. Clericuzio, G. Ernst, and M. Conforti, 59-71. Treviso-Costabissara.

- ed. 2012a. Lo Specchio Alto: astrologia e filosofia fra Medioevo e prima età moderna. Pisa: F. Serra.

- 2012b. La polemica antiastrologica di Giovanni Pico della Mirandola. In Il linguaggio dei cieli. Astri e simboli nel Rinascimento, ed. Germana Ernst and Guido Giglioni, 91-107. Rome: Carocci.

Flórez Miguel, Cirilo, Pablo García Castillo, and Roberto Albares Albares. 1988. El humanismo científico. Salamanca: Caja de Ahorros.

-1989. La ciencia del cielo: astrología y filosofía natural en la Universidad de Salamanca. Salamanca: Caja de Ahorros.

- 1990. Pedro S. Ciruelo: Una enciclopedia humanista del saber. Salamanca: Caja de Ahorros.

Fubini, Ricardo. 2001. L'umanesimo italiano e i suoi storici: Origini rinascimentali-critica moderna. Milan: Franco Angeli.

2006. Humanism and scholasticism: toward an historical definition. In Interpretations of renaissance humanism, ed. Angelo Mazzoco, 127-136. Leiden/Boston: Brill.

Gagné, J. 1969. Du quadrivium aux Scientiae Mediae. In Arts libéraux et philosophie au moyen âge, 975-986. Paris: Vrin.

Galle, Griet. 2003. Peter of Auvergne, questions on Aristotle's De Caelo-A critical edition with an interpretative essay. Leuven: Leuven University Press.

Gómez Martínez, Marta. 2006. Sacrobosco en castellano. Salamanca, Ediciones Universidad de Salamanca.

Gómez Sierra, Esther. 1999. Home and away in Paris: Pedro Sánchez Ciruelo and his Disputatorius dyalogus. In Latin and vernacular in Renaissance Spain, ed. Barry Taylor and Alejandro Coroleu, 83-104. Manchester: Manchester Spanish and Portuguese Studies, Cañada Blanch Centre for Advanced Hispanic Studies. 
2000. Pedagogia y amicitia. Los dialogos latinos de Pedro Ciruelo. In Actas del VIII Congreso de la Asociación Hispánica de Literatura Medieval, ed. M. Freixas and S. Iriso, 843-856. Santander: Asociación Hispánica de Cultura Medieval.

Goulding, R. 2006. Histories of science in early modern Europe. Introduction. Journal of the History of Ideas 67 (1): 33-40.

Grafton, Anthony. 1991. Defenders of the text: The traditions of scholarship in an age of science. Cambridge, MA: Harvard University Press.

1992. Kepler as a reader. Journal of the History of Ideas 53 (4): 561-572.

1997. From Apotheosis to Analysis: Some Late Renaissance Histories of Classical Astronomy. In History and the Disciplines: The Reclassification of Knowledge in Early Modern Europe, ed. Donald R. Kelley. Rochester, 261-76. New York: University of Rochester Press.

. 1999. Cardano's cosmos. The worlds and works of a Renaissance astrologer. Cambridge, MA: Harvard University Press.

Grant, Edward. 1996. Planets, stars, and orbs: The Medieval cosmos, 1200-1687. Cambridge: Cambridge University Press.

Grendler, Paul. 2002. The Italian Renaissance in the past seventy years: Humanism, social history, and early modern in Anglo-American and Italian scholarship. In The Italian Renaissance in the twentieth century, ed. Allen J. Grieco, Michael Rocke, and Fiorella Gioffredi Superbi, 3-24. Florence: Olschki.

Homza, Lou Ann. 1992. Religious humanism, pastoral reform and the Pentateuch in early modern Spain. Pedro Ciruelo's journey from grace to law. PhD Thesis, University of Chicago.

. 1997. Erasmus Hero or heretic Spanish Humanism and the Valladolid assembly of 1527. Renaissance Quarterly 50: 78-118.

. 2000. Religious authority in the Spanish Renaissance. Baltimore/London: The Johns Hopkins University Press.

Jardine, Nicholas. 1984. The birth of history and philosophy of science: Kepler's 'a defence of Tycho against Ursus' with essays on its provenance and significance. Cambridge: Cambridge University Press.

1988. Epistemology of the sciences. In The Cambridge history of Renaissance philosophy, ed. C.B. Schmitt, Q. Skinner, E. Kessler, and J. Kraye, 685-711. Cambridge: Cambridge University Press.

- 1998. The places of astronomy in early modern culture. Journal for the History of Astronomy 29: 49-62.

Kirwan, Richard, ed. 2016. Scholarly self-fashioning and community in the early modern university. London/New York: Routledge.

Laird, W.R. 2016. Galileo and the mixed sciences. In Method and order in Renaissance philosophy of nature: The Aristotle commentary tradition, ed. Daniel A. di Liscia and Eckhard Kessler, 253-270. London: Routledge.

Lanuza Navarro, Tayra M.C. 2017. Astrology in court: The Spanish inquisition, authority, and expertise. History of Science 55 (2): 187-209.

Latassa Ortiz, Félix. 1798. Biblioteca nueva de los escritores aragoneses que florecieron desde el año de 1500 hasta 1599. Pamplona: J. Domingo.

Lorente Pérez, J.M. 1921. Biografía y análisis de las obras de matemática pura de Pedro Sánchez Ciruelo. Madrid: Junta para la Ampliación de Estudios.

Mancosu, P. 1992. Aristotelian logic and Euclidean mathematics: Seventeenth-century developments of the Quaestio de Certitudine Mathematicarum. Studies in History and Philosophy of Science 23 (2): 241-265.

- 1996. Philosophy of mathematics and mathematical practice in the seventeenth century. New York/Oxford: Oxford University Press. 
Mandosio, Jean-Marc. 1994. Entre mathématiques et physique: Note sur les 'sciences intermédiaires' à la Renaissance. In Comprendre et maitriser la nature au Moyen Age: Mélanges d'histoire des sciences offerts à Guy Beaujouan, 115-138. Geneve: Droz.

Marr, Alexander, ed. 2009. The worlds of Oronce Fine. Mathematics, instruments and print in Renaissance France. Donington: Shaun Tyas.

Martins, Roberto de Andrade. 2003. Las Fuentes Literarias del Tratado de la esfera de Sacrobosco. In Epistemología e Historia de la Ciencia. Selección de Trabajos de las XIII Jornadas, ed. Víctor Rodríguez and Luis Salvatico, 307-314. Córdoba: Universidad Nacional de Córdoba.

Mateo Ripoll, Verónica. 2002. Sobre una edición ignota de la Reprobación de supersticiones del maestro Ciruelo. Dynamis 22: 437-459.

Mateos Royo, J.A. 1997. Sobre tasas y monedas, ferias y usuras: municipio y mercado en Daroca bajo Juan II y Fernando el Católico (1459-1516). Aragón en la Edad Media 13: 195-216.

- 2002. Municipio y enseñanza pública en Aragón: la escuela de Gramática de Daroca (ss. XVI-XVII). Revista de Historia Moderna 20: 117-148.

Mazzoco, Angelo, ed. 2006a. Interpretations of Renaissance humanism. Leiden/Boston: Brill. . 2006b. Kristeller and the vernacular. In Kristeller reconsidered: Essays on his life and scholarship, ed. John Monfasani, 176-177. New York: Italica Press.

McKirahan, Richard D. 1978. Aristotle's subordinate sciences. The British Journal for the History of Science 11: 197-220.

Molland, George. 1997. Roger Bacon's De laudibus mathematicae. A preliminary study. In Texts and contexts in ancient and Medieval science, ed. Edith Sylla and Michael McVaugh, 68-83. Leiden: Brill.

Moyer, Ann E. 2014. The quadrivium and the decline of Boethian influence. In A companion to Boethius in the Middle Ages, ed. Noel H. Kaylor and Philip E. Phillips, 479-517. Leiden: Brill.

Muñoz Delgado, Vicente. 1964. La lógica nominalista en la Universidad de Salamanca (1510 1530). Madrid: Publicaciones del Monasterio de Poyo.

. 1966. La lógica como scientia sermocinalis en la obra de Pedro Sánchez Ciruelo. Estudios

22: $23-52$.

- 1967. La lógica en Salamanca durante la primera mitad del siglo XVI. Salmanticensis 14: 171-207.

Navarro Brotons, Víctor. 1995. El renacimiento científico (siglo XVI) y la enseñanza de las disciplinas matemáticas en las universidades de Valencia y Salamanca. In II congreso internacional sobre historia de las universidades hispánicas, ed. Mariano Peset, 141-159. Valencia: Universitat de València.

- 1998. El Renacimiento científico (siglo XVI) y la enseñanza de las disciplinas matemáticas en las Universidades de Valencia y Salamanca. In Doctores y Escolares, ed. J.L. Peset, vol. I, 141-159. Valencia: Universidad de Valencia.

. 2006. The teaching of the mathematical disciplines in sixteenth-century Spain. Science and Education 15: 209-233.

. 2014. Disciplinas, saberes y prácticas: Filosofía natural, matemáticas y astronomía en la sociedad española de la época moderna. Valencia: Universidad de Valencia.

Navarro Brotons, Víctor, Vicente L. Salavert Fabiani, Victoria Roselló Botey, and Víctor Darás Román. 1999. Bibliographia Physico-Mathematica Hispanica. Vol. I, 1475-1600. Valencia: Instituto de Historia de la Ciencia y Documentación 'López Piñero' Universitat de València-CSIC.

Noreña, Carlos G. 1975. Studies in Spanish renaissance thought. The Hague: M. Nijhoff.

North, John D. 2009. Types of inconsistency in the astrology of Ficino. In Christian Humanism, ed. A. McDonald et al., 281-302. Leiden: Brill.

Oosterhoff, Richard J. 2018. Making mathematical culture: University and print in the circle of Lefèvre d'Étaples. Oxford: Oxford University Press.

Pantin, Isabelle. 1987. La lettre de Melanchton a Simon Grynaeus: Avatars d'une défense de l'astrologie. In Divination et controverse religieuse en France au XVI siècle, ed. R. Aulotte, 85-101. Paris: École normale supérieure de jeunes filles. 
2013. Oronce Finé mathématicien et homme du livre: la pratique éditoriale comme moteur d'évolution. In Mise en forme des savoirs à la Renaissance. À la croisée des idées, des techniques et des publics, ed. Isabelle Pantin and Gérald Péoux, 19-50. Paris: Armand Colin.

Picatoste Rodríguez, F. 1891. Apuntes para una biblioteca científica española del siglo XVI. Madrid: Tello.

Plessis d'Argentré, Charles Du. 1724. Collectio judiciorum de novis erroribus. Vol. I. Paris: Duchesne.

Popper, Nicholas. 2006. Abraham, Planter of Mathematics: Histories of mathematics and astrology in early modern Europe. Journal of the History of Ideas 67 (1): 86-106.

Rabin, Sheila. 1997. Kepler's attitude toward Pico and the anti-astrology polemic. Renaissance Quarterly 50 (3): 750-770.

Rey Pastor, Julio. 1926. Los matemáticos españoles del siglo XVI. Toledo: A. Medina.

Ribeiro do Nascimento, C.A. 1974. Le statut épistémologique des "sciences intermédiaires" selon S. Thomas d Aquin. Cahiers d'Etudes d'Études Médiévales 2: 33-95.

Rinaldi, Michele. 2002. Sic itur ad astra. Giovanni Pontano e la sua opera astrologica nel quadro della tradizione manoscritta della Mathesis di Giulio Firmico Materno. Naples: Loffredo.

Rodrigo Esteban, María Luz. 1999. La ciudad de Daroca a fines de la Edad Media. Selección documental (1328-1526). Daroca: Centro de Estudios Darocenses/Institución Fernando el Católico.

- 2004. Pedro Sánchez Ciruelo y el estudio general de Artes de Daroca. El Ruejo 5: 139-156.

Rodríguez Vidal, R. 1981. Pedro Ciruelo. Darocense (Un intelectual ejemplar). Zaragoza: Institución Fernando el Católico/CSIC.

Serrano Montalvo, Antonio. 1995-1997. La población de Aragón según el Fogaje de 1495. Zaragoza: Institución Fernando el Católico/ Instituto Aragonés de Estadística.

Smoller, Laura A. 1994. History, prophecy, and the stars: The Christian astrology of Pierre D'Ailly, 1350-1420. Princeton, NJ: Princeton University Press.

Tausiet Carles, María. 1992. Religión, ciencia y superstición en Pedro Ciruelo y Martín de Castañega. Revista de Historia Jerónimo Zurita 65-66: 139-147.

Thorndike, Lynn. 1934. A history of magic and experimental science. Vol. IV. New York: Columbia University Press.

- 1941. A history of magic and experimental science. Vol. V. New York: Columbia University Press.

- 1949. The Sphere of Sacrobosco and its commentators. Chicago: The University of Chicago Press.

Thorndike, Lynn, and Pearl Kibre. 1963. A Catalogue of Incipits of Mediaeval Scientific Writings in Latin. Rev. and augm. London: Mediaeval Academy of America.

Valle, Carlos del. 1999. Un poema hebreo de Alfonso de Zamora en alabanza de la versión latina bíblica de Pedro Ciruelo. Sefarad 59 (2): 419-437.

Valleriani, Matteo. 2017. The tracts on the Sphere: Knowledge restructured over a network. In The structures of practical knowledge, ed. Matteo Valleriani, 421-473. Dordrecht: Springer.

Vanden Broecke, Steven. 2003. The limits of influence. Pico, Louvain and the crisis of Renaissance astrology. Leiden/Boston: Brill.

- 2016. From cosmic governance to governmentality: Shaping subulunary order in seventeenth century French critiques of astrology. In Unifying heavens and earth: Essays in the history of early modern cosmology, ed. M.A. Granada, P.J. Boner, and D. Tessicini, 317-342. Barcelona: Universitat de Barcelona.

Vasoli, Cesare. 2008. La polemica antiastrologica di Giovanni Pico. In Nello specchio del cielo. Giovanni Pico della Mirandola e le Disputationes contro l'astrologia divinatoria, ed. Marco Bertozzi, 1-18. Firenze: Olschki.

Villoslada, R.G. 1938. La Universidad de Paris durante los estudios de Francisco de Vitoria, O.P. (1507-1522). Roma: Università Gregoriana.

Voss, Angela. 1998. The music of the spheres: Marsilio Ficino and Renaissance harmonia. Culture and Cosmos 2 (2): 16-38. 
Walker, D.P. 1958. Spiritual and demonic magic. From Ficino to Campanella. London: Warburg Institute.

Wallace, William A. 1969. The Calculatores in early sixteenth-century physics. British Journal for the History of Science 4: 221-232.

. 1981. Chapter. 5: The Calculatores in the sixteenth century. In Prelude to Galileo. Essays on Medieval and sixteenth century sources of Galileo's thought, 78-90. Dordrecht: Reidel.

Westman, Robert S. 1980. The astronomer's role in the sixteenth century: A preliminary study. History of Science 18: 105-147.

- 2011. The Copernican question. Prognostication, skepticism, and celestial order. Berkeley/Los Angeles: University of California Press.

- 2016. Copernicus and the astrologers: Dibner library lecture, December 12, 2013. Washington, DC: Smithsonian Libraries.

Wilkinson, Alexander S. 2010. Iberian books: Books published in Spanish or Portuguese or on the Iberian Peninsula before 1601. Leiden/Boston: Brill.

Zambelli, Paola, ed. 1986. Astrology Hallucinati: Stars and the end of the world in Luther's time. Berlin: W. de Gruyter.

- 1992. The Speculum astronomiae and its enigma: Astrology, theology, and science in Albertus Magnus and his contemporaries. Dordrecht/Boston: Kluwer.

1994. Una reincarnazione di Pico ai tempi di Pomponazzi. Milan: Il Polifilo.

Zamora Calvo, M.J. 2008. Ciruelo y sus juicios contra la superstición. In La fractura historiográfica: las investigaciones de Edad Media y Renacimiento desde el Tercer Milenio, ed. Javier San José Lera et al., 781-797. Salamanca: Seminario de Estudios Medievales y Renacentistas.

Open Access This chapter is licensed under the terms of the Creative Commons Attribution 4.0 International License (http://creativecommons.org/licenses/by/4.0/), which permits use, sharing, adaptation, distribution and reproduction in any medium or format, as long as you give appropriate credit to the original author(s) and the source, provide a link to the Creative Commons license and indicate if changes were made.

The images or other third party material in this chapter are included in the chapter's Creative Commons license, unless indicated otherwise in a credit line to the material. If material is not included in the chapter's Creative Commons license and your intended use is not permitted by statutory regulation or exceeds the permitted use, you will need to obtain permission directly from the copyright holder.

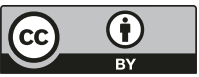




\title{
Chapter 4 \\ Francesco Capuano di Manfredonia
}

\author{
Elio Nenci
}

\begin{abstract}
One of the most important commentaries on Sacrobosco's Tractatus de sphaera was written by Francesco Capuano da Manfredonia and printed toward the end of the year 1499 in Venice. Capuano was professor of Astronomy at Padua and had already published a commentary on Peuerbach's Theoricae planetarum in 1495. He subsequently entered into the ranks of the Lateran Canons Regular, taking the name Giovanni Battista. Later editions of his commentary on Sacrobosco's Tractatus (Venezia, 1518 and 1531) were published under the name Giovanni Battista Capuano and contain a revisited text of that work. The two different redactions of the commentary on the Sphaera allow us to illustrate the radical transformation the text underwent. The two redactions of the prologue that opens the commentary are compared.
\end{abstract}

\section{Introduction}

Francesco Capuano, the author of some important commentaries on Georg Peuerbach's (1423-1461) Theoricae novae planetarum and Johannes de Sacrobosco's (died 1256) Sphaera, is not well known. The dearth of information about his life makes it objectively difficult to reconstruct his scientific career in any detail. It might have been possible to remedy the situation through an analytical and wide-ranging study of his works, but no attempt to conduct such a comprehensive study has ever been conducted - it remains a desideratum. The present enquiry will offer a short discussion of what an investigation of this sort might lead to.

In order to meet this goal, I will focus my enquiry on the text devoted to Sacrobosco's Sphaera. Moreover, I will not be taking specific passages from this medieval author's work into account, but will rather concentrate on the question of the philosophical and scientific status of astronomy, which Capuano discusses in the prologue to his commentary. While this topic is not explicitly addressed in the

E. Nenci $(\bowtie)$

Università Statale di Milano, Milano, Italy

e-mail: elio.nenci@unimi.it 
Sphaera, it acquired a central importance for the many commentators on the text. First of all, it must be noted that in his work Sacrobosco systematically avoided investigating natural philosophical topics in depth, possibly in order to maintain the strict distinction between different disciplines adopted in medieval universities. However, this approach would appear to have been abandoned early on, with the rediscovery of Aristotle's (348-322 BCE) works on natural philosophy, and in particular with the increasingly detailed study of De coelo.

In the Expositio of the Sphaera attributed to Michael Scot (ca. 1175-ca. 1234), for instance, systematic use is made of Aristotle's works. Indeed, they are often used so extensively that the expositio takes the form of a genuine quaestio. Consider, for instance, the discussion about the 'elements,' which is only touched upon in Sacrobosco's text, but which here takes the form of a reassessment of the positions expressed on the topic by the Greek philosopher in his Metaphysics, Physics, De coelo, De generatione et corruptione, and Metereologica (Thorndike 1949, 247-342). On the other hand, the topics discussed in the various texts, particularly the Sphaera and De coelo, were so closely related that it was almost impossible to treat them separately. Thus, the discussion increasingly took the form of a unitary enquiry, which nonetheless implied an extensive reflection on the relations between the various branches of knowledge.

In the light of all this, I will attempt to identify the specific ways in which Capuano addressed the problem of the place of astronomy within the more general sphere of knowledge. The fact that two different redactions of the commentary on the Sphaera are available will allow me to illustrate the radical transformation the text underwent between the first draft of the prologue, which takes up just over a page in the editions known to us, and the second draft, which instead extends across no less than ten pages. I will argue that this significant change is a direct consequence of the author's choice to join a religious order: in doing so, he took it upon himself to justify the need to study astronomy, and at the same time to establish the limits of this discipline. His readership changed and, as we shall see, this significantly contributed to the greater extension and complexity of the second redaction of the prologue.

\section{Bibliographical Fragments}

Up until the 1880s, very little was known about our author, and even this limited information was wholly based on his printed works. We can get an idea of the status quaestionis at the time from a short contribution by Pietro Riccardi entitled Intorno ad alcune rare edizioni delle opere astronomiche di Francesco Capuano da Manfredonia, which was published in volume 14 of "Memorie dell'Accademia di Scienze, Lettere ed Arti di Modena" in 1874 (presented at the Accademia in 1871 and separately published there in 1873). Riccardi had systematically perused the previous literature, yet had failed to come up with any significant new information compared to what could be inferred from the frontispieces and dedications of the 
two printed texts. This was a purely bibliographical study, which regrettably relied for the most part on a single source, Gabriele Pennotto's Generalis totius sacri ordinis Clericorum Canonicorum historia tripartita (Rome, 1624), which provided an arbitrary date for Capuano's death. Riccardi wrote:

Bringing together the little information transmitted by these writers about his life and works, it seems possible to determine:

1. That Francesco Capuano was born in Manfredonia, probably in the first half of the fifteenth century, and died in Naples, according to Pennotto, around 1490, at the time of King Ferdinand of Aragon.

2. That in 1475 , and possibly for a few years, he practised astronomy and philosophy (as the natural and mathematical sciences were referred to at the time) at the famous University of Padua.

3. That he illustrated and commented on the treatises Sphaera by Sacrobosco and Theoricae Novae Planetarum by Georg von Peuerbach.

4. That later in his life he joined the order of the Lateran Canons Regular.

5. After becoming a man of the cloth he took the name Giovanni Battista in place of his given name Francesco. ${ }^{1}$

The dates drawn from Pennotto- and which de facto anticipated Capuano's scientific career by over one generation-ought to have struck Riccardi as questionable, had he paid more attention to the dates of publication of the works and the dedications they contained. Antonio Favaro realised as much and, by accessing the archives of Padua University, was able to set our author within the correct time frame. In a work entitled Le matematiche nello Studio di Padova dal principio del secolo XIV alla fine dl XVI (presented at the Accademia di Scienze, Lettere ed Arti di Padova in 1880 and published there in the same year), the great Galileo scholar pointed to the existence of a document attesting to Capuano's graduation in 1494 (Favaro 1880, 44-47). In the light of this, the mathematician could no longer be regarded as an author who suddenly burst upon the scene of astronomical studies in the late fifteenth century; rather, he was a young professor who in 1495 published his commentary on Peuerbach's Theoricae novae planetarum in Venice.

After these important findings, we must wait until 1974 to obtain more detailed information on the documents preserved in the Padua archives. That year, a work giving some room to Capuano was published by Paolo Sambin in "Quaderni per la storia dell'Università di Padova" under the title Professori di astronomia e matematica a Padova nell'ultimo decennio del Quattrocento. This contribution informs us that on the $6^{\text {th }}$ of November 1494 Francesco Capuano and another Apulian scholar, Girolamo Palmieri da Ostuni, had submitted a request for a reduction of the fees due

\footnotetext{
${ }^{1}$ (Riccardi 1873, 25-26): "Raccogliendo le scarse notizie lasciateci da questi scrittori intorno alla vita ed alle opere di lui, sembra potersi accertare: (1) che Francesco Capuano nacque in Manfredonia, probabilmente nella prima metà del secolo XV, e morì in Napoli, secondo il Pennotto, circa nel 1490, al tempo del Re Ferdinando d'Aragona. (2) che nel 1475, e forse per alcuni anni, professò l'astronomia e la filosofia (come solevansi allora chiamare le scienze fisicomatematiche) nel celebre studio di Padova. (3) che illustrò e commentò il trattato della Sfera del Sacrobosco e le Teoriche dei pianeti di Giorgio Peurbach o Purbach. (4) che nel seguito di sua vita abbracciò l'ordine dei Canonici regolari lateranensi. (5) che abbandonando il secolo assunse il nome di Giovanni Battista, in luogo del nome battesimale di Francesco."
} 
for their examination and proclamation ceremony. On account of their poverty and of the war being waged in their homeland, the two iuvenes requested that at least one of them be exempted from paying the fees. The request was granted (Sambin 1974, 63; Martellozzo Forin 2001, 1228-29). On the $12^{\text {th }}$ of November 1494 Capuano passed his tentativum in the arts and medicine, and was unanimously approved by his promotores, including Nicoletto Vernia and Pietro Trapolino, and, for medicine, Gabriele Zerbo (Sambin 1974, 63; Martellozzo Forin 2001, 1230). Trapolino and Zerbo bestowed the 'doctoral insignias' upon him during the ceremony held on the $15^{\text {th }}$ of November 1494 (Sambin 1974, 63-65; Martellozzo Forin 2001, 1231-32).

This information allows us to directly connect our author to the leading exponents of Aristotelianism in Padua in those years, giving us a clearer picture of the cultural context in which Capuano's early career unfolded.

Thanks to the publication of the Acta graduum academicorum Gymnasii Patavini ab anno 1471 ad annum 1500 in 2001, we are now in a position to trace this young scholar's career in even greater detail. On the $28^{\text {th }}$ of July 1492 "Franciscus Capuanus de Manfredonia, art. scholare" was a witness to the bestowal of a doctoral title in Padua (Martellozzo Forin 2001, 1098). The same role was played by "Franciscus Manfredonius," by now referred to as magister, on the $14^{\text {th }}$ of December 1493 (Martellozzo Forin 2001, 1174). In November 1494 he completed his studies, and then acted as a witness on at least five occasions between the $18^{\text {th }}$ of November 1494 and the $4^{\text {th }}$ of September 1495 (Martellozzo Forin 2001, 1263-64, 1268, 1272).

Unfortunately, after this date the documents from Padua are no longer helpful, so we are forced to turn to our old sources again, starting from Celso Rosini's Lyceum Lateranense (Cesena, 1649). The first volume of this work includes an extensive biography of Capuano, which to this day constitutes an unavoidable point of reference as regards his work within the schools of the Lateran Canons Regular in Padua and Naples. Unknown to Riccardi, but duly noted by Favaro, this biography does not provide any precise dates either for Capuano's entry into the ranks of the Canons Regular or his death. However, this biography would allow us to outline a provisional chronology, which would help us make sense of the information provided in the frontispieces and dedicatory letters prefacing Capuano's works, were it not that it too places the activity of the mathematician at 1475 , giving rise to quite a few problems of evaluation.

As already noted, the commentary on Peuerbach's Theoricae novae was published in Venice in 1495-to be more precise, in August of that year (Chap. 6). Both in his dedication to Ferdinand II of Naples and in the title of the work, Capuano states that he is a public professor of astronomy at Padua University. The same claim is to be found in the opening of the first edition of his commentary on Sacrobosco's Sphaera (Venice, 1499), which moreover includes a succinct dedication to Lorenzo Donato (Donà), “quaestor Patavinus," who attended many graduation ceremonies in the years 1495-1496 (Martellozzo Forin 2001, 1270, 1279, $1288,1329)$. The information included in the 1499 edition was reprinted in the edition of the commentary published in Venice in 1508, where it was featured as 
part of a collection of astronomical texts that also included Pierre d'Ailly's (ca. 1350-1420) Quaestiones subtilissimae on Sacrobosco's work and a Compendium sphaerae written by Robert Grosseteste (ca. 1175-1253).

In 1518 two almost identical collections of astronomical works were published in Venice, one by the heirs of Ottaviano Scoto, the other by Lucantonio Giunta (1457-1538), which also included the commentaries on the Theoricae novae and the Sphaera written by Lateran Canon Regular Giovanni Battista Capuano. The commentary on Sacrobosco's work featured a new dedication, addressed to the canons who were Capuano's pupils, and who had begged him to get back to work on the text he had already published. Capuano had agreed to meet this request despite his busy schedule and had substantially revised his commentary, removing certain parts, making some additions, and correcting the text here and there. ${ }^{2}$ This new redaction of the commentary, prefaced by the new dedication, was reprinted in Venice in 1531 as part of a large new collection of astronomical texts.

Based on the information provided so far, we might conclude that Capuano entered religious life between 1508 and 1518, yet the 1508 edition of his commentary might only be a reprint which was not up to date with regard to the author's new title and profession. This may be inferred from a passage inserted in the 1518 and 1531 editions, in which Capuano claims to have witnessed a lunar eclipse on the $15^{\text {th }}$ of August 1505, "with all the associates and fathers." ${ }^{3}$ Rosini's testimony might be helpful here to determine the exact date in which Capuano ceased to be a layman, even though, as already noted, the author of the Lyceum Lateranense pushes the date for Capuano's teaching career forward to about 1475. This source, then, is best approached with a degree of caution. Rosini claims that Capuano requested to join the Lateran Canons when these were holding their general chapter in Ravenna, and that he was told not to leave Padua but to wait in the monastery of San Giovanni in Verdara. According to Pennotto, general chapters were held in Ravenna in the years $1502,1511,1514$ and 1515 . At this stage, 1502 would appear to be the most likely date for Capuano's entrance into the Lateran Canons, although it should be noted that later on in his account Rosini appears to set this event in the year 1476 or thereabouts. He speaks of it as occurring roughly forty years after the donation of the church of San Giovanni in Verdara to the Canons, which was made by Cardinal Antonio Correr in 1436.

\footnotetext{
${ }^{2}$ In the new dedication, Sacrobosco-Capuano 1531, 57v, we read: "Exegistis a me singulari quadam cum instantia, venerabiles et optimi auditores, ut opus de Siderali disciplina (quam Astronomiam vocant) nova denuo impressione ad multorum cum voluptatem, tum institutionem reficiendum curarem....Ego etsi plurimis obruar negociis, simque adeo quot diebus in legendis lectionibus occupatus, ut mihi tempus ad vite commodum vix suppeditet, me tamen non invitum et vestra studia, et aegregia charitas in vos mea cogit, ut lubens vestris desideriis acquiescam....Vestri igitur gratia Siderale opus revidendum exactissime prius putavi, subinde ex eo plura quom variassem, depresissem, addidissem, castigatius illud atque emendatius iterato imprimendum tradidi, nomini dicato vestro."

${ }^{3}$ Shank 2009, 295) has used this chronological reference to date the whole revision of the text to 1505 ; in my view, this is a purely speculative inference.
} 
There is no need here to tackle these chronological problems any further. However, it should be noted that other difficulties of the same sort emerge in relation to other areas of Capuano's life. Let us keep to Rosini's information. He informs us that for roughly four years Capuano completely devoted himself to his religious training, after which time he reluctantly resumed his teaching work in the Paduan convent, where the more gifted clerics would be sent to study Aristotle's natural philosophy. Capuano apparently taught at San Giovanni in Verdara for twelve yearsfirst philosophy and then mathematics. In fact, he could even be regarded as having introduced mathematical studies into the schools of the Lateran Canons. After teaching in Padua, he moved to Naples, where he served as the abbot of San Pietro in Aram. Here he significantly increased the number of people attending the church and passed away at a ripe old age.

\section{The Venetian Collections of Astronomical Works Containing the Commentary on Sacrobosco's Sphaera Written by Francesco Capuano}

As we have seen, Capuano's work was often published together with other texts about the Sphaera in collections that were steadily enlarged over the years. Since its publication, then, the work was destined to be read in parallel to works of a very different nature and provenance. I will now provide a succinct outline of the most interesting features of the collections including Capuano's commentary, in such a way as to highlight their peculiarities, while at the same time noting the differences and similarities distinguishing the various approaches to Sacrobosco's text. I make no claim here to provide an exhaustive and complete exposition of all the texts featured in these collections. Still, it might be useful to present a chart listing the titles of the various works featured in the Venetian collections $(1499,1508,1518 \mathrm{a}, 1518 \mathrm{~b}$, 1531) alongside Sacrobosco's Sphaera and Georg Peuerbach's Theoricae novae planetarum:

\begin{tabular}{l|l}
\hline Commentaries on Sacrobosco's Sphaera \\
\hline Cecco d'Ascoli (Francesco Stabili), Commentarius & $1499,1518 \mathrm{a}, \mathrm{b}$ \\
\hline $\begin{array}{l}\text { Francesco [Giovanni Battista] Capuano, Commentarius o } \\
\text { Expositio }\end{array}$ & $\begin{array}{l}(1 \mathrm{ed} .): 1499,1508,(2 \mathrm{ed} .): \\
1518 \mathrm{a}, \mathrm{b}, 1531\end{array}$ \\
\hline $\begin{array}{l}\text { Jacques Lefèvre d'Étaples, Commentarius o Paraphrases et } \\
\text { annotationes }\end{array}$ & $1499,1508,1518 \mathrm{a}, \mathrm{b}, 1531$ \\
\hline Pierre d'Ailly, Quaestiones subtilissimae XIV & $1508,1518 \mathrm{a}, \mathrm{b}, 1531$ \\
\hline Bartolomeo Vespucci, Annotationes & 1508 \\
\hline Michael scot, Quaestiones o Expositio brevis et quaestiones & $1518 \mathrm{a}, \mathrm{b}, 1531$ \\
\hline Prosdocimo de' Beldomandi, Commentaria & 1531 \\
\hline
\end{tabular}




\begin{tabular}{l|l}
\hline Other works devoted to the Sphaera & $1508,1518 \mathrm{a}, \mathrm{b}, 1531$ \\
\hline Robert Grosseteste, Compendium or Tractatulus & $1518 \mathrm{a}, \mathrm{b}, 1531$ \\
\hline Campanus of Novara, Tractatus de Sphaera & $1518 \mathrm{a}, \mathrm{b}, 1531$ \\
\hline Campanus of Novara, Tractatus de sphaera solida & $1518 \mathrm{a}, \mathrm{b}$ \\
\hline Campanus of Novara, Tractatus de computo maiori & $1518 \mathrm{a}$ \\
\hline \begin{tabular}{l} 
Thebit ben Corat, De imaginatione Sphere \\
\hline Works devoted to the Theoricae planetarum
\end{tabular} & {$[1499], 1508,1518 \mathrm{a}, \mathrm{b}, 1531$} \\
\hline $\begin{array}{l}\text { Francesco [Giovanni Battista] Capuano, Expositio Theoricae } \\
\text { novae (Peuerbach) }\end{array}$ & $1508,1518 \mathrm{a}, \mathrm{b}, 1531$ \\
\hline $\begin{array}{l}\text { Johannes Regiomontanus, Disputatione contra cremonensia } \\
\text { deliramenta }\end{array}$ & $1518 \mathrm{a}, \mathrm{b}, 1531$ \\
\hline \begin{tabular}{l} 
Gerard [John sic!] of Cremona, Theorica Planetarum \\
\hline Al-Bițūjīi (Alpetragius), Theorica planetarum
\end{tabular} & 1531 \\
\hline Other works & $1518 \mathrm{a}, \mathrm{b}$ \\
\hline Theodosius of Bithynia, De spheris & $1518 \mathrm{a}, \mathrm{b}$ \\
\hline Ptolemy, De speculis &
\end{tabular}

The 1499 edition contained two works that were destined to accompany Capuano's text even in the later Venetian editions of 1508, 1518 and 1531: the commentary on Peuerbach's Theoricae novae written by Capuano himself and the commentary on Sacrobosco's work composed by Jacques Lefèvre d'Étaples (ca. 1455-1536) (Chap. 2).

In this first collection, Capuano's work was juxtaposed, although it might be more appropriate to say 'counterposed,' to the commentary on the Sphaera written by Cecco d'Ascoli (Francesco Stabili) (1257-1327), the author of an exposition steeped in astrological thought. It is worth recalling that this author had been brought to trial by the Inquisition precisely on account of certain statements based on astrology, first in Bologna in 1324 and then in Florence in 1327, when he was sentenced to death. ${ }^{4}$ Compared to this text, Capuano's commentary must have been perceived as a far more rigorous exposition, from both a philosophical and astronomical standpoint. In Capuano's work, Aristotle's texts on natural philosophy, Ptolemy's (ca. 100-ca. 170) Almagest and Al-Farghānī's (ca. 800-870) Compendium of the Science of the Stars serve as the basis for explicating Sacrobosco's work. Only very rarely are other sources mentioned. ${ }^{5}$ For instance, we only need to read the commentary on the final section of Book 1 of the Sphaera, concerning the measurement of the circumference and diameter of the Earth, to appreciate the difference between the two authors' approaches. Sacrobosco's text only presents the result of Eratosthenes' measurement, as transmitted by Macrobius's (ca. 385-430) commentary on the Somnium Scipionis, and then succinctly explains how it is possible to use

\footnotetext{
${ }^{4}$ On Cecco d'Ascoli's astronomical work, see (Weill-Parot 2007) and (Gottschall 2007).

${ }^{5}$ The Compendium of the Science of the Stars is one of the main sources for Sacrobosco's Sphaera. written around 833, it was translated into Latin in the twelfth century, later becoming a reference text for the study of Ptolemaic astronomy.
} 
an astrolabe to measure an arc of the terrestrial meridian coinciding with a degree of the celestial circumference. The author of the Sphaera therefore avoided using the different value given for the circumference of the Earth in Al-Farghānī's Compendium, thereby offering a highly simplified presentation of the whole question. Both commentators report the different measurement given in the work by the Arab author, but whereas Capuano dwells at length on the part concerning the astrolabe, directly drawing upon Ptolemy's Planisphaerium, Cecco d'Ascoli questions the relevance of this research. What truly matters for him is not "to know the quantity of the Earth," but "to learn the properties of the geographical regions" (scire proprietates situum) — which is to say the astrological properties that can be associated with each geographical area. In his view, the former kind of research is of little practical use, whereas the latter in some way allows one to attain true knowledge, which is to say "foreknowledge of future events" (ad praescientia futurorum).

The 1508 edition instead left out Cecco d'Ascoli's commentary, which was nonetheless newly included in the 1518 editions, while adding two works that continued to be present in later editions: the Compendium sphaerae written by Robert Grosseteste and especially Pierre d'Ailly's Quaestiones subtilissimae on Sacrobosco's work. These Quaestiones are highly relevant and make up a very interesting text, touching upon some of the most widely debated issues in basic medieval astronomy: e.g. the number of heavenly spheres, the variation of the inclination of the ecliptic, and whether eccentric orbits and epicycles are necessary in order to 'save the appearances of planetary motions' (Chap. 2).

In the 1518 editions, the Expositio of the Sphaera attributed to Michael Scot and Campanus of Novara's (ca. 1220-1296) Tractatus de sphaera made their appearance. To these works was added, in 1531, the important commentary on Sacrobosco's work written by Prosdocimo de' Beldomandi (ca. 1370-1428): a distinguished reader of mathematics at the University of Padua in the early fifteenth century and hence a predecessor of, and possible source for, Capuano. We will see how both these authors drew upon the tradition of Pietro d'Abano's (ca. 1250-ca. 1315), albeit independently from one another. ${ }^{6}$

\footnotetext{
${ }^{6}$ Pietro d'Abano, who has traditionally been regarded as the founder of so-called Paduan Aristotelianism, will here be considered only in relation to his astronomical and astrological work Lucidator dubitabilium astronomiae. Along with the Tractatus de motu octave spere, this work would appear to have enjoyed rather limited circulation, chiefly at a local level. What were far better known were his Conciliator differentiarum quae inter philosophos et medicos versantur and commentary on the pseudo-Aristotelian Problemata. On the figure of Pietro d'Abano and his importance for the Paduan philosophical tradition, see (Marangon 1977). It should be mentioned that Pietro d'Abano is also credited with some magical works.
} 


\section{The Commentary on Sacrobosco's Sphaera: A Comparative Analysis of the Two Redactions of the Prologue}

An analysis of Capuano's work allows us not just to compare two chronologically distant redactions of the same commentary but also to contextualize the textual changes made with reference to two clearly distinct readerships: on the one hand, the students in arts faculties; on the other, clerics belonging to a religious order that followed the rule of St Augustine. The former often learned astronomy as part of an educational programme that would eventually lead them to study medicine; the latter, who had no need for specific training in astronomy, apparently enjoyed a greater freedom of research, but de facto operated within a hierarchy of the various branches of learning that set specific limits to the scope of astronomical knowledge. We need only consider here the recurrent polemic against judicial astrology. In Capuano's university days, this significant branch of astronomy had harshly been criticized in the Disputationes adversus astrologiam divinatricem, composed by Giovanni Pico della Mirandola (1463-1494) in the years 1493-1494. ${ }^{7}$

What has just been stated emerges quite clearly from the two redactions of the prologue that opens the commentary. The text published in 1499 perfectly fits within an educational course based on the in-depth study of Aristotelian natural philosophy. The fundamental aspects of the logical-demonstrative thought at the basis of this philosophy are tacitly assumed, as they are approached separately as part of the same course of study. There is no need to prove the scientificity of astronomy: this is taken for granted, as is its place within the field of learning in general. Within this context, introducing actual exegetical practice is a secondary task, which in most cases takes the form of an almost rhetorical exercise.

In the first version of the prologue, the young layman Francesco Capuano only recalls what makes astrology a 'worthy' object of study. The dignitas and utilitas of the discipline are succinctly illustrated through a series of references that were to become standard. The first is to the opening section of Aristotle's De anima, where the philosopher sets out to explain how the greater or lesser dignity of a discipline

\footnotetext{
${ }^{7}$ Based on the assumption that the heavenly bodies exercise a crucial action, or influence, on terrestrial natural phenomena, astrologers would study the specific positions of the planets and constellations at a given time, or stretch of time, so as to the then offer their 'judgement' with regard to future events in the lives of individuals or even peoples. The position of the heavenly bodies at the time of a person's birth, or conception, constituted the basis for individual 'horoscopes,' whereas more general 'forecasts' were chiefly based on the positions of the furthest planets, which is to say those that took longer to run their course. Commonly used in medicine, this branch of astronomy was regarded as an important aid to diagnostic and therapeutic practices. Medieval Christian philosophers always sought to limit the scope of astrology, which, when taken at face value, could lead to a form of determinism that threatened to undermine the Christian faith. The defence of human free will and the affirmation of the existence of 'contingent' events that man cannot foresee were among the key topics in the polemic against astrology. For an overview of these issues in relation to the Renaissance, see (Hübner 2014; Federici Vescovini 2014).
} 
with respect to other disciplines may be determined in two ways: either on the basis of the importance and excellence of the object under investigation, or by reference to the degree of certainty of the demonstrations employed. The text strongly affirms that a kind of knowledge pertaining to 'nobler' objects is preferable, and this is once again proven by invoking the auctoritas of certain passages from De coelo, Metaphysica and De partibus animalium. It is better to know a little about 'nobler' things than to know a lot about 'baser' ones (Sacrobcosco and Capuano 1499, sign. [c Ir]).

Given this maxim, Capuano only needed to justify the greater nobility of celestial bodies compared to all others natural bodies, which was not a difficult task for an author operating within an Aristotelian framework. Hence Capuano chose to focus on a passage from Averroes' commentary on Book I of De coelo (comm. 22) which provided the required proof of nobility by emphasizing the mediating role of celestial bodies: connected not so much to the sublunary world, as to 'the eternal incorporeal being,' the circular motion of the heavens was regarded as that which ensured the action of the eternal principle in time. ${ }^{8}$ In the light of this passage, Capuano established a highly defined hierarchy of disciplines: astronomy lay above the natural sciences and mathematics, and just below theology. ${ }^{9}$ However, a different picture emerged when these disciplines were considered in relation to the degree of rigour marking the arguments used in related treatises: for according to this criterion, the highest degree of certainty was assigned to mathematical demonstrations and therefore-as Averroes himself had noted in his commentary on Book II of the Metaphysics (comm. 16) - astronomy could even be ranked above theology, and below mathematics alone (Aristotle and Averroes 1552, 17v). All these considerations combined definitely confirmed the nobility of astronomical knowledge.

If we instead move on to examine the second version of the prologue, which was produced several years later by the Lateran Canon Giovanni Battista Capuano, we note that the arguments made in the first redaction only serve as a brief introduction to some more extensive arguments developed according to the standard model of the medieval quaestio. The author asks himself: is astronomy a science? Is there a science of celestial bodies? If so, how should we rank astronomy vis-à-vis the other sciences? Finally, is astronomy a mathematical science?

\footnotetext{
${ }^{8}$ (Aristotles and Averroes 1550, 9v): “...et innuit per hoc ligamenta inter generabilia et incorruptibilia, et corpus ingenerabile et incorruptibile, et ligamentum istius corporis cum ente aeterno non corporeo; necessarium est, enim, ut sit corpus ingenerabile et incorruptibile, quod nunquam in suo substantia transmutatur, nisi tantum in loco, ita quod ipso transmutato semper in loco remanente, substantia non cessat agere alias mutationes paedictas in corporibus, quae sunt sub ipso; et etiam non cessat generare recipientia ista necessarium est, enim, ut inter principia aeterna et res generabiles sit ens talis modi; et si non esset ita, impossibile esset quod a principiis aeternis proveniret aliqua actio temporalis."

${ }^{9}$ (Sacrobcosco and Capuano 1499, sign. [c Ir]): "Quinimmo omnium generabilium et corruptibilium causa ex omnium sententia philosophorum, corpus coeleste inter omnia corpora praestantissimum est, qua de re astronomia excellit et mathematicas scientias et naturales disciplinas, minime autem divinam."
} 
Clearly, these are all issues that had played a far from marginal role in philosophical reflection for the past two centuries, and which Capuano developed with due adroitness by constantly referring to some of the most important authors in the medieval philosophical tradition: Robert Grosseteste, Albertus Magnus (ca. 1200-1280), and especially Thomas Aquinas (1225-1274). The need for a preliminary enquiry on the scientific status of astronomy would appear to be directly related to the new role acquired by Capuano within his order. As the first person to introduce the teaching of science among the Lateran Canons, he needed to define the nature of astronomical knowledge as rigorously as possible. Hence his constant use of Aristotle's Posterior Analytics, the reference text for anyone investigating the structure of the kind of demonstrative reasoning used in mathematical sciences. At the same time, however, Capuano was also aware that it would be impossible for the Church to accept any epistemological positions that might be seen to promote astrological determinism. The second draft of the prologue may be regarded as a wideranging discussion of such issues: an attempt by Capuano to strike a balance between these two requirements by drawing upon the medieval philosophical tradition.

Here I will only provide a schematic overview of what is stated at the beginning of the first quaestio (is astronomy a science?) in order to clarify the nature of the important additions made to the second redaction of the prologue. Capuano presents four arguments that would lead us to deny astronomy its status as a science.

1. Capuano notes that in Book I of De anima Aristotle affirms the need to know 'accidents' in order to build any scientific knowledge. Connected to sense organs, this kind of knowledge can only be very limited in the case of astronomy, which makes use of sight alone, directing it towards exceedingly distant bodies. If we then add the fact that the 'heavens' are only known through the imagination, we can only deny the possibility of the existence of a science of celestial bodies (Sacrobcosco and Capuano 1531, 58r).

2. The same conclusion can be reached by emphasizing the fact that astronomy assumes pieces of information that cannot directly be traced back to any sensory experience: for example, the existence of a movement of precession for the sphere of the fixed stars. No human being can observe such a movement, given that its perception requires an observer being at work for approximately a 100 years (Sacrobcosco and Capuano 1531, 58r-v).

3. Getting back to the role of the knowledge of 'accidents' for the establishment of a science, Capuano notes that any form of knowledge exclusively based on them cannot be regarded as scientific. This idea is drawn directly from Aristotle's exposition in Book I of the Posterior Analytics. But is astronomy not the knowledge of the positions, movements, magnitudes and shapes of celestial bodies? These are all 'accidents;' hence, according to this premiss too, we would have to deny the possibility of an astronomical science (Sacrobcosco and Capuano 1531, $58 \mathrm{v})$. 
4. Finally, again on the basis of the Posterior Analytics and of sacred theology, it is necessary to reject the claim to scientificity made for judicial astrology, an essential part of the discipline of astronomy. Theology proves the 'non-binding ' nature of the action exerted by the heavenly bodies on the lower world; but, according to Aristotle, scientific demonstration (i.e. demonstrative syllogisms) must rest on necessary premises; hence, it is impossible to uphold the scientificity of this branch of astronomy (Sacrobcosco and Capuano 1531, 58v).

As one would expect, Aristotle's work served as the main source for the supposed arguments against the scientificity of astronomy, but it also contained all the elements that might be used to refute such arguments, and to establish astronomy as a 'most noble science.' It was here that Capuano brought into play the exegetical work of the aforementioned philosophers, who had often sought to solve the 'apparent contradictions' riddling Aristotle's texts by identifying some additional distinctions.

As previously noted, one of the major innovations in this second redaction of the prologue is the widespread use of the Posterior analytics, which offered not just a complete general theory of mathematical demonstration, but also some important insights with regard to the so-called 'sciences subordinate to mathematics.' These included harmonics, optics, and astronomy. All these sciences studied particular natural phenomena on the basis of principles and demonstrations drawn from arithmetic and geometry. The mathematical disciplines were used to explain the cause of phenomena, to account for why they occurred, whereas it was left to the general science of physics to explain what they were.

In order to get an idea of the importance of the Aristotelian text, we can briefly consider the opening of Capuano's argument. Just after listing all the authors championing the scientificity of astronomy, he begins his discussion by setting out from Robert Grosseteste's commentary on the Posterior Analytics. According to our author, in his work the British philosopher has identified three different ways of knowing, from which three different types of science derive. One can know "propriissime, proprie et minus proprie." In the first case, one possesses 'propter quid' knowledge, the kind of knowledge on which science rests according to its strictest definition, since it derives its conclusions from immediate and necessary causes. In the second type of knowledge, one approaches something unknown through something known in two different ways: by setting out from either a cause or an effect; this type encompasses both 'propter quid' demonstrations and 'quia' ones. Finally, the last type of knowledge includes both that which can be known via demonstration and what can be known without it. With respect to the latter, this type of knowledge may also be seen to include the knowledge of principles. ${ }^{10}$

\footnotetext{
${ }^{10}$ (Sacrobcosco and Capuano 1531, 58v): "Quantum ad primum est sciendum quod cum a scientia denominetur scire, quot modis contingit scire, tot modus dicitur scientia, scire autem proprio modo contigit tripliciter, ut habetur a Linconiensi primo posteriorum, scilicet propriissime, proprie et minus proprie. Scire nanque propriissime est causam rei habere et quoniam illius est causa et non contigit aliter se habere, ut primo posteriorum; et tale scire dicitur propter quid. Scire autem
} 
Clearly, this approach might offer some interesting perspectives for a reinterpretation of some of the astronomical examples presented in the Posterior Analytics. Let us think of the issue of the scintillation of the fixed stars compared to the planets, discussed in I,13. Here the Greek philosopher had stressed the crucial need to distinguish between 'propter quid' demonstrations and 'quia' ones, particularly when operating within the same science: for it is possible to reach a correct conclusion on the basis not of the first cause but rather of what is known better. Thus the syllogism inferring the proximity of the planets from their lack of scintillation might be valid, but it is a 'quia' demonstration, which is not to be confused with the 'propter quid' conclusion, according to which it is the proximity of the planets that is the cause of their lack of scintillation. ${ }^{11}$

However, Capuano was not interested in exploring such cases in detail. Rather, he chose to embark on a lengthy and articulate discussion on the various forms of knowledge, starting from the distinction between practical and theoretical disciplines. The former depends on us and on our will, and can further be divided into active and factual disciplines - the latter dealing with what pertains to nature. Setting out from these initial distinctions, which have Book VI of Aristotle's Metaphysics as their point of reference, Capuano briefly outlines first the so-called artes mechanicae, and then grammar, logic and rhetoric, and finally ethics, economics and politics. The sciences springing from nature are instead divided according to their degree of abstraction through a process that starts with natural philosophy, continues with mathematics, and ends with metaphysics (Sacrobcosco and Capuano $1531,58 \mathrm{v}-59 \mathrm{r})$. The need to draw an exact distinction between astronomy and the natural sciences that emerges here is met within the framework of the notion of 'subordinate science' expounded in Book I of the Posterior Analytics. This is immediately connected to what Aristotle states in Book II of his Physics, where astron-

proprie est habere noticiam ignoti per aliquid notum sive illud sit causa sive effectus, et hoc scire est tam per demonstrationem propter quid quam quia. Scire vero minus proprie est cuiuscunque veritatis noticiam habere, vel per demonstrationem seu sine ea; et tale scire extenditur etiam ad cognitionem principiorum, quae accipitur sine discursu, primo et secundo posteriorum."

${ }^{11}$ (Aristotle and Tredennick 1960, An. Post., I, 13, 78a22-39): "Knowledge of a fact and knowledge of the reason for it differ when both fall under the same science, under several condition: (1) if the conclusion in not drawn from immediate premisses (for then the proximate cause is not contained in them, and knowledge of the reason depends upon the proximate cause); (2) if premisses are immediate, but is drawn not from the cause but from the more familiar of two convertible terms; for it may well be that of two reciprocally predicable terms that which is not the cause sometimes the more familiar, so that the demonstration will proceed by it; e.g. the proof that the planets are near because they do not twinkle. Let C stand for 'planets' B for'not twinkling,' and C for 'being near.' Then it is true to state B of $\mathrm{C}$; because the planets do not twinkle. But is also true to state $\mathrm{A}$ of $\mathrm{B}$; because that which does not twinkle is near (this may have been assumed either by induction or through sense-perception). The A must apply to $\mathrm{C}$; and so it has been proved that the planets are near. Thus this syllogism proves not the reason but the fact; for it is not because the planets do not twinkle that they are near, but because they are near that they do not twinkle." 
omy is regarded as an 'intermediate science' between natural philosophy and mathematics. ${ }^{12}$

At first sight, this might seem like one of the many treatments of the subject that were circulating in the Middle Ages. However, here and there in the text a more unusual source emerges, first in between the lines, and then explicitly in a rather lengthy passage. The source in question is Pietro d'Abano's Lucidator dubitabilium astronomiae, a work composed between 1303 and 1310 but only published in 1988 by Graziella Federici Vescovini. Up until now, the text has only been known in three manuscript copies from the Bibliothèque Nationale in Paris (lat. 2598), the Bibliothèque Universitaire de la Sorbone (lat. 581), and the Vatican Library (Pal. Lat. 1171) (Pietro d'Abano 1988, 44-47). A fourth copy had been preserved by manuscript lat. VI, 156 (2672) of the Biblioteca Marciana in Venice, but was at some stage removed from the codex. This last manuscript would have been the most important one for us, since it came from the library of San Giovanni in Verdara and hence must have been used by Capuano himself (Pietro d'Abano 1988, 47-48). ${ }^{13}$

The passages invoked in the prologue chiefly concern astrology and come from the differentia prima of the Lucidator, where Pietro d'Abano discusses precisely the question of the scientific status of astronomy-astrology. Is astrology, with everything it entails, a science? "An astrologia sit scientia cum eius appenditiis" is the question Pietro addresses - and it must be noted that throughout the introductory section of this differentia the terms 'astrology' and 'astronomy' are perfectly interchangeable. It is therefore with an explicitly critical intent that Pietro d'Abano mentions the position of those who infer the existence of two separate disciplines from the use of the two terms. Reason and etymology instead prove this distinction to be untenable. What we have is a single 'science,' whether it theoretically discusses planetary motions or operatively seeks to predict the 'effects' of these motions within the sublunary realm:

\footnotetext{
${ }^{12}$ (Sacrobcosco and Capuano 1531, 59r): "Secundum notandum est quod astrologia [i.e. astronomia] est scientia tractans de corporibus coelestibus partibus eorum et passionibus, et quia corpora coelestia sunt naturalia, ex quo meventur per se, id est non secundum accidens (secundo physicorum, textus 3) sequitur quod circa eadem corpora versatur physicus et astrologus [astronomus], quare patet cum astrologia [astronomia] accipiat considerationem vel subiectum a naturali, quod ei subalternata (primo posteriorum), quod intelligit Aristoteteles (secundo physicorum, textus 19) quando astronomiam dicit esse mediam inter naturalem et mathematicam."

${ }^{13}$ One might posit here an indirect knowledge of Pietro d'Abano's text, possibly via the work of Prosdocimo de' Beldomandi, the author of a commentary on the Sphaera that Capuano is likely to have been familiar with. However, the two quotes from Pietro d'Abano featured in Prosdocimo's work derive: 1) from the Conciliator (Sacrobosco and Capuano 1531, 7b; 2) from the Tractatus de motu octave spere (Sacrobosco and Capuano 1531, 11a). On the latter work, see G. Vescovini's edition in (Pietro d'Abano 1988, 347-65). In the light of this, it is possible to infer that Capuano directly drew upon the Lucidator.
} 
(Lucidator, 108,21-109,9) Propter primum sciendum quod quidam assignarunt differentiam inter astronomiam et astrologiam dicentes astronomiam fore illam que partem motus pertractat; astrologia autem que iudicia instruit.

Sed illud neque ratio construit, aut multorum usus persuadet: cum astronomia dicatur ab "astro" et "nomos," lex. Astrologia vero a "logos," ratio, sermo, vel logia, locutio, hoc autem indifferentia: similiter alterutrumque invenio in alterutra eius partem utramque proferri.

Est autem ea scientia quantitatum et motuum celestium corporum in se ac eorum effectibus universaliter considerativa. Ipsa enim metitur magnitudines celestes et ipsarum distantias, coniunctiones et figuras earumdem pertractans, motusque ipsarum coniecturans universales et singulares cuiuslibet astri, que scientia solet "de motibus"... appellari: que ipsius est ut theorica tacta, eo quod dicebatur quantitatum. Et reliqua applicatur etiam huius ad hec inferiora precise impressiones consequentes attendendo: que scientia iudicalis nominatur ex causis, velut practica.
(Capuano, Prologus,

Venezia 1531, 60r) Nota etiam quod aliqui ponunt differentiam inter theoricam et practicam non solo quae dicta est, sed etiam in nomine, nominantes theoricam quae est de motibus coelorum velocitate quantitate sphaerarum distantia situ aliisque passionibus eorum; astronomia ab astro et nomos quod est lex. Practica vero quae est de iudiciis causatis in his inferioribus, astrologia ab astro et logos quod est ratio sermo vel locutio.

Pietro d'Abano, therefore, disagrees with those who draw a clear-cut distinction between astronomy and astrology, regarding the former as a discipline devoted to the study of planetary motions and the latter as one focusing on the formulation of horoscopes and forecasts. From an etymological and terminological standpoint, this distinction is unfounded..$^{14}$ In Pietro's view it would be more correct to affirm the existence of a single science devoted to the study both of the motions of heavenly bodies and of their universal effects. No doubt, there is a mathematical side to this astronomy-astrology, which focuses on all the quantitative aspects of such 'motions.' This might be described as 'theory,' yet it can in no way be separated from the 'practice,' insofar as it is precisely on the basis of the results attained by the former that the latter is capable of foreseeing the consequences of celestial influences in the sublunary world.

It is evident that the medieval author's text has not just been substantially abridged, but also weakened in a way. Capuano downplays the author's staunch affirmation of the scientificity of judicial astrology, and would appear to stress the differences between the two branches of astronomy-astrology rather than their similarities - to the point of depriving etymological considerations of all probative force (Chap. 3). Be that as it may, Capuano also holds that judicial astrology is a knowledge worth pursuing, or even one necessary to practise medicine. Indeed, with regard to this point he fully agrees with Pietro d'Abano and the auctoritates he quotes, all of whom affirm that it is necessary for physicians to know astrology, for else they would be incapable of establishing the most suitable days for taking

\footnotetext{
${ }^{14}$ This part of Pietro d'Abano's argument falls within a debate that was first launched in the West by Isidore of Seville's Etymologiae (III,27), which sought to establish the essential difference between 'astronomia' and 'astrologia.'
} 
certain medications (Haly Abbas), or might even harm their patients-for instance, by executing a phlebotomy on a certain part of the body just when the moon finds itself in the corresponding sign (Centiloquium). ${ }^{15}$

(Lucidator, 130,25-131,6) Laudat

[Galenus] etiam non parum astronomiam in libro $D e$ pronosticatione secundum lunam sibi ascripto; ita cuiusmodi medicus est, qui astrologiam ignorat, nullus debet se in eius manus ponere....

Unde Haly Abbas, Theorice primo "eget quoque medicus astrologia, qua medicamentibus electis utitur et temporibus, quibus luna est, beatis et felicibus, contemperata planetis et sub competentibus figuris." Quare in Centiloquio: si quis purgatorium sumpserit luna existente cum Iove, operationis ispsius minuetur effectus, atque tangere ferro luna stante in illius membri signo horribile.
(Capuano, Prologus, Venezia 1531, 60v) Ideo consulit Galenus in libro De pronosticis: "Ut nullus se confidat in manus medici astrologiam ignorantis." Unde Haliabas "astrologia eget medicus, qua medicationibus utatur temporis letis, quibus luna beatis et foelicibus contemperata planetis, et sub competentibus figuris." Et Ptolomeus in Centiloquio declarat quam parum prosint medicamina temporibus incongruis exhibita, si quis purgatorium sumserit luna existente cum Iove, ipsius minuetur effectus, et per contrarium quam periculosum operari in corpore humano luna statu et situ non considerato "Tangere, inquit ibidem, membrum ferro luna existente in illius membro signo horribile."

The choice of an author so openly endorsing astrological knowledge might have caused quite a few problems to a man of the Church. This would have been especially true if differentia 1 of the Lucitador had been taken into account, as here a close connection is drawn between astrology and a whole range of magical practices that had already been condemned. While in the first quote Capuano had altered the nature of the text from his source, and while in the second quote he had somehow conformed to a common sensibility, the need remained for him to clearly establish the limits of this kind of knowledge. Some questions were unavoidable. What level of scientificity does judicial astrology possess? How compelling are its conclusions? Capuano answered these questions at the end of his quaestio, where he picked up the fourth argument developed against astrology. The 'non-binding' nature of the action of celestial bodies upon the lower world established by theology seemed to deny the possibility of astrology as defined by Aristotle in the Posterior Analytics. How could this impasse be solved?

One interesting insight could be found in Aquinas, who in article 5 of Quaestio 95 (part two, section two) of his Summa Theologiae had addressed the question of the legitimacy of astral divination. Here the question had been addressed chiefly by investigating the nature of the cause-effect relation and emphasizing the existence of 'effects' that escape heavenly causation: first of all, what occurs by accident, and

\footnotetext{
${ }^{15}$ Pietro d'Abano also discusses these issues in differentia 1 (Utrum medico sit necessarium alias scire speculationis scientias necne) of the Conciliator, where he enquires whether a physician needs to be familiar with other forms of scientific knowledge.
} 
then, even more notably, acts that derive from the exercising of free will. ${ }^{16}$ However, this was not the path that Capuano chose to follow in order to answer the abovementioned questions. Rather than focusing on the nature of the 'effects,' he turned his attention to the nature of the 'causes,' investigating in what way astrological predictions can be said to entail 'necessity.' In order to do so, he resorted to the concepts of 'partial cause' and 'conditional necessity,' ideas widely deployed in the theological field, at times precisely against the claim that astrology can predict the future. ${ }^{17}$ Arguably the most relevant point of reference here was once again Aquinas, who in article 6 of Quaestio 115 in the first part of the Summa had investigated precisely how the 'necessity' of the causation brought about by heavenly bodies was to be understood. Aquinas had noted that heavenly bodies cannot act on lower things, if not through the causes proper to the latter, and that, analogously, the disposition of matter, the distance from the place of the action and other possible conditions can prevent the achievement of an 'effect.' 18

I will not carry this enquiry any further, because I believe that what has been argued so far is enough to show the considerable importance of the issues discussed in this new redaction of the prologue. I will only focus on the example of the transformation of the text provided by the two passages drawn from Pietro d'Abano's Lucidator. It is worth recalling that Capuano did not develop an interest in this work by Pietro d'Abano within the context of any cultural and religious battle against astrology. After becoming a man of the cloth, Capuano found himself adopting a more nuanced stance with regard to this form of knowledge. The availability of the Lucidator, a text composed by one of the most distinguished representatives of the University of Padua, simply offered him a great opportunity to further enrich the

\footnotetext{
${ }^{16}$ (Aquinas 1947): "Now two kinds of effects escape the causality of heavenly bodies. In the first place all effects that occur accidentally, whether in human affairs or in the natural order.... In the second place, acts of the free-will, which is the faculty of will and reason, escape the causality of heavenly bodies." https://dhspriory.org/thomas/summa/SS/SS095.html\#SSQ95A5THEP1. Accessed June 2019.

${ }^{17}$ (Sacrobosco and Capuano 1531, 61r): "Ad quartum de effectibus provenientibus a motibus coelorum talem habemus scientiam, qualiter ab eis dependent; dependent autem ab eis non tanquam a causa totali sed partiali et..., dependet etiam a causis suis particularibus, praecipue materia, qua diversimode disposita possunt effectus illi impediri, ideo non sunt necessari, ideo pronosticantur non necessarii. Unde qualis necessitas est in eis, taliter etiam scintur, est nanque necessitas conditionata, quare et scientia conditionata, et conditionaliter etiam praedici debent." Duplices autem effectus subtrahuntur causalitati caelestium corporum. Primo quidem, omnes effectus per accidens contingentes, sive in rebus humanis sive in rebus naturalibus....Secundo autem, subtrahuntur causalitati caelestium corporum actus liberi arbitrii, quod est facultas voluntatis et rationis."

${ }^{18}$ (Aquinas 1947): "The heavenly bodies are causes of effects that take place here below, through the means of particular inferior causes, which can fail in their effects in the minority of cases. The power of a heavenly body is not infinite. Wherefore it requires a determinate disposition in matter, both as to local distance and as to other conditions, in order to produce its effect. Therefore as local distance hinders the effect of a heavenly body (for the sun has not the same effect in heat in Dacia as in Ethiopia); so the grossness of matter, its low or high temperature or other such disposition, can hinder the effect of a heavenly body." https://dhspriory.org/thomas/summa/FP/FP115. html\#FPQ115A3THEP1. Accessed June 2019.
} 
traditional discussion on the scientific status of astrology. Pietro d'Abano's work, however, also constituted a potential danger for its readers. For it not only affirmed the 'scientificity' of astrology in no ambiguous terms, but also offered a statement of 'faith' in the magical sciences. It seems most likely, therefore, that access to this book was carefully restricted.

To bring this brief analysis of the two prologues to a close, it may be argued that they provided a general outline of the kind of knowledge expounded in Sacrobosco's Sphaera. Their different approach, length and structure show that they were tailored to the needs and knowledge of the final readers of Capuano's commentary. Liberal arts students in early sixteenth century Padua simply needed to be able to correctly define the place of Sacrobosco's work within the conceptual framework of Aristotelian natural philosophy. The clerics from the Convent of San Giovanni in Verdara instead set out from different assumptions: what they needed was a preliminary definition of the scientific status of astronomy-astrology, an issue which was directly connected to that of the place of this discipline within the more general sphere of learning. This was a hierarchically ordered sphere, in which theology strictly limited the field of application of astrological prognostication, without excluding it completely from the field of knowledge. Once duly stripped of any claim to be 'binding,' astrological forecasts remained valuable; at times, as in the case of medicine, for instance, they could even be regarded as indispensable tools for correctly exercising activities of the utmost importance.

\section{References}

Aquinas, Thomas. 1947. The Summa Theologica. Trans. Fathers of the English Dominican Province, Benziger Bros. edition. https://dhspriory.org/thomas/summa/.

Aristotle, and Averroes. 1550. Aristotelis Stagiritae omnia quae extant opera, nunc primum selectis translationibus, collatisque cum graecis emendatissimis exemplaribus, margineis scholiis illustrata, et in novum ordinem digesta, Additis etiam nonnullis libris nunquam antea latinitate donatis, vol. 5, De coelo, De generatione et corruptione, Meteorologicorum, De plantis libri cum Averrois Cordubensis variis in eosdem commentariis. Venetiis: Iunctas.

Aristotle, and Averroes. 1552. Aristotelis Stagiritae omnia quae extant opera, nunc primum selectis translationibus, collatisque cum graecis emendatissimis exemplaribus, margineis scholiis illustrata, et in novum ordinem digesta, Additis etiam nonnullis libris nunquam antea latinitate donatis, vol. 8, Metaphysicorum XIIII cum Averrois Cordubensis in eosdem commentariis et epitome. Venetiis: Iunctas.

Aristotle, and Hugh Tredennick. 1960. Posterior analytics. Cambridge/London: Harvard University Press.

d'Abano, Pietro. 1988. Il Lucidator dubitabilium astronomiae di Pietro d'Abano, ed. Graziella Federici Vescovini. Padova: Programma e 1+1 Editori.

de Sacrobosco, Johannes, and Francesco Capuano. 1499. Sphera mundi cum tribus commentis nuper editis verum. Cicchi Esculani Francisci Capuani de Manfredonia Iacobi Fabri Stapulensis. Venetiis: Simonem Papiensem dictum Bivilaquam. http://hdl.handle.net/21.11103/ sphaera.100021.

de Sacrobosco, Johannes and Francesco Capuano. 1508. Nota eorum quae in hoc libro continentur: Oratio de laudibus astrologiae habita a Bartholomeo Vespucio florentino in almo Patavio 
gymnasio anno. 1506. Textus Sphaerae Ioannis de Sacro Busto. Expositio sphaerae...Francisci Capuani de Manfredonia. Annotationes nonnullae eiusdem Bartholomei Vespucii hinc inde intersertae. Iacobi Frabri [!] stapulensis Commentarii in eandem sphaeram. Reverendissimi domini Petri de Aliaco...in eandem quaestiones subtilissimae numero 14. Reverendissimi... Roberti linconiensis sphaerae compendium. Disputationes Ioannis de Regio Monte contra cremonensia deliramenta. Theoricarum novarum textus [Georgii Purbachii], cum expositione eiusdem Francisci Capuani omnia nuper diligentia summa emendate. Veneta: Ioannem Rubeum et Bernardinum fratres Vercellenses ad instantiam Iunctae de Iunctis florentini. http:// hdl.handle.net/21.11103/sphaera.100915.

. 1518a. Sphera cum commentis in hoc volumine contentis, videlicet: Cicchi Esculani cum textu; Expositio Ioannis Baptiste Capuani in eandem; Iacobi Fabri Stapulensis; Theodosii de Speris; Michaelis Scoti; Quaestiones Reverendissimi domini Petri de Aliaco etc.; Roberti Linchoniensis Compendium; Tractatus de Sphera solida; Tractatus de Sphera Campani; Tractatus de computo maiori eiusdem, Disputatio Ioannis de Monte Regio; Textus Theorice cum expositione Ioannis Baptiste Capuani; Ptolomeus de Speculis; Venetiis: Octaviani Scoti http://hdl.handle.net/21.11103/sphaera.101057.

- 1518b. Sphera mundi noviter recognita cum commentariis et authoribus in hoc volumine contentis videlicet Lichi [!] Eschulani cum textu Ioannis Baptiste Capuani Iacobi Fabri Stapulensis...Theorica planetarum Ioannis Cremonensis...quam in alijs hactenus impressis non reperies. Venetiis: Luceantonii de Giunta Florentini. http://hdl.handle.net/21.11103/ sphaera.100047.

- 1531. Spherae Tractatus Ioannis De Sacro Busto Anglici Viri Clariss. Gerardi Cremonensis Theoricae Planetarum Veteres. Georgii Purbachii Theoricae Planetarum Novae. Prosdocimi de Beldomando patavini super tractatu spharico commentaria...Ioannis Baptistae Capuani sipontini expositio in sphara et theoricis. Ioannis de Monteregio disputationes contra theoricas Gerardi...Alpetragii Arabi Theorica Planetarum nuperrime Latinis mandata literis a Calo Calonymos hebreo neapolitano, ubi nititur salvare apparentias in motibus Planetarum absq[ue] eccentricis et epicyclis. Venetiis: Luceantonii Iunte Florentini. http://hdl.handle. net/21.11103/sphaera.100999.

Favaro, Antonio. 1880. Le matematiche nello Studio di Padova dal principio del secolo XIV alla fine dl XVI. Padova: Tipografia G.B. Randi.

Federici Vescovini, Graziella. 2014. The theological debate. In A companion to astrology in the renaissance, ed. Brendan Dooley, 99-140. Leiden/Boston: Brill.

Gottschall, Dagmar. 2007. Cecco d'Ascoli e Corrado di Megenberg. In Cecco d'Ascoli. Cultura, scienza e politica nell'Italia del Trecento, Atti del convegno di studio svoltosi in occasione della XVII edizione del Premio internazionale Ascoli Piceno (Ascoli Piceno, Palazzo dei Capitani, 2-3 dicembre 200), ed. Antonio Rigon, 153-166. Roma: Istituto storico italiano per il Medioevo.

Hübner, Wofgang. 2014. The culture of astrology from ancient to renaissance. In A companion to astrology in the renaissance, ed. Brendan Dooley, 17-58. Leiden/Boston: Brill.

Marangon, Paolo. 1977. Alle origini dell'aristotelismo padovano. Padua: Antenore.

Martellozzo Forin, Elda. 2001. Acta Graduum Academicorum Gymnasii Patavini Ab Anno 1471 Ad Annum 1500. Padova: Antenore.

Pennotto, Gabriele. 1624. Generalis totius Sacri Ordinis Clericorum Canonicorum Historia tripartita: cuius in prima parte De clericali Sanctissimi P. Augustini Instituto, et Habitu. In Secunda De origine, procursuq[ue] totius Ordinis Canonicorum Regularium. In Tertia De Congr. Canonic. Salvatoris Lateranensi locupletissime disseritur. Romae: Typographie Camerae Apostolicae.

Peuerbach, Georg. 1495. Theorice nove planetarum cum commento [Fraciscus Capuanus]. Venetiis: Simonem Bevilaqua.

Riccardi, Pietro. 1873. Intorno ad alcune rare edizioni delle opere astronomiche di Francesco Capuano da Manfredonia, Memorie dell'Accademia di Scienze, Lettere ed Arti di Modena. Vol. 14, 25-45. Modena: Luigi Gaddi. 
Rosini, Celso. 1649. Lyceum Lateranense Illustrium Scriptorum Sacri Apostolici Ordinis Clericorum Canonicorum Regularium Salvatoris Lateranensis Elogia. Cesenae: Nerii 1: 445-448.

Sambin, Paolo. 1974. Professori di astronomia e matematica a Padova nell'ultimo decennio del Quattrocento. Quaderni per la storia dell'Università di Padova 7: 59-67.

Shank, Michael H. 2009. Setting up Copernicus? Astronomy and natural philosophy in Giambattista Capuano da Manfredonia's Expositio on the Sphere. Early Science and Medicine 14: 290-315.

Thorndike, Lynn. 1949. The sphere of Sacrobosco and its commentators. Chicago: University of Chicago Press.

Weill-Parot, Nicolas. 2007. I demoni della Sfera: La "nigromanzia" cosmologico-astrologica di Cecco d'Ascoli. In Cecco d'Ascoli. Cultura, scienza e politica nell'Italia del Trecento, Atti del convegno di studio svoltosi in occasione della XVII edizione del Premio internazionale Ascoli Piceno (Ascoli Piceno, Palazzo dei Capitani, 2-3 dicembre 2005), ed. Antonio Rigon, 103-131. Roma: Istituto storico italiano per il Medioevo.

Open Access This chapter is licensed under the terms of the Creative Commons Attribution 4.0 International License (http://creativecommons.org/licenses/by/4.0/), which permits use, sharing, adaptation, distribution and reproduction in any medium or format, as long as you give appropriate credit to the original author(s) and the source, provide a link to the Creative Commons license and indicate if changes were made.

The images or other third party material in this chapter are included in the chapter's Creative Commons license, unless indicated otherwise in a credit line to the material. If material is not included in the chapter's Creative Commons license and your intended use is not permitted by statutory regulation or exceeds the permitted use, you will need to obtain permission directly from the copyright holder.

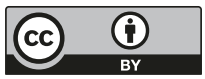




\title{
Chapter 5 \\ Conrad Tockler's Research Agenda
}

\author{
Matteo Valleriani and Nana Citron
}

\begin{abstract}
Conrad Tockler, alias Noricus, was a university professor in Leipzig at the beginning of the sixteenth century and Rector magnificus of the university from 1512 on. He was a physician adept at astrological medicine and was also a fairly skilled mathematician. His publication list begins in 1502 with a Libellus de sole, a commented reprint of Marsilius Ficinus's homonimous work. Tockler also authored two different commented editions of Johannes de Sacrobosco's Tractatus de sphaera. In his view, cosmological knowledge was directly connected with his medical activities via astrology.

The paper reconstructs the intellectual context in which Tockler was active with the aim to understand how much he can be considered innovative, or whether he was in truth a late expression of an already declining late Medieval knowledge system that unified astronomy, astrology, and medicine in form of a structure pivoted around cosmological knowledge.
\end{abstract}

\section{Introduction}

Conrad Tockler (1470-1530) was born in Nuremberg-for this reason he went by "Noricus" - and came from a well-to-do family. His first contact with the university took place at the age 13, when he matriculated at Leipzig (Erler 1895-1902, 1, 398), and he remained in this city until his death. In 1502, he earned the degree of Magister artium, and in 1510 he finished his medical studies. His shining moments

M. Valleriani ( $\triangle)$

Max Planck Institute for the History of Science, Berlin, Germany

Technische Universität Berlin, Berlin, Germany

University of Tel Aviv, Tel Aviv, Israel

e-mail: valleriani@mpiwg-berlin.de

N. Citron $(\bowtie)$

Max Planck Institute for the History of Science, Berlin, Germany

e-mail: ncitron@mpiwg-berlin.mpg.de 
arrived after graduation, first when he joined the faculty of medicine as a professor, and then when he was appointed Rector magnificus of the entire university in 1512. He had to leave the university in 1518, apparently because of drug abuse, but was finally re-admitted to the university as a professor under the aegis of Duke George of Saxony (1471-1539) (Kreussler 1810, 45; Grosse 1839, 1, 309). Upon his death, as he had no living heir, Tockler's possessions were confiscated by the Duke, who then opened a third chair for medicine - a chair in physiology alias theoretical medicine-by using the finances acquired from this confiscation. The chair was named in honor of the deceased professor: the Tockleriana (Doppelmayr 1730, 36; Schmidt-Thieme 2002). ${ }^{1}$ It remained operative at least until the eighteenth century (Rabl 1909, 2).

There is no encompassing bibliography of Tockler. ${ }^{2} \mathrm{He}$ authored quite a number of judicia, almanacs, and practica in Latin, German, and Czech. It is well known that most of these kinds of prints had a limited life and were mostly destroyed or their paper re-used once their dates of validity had passed. Tockler seems to have been particularly active in the production of these kinds of works, which testifies to the relevance of his public profile in the city of Leipzig, especially between 1503 and 1514. Besides this group of works, there are the textbooks produced for his intensive teaching activity at the university. These works, many of which remained unpublished, clearly show that the peaks of Tockler's intellectual production were concomitant with his two major career steps in 1503 and in 1510. Their content ranges from music to arithmetic and from optics to astronomy and cosmology. Tocker published a commentary on the Sphaera of Sacrobosco in 1503 and a second updated edition of the same in 1509 (de Sacrobosco et al. 1503, 1509). Outside these two major groups of works, a few other works seem to indicate Tockler's

${ }^{1}$ For the transcription of the decree that instituted the new chair, see (Freytag 1752-1753, 2, 1417-18).

${ }^{2}$ Many of Tockler's works remained unpublished. Nevertheless, they were preserved thanks to the decision of Duke George to confiscate all the possessions of Tockler. The Österreichische Nationabibliothek still possesses a collection under the title "Philosophische Sammelhandschrift," which is basically the main collection of Tockler's unpublished texts, which he was using for his lecturing. This collection contains: (a) Tockler's commentary on John Peckham's (1230-1292) Perspectiva communis with a short introduction (Tockler 1502-1506, 1r-37v), (b) further annotations of Tockler on Peckham's work (Tockler 1502-1506, 39r-52r), (c) Tockler's commentary on Georg von Peuerbach's Theorica planetarum with a short introduction to describe the different branches of mathematics (Tockler 1502-1506, 57r-120v), (d) a collection of 130 statements of astrological nature (Tockler 1502-1506, 121r-123v), (e) two variants of Jean de Murs's (12901351) Musica speculativa (Tockler 1502-1506, 124r-136r, 139r-154r). A further collection of manuscripts, entitled "Mathematische und astronomische Sammelhandschrift" and ascribed to the mathematician, astrologer, and famous publisher of many of Johannes Regiomontanus's works, Johannes Schöner (1477-1547), also contains texts and fragments of Conrad Tockler, most of which have not been analyzed in depth for the purpose of this work. Most of these texts are concerned with the theorica et practica of many types of solar clocks and further instruments as well as a short treatise on measuring volumes of barrels (arte visoria). For Tockler's texts with documents of Schöner inserted in-between, see (Schöner and Tockler 16th cent., 10r-51r). 
specific interests as well as further social aspects of his life. The first of these is the 1502 (Ficinus and Tockler 1502) printed edition of Marsilius Ficinus's (1433-1499) Librum de sole (Ficinus 1493). ${ }^{3}$ The second work that does not fit in well with the others is a collection of 130 astrological statements (Liber centium et triginta verborum in astrologica scientia probatorum) (Tockler 1502-1506, 121r-23v). This unpublished work, written in 1506, is dedicated to George, Duke of Saxony, a testimony to the social connection between the then university lecturer of mathematics and the court.

At first sight, mathematics, medicine, and astrology seem to be the knowledge domains within which Tockler defined his intellectual and social profile. After a closer look at his works, his research agenda as well its intellectual profile will be reconstructed in depth.

\section{Tockler's Reception of Marsilius Ficinus}

The humanist Marsilius Ficinus is well remembered for his important role in the process of re-vitalizing Platonic and neo-platonic ideas as a knowledge system consistent with the Christian theology of the early modern period. His philosophical system influenced culture, science, and natural philosophy for generations. As Paul Oskar Kristeller has clearly shown, Ficinus's metaphysic is supported by the ontological assumption that all ideas are symbolically represented by real objects. Thus, God is an archetype of the sun in the cosmos, and light is consequently not only a physical phenomenon but one that has a strong influence on both the material and spiritual aspects of human life (Kristeller 1972, 72-108). Less known is Ficinus's engagement in medicine. Certainly because of the persistent recurrence of the plague during the fifteenth century, Ficinus, against the background of his unifying vision of the cosmos, related cosmological and astronomical aspects to the quality of the air in the sublunar world-in his opinion, the ultimate cause of the plague. Although this idea was certainly spread long before Ficinus's work, it became a predominant medical explanation of the plague only once it was fully integrated into an allencompassing worldview. These medical ideas were first expressed in handwritten texts such as the Italian "Suggestions against the pestilence" (Ficino and Musacchio 1983) or the more famous De vita libri tres (Kaske and Clark 1989). It is very rare, however, to find such practical aspects of Ficinus's ideas directly associated with his philosophical and theological vision of the world. An exception to this rule is represented by De sole (Ficinus 1493), which, as a printed book, possibly experienced faster circulation. ${ }^{4}$ The book begins with the physical characteristics of the sun and its light: They warm up, they generate, and they cause motion. The argument then

\footnotetext{
${ }^{3}$ The work Librum de sole was published together with two other works of Ficinus: Librum de lumine and Apologia in librum suum de Sole \& Lumine.

${ }^{4}$ For a modern Latin edition, with Italian translation, of Ficinus's De sole, see (Garin 1952, 970-1009).
} 
moves to cosmological subjects such as the size of the sun, its position, and its relation to the constellations of the Zodiac, as well as the relation of these to the seasons. All the planetary motions, positions, and configurations are then discussed with particular attention to facets concerning their astrological meanings and influences. The generative power of the sun and its light are then exemplified by discussing the generation of the humors and, after a theological disquisition, the text concludes by investigating the relations between the divine sun and the sky on one hand and the quality of the air on the other. In only fifteen folios, Ficinus offers a quick runthrough from his metaphysics down to his medical considerations.

Tockler re-published Ficinus's work nine years after the original publication (Ficinus and Tockler 1502), but he did not leave comments alongside Ficinus's text. Instead, he added a short introduction to the text by means of which he indicated his own specific interest: natural theology. By this term, he meant a theological view according to which the investigation of God's influence is achieved through an investigation of the physical rules of the cosmos. The astrological approach is therefore inherent to this worldview. Tockler clearly specified that the main goal of this text is to show how all aspects of life are deeply influenced by the sun, whose function is "creare atque vitam movere, augere, proficiere, nutrire, mondare, et renovare" (Ficinus and Tockler 1502,1v).

Finally, Tockler goes back to Ficinus's idea that light is also the cause of motion. This mechanical concept makes use of the pneumatic experience relating the elements of air and water and it is reminiscent of the Heronian fountain: Two closed containers are connected to each other by a pipe, one empty and the other filled with water, with a hole on the top; when light hits the air in the empty container, it heats it up, causing the air's volume to expand; the expansion of air applies pressure to the pipe and some water is consequently pushed out through the hole. This device and its underlying phenomenon were known since antiquity, though the works of Hero of Alexandria (1st cent. AD) were not yet circulating in the period of Ficinus and Tockler. ${ }^{5}$ In spite of the vagueness of Ficinus's explanation, Tockler made the point more precise by specifying that the investigation of the effect of sunlight is necessary to comprehend the process of air's condensation and rarefaction, which is in turn fundamental to medicine in terms of its applicability to respiratory problems.

Already at this early stage of his career, Tockler clearly showed that his main interest was in astrological medicine, a set of practical inquiries that was nonetheless integrated into a great metaphysical system drawn from the works of Marsilius Ficinus. As a matter of fact, his further works, whether contextually emerging from his teaching activities or not, show that his research agenda aimed to make Ficinus's ideas operative.

\footnotetext{
${ }^{5}$ For further information on Hero of Alexandria's pneumatics and it's renaissance in the early modern period, see (Valleriani 2010, 2014).
} 


\section{The Textbooks and the Teaching}

The group of Tockler's textbooks is quite prominent and the historical sources show that, as a teacher, he covered the full spectrum of subject matter in the framework of the quadrivium.

The statutes of the University of Leipzig valid for this period (1499-1522) show that the traditional spectrum of the quadrivium was covered. Dividing between lessons and exercises, both for the magister and the bachelor course of studies, students were supposed to attend classes in geometry ("Euclidis," for two or three quarters of a year), perspectiva communis (12-14 weeks), music ("musica muris," for 3-4 weeks), theorica planetarum (for 5-6 weeks), arithmetic ("arismetica communis," for 3-4 weeks), and cosmology ("De coelo et mundo," lessons for 3-4 months and exercises for 4 months during the magister), preceded by exercise classes during the bachelor on the spera materialis for 6 weeks (Zarncke 1861, 461-462).

Tockler's own teaching activity was well documented by Georg Erler for the entire course of Tockler's professorship in the faculty of liberal arts. Except for the summer semester of 1503, he regularly taught from the winter semester 1502 until the winter semester 1510. He taught classes in spera materialis $(1502,1504,1506$, and $\left.1507^{6}\right)$, aritmetica communis (1502), musica muris (1502), theorica planetarum (1504), Euclidis (1504, both semesters in 1506, 1507, 1508, and both semesters in 1509 and 1510), and perspectiva communis $(1504,1505$, both semesters in 1506 , 1508, and both semesters in 1509 and 1510) (Erler 1895-1902, 2, 389-460). On the basis of Erler's reconstruction, it appears therefore that Tockler was mostly teaching geometry and perspectiva communis, whereas he taught subjects like music only during his first years of activity. Moreover, it appears that classes such as music were not taught regularly anymore after 1503 . Nevertheless, as the entries concerning his teaching on the Sphaera in 1506 and 1507 show, Erler's reconstruction is certainly not complete.

In spite of the fact that Tockler almost certainly introduced students to the work of Euclid nearly every semester, there is no printed book or handwritten manuscript as a source proving this specific activity. Instead, his commentary on Peckham's Perspectiva communis, his texts on arithmetic and on speculative music, the two editions of his commentary on the Sphaera of Sacrobosco, as well as his works on calendric and on the calculation of the mean motions of the sun and the moon are still at our disposal.

\footnotetext{
${ }^{6}$ Tockler's teaching on the Sphaera in 1506 and 1507 is testified to by his annotations on an Venetian edition of the treatise of Sacrobosco published in 1499 (http://hdl.handle.net/21.11103/ sphaera.100021). Tockler's copy of this edition of the treatise is still preserved at the Library of the University of Leipzig under the signature "Astron. 15." Tockler's annotation is on the retro of the cover of the book.
} 


\subsection{A Commentary on John Peckham's Perspectiva communis}

In the same year of the publication of Tockler's re-edition of Ficinus and Tockler 1502), Tockler prepared a commentary on John Peckham's (1230-1292) Perspectiva communis, a late medieval prominent work on optics (Tockler 1502-1506, 1r-37v). ${ }^{7}$ Tockler's work is not at all a copy of Peckham's. Tockler used what David C. Lindberg called the unrevised version of Peckham's work (Lindberg and Pecham 1970, 12-20) but he copied only the propositions and expanded on them with his own commentaries. This handwritten and unpublished text, signed by Tockler, is accompanied by sophisticated hand-colored diagrams, a preface, and a further Consideration before the text actually begins (Tockler 1502-1506, 1r-v). Tockler's Consideration declares the 'agenda of the commentator' in this text. Quite surprisingly, he justifies the study on optics and theory of vision by referring to the works of Iamblichus Platonicus (245-325), better known as Iamblichus Chalcidensis. Iamblichus was a neoplatonic philosopher and mathematician whose texts, especially his Life of Pythagoras (Iamblichus and Taylor 1986), play a role in Ficinus's works on esthetics and theology. ${ }^{8}$ In De sole, Ficinus states that it was Iamblichus who defined light as the act and visible image of divine intelligence (Ficinus 1493, chap. 2; Garin 1952, 972).

Since the time of its original compilation, Peckham's text was used in the frame of university teaching activity. The same was certainly true at the beginning of the sixteenth century and in the case of Conrad Tockler. From the perspective of the Ficinian program, as Tockler embraced it, Peckham's work furnishes the geometric basis for an understanding of the movement of the sun's rays. The principles of radiation, such as refraction and reflection, as well as Peckham's principle according to which the difference in strength between rays depends on their inclination (Lindberg and Pecham 1970, 33-51), must have provided Tockler with a sort of geometric, astronomic, and astrological infrastructure to precisely determine the influence of the motion of the celestial bodies on earth. Such a program was not entirely new. Back in the late Medieval period, the subjects of light, light's rays, and optics were absolutely central and, besides Peckham, were also discussed by Robert Grosseteste (ca. 1175-1253) and Roger Bacon (ca. 1219-ca. 1292). As Yael Kedar puts it, "light, the source of all causal action, became thus the key to the study of the material universe" (Kedar 2017, 2). However, Tockler reframed it against the background of the recently published Ficinian program that he was realizing.

\footnotetext{
${ }^{7}$ For a critical edition of Peckham's Perspectiva communis, see (Lindberg and Pecham 1970).

${ }^{8}$ Tockler's commentary on Peckham's Perspectiva communis seems to have been prepared for print, as it is a clean compilation with final emendations. As no edition of this text exists, it is not possible in the frame of this work to compare the original text with the commentary in its entirety.
} 


\subsection{Two Textbooks on Arithmetic}

One year later, Tockler published two further texts, this time on the subject of mathematics. These texts were deeply connected to each other. In fact, the first (Tockler 1503b) represents the main text and the second its commentary (Tockler 1503a). ${ }^{9}$

In their broad outlines, the texts certainly represent an abridged version of the traditional Boethian text De institutione arithmetica. ${ }^{10}$ Nevertheless, they also reflect the fundamental changes that had occurred during the late Middle Ages. They include, for instance, Arabic numeration. The texts were the basis for an introduction to what today could be called 'number theory'. This was-and had always been-quite usual for university arithmetic instruction. In particular, the texts explain a series of fundamental types of proportions that were then propaedeutic for the teaching of music and, of course, for that of astronomy. It concerned the cosmos and its harmony (musica mundana). As Doroty V. Schrader says,

Arithmetic corresponded roughly to present-day number theory, being a philosophical approach to what is implied in number; it was a mathematical discussion of properties of numbers, proof, and formal demonstration, a mixture of mathematical rigor and pseudoscientific, semi-magical mysticism. (Schrader 1967, 266) ${ }^{11}$

A careful comparison with university textbooks for arithmetic reveals that Tockler's texts are original compositions, albeit abridged ones. This might explain the fact that, contrary to many of his other textbooks, these ones were printed. It is also interesting to note that the main title-Common arithmetic-seems to have been in use in the same period, especially in South Germany. ${ }^{12}$

\subsection{Two Textbooks on Speculative Music}

Speculative music was one branch of the musical discipline of the quadrivium. Following the traditional Boethian division, music was divided into mundana, humana, and instrumentalis. Speculative music was oriented toward the subjects of musica mundana, that is, it was mostly regarded as a mathematical discipline for investigating cosmological harmony. Traditionally associated with Boethius's (born

\footnotetext{
${ }^{9}$ Usually, early modern commentaries show the main text interrupted by passages of commentary written in smaller characters. While the difference in the size of characters in print is maintained according to this practice, Tockler's texts are nevertheless distinct. The way these texts are connected to each other is explained in (Tockler 1503b, last page).

${ }^{10}$ For a modern translation of Boethius's De institutione arithmetica, see (Masi 1983).

${ }^{11}$ For an extensive analysis of the function of music according to Boethius, according to which speculative music was also regarded as an introduction to philosophy, see (Heilmann 2007, 242-90).

${ }^{12}$ Dorty V. Schrader mentions that the course on arithmetic at the University of Ingolstadt prescribed "the first book of Euclid, Algorism, and common arithmetic" (Schrader 1967, 273).
} 
480) text De institutione musica, university teaching could rely on a further series of texts including Jean de Murs's (ca. 1290-ca. 1355) Musica speculativa, written at the beginning of the fourteenth century, which probably was the most relevant and widespread. ${ }^{13}$ As Christoph Falkenroth points out, Jean de Murs's text was usually integrated into three different intellectual frames. The first was more concerned with mathematical subjects. This is the traditional frame of the quadrivium, which also encompasses astronomy, geometry, and arithmetic. The second included Jean de Murs's text in a more hybrid frame that might take into account astronomical and cosmological works and, together with these, works on astrology and optics. The third frame is more concerned with music as such, without disregarding its practical aspects (de Muris and Falkenroth 1992, 29). Tockler's work with Jean de Murs's text is to be interpreted as belonging to the second intellectual frame.

Tockler compiled two different manuscripts for the teaching of speculative music in Leipzig, both in 1503. One of the two texts is a one-to-one copy of Jean de Murs's Musica speculativa (Tockler 1502-1506, 124r-36r). Apparently Tockler had at his disposal the longer version of the work, which includes the introduction of the original author (de Muris and Falkenroth 1992, 77-91). In the other manuscript (Tockler 1502-1506, 139r-54r), Tockler did not copy Jean de Murs's introduction but chose instead to add a few pages before the beginning of the first proposition (Tockler $1502-1506,139 \mathrm{r}-140 \mathrm{v}$ ). These pages contain the fundamental concepts of musical research in the spirit of Pythagoras (ca. 570-ca. $495 \mathrm{BCE}$ ), as explained at length already in the fourth century by St. Augustine (354-430) in the first book of his De musica (Heilmann 2007, 267-71). ${ }^{14}$ With the title Musica est scientia recte modulandi, Tockler connects in this text the purely mathematical and numerological meaning of music in the ancient context with the more modern attention, expressed by Jean de Murs, on the technical aspects of music notation, which developed as a result of the advent of the polyphonic musical style in the late Medieval period (Marongiu 2012, 29-70).

\footnotetext{
${ }^{13}$ For a critical edition of Jean de Murs's Musica speculativa, which however is not informative concerning the scientific content of the work, see (de Muris and Falkenroth 1992). Apparently, Jean de Murs decided to write his text, which is an abridge of the one of Boethius, as a reaction to the decline of interest in the formation on music theory. Such a decline was due to the embedment into the teaching of further Aristotelian texts. In one of these, De caelo, Aristoteles developed a physical argument against cosmological harmony (Aristoteles and Stocks 1922, Book 2.9). Such an argument, according to which the physical sound of the spheres cannot exist, had a profound impact and certainly meant the beginning of the declining phase of such a study. Nevertheless, a more mathematics-oriented interpretation of the musica mundana came back on the agenda, apparently, also in the frame of teaching, at the end of the fifteenth century as a consequence of the reemerging Platonism. For more information, see (Haar 1960, 299-328; Břenková 2015).

${ }^{14}$ The introduction of Tockler's manuscript shows a paraphrased extract from the first of the six books of St. Augustine's De musica. Most of St. Augustine's work investigates the relation between rhythm, grammar and linguistic metric. De musica circulated widely during the late Middle Ages and, at the time when Tockler prepared his manuscript for teaching, the first print of the entire work was already accomplished, namely in 1491 in Venice by the printer Dionysius Bertochus.
} 
The order and function of the two texts for teaching remains somewhat unclear, though the temporal difference might only be a matter of months. What is sure is that the colophon of the mixed manuscript shows that this was the text for the public lectures Tockler evidently delivered in Leipzig. This is again a clean text without emendations and accompanied by hand-colored mathematical diagrams. In spite of this attention and in order to achieve an elegant copy, the manuscripts do not seem to show any original work of Tockler on this subject apart perhaps from the composition of de Murs's text with an extract of St. Augustine's De musica. ${ }^{15}$

\subsection{A Commentary on Georg von Peuerbach's Theorica planetarum}

In 1505, Tockler completed a further substantial step of his research agenda with the final compilation of a dense commentary on Georg von Peuerbach's (1423-1461) Theorica planetarum (Peuerbach 1474; Tockler 1502-1506, 57r-120v). Only one copy of Tockler's own manuscript is preserved. It clearly shows that this text was also intended for publication, as it contains only a few emendations. ${ }^{16}$ The title page contains a mention of the University of Leipzig, indicating that this text was also conceived for teaching purposes. In addition, the commentary is preceded by an introduction to arithmetic to assist the younger students. This introduction to arithmetic does not coincide with either of the two printed texts on arithmetic mentioned above. It nevertheless shows clear similarities with the one entitled Commentatio arithmeticae communis (Tockler 1503a).

Consistent with the Ficinian approach that correlates theological aspects to the reality of objects, Tockler chose to support his agenda by making use of a mathematical astronomy that was perceived as having a strong ontological value (Chap. 6). The orbits of the planets as described by Peuerbach were in fact considered real spheres and not mere mathematical constructs useful for the determination of the positions of the planets but deprived of any reality (Barker 2011; Malpangotto 2016).

That this work was intended as a further expansion of the Ficinian program is declared by Tockler in the letter of dedication to George, Duke of Saxony, by means of which he opens the text (Tockler 1502-1506, 58r-59v). After having explained that astronomy is a science based on the accomplishments of Ptolemy (born 100 AD), Tockler mentions that astronomy is especially important for understanding the behavior of the sun and moon, and in particular because "Sol est rex celi / statua Dei." This is a clear paraphrase of the title of chapter nine of Ficinus'

\footnotetext{
${ }^{15}$ As Tockler's texts on speculative music have not been taken into consideration while preparing the critical edition of Jean de Murs's Musica speculativa, it cannot be excluded that a closer inspection of the manuscripts would reveal original variations by Tockler inserted into the body of de Murs's text.

${ }^{16}$ Unfortunately, no critical edition has been accomplished to date in the case of Tockler's commentary on Peuerbach's Theorica planetarum.
} 
De sole - Sol statua Dei. Comparatio Solis at deum-, which is then drawn into a long disquisition concerning the influence of the planets on the four elements which constitute everything in the sublunar world (Ficinus 1493, chap. 2; Garin 1952, 990).

Tockler's basic agenda had therefore already taken shape by 1505 . The sun, which is the representation of God, is the dominant planet. Its influence is literally irradiated, following clear rules that are expressed geometrically (as taught by Peckham). The sun and the other planets exert an influence not directly on human beings or inanimate objects, but on their constituents, that is, the elements. Following Tockler's dedication letter to the commentary on the Theorica, this influence can take very different forms. Ranging from fire to earth, Tockler expresses the influence on both material and psychic aspects of life. The focus, however, is almost exclusively on medical matters, which represent the frame in which and the reason why, according to Tockler, students needed to learn how to calculate the positions of the planets.

After the dedication letter and the introduction to arithmetic, the 55-folio-long commentary on Peuerbach follows. This is sumptuously enriched by a series of hand-colored diagrams and, as mentioned, lightly spotted by some emendations. One of them seems to be of particular relevance, because it is to be found in other texts, as discussed below. The emendation concerns the reference Tockler made to Ptolemy's Almagest. Throughout the entire manuscript, such reference is substituted by the reference to Regiomontanus's (1436-1476) Epitoma Ioannis de Monte Regio in Almagestum Ptolomei, published for the first time just 9 years before Tockler finished this commentary (Regiomontanus 1496). When the references were specific to certain sections of the work of Ptolemy, however, they were not changed once the substitution took place. This seems to indicate that Tockler was initially using Peuerbach's and Regiomontanus's works as if it were Ptolemy's work itself. This peculiarity is strongly connected to the transformation that took place between the publication of Tockler's two commentaries on the Sphaera of Sacrobosco, published respectively in 1503 and 1509 (de Sacrobosco et al. $1503,1509)$.

\subsection{Two Editions of a Commentary on the Tractatus de sphaera of Sacrobosco ${ }^{17}$}

Both editions contain a Latin translation of a work by Thābit ibn Qurra (836-901), known in the Latin tradition under the title De recta imaginatione spere. This was originally written around the end of the ninth century and dealt with the construction of celestial lines according to the equatorial, equinoctial, and horizontal references

\footnotetext{
${ }^{17}$ In the following discussion, it will not be possible to always give precise indications for the passages of the commentaries discussed in this section because the editions do not have page numbers.
} 
Fig. 5.1 Image accompanying the Latin translation of Thābit ibn Qurra's De recta imaginatione spere in both of Tockler's editions of the commentary on the Sphaera of Sacrobosco. From (de Sacrobosco et al. 1503, Aiii r). Bavarian State Library Munich, Res/2 A.lat.a. 199\#Beibd.5, http://mdz-nbn-resolving. de/

urn:nbn:de:bvb:12bsb00015066-8

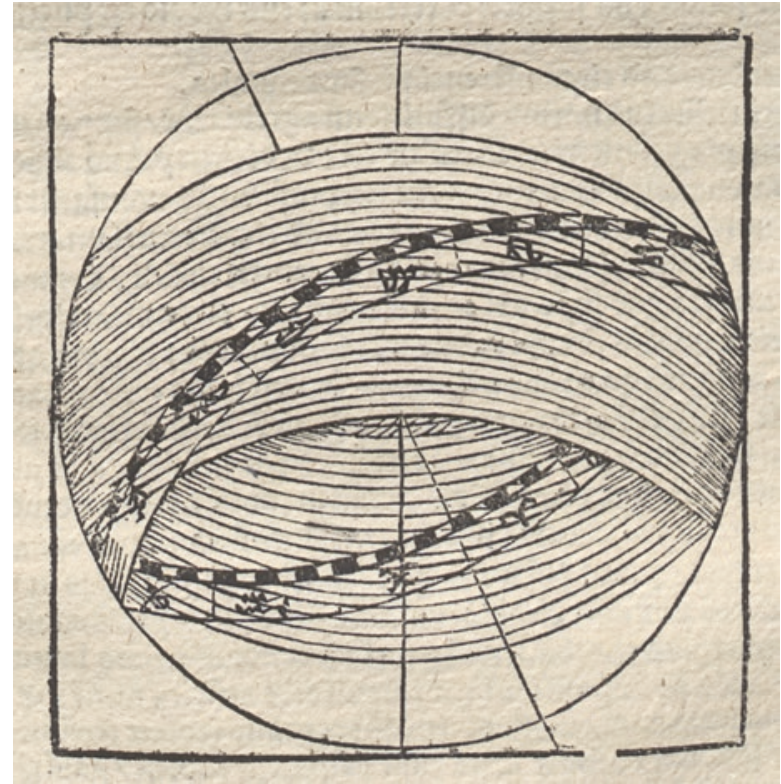

(Carmody 1955, 236). (Fig. 5.1). In the corpus of the early modern printed commentaries on the Sphaera of Sacrobosco, this text appears three times. The first two appear in the editions of Tockler and the third one in the monumental 1518 Venetian commentary on Sacrobosco's Sphaera published by Ottaviano Scoto. ${ }^{18}$ Through a comparison between these three texts, it becomes evident that Tockler managed to insert some changes, in particular a short introductory part of the text (revisus et additus), though they were not pertinent to the scientific content of the text.

While this text remained fundamentally unchanged between the first and the second edition, the overall work indeed underwent quite a profound transformation. First of all, the second edition contains a short introduction to the whole book, a kind of mission statement. In this text, Tockler draws the attention of the reader to the reason for studying cosmology. He does so by discussing the relationship of astronomy, conceived as mathematical astronomy, and astrology, as the science that investigates the influences and mutations operated by the celestial bodies on the sublunar world. ${ }^{19}$ Tockler clearly distinguished them from each other and stated the dependency of astrology on the first. However, he added, both astrologers and astronomers need to begin their studies with the doctrine of the celestial circles,

\footnotetext{
${ }^{18}$ Ottaviano Scoto was an active publisher between 1479 and 1498. For Ottaviano Scoto's production of commentaries on Sacrobosco's Sphaera, see: http://hdl.handle.net/21.11103/ sphaera.100310. The Repertorium of the medieval texts does not mention the 1503 edition. For more information, see (Schönberg et al. 2012, 4, 3631-32). See also (Carmody 1956, 118-19). Thābit's text was then printed again during the early modern period in 1559 , but not in the corpus of Sacrobosco's Sphaera (Hasse 2016, 405-06).
}

${ }^{19}$ For the role and function of astronomy during the early modern period, see (Omodeo 2017). 
which is the content of Sacrobosco's Sphaera. In this introduction, Tockler also immediately mentioned what he considered the two main masters of these disciplines: While for mathematical astronomy Ptolemy is unsurprisingly mentioned, astrology is placed under the guardianship of Leopoldus alias Leopold of Austria. ${ }^{20}$

Leopold's treatise is a compilation of astrological works prepared during the second half of the thirteenth century. The identity of the author remains, however, quite unclear, as it could be ascribed to more than one member of the Dukedom of Austria in the same period. According to Benjamin N. Dykes, Leopold's intention was to create a sort of handy book able to touch on all relevant aspects of the discipline and therefore to allow the reader to acquire a sophisticated knowledge without having to consider the many relevant treatises circulating in the same period. ${ }^{21}$ Leopold's book is sub-divided into ten treatises, each of them dedicated to a different subject. The first two are short introductions to cosmology and to the scheme of the motion of the planets (theorica planetarum ${ }^{22}$ ), respectively. Leopold introduces a cosmos consisting of ten spheres. Besides the usual seven spheres for the seven planets, the tenth represents the primum mobile and the ninth the one which "shows" the constellations of the zodiacal signs as projected from the eighth sphere, which is the one of the fixed stars. The reason for such a proliferation of spheres is the will to associate a sphere with each detected movement (Chap. 8). The primum mobile was therefore associated with the diurnal motion, while the ninth sphere was needed for the movement of the precession of equinoxes, and the eight was seen as showing the movement traepidatio, as it had often been called since the twelve century (Nothaft and Philipp 2017; Leopold of Austria and Dykes 2015, 21-24). ${ }^{23}$ It is only with the third treatise - a defense of astrology—-that Leopoldus's work enters the subject matter.

While Tockler was writing his books, the text of Leopoldus was experiencing a revival because of its editio princeps, which was produced in 1489 in Augsburg by Erhard Ratdolt (ca. 1447-ca. 1527). ${ }^{24}$ Therefore, Tockler was making use of a text which was old and authoritative and yet new and circulating (at least in his geographic area) at the same time.

Another fundamental difference between the two editions is represented by the insertion of a new text between the first and second chapter of the commentary on

\footnotetext{
${ }^{20}$ For a modern commented translation of Leopold's treatise, see (Leopold of Austria and Dykes [13th cent] 2015).

${ }^{21}$ For an introduction to Leopold's treatise, see ibid. (Leopold of Austria and Dykes [13th cent] 2015, 1-19). Dykes, however, reaches the conclusion that in spite of this agenda, Leopold's treatise would have appeared too obscure to a reader new to astrology.

${ }^{22}$ Leopold introduced a conception of the sphere of the planets that has similarities with the one developed later by Peuerbach, as each planet is contained in three shell-like orbs.

${ }^{23}$ While Leopold of Austria certainly included the three movements in his cosmological vision, he was nevertheless not completely sure concerning their associations with the spheres. In Prop. 18 of the first treatise, for instance, he admitted that the precession of the equinoxes is associated to the ninth $o r$ the eighth sphere (Leopold of Austria and Dykes [13th cent] 2015, 24).

${ }^{24}$ For Erhard Ratdolt and his activity concerning the corpus of Sacrobosco's Sphaera, see http:// hdl.handle.net/21.11103/sphaera.100947
} 
the Sphaera. This text is a detailed instruction about the mechanical composition of the armillary sphere (Ordinatio spere materialis) (de Sacrobosco et al. 1509, 36r-38r). The text, which is divided into five parts, was prepared in the same year of the second edition, as a separate manuscript found at the Österreichische Nationalbibliothek shows (Schöner and Tockler, 16th cent, 28r-29r). This original contribution of Tockler, which bears the date in the printed text before the second chapter of the commentary begins, was probably meant to be even more extended and to embrace more subjects related to instruments. The above-mentioned manuscript in Vienna indeed contains many descriptions of the construction of solar clocks. $^{25}$

Besides these differences at the level of the structure and design of the book, differences can be noted on a deeper level of analysis. Tockler had his books printed by Martin Landsberg, ${ }^{26}$ a pioneer of the new print technology active in Leipzig between 1485 and his death in 1523, and also the owner of an additional bookstore in Frankfurt Oder from 1506 on. As a publisher, he printed eleven books containing the text of Sacrobosco, four of them with only the tract on the Sphaera and seven with the tract and a commentary on it. The text of the original tract of Sacrobosco appears in all of them exactly in the same way and accompanied by the same images. When Tockler therefore decided to publish his work, he could count on a publisher, who came from an established tradition. The only task he had to accomplish was to prepare the passages of the commentary and decide where to insert them. ${ }^{27}$

The content of Tockler's commentary follows two major directions. According to the first, Tockler tended to just explain the content of the original work. This is clearly the result of the century-long tradition of commentaries in university textbooks prepared for a class. The other direction is clearly dictated by the wish of Tockler to immediately link cosmological topics with astrological and medical knowledge.

Sacrobosco introduced the subject of the number of cosmic spheres after providing geometric definitions of the sphere at the beginning of the first book. As is well known, the number of spheres for Sacrobosco is nine: the primum mobile, the Firmament, and the seven planets. The image connected to this text but inserted in Tockler's commentary indeed reproduces a cosmos comprised of nine spheres, yet where the primum mobile contains the sign of the zodiac, which indicates the influence of Leopold's cosmology (Fig. 5.2).

Tockler's commentary on this begins with the statement that the spheres do not move each other in the same way as a body moves another body. There is no bodily

\footnotetext{
${ }^{25}$ For more information, see fn. no. 2.

${ }^{26}$ For Martin Landsberg and his activity concerning the corpus of Sacrobosco's Sphaera, see http:// hdl.handle.net/21.11103/sphaera.100808

${ }^{27} \mathrm{~A}$ close inspection of the images, however, reveals that from time to time the woodblocks were re-shaped after consumption. Moreover, by comparing several of Landsberg's editions, it becomes evident that woodblocks were often turned upside down inadvertently. All editions have the same image on the title page, a very common one depicting an armillary sphere, but in Tockler's 1509 edition it is set upside-down.
} 
Fig. 5.2 Representation of the cosmos in Tockler's second edition of his commentary on the Sphaera of Sacrobosco. The cosmos consists of nine spheres, but the primum mobile also contains the constellations of the signs of the Zodiac separated from the Firmament, as influenced by the cosmological view of Leopold of Austria. From (de Sacrobosco et al. 1509, Aiv v). Bavarian State Library Munich, 2 A.gr.b. 213\#Beibd.2, urn:nbn:de:bvb:12bsb00014923-9

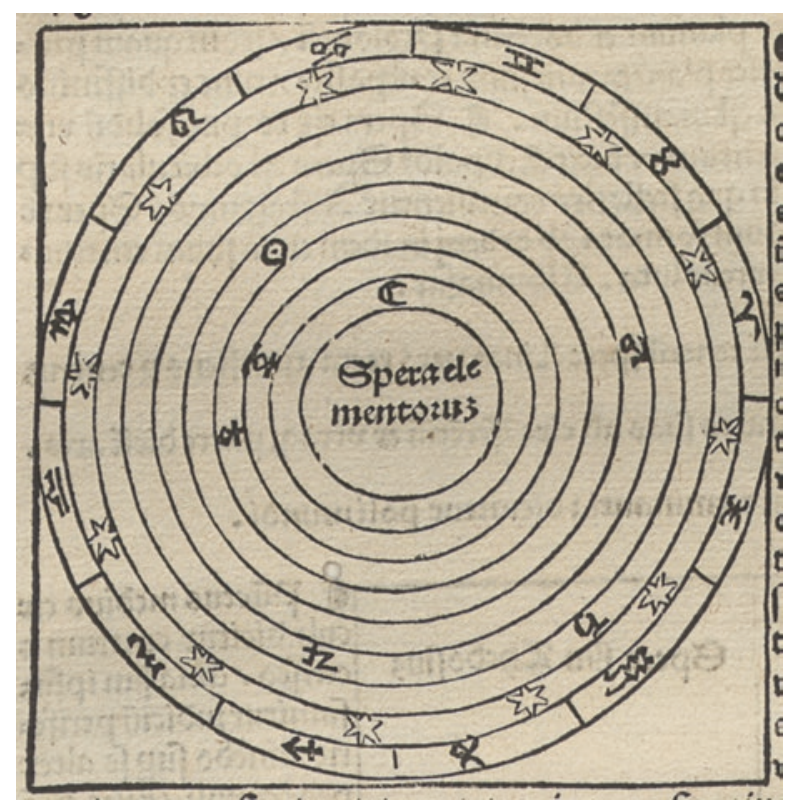

contact but rather a spiritual contact, a pure influence. Such influence is nevertheless identifiable with a visible phenomenon, light. Light spreads through the entire cosmos from one unique point, following geometric rules for the concave and convex shapes of the cosmological spheres, as explained in propositions five and six of the first part of Peckham's Perspectiva communis. At this point, Tockler's text proceeds with a long enumeration of the kinds of astrological influences that are assigned to each planet, starting from the outermost planetary sphere of Saturn. When it comes to the sun, this is identified with the light source, and for a more abstract explanation of the influence of the sun, Tockler refers to his publication of Ficinus's De Sole. The same passage of the commentary then deepens the question of the number of the spheres but does not make any declaration to at least explain the presence of the zodiacal signs on the sphere of the primum mobile, separated from the sphere of the fixed stars. Instead, he just informs those wishing to know whether the spheres number nine or ten that this information "scriptum est in Theoricis nostris planetarum," referring therefore to his own commentary on Peuerbach's Theorica planetarum. Indeed, Tockler discusses the subject in the last page of the handwritten dedicatory letter that accompanies the commentary and specifies that in his opinion, in truth there are nine celestial spheres in the world, while the tenth is the prime mover. In the terrestrial world there are nine spheres of elements, while the tenth is the place of the human beings. ${ }^{28}$

\footnotetext{
${ }^{28}$ The original text reads: “...in mundo vero celesti sint novem spherem. Decima vero sit primum mobile. In mundo terrestri novem spere elementorum decima sit habitatio hominum." From: (Tockler 1502-1506, 59v).
} 
Tockler never published a description of his vision that there are no less than twenty spheres, ten in the superlunar world and ten in the sublunar one. The curious issue, however, is that he only considered nine of the spheres of the superlunar world celestial, whereas the sphere of the primum mobile was just the tenth that carries everything. ${ }^{29}$

In connection with the discussion concerned with the number of the sphere in the first chapter of his commentary, Tockler uses the opportunity to introduce the first relevant aspects of astrological medicine, namely, the theory of critical days as attributed to Galen.

After the description, then, of the major circles of the astronomic sphere, in chapter two Tockler inserted a long commentary to explain the fundaments of astrological medicine, namely the knowledge that connects cosmology, astronomy, meteorology, and medicine. This would then turn out to be the background against which works such as practica could be compiled. ${ }^{30}$ Tockler attributes the paternity of this knowledge to Avicenna (ca. 980-1037).

If astrology was Tockler's main interest since the very beginning, and he stated this explicitly in the first edition of the commentary, one still observes significant changes between the first and second editions. The most relevant one is probably due to the fact that at the time of the first edition, Tockler had not yet have worked throughout Peuerbach's Theorica. As a matter of fact, the second edition is decidedly more advanced from the point of view of mathematical astronomy. In spite of the fact that the two commentaries, if compared page by page, look almost identical, Tockler actually reworked the entire text line by line. Many passages and tables were taken out and replaced or modified, especially those containing the values of astronomic observations and explanations of the motions of the single planets. ${ }^{31}$

This improvement is moreover demonstrated by a radical change to which sources the text mentions. Beyond the fact that Peuerbach's text was completely absent in the first edition, several corrections show that Tockler underwent an impressive period of study in the intervening years. In his works, Tockler was extremely generous in displaying his sources. Ancient as well Arabic sources in astronomy and astrology show his wide spectrum of interests and specializations. Some of them, however, were mentioned with great imprecision in the first edition.

\footnotetext{
${ }^{29}$ Considering Tockler's vision in its entirety, similarities seem to arise with the vision of Abu Nas Muḥammad ibn Muḥammad al Fārābī (ca. 872-ca. 950), who in turn might have influenced the cosmological vision of Robert Grosseteste, another supporter of the ten-spheres and irradiation model. For more information, see (Sparavigna 2014).

${ }^{30}$ For Tockler's activity as a compiler of practica and almanacs, see the section below "Works of Astrological Character."

${ }^{31}$ An example of such changes the commentary passages at the end of the first chapter-where Sacrobosco discussed the subject of the diameter of the Earth - can be used for comparison, as all the given dimensions and their respective calculations and results have been changed. An actual example for Tockler's use of Peuerbach's Theorica planetarum is in his commentary on chapter two of Sacrobosco's description of the distance between the Zenith and the equinoctial circle. At the end of this passage, Tockler calculates the elevation of the Sun when it enters the sign of Aries, taking Leipzig as point of reference.
} 
For instance, Tockler makes extensive use of Muhammad ibn Zakariya al-Razi's (854-925) medical Aphorisms, which he erroneously cites in the first edition under the name of the Caliph Al-Mansur (714-775). As in the case of the manuscript of Tockler's commentary on Peuerbach's Theorica, all mentions of Ptolemy's Almagest that can be found in the first edition of the commentary were replaced in the second with mentions of Regiomontanus's Epitoma.

Concerning Tockler's teaching on the Sphaera, there remains an anomaly that deserves some attention. It concerns Tockler's own annotated copy of another edition of Sacrobosco's treatise, published in Venice in 1499 and still preserved at the Library of the University of Leipzig. ${ }^{32}$ As Tockler's annotations on the back of the cover show, he was using this book to teach at least during the years 1506 and 1507. Considering the year of the first edition of his own commentary, this anomaly could be explained by the hypothesis that no copy of his 1503 treatise was available on the market anymore. A second hypothesis would be that he did not have his own library to rely upon because of the pestilence that was claiming victims during those years in the area of Leipzig. One of the annotations dated 1507 indeed specifies that he had been teaching on the Sphaera in the Lecture Hall on Ritterstr., which was a place used for teaching during outbreaks of pestilence. Tockler also wrote that, in spite of the plague, sixty-four students attended his class. ${ }^{33}$

The 1499 Venetian edition possessed by Tockler was published by Simone Bevilaqua, ${ }^{34}$ and contains the commentaries on De sphaera of Sacrobosco by Cecco d'Ascoli (1257-1327), Francesco Capuano di Manfredonia (15th cent.) (Chap. 4) and Jacques Lefèvre d'Étaples (ca. 1455-1536) (Chap. 2). From the analysis of the annotations, which were somewhat extensive only in connection with Cecco d'Ascoli's commentary, it seems that Tockler was not at all interested in any of the commentaries printed in this edition. The annotations' function is clearly descriptive of the content of the original text of Sacrobosco. Cecco d'Ascoli's commentary is indeed elegantly printed around the original text of Sacrobosco, which is in turn set into boxes at each page and printed with a greater font size and line spacing. Tockler's handwriting can only be found among the lines of the original text and at the margins of the page, at the height where the original text is set on the printed plate. In the original text, he added some words to slightly expand the content, ${ }^{35}$ while at the margin he added explicative texts which do not correspond in any way to the commentaries he printed in his own editions.

Although a more systematic analysis might reveal further aspects of it, this historical source poses the question of the relation between the lecturers' own

\footnotetext{
${ }^{32}$ For Tockler's annotated copy of this edition of the Sphaera, see Footnote 6.

${ }^{33}$ According to the habit of the time, this note was first written on a piece of paper and then glued onto the book. A reproduction of Tockler's note is published in (Sudhoff 1909, 87-88, Tab. XVI).

${ }^{34}$ For Simone Bevilaqua and his activity concerning the corpus of Sacrobosco's Sphaera, see http://hdl.handle.net/21.11103/sphaera.100340

${ }^{35} \mathrm{An}$ example is the last part of the last sentence of the famous proemium of the text. This reads:

"...\& de causis [de sole et lune] ecclypsium," where "de sole et lune" is the handwritten addition of Tockler.
} 
commentaries and the real content of their teaching. As mentioned, however, the use of this source might have been due to exceptional circumstances and as such might not be entirely representative. For sure, it shows the depth of Tockler's dedication to his teaching activity.

\subsection{Textbooks on the Calendar and Mean Motions}

The last two works in the series of Tockler's textbooks were both published in 1511 (Tockler 1511a, 1511b). The first was a work on the calendar-a canon to define the solar and lunar cycles and to pre-determine the movable feasts-and the second on a canon to determine the mean motions of the sun and the moon, as well as of the five remaining planets. Both booklets were printed by Martin Landsberg with a note on the title page that they were meant to be 'read in public' (publice lecti), clearly indicating that they were intended for university teaching. A closer look reveals that these texts were supposed to accompany mathematical instruments by means of which both the determination of the movable feasts and of the position of the planets could be easily achieved. ${ }^{36}$ According to Tockler's description, these instruments were volvelles. Unfortunately, the instruments are not included in the books, either in the form of drawings or of diagrams to be cut out and recomposed. ${ }^{37}$ In the case of the canon for the determination of the mean motions of the sun and the moon, however, the appendix shows that it must have been quite a sophisticated volvelle, as 26 scales of measurements are listed. As he stated, Tockler was certainly teaching on the basis of such instruments. However, it is also quite probable that he was using them especially in the frame of his social contacts with the court as a freshly graduated physician and expert on astrology (and therefore on astrological medicine). As a matter of fact, he probably was promoting himself at the faculty of medicine and as a Rector by means of these works.

\section{Works of Astrological Character}

Deepening his skills in calendric calculations and finding the mean motions of the sun and moon was clearly a prerequisite for his compilation of judicia, almanacs, and practica. ${ }^{38}$ Tockler produced a great amount of such works and not all of those which survived could be analyzed here. Ten documents dated between 1503 and

\footnotetext{
${ }^{36} \mathrm{~A}$ clear indication of the deictic character of these texts are in (Tockler 1511a, Canon sextus) and in (Tockler 1511b, Canon primum).

${ }^{37} \mathrm{~A}$ closer look at the collection of mathematical and astronomic writings (Schöner and Tockler 16th cent.) might reveal some of these instruments.

${ }^{38}$ For a description of the genres judicia, almanacs, and practica, and a discussion about their emergence, see (Kremer 2017).
} 
1514 were collected for the purpose of this work: one judicium, four practica, and five almanacs. Judicia and practica are genres that very much resemble each other. The major difference stems from the fact that while judicia were written in Latin, practica was the genre developed in German. In spite of the fact that judicia and practica tended to be very similar, their contents were also modeled according to the audiences these works targeted. The enormous success of the German practica between the fifteenth and the sixteenth centuries testifies to a widespread interest in these genres that went far beyond the social boundaries of the intelligentia.

Judicia are texts that contain predictions of social and political events, such as wars, pestilences, or important marriages. Practica contain the same kind of information but seem to be more focused on information relating to medicine. As an example, Tockler's practica for the year 1515 in Leipzig will be closely analyzed (Tockler [1514]) (Fig. 5.3).

The text is constituted of eight folios and the title page bears an image that depicts the main characteristics of the year, which are consequences of the conflict between Mercury and Jupiter. The title itself promises that, after the actual judicial forecast, the reader will find a summary of the regimen sanitatis extracted from the work of the hochberühmten Mayster Avicenna. The text is organized into chapters, each devoted to a forecast for a particular subject and/or a particular group of people. The first chapter, however, is a sort of introduction that explains the general situation of the configuration of the planets and its influence on the pestilence in Europe and in the region around Leipzig. The following twelve chapters handle subjects that range from 'war' and 'sicknesses' to the harvest of several agricultural products and the fate of Wanderer (journeyman years) and virgins. Of course, there are also chapters specifically dedicated to the local authorities, the Pope, and the Roman Catholic Emperor. This section is then followed by one dedicated to a meteorological forecast. This is structured through the series of new moons for the entire year. For each new moon, the date and the kind of weather to be expected are described in detail. The final regimen is in turn divided into two further parts. The first is concerned with dietetics and makes direct reference to Avicenna. Here the reader can find, in the form of short statements, useful suggestions on how to maintain a good state of health. The first statement, for instance, suggests moderating the quantity of food and drinks that are ingested. The second section instead summarizes which aspects of Leipzig citizens' health will face particular danger in 1515 according to their Zodiacal sign. Cancers, for instance, were expected to have problems specifically related to their lungs and stomach.

Tockler was also a proud compiler of almanacs. These were leaves of paper that could be put on the wall like modern calendars. The major function of the almanacs was to summarize the information concerning the dates of the major liturgic festivities - the movable feasts - and especially to help the citizens make decisions on each day of the year concerning their health. This was a direct and very practical output of medical astrology and was mostly directed to specific actions and especially to bloodletting, as this was considered one of the most efficient means of maintaining one's health. In his almanac for the city of Leipzig for the upcoming 


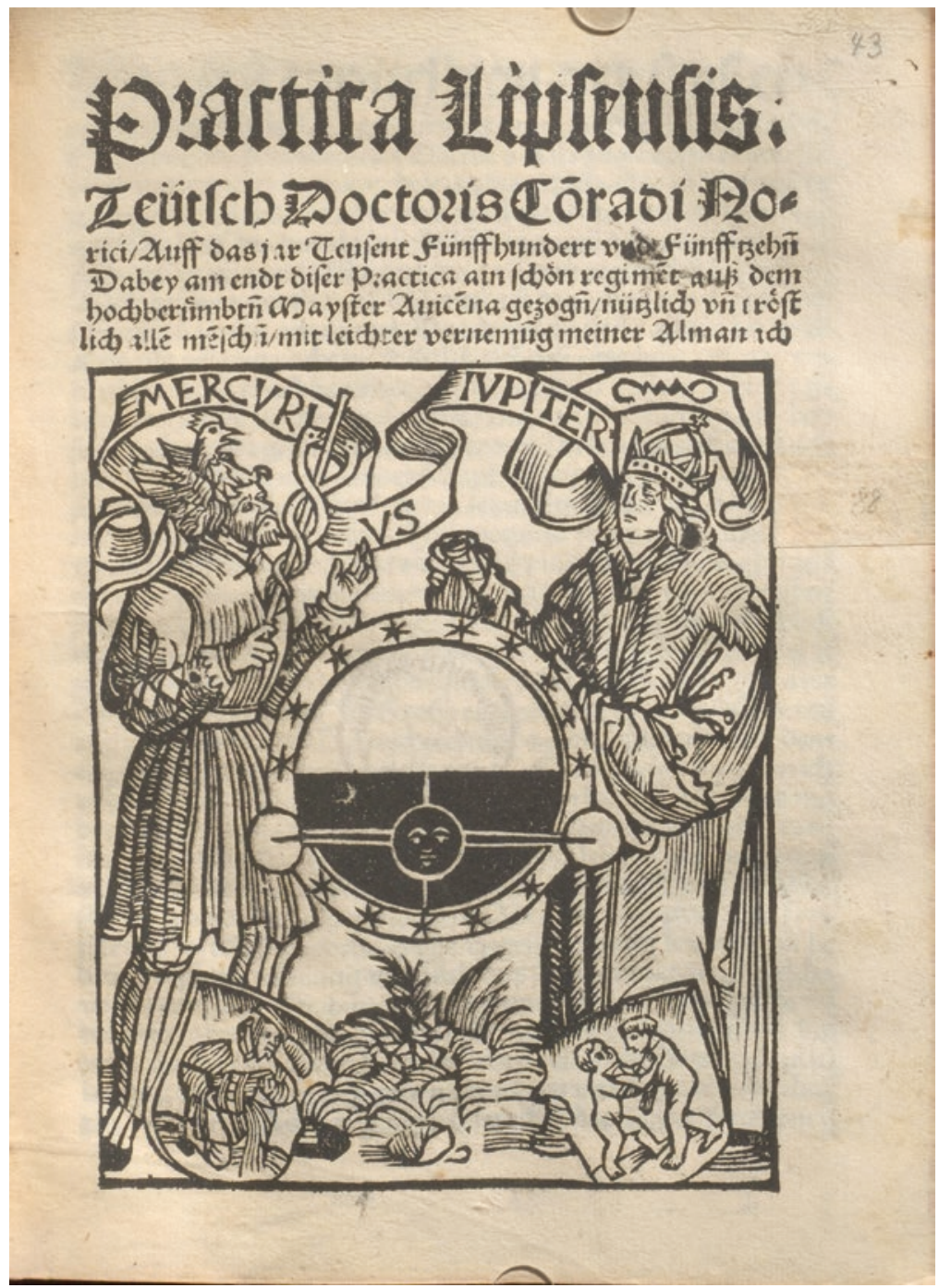

Fig. 5.3 Title page of Tockler's practica for the city of Leipzig for the upcoming year, 1515. The conflict between Mercury and Jupiter dominates the events of the year to come. From (Tockler [1514], fol. 43r). University Library Erlangen-Nürnberg, H61/4 TREW.S 83/119\#88, https://nbnresolving.org/urn:nbn:de:bvb:29-bv008943848-9

year of 1507 (Tockler 1506a), Tockler wrote how the almanac should be read (Fig. 5.4). This legend lists ten symbols and their explanations. Each day of the year is then associated with one or more symbols. Their meanings are the following: (a) new moon, (b) first quarter of the moon, (c) full moon, (d) last quarter of the moon, (e) bloodletting in good quantity is recommended, (f) bloodletting is recommended in a moderate quantity, (g) taking a good quantity of medicine is recommended, 


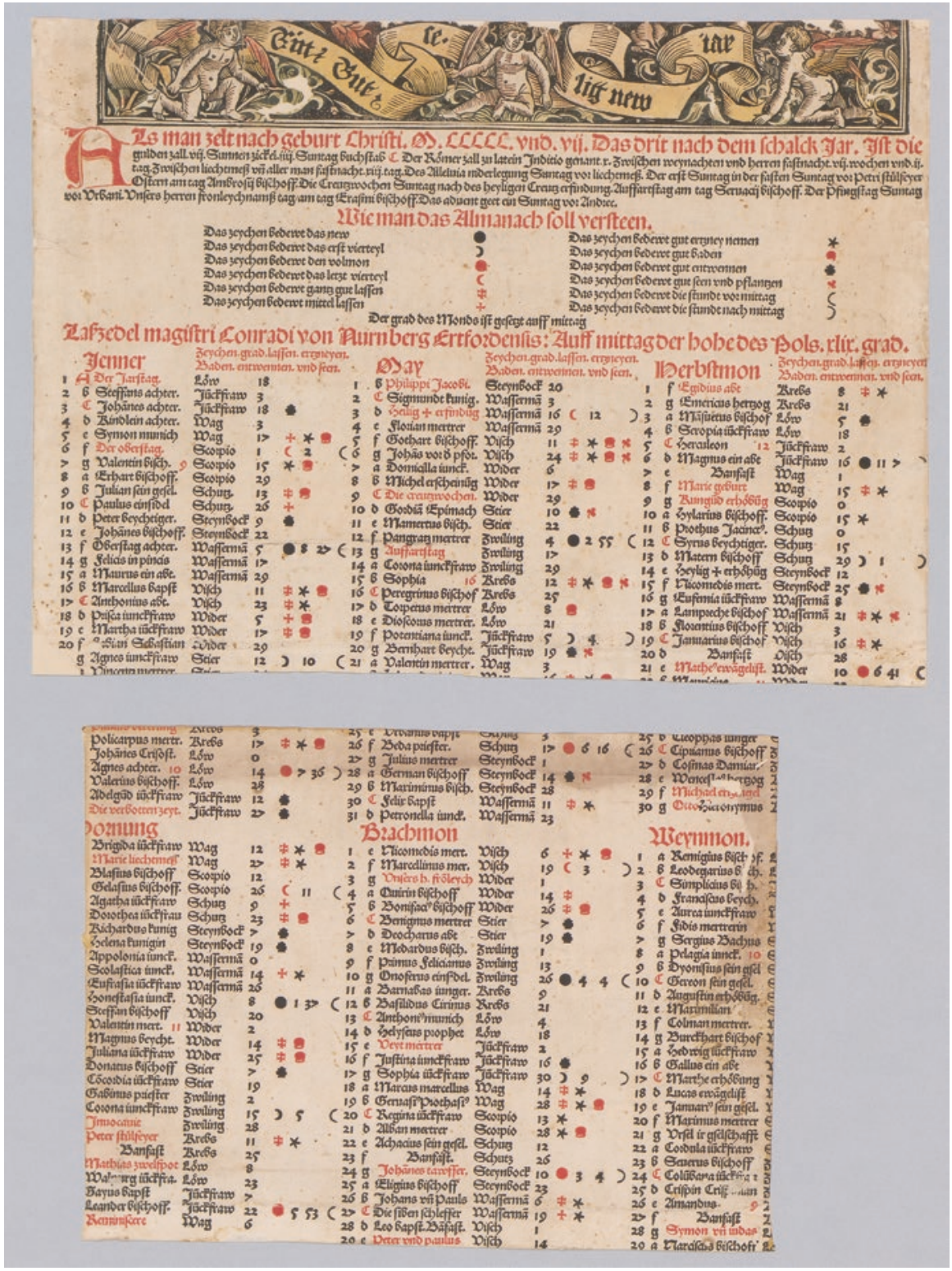

Fig. 5.4 Almanac for the city of Leipzig for the year 1507. The legend "how to read the almanac" is at the top of the leave. From (Tockler 1506b). The National Library of the Czech Republic, Warm fragm. 503

(h) bathing is recommended, (i) appropriate for weaning, (j) appropriate to sow and to plant, (k) during the hours before midday, l) during the hours after midday. The $19^{\text {th }}$ of January 1507 , for instance, was the day of the Virgin Martha, the day when Taurus was at the seventeenth degree, and a good day for an abundant bloodletting and taking a bath. 
Two further curious aspects concern the spread and the transformation of these works. The first is their language. For the same years and the same city (Leipzig) it is still possible to find the same almanac published by different printers in different languages. For instance, the same almanac for the year 1507 exists also in Czech (Tockler 1506b). This was probably due to the flow of migrants into this region from Czech-speaking territories, bringing many new citizens to this traditionally Germanspeaking city. Other almanacs are in Latin. This testifies to the great demand for these works and for the consequent fact that Tockler must have been well known in the city. The second aspect to consider is that a comparison with later almanacs, such as the one in Latin for the year 1511, clearly shows that Tockler's level of sophistication in his calculations increased in that the legends increasingly differentiate between quantities and times for each of the mentioned activities.

The last astrological work, already mentioned above, is a collection of 130 astrological statements compiled in 1506 (Tockler 1502-1506, 121r-23r). These statements are formulated so as to have general validity; the text therefore cannot be seen as a judicia, as it does not refer to a specific year and is not a forecast strictly speaking. But the subjects are indeed those of the judicia and practica. Statement number forty-seven, for instance, tells that "Saturn, when it is in its retrograde motion in Libra, creates tensions between rulers from the West and those from the North" (Tockler 1502-1506, 122r). In the colophon it is moreover explained that this work was compiled under commission. One can therefore circumstantially infer that this is a sort of compact and handy summary of the basics of judicial astronomy, apparently a subject in which the Duke of Saxony was particularly interested. ${ }^{39}$

This text was compiled in the same year Tockler prepared the commentary on Peuerbach's Theorica, and both texts are dedicated to George, the Duke of Saxony. These are, however, not the only common characteristics. As a matter of fact, the first statement reads "Sol est rex celi: statua dei" (Tockler 1502-1506, 121r). Thus, the Ficinian program of identifying the sun with the principle of the life of the cosmos is once again at the core of Tockler's agenda.

\section{Tockler's Research Agenda in its Social Context}

At a very early step of his intellectual and social career, Tockler had already laid the fundaments for his entire research agenda. With the re-publication of Ficinus's $D e$ sole, only nine years after the original publication, Tockler showed that he had a clear idea of his interests. In particular, it was Ficinus's ontology, the requirement that any effect must be associated with a corporeal substance and a natural phenomenon, that served as a basis for Tockler's move into natural theology, within whose

\footnotetext{
${ }^{39}$ Tockler's text of astrological statements is clearly compiled following the example of the socalled Ptolemy's Centiloquium, an extremely influential text on astrology often also used in teaching. For more information, see (Sela 2003, 321).
} 
bounds he sought to scientifically determine the fate of the cosmos and of human beings.

Peckham's geometry of light - the material means of the diffusion of God's will through the movements of the celestial bodies - and its dynamic principles, according to which strong or weak effects on the sublunar world could be defined, turned out to be the perfect instrument for investigating how cosmological influences operate. However, this step required an increasingly sophisticated mathematical astronomy, which was offered by Peuerbach's Theorica and its ontological assumption of the planetary orbs' reality.

All of Tockler's texts were also conceived for his lecturing activity at the university. In this context, it is easy to understand why he also relied on the mandatory commentaries on Sacrobosco's Sphaera to pursue his objective of closely connecting cosmology, astronomy, medicine, and astrology. The Sphaera was a duty and an opportunity at the same time, and after the mathematical turn of 1506, a new updated edition turned out to be necessary.

There is a clear continuity between his public role and his scientific agenda, which also included other fields, such as speculative music and theory of numbers. Clearly Tockler was not interested in any practical use of arithmetic (rather called 'logistic') or of music. His interest was directly only toward the cosmos and therefore to the series of arithmetical proportions needed to understand the musica mundana, the harmony of the cosmos that could only be conceived mentally, not listened to.

The collection of astrological statements rounds off the public profile of Tockler, demonstrating his close relationship to the court and therefore to the city. The intensive work on almanacs and practica are the clear effect of this perfect social integration in the intellectual and social tissue of the place where he was active. Through his personal Ficinian program, Tockler was therefore able to embed in one and the same agenda the roles of university teacher and "social" physician, giving general advice on how to conduct a healthy life, advice which was virtually present in any building with an almanac hanging on the wall. Finally, the last works Tockler published, regarding calendars and calculating the means of planetary motions, show that his interest had not changed but his approach was increasingly dictated by the need for a more sophisticated mathematical apparatus, which he did not neglect to impart to his pupils.

\section{Conclusions}

At first sight, Tockler's intellectual profile looks like a reminiscence of the late Medieval university framework. However, the re-emergence of neo-platonic tendencies eventually gave an impulse to re-visiting the late Medieval doctrines through the lens of astrological medicine and Christian theology (Chap. 3). By comparison, most of the commentaries on Sacrobosco's Tractatus de sphaera after the 1530s no longer engaged with astrological and medical subjects. Instead, themes related 
to cosmography and geography and to technical developments in the realm of mathematical instruments began to be the dominant subjects at the beginning of the sixteenth century. ${ }^{40}$

The texts of Peckham and Leopold, for instance, as well as those of Boethius and Jean de Murs, the background against which Tockler prepared his own texts, are indeed all compilations either from antiquity or from the early days of the Western university. Nevertheless, Tockler commented on most of them and in this way was able to update their content. In the case of Leopold's treatise, moreover, he could rely on a printed edition that was produced just a few years before he published the first edition of his commentary on the Sphaera.

Finally, many further texts that evidently played a major role in his research were all new or relatively new but only recently printed. This is the case for instance for Peuerbach's Theorica, the text that probably exerted the most profound influence on Tockler's agenda after Ficinus. At the time of Tockler's commentary on Peuerbach, the original text was only twenty-eight years old. The most relevant cases, however, are those of Ficinus and Regiomontanus's Epitoma. Both works were more or less contemporary to Tockler's own, seeing as they began to circulate during his university studies.

To conclude, the case of Tockler makes clear that the lines of continuity between the late Middle Ages and early modern times are stronger than what historians often are willing to admit, and shows that this was also due to the "re-issuance" of medieval works into the market of the printed book. Tockler was completely up to date for the times, in spite of the fact that he was relying on texts that were already older than 100 or even 150 years. Still, from the historical perspective of the corpus of the commentaries on Sacrobosco's Sphaera, which reached its apex in the second half of the sixteenth century, the currency of Tockler's work appears to be in steady decline. This was due to the incipient beginning of the decline of astrology as a scientific discipline in the universities and, in a broader sense, to a split between the new practical science of the early modern period and neoplatonic culture.

\section{References}

Aristoteles, and John L. Stocks. 1922. De caelo. Oxford: Clarendon Press.

Barker, Peter. 2011. The reality of Peurbach's orbs: Cosmological continuity in fifteenth and sixteenth century astronomy. In Change and continuity in early modern cosmology, ed. Patrick J. Boner, 7-32. Dordrecht: Springer.

Břenková, Kristýna. 2015. Musica speculativa Johannis de Muris. Bachelor Bachelor Thesis, FILOSOFICKÁ FAKULTA. Univerzita Palackého v Olomouci.

Carmody, Francis J. 1955. Notes on the astronomical works of Thābit ibn Qurra. Isis 46 (3): 235-242.

\footnotetext{
${ }^{40}$ For an overview of general scientific tendencies reflected in the transformative process the commentaries of Sacrobosco's Sphaera underwent, see (Valleriani 2017).
} 
1956. Arabic Astronomical and Astrological Sciences in Latin Translation: a Critical Bibliography. Berkeley: University of California Press.

de Muris, Johannes, and Christoph Falkenroth. 1992. Die Musica speculativa des Johannes de Muris. In Beihefte zum Archiv für Musikwissenschaft, Archiv für Musikwissenschaft, vol. 34. Stuttgart: Franz Steiner Verlag.

de Sacrobosco, Johannes, Conrad Tockler, and Thābit ibn Qurra. 1503. Textus Spere materialis Joannis de Sacrobusto cum lectura Magistri Conradi Norici in florentissmo Lipsensi gymnasio: nuper exarata. Verba Thebit acutissimi Astronomi de imagine tocius mundi atque corporis sperici compositione: introducendis ipsis incrementum magnum prebentia: per eundem: addita. Leipzig: Martin Landsberg. http://hdl.handle.net/21.11103/sphaera.100931.

— 1509. Textus Spere materialis Joannis de Sacrobusto cum lectura Magistri Conradi Norici in florentissimo Lipsensi gymnasio nuper exarata. Verba Thebit acutissimi Astronomi de imagine totius mundi atque corporis sperici compositione: introducendis ipsis incrementum magnum prebentia: per eundem! addita. Ordinatio spere materialis: et decem circulis ! huic operi inseriuens: per Magistrum Conradum Noricum novitem addita et diligenter revisa. Leipzig: Martin Landsberg. http://hdl.handle.net/21.11103/sphaera.101042.

Doppelmayr, Johann Gabriel. 1730. Historische Nachricht Von den Nürnbergischen Mathematicis und Künstlern welche fast von dreyen Seculis her Durch ihre Schrifften und Kunst-Bemühungen die Mathematic und mehreste Künste in Nürnberg und vor andern trefflich befördert, und sich um solche sehr wohl verdient gemacht; zu einem guten Exempel, und zur weitern rühmlichen Nachahmung. Nürnberg: In Verlegung Peter Conrad Monaths. Gedruckt bei Joh. Ernst Adelbuinern.

Erler, Georg. 1895-1902. Die Matrikel der Universität Leipzig, 3 vols. Leipzig: Giesecke \& Devrient.

Ficino, Marsilio, and Enrico Musacchio. 1983. Consilio contro la pestilenzia. Bologna: Cappelli.

Ficinus, Marsilius. 1493. In librum de sole. Florentiae: Ex archetypo Antonius MIschominus.

Ficinus, Marsilius, and Konrad Tockler. 1502. Preclari oratoris et philosophi Marsili Ficini Libellus de Sole. Leipzig: Wolfgang Stöckel.

Freytag, Friderich Gotthilf. 1752-1753. Adparatus litterarius ubi libri partim antiqui partim rari recensetur. 3 vols. Lipsiae: Ex officina Weidmanniana.

Garin, Eugenio. 1952. Prosatori latini del Quattrocento. Milano-Napoli: Riccardo Ricciardi Editore.

Grosse, Karl. 1839. Geschichte der Stadt Leipzig von der ältesten bis auf die neueste Zeit. Vol. 1. Leipzig: C. B. Polet.

Haar, James. 1960. Musica mundana. In Variations on a pythagorean theme. Cambridge, MA: Harvard University.

Hasse, Dag Nikolaus. 2016. Success and suppression. Harvard University Press.

Heilmann, Anja. 2007. Boethius' Musiktheorie und das Quadrivium. Eine Einführung in den neuplatonischen Hintergrund von De institutione musica. Göttingen: Vandenhoeck \& Ruprecht.

Iamblichus, and Thomas Taylor. 1986. Life of pythagoras. Translated from the greek by Thomas Taylor, 1818. Rochester: Inner Traditions International.

Kaske, Carol V., and John R. Clark. 1989. Marsilio Ficino: Three books on life. A critical edition and translation with introduction and notes. Tempre: The Renaissance Society of America.

Kedar, Yael. 2017. Laws of nature. In Encyclopedia of medieval philosophy: Philosophy between 500 and 1500, ed. Henrik Lagerlund, 1-5. Dordrecht: Springer Netherlands.

Kremer, Richard L. 2017. Incunable almanacs and practica as practical knowledge produced in trading zones. In The structures of practical knowledge, ed. Matteo Valleriani, 333-369. Dordrecht: Springer.

Kreussler, Heinrich G. 1810. Geschichte der Universität Leipzig. Dessau: Solbrig.

Kristeller, Paul Oskar. 1972. Die Philosophie des Marsilio Ficino. Frankfurt am Main: Vittorio Klostermann.

Leopold of Austria, and Benjamin N. Dykes. [13th cent] 2015. A Compilation of the Science of the Stars. Trans. and Ed. Benjamin N. Dykes. Minneapolis: The Cazimi Press. 
Lindberg, David C., and John Pecham. 1970. John Pecham and the science of optics. Perspectiva communis. Madison: The University of Wisconsin Press.

Malpangotto, Michela. 2016. The original motivation for Copernicus's research: Albert of Brudzewo's Commentariolum super Theoricas novas Georgii Purbachii. Archive for History of Exact Sciences 70 (4): 361-411. https://doi.org/10.1007/s00407-015-0171-y.

Marongiu, Massimo. 2012. L'ars nova. Poesia e musica nel trecento italiano. In Comparative modern literatures. Italy: University of Cagliari. http://www.maroniusenea.it/introduzione.htm.

Masi, Michael. 1983. Boethian number theory. A translation of the de institutione Arithmetica. Amsterdam: Rodopi.

Nothaft, C., and E. Philipp. 2017. Criticism of trepidation models and advocacy of uniform precession in medieval Latin astronomy. Berlin/Heidelberg: Springer.

Omodeo, Pietro Daniel. 2017. Utilitas astronomiae in the renaissance: The rhetoric and epistemology of astronomy. In The structures of practical knowledge, ed. Matteo Valleriani, 307-331. Cham: Springer.

Peuerbach, Georg. 1474. Theoricae novae planetarum Georgii Purbachii astronomi celebratissimi. Nunrberg: Regiomontanus.

Rabl, Carl. 1909. Geschichte der Anatomie an der Universität Leipzig. Leipzig: Johann Ambrosius Barth.

Regiomontanus, Joannes. 1496. Epitome Joannis de monte regio in almagesti ptolomei. Venetiis: Johannes Hamann.

Schmidt-Thieme, Barbara. 2002. Konrad Tockler, genannt Noricus. In Verfasser und Herausgeber mathematische Texte der frühen Neuzeit, ed. Rainer Gebhardt, 95-102. Annaberg-Buchholz: Adam-Ries-Bund.

Schönberg, Rolf, Andrés Quero Sánchez, Brigitte Berges, and Jiang Lu. (eds.). 2012. Repertorium editierter Texte des Mittelalters aus dem Bereich der Philosophie und angrenzender Gebiete. A-Z. 2nd ed.. 4 vols. Berlin: Akademie Verlag.

Schöner, Johannes, and Conrad Tockler. 16th cent. Mathematische und astronomische Sammelhandschrift. Österreichische Nationalbibliothek. Sammlung von Handschriften und alten Drucken. Cod. 5280 Han.

Schrader, Doroty V. 1967. The arithmetic of the Medieval universities. The Mathematics Teacher 60 (3): 264-278.

Sela, Shlomo. 2003. Abraham ibn Ezra and the rise of Medieval Hebrew science. Leiden: Brill.

Sparavigna, Amelia Carolina. 2014. The ten spheres of Al-Farabi: A medieval cosmology. International Journal of Sciences 3 (6): 34-39.

Sudhoff, Karl. 1909. Die medizinische Fakultät zu Leipzig im ersten Jahrhundert der Universität. Jubiläumsstudien von Karl Sudhoff. Mit 16 Tafeln. Leipzig: Johann Ambrosius Barth.

Tockler, Conrad. 1502-1506. Philosophische Sammelhandschrift. Österreichische Nationalbibliothek. Sammlung von Handschriften und alten Drucken. Cod. 5274 Han.

-1503a. Commentatio Arithmeticae communis. Leipzig: Martin Landsberg.

.1503b. Textus Arithmetice Communis: qui p[er] magisterio fere cunctis in Gymnasijs, ordinarie solet legi, correctus corrobatusque, perlucida quadam atque prius no[n] habita Commentatione. Leipzig: Martin Lansberg.

- 1506a. Almanac for the city of Leipzig and for the year 1507. Nürnberg: Höltzel, Hieronymus.

— 1506b. Minuce na rok 1507. Nürnberg: Höltzel, Hieronymus at the cost of Nicholas Bakalar.

- 1511a. Canones ad inveniendum ciclum solarem lunarem, indictionalem, intervallum, concurrentes, festa mobilia, et ea quae ab ecclesia Rhomana, appropriato instrumento expressa, magis sunt observata, per Conradum Noricum. Leipzig: Martin Landsberger.

— 1511b. Canones motuum medii medij solis et lunae aliarum denique quinque stellarum erraticarum, appropriato instrumento cognoscibiles, cum pulchris annotatis per Conradum Noricum. Leipzig: Martin Landsberg. 
1514. Practica Lipsensis teütsch doctoris Conradi Norici, auff das Jar tausent fünffhundert und fünfftzehen: Dabey am Endt diser Practica ain schön Regiment auß dem hochberümbten Mayster Avicenna gezogen. Augsburg: Fischer.

Valleriani, Matteo. 2010. The garden of Pratolino: Ancient technology breaks through the barriers of modern iconology. In Ludi Naturae-Spiele der Natur. Transformationen eines antiken Topos in Wissenschaft und Kunst, ed. Natascha Adamowsky, Robert Felfe, and Hartmut Böhme, 120-41. München: Fink Verlag.

Valleriani, Matteo. 2014. Ancient pneumatics transformed during the early modern period. Nuncius 29: $127-174$.

Valleriani, Matteo. 2017. The tracts on the Sphere. Knowledge restructured over a network. In The structures of practical knowledge, ed. Matteo Valleriani, 421-473. Dordrecht: Springer.

Zarncke, Friedrich. 1861. Die Statutenbücher der Universität Leipzig aus den ersten 150 Jahren ihres Bestehens. Leipzig: S. Hirzel.

Open Access This chapter is licensed under the terms of the Creative Commons Attribution 4.0 International License (http://creativecommons.org/licenses/by/4.0/), which permits use, sharing, adaptation, distribution and reproduction in any medium or format, as long as you give appropriate credit to the original author(s) and the source, provide a link to the Creative Commons license and indicate if changes were made.

The images or other third party material in this chapter are included in the chapter's Creative Commons license, unless indicated otherwise in a credit line to the material. If material is not included in the chapter's Creative Commons license and your intended use is not permitted by statutory regulation or exceeds the permitted use, you will need to obtain permission directly from the copyright holder.

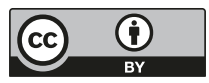




\title{
Chapter 6 \\ John of Glogów
}

\author{
Peter Barker
}

\begin{abstract}
John of Glogów taught at Kraków from 1468 until his death. He wrote on grammar, logic, medicine and especially astronomy, including a commentary on Johannes de Sacrobosco's Sphaera (1506). An unusual feature of his Sacrobosco commentary is the extended use of the three-dimensional orb models popularized in Peuerbach's Theoricae novae planetarum (Nuremberg 1474) and also used by Glogów's colleague Albert of Brudzewo. To situate Glogów's work, I describe the development of celestial orbs in astronomy by Islamicate followers of Ptolemy and their European reception. Early modern Europeans debated the physical reality of eccentrics, epicycles, and the corresponding orbs with the followers of Averroes. After reviewing Glogów's criticisms of Sacrobosco, I conclude that he clearly sides with Ptolemy, Peuerbach and Brudzewo against Averroes. His work shows that astronomers after Peuerbach attributed physical reality to their theories, and claimed increasing autonomy for mathematical sciences against physics.
\end{abstract}

\section{Introduction}

In 1506 John of Glogów (Jan Głogowczyk, Johannes Glogoviensis, ca. 1445-1507) completed a commentary on the Sphaera of Johannes de Sacrobosco (died ca. 1256). Glogów's commentary was printed at Kraków, reprinted there in 1513, and again in Strasbourg in 1518. His commentary was typical of many new works on Sacrobosco written during this period. Rather than simply presenting and explaining Sacrobosco's text, fifteenth and sixteenth century commentaries frequently presented new material, as Kathleen Crowther has recently shown in detail (Crowther et al. 2015). In the case of Glogów, the new material was the system of celestial orbs that had first appeared in print in Georg von Peuerbach's (1423-1461) Theoricae

\footnotetext{
P. Barker $(\bowtie)$

University of Oklahoma, Norman, OK, USA

e-mail: barkerp@ou.edu 
novae planetarum (Nuremberg, 1474). ${ }^{1}$ As Robert Westman points out, the term 'theorica' should be read in contrast to the term 'practica' (Westman 2011, 40-43), which correspond roughly to the modern 'theory' versus 'practice' or 'application.' For the science of the stars, astrology formed the practica, in contrast to the astronomy presented in the theorica. Both the Sphaera of Sacrobosco and its commentaries fall on the astronomy side of this divide, although, in the case of Glogów he clearly indicates its connection to astrology. The term 'practica' was also used for a genre of astrological prognostications, including most importantly the annual prognostications drawn up for a particular place or nation by German speaking astrologers. Glogów contributed a large number of items to this genre (Glogów 1478-1479, 1479-1480, 1480-1481, 1499-1500, 1501-1502, 1502-1503). Indeed, for most Renaissance scholars, it would be fair to say that their main motive for contributing to astronomy was to support astrology, and this connection appears in the work of both Glogów and his student and colleague Albert of Brudzewo (ca. 1445-1495).

Peuerbach's book reignited a long running dispute in the Latin West between followers of the Alexandrian astronomer Claudius Ptolemy (ca. 100-ca. 160) and followers of the Iberian philosopher Averroes (1126-1198). Glogów took a clear position on one side of this dispute in his commentary. Followers of Ptolemy used physical orbs representing eccentrics and epicycles to produce the motions described mathematically in Ptolemy's Almagest. Followers of the Iberian philosopher insisted that all celestial orbs must be centered on the earth. After a brief biography of Glogów, I will describe the historical development of the orb models used in Peuerbach's Theorica and Glogów's commentary on Sacrobosco. I will go on to examine the latter book's significance in the wider context of the dispute with the Averroists, and finally consider how the celestial orbs appear in Glogów's book, comparing his presentation with the text of Sacrobosco that he comments on.

Glogów was educated at the Jagiellonian University of Kraków from 1462-1468 and subsequently became an influential teacher there until his death in 1507 (Goddu 2010, 27). His nearly 40 years of teaching overlapped the career of his student Albert of Brudzewo, as well as Nicolaus Copernicus's (1491-1495) early education (Barker 2013a, b; Malpangotto 2016; Sylla 2017). Glogów's duties are known in detail for 1487-1506. Between 1487 and 1500 he taught logic and grammar, with the addition of De anima in 1491, De caelo in 1493 and Aristotelian physics in 1499 (Szczegola 1967, 23-24; Goddu 2010, 31). He spent the academic year 1497-1498 at the University of Vienna (Goddu 2010, 36). He seems to have taught Sacrobosco only in 1506 , the year his commentary was printed.

\footnotetext{
${ }^{1}$ As I am not satisfied with any of the terms that might be used translate it into modern English, in the present paper I will retain the contemporary term theorica (pl. theoricae) as far as possible, for a variety of uses. A theorica (small ' $\mathrm{t}$ ') is a model offering a basis for calculating planetary positions against the fixed stars, expressed as angles from a fixed line of reference. The theoricae for individual planets may be quite separate; the appearance of particular features in one should lead to no expectation that a similar feature will appear in adjacent planets, or as universal feature of the theoricae of all planets. Second, a Theorica (capital ' $\mathrm{T}$ ') is a book presenting theoricae. The most important instances are the anonymous traditional Theorica planetarum often attributed to (Gerard of Cremona 1472), and Georg Peurbach's Theoricae novae planetarum (Peuerbach 1474).
} 
John of Glogów was what is now called an "early adopter" of the new technology of printing. The first publications I have found were in astronomy and astrology, beginning with a description of solar and lunar eclipses, including a practica, a yearly list of astrological prognostications, covering the weather, health and politics, for the year 1479. This, and several later practica by Glogów (e.g. for the years 1480, 1481), were published by Marcus Brandis (flourished after 1473; otherwise known as “the printer of Isidoru's Soliloquia”), at Merseburg in Saxony, which lies south of Halle and west of Leipzig. Shortly before 1500 Glogów established a working relationship with Jan Haller (ca. 1467-1525), who became the most important bookseller and publisher in Kraków itself, and began to publish books on many of the subjects fundamental to university education for early sixteenth century students (Benzing 1966). Glogów's book on Aristotle's (348-322 BCE) Posterior analytics as treated by Johannes Versoris (died ca. 1485) was printed by Wolfgang Stöckel (died ca. 1539) in Leipzig, for Haller, in 1499. Glogów's commentary on the second of four parts of the versified Latin grammar of Alexander de Villa Dei (1170-1250), and his books on Donatus's Ars minor, and Peter of Spain's Parva logicalia were printed in the same way in 1500 . Haller was also credited as publisher of the book on the Posterior analytics in 1501, when it was republished by Hartfelder in Metz. Haller himself, in Kraków, produced a new version of the Donatus in 1503, and a new work on Porphyry's Isagoge plus another edition of Villa Dei's grammar in 1504. In 1506-1507 Haller published another of Glogów's prognostications, which like the 1502 version gave times for blood-letting and other medical procedures. In 1507, the year of Glogów's death, Haller published another new work, the Computus Chirometralis, with a revised edition in 1510. In fact the Haller firm continued to publish Glogów's books after it absorbed the press of Florian Ungler (died 1536), and there is no evidence that Glogów used any other publisher in Kraków. Hence, although the 1506 Introductorium compendiosum in Tractatum Spere identifies only its place of publication, which is Kraków, we may be fairly certain that Haller was the publisher. And the case is strengthened by the second edition in 1513, which was printed by Ungler for Haller. Johann Knoblauch (died 1528) in Strasbourg began to republish the books on Donatus, Peter of Spain, and other topics in the humanities, in 1515. He apparently published the third edition of Glogów's commentary on Sacrobosco in 1518 (again reasoning from the city, and the printer's prior activity).

Szczegola, Glogów's modern biographer, claims that his contributions to the science of the stars included "between 50 and 60 titles" published at Leipzig, Merseburg, and Kraków, including many practica, the Computus Chirometralis (Glogów 1507, 1511a, b), the posthumous Introductorium Astronomie in Ephemerides (Glogów 1514a, b), which Szczegola calls an Introductorium cosmographiae, a Summa astrologiae (perhaps the Tractatus preclarissimus in judiciis astrorum, Glogów 1514b) and a Defensio astrologiae ("Persuasio brevis quomodo astrologiae studium religioni christianae non est adversus"/“A brief argument on how the study of astrology is not contrary to the Christian religion"), which I have been unable to locate, as well as the Sacrobosco commentary (Szczegola 1967, 72-73, 78-90). 


\section{Astronomical Orbs from Ptolemy to Peuerbach}

Glogów's commentary on Sacrobosco takes a position in a dispute that goes back to the origins of astronomy as an exact science in the West. The very earliest mathematical models of planetary motion were developed by Artistotle's contemporary Eudoxus of Cnidos (died 347 BCE), who devised sets of earth centered circles, rotating about their diameters, and suspended one inside another so that a planet carried on the innermost circle accrued all the motions of the circles supporting it. Eudoxus seems to have provided only the bare mathematical model. Aristotle, however, physicalized it, by replacing each of Eudoxus's original circles with an orb of the same diameter and rotating on the same axis. However, it was already accepted that some planets were further away than others. Saturn, for example, was assumed to be the outermost planet because it took more than 30 years to return to the same point relative to the stars. Jupiter was inside it, with a period of about 12 years. But the orbs carrying Jupiter could not simply be attached to the innermost orb of Saturn, without unintentionally transmitting all the motions of Saturn to the orbs of Jupiter. To prevent this, Aristotle inserted counteracting orbs between the sets moving each planet, giving a grand total of 55 spheres for all the planets (North 2008, 73-84).

In addition to moving against the background of fixed stars, the outer planets Mars, Jupiter and Saturn also vary in brightness. The most obvious explanation for this was that they changed their distance from the earth, something that could not happen in Eudoxus's and Aristotle's constructions, where all motions were centered on the earth and strictly concentric. By the time Claudius Ptolemy synthesized and improved contemporary astronomy, earth centered models had been replaced by models using a large circle (the carrying circle or deferent) to carry the center of a small circle (called the epicycle). The center of the deferent was located at or near the center of the earth, but displacing its center, and especially placing the planet on the smaller epicycle it carried, allowed planets to vary their distances from the center of the cosmos. A carrying circle with a displaced center was termed an eccentric, thus the basic mathematical tools in astronomy at the time of Ptolemy, eccentrics and epicycles, both used circles with centers that were not the center of the earth. To this, Ptolemy added his own unique contribution-the equant-probably in an attempt to align the directions and durations of planets' reverse motions (Evans 1998, 384-92; North 2008, 114-18). Taking a diameter of the deferent through the geometrical center of the deferent itself and the center of the earth, the equant is a point on this line that is the same distance away as the earth but on the opposite side of the deferent center. Ptolemy made this point the center of uniform rotation for the epicycle, greatly improving empirical accuracy, but at a cost in physical terms.

In his major book on astronomy, now known as the Almagest, Ptolemy, like Eudoxus, provided only mathematical models (Toomer 1998). Taking the same step that Aristotle had for Eudoxus, Ptolemy attempted to provide a physical basis for these models in a subsequent book, now known as the Planetary Hypotheses (Goldstein 1967). Basically he showed that eccentric and epicycle circles could be generated by sets of orbs - the partial orbs printed for the first time in Johannes 
Regiomontanus' (1436-1476) version of Peurbach 1474, and illustrated in the images later in this paper taken from Glogow's commentary on Sacrobosco. However, there are two complications to this simple story. First, the circles generated by rotating orbs are the traces of points, usually on the equator of the orb, which itself rotates about a diameter corresponding to the poles, each 90 degrees from the equator. This diameter passes through the geometrical center of the orb, perpendicular to the plane of the equator. But the equant is not at the center of the eccentric circle or the corresponding orb, so the equant motion cannot be represented by the natural rotation of an orb, about an axis through its geometrical center. In fact, it is not clear that the motion about the equant point has any physical significance for an orb with a different geometrical center (Andersen et al. 2006, 117-46). These difficulties were unresolved by Ptolemy but assumed a special significance as astronomy developed in the Islamicate world.

As in the case of Ptolemy, the development of astronomy in the Islamicate world was motivated by the needs of astrology. Initially, Islamicate scholars drew on sources from India, Persia, Byzantium, and, in translation, the earlier Greek tradition (Saliba 2007, Chaps 1-3). From Ptolemy they received both his works on astronomy and astrology, the Almagest, the Planetary Hypotheses, and the Tetrabiblos. Between the reign of Caliph al-Ma'mun (reigned 813-833) and the career of Abū Sāōd Aḥmad ibn Muḥammad ibn 'Abd al-Jalīl al-Sijzī (ca. 945-ca. 1020), Ptolemy's works became the paradigm defining all Islamicate astronomy (Sayili 1960, 79-80; Brummelen and Glen 2007). Sijzī wrote the first Ptolemaic introduction to astronomy, or hay'a, without using partial orb models like those found in later in Peuerbach and Glogow. But by this time advanced practitioners of astronomy had begun to recognize the problem posed for orb models by the equant. Ibn al-Haytham (965-1040), who spent the latter part of his life in Cairo, wrote a comprehensive critique of Ptolemy's models, pointing out, among others, the problem with the equant (Voss 1985). Ibn al-Haytham's critique had two outcomes.

After more than a century of uncertainty Nașīr al-Dīn al-Ṭūsī (1201-1274) and his colleagues at the Marāgha observatory in northern Persia provided a variety of solutions to the problems raised by Ibn al-Haytham (Ragep 1993, 50, Table 1, for a list of the problems). One major method, developed by Țūsī himself, used two circular motions to produce reciprocating motion on a straight line. ${ }^{2}$ Replacing the circles by orbs gave a three dimensional device that, when added to the partial orbs representing eccentrics and epicycles, yielded results comparable to the equant, but used only orbs that rotated about their own diameters. A second device, developed by Ṭūsī's colleague Mu'ayyad al-Dīn al-'Urḍ̄i (died ca. 1266), eliminated the equant by redefining the eccentricity of the deferent circle, again allowing an orb model with components that rotated about diameters (Schmidl 2007). Both of these methods later appeared (without attribution) in the work of Copernicus in Poland (Swerdlow 1973; Swerdlow and Neugebauer 1984). The methods introduced by Ṭūsı̄'s and his colleagues rapidly became the new paradigm in Islamicate astronomy

\footnotetext{
${ }^{2}$ For TTūsì’s method, see the animations at: https://people.sc.fsu.edu/ dduke/models. Accessed June 2019.
} 
East of Cairo. This change has been described as a scientific revolution (Saliba 1987). Although Ptolemy was still used as a source book, advanced treatments of astronomy all employed devices that avoided the equant and all gave orb models based on these devices that had no objectionable features. Work in this new tradition continued as late as the eighteenth century, when the astronomers of Mughal princepractitioner Sawai Jai Singh (reigned 1699-1743) wrote a commentary on the section the Țūsī's book where he introduced the device that replaced the equant (Sharma 1995; Kusuba and Pingree 2002). Although this new paradigm reached the Latin West in various ways, it never became dominant (Barker and Heidarzadeh 2016; Ragep 2017). Instead, the astronomical tradition in Europe modeled itself on Islamic astronomy before Țūsî. The most important advanced text remained Ptolemy's Almagest. The two most common introductory book's Sacrobosco's Sphaera and the Theorica planetarum, both presented themselves as introductions to the Almagest. None of these books used orb models. ${ }^{3}$ Although the orb models that were now a standard feature of Islamicate astronomy did appear in Europe, their supporters had to counter criticisms directed at the very legitimacy of epicycles and eccentrics. These criticisms, made by Averroes (Ibn Rushd) were a second consequence of Ibn al-Haytham's work, and they had much greater influence in Western Europe than they did in the Islamicate world.

\section{The Dispute with the Averroists in Europe}

Averroes's primary criticisms of Ptolemaic astronomy depended on the alleged physical impossibility of eccentrics and epicycles, according to a strict reading of Aristotle's physics. Eccentrics and epicycles, whether circles or orbs, rotated about centers that were not the center of the earth. But according to Averroes's reading of Aristotle, all celestial motion had to be centered on the earth. Hence, according to Averroes, eccentrics and epicycles were physically impossible even if they produced predictions in accord with observation. Averroes's contemporary Alpetragius (al-Bițūjīī, flourished ca. 1150-1200) attempted to revive Eudoxus's earth-centered orbs as a technical alternative to Ptolemaic models, and his work was well known in Europe (Goldstein 1971). Attempts to develop a strictly geocentric astronomy continued in the Andalusian Jewish community into the early modern period, and a Jewish scholar was also responsible for a new translation of Alpetragius as late as 1531 (Morrison 2016; Calonymus 1531). Despite these efforts no real alternative to Ptolemaic astronomy emerged in Europe, and Averroes's criticisms and Alpetragius's theories were ignored east of Cairo, probably for several reasons. First, as in Europe, Islamicate followers of Tūūi and his colleagues recognized that the Averroists failed to provide any mean of calculating planetary positions. Ptolemaic astronomy in

\footnotetext{
${ }^{3}$ During the discussion at the conference from which this book derives, Angela Axworthy suggested that the ontological discussion of spheres and substances in Sacrobosco Books I-III might predispose students to 'ontologize' the circles in Book IV.
} 
Europe, and Ptolemaic astronomy as modified by Țūsī elsewhere, remained the only practical method of making predictions. Second, in the Eastern Islamicate world annular eclipses were a generally recognized phenomenon. Usually, during a total eclipse, the moon completely covers the sun. However sometimes, when the center of the moon coincides with the center of the sun, the moon does not completely cover the sun, but leaves a bright ring (Latin: annulus) all around the moon's edge. Islamicate astronomers agreed that this phenomenon demonstrated that the moon was further from the earth during an annular eclipse. Variation of distance ruled out the possibility that the moon was carried by an orb concentric to the earth, and seemed to require eccentrics and epicycles.

Almost from the time of their appearance, Averroes's commentaries on Aristotle's De caelo created a school of philosophers writing in Latin who supported his strict geocentrism and attacked Ptolemaic eccentrics and epicycles as physically impossible, which, by default, supported an astronomy using only earth-centered orbs. While most supporters of Averroes were people whose main professional interest was philosophy or theology, they included people who worked in technical astronomy, for example, Richard of Wallingford (ca. 1292-1336) (North 2008, 258-62). This is surprising, as Europeans also recognized that no strictly geocentric astronomer, including Alpetragius, was ever able to convert their physical models into algorithms that would accurately predict the positions of celestial bodies. A younger contemporary of Glogów and Brudzewo described the situation in a book that appeared in 1543:

Some use only earth-centered circles, others eccentrics and epicycles, but they do not fully achieve what they seek. For although those who rely on earth-centered circles demonstrated that some non-uniform motions could be compounded from them, they were unable to establish anything certain that indisputably corresponded to the phenomena from this. ${ }^{4}$

Although there may have been earlier Latin exponents of partial orbs, who have not yet come to light, a convenient starting point to understand the dispute with the Averroists in Europe is the work of Roger Bacon (ca. 1214-1294), who was a contemporary of both Sacrobosco and the author of the Theorica planetarum. In his Opus tertium, Bacon presented the partial orb construction later used in the Theoricae novae, although Bacon himself rejected such devices in favor of concentric spheres (Grant 1996, 278ff; Lerner 2008, I:115). Bacon testifies to one of the accidents of history. Although Ptolemy's Almagest was available in Europe by the twelfth century, the Planetary Hypotheses was never available in its entirely (Goldstein 1967). Consequently, people like Roger Bacon presented the orb models as the ymaginatio modernorum, something thought up by contemporaries, and specifically their Islamicate contemporaries. In addition to the attacks by Averroes, the seeming lack of endorsement by Ptolemy further undermined the status of orb

\footnotetext{
${ }^{4}$ (Copernicus 1543, iiii V): "Alii namque circulis homocentris solum, alii eccentris et epicyclis, quibus tamen quaesita ad plenum no asequuntur. Nam qui homocentris consisti sunt, etsi motus aliquos diversos ex eis componi posse demonstraverint, nihil tamen certi, quod nimirum phaenomenis respondereret, inde statuere potuerunt."
} 
models in Europe. The result was a controversy that lasted until the time of Galileo Galilei (1564-1642) (Andersen et al. 2006, 117-29).

While William of Auvergne (died 1249) defended the Averroist concentric approach, Thomas Aquinas (1225-1274), and John of Jandun (died 1328), who both taught at Paris, denied or qualified the orbs' reality (Grant 1996, 280-81 and n. 34). However the partial orbs, much as they appear in Peuerbach, were presented at length by Bernard of Verdun. Bernard's dates are uncertain, but his book was probably written after Bacon's work and towards the end of the twelfth century (Bernard of Verdun, ed. Hartmann 1961). Lerner notes Duhem's claim that Bernard had many supporters in Paris from the end of the thirteenth century into the fourteenth century (Lerner 2008, I:117-18, text to n. 44). Another Parisian, Henry of Langenstein (also known as Henry of Hesse, ca. 1325-1397), who opposed epicycles and eccentrics, went on to teach at the University of Vienna, which was the academic home of Peuerbach and Regiomontanus (Kren 1968, 269-81; Lerner 2008, I:114). So Peuerbach's lectures ending in 1454, which became the basis for the Theoricae novae both in manuscript and in print, may be as seen as a response to Averroist denials of eccentrics and epicycles that were comparatively recent and local. In the interval between Langenstein and Peuerbach, Pierre d'Ailly (ca. 1350-1420) presented the partial orbs with particular clarity, supporting their existence as real parts of the heavens, in a set of questions on the Sphaera that would be frequently republished after the advent of printing (Ciruellus 1498; Grant 1996, 281-83; Shank 2009) (Chap. 3). Another intermediary was Prosdocimo de Beldomandi (ca. 1380-1428), whose commentary on Sacrobosco circulated in manuscript and was printed in 1531 (Prosdocimus de Beldomando 1531; Markowski, 1981; Axworthy 2016) (Chap. 8).

The early years of printing supported a wave of new initiatives to improve classic texts and to supply university students, one of the few captive markets for the new technology (Crowther and Barker 2013). Peuerbach's Theoricae novae was printed no later than 1474 at Nuremberg by his student Regiomontanus as part of a project to provide printed editions of works in mathematics and astronomy (Zinner 1990, 22; Aiton 1987). The original theorica, which now became known as the theorica veteres, was also printed in 1472, in Ferrara, attributed to Gerard of Cremona (ca. 1114-1187), and in Padua, attributed to Gerard of Sabbioneta, showing the uncertainty about its author. The original Theorica was rapidly supplanted by the Theoricae novae and its commentaries. The older theorica was printed only eight times between 1467 and 1531, while the Theoricae novae and its commentaries went into hundreds of editions from 1474 through the mid seventeenth century (Aiton 1987, 7, n. 8; Barker 2011, 11-12). However, the opportunities presented by printing were also used by a new generation of Averroists, especially in Italy. New editions of both Aristotle's and Averroes's work appeared beginning in 1472-1474 (exactly the same period as the printing of Peuerbach's Theoricae novae in Nuremberg), and including Aristotle's work with Averroes's commentaries appended to or surrounding them (Hasse 2016, 78-79, 347-54). Consequently Averroes's objections to eccentrics and epicycles reached a new audience and were articulated in new ways. 
Among the most influential Averroists of the late fifteenth century were Agostino Nifo (ca. 1470-ca. 1540) and Alessandro Achillini (1463-1512). Nifo took the Averroist side in debates with Francesco de Capuano (flourished 1496-1531), who was writing his own commentaries on Sacrobosco and Peuerbach (Barker 2011, 14-17) (Chap. 4). The latter contained the most detailed rebuttal of Averroes that I have found in the theorica and sphaera literature, which may go some way to explaining why it was printed at least seven times between 1496 and 1531, despite its size (Aiton 1987, 7). At the same time that Nifo and Capuanus were at work, Achillini composed a book on the nature of the celestial orbs, using Averroes's arguments in the technical vocabulary of Peuerbach to attack the celestial orbs (Barker 2011, 17). Nifo drew attention to the continuing importance of the objections to eccentrics and epicycles by adding figures in his edition of Averroes commentary on Aristotle's Metaphysics (Nifo 1496, Images: 117r, Comment 45). ${ }^{5}$

This brief history of the dispute between the followers of Averroes and the followers of Ptolemy, and Peuerbach, shows that Glogów's Sacrobosco commentary was composed, and printed, in the context of the dispute over the structure of the celestial orbs. Both parties accepted the reality of total orbs- the orbs concentric to the earth corresponding to the zones of each planet in turn. The dispute was about the inner structure of these orbs. The Averroists insisted that these orbs could only be divided, like the layers of an onion, into other concentric orbs. The followers of Peuerbach divided them into spherical epicycles carried by uniform eccentric orbs, enclosed by non-uniform complementary orbs. Glogów asserts the reality of this alternative configuration of the heavens.

Glogów's commentary was composed for the use of students learning astronomy at the University of Kraków. Several other major figures taught astronomy there in the same period. The most important was Albert of Brudzewo who completed a parallel commentary, not on Sacrobosco, but on the Theorica novae planetarum itself, no later than 1482 (Barker 2013a). Brudzewo's work is one of the most significant pieces of evidence for the reception of Peuerbach's ideas, and the first full length commentary written after the appearance of the Theoricae novae itself. It begins with criticisms of Averroes and then presents Peuerbach's ideas in a positive light, asserting the physical reality of the orbs. So Brudzewo not only sides with the followers of Ptolemy by supporting Peuerbach, he explicitly attacks the opposing camp. But Glogów's commentary on Sacrobosco is not quite the first to advocate Peuerbach's orbs. An important antecedent is the version by Pedro Ciruelo (1470-1554) that appeared in Paris in 1498 (Barker 2011, 15-16) (Chap. 3). Glogów too was taking a position that was pro-Ptolemy and anti-Averroes, by introducing Peuerbach's orbs in a commentary on Sacrobosco. His long association with Kraków, and with Brudzewo, suggests that he would be explicitly aware of the Ptolemaist-Averroist dispute.

\footnotetext{
${ }^{5}$ This dispute continued well after the death of Glogów. See, for example (Chap. 8).
} 


\section{Sacrobosco on the Celestial Circles, and Glogów on the Celestial Orbs}

In the fourth chapter, or part, of the Tractatus de sphaera, Sacrobosco gives a very brief introduction to the mathematical tools used by Claudius Ptolemy in the Almagest, and all subsequent astronomers, to describe the motions of the sun, moon and planets. Sacrobosco's exposition is barely more than a list the main concepts, all of which are presented as circles of various types. It takes up less than 400 words in Latin and a mere four paragraphs in the English translation by Thorndike (Thorndike 1949, 113-15, 140-41). In his commentary, Glogów greatly extends Sacrobosco's presentation, arguing that Sacrobosco is wrong about several fundamental issues. He insists that the circles mentioned by Sacrobosco are not real things, but that the orbs introduced by Peuerbach are, implicitly assuming that any astronomical model must be (in principle) adequate to explain the causes of planetary motion. As circles and other mathematical objects have no causal powers they cannot be what moves the planets. In their place, Glogów introduces the same sets of celestial orbs that students would encounter in Peuerbach's book and Brudzewo's Little Commentary on it (Barker 2013a), and he provides his own illustrations. As the study of the Sphaera always preceded study of the Theorica, we must assume that for students at Kraków, the exposition in Glogow's commentary on the Sphaera was intended to be their first introduction to these matters.

Sacrobosco begins with the model for the sun, which in Ptolemy consists of a single eccentric circle. Sacrobosco defines the term 'eccentric' and also the furthest and nearest points of the circle from the center of the world, which are termed 'auxes' in Latin. He goes on to describe two motions of the sun: its daily motion of about one degree and its precessional motion (although he does not call it that) of one degree in 100 years. Sacrobosco fails to note that the first motion is recurrent while the second is cumulative, or to give any real explanation for the second motion. But about the first he says:

It should be noted that the sun has a single circle in which it is moved in the plane of the ecliptic, and it is eccentric. ${ }^{6}$

To this Glogów replies:

It should be understood, therefore, that when the author [Sacrobosco] says in the text that the sun has a single orb or circle in which it is moved, this comment of the author should be understood to be about the total orb. For each planet has at least three orbs. The total orb is constituted by the three partial orbs. Hence in this way [unde sicut] the author of the Theoricae [Peuerbach] says "The sun has three orbs...."7

${ }^{6}($ Glogów 1506, [l v R]): "Notandum q[uam] sol habet unicum circulum p[er] que[m]movetur in sup[er]ficie linee ecliptice et est eccentricus." Although (Thorndike 1949, 113 n. 3), has two sources that include 'linee,' he omits it, as do I in translating his line.

${ }^{7}$ (Glogów 1506, [1 v R-V]): "Scie[n]du[m] igit[ur] qu[od] autor in textu dicit qu[am] sol hab[et] unicu[m] orbem vel circulu[m] i[n] quo movet[ur] hoc dictu[m] auctoris intellige[n]du[m] e[st] de orbe totali. Quilib[et] enim planeta hab[et] tres [1 v V] orbes ad $\min [\mathrm{us}]$ : ex quib[us] trib[us] partialib[us] co[n]stituit[ur]: et e[st]orbis totalis un[de] sic[ut] i[n]q[ui]t autor theorica[rum] Sol 
Fig. 6.1 Theorica figure for the sun. From (Glogów 1506, fol. [1 v V]). Bavarian State Library, Res/4 A.gr.b. 430\#Beibd.2. urn:nbn:de:bvb:12bsb10198086-2

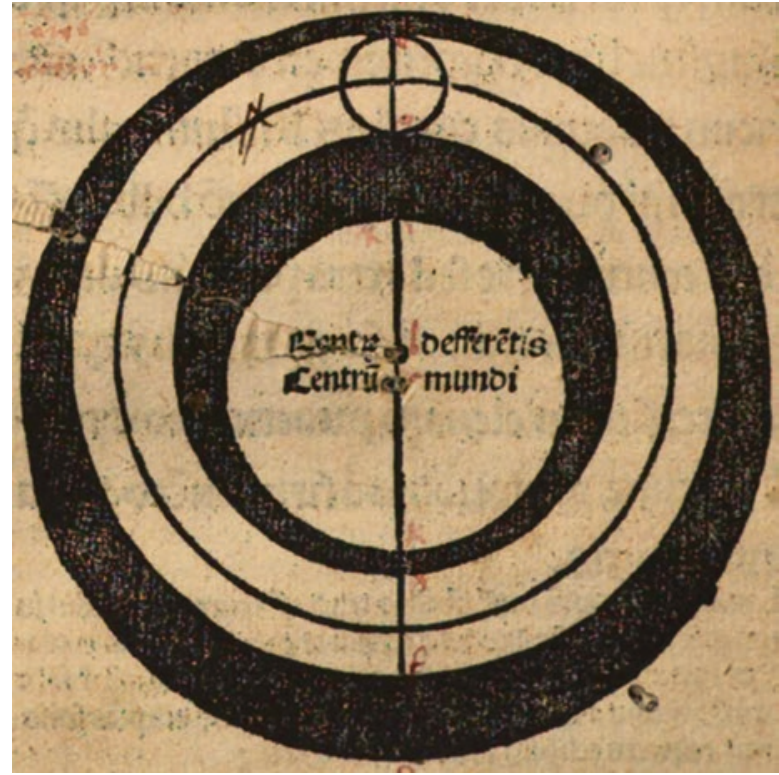

Glogów goes on to quote the first paragraphs of Peuerbach's Theoricae novae, explaining that the body of the sun is fixed in an eccentric orb and moved by it in its annual motion, while two complementary orbs, that together make the three-orb system concentric to the center of the world, also rotate slowly and keeping pace with each other so that they shift the direction of the auxes (nearest and farthest points) of the eccentric. He illustrates the partial orbs with (Fig. 6.1) which is a redrawn version of the figure on the first page of Peuerbach's Theoricae (Fig. 6.2). It is sometimes difficult to decipher these images. The figures show a cross-section through the set of three orbs that move the sun. It is perhaps easier to recognize the various parts if the entire image is rotated, and the parts separated, making their three-dimensionality more apparent (Fig. 6.3). Note the correlation between colors of the parts in the image from Peuerbach (Fig. 6.2) and the rotated version (Fig.6.3). Considered as three-dimensional objects, the image shows three hemispheres, or more correctly, hemi-orbs. One of these (white) is a conventional orb with both surfaces centered on the same point, and hence a uniform thickness. The remaining two objects, or complementary orbs, are colored uniformly. Because their spherical surfaces have different centers they are not uniform in thickness, giving them their characteristic 'crescent moon' appearance when shown in cross section (Figs. 6.1 and 6.2). Looking at (Fig. 6.3) you should be able to see that if the existing

habet tres orbes...;" (Glogów 1518, K ii R): "Sciendum igitur qu[od] autor in textu dicit qu[am] sol habet unicum orbem vel circulus in quo movetur, hoc dictum auctoris intelligendum est de orbe totali. Quilibet enim planeta habet tres orbes ad minus: ex quibus tribus partialibus constituitur: et est orbis totalis. Unde sicut inquit autor theoricarum: Sol habet tres orbes...." 
Fig. 6.2 Theorica figure for the sun. From (Sacrobosco et al. 1482, fol. e 1 V). Bavarian State Library, 4 Inc.c.a. 256, urn:nbn:de:bvb:12bsb00054605-7
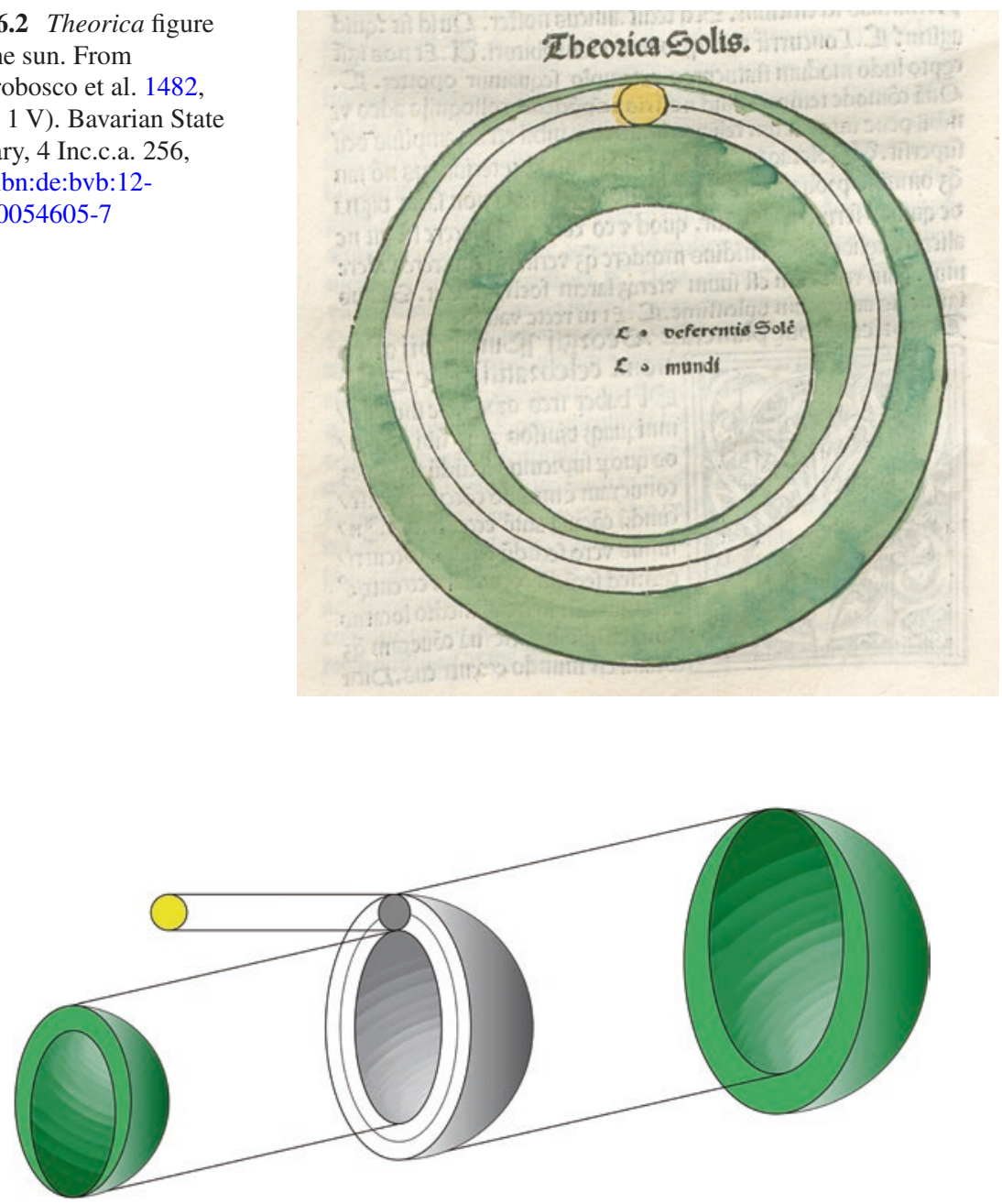

Fig. 6.3 Peuerbach theorica figure for the sun, rotated and separated. http://astronomy.voxcanis. $\mathrm{com} /$

hemi-orbs are reflected in the plane of the original figure, they would become complete orbs, that is solid objects bounded by two spherical surfaces. The inner white orb carries the body of the sun and rotates, without friction, between the colored complementary orbs to create the annual motion of the sun. The two complementary orbs rotate so that they always maintain the same relative orientation- the thinnest part of one is always nearest the thickest part of the other-creating the motion of precession by moving the direction of the auxes of the white orb. ${ }^{8}$

\footnotetext{
${ }^{8}$ To see these motions, visit http://astronomy.voxcanis.com and scroll down to see the animation. Accessed June 2019.
} 
Looking now at Glogów's figure and comparing it to Peuerbach's (Figs. 6.1 and 6.2), we note that the center of the world is indicated at the center of the figure, with the center of the deferent slightly above it. The latter is the geometrical center for the white part of the figure, which is the cross-section of the eccentric orb of uniform thickness carrying the sun. The sun is shown by the small circle touching both edges of the white orb at 12 o'clock. The complementary orbs-shown in blackare not very well drawn. Although the figure clearly conveys the important information that the thickest part of the outer orb is closest to the thinnest part of the inner orb, and vice versa, the thinnest parts of both orbs should be much thinner than shown here. In fact the two surfaces of the complementary orbs and the concentric orb should all meet at a point. Note also that a circle has been drawn down the center of the white part of the figure (the cross section of the eccentric orb). This line traces the motion of the center of the sun and corresponds to the eccentric circle that appears in Ptolemy's Almagest model and Sacrobosco's description. As we will see, Glogów makes an explicit comparison between this circle and the orbs he is presenting.

Sacrobosco and Peuerbach follow the order of Ptolemy and the older Theorica in introducing the model for the sun first. In Peuerbach's case, however, this is doubly important, because the orb model for the sun forms the basis for the planetary models. In addition to the eccentric circle, the Almagest planetary models require an epicycle, a subsidiary circle the center of which is 'carried' by the eccentric circle. In the orb models this is achieved by replacing the body of the sun with a solid sphere, which carries the planet embedded within its outer surface, so that the sphere of the planet's body and the sphere of the epicycle touch internally at a single point. The first application of this construction is to the moon (Fig. 6.4).

Sacrobosco says this about epicycles:

Every planet except the sun has three circles, namely, an equant, deferent, and epicycle.... Also every planet except the sun has an epicycle. An epicycle is a small circle the circumference of which carries the body of the planet and the center of the epicycle is always carried along the circumference of the deferent. ${ }^{9}$

Referring to (Fig. 6.4) and treating the concepts in the reverse of Sacrobosco's order, look first at the three circles at 12 o'clock. The largest of these circles touches each of the complementary spheres at one point (12 o'clock and six o'clock for that circle itself). Imagine that this circle is the circumference of a hemisphere, embedded in the white eccentric orb in the same way that the body of the sun was embedded in the previous model. Now imagine embedding a much smaller spherical planet inside this sphere, so that it touches the surface of the epicycle sphere internally at a single point (for simplicity, say, again, 12 o'clock). Next imagine that the epicycle sphere rotates about it center around an axis that is perpendicular to the

\footnotetext{
${ }^{9}$ (Glogów 1506, [1 vi V]): "Quilibet aute[m] planeta tres habet circulos pr[a]eter solem s[e] c[undum] equa[n]tem, deferentem et epiciculum." (Thorndike 1949, 114) has 'scilicet' for 'secundum'. (Glogów 1506, m ii R): "Quilibet etiam planeta p[rae]ter solem habet epiciculum. Est autem epicicul[us] circulus parvul[us] p[er] cuius circumferentiam defertur corpus planete et centrum epiciculi semper defertur in circumferentia deferentis."
} 
Fig. 6.4 Theorica diagram for the moon. From (Glogów 1506, fol. [1 vi V]). Bavarian State Library, 1,550,533 Res/4 A.gr.b. $430 \#$ Beibd.2. urn:nbn:de:bvb:12bsb10198086-2

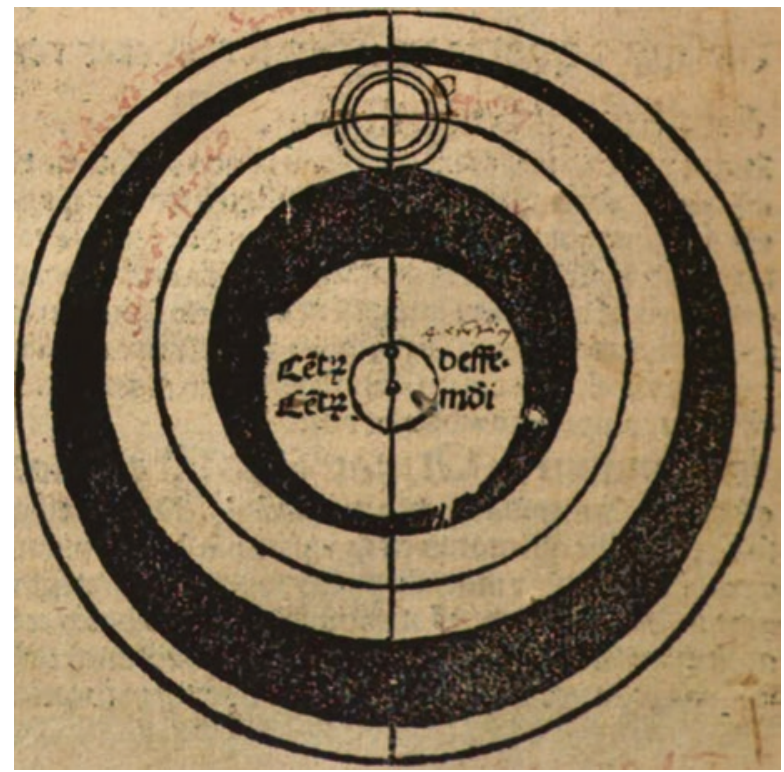

plane of the image on the paper. Then, as the epicycle sphere rotates, the inner edge of the planet will describe a second circle. This is the smallest of the three circles we are examining. Finally, as the planet is carried around by the epicycle, its center will describe the third circle in the figure, intermediate in size between the larger and smaller ones. This circle will correspond to the epicycle circle in Ptolemy's Almagest model, just as the line down the center of the eccentric orb's cross section corresponds to the eccentric deferent circle.

So actually the introduction of epicycles in the orb models is an iterative procedure. The epicycle-formerly the body of the sun-is carried around the center of the cosmos by an eccentric orb the thickness of which is defined by the size of the epicycle, and in so doing, its center traces out the circle drawn down the center of the cross section of the eccentric. Within the epicycle, the planet is carried in an exactly similar way, so that its center traces out its own circle. In principle, no more of the epicycle is required than the depth needed to accommodate the planet. Using only this part of the epicycle sphere would make the orb carrying the planet isomorphic to the orb carrying the epicycle itself. The only real difference is that the larger mechanism (the eccentric orb) cannot be represented by a solid orb, because there needs to be a space inside the eccentric. The inner complementary orb makes this space concentric with the center of the world. In the case of the sun, the orb set for Venus fits inside the inner complementary orb. The orb set for Mercury fits inside the inner complementary orb for Venus, and the orb set for the moon fits inside the inner complementary orb for Mercury. However, there was no practical need for a space in the center of the epicycle orb, so it was usually treated as solid all the way through. The epicycle sphere is used in the orb models for all the planets except the sun, although there are special complications in the cases of the moon and Mercury. 
Sacrobosco says several unhelpful things about the moon, trying to ignore the peculiarities of the lunar model and treat all the remaining planets and the moon using the same terms, and, by implication, concepts:

Every planet except the sun has three circles, namely, equant, deferent, and epicycle. The equant of the moon is a circle concentric with the earth and in the plane of the ecliptic. Its deferent is an eccentric circle not in the plane of the ecliptic. Indeed, one of its halves slants toward the north and the other toward the south. Consequently the deferent intersects the equant in two places, and the figure of that intersection is called the "dragon" because it is wide in the middle and narrow toward the ends. That intersection, then, through which the moon is moved from south to north is called the "head of the dragon," while the other intersection through which it is moved from north to south is called the "tail of the dragon." The deferent and equant of each planet are equal. ${ }^{10}$

There are so many near falsehoods and infelicities in this passage it is hard to know where to begin. The equant is the main mathematical innovation in the Almagest, and this is the worst possible way to introduce it to novices. In the planetary models Ptolemy was faced with the problem that using an eccentric circle and an epicycle did not produce predictions that fitted observation. By a process that probably compared directions of retrogressions with durations of retrogressions, Ptolemy introduced equant points (Evans 1998, 384-92). The equant point is symmetrically placed at the same distance from the center of the eccentric as the center of the cosmos but on the opposite side. Each planet has one. These points, not the geometrical centers of the deferents, now serve as the centers of uniform rotation for any point on the circumference of the eccentric circle, and especially the point which is the center of the epicycle. However these are points, not circles. It is true that there is a circle in the moon model which has a somewhat similar function, and that it is sometimes referred to as the moon's equant. This circle is one of the differences between (Fig. 6.1) and (Fig. 6.4); it is the circle closest to the center of the (Fig. 6.4) that has no corresponding circle in (Fig. 6.1). But this is utterly misleading about the equants that occur in all the other models, which the student will now also expect to be circles.

To make matters worse Sacrobosco goes on to explain the Head and Tail of the Dragon using the equant. As the moon's path is slanted with respect to the sun's path across the sky, the moon crosses the sun's path twice each month. The passage from South to North (or ascending node) is rather grandiloquently called the Head of the Dragon, and the passage from North to South the Tail of the Dragon. These points are important because a total eclipse can only occur when the moon is in one of them. They are usually defined as the intersection points of the plane of the moon's

\footnotetext{
${ }^{10}$ (Glogów 1506, [1 vi V]): "Quilibet aute[m] planeta tres habet circulos pr[a]eter solem s[e] c[undum] equa[n]tem deferentem et epiciculum. Equa[n]s quidem lune est circulus co[n]centricus cum terra et est in sup[er]ficie ecliptice. Eius aute[m] deferens est circulu[s] ece[n]tricus nec est in sup[er]ficie ecliptice immo una eius p[ar]s et mediatas declinat v[er]sus septe[n]trione[m] et alia $\mathrm{v}$ [er]sus austrum et intersecat defere[n]s equante[m] in doubus locis. [m i R] Et figura intersectionis appelelatur draco quoniam lata et in medio et angustior versus finem. Intersectio ig[itur] illa $\mathrm{p}$ [er] qua[m] movetur [1]una ab austro versus aquilonem apellatur caput draconis. Reliqua [ver]o intersectio p[er] q[uam] movetur a septe[n]trio[n]e i[n] aust[rorum] d[ici]t[ur] cauda draconis. [m [i] V] Defere[n]tes quidem et equantes cuius ub[m] planete sunt equales."
} 
Fig. 6.5 Diagram for the Head and Tail of the Dragon. From (Glogów 1506, fol. m [i] V). Bavarian State Library, Res/4 A.gr.b. 430\#Beibd.2. urn:nbn:de:bvb:12bsb10198086-2

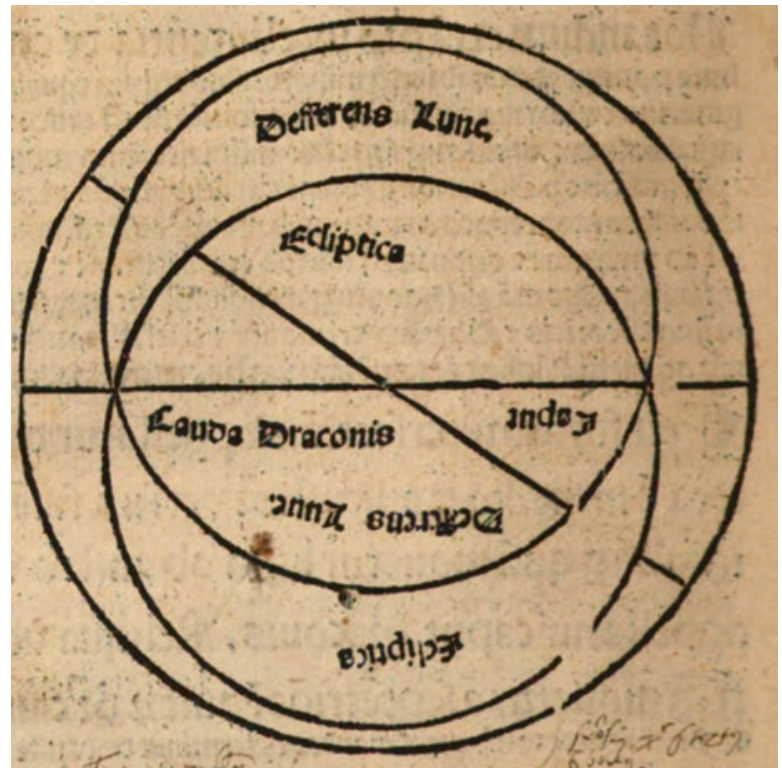

path and the plane of the sun's path (or ecliptic). However Sacrobosco tells us that they are defined by the intersection of the plane of the moon's path and the equant circle he has just introduced. Now it is true that the moon's equant circle is in the plane of the sun's path (as Sacrobosco says). And it is true that the circles drawn about equant points may be any size you please, in all the other models except the moon. But it is not true for the moon's equant circle that it can be made any size. One of the circle's main functions is to carry the center of the eccentric deferent which carries the epicycle that carries the moon (this device is now known colloquially as a 'crank,' because of its similarity to the mounting of a bicycle pedal). So the size of the moon's equant circle is constrained by the size of the eccentric. Hence Sacrobosco's comment "Deferent and equant of each planet are equal," is simply not true in the case of the moon. Considered as circles, the deferent of the moon and the equant circle of the moon will never intersect, although of course their planes do. It is for this reason that the Head and Tail of the Dragon are usually explained using the ecliptic, which may be drawn to any arbitrary size, and made to intersect the deferent of the moon whether ecliptic and deferent are considered circles or planes. Glogów corrects this in his own figure for the Head and Tail of the Dragon (Fig. 6.5).

More importantly, in his discussion Glogów introduces a firm line between mathematical objects and physical objects. "Let it be noted," he says, "for understanding the text, that the Head and Tail of the Dragon is neither a star nor a real part of the sky" (non est stella nec pars celi realis). ${ }^{11}$

\footnotetext{
${ }^{11}$ (Glogów 1506, m [i] R): "Notandum p[ro] intellectu text[us] q[uod] caput et cauda draconis no[n] e[st] stella nec p[ar]s celi realis." See also (Glogów 1518, K iiii R, para 1): "Notandum pro intellectu textus q[uod] caput et cauda draconis non est stella nec pars celi realis."
} 
Sacrobosco tells his students that the motion of the moon can be defined by three circles, the equant, the deferent and the epicycle. By contrast Glogów tells us that understanding the motion of the moon requires four orbs and a small sphere. The epicycle sphere is self explanatory. But why four orbs? Three of these orbs are the eccentric deferent and the two complementary orbs required to line up the center of the orb system with the center of the cosmos. These look just like the orbs introduced in the case of the sun. However, if you look again at (Fig. 6.4), you will see an additional (white) orb encompassing the whole system, which serves an important function in connection with the Head and Tail of the Dragon. Quite simply, the moon does not cross the ecliptic in the same position every month; the Head and Tail of the Dragon move consistently more than one degree each month and more than 19 degrees each year. The fourth and outermost orb of the moon carries the entire inner orb system around with it, at this speed. Having corrected the annual motion by the precession rate of one degree per century for the sun, Sacrobosco completely ignores this much larger correction for the precession of the moon's nodes. Glogów does not mention these numbers, but his figure and text include the crucial fourth orb. ${ }^{12}$

Sacrobosco's text runs on from the passages about the moon to the other planets:

The deferent and equant of each planet are equal. And understand that both the deferent and equant of Saturn, Jupiter, Mars, Venus, and Mercury are eccentric and outside the plane of the ecliptic, and yet those two [deferent and equant] are in the same plane. ${ }^{13}$

The unwary student might read the first sentence as a continuation of the claims about the moon and its equant, but as we have already seen the deferent and equant of the moon are not equal. The situation is different in the case of the other planets. After identifying the center of the eccentric, which will be some distance from the center of the cosmos, and the equant, which is a symmetrical point twice as far away, it was common practice to construct an equant circle (Fig. 6.6). This was done by taking the radius of the deferent and drawing a circle of same radius centered on the equant point. As the epicycle center projects equal arcs in equal times on this circle, it is a handy device for finding the unequal arcs that the epicycle center describes on the eccentric; mark equal intervals on the equant circle and join them by lines to the deferent center, to find the corresponding points on the deferent circle. However, there is nothing special about choosing this radius for the equant circle; a circle of any radius will work. The choice to make it the same size as the deferent is mere convenience, and makes it sure to fit in the same figure. And, of course, as it is a tool for use with the eccentric circle, the equant circle is in the same plane, which is not the plane of the ecliptic. Except for this last point, almost all of this is lost in Sacrobosco, who never mentions equant points, nor that the equant

\footnotetext{
${ }^{12}$ (Glogów 1506, [1 vi V]): "Deinde habet orbe[m] mundo co[n]centricum, aggregatum ex aliis tribus ambiente[m]." See also: (Glogów 1518, K iii V, line 1): "Deinde habet orbem mundum concentricum, aggregatum ex aliis tribus ambientem. "("Next [the moon] has an orb concentric to the [center of the] world, holding together and surrounding the other three").

${ }^{13}$ (Glogów 1506, [m [i] V]): "Defere[n]tes quidem et equantes cuius ub[ique] planete sunt equales. Et sciendum q[uod] tam defferens [sic] q[uam]que eq[ua]ns Saturni Jovis Martis Veneris et Merrcurii sunt eccentrici et extra superficie[m] ecliptice et tame[n] illi duo sunt in eadem sup[er]ficie."
} 
Fig. 6.6 Diagram for stations and retrogressions showing epicycle orb, eccentric and equant circles. From (Glogów 1506, fol. m iii R).

Bavarian State Library, Res/4 A.gr.b. 430\#Beibd.2. urn:nbn:de:bvb:12bsb10198086-2. Neither the red spot nor the impressed lines are part of the original image

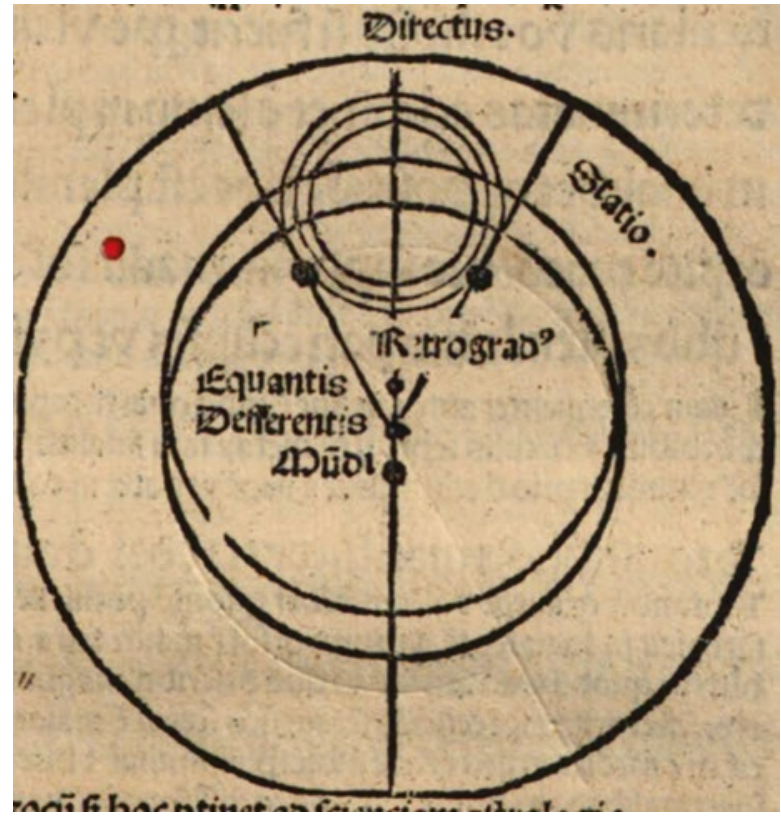

circle is constructed to an arbitrary scale, in contrast to the size the eccentric which is constrained by the motion of the planet, and especially by the need to nest the models for each planet in the correct order, from the moon on the inside to Saturn on the outside. Here again Sacrobosco treats the mathematical concept 'equant circle' as if it was on the same level as 'deferent' or 'epicycle' which have physical counterparts. Glogów sharply contradicts him. In contrast to the real physical orbs corresponding to the deferent and epicycle:

The equant is an imaginary circle, the imagining of which is devised in this way by astronomers, [since] each planet does not move uniformly around the center of the world, nor move uniformly around the center of its deferent, orbs have been imagined by astronomers for the other planets apart from the sun through which their irregularity can be reduced to regularity. ${ }^{14}$

Sacrobosco gives no details about the deferents of the planets, beyond saying they are eccentric circles. For Glogów however:

The three outer planets [each] have three real (realis) orbs separated from each other and imagined similarly (similem imaginationem) to the three orbs of the sun. And in the middle of the orb which is eccentric in the simple sense [each planet] has an epicycle in which the

\footnotetext{
${ }^{14}$ (Glogów 1506, m [i] R para. 1): “[E]quans est circulus imaginarius cuius imaginatio ab astronomis sic est inventa q[uem] eni planete non equaliter moventur semp[er] sup[er] ce[n]tro mu[n]di, nec semp[er] move[n]tur eq[ua]liter sup[er] ce[n]tro deferentiu[m] su[orum] Astronomi ymaginati sunt in aliis planetis a sole per quem illa difformitas reduceretur ad uniformitatem." See also (Glogów 1518, K iii V): "Equans est circulus imaginarius cuius imaginatio ab astronomis sic est inventa q[uem] a eadem planete non equaliter moventur super super [sic] centro mundi."
} 
body of the planet is fixed, and from its motion the body of the planet is moved. The author of the Theoricae asserts the same thing in the same way for Venus and Mercury. So it should be understood that they call these orbs of the planets "circles" in the old Theorica, which are real orbs having a thickness in their substance, but then in truth they are not circles. ${ }^{15}$

Sacrobosco, of course, goes on, "An epicycle is a small circle the circumference of which carries the body of the planet and the center of the epicycle is always carried along the circumference of the deferent," seeming to say, perhaps here most clearly, that the circles move the planets. Glogów responds again, "Last [the author of the Theoricae novae] has an immense sphere which is called an epicycle in the depth of the third [eccentric] orb. The body of the moon is fixed in this epicycle." 16

The main point of Glogów's corrections to Sacrobosco is his insistence that the parts of theorica models must be physically real, while mathematical concepts like points (the Head and Tail of the Dragon) and lines (the eccentric and epicycle circles) are not. Glogów emphasizes the point again by quoting Euclid's definition of a circle, showing the parts of the definition do not apply to orbs, and repeating: "In the Theoricae [novae] there is a real sphere in sky, which leads us to knowledge of the heavens, but the Theorica [veteres] call [it] a circle."17

Glogów's commentary on Sacrobosco asserts the reality of Peuerbach's configuration of the heavens against the claims of contemporary Averroists like Nifo and Achillini. From this we can deduce two further claims, made explicitly or implicitly by astronomers like Glogów. To begin with, and contrary to most historians of science throughout the twentieth and into the twenty-first century (North 2008, 335-36), Copernicus was not the first early modern astronomer to insist that astronomical models had to correspond to real physical things. Glogów's criticisms of Sacrobosco show clearly, as does Brudzewo's Little Commentary on Peuerbach, that, well before Copernicus, European astronomers who adopted the New Theorica

\footnotetext{
${ }^{15}$ (Glogów 1506, m [i] V): "Quilibet triu[m] superiorum tres orbes habet reales a se divisos secundu[m] ymaginatione $[\mathrm{m}]$ triu[m] orbiu[m] solis. In orbe tame[n] medio qui ecce[n]tric[us] $\mathrm{e}$ [st] simplicit[er] epiciclu[m] $\mathrm{h}$ [abet] in quo corp[us] planete figit[ur], et ab cuius motu[m] movetur corpus planete, hoc ide[m] in Venere et Mercurio esse idem. Autor theoricarum affirmat. Sciendu[m] etiam q[uam] theoriste [ $\mathrm{m}$ ii R] orbes istas planetarum qui sunt reales orbes spissitudinem in ea.[rum] substa[n]tia habe[n]tes vocant circulos $\mathrm{cu}[\mathrm{m}]$ tame[n] secu[n]dum veritatem non sunt circuli[.]" See also (Glogów 1518, K iiii R para 4): "[Qulibet] trium superiorum tres orbes habet reales a se divisos secundum imaginationem trium orbes solis. In orbe tamen medio qui eccentricus est simpliciter[,] epiciclum habet in quo corporum planete figitur, et cuius motum movetur corpus planete. Hoc idem in Venere et Mercurio esse idem autor theoricarum affirmat. Sciendum etiam quam theoriste orbes istas planetarum qui sunt reales orbes spissitudinem in earum substantia habentes vocant circulos, cum tunc secundum veritatem non sunt circuli."

${ }^{16}$ (Glogów 1506, [1 vi V]): "Ultimo habet sperulam que vocat epicyculus, p[ro]fund[it]ate orbis tercii in me[n]sam in quo q[ui]de[m] epiciculo corpus lunare figitur." See also (Glogów 1518, KiiiV: lines 2-5): "Ultimo habet spherulam que vocat epiciculus, profunditate orbis tertii immensam: in quo epiciculo corpus lunare figitur."

${ }^{17}$ (Glogów 1506, m ii R, para. 1): “...in celo e[st] realis orbis in theoricis q[uam] maneducu[n]t nos in cognitionem celestium aput theoristas vocant circulus." See also (Glogów 1518, K iiii R para 4): "...in celo est realis orbis in theoricis que manuducunt nos in cognitionem celestium, apud theoristas vocant circulus."
} 
were attributing physical reality to the elements of their models. These views were widely shared in commentaries on both Sacrobosco and Peuerbach published in Germany, France and Venice (Faber de Budweyß 1495; Capuanus de Manfredonia 1495; Ciruellus 1498; Faber Stapulensis 1503; Barker 2011).

Second, as these author's assertions about celestial orbs did not conform to Aristotle's physics, as understood by many influential contemporaries, their reasoning about the existence of eccentrics and epicycles claimed for astronomy (and other mathematical sciences) the ability to arrive at conclusions that had once been the sole preserve of traditional physics. Copernicus's views on these matters should therefore be located within an existing astronomical tradition. Copernicus contributed to this movement, even if he did not begin it (Barker 2013b). However the most important consequences of these changes may be seen in the program initiated in the sixteenth century by figures from Christophorus Clavius (1538-1612) to René Descartes (1596-1650), to establish science on a new basis that derived its certainty from mathematics applied to observation, rather than prior physical principles (Dear 1995; Schuster 2012). Until quite recently it was common for historians of astronomy to insist that requiring physical significance of mathematical theories was a novelty introduced by Copernicus himself, and that all previous astronomy offered no more than mathematical fictions. As we have seen, there were contemporaries of Peuerbach's followers claiming that the orbs were fictitious, but they were adherents of another school in astronomy. They followed Averroes in rejecting eccentrics and epicycles not because they illegitimately substituted orbs for circles or vice versa, but because they were regarded as physically impossible, whether as circles or as orbs. Glogów's commentary is an important example of many works that rejected this orthodoxy. ${ }^{18}$

\section{References}

\section{Primary Sources}

Calonymus, Calo. 1531. Alpetragii Arabi Theorica planetarum...absque eccentricis et epicyclis. Venice: L. A. Junta.

Capuanus de Manfredonia, Franciscus. 1495. Theoricae novae planetarum Georgii purbachii. Venice: S. Bevilaqua.

Ciruellus, Petrus. 1498. Uberrimum sphere mundi. Paris: Guy Marchant for Jean Petit.

Copernicus, Nicolaus. 1543. De revolutionibus orbium coelestium. Nuremberg: Petreius.

Cremona, Gerard of. 1472. Magistri Gerardi Cremonensis viri clarissimi theorica planetarum feliciter incipit. Ferrara: Andreas Belfortis.

\footnotetext{
${ }^{18}$ I would like to thank Angela Axworthy, Matteo Valleriani and, especially, Kathleen Crowther, for noteworthy help, and the other participants for valuable discussion at the at the 2018 conference "The Authors of the Early Modern Commentaries on De sphaera," February 13-15, 2018, at the Max Planck Institute for the History of Science in Berlin.
} 
de Sacrobosco, Johannes, Georg von Peuerbach, and Johannes Regiomontanus. 1482. Novicijs adolescentibus: ad astronomicam rempublicam capessendam aditum impetrantibus. Venice: Erhard Ratdolt. http://hdl.handle.net/21.11103/sphaera.100692.

Faber de Budweyß, Wenceslaus. 1495. Opusculum Ioannis de Sacro Bosco spericum. Leipzig: Martin Landsberg. http://hdl.handle.net/21.11103/sphaera.100886.

Faber Stapulensis, Jacobus. 1503. Astronomicon. Paris: W. Hopyl and H. Estienne.

Glogów, John of. 1478-1479. Eclipsis luna gemine totales et una solis p[ar]cial[is] hoc anno testimonio celoru[m] eveniet...accidentia stellaru[m]...Anno d[omi]ni millesimoquadrin-ge[n] tesimo septuagesmonono evenie[n]ia. Ego magister Johannes de Glogovia maori scibere institui. [Merseburg: By the printer of Isidorus' Soliloquia (Marcus Brandis)] HAB shelfmark: H: N $128.4^{\circ}$ Helmst. (12).

. 1479-1480. Accidentia stellarum...Anno d[omi]ni Mccclxxx ventura. Ego magister johan[n]es de glogovia maiori...scribere institui...[Merseburg: By the printer of Isidorus' Soliloquia (Marcus Brandis), 1479-80.] HAB shelfmark: H: N 128.4 Helmst. (13).

_. 1480-1481. [Prognosticon, for Kraków, 1481]. [Leipzig: Marcus Brandis].

-1499. Johannes Versoris Quaestiones super Posteriora analytica Aristotelis (cum textu) Johannes Glogoviensis. Leipzig: Wolfgang Stöckel, for Johannes Haller.

—. 1499-1500. Iudicium Cracoviense ad annum 1500. [Leipzig: Martin Landsberg]. Jagiellonian University Library, call number: BJ. St. Dr. Inc. 2673.

-1500a. Doctrinale puerorum, pars secunda, cum commento Ioannis Glogoviensis. Leipzig: Wolfgang Stöckel for Ioannes Haller. Jagiellonian University Library, call number: BJ. St. Dr. Inc. 3254.

- 1500b. Exercitium super omnes tractatus Parvorum logicalium Petri Hispani, cum textu. Leipzig: Wolfgang Stöckel for Johannes Haller. Jagiellonian University Library, call number: BJ. St. Dr. Inc. 2596. Haller.

1500c. De octo partibus grammaticis Donati. Leipzig: Wolfgang Stöckel for Iohannes

- 1501-1502. Ad honorem cel[e]situdinemque dei omnipotentis qui omnium rerum naturas prudentissime instituit et ut celestia inferiora gubernarent [et]ordinauit[.] Ego Magister Johannes Glogouiensis Tempora electa ad fleubothomandum et medicinarum solutivarum observanda iuxta motum lune in duodecim signis zodiaci ad annum domini. 1502. currentem describere institui. [Leipzig: Martin Landsberg]. Jagiellonian University Library, call number: BJ. St. Dr. Cim. vol. 49.

- 1502-1503. Accidentia stellarum anno christi Hiesu saluatoris benedicti illesimoquingentesimotertio currente in mundo inferiori nutu dei ventura per magistrum Johannem Glogouiensem iuxta priscorum sapientu[m] experientias et regulas...feliciter recollecta. Leipzig: Martin Landsberg.

—. 1503. Minoris Donati de octo p[ar]tibus or[ati]onis co[m]pe[n]diosa interp[re]tatio p[er] magistrum Johanne[m] Glogouie[n]sem p[ro] iuniorum institutio[n]e in Florigera Cracouie[nsis]. Vniue[r]sitate breuiter in vnum recollecta. Kraków: Jan Haller. http://jbc.bj.uj. edu.pl/publication/390295/content. Accessed June 2019.

—. 1504a. Argumentu $[\mathrm{m}]$ i $[\mathrm{n}]$ libru $[\mathrm{m}]$ porphiry peripatetici ysagogicum in Kathegorias arestotilis...Ego magister Johannes Glogoviensis universitatis...Cracoviensis-collegiatus... magistri Johannis Versoris super veteri arte questiones in leviorem modu resolvere institui.... Kraków: Jan Haller.

- 1504b. Exercitium secundae partis Alexandri per magistrum Joannem Glogouiensem. Kraków: Kaspar Hochfeder for Jan Haller.

- 1506. Introductorium Compendiosum in Tractatum Spere material magni Joannis de Sacrobusto Qui abbreuiauit ex almagesti Sapientis Ptholomei Claudij alexandrini ex pheludio et geniti et magistrum Joannem Glogouiensem...Anno 1506; In vniuersitate Cracouiensi feliciter Recollectum. [Haller]: Cracow. http://hdl.handle.net/21.11103/sphaera.100920.

1506-1507. Tempora electa ad fleubothomandum et medicinarum solutivarum observanda iuxta motum Lune in duodecim signis celi Zodiaci. Almanach ad annum 1507. Kraków: Jan Haller. Jagiellonian University Library, call number: BJ St. Dr. Cim. vol. 39. 
1507. Computus Chirometralis, in fine: habes...lector co[m]puti Chirometralis opus (resolutu[m] emendatu[m] et...castigatum ad unum ciclum...76. Annoru[m] qui incipit a. 1482 et durabit ad a. 1558 per magistru[m] Joanne [m] Glogocciensem...Anno 1507, quo datu est in luce et impressum. Kraków: Jan Haller. http://www.wbc.poznan.pl/dlibra/ applet?mimetype $=$ image $\% 2 \mathrm{Fx}$. djvu\&sec $=$ false \&handler $=$ djvu_html $5 \&$ content_url=\%2FCont ent $\% 2$ F254559\%2Fdirectory.djvu\&p=5. Last accessed 13 June 2018.

- 1511a. Computus Chirometralis, Denuo reuisum et impressum. Kraków: Jan Haller.

1511b. Exercitium nove logice seu librorum priorum et elenchorum Magistri Johannis

Glogovia: pro Junioribus recollectum ac noviter emendatum. Kraków: Jan Haller. HAB shelfmark: M: Lg Sammelbd. 2 (2).

- 1513. Introductiorum Compendiosum in tractatum Spere materialis magistri Joannis de Sacrobusto quem abbreuiauit ex almagesti Sapientis Ptholomei Claudij alexandrine...magistrum Joannem Glogovinensem foeliciter recollectum. Kraków: Florian Ungler \& Jan Haller. http://hdl.handle.net/21.11103/sphaera.100913.

- 1514a. Introductorium Astronomie in Ephemerides, p[er] Magistru[m] Ioanne[m] Glogouiensem in conmune [m] studentu[m] in arte stellaru[m] \& studio Astronomie p[er] ficere cupientiu[m] vtilitatem In achademia Cracouiensi fauste recollectum]. Kraków: Florian Ungler \& Jan Haller.

- 1514b. Tractatus preclarissimus in judiciis astrorum de mutationibus aeeris, ceterisque accidentibus singulis annis evenientibus... per Ioannem Glogoviensem... atque noviter bene rev. Kraków: Florian Ungler \& Jan Haller.

- 1518. Introductorium compendiosum in tractatu[m] sphere materialis m[a]g[ist]ri Joannis de Sacrobusto...per m[a]g[ist]r[u]m Joanem Glogouiensem feliciter recollectu[m]. Argentine: Knoblauch. http://hdl.handle.net/21.11103/sphaera.100260.

Nifo, Agostino. 1496. Summi philosophi Aristotelis...cum Averrois Cordubensis expositionibus. Venice: Octavian Scot.

Peurbach, Georg. 1474. Theoricae novae planetarum. Nuremberg: Regiomontanus.

Prosdocimus de Beldomando. 1531. Patavinus Astronomiae studiosus. S.P.D. Sphaerae mundi. Fols. $1 \mathrm{R}$ to $56 \mathrm{R}$ in Spherae tractatus. Ioannis de Sacrobusto Anglici viri clariss. Venice: Lucantonio Giunta. http://hdl.handle.net/21.11103/sphaera.100999.

Sabbioneta, Gerard of. 1472. Sphaera mundi. [Venice]: [Florentius de Argentina]. http://hdl.handle. net/21.11103/sphaera.100685.

Verdun, Bernard of. 1961. In Bernardus de Virduno Tractatus super totam astrologiam, ed. Hartmann. Werl, Westf: Dietrich-Coelde.

\section{Secondary Literature}

Aiton, Eric J. 1987. Peurbach's Theoricae novae planetarum: A translation with commentary. Osiris 3: 5-43.

Andersen, Hanne, Peter Barker, and Xiang Chen. 2006. The cognitive structure of scientific revolutions. Cambridge: Cambridge University Press.

Axworthy, Angela. 2016. Prosdocimo de' Beldomandi and Bartolomeo Vespucci on the geometrical definitions of the sphere in Sacrobosco's Sphaera, Lecture, History of Science Department, University of Oklahoma, 28 April 2018.

Barker, Peter. 2011. The reality of Peurbach's orbs. In Change and continuity in early modern cosmology, ed. Patrick J. Boner, 7-32. New York: Springer.

2013a. Albert of Brudzewo's Little commentary on George Peurbach's Theoricae novae planetarum. Journal for the History of Astronomy 44: 1-24.

- 2013b. Why was Copernicus a Copernican? Metascience 2: 1-6.

Barker, Peter, and T. Heidarzadeh. 2016. Copernicus, the TTūsī couple and east-west exchange in the fifteenth century. In Man and cosmos, ed. M.A. Grenada and P. Boner, 19-57. Barcelona: University of Barcelona Press. 
Benzing, Josef. 1966. Haller, Johann. Neue Deutsche Biographie 7:552. https://www.deutschebiographie.de/pnd123913934.html\#ndbcontent. Accessed June 2019.

Crowther, Kathleen, and Peter Barker. 2013. Training the intelligent eye: Understanding illustrations in early modern astronomy texts. Isis 104: 429-470.

Crowther, Kathleen M., et al. 2015. The book everyone read. Journal for the History of Astronomy 46 (1): 4-28.

Dear, Peter. 1995. Discipline and experience: The mathematical way in the scientific revolution. Chicago: University of Chicago Press.

Evans, James. 1998. Theory and practice of ancient astronomy. Oxford: Oxford University Press.

Goddu, André. 2010. Copernicus and the Aristotelian tradition. Leiden: Brill.

Goldstein, Bernard R. 1967. The arabic version of Ptolemy's Planetary hypotheses. Philadelphia: Transactions of the American Philosophical Society 57 (4): 3-55.

- 1971. Al-Bitrūjī: On the principles of astronomy. Vol. 2. New Haven: Yale University Press.

Grant, Edward. 1996. Planets, stars and orbs. Cambridge: Cambridge University Press.

Hasse, Dag N. 2016. Success and suppression. Cambridge, MA: Harvard University Press.

Kren, Claudia. 1968. Homocentric astronomy in the Latin west: The De reprobatione ecentricorum et epiciclorum of Henry of Hesse. Isis 59: 269-281.

Kusuba, Takanori, and David Pingree. 2002. Arabic astronomy in Sanskrit: Al-Birjandi on the Tadhkira II, chapter II and its Sanskrit translation. Leiden: Brill.

Lerner, Michel-Pierre. 2008. Le monde des sphères. Vol. 2. Paris: Les Belles Lettres.

Malpangotto, Michela. 2016. The original motivation for Copernicus's research: Albert of Brudzewo's Commentariolum super Theoricae novas Georgii Peurbachii. Archive for History of Exact Sciences 70 (4): 361-411.

Markowski, Mieczysław. 1981. Die kosmologischen Anschauungen des Prosdocimo de' Beldomandi. In Studi sul XIV secolo in memoria di Anneliese Maier, ed. Alfonso Maierù and Agostino Paravicini Bagliani, 263-273. Rome: Edizioni di Storia e Letteratura.

Morrison, Robert G. 2016. Joseph ibn Nahmias—the light of the world: Astronomy in al-Andalus. Berkeley: University of California Press.

North, John D. 2008. Cosmos: An illustrated history of astronomy and cosmology. Chicago: University of Chicago Press.

Ragep, F. Jamil. 1993. Nasir al-Din al-Ṭūsı̄'s memoir on astronomy, 2 vols. New York: Springer.

Ragep, F.Jamil. 2017. From Tūn to Torun: The twists and turns of the Țūsī couple. In Before Copernicus: The cultures and contexts of scientific learning in the sixteenth century, ed. R. Feldhay and F.J. Ragep, 161-197. Montreal and Kingston: McGill-Queens University Press.

Saliba, G. 1987. The rôle of Maragha in the development of Islamic astronomy: A scientific revolution before the Renaissance. Revue de Synthèse 108 (3-4): 361-373.

Saliba, G. 2007. Islamic science and the making of the European Renaissance. Boston: MIT Press.

Sayili, Aydin. 1960. The observatory in Islam and its place in the general history of the observatory. Ankara: Türk Tarīh Kurumu Basimevi.

Schmidl, Petra G. 2007. Urḍī. In The biographical encyclopedia of astronomers, ed. T. Hockey et al., 1161-1162. New York: Springer. https://doi.org/10.1007/978-0-387-30400-7_1404.

Schuster, John. 2012. Physico-mathematics and the search for causes in Descartes'optics - 16191637. Synthese 185 (3): 467-499.

Shank, Michael. 2009. Setting up Copernicus? Astronomy and natural philosophy in Giambattista Capuano da Manfredonia's Expositio on the Sphere. Early Science and Medicine 14 (1): 290-315.

Sharma, Virendra Nath. 1995. Sawai Jai Singh and his astronomy. Delhi: Motilal Banarsidass Publishers.

Swerdlow, Noel M. 1973. The derivation and first draft of Copernicus's planetary theory: A translation of the Commentariolus with commentary. Proceedings of the American Philosophical Society 117: 423-512.

Swerdlow, Noel M., and O. Neugebauer. 1984. Mathematical astronomy in Copernicus's De revolutionibus. New York: Springer. 
Sylla, Edith Dudley. 2017. The status of astronomy as a science in fifteenth century Cracow: Ibn al-Haytham, Peurbach and Copernicus. In Before Copernicus: The cultures and contexts of scientific learning in the sixteenth century, ed. R. Feldhay and F.J. Ragep, 45-78. Montreal and Kingston: McGill-Queens University Press.

Szczegola, Hieronim. 1967. Jan Glogowczyk. Katowice: Wydawnictwo "Slask".

Thorndike, Lynn. 1949. The Sphere of Sacrobosco and its commentators. Chicago: University of Chicago Press.

Toomer, G.J. 1998. Ptolemy's Almagest. Princeton: Princeton University Press.

van Brummelen, Glen. 2007. Sijzī. In The biographical encyclopedia of astronomers, ed. T. Hockey et al., vol. 1059. New York: Springer. https://doi.org/10.1007/978-0-387-30400-7_1279.

Voss, Don L. 1985. Ibn al-Haytham's “Doubts concerning Ptolemy:” A translation and commentary. PhD dissertation, University of Chicago, Chicago.

Westman, Robert R. 2011. The Copernican question. Berkeley: University of California Press.

Zinner, E. 1990. Regiomontanus: His Life and Work. Trans. E. Brown. Amsterdam: Elsevier.

Open Access This chapter is licensed under the terms of the Creative Commons Attribution 4.0 International License (http://creativecommons.org/licenses/by/4.0/), which permits use, sharing, adaptation, distribution and reproduction in any medium or format, as long as you give appropriate credit to the original author(s) and the source, provide a link to the Creative Commons license and indicate if changes were made.

The images or other third party material in this chapter are included in the chapter's Creative Commons license, unless indicated otherwise in a credit line to the material. If material is not included in the chapter's Creative Commons license and your intended use is not permitted by statutory regulation or exceeds the permitted use, you will need to obtain permission directly from the copyright holder.

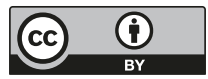




\title{
Chapter 7 \\ Sacrobosco's Sphaera in Spain and Portugal
}

\author{
Kathleen M. Crowther
}

\begin{abstract}
This paper analyzes sixteenth-century commentaries on Johannes de Sacrobosco's Sphaera in Portuguese and Spanish. Between the fifteenth and seventeenth centuries, there were more translations of the Sphaera into Castilian and Portuguese than into all other European vernaculars combined. A major reason for the interest in Sphaera translations in Spain and Portugal was that the basic astronomical and geographical knowledge contained in this text could be used for navigation. Because of their enormous interests in overseas exploration and colonization, Iberian monarchs supported the development of cosmography, a subject that combined mathematics, astronomy, and geography. The astronomical information in the Sphaera was also valued on the Iberian Peninsula for its applications to astrology. Finally, the Sphaera was critical to a Christian education because it taught readers to appreciate the wonders of God's creation. Spanish and Portuguese commentaries on Sacrobosco's Sphaera reflect this mix of practical, political, and spiritual concerns.
\end{abstract}

\section{Introduction}

In 1792, French philosophe Nicolas Masson de Morvilliers (1740-1789) characterized Spain as "the most ignorant nation in Europe" (Navarro-Brotóns and Eamon 2007, 27). A weak and ineffective government, combined with a powerful and oppressive Catholic clergy and Inquisition, and a lazy and superstitious population meant that Spain was an intellectual backwater. "Spanish science" was an oxymoron. All the progress of the Scientific Revolution and the Enlightenment took place far away from the Iberian Peninsula and had limited impact there. This dismissive and caricatured view of Spain and its intellectual history is, of course, no longer tenable. Several generations of historians of Spanish science have made abundantly

K. M. Crowther $(\triangle)$

University of Oklahoma, Norman, OK, USA

e-mail: kcrowther@ou.edu 
clear that early modern Spain and Portugal had a lively scientific culture (Portuondo 2017). This culture was distinctive, characterized by a focus on the practical problems and empirical evidence produced by voyages of exploration and colonization and often conducted in vernacular languages (Leitão and Sánchez 2017). But Spanish and Portuguese scientists were also active participants in European-wide natural philosophical debates and made distinctive contributions to the Scientific Revolution of the sixteenth and seventeenth centuries.

In this paper I examine a group of commentaries on Johannes de Sacrobosco's (died ca. 1256) Sphaera produced by Portuguese and Spanish authors. The Sphaera was one of the most popular scientific texts in early modern Spain and Portugal. In the sixteenth and seventeenth centuries there were at least ten printed Sphaeras, most with commentaries, in Spanish and Portuguese, and many more manuscript versions (Martins 2004, 371-73). The sheer number of Sphaeras with commentaries suggests that there was a lively conversation about astronomy and cosmology on the Iberian Peninsula. Close reading of some of these treatises helps to illuminate the scientific culture of early modern Spain and Portugal, and allows us to see the features that both distinguish this scientific culture from that of other parts of Europe as well as what connects it to the larger European intellectual scene. Although historians of science have by and large moved "beyond the Black Legend," there is much about early modern Spanish and Portuguese contributions to and involvement with science that remain unclear, and Iberian science is still poorly integrated into larger histories of the Scientific Revolution. Analysis of Sphaera commentaries demonstrates that Spanish and Portuguese authors were engaged with a range of issues, practical, natural philosophical, and theological, that they were engaged with the work of scholars across Europe, and that their work was read far beyond the borders of Iberia.

\section{The Iberian Context}

Spain and Portugal were engaged in voyages of exploration and colonization earlier than the rest of Europe. A major reason for interest in the Sphaera in Spain and Portugal was that the basic astronomical and geographical knowledge contained in this text could be used for navigation (Martins 2004). Because of their enormous interests in overseas exploration, exploitation, and colonization, the Spanish and Portuguese monarchs actively supported the development of cosmography, a subject that combined mathematics, astronomy, and geography. These intellectual disciplines were vital to the success of colonial operations. Astronomical knowledge served vital state interests - and received state support-in a way that it did not in other parts of Europe.

The Portuguese were the first to venture into parts of the Atlantic Ocean not previously traversed by Europeans. The Portuguese voyages began with the conquest of the North African city of Ceuta in 1415. This military victory was followed by decades of exploration of the west coast of Africa sponsored by the Portuguese 
monarchy, or more precisely, by Prince Henry the Navigator (1394-1460), younger son of King João I (1357-1433). In 1488, a voyage headed by Bartholomeu Dias (ca. 1450-1500) rounded the southern tip of Africa, the Cape of Good Hope, which gave the Portuguese access to the Indian Ocean and thus a maritime route to Asia (Leitão 2003, 229-30; Leitão 2009). The scale and scope of these voyages was unprecedented, as were the logistical, administrative, technological, and navigational challenges they posed. Sometime in the second half of the fifteenth century, the Portuguese Crown established the Armazéns da Guineé Índia (Storehouse of Guinea and the Indies) to meet these challenges. The Armazéns coordinated the African voyages and managed the flow of information, people, and objects coming from them. One responsibility of the Armazéns was the improvement of navigational tools and techniques as well as the training of navigators (Leitão and Sánchez 2017, 202-03). Much of this work involved the basic astronomical knowledge to be found in Sacrobosco's Sphaera. For example, between 1455 and 1475, the Portuguese developed a method for determining latitude at sea using measurements of the height of the North Star taken with a mariner's astrolabe (Leitão 2009, 30). The demand for men with training in practical mathematics and astronomy grew as the global reach of the Portuguese extended. In 1547, the Crown established the position of chief cosmographer, a man tasked with training pilots as well as examining nautical charts and instruments (Leitão 2003, 233).

The other major site for the teaching of astronomy and mathematics in early modern Portugal was the Jesuit Colegio de Santo Antão in Lisbon, which was established in 1553 (Leitão 2003, 234; Leitão 2007). At the request of King João III, the Colegio added the Aula da Esfera (Course on the Sphaera), a set of lectures on mathematical topics, in 1574. This course was initially only for Jesuit students, but became public in 1590. According to Carolino and Leitão, "great importance [was] attached to nautical questions: elements of cosmography, rules of nautical astronomy and navigation, uses of nautical instruments (astrolabe, quadrant, etc.), the design and construction of nautical charts and globes, etc." (Carolino and Leitão 2006, 162). In keeping with its practical teaching agenda, instruction at the Aula da Esfera was in Portuguese, not Latin (Leitão 2006, 374).

In Spain, two state-supported institutions were established "to coordinate the colonization and exploitation of the New World: the Casa de la Contratación or House of Trade in Seville and the Council of the Indies" (Portuondo 2009, 4). The Casa was founded in 1503 to coordinate and regulate commerce and navigation to the Americas and the Indies (Portuondo 2009; Barrera-Osorio 2006; Sandman 2001). The Casa needed men who could prepare instruments and charts for navigation, teach methods of navigation, and make maps. The chief cosmographer at the Casa was responsible for licensing pilots and administered an exam to make sure they knew how to use navigational instruments. Cosmographers at the Casa produced numerous navigation manuals in Spanish for pilots and navigators in the first half of the sixteenth century (Portuondo 2009; Sandman 2001). Most of these manuals contained material either directly translated from or heavily based on Sacrobosco's Sphaera (Portuondo 2009; Martins 2004). The Casa brought together university-educated scholars and practically-trained navigators and sought to foster 
cooperation between those with theoretical expertise and those with practical experience. However, the relations between these two groups were far from smooth. Cosmographers promoted the use of astronomical instruments - most notably the astrolabe, which was used to find latitude at sea. Navigators, on the other hand, preferred to use the compass and dead reckoning (Sandman 2001). Because Sacrobosco's Sphaera offered a basic introduction to astronomy, a number of cosmographers saw it as a valuable resource in convincing pilots, as well as royal and aristocratic patrons, of the usefulness of astronomical knowledge.

In Portugal, astronomy and mathematics were neglected at the universities of Evora and Coimbra, although they were taught at the Armazéns and the Aula da Esfera (Carolino and Leitão 2006, 162). By contrast, in Spain astronomy and mathematics flourished at the universities of Salamanca, Valencia, Alcalá, and Seville (Navarro-Brotóns 2006). At all of these institutions the Sphaera was an important teaching text. The University of Salamanca was a key early site for the development of cosmography (Chabás 2006). The curriculum included subjects like cartography, and incorporated information from voyages to the West Indies and the Americas. Beginning in 1529, the university's statutes specified that the mathematics professor teach arithmetic, geometry, astrology, perspective, and cosmography. This statute was instituted because the Spanish Crown was concerned that there be enough men trained in cosmography, because the subject was critical for navigation and for the mapping of Spain's overseas possessions. The other three universities followed suit over the course of the sixteenth century. These statutes meant that university professors in Spain who taught mathematical subjects, including the Sphaera, taught a more diverse body of students than at other European universities. Their students included traditional university students, but also practical men training for careers in navigation and cartography. To accommodate both these groups, instruction in mathematical subjects was often in Spanish rather than Latin. In the sixteenth century, at the University of Salamanca, basic astronomy, including Sacrobosco's Sphaera, was taught in Castilian rather than Latin. In 1529, and again in 1538, the university statutes specified that all instruction should be in Latin, except for "grammar, music, rhetoric and astrology [i.e. astronomy]" (Gómez Martínez 2006, 205).

The astronomical information in the Sphaera was also valued on the Iberian Peninsula, as elsewhere in Europe, for its applications to astrology. Astrology was critical to medical practice, as well as to political and personal decision-making. Several professors at the Jesuit Colegio da Santo Antão in Lisbon taught courses on astrology as part of the Aula da Esfera (Leitão 2006; Carolino 2017). In Spain, astrology was taught at the universities of Valencia, Salamanca, Alcalá de Henares, and Valladolid from the late fifteenth to the early eighteenth centuries (LanuzaNavarro 2017a, b, 413-18). It was also taught at the Casa de Contratación and the Academia de Matemáticas in Seville. Members of the Spanish royal family and court regularly consulted astrologers throughout the sixteenth and seventeenth centuries (Lanuza-Navarro 2007, 75-77). And in both Portugal and Spain, astrology was considered integral to medical theory and practice (Lanuza-Navarro 2006) (Chaps. 3 and 10). 
Alongside a strong emphasis on the practical uses of astronomy and mathematics, Iberian scholars were also engaged with the same natural philosophical questions about the structure of the cosmos that preoccupied scholars in other parts of Europe. Some of their natural philosophical speculations were incorporated into commentaries on the Sphaera. Although, as noted above, the teaching at the Aula da Esfera was focused on the practical uses of astronomy and mathematics, it also "served as an exceptional channel of communication with the scientific centers of Europe" (Leitão 2003, 236). Two Italian Jesuits who taught at the Aula da Esfera, Cristoforo Borri and Giovan Paolo Lembo, both discussed Galileo's telescopic observations of 1610 and 1611. Lembo carried out his own telescopic observations in Lisbon, and his lecture notes indicate that he "addressed the cosmological consequences of these new observations, discarding the traditional Ptolemaic system and proposing a semi-Tychonic system instead" (Leitão 2003, 236).

In Spain, new cosmological discoveries and ideas were discussed at both the universities and at the Casa and Consejo. For example, Jerónimo Muñoz (ca. 1520-1591), who taught astronomy and mathematics at the universities of Valencia and Salamanca, was one of the many European scientists to observe and write about the supernova of 1572. For Muñoz, the supernova challenged the Aristotelian notion that change was impossible in the celestial realm. In some of his unpublished work and letters to other European astronomers like Tycho Brahe (1546-1601), he espoused an understanding of the relationship between the celestial and terrestrial realms drawn from Stoic philosophers. He denied the existence of celestial orbs and instead asserted that the planets moved through the heavens like birds through the air or fish through the water. He also discussed Nicolaus Copernicus' (1473-1543) heliocentric system with his students, although he did not endorse it (NavarroBrotóns 1995, 57). In fact, as Victor Navarro-Brotóns has shown, "the work of Copernicus circulated freely in sixteenth-century Spain, where its technical and empirical aspects were greatly admired and used" (Navarro-Brotóns 1995, 63). In 1561, the statutes of the University of Salamanca specified that in the second year of the astronomy course the professor must teach either "the Almagest of Ptolemy, or its Epitome by Regiomontanus, or Geber, or Copernicus," and that the students could vote on which text they wanted (Navarro-Brotóns 1995, 55). In 1594, these statutes were amended and the teaching of Copernicus was made mandatory, no longer subject to the vote of the students (Navarro-Brotóns 1995, 59). The 1594, statutes were reproduced with no change in 1625 , despite the prohibition of Copernicus' work by the Roman Inquisition in 1616 (Navarro-Brotóns 1995, 60). In fact, De revolutionibus was "never placed on any Spanish Inquisitorial index" (Navarro-Brotóns 1995, 63), which does not mean Spanish astronomers were free to adopt heliocentrism but does indicate that it was possible to teach and discuss Copernicus in Spanish universities. As Navarro-Brotóns notes, only one Spanish scholar, Diego de Zúñiga (1536-1597), is known to have actually endorsed the Copernican system. Others used the Prutenic tables, which were calculated using Copernicus' mathematical models, and other parameters drawn from De revolutionibus, in much the same way that Copernicus was taught at the University of Wittenberg (Navarro-Brotóns 1995, 59; Westman 1975). Finally, interest in 
Copernicus spread outside universities, because the Prutenic tables and other technical aspects of Copernicus' work had applications in navigation. For example, Juan Cedillo Diaz (ca. 1560-1625), who studied at Salamanca and became chief cosmographer at the Consejo de Indias and professor at the Mathematical Academy in Seville in 1611, made a free Spanish translation of the first three books of Copernicus' De revolutionibus sometime between 1620 and 1625 (Granada and Crespo 2019; Navarro-Brotóns 1995, 63; Esteban Piñeiro and Gómez Crespo 1991).

Beyond these practical and philosophical issues, there was a long tradition, going back to Plato, of regarding the study of astronomy as essential to the cultivation of virtue. For many medieval and early modern people, the Sphaera was critical to a Christian education because it taught readers to appreciate the wonders of God's creation. Spanish and Portuguese translations of and commentaries on Sacrobosco's Sphaera reflect this mix of practical, philosophical, and spiritual concerns.

\subsection{Tractado da Spera (Lisbon, 1510)}

In around 1510, an anonymous Portuguese translation of the Sphaera appeared in Lisbon (Bensaude 1914; Martins 2004, 371). This is the first printed Sphaera in any European vernacular, although there were certainly vernacular versions in manuscript both earlier and later. This Portuguese translation, titled Tractado da Spera (Treatise on the sphere), does not have a formal commentary in the academic sense, but it does have significant extra material attached to it. This Sphaera was appended to a treatise on navigation titled Regimento do estrolabio \& do quadrante pera saber ha declinaçam \& ho logar do soll em cada hora in dia \& asy pera saber ha estrella do norte (Rules of the astrolabe and the quadrant to find the declination and the place of the sun every hour of the day and also to know the north [pole] star). This short treatise contained instructions for using a mariner's astrolabe and quadrant. It was one of the very first printed books to contain instructions for two new methods for determining latitude at sea: the first using the height of the North Star and the second using the height of the noon sun. As Leitão points out, both of these methods were devised by the Portuguese sometime in the second half of the fifteenth century to meet the challenges of exploring the west coast of Africa (Leitão 2009, 30-32). The practical information in this translation of the Sphaera summarized the results of several decades of collaborative scientific work to solve some of the problems of navigating into previously unknown waters. The book was published in a small handy format that could conceivably have been carried on a sea voyage. This Portuguese Sphaera stands at the beginning of a long line of navigational manuals that incorporate the Sphaera. Multiple versions of these manuals were produced in Spain and Portugal and subsequently the formula was copied in other countries (Leitão 2009, 36; Portuondo 2008, 63).

In addition to information on navigational instruments, this Sphaera includes a Portuguese translation of a letter originally written in Latin by Hieronymus Münzer (ca. 1447-1508) to King João II of Portugal (1455-1495) in the summer of 1493 
(Pohle 2017, 63). Münzer was a Nuremberg physician, humanist scholar, traveler, and one of the authors of the famous Nuremberg Chronicle. In the letter of 1493, Münzer informs João II that the Holy Roman Emperor Maximilian I (1459-1519) recommended that João pursue a westward route to "Cathay." He further recommended Martin Behaim (1459-1507), a German cosmographer already known to João (Pohle 2017), to lead this voyage. What Maximilian, Münzer, and Behaim had in mind was a westward passage across the Atlantic to China, but at a much more northerly latitude than the route Christopher Columbus (1451-1506) had taken in 1492. There was already doubt that Columbus had actually succeeded in finding a route to the Indies, although Columbus himself vehemently asserted that he had. It would not have been unreasonable for any of the people involved in this scheme to believe that a better route might be found (one that actually ended in the Far East) (Hunter 2011). Münzer visited João in 1494 as an emissary of Maximilian (Horst 2017, 18; dos Santos Lopes 2017, 77), and it seems likely he discussed the plan further with the Portuguese monarch.

The letter from Münzer to João II functions as a kind of commentary on the contents of the Sphaera. Münzer urges the king to take both ancient authorities and more recent experience into account in considering the feasibility of finding a new sea route to China. Münzer writes that Aristotle (348-322 BCE), Seneca (ca. 1-65), Pierre d'Ailly (1351-1420), "and many other illustrious men, have said that the beginning of the habitable Orient is very close to the end of the habitable West. The proof is in the elephants, which abound in these two places, and similarly in the reeds which the storm from the east throws on the coast of the Azores islands" (Bensaude 1914, 61). But he is also critical of the errors of ancient and medieval authorities and opposes their errors to recent experience, which must carry greater weight. "Do not let yourself be troubled by Alphraganus and others without experience," he writes, "who say that only a quarter of the land is above the sea level, and that the earth in the other three quarters is drowned under the sea, because in things pertaining to the dwelling of the earth, we must believe rather the experience and probable stories than fantastic imaginations. You certainly know that many authoritative astronomers have denied that there is any habitable land in the tropics and in the equinoctial regions. But you have proved by experience that these things were false and foolish" (Bensaude 1914, 61).

We have evidence that this Sphaera was read outside of Portugal and by at least one humanist with interests in overseas exploration. There is only one extant copy of the book, in the Bavarian State Library (Bayerische Staatsbibliothek). This copy originally belonged to the German humanist Conrad Peutinger (1465-1547), who assembled one of the largest private libraries in Europe. At his death he owned around 200 manuscripts and 10,000 printed books. He collected many books and manuscripts having to do with geography, travel, and navigation, and was very interested in the overseas "discoveries" of the Portuguese in Africa and the "New World" (dos Santos Lopes 2017, 78). He had a number of Portuguese books and manuscripts in his collection. Peutinger had multiple connections to Portugal and multiple reasons for being interested in Portuguese voyages of exploration. Born into a wealthy Augsburg family, Peutinger was educated at the universities of Basel, 
Padua, and Bologna, and he was acquainted with the leading humanist scholars of his age. He achieved a high-level administrative position in the city of Augsburg, and eventually became one of the Holy Roman Emperor Maximilian I's chief confidants, advisors, and diplomats. In this role, he may certainly have been aware of Maximilian's overture, through Münzer, to the Portuguese King João II, to convince him to support an expedition to China by sailing across the Atlantic Ocean. Peutinger had other reasons to be interested in and familiar with Portuguese voyages. He was married to Margarete Welser (1481-1552), member of a wealthy Augsburg patrician family. The Welsers were merchants with far ranging operations. They were the first Germans who, after the discovery of the Indies, established a sales office in Lisbon. They were also the first Germans who joined their ships with Portuguese fleets heading East (dos Santos Lopes 2017, 78).

Many of the Portuguese books in Peutinger's collection were sent to him by Valentim Fernandes, a German printer who moved to Lisbon and was active there from 1494 to 1518 (dos Santos Lopes 2012, 2017, 78; Hendrich 2017; Blackmore 2009, 25-26). Fernandes is a reasonable candidate for the printer of this Portuguese sphere although he is not identified on the title page. In this period there were only about eleven printers active in Lisbon. Fernandes published other books connected to exploration, including a translation into Portuguese (which he prepared) of the travels of Marco Polo (1254-1324) (Livro de Marco Paulo, 1502). Further, he had a close relationship with both the Portuguese court and with Germans resident in or visiting Portugal. He would certainly have been familiar with the representatives of the Welser family. When Hieronymus Münzer visited Lisbon in 1494 on a diplomatic errand for Maximilian I, Fernandes served as his translator. As noted, Fernandes had an ongoing relationship with Conrad Peutinger and sent him a number of Portuguese books. Although this Sphaera is small and unprepossessing, it reflects a dense network of connections between the Holy Roman Empire and Portugal in the early sixteenth century, and intense interest in voyages of exploration on the part of a wide variety of people-humanists, diplomats, monarchs, printers, and sailors (Horst et al. 2017).

\subsection{Francisco Faleiro, Tratado del esphera y del arte del marear (Seville: Juan Cromberger, 1535)}

Another translation of the Sphaera ostensibly aimed at navigators was Francisco Faleiro's Treatise on the sphere and on the art of navigation, published in Seville in 1535 (Faleiro 1535). Faleiro was a Portuguese cosmographer who came to Spain in 1518 and worked at the House of Trade from 1519 to 1532. Faleiro's text is, as the title suggests, two separate books: the first a partial translation of Sacrobosco's Sphaera and the second a treatise on navigation. The translation of the sphere contains numerous illustrations to facilitate understanding, and some commentary on the original text. In the treatise on navigation, Faleiro proposed a solution to a problem that plagued navigators, the magnetic variation of the compass (Collins 2013). 
Magnetic variation causes compass needles to deviate from true north. For navigation in smaller areas like the Mediterranean the deviation is not great enough to cause problems. But on long ocean voyages it is. As Maria Portuondo notes, "Navigation manuals became a forum for advocating different ways of coping with the problem, either by designing instruments that 'corrected' the compass reading or trying to use the needle's deviation as an indicator of longitude" (Portuondo 2008, 64).

Faleiro translated portions of the Sphaera, rearranged them, and added new material, reflecting the book's function as a teaching text for men who were going to sea. Indeed, like the Portuguese Sphaera discussed above, the text is small enough that it was conceivably taken to sea for use as a reference. However, despite this clearly practical context, Faleiro's Sphaera is notable for the repeated emphasis on the importance of cosmographical knowledge in cultivating Christian piety. In the introduction, Faleiro claims he has translated the Sphaera "for those like me who do not have polished Latin," so that they might be able to learn about "the admirable works and marvels of God." Contemplation of the divine works of creation will lead the reader to a deeper knowledge and love of God. The Christian who learns about the heavens "will know much more clearly the greatness, power, and wisdom with which such work was made, and with much more understanding, joy and knowledge give praise to the Lord, as the psalmist says: The heavens declare the glory of God."2

Faleiro expanded on various sections of the Sphaera and cut others entirely. In his discussion of the planets he comments on their influences on human life and health. For example, he informs readers that Saturn is cold and dry, connected to the humor melancholy, and has a generally negative effect on human life. This was all quite standard astrological fare, but it was not in Sacrobosco's original text. Faleiro uses it to emphasize the interconnectedness of the heavens and the earth, and the magnificence of God's plan for the world. Faleiro cut out the last section of Sacrobosco's Sphaera, which introduced mathematical models for the motions of the sun and the moon. Perhaps he deemed them too technical and unnecessary for his projected audience.

Faleiro also corrected and updated Sacrobosco's original text by referring to knowledge gained through the recent experiences of Portuguese and Spanish explorers. For example, Sacrobosco had asserted that there were five climactic zones: a torrid zone around the equator which was too hot to sustain life, two frigid zones around the Arctic and Antarctic poles which were too cold to sustain life, and two temperate zones which were the right temperature to sustain life. Faleiro pointed out

\footnotetext{
${ }^{1}$ (Faleiro 1535, fol. a ii v): “...para que los que como yo no alcancaren la polida latinidad: a esta falta no dexen de saber algo por natural razon delas admirables obras y maravillas de dios."

${ }^{2}$ (Faleiro 1535, fol. a iii): "Mas el christiano que por todo esto passare contemplando y viendo como el esphera y la orden della es la mas excelente y admirabile obra entre todas las obras despues de la que dios a su semejanca hizo: con mucha mas claridad conocera la grandeza / poder / y saber del que tal obra hizo: y con much mas conocimiento / gozo y saber dara loores al señor: y conel psalmist dira. Celi enarrant gloriam dei."
} 
that Portuguese voyages to the Cape of Good Hope and Brazil demonstrated that no portion of the earth was uninhabitable. And far from being arid deserts, the equatorial regions were remarkably fertile. According to travelers's reports, "cucumbers and melons, pears, lettuce, eggplant, and many other fruits" 3 grew year-round in the torrid zone, rather than only in a particular season as in the temperate zone. However, the peoples of this region were sometimes strange-Magellan allegedly found people almost the size of giants on his voyages of 1520-1521. In general, Faleiro informs his readers, "The temperate zone is populated by the best part of people, most endowed with reason and of better understanding and more skill than people who inhabit the other zones."

In this section, Faleiro uses Sacrobosco to represent received and authoritative knowledge, and he opposes this authoritative knowledge drawn from books with experience. But Sacrobosco's statement that the torrid and frigid zones of the earth were uninhabitable was by no means a universally accepted claim in antiquity or the Middle Ages. For example, in the 1260s Campanus of Novara (ca. 1220-1296) composed an astronomical textbook, one that Lynn Thorndike describes as "evidently....indebted" to Sacrobosco's Sphaera, in which he argued that the climate at the equator was temperate (Thorndike 1949, 28). Long before European voyages of exploration began in the fifteenth century, commentators on Sacrobosco's Sphaera refuted his claim that the torrid and frigid zones were uninhabitable, drawing on reason, experience, and authoritative texts. One of the earliest commentaries on the Sphaera is by Robertus Anglicus (13 ${ }^{\text {th }}$ cent.) and was composed around 1271 (Thorndike 1949, 28). On the subject of the torrid zone, Robert argued "that the equatorial region is habitable and not merely habitable but fine to live in" (Thorndike 1949, 239). He cited Avicenna (980-1037) and Isidore as authors who asserted that the torrid zone was habitable, but he also reasoned that since days and nights are always equal at the equator, the heat of the day would always be balanced out by the cool of the night, creating a temperate climate. Nevertheless, these passages on the climactic zones in Faleiro's Tratado del esphera reflect the high value he placed on experiential knowledge. He could have cited various ancient and medieval authorities who argued that the equatorial region was temperate, but he chose to highlight the reports of mariners. In so doing he created a sense of progress, of modern knowledge surpassing ancient wisdom. Many historians of Spanish and Portuguese science identify this kind of valorization of experiential and empirical evidence as a distinctive feature of "Iberian science" and a major contribution to the development of modern science (Leitão and Sánchez 2017; Portuondo 2009; Barrera-Osorio 2006). As Henrique Leitão and Antonio Sánchez write, "All Iberian literature connected to maritime discoveries in this period exhibits a vigorous and self-conscious departure from ancient authorities. The new knowledge was not acquired by logical

\footnotetext{
${ }^{3}$ (Faleiro 1535, fol. ciii): “...pepinos y melones / peras / lechugas / berenjenas: y otras muchas frutas...."

${ }^{4}$ (Faleiro 1535, fol. ciiii): "Esta templada zona es poblada por la mayor parte de gentes mas acogidas a razon y de mejores entendimientos y mas abiles y para mas que las otras gentes de que son abitadas las otras zonas."
} 
syllogisms and deductive reasoning, but by experience-i.e., by direct empirical evidence" (Leitão and Sánchez 2017, 208).

Faleiro is also concerned to explain how this newly acquired geographical knowledge can be incorporated into biblical interpretation. He concludes that Asia and Europe are in the temperate zone, while most of Africa is in the torrid zone. And it is in the temperate zone that all the important historical events have occurred. The first human beings were created and sinned for the first time in the temperate zone. Noah built his ark in the temperate zone. The twelve tribes of Israel were dispersed in the temperate zone. And so on. All the events of biblical and world history occurred in Europe and Asia. Africa was in this account devoid of history and significance (Faleiro 1535, fol. ciiii-ciiii v). It is worth pointing out that by the time Faleiro wrote, the Portuguese slave trade had been going on for almost a century and was one of the most lucrative aspects of Portuguese overseas operations (Saunders 1982). Faleiro's low estimation of the peoples of Africa must be seen in the context of ongoing efforts to provide legal, philosophical, and moral justification for human trafficking.

Significantly, there is very little in Faleiro's translation of the Sphaera that refers to the practical uses of astronomy in navigation. That is all reserved for the second half of the book, on the art of navigation. The material in the Sphaera was clearly necessary for the reader to make sense of the navigational tools and techniques described in the second part, but Faleiro cast his version of the Sphaera as a pious contemplation of the wonders of the cosmos God created and the unfolding of human history according to God's plan.

\subsection{Pedro Nuñes, Tratado da sphera com a Theorica do Sol e da Lua (Lisbon: Germão Galharde, 1537)}

In 1537, Pedro Nuñes (1502-1578), one of the most prominent European mathematicians of the sixteenth century, published a Portuguese translation of the Sphaera with commentary (Nuñes 1537). Nuñes's book was called Tratado da sphera com a Theorica do Sol e da Lua (Treatise on the sphere and Theorica of the sun and moon). It also included a translation of the first book of Ptolemy's (died 160) Geography, a translation of the chapters on the sun and moon from Georg Peuerbach's (1423-1461) Nova Theorica, and two treatises on navigation (the first on "certain doubts about the navigation" and the second on the nautical chart). Nuñes was educated at the University of Salamanca and then the University of Coimbra in Lisbon. Between 1544 and 1562 he held the Chair of Mathematics at Coimbra, a position that required him to teach arithmetic, geometry, perspective, music, and astronomy (Leitão 2009, 81; Carolino and Leitão 2006, 159; Leitão 2002 15-27). Although he was a brilliant mathematician, he seems to have been an indifferent teacher. Carolino and Leitão comment dryly that his "classes in Coimbra seem to have been constantly plagued by lack of attendance, both by students and 
by Nuñes himself" (Carolino and Leitão 2006, 159). In 1547, he was appointed to the newly created position of chief cosmographer, a position that gave him responsibility over navigators, cartographers, and instrument makers, as well as access to the royal court (Leitão and Sánchez 2017, 204; Leitão 2003, 233). Nuñes's translation and commentary on the Sphaera reflects his multiple roles as university professor, royal adviser, and trainer of pilots. His book contained a great deal more theoretical information on astronomy and mathematics than did either of the two Sphaerae I have discussed so far. In the first half of the sixteenth century there was considerable disagreement about just how much theoretical knowledge navigators needed (Sandman 2001; Portuondo 2009; Almeida 2008). Some, like Nuñes, felt that navigators needed a very solid grounding in mathematics, astronomy, and cosmology to do their jobs safely and effectively. At the other extreme were those who were satisfied with rote memorization of rules and the use of tables. As Bruno Almeida notes, Nuñes distinguished between "ars navigandi" and "ratio navigandi." The "art" of navigation was based on known sets of rules, procedures, and instruments." "Rational" navigation, which Nuñes held to be far superior, was "based in the understanding and use of mathematical principles" (Almeida 2012, 462).

Nuñes, like Faleiro, referred to Portuguese voyages of exploration to refute the idea that there were parts of the earth that were uninhabitable: "The navigations of the Portuguese show us that there is no land so distempered by hot or by cold that it is not inhabited." In addition, he tried to introduce greater mathematical precision and rigor into Sacrobosco's Sphaera. For example, he adds a reference to the spherical geometry of Theodosius (ca. 160-ca. 100 BCE) to Sacrobosco's discussion of the movement of the sun and the unequal lengths of the day. The passage in Sacrobosco reads,

In the right sphere the horizon, since it passes through the poles of the world, divides all those circles into equal parts, whence the arcs of days are the same as those of nights for persons living at the equator. Hence it is evident that for persons living at the equator it is always equinox, wherever the sun may be in the firmament. (Thorndike 1949, 133).

Nuñes adds,

Theodosius, in proposition 19 of his first book, demonstrates that every major circle passing through the poles of another circle cuts it in two equal parts and right angles. And in [proposition] 18, he demonstrates that if you cut a minor [circle] in half, you must pass through the poles. ${ }^{6}$

Nuñes also includes a new mathematical demonstration about the climactic zones (Nuñes 1537, fols. c-ciii v). At the end of book three in the Sphaera Sacrobosco describes the seven climes into which the habitable portion of the earth

\footnotetext{
${ }^{5}$ (Nuñes 1537, fol. b): "As navegaçones dos portugueses nos a mostratan que não ha terra tam destemperada per quente ne per fria em que não aja homes."

${ }^{6}$ (Nuñes 1537, fol. Biii.): “Theodosio demonstrou a 19. proposição do seu primeiro livro que todo circulo mayor que passa pellos polos de outro circulo o corta en duas partes yguais e per angulos reytos: e na. 18. demostra que se cortar a algun menor pella metade he necessario que passe pellos polos delle."
} 
was divided. Sacrobosco defines these by the average length of the longest day of the year in each, ranging from $13 \mathrm{~h}$ in the southernmost to 16 in the northernmost. The climes were of unequal size as well, ranging from 440 miles across to 185 . In other words, the climes closer to the equator were wider, those closer to the north pole narrower. But Sacrobosco provides no rationale for these numbers. Nuñes proposes a mathematical demonstration of the varying width of the climate zones. Matteo Valleriani has traced the way in which this particular section was incorporated into a large number of subsequent Sphaera commentaries (Valleriani 2017). The French humanist Elié Vinet (1509-1587) translated this section of Nuñes's commentary into Latin and incorporated it into his own commentary on Sacrobosco's Sphaera. Vinet's commentary was reprinted numerous times, first in Paris and then in several major European cities. In this way, Nuñes' mathematical demonstration spread all over Europe.

\subsection{Jerónimo de Chaves, Tractado de la sphera que compuso el doctor Ioannes de Sacrobusto con muchas additiones (Seville: Juan de Leon, 1545)}

In 1545, Jerónimo de Chaves (1523-1574) published a translation of Sacrobosco's Sphaera with commentary (de Chaves 1545). Jerónimo de Chaves was a mathematician, astronomer, and cosmographer who held important positions at the House of Trades. He followed in the footsteps of his father, Alonso de Chaves (1492-1586), who was also a cosmographer at the House of Trades (Sánchez Martínez 2010; Martins 2004, 376; Sandman 2001). Jerónimo de Chaves's sphere was called Treatise of the sphere composed by doctor Johannes de Sacrobosco with many additions. His treatise contains more theoretical material and less practical material than any of the Sphaeras I discussed above. Chaves' translation of Sacrobosco's Sphaera contains a quite extensive commentary. However, despite his later role as a teacher of navigators, the commentary contains very little directly related to navigation. In the prologue, he claims that he chose to translate the Sphaera "for the pleasure and common usefulness of my country and my friends." ${ }^{.7}$ But he makes clear that he had far more in mind than the usefulness of this text as a basis for navigation. He claims that he wanted to make accessible to those who could not read Latin, "the most sublime science and art of Astronomy," which reveals the "Majesty, Wisdom and infinite Power" of the creator (de Chaves 1545, fol. iii). Chaves' view of the "utility" (utilidad) of astronomy was quite broad (Omodeo 2017). He asserts that the material in Sacrobosco's Sphaera was essential for philosophers, physicians, and astrologers. It was also necessary if one wanted to comprehend "certain passages

\footnotetext{
${ }^{7}$ (de Chaves 1545, fol. iii): “...dela delectation y utilidad commun de mipatria y amigos....”

${ }^{8}$ (de Chaves 1545, fol. iii): “...tan sublimada sciencia y arte de la Astronomia....”

${ }^{9}$ (de Chaves 1545, fol. iii): “...su Magestad, Saber, y infinito Poder...."
} 
and obscure verses of poets." ${ }^{10}$ Here he seems to have had in mind primarily Virgil (70-19 BCE), whose Georgics is cited throughout the commentary, as well as Lucan (39-65). Navigation only comes in at the end of Chaves's list of reasons for learning astronomy. There are only a couple of references in the entire book to "those who sail the Atlantic." ${ }^{11}$ Very little material in the book touches on problems of navigation or cosmography relevant to exploration of the "New World." Chaves includes a discussion of the location of the meridian at the "Fortunate Isles" (or the "Canaries"), a topic of much contention between Spanish and Portuguese cosmographers (Sandman 2001). He includes a table of the positions of fixed stars but does not include any "new" stars or constellations, like the Southern Cross (de Chaves 1545, fol. xlviii v). Similarly, he includes a table of the longitudes and latitudes of various places, but all in Spain, nothing in the "New World" (de Chaves 1545, fol. 1 v-li).

While Chaves's translation of Sacrobosco's Sphaera may well have appealed to people who could not read Latin (or who could not read Latin well), he had a more learned audience in mind as well. He claimed that his version of the Sphaera had more extensive commentary, including "many demonstrations, figures and supplementary tables,"12 than most other editions of Sacrobosco, even those in Latin. And indeed, his explanations and expansions on Sacrobosco's original text are long and detailed, and his text is richly illustrated. Much of his commentary engages with natural philosophical issues that concerned his contemporaries, both in Spain and in other parts of Europe. For example, he discusses celestial orbs in much greater detail than Sacrobosco did. In his commentary on Sacrobosco's first book, Chaves explains the difference between an orb and a sphere and includes a picture of an orb whose concavity has a different center than its outer surface. This material was certainly not necessary for navigation, but it was an important prelude to a discussion of the structure of celestial orbs in the more advanced astronomy text by Georg Peuerbach, the New Theorica (Crowther and Barker 2013). Chaves wrote this in a period when European astronomers, including Spanish astronomers like Jerónimo Muñoz, were debating whether celestial orbs existed or not, and if they did, what their internal structure was (Barker 2011) (Chap. 6). Chaves also discusses the phenomenon of trepidation (de Chaves 1545, fols. xiii, xvii) and debates about the number of celestial spheres (de Chaves 1545, fol. xv v). Again, none of this material was necessary for navigation, but it was all part of learned discussions of astronomy in this period.

Chaves updated Sacrobosco's original text with new information gained from the Portuguese and Spanish voyages of exploration. For example, he explains how to determine the longitude of a place using the timing of lunar eclipses (fol. xlviii), a method much discussed by cosmographers interested in mapping Spain's overseas possessions. Another good example is in the section on the five climactic zones, which Chaves, like Faleiro and Nuñes, notes are all both habitable and inhabited.

\footnotetext{
${ }^{10}$ (de Chaves 1545, fol. iii v): “...algunos lugares y versos obscuros de Poetas...."

${ }^{11}$ (de Chaves 1545, fols. xxvii v, xxx): "Los que navegan el mar Oceano...."

${ }^{12}$ (de Chaves 1545, fol. iii-fol. iii v): “...muchas demonstrationes, figuras y tablas supputatorias...."
} 
Like Faleiro, Chaves comments on the supposed characters of people in the different climactic zones. According to Chaves, the people in the torrid and frigid regions were wilder and more animal-like than the inhabitants of the temperate zone. People in the torrid region were exposed to excessive heat "which burns their bodies, and blackens them, and dries the humors, and bakes their faces, and weakens their limbs." ${ }^{13}$ Their hair is "black and frizzy" (negros, y crespos) and their social customs are "wild and without temperance" (silvestres y sin temperamento). People in the frigid zones are very pale, with red hair and large soft bodies. They too are savage and uncivilized. Chaves claims, "There are in these lands or cold areas, men who eat human flesh, and drink blood: as there are also in the torrid zone." ${ }^{14}$ The torrid and frigid zones are full of "evil people, and devils, and beasts who are inimical to human nature." ${ }^{15}$ By contrast, the inhabitants of the temperate zone are "better and healthier men." ${ }^{16}$ These passages show how Sphaera commentators corrected Sacrobosco's text, but also how they fit new information into pre-existing intellectual frameworks, in this case climactic theories of human difference that were derived from Hippocrates (ca. 460-ca. 370 BCE). And as I commented in reference to Faleiro's text, by the time that Chaves wrote this, the Portuguese slave trade had been underway for a century and there were several 1000 men, women, and children of African origins, both enslaved and free, living in Portugal and Spain (Saunders 1982). Chaves did not so much "observe" these people as reproduce racial and ethnic stereotypes that had been prevalent in Europe for centuries. The description of Africans as "black" and of blackness as physically, morally, and spiritually inferior to whiteness long predates voyages of exploration (Heng 2011). The thirteenthcentury encyclopedist Bartolomeus Anglicus (1190-1250) also described the people of Africa as black, frizzy-haired, cowardly, and full of guile in his De proprietatibus rerum (Heng 2011,316). As in Faleiro's case, Chaves's comments on racial differences need to be seen as part of a justification for enslavement and colonization.

\subsection{Martin Cortes. Breve Compendio de la Esfera y de la Arte de Navegar (Seville, 1551)}

One of the most successful translations and commentaries on Sacrobosco's Sphaera produced in Spain was the Brief Compendium of the Sphaera and of the Art of Navigation by Martin Cortes (1510-1582), published in 1551 in Seville (Cortes 2003). Martin Cortes taught cosmography and navigation to pilots in Cadiz and was

\footnotetext{
${ }^{13}$ (de Chaves 1545, fol. liiii v): “...les quema sus cuerpos, y los ennegresce, y desecca los humores, y assa les los rostros, y enflaquece sus miembros."

${ }^{14}$ (de Chaves 1545, fol. liiii v): "Y hallanse enestas terras ò zonas frias, hombres que comen carne humana, y beven la sangre: segun que tambien se hallan enla torrida zona."

${ }^{15}$ (de Chaves 1545, fol. liiii v): “...malignos, y diablos: y crianse bestias que son empecientes a la naturaleza humana...."

${ }^{16}$ (de Chaves 1545, fol. liiii v): “...los hombres mejor y mas sanos....”
} 
at some point royal cosmographer (Barrera-Osorio 2008). Cortes's book is divided into three parts. The first is heavily based on Sacrobosco's Sphaera, the second contains material from Sacrobosco's Sphaera along with navigational material, and the third is instructions on the construction and use of navigational instruments (Martins 2004, 378). The translation of the Sphaera is indebted to Jerónimo de Chaves's earlier translation, and parts of the sections on navigation are copied from Pedro Medina's (1493-1567) Art of Navigation of 1545. Cortes, however, claimed great originality for his book. In his dedicatory letter to the Spanish king Charles V, Cortes claims to have been "the first person to reduce navigation to a brief compendium, setting out infallible principles and clear demonstrations, writing the practice and theory of it, giving the true rules to sailors, showing the way to pilots, making them instruments to know how to take the height of the sun, to know the ebb and flow of the sea, ordering charts and compasses for navigation, advising them of the course of the sun, the movement of the moon, and a clock for the day so true that in all the lands it indicates the hours without any defect, another clock infallible for the nights, discovering the secret property of the stone magnet, explaining the [deviation] of their needles." 17

Although the claims of originality are greatly overstated, the third part of the book does indeed contain instructions for making and using sea charts (fols. 1xi vlxviii), measuring the height of both the North Star and the sun in order to determine one's longitude at sea (fol. lxxiii), as well as the construction and use of the mariner's astrolabe (fol. lxxv v-lxxviii) and other nautical instruments.

Although written in Spanish for the ostensibly practical purpose of instructing navigators, the Breve compendio bristles with references to ancient, medieval, and modern writers, including Aristotle (passim), Lucretius (fol. xiii), Pliny (fol. xxi), Albertus Magnus (fol. xii), Avicenna (fol. xii), Averroes (fol. xi), Alfonso X (fol. xv), Arzachel (fol. xv), Regiomontanus (fol. xxvii), Faber Stapulensis (fol. xx), and Franciscus Capuanus de Manfredonia (fols. xvii, xxxi). ${ }^{18}$ And Cortes addresses a number of natural philosophical questions that would not have had practical implications for navigators, including debates about the number of celestial spheres (fol. xii v) and the phenomenon of trepidation (fol. xv v). He also raises the "Pythagorean" argument for a moving earth, if only to reject this idea. Cortes offers both physical and scriptural evidence that the earth is stationary (fols. xiii-xiii v).

Like many other Iberian authors, Cortes incorporates information gleaned from voyages of exploration into his commentary on Sacrobosco. While his citations to a

\footnotetext{
${ }^{17}$ (Cortes 2003, fol. ii v): “...mas digo aver sido yo el primero que reduxo la navegacion a breve compendio / poniendo principios infalibles y demonstraciones evidentes / escriviendo pratica y theorica della / dando regla verdadera a los marineros / mostrando camino a los pilotos / haziendoles instrumentos para saber tomar el altura del sol / para conoscer el fluxo yre fluxo del mar / ordenarles cartas y bruxolas para la navegacion / avisandoles del curso del sol / movimiento de la luna / relox para el dia y tan cierto que en todas las terras señala las horas sin defecto alguno / otro si relox infalible para las noches / descubriendo la propriedad secreta dela piedra yman / aclarando el nordestear y norvestear / delas agujas."

${ }^{18}$ On Francesco Capuano da Manfredonia's commentary on De sphaera see (Chap. 4).
} 
variety of authors demonstrate his erudition, he consistently valorizes experience over texts and describes the knowledge of his contemporaries as superior to that of earlier generations. "Navigation, as well as the other arts..., has been increasing little by little until it has come to perfection," 19 he writes in his dedication letter to Charles V. He uses the evidence of recent voyages to refute Sacrobosco's statement that the torrid and frigid zones are uninhabitable (fols. xxi-xxii), and also notes that it was the moderns, not the ancients, that discovered the West Indies (fol. iiii).

Finally, Cortes sets astronomical and navigational knowledge in an explicitly Christian framework. He begins the book with a chapter on the creation of the world, which starts, "The great God is the beginning and cause of the entire universe," 20 and goes on to detail the different aspects of creation and the special place of human beings. And in his discussion of the solstices and equinoxes, Cortes states that Jesus Christ was conceived on the vernal equinox and born on the winter solstice, while John the Baptist (first cent. BCE-ca. 28) was conceived on the autumnal equinox and born on the summer solstice (fols. Xxxi-xxxi v). In this way, the solar year is connected to salvation history. Cortes's Breve compendio was even more popular in England than it was in Spain. It was translated into English and went through nine English editions between 1551 and 1630 (Martins 2004, 377). This text was one of the means by which a great deal of new information and technology relevant to navigation was disseminated from the Iberian Peninsula to other parts of Europe.

\subsection{Rodrigo Saenz de Santayana y Spinosa, La Sphera de Iuan de Sacrobosco (Valladolid: Adrian Ghemart, 1567)}

One of the largest and most extensive Sphaera commentaries in Spanish is the edition published by Santayana y Spinosa 1567 in Valladolid (Santayana y Spinosa 1567). Very little is known about this author, other than that he was born in about 1540 and was a member of the nobility (Martins 2007, 331). Santayana y Spinosa asserts that knowledge of God's creation, and especially knowledge of "the composition and order of the celestial machine, the movements and courses of the circular spheres, the virtues and influences of the stars and celestial constellations"21 will bring the pious Christian to a deeper knowledge and love of the God. On the frontispiece, there is a line from Psalm 19: "the heavens declare the glory of God; and the firmament sheweth his handywork." Throughout the text the emphasis is on contemplating the wonders of God's creation. However, Santayana y Spinosa does

\footnotetext{
${ }^{19}$ (Cortes 2003, fol. iiii): "La navegacion asi como las otras artes de cada dia se ha ydo augmentando y poco a poco ha venido a tener su perfection...."

${ }^{20}$ (Cortes 2003, fol. ix): "El immenso dios principio y causa de todo el universe...."

${ }^{21}$ (Santayana y Spinosa 1567, fol. 1): “...la compustura y orden de la machina celestial, los movimientos y cursos de sus circulares Spheras, la virtudes e influencias de las Estrellas y constellaciones celestials...."
} 
assert that understanding the heavens is crucial to understanding life on earth, because the heavenly bodies influence earthly bodies, including the human body. As he puts it, "He who knows [astrology] can avoid many influences of the stars, because he knows his own nature, and he can prepare beforehand."22 Only a man who actually understood how he was influenced by the stars could take charge of his destiny. Santayana y Spinosa includes a significant amount of astrological material in his commentary, including a spirited defense of the utility and validity of astrology, complete with references to Thomas Aquinas (1225-1274), Pedro Ciruelo (1470-1554) (Chap. 3), Albumasar (787-886), and Cecco d'Ascoli (1269-1327) (Martins 2007, 332).

Santayana y Spinosa includes natural philosophical speculations about the cosmos in his commentary on Sacrobosco's text, including consideration of the heliocentric system of Nicolaus Copernicus. In one section of the Sphaera, Sacrobosco explains that the earth is at rest in the center of the cosmos, and he briefly gives some Aristotelian arguments about why this must be the case. Santayana y Spinosa, like a number of sixteenth-century commentators on Sacrobosco, expanded on this, clearly in response to the newly proposed heliocentric system. Although Santayana y Spinosa does not refer to Copernicus by name, he refers to "Pythagoreans" (Santayana y Spinosa 1567, fol. 20), a common designation of Copernicans in the period. Of course, when Sacrobosco wrote the Sphaera in the first half of the thirteenth century, there was little reason to question this view. But after the 1543 publication of Copernicus' De revolutionibus orbium coelestium, some Sphaera commentators felt the need to address the question of the motion or rest of the earth in more detail. Most, including Santayana y Spinosa, did not accept Copernicus' admittedly rather weak arguments for a moving earth, but it is nonetheless interesting that they were clearly aware of Copernicus' book and expected that at least some of their readers were as well. Santayana y Spinosa explains that the earth must be immobile because "every heavy body naturally desires the lowest and deepest place, and this is the center and middle of the entire Firmament." ${ }^{23}$ And because it is "the natural place of the [element] earth, [thus once it reaches this place] it remains in firmness and stillness." 24 Any movement of the earth away from the center "would be by violence and not naturally." ${ }^{25}$ This reiterates an argument found in Aristotle's De caelo, and was one of the standard objections to the physical reality of the Copernican system.

Santayana y Spinosa was only in his mid-twenties when he published his translation and commentary on the Sphaera. Unlike the other authors I have discussed in this paper, his motivations were unclear-he was not affiliated with a university or

\footnotetext{
${ }^{22}$ (Santayana y Spinosa 1567, fol $1 \mathrm{v}$ ): "Porque el que es sabio...puede evitar muchas influencias delas Estrellas, conosciendo su naturaleza, y preparar se antes de su venida."

${ }^{23}$ (Santayana y Spinosa 1567, fol 19 v): “...que todo cuerpo pesado naturalmente desea el lugar mas baxo y mas hondo, y este es el Centro y medio de todo el firmament...."

${ }^{24}$ (Santayana y Spinosa 1567, fol $19 \mathrm{v}$ ): "Y por ser aquel el natural lugar de la tierra, permanesce en firmeza y quietud...."

${ }^{25}$ (Santayana y Spinosa 1567, fol 19 v): “...lo qual seria por violencia y no naturalmente....”
} 
with the Casa de Contratacion. Further, as Roberto de Andrade Martins has pointed out in his analysis of Santayana y Spinosa's Sphera, the man's grasp of astronomy appears rather weak at points. He makes a number of basic errors, including confusing the phases of the moon with eclipses, misstating Aristotelian arguments for the rotundity of the earth, and misunderstanding the concepts of the horizon and the major circles (Martins 2007, 333-34). Further, parts of the text appear to have been copied from Chaves' translation (Martins 2007, 335). While it is impossible to draw any firm inferences from Santayana y Spinosa's translation and commentary on the Sphaera since so little is known of his life and career, his enthusiastic if naïve text seems to indicate interest in astronomical and cosmological knowledge beyond the circles of university professors, cosmographers, and navigators.

\subsection{Diego Pérez de Mesa, Comentarios de Sphera (1596)}

The last Sphaera commentary that I will discuss is one by Diego Pérez de Mesa (1563-ca. 1632), composed sometime around 1596. According to Víctor NavarroBrotóns, Pérez de Mesa studied at the University of Salamanca under Jerónimo Muñoz, arguably the most famous Spanish astronomer of the period. Muñoz was then chair of astronomy and mathematics. He wrote a widely read work on the supernova of 1572. As I noted before, several Spanish universities of the period specified that Copernicus either could or should be taught by the professor of astronomy. Muñoz discussed Copernicus' work in writing and with students, although he did not endorse heliocentrism. After studying in Salamanca, Pérez de Mesa took up the chair in astronomy at Alcalá de Henares. In 1595, at the request of the King Philip II, Pérez de Mesa moved to Seville. Here he took up a position newly created to train navigators and cosmographers. He taught both university students and men training to be pilots, giving classes on arithmetic, algebra, geometry, astrology, and navigation. All his classes were in Spanish. Although he wrote several books, most, including his Comentarios de Sphera, remained in manuscript (Navarro-Brotóns 2006, 92-93).

In his preface, he describes cosmography as "a science of the heavens and the world" (una siencia del cielo y mundo). It concerns practical subjects like geography and navigation, but it also engages "many beautiful questions of philosophy, such as whether the fourth element fire is in the concavity of the moon, and if it is possible that the earth and the celestial bodies move together, and if the stars move by themselves or together with their orbs." ${ }^{26}$ Pérez de Mesa's commentary ranges over all of these natural philosophical questions and more, as well as practical applications of astronomy. Pérez de Mesa also wrote separate treatises on navigation and

\footnotetext{
${ }^{26}$ (Pérez de Mesa 2009, fol. 1): “...muchas questiones hermossimas de la misma filosofia como es hay fuego quarto Elementi en el concavo de la luna puesto si es posible que se muevan juntamente la tierra y los cuerpos celestiales y si se mueven las estrellas por si solas o juntamente con las orbes...."
} 
astrology. Both of these, like the Comentarios, remained in manuscript. His work reflects familiarity with authors both ancient and modern. Among the moderns, he cites Nicolaus Copernicus, Girolamo Cardano (1501-1576), Francisco Valles (1524-1592), and Jerónimo Muñoz. He includes discussion of Copernicus' heliocentric system, devoting a section to arguments for and against a moving earth. $\mathrm{He}$ also incorporates new information gleaned from voyages of exploration into his philosophical discussions. A particularly striking example of this is in his discussion of the four elements. He begins, conventionally enough, by stating that "earth has the lowest place of all the elements." ${ }^{27}$ Earth is the heaviest element and it naturally moves down to the center of the cosmos. Here he notes that this is an objection to the Pythagoreans, Aristarchus (310-230 BCE), and Copernicus, all of who would "put the earth among the stars." 28 This is an argument that comes straight out of Aristotle and would have surprised no one. His discussion of the element water, however, is considerably less conventional. Water is the second heaviest element, according to Pérez de Mesa, and it covers the earth. But unlike earth, which moves in straight lines, water has a circular motion: "water moves in circles over the surface of the earth." ${ }^{29}$ His evidence for this position, which he acknowledges is a controversial one, is "the experience and certain reports of all navigators." ${ }^{30}$ Sailors, he writes, know that ocean currents move in circles. He gives multiple examples of this phenomenon, ranging from the Pacific Ocean, the Indian Ocean, the Atlantic Ocean, the North Sea, and the Mediterranean.

In addition to his discussion of natural philosophical questions, Pérez de Mesa includes practical uses of astronomy. For example, when he discusses the meridian, which Sacrobosco defined as "a circle passing through the poles of the world and through our zenith," he explains how to calculate one's longitude using a table of the height of the sun at midday. His commentary, like Nuñes work, is full of mathematical demonstrations that lend greater rigor and precision to Sacrobosco's text.

\section{Conclusions}

My goal has been to demonstrate the rich variety of Iberian treatises of De sphaera in the sixteenth century, and to examine what they can tell us about scientific culture on the Iberian Peninsula in this period. The seven treatises that I have described are different in tone, format, and content. Some were aimed at practical men-pilots and navigators who would need to use cosmographical knowledge at sea. But most also included considerable information relevant to astrology, history, and religious

\footnotetext{
${ }^{27}$ (Pérez de Mesa 2009, fol. 4): "La tierra tiene el lugar mas baxo de todos los Elementos...."

${ }^{28}$ (Pérez de Mesa 2009, fol. 4): “...las quales la ponía entre las estrellas....”

${ }^{29}$ (Pérez de Mesa 2009, fol. 4): “...el agua se mueve sircularmente sobre la superficie de la tierra...."

${ }^{30}$ (Pérez de Mesa 2009, fol. 4): “...la espiriencia y siertas rrelaciones de todos los navegantes....”
} 
piety. Some commentators, like Chaves and Santayana y Spinosa, situated astronomical knowledge in a religious and moral context rather than a practical context, although they too included some information about astrology and navigation. These texts were aimed at more elite, highly educated readers who might be more interested in natural philosophical questions. But what is distinctive and fascinating about Spanish and Portuguese science in this period is that the boundaries between these groups - practical and elite-were much more porous than they were in other parts of Europe. It is also the case that many Spanish and Portuguese treatises of $D e$ sphaera were read and used all around Europe.

\section{References}

\section{Primary Sources}

Bensaude, Joaquim. 1914. Histoire de la science nautique portugaise à l'époque des grandes découvertes. In Regimento do estrolabio e do quadrante. Tractado da spera do mundo. Reproduction fac-similé du seul exemplaire connu appurtenant à la Bibliothèque Royale de Munich, vol. 1. Munich: Carl Kuhn. http://hdl.handle.net/21.11103/sphaera.100916.

Cortes, Martin. 2003. Breve Compendio de la Sphera y de la Arte de Navegar (Facsimile). Valladolid: Maxtor.

de Chaves, Jerónimo. 1545. Tractado de la sphera que compuso el doctor Ioannes de Sacrobusto con muchas additiones. Seville: Juan de Leon. http://hdl.handle.net/21.11103/sphaera.101033.

Faleiro, Francisco. 1535. Tratado del esphera y del arte del marear: con el regimie[n]to de las alturas: co[n] algu[n]as reglas nиeиате[n]te escritas mиy necessarias. Seville: Juan Cromberger. http://hdl.handle.net/21.11103/sphaera.101182.

Nuñes, Pedro. 1537. Tratado da sphera com a Theorica do Sol e da Lua. E ho primeiro liuro da Geographia de Claudio Ptolomeo Alexa[n]drino. Lisbon: Germão Galharde. http://hdl.handle. net/21.11103/sphaera.101010.

Pérez de Mesa, Diego. 2009. Comentarios de sphera. Reproducción digital del manuscrito original. Localización: Biblioteca Nacional (España). Sig. Mss. 8882. http://www.cervantesvirtual. com/nd/ark:/59851/bmchx1t7. Accessed June 2019.

Santayana y Spinosa, Rodrigo de Saenz. 1567. La Sphera de Iuan de Sacrobosco. Nueva y fielmente traduzida de Latin en Romance, por Rodrigo Saenz de Santayana y Spinosa. Valladolid: Adrian Ghemart. http://hdl.handle.net/21.11103/sphaera.101077.

\section{Secondary Literature}

Almeida, Onésimo T. 2008. Science during the Portuguese maritime discoveries: A telling case of interaction between experimenters and theoreticians. In Science in the Spanish and Portuguese empires, 1500-1800, ed. Daniela Bleichmar, Vos De Paula, Kristin Huffine, and Kevin Sheehan, 78-92. Stanford: Stanford University Press.

Almeida, Bruno. 2012. On the origins of Dee's mathematical programme: The John Dee-Pedro Nuñes connection. Studies in History and Philosophy of Science 43: 460-469.

Barker, Peter. 2011. The reality of Peurbach's orbs. In Change and continuity in early modern cosmology, ed. Patrick J. Boner, 7-32. New York: Springer. 
Barrera-Osorio, Antonio. 2006. Experiencing nature: The Spanish American empire and the early scientific revolution. Austin: University of Texas Press.

2008. Empiricism in the Atlantic world. In Science and empire in the Atlantic world, ed. James Delbourgo and Nicholas Dew, 178-193. New York/London: Routledge.

Blackmore, Josiah. 2009. Moorings: Portuguese expansion and the writing of Africa. Minneapolis: University of Minnesota Press.

Carolino, Luís Miguel. 2017. The Jesuit paradox: Intellectual authority, political power, and the marginalization of astrology in early modern Portugal. Early Science and Medicine 22: 438-463.

Carolino, Luís Miguel, and Henrique Leitão. 2006. Natural philosophy and mathematics in Portuguese universities, 1550-1650. In Universities and science in the early modern period, ed. Mordechai Feingold and Victor Navarro-Brotons, 153-168. Dordrecht: Springer.

Chabás, José. 2006. The university of Salamanca and the renaissance of astronomy during the second half of the 15th century. In Universities and science in the early modern period, ed. Mordechai Feingold and Victor Navarro-Brotons, 29-36. Dordrecht: Springer.

Collins, Edward. 2013. Francisco Faleiro and scientific methodology at the Casa de la Contratación in the sixteenth century. Imago Mundi: The International Journal for the History of Cartography 65: 25-36.

Crowther, Kathleen, and Peter Barker. 2013. Training the intelligent eye: Understanding illustrations in early modern astronomy texts. Isis 104: 429-470.

dos Santos Lopes, Marília. 2012. From discovery to knowledge: Portuguese maritime navigation and German humanism. In Portuguese humanism and the republic of letters, ed. Maria Berbara and Karl A.E. Enenkel, 425-445. Leiden: Brill.

- 2017. Importing knowledge: Portugal and the scientific culture in fifteenth and sixteenth century's Germany. In Renaissance craftsmen and humanistic scholars: Circulation of knowledge between Portugal and Germany, ed. Thomas Horst, Marília dos Santos Lopes, and Henrique de Sousa Leitão, 73-89. Frankfurt am Main: Peter Lang Edition.

Esteban Piñeiro, Mariano, and Félix Gómez Crespo. 1991. La primera version castellana de de revolutionibus orbium caelestium: Juan Cedillo Diaz (1620-1625). Asclepio 1: 131-191.

Gómez Martínez, Marta. 2006. Sacrobosco en castellano. Salamanca: Ediciones Universidad de Salamanca.

Granada, Miguel Ángel, and Félix Gómez Crespo, eds. 2019. Ydea astronomica de la fabrica del mundo y movimiento de los cuerpos celestiales. Traducción de De revolutionibus I-III, de Nicolás Copérnico [by] Juan Cedillo Díaz. Barcelona: Universitat de Barcelona.

Hendrich, Yvonne. 2017. De insulis et peregrinatione lusitanorum-Valentim Fernandes als Vermittler von Information zwischen Portugal und Oberdeutschland zu Beginn des 16. Jahrhunderts. In Renaissance craftsmen and humanistic scholars: Circulation of knowledge between Portugal and Germany, ed. Thomas Horst, Marília dos Santos Lopes, and Henrique de Sousa Leitão, 103-120. Frankfurt am Main: Peter Lang Edition.

Heng, Geraldine. 2011. The invention of race in the European middle ages I: Race studies, modernity, and the middle ages. Literature Compass 8/5: 315-331.

Horst, Thomas. 2017. The relationship between Portugal and the holy Roman Empire at the beginning of the early modern period: A brief introduction. In Renaissance craftsmen and humanistic scholars: Circulation of knowledge between Portugal and Germany, ed. Thomas Horst, Marília dos Santos Lopes, and Henrique de Sousa Leitão, 9-35. Frankfurt am Main: Peter Lang Edition.

Horst, Thomas, Marília dos Santos Lopes, and Henrique de Sousa Leitão, eds. 2017. Renaissance craftsmen and humanistic scholars: Circulation of knowledge between Portugal and Germany. Frankfurt am Main: Peter Lang Edition.

Hunter, Douglas. 2011. The race to the new world: Christopher Columbus, John Cabot, and a lost history of discovery. London: St. Martin's Press.

Lanuza-Navarro, Tayra M.C. 2006. Medical astrology in Spain during the seventeenth century. Cronos 9: 59-84. 
2007. Astrological prognostications in seventeenth-century in Spain. In Más allá de la Leyenda Negra: Espana y la Revolución Científica/beyond the black legend: Spain and the scientific revolution, ed. Victor Navarro-Brotóns and William Eamon, 73-86. Valencia: Instituto de Historia de la Ciencia y Documentación López Piñero.

2017a. Astrology in court: The Spanish inquisition, authority, and expertise. History of Science 55: 187-209.

2017b. From intense teaching to neglect: The decline of astrology at the university of Valencia and the role of the Spanish Novatores. Early Science and Medicine 22: 410-437.

Leitão, Henrique, ed. 2002. Pedro Nuñes 1502-1578 novas terras, novos mares e o que mays he: novo ceo e novas estrellas. Lisbon: Biblioteca Nacional.

2003. Jesuit mathematical practice in Portugal, 1540-1759. In The new science and Jesuit science: Seventeenth century perspectives, ed. Mordechai Feingold, 229-247. Dordrecht: Kluwer Academic Publishers.

- 2006. Entering dangerous ground: Jesuits teaching astrology and chiromancy in Lisbon. In The Jesuits II: Cultures, sciences and the arts 1540-1773, ed. John O'Malley et al., 371389. Toronto: University of Toronto Press.

2007. A Ciencia na Aula da Esfera no Colégia de Santo Antão 1590-1759. Lisbon: Comissariado Geral das Comemorações do V Centenário do Nascimento de São Francisco Xavier.

2009. The Portuguese discoveries and the science in Europe. Lisbon: Alêtheia Editores.

Leitão, Henrique, and Antonio Sánchez. 2017. Zilsel's thesis, maritime culture, and Iberian science in early modern Europe. Journal of the History of Ideas 78: 191-210.

Martins, Roberto de Andrade. 2004. La herencia de Sacrobosco en España: intercambio entre estudios universitarios y la práctica de navegación durante el siglo XVI. In Epistemología e Historia de la ciencia. Selección de trabajos de las XIV jornadas, ed. Pío García and Patricia Morey, 371-379. Córdoba: Universidad Nacional de Córdoba.

- 2007. El comentario de Santayana y Spinosa (1568) al Tratado de la esfera de Sacrobosco. In Epistemología e historia de la ciencia. Selección de trabajos de las XVII jornadas, ed. Luis Salvatico and Pío García, 331-338. Córdoba: Universidad Nacional de Córdoba, Facultad de Filosofía y Humanidades.

Navarro-Brotóns, Victor. 1995. The reception of Copernicus in sixteenth-century Spain: The case of Diego de Zuniga. Isis 86: 52-78.

Navarro-Brotóns, Víctor. 2006. The cultivation of astronomy in Spanish universities in the latter half of the 16th century. In Universities and science in the early modern period, ed. Mordechai Feingold and Victor Navarro-Brotóns, 83-98. Dordrecht: Springer.

Navarro-Brotóns, Víctor, and William Eamon. 2007. Spain and the scientific revolution: Historiographical questions and conjectures. In Más allá de la leyenda Negra: Espana y la revolución cientifica/Beyond the black legend: Spain and the scientific revolution, ed. Victor Navarro-Brotóns and William Eamon, 27-38. Valencia: Instituto de Historia de la Ciencia y Documentación López Piñero.

Omodeo, Pietro D. 2017. Utilitas astronomiae in the renaissance: The rhetoric and epistemology of astronomy. In The structures of practical knowledge, ed. Matteo Valleriani, 307-332. Dordrecht: Springer.

Pohle, Jürgen. 2017. Kaiser Maximilian I. und die Rezeption der portugiesischen Entdeckungen in Nürnberger Kaufmanns- und Gelehrtenkreis am Ende des 15. Jahrhunderts. In Renaissance craftsmen and humanistic scholars: Circulation of knowledge between Portugal and Germany, ed. Thomas Horst, Marília dos Santos Lopes, and Henrique de Sousa Leitão, 57-71. Frankfurt am Main: Peter Lang Edition.

Portuondo, María M. 2008. Cosmography at the Casa, Consejo, and Corte during the age of discovery. In Science in the Spanish and Portuguese Empires, 1500-1800, ed. Daniela Bleichmar, Paula De Vos, Kristin Huffine, and Kevin Sheehan, 57-77. Stanford: Stanford University Press.

. 2009. Secret science: Spanish cosmography and the new world. Chicago: University of Chicago Press. 
2017. Iberian science: Reflections and studies. History of Science 55: 123-132.

Sánchez Martínez, Antonio. 2010. Los métodos pedagógicos de la Corona para disciplinar la experiencia de los navegantes en el siglo XVI. Anuario de Estudios Americanos 67: 133-156.

Sandman, Alison Deborah. 2001. Cosmographers vs. pilots: Navigation, cosmography, and the state in early modern Spain. PhD dissertation, University of Wisconsin-Madison, Chicago.

Saunders, A. 1982. A social history of black slaves and freedmen in Portugal, 1441-1555. Cambridge: Cambridge University Press.

Thorndike, Lynn. 1949. The sphere of Sacrobosco and its commentators. Chicago: University of Chicago Press.

Valleriani, Matteo. 2017. The tracts on the Sphere: Knowledge restructured over a network. In The structures of practical knowledge, ed. Matteo Valleriani, 421-470. Dordrecht: Springer.

Westman, Robert. 1975. The Melanchthon circle, Rheticus, and the Wittenberg interpretation of the Copernican theory. Isis 66: 165-193.

Open Access This chapter is licensed under the terms of the Creative Commons Attribution 4.0 International License (http://creativecommons.org/licenses/by/4.0/), which permits use, sharing, adaptation, distribution and reproduction in any medium or format, as long as you give appropriate credit to the original author(s) and the source, provide a link to the Creative Commons license and indicate if changes were made.

The images or other third party material in this chapter are included in the chapter's Creative Commons license, unless indicated otherwise in a credit line to the material. If material is not included in the chapter's Creative Commons license and your intended use is not permitted by statutory regulation or exceeds the permitted use, you will need to obtain permission directly from the copyright holder.

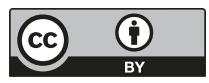




\title{
Chapter 8 \\ Oronce Fine and Sacrobosco: \\ From the Edition of the Tractatus de \\ sphaera (1516) to the Cosmographia (1532)
}

\author{
Angela Axworthy
}

\begin{abstract}
This paper considers the contribution of the French mathematician Oronce Fine to the diffusion and transformation of Johannes de Sacrobosco's Tractatus de sphaera by considering his 1516 edition of the Sphaera and his Cosmographia, sive sphaera mundi (in Protomathesis, 1532). The article first describes Fine's life and career, as well as his work as editor of the Sphaera. In a second part, it considers what Fine, in the Cosmographia, has drawn and left aside from the Sphaera, revealing the consequent transformations to the teaching of Sacrobosco's theory of the sphere and its adaptation to the cultural and intellectual environment in which Fine evolved. A last part considers the treatment, in the Cosmographia, of the cosmological representations transmitted by Sacrobosco and by subsequent interpreters of Ptolemaic astronomy concerning the number of celestial spheres and its relation to judicial astrology.
\end{abstract}

\footnotetext{
A. Axworthy $(\square)$

Technische Universität Berlin, Berlin, Germany

Max Planck Institute for the History of Science, Berlin, Germany

e-mail: aaxworthy@mpiwg-berlin.mpg.de 


\section{Introduction ${ }^{1}$}

Oronce Fine or Finé ${ }^{2}$ (1494-1555), a French mathematician from the Dauphiné, is chiefly known to historians of science for having been the first to teach mathematics as a royal lecturer within the institution founded by François I in March $1530,{ }^{3}$ but also for his work as a cartographer, ${ }^{4}$ as a designer and maker of mathematical instruments, ${ }^{5}$ as well as an engraver and an editor of scientific books. ${ }^{6}$

If it should be admitted that Fine played an important role in the development of mathematics in sixteenth-century France, it is not primarily by the content of his works or of his teaching, which historians of mathematics have not regarded as significant to the advancement of the mathematics of his time (Ross 1975; Poulle $1978)^{7}$ and which was criticized in Fine's lifetime by Pedro Nuñez (1502-1578) and Jean Borrel (Johannes Buteus) (1492-1564/72) in books aimed to expose the mistakes contained in his treatises (Nuñez 1546; Borrel 1554, ${ }^{8}$ 1559). ${ }^{9}$ It is rather

\footnotetext{
${ }^{1}$ The author would like to thank Roberto de Andrade Martins, Peter Barker, Jamie Brannon, Marius Buning, Kathleen Crowther, Charlotte Girout, Thomas Horst, Tayra Lanuza Navarro, Elio Nenci, Richard Oosterhoff, Isabelle Pantin, and Matteo Valleriani, for the insightful comments and exchanges on the theses of this paper.

${ }^{2}$ The issue whether the last syllable of Fine's name should or should not be accentuated is often discussed by his biographers (Rochas 1856-1860, I, 384; Gallois 1918, 1-25; Ross 1971, 8-9; Poulle 1978; Dupèbe 1999, II, 519; Axworthy 2016, 7). The main difficulty with regards to this question is that the Latin spelling of Fine's name is not fixed, not even in the manuscripts. While some French authors contemporary to Fine place an accent on the final syllable (Dupèbe 1999, II, 519), Fine's friend, Antoine Mizauld made "Fine" rhyme with "doctrine." Moreover, most historians of the Dauphiné, where Fine's family finds its origins, agree on the fact that the last syllable should not be accentuated, at least in its written form. Since this issue remains to be discussed, we have chosen to use here the non-accentuated form, which allows more flexibility.

${ }^{3}$ On Fine's role as royal lecturer in mathematics, see (Lefranc 1893, 120, 131, 178, 394; Margolin 1976; Tuilier 2006a, b; Pantin 2006; Dhombres 2006; Pantin 2009a; Axworthy 2016, 16-19).

${ }^{4}$ On Fine's cartographical work, see (Gallois 1890, 38-54, 1918, 1935; Langlois 1922; Bataillon 1951; Kish 1965; Dainville 1970; Karrow 1993, 68-90; Conley 1996, 115-132; Lestringant and Pelletier 2007; Brioist 2009b).

${ }^{5}$ On Fine's work on mathematical instruments, see (Destombe 1951; Hillard and Poulle 1971; Eagleton 2006, 2009; Turner 2009).

${ }^{6}$ On Fine's work as an editor and engraver, see (Johnson 1928; Brun 1934, 1966, 1969, 43-48; Ross 1971, 32-58; Margolin 1976; Conley 1996, 91-115; Dupèbe 1999, II, 523-24; Pantin 2009b, 2010, 2012, 2013a; Oosterhoff 2014, 2016, 2017).

${ }^{7}$ This is in particular how E. Poulle (Poulle 1978) described Fine's mathematical work: "Fine's scientific work may be briefly characterized as encyclopedic, elementary, and unoriginal. It appears that the goal of his publications, which ranged in subject from astronomy to instrumental music, was to popularize the university science that he himself had been taught."

8 "Confutatio quadraturae circuli ab Orontio Finaeo factae."

${ }^{9}$ On Fine's mathematical mistakes and their public denunciations, in particular by Nuñez, see (Baldi 1998, 442-55; Ross 1971, 259-66; Clagett 1978, 1176-78 and 1209-24; Leitão 2009; Almeida 2017).
} 
through his project to promote mathematical teaching in France, ${ }^{10}$ a project he carried out — besides his life-long career as a royal lecturer in mathematics — by writing and publishing a substantial number of mathematical treatises, through which he contributed to the dissemination and expansion of the mathematical culture of his time $^{11}$ in the continuity of the endeavor led in this direction by Jacques Lefèvre d'Étaples (ca. 1450-1536) (Chap. 2), Pedro Sanchez Ciruelo (1470-1548) (Chap. 3 ), and their disciples ${ }^{12}$ in Paris from the end of the fifteenth century on, as well as by assiduously calling upon the perfection and value of mathematics, as he did in particular in his Epistre exhortative touchant la perfection et commodite des ars liberaulx mathematiques (Fine 1531a). ${ }^{13}$

François I founded the institution of the royal lecturers on the suggestion of his librarian Guillaume Budé (1467-1540), in order to create a college where humanists would teach subjects such as Greek and Hebrew which were neglected by the university curriculum, but which were considered necessary to the study and interpretation of ancient pagan and Christian authors. ${ }^{14}$ The foundation of a chair of mathematics shortly after the creation of the first royal lectureships in Greek and Hebrew $^{15}$ indicates that the teaching of mathematics provided at the University of Paris was judged insufficient, in spite of the efforts made in the previous decades by the circles of Lefèvre and Ciruelo to change this situation. ${ }^{16}$ This is confirmed by the discourse held by Fine and by his successor Petrus Ramus (1515-1572) on the

\footnotetext{
${ }^{10}$ On Fine's role in the development of mathematical teaching in sixteenth-century France, see (Ross 1971, 23-35; Margolin 1976; Tuilier 2006b; Pantin 2009a; Axworthy 2016, 27-37).

${ }^{11}$ Bibliographical lists of Fine's works are proposed in (Ross 1971, 398-449; Hillard and Poulle 1971; Ross 1974; Pantin 2013a; Axworthy 2016, 407-19).

${ }^{12}$ On these authors and on their role in the diffusion of mathematics in the Parisian academic sphere, see (Rey Pastor 1934; Ross 1971, 11-15; Margolin 1976; Pantin 2009a, 2013a; Oosterhoff 2015, 2016, 2018) (Chaps. 2 and 3).

${ }^{13}$ Fine wrote this versified eulogy of mathematics, addressed to François I, either before or shortly after his nomination as a royal lecturer around 1530 (Ross 1971, 21; Margolin 1976; Pantin 2009a, 2010; Axworthy 2016, 18).

${ }^{14}$ The first royal lectureships were dedicated to Greek and Hebrew and were attributed to Pierre Danès and Jacques Toussain for Greek and to François Vatable and Agathius Guidacerius for Hebrew. On the creation of these lectureships and on their first appointees, see (Irigoin 2006; Kessler-Mesguich 2006; Tuilier 2006a). Another institution which was oriented towards the pedagogical needs of humanists and which was founded in France in the same period is the Collège de Guyenne, established in Bordeaux in 1533.

${ }^{15}$ On the date of creation of the first royal lectureships, at least on the dates of the first lessons provided in this framework, see (Lefranc 1893, 109; Ross 1971, 21; Tuilier 2006a). On the date of foundation of the first royal chair of mathematics in particular, see (Lefranc 1893, 394; Hillard et al. 1971; Tuilier 2006a, b; Pantin 2009a; Axworthy 2016, 17-18).

${ }^{16}$ On the teaching of mathematics at the University of Paris at the beginning of the sixteenth century, see (Margolin 1976; Tuilier 2006b; Pantin 2009a; Cifoletti 2009; Oosterhoff 2018, 78-79).
} 
ignorance of the students and masters of the Parisian Faculty of the Arts in mathematics (Dupèbe 1999, II, 523; Tuilier 2006a; Pantin 2006, 2009a; Oosterhoff 2015). ${ }^{17}$

As the first royal lecturer in mathematics, Fine's main assignment was to offer greater visibility to the mathematical arts in France and to reform the traditional mathematical curriculum by introducing, in addition to the mathematical content generally taught within the universities (Boethian theories of numbers and of consonances, Euclidean plane geometry, and Ptolemaic geocentric astronomy), ${ }^{18}$ more practical branches of mathematics, through which the utility of mathematics would be more easily displayed, both for the disciplines taught in the higher faculties (medicine, law, and theology) and for the moral and material aspects of human life.

Fine's mathematical teaching program as a royal lecturer was made public through the Protomathesis, ${ }^{19}$ a quadripartite mathematical compendium published in 1532, shortly after his assignment to this function. This monumental work provided a teaching on practical arithmetic (De arithmetica practica libri IIII), on theoretical and practical geometry (De geometria libri II), on cosmography (De Cosmographia, sive sphaera mundi libri $V$ ), as well as on gnomonics (or the art of sundials) (De solaribus horologiis et quadrantibus libri IIII). ${ }^{20}$ Mixing theoretical

\footnotetext{
${ }^{17}$ (Euclid 1536, sig. *2r): "Dum celebres illas et fidissimas artes, quae solae Mathematicae, hoc est, disciplinae merverunt adpellari: raros admodùm offendi (etiam in numerosa auditorum multitudine) qui satis fido ac liberali animo, tam utile ac jucundum philosophandi genus, à limine (ut aiunt) salutare, ne dicam ad illius penetralia, penitioràque secreta, pervenire dignarentur.... Qui enim ad lauream adspirant philosophicam, jurejurando profitentur arctissimo, sese praenominatos Euclidis libros audivisse. An verò illius elementa, multis ab hinc annis, usque ad nostra viderint, ne dicam intellexerint, tempora (paucis forsitam exceptis, quos aequus amavit Juppiter) non ausim honestè confiteri." See also Ramus (Ramus and Talon 1599, 376): "Mathematicas artes adhuc in publicis Philosophici studii legibus et institutis nullum honorem, nullum separatim locum habuere, ut Mathematum prorsus ignarus, tamen legibus Parisiensis Academi, philosophicam lauream consequatur." (Pantin 2006; Axworthy 2016, 13-14).

${ }^{18}$ On the mathematical textbooks read at the faculty of the arts at the beginning of the sixteenth century, see (Chap. 5).

${ }^{19}$ This title, which corresponds to the Latin transliteration of a Greek term composed of the suffix $\pi \rho o \tau o$ - (first) and of the substantive $\mu \dot{\alpha} \theta \eta \sigma l_{\zeta}$ (teaching, knowledge), literally means "first teaching" and intends to assert thereby the propaedeutic function of mathematics (Axworthy 2009, 2016, 127-43).

${ }^{20}$ Although the Protomathesis displays a quadripartite structure, it does not perfectly mirror the structure of the quadrivium since Fine then replaced music (or the theory of consonances) with gnomonics. Fine did, however, contribute to the diffusion of the Boethian theory of consonances through the publication of the Epithoma musice instrumentalis ad omnimodam Hemispherii seu Luthine et theoricam et practicam in 1530 (Fine 1530), where this theory of harmony is also taught along its applications to the reading, composing, and playing of lute pieces. Thus, the fact that the Protomathesis does not include any treatise on music could be due to the fact that Fine had already published, or was about to publish, the Epithoma musice instrumentalis when he was assigned to the position of royal lecturer in mathematics and therefore did not consider it necessary to publish another treatise on music, or to publish again the text of the Epithoma within his mathematical compendium. Indeed, as indicated by the date of 1530 on the title pages of the Geometria and of the Cosmographia (Fine 1532, 49r, 101r), the publication process of the Protomathesis started at the latest in 1530. Notwithstanding, the fact that, in the Protomathesis, music is in a sense "replaced" by gnomonics proposes a representation of mathematics which differs from the tradi-
} 
and practical knowledge (from Euclidean geometry and the theory of the sphere to the construction and use of surveying instruments and sundials), ${ }^{21}$ the publication of the Protomathesis was important for the new image it provided of mathematics, in France and beyond. ${ }^{22}$ As shown by Isabelle Pantin, the publication of this work, as well as of the many separate and successive editions of the different treatises that compose it, ${ }^{23}$ also helped shape the Parisian style of printed scientific books (Pantin 2010, 2013a, Oosterhoff 2016). ${ }^{24}$

Astronomy held a central role in Fine's mathematical work. This is manifested by the dominant number of treatises on astronomy, astrology and astronomical instruments, amid the numerous works he wrote, published and edited. ${ }^{25}$ Among the latter, the two first books on which he worked as an editor were the Theorica planetarum of Georg Peurbach (1423-1461), which was published in Paris in 1515 (Pantin 2009b, 2012, 2013a), ${ }^{26}$ as he was studying at the Collège de Navarre, and the Tractatus de sphaera of Johannes Sacrobosco (died ca. 1256) ${ }^{27}$ in 1516 (Pantin, 2009b, 2010, 2013a; Pettegree and Walsby 2012, 1020-21).

A central role was also attributed to astronomy within Fine's mathematical teaching program, since the Cosmographia, sive mundi sphaera (of which four out of five books deal with spherical astronomy) stands, among the different treatises that compose the Protomathesis, simultaneously as the culminating point of the quadrivium, ${ }^{28}$

tional model drawn from the model of the quadrivium (as represented, for example, by the mathematical section of the Margarita philosophica of Gregor Reisch, which Fine worked to edit around 1523) and which aims to promote practical mathematics.

${ }^{21}$ On Fine's practical mathematics, see (Métin 2004; Guyot and Métin 2004; Dhombres 2006; Eagleton 2009; Dupré 2009; Brioist 2009a; Mosley 2009; Pantin 2006, 2009a, 2010; Oosterhoff 2014, 2016; Axworthy 2016, 249-300).

${ }^{22}$ This work was translated into Italian (along with a treatise on burning mirrors, published in 1551) by Cosimo Bartoli in 1587 as Opere di Orontio Fineo del Delfinato divise in cinque Parti.

${ }^{23}$ The Arithmetica practica was reprinted in 1535, 1542, 1544 and 1555; the second book of the Geometria was reprinted in 1544, 1556, 1558, 1584, 1586; the Cosmographia was reprinted twice in 1542 (unabridged and abridged versions), in 1551, 1552, 1555 and, in French, in 1551 and 1552. See (Fine 1535, 1542a, 1544a), for the bibliographical references of these reprints.

${ }^{24}$ On the Parisian context of scientific book printing, see also (Crowther et al. 2015; Valleriani 2017).

${ }^{25}$ (Peurbach and Fine 1515; Sacrobosco and Fine 1516; Ricci and Fine 1521; Sacrobosco et al. 1521; Fine 1526, 1527, 1528, 1529, 1532, 1543a, b, 1544b, 1545, 1553a, b, c, 1557; Borrhaus 1551; Mizauld 1552). To this, we could add (Reisch and Fine 1535). See also the lists of Fine's works compiled in (Ross 1971, 398-449; Hillard and Poulle 1971; Pantin 2013a; Axworthy 2016, 407-11).

${ }^{26}$ Fine published in 1525 a revised version of his edition of Peurbach's Theorica (Peurbach and Fine 1525), which only featured the original text (without the commentary of Francesco Capuano de Manfredonia (fl. 15th cent.) (Peurbach 1495), with which it was published in 1515), but with a clearer layout and with the inclusion of marginalia, using for Peurbach's text some of the figures initially drawn for the commentaries (Pantin 2013a). He also published in 1528 a treatise in French entitled La Theorique des cielz, mouvemens, et termes practiques des sept planetes (Fine 1528), which may be regarded as an adaptation or a paraphrase of Peurbach's Theorica planetarum.

${ }^{27}$ On the life and works of Sacrobosco, see (Pedersen 1985).

${ }^{28}$ On the traditional order of teaching of the various parts of the quadrivium and its reception by Fine, see (Axworthy 2016, 50-53). 
following arithmetic and geometry (music having been left aside), and as the condition of the application of mathematics to a more practical and specialized type of knowledge, then mainly represented by cartography (through the fifth book of the Cosmographia) and gnomonics (the last part of the Protomathesis).

The importance of astronomy in Fine's mathematical work is also displayed by the manner in which he represented himself in the frontispieces of his editions and treatises pertaining to astronomy ${ }^{29}$ depicting himself in the place of the astronomer, where the figure of Ptolemy (ca. 85-ca. 165) was often positioned in the frontispieces of late fifteenth-century astronomical textbooks - that is, beneath the sphere of the universe (sometimes represented as an armillary sphere), holding a book (open or closed) and/or an astronomical instrument, the muse Urania placed besides him (Pantin 1993; Conley 1996, 98-115; Pantin 2009b; Barker and Crowther 2013). ${ }^{30}$ Although he perpetuated in this way a preexisting visual tradition, it is notable (as Pantin points out) that Fine, who usually engraved the visual material contained in his editions and treatises, did not produce comparable illustrations for his works on other mathematical disciplines (Pantin 2009b). ${ }^{31}$ It also seems significant that the astronomical frontispiece which is associated with the first edition of his Cosmographia-where Fine represented himself sitting under a celestial sphere while holding both an astronomical instrument and an open book-was used twice in the Protomathesis, once at the head of the entire compendium (after the general index) and once at the head of the Cosmographia, though with two different epigrams: one applied to mathematics in general, and more specifically to arithmetic and to the role of the knowledge of numbers and measure for the knowledge of the creation and of its components, ${ }^{32}$ and the second applied to astronomy, commending the usefulness of the science of stars for the contemplation of the divine order. ${ }^{33}$ The use of this frontispiece to introduce the whole compendium, along with the accompanying epigram explaining the importance of mathematics for the knowledge of the causes of the wordly substances, also confirms the central and overarching role of astronomy within the quadrivium according to Fine.

\footnotetext{
${ }^{29}$ An exception to this is his Theorique des cielz (Fine 1528), which was published anonymously and only reprinted with Fine's name postumously, that is in 1557, 1558, 1607, and 1619.

${ }^{30}$ On the intellectual filiation between Ptolemy and Fine, see (Pantin 1993, 2009b; Conley 1996, 98-114).

${ }^{31}$ Yet, such frontispieces existed for other mathematical disciplines in the contemporary literature, as in the Margarita philosophica of Gregor Reisch, which Fine edited.

${ }^{32}$ (Fine 1532, AA8v): "Cùm natura sagax numero mensùque crearit / Singula, ponderibus clauserit inde suis: / Non poteris rerum proprias discernere causas, / Ni teneas numeros, et geometra simul." The frame of the frontispiece features these verses: "Disce prius numeros tellurisque ordine mensus: nam facilem cura haec sternet ad alta viam." This epigram was taken up and slightly modified in ulterior versions of the Arithmetica practica. On the evolution of the epigram in this context, see (Pantin 2009b; Axworthy 2016, 54-56).

${ }^{33}$ (Fine 1532, 101v): "Florida divinae quisquis secreta mathesis / Scire cupis, facili mente fruare decet / Nam licet assiduo possis superare labore, / Mens generosa tamen plurima sola capit." In the frame, "Excute sollicito fragiles de pectore curas: et studeas superas arte subire domos." These verses were used again in the unabridged 1542 edition of the Cosmographia, but in the place of the epigram of the 1532 frontispieces.
} 
Moreover, although Fine greatly emphasized the need to develop, in France, the teaching of all mathematical disciplines, theoretical and practical, he also regularly asserted in his prefaces the predominant importance of astronomy over the other parts of the quadrivium with respect to the primary purpose of mathematics according to the ancient model of education - that is, to open the path to wisdom and to the knowledge of the divine order that governs the universe, in conformity with Platonic epistemology (Barker and Crowther 2013; Axworthy 2016, 151-64) ${ }^{34}$ He followed in this regard the discourse held by Johannes Regiomontanus (1436-1476) in the inaugural oration of his lessons at the University of Padua in 1464 (Pantin 2009a), where astronomy is described both as the crowning of the quadrivium and as the reason for which the other parts of mathematics should be studied. ${ }^{35}$

With respect to the scope of the present volume, the aim of this paper is to examine the significance and transformation of Sacrobosco's astronomical teaching, both in Fine's work as an editor of the Tractatus de sphaera and as the author of the Protomathesis and, more precisely, of the Cosmographia, sive sphaera mundi. ${ }^{36}$ Following a brief biographical outline, I will first describe Fine's work for the 1516 edition of the Sphaera to examine afterwards how the Cosmographia, his major astronomical work, relates to the content of Sacrobosco's treatise. I will conclude this paper by considering Fine's conceptions (as they appear in the Cosmographia) on the cosmological representation transmitted by Sacrobosco and by subsequent interpretations of Ptolemaic astronomy concerning the number of celestial spheres, as an illustration of the uses and transformations of cosmological knowledge in the tradition of Sacrobosco's teaching of spherical astronomy.

\footnotetext{
${ }^{34}$ On the propaedeutic role of mathematics according to Fine, see (Pantin 2009a; Axworthy 2009, 2016, 127-49). On the discussions prior to Fine concerning the relation of astronomy to mathematics in general, but also to the other parts of philosophy involved in the contemplation of the universe, see (Chaps. 2, 3 and 4,).

${ }^{35}$ (Regiomontanus 2008, 137): "Inter omnes autem hasce disciplinas astronomia instar margaritae non modo sorores suas, reliquas inquam scientias medias, verum etiam omnium disciplinarum matres geometriam et arithmeticam longe antecellit; cujus ortum prae vetustate nimia haud satis comperimus ita ut aeternam aut mundo concreatam non inique putaveris." (Fine 1542a, sig. *2rv): "Quanquam enim ipsae Mathematicae, omne philosophandi genus adaperiant, et in universum cunctis opitulentur artibus: eò tamen omnes tendere videntur, ut Caeli suscipiendi peculiarem sortitae sint curam. Quam beatissimam contemplationem, Astronomiam vocant." (Fine 1551a, sig. aa2r-aa3v): "Ipsa autem caelestium rerum eruditio, earum disciplinarum beneficio comparatur, quae mathematicae nuncupantur: quarum videlicet essentialis puritas, fida atque inviolabilis certitudo, humana divinis, terrenave caelestibus vel facilè conciliat. Et proinde inter ispius mathematicae partes, ea longè praestantior esse videtur, quae Astronomia dicitur: utpote, in cujus gratiam caeterae omnes videntur excogitatae, et quae caelestia simul et terrestria ratiocinatur corpora." (Fine 1555, sig. 2v): "Omnis itaque philosophia, omnisque certa et inviolabilis doctrina, qualis est Mathematica, eò potissimùm tendere videtur, ut in veram caelestium rerum cognitionem mortales inducat."

${ }^{36}$ For this paper, I will mostly refer to the first edition of the Cosmographia, which was first printed 1530 (as indicated by the title page of this particular treatise) though it was published in 1532 with the other parts of the Protomathesis. Because the denomination Cosmographia comes in this edition before that of Sphaera mundi-this is not the case in the later editions-I will use the shortened title Cosmographia.
} 


\section{Fine's Life and Career}

Fine was born in 1494 in Briançon to a family of high social rank, which constituted a stimulating environment for the development of scientific interests during the first years of his life (Thomé de Maisonneufve 1922; Thomé de Maisonneufve 1924, 5-10; Ross 1971, 8-11). ${ }^{37}$ His grandfather and his father, Michel Fine (fl. 1474-1490) and François Fine (fl. 1494-1499), were both physicians (Wickerheimer 1979, 154, 553). The former wrote a treatise on the plague, whose posthumous publication Oronce contributed to in 1522 (Fine 1522; Dupèbe 1999, II, 521). The latter is said to have built an equatorium, which William Gilliszoon of Wissekerke (ca. 1444) described in his Liber desideratus super celestium motuum indagatione sine calculo (Wissekerke 1538, sig. A2r-v; Poulle 1961). When his father died, he was sent to Paris and entrusted to Antoine Silvestre, a family friend from Briançon who taught arts at the Collège de Montaigu and theology at the Collège de Navarre (Launoy 1677, 646-47; Élie 1951), where Fine studied. Fine obtained his Master of Arts in 1516 at the Collège de Navarre (Launoy 1677, 678), where he started the same year to teach mathematics both privately and publicly at least until 1527 (Dupèbe 1999, II, 533). ${ }^{38} \mathrm{He}$ began in parallel to study at the faculty of medicine, obtaining his bachelor's degree in 1522 (Concasty 1964, 50b, 54a-b; Dupèbe 1999, II, 526-27). From 1528 on, he taught mathematics at the Collège de Maître Gervais (Dupèbe 1999, II, 540-41; Boudet 2007; Pantin 2009a, 2013a).

François I's choice to assign Oronce Fine to the first royal chair of mathematics was likely influenced by the support Fine received from humanists close to the royal court (Dupèbe 1999, II, 530, 533, 538), as well as by his multifaceted mathematical activity in the years 1515-1530 (Pantin 2006, 2009a; Axworthy 2016, 14-17). These were the years during which he worked on his first editions and illustrations of mathematical and non-mathematical works (Peurbach and Fine 1515; Sacrobosco and Fine 1516; Le Huen 1517 ${ }^{39}$; Bassolis and Fine 1517a, b; Martínez Silíceo and Fine 1519; Ricci and Fine 1521; Fine 1522; Reisch and Fine 1535) ${ }^{40}$ and published under his name several mathematical treatises (mostly pertaining to astronomy) (Fine 1526, 1527, 1528, 1529, 1530), as well as a map of France (Fine 1525). He also practiced during this time as a court astrologer. ${ }^{41}$

\footnotetext{
${ }^{37}$ More generally, on Fine's life, education, and career, see (Thévet 1584, 564r-66v; Baldi 1998, 442-55; Thorndike 1941, 284-86; Escallier 1957; Ross 1971, 8-30; Poulle 1978; Aked 1990; Marr 2009; Pantin 2009b, 2013a; Oosterhoff 2016; Axworthy 2016, 12-22).

${ }^{38}$ J. Dupèbe (Dupèbe 1999, II, 522) surmises that he was teaching in 1515 at the Collège de Montaigu, when he edited Peurbach's Theorica planetarum.

${ }^{39}$ Fine engraved, for this work, a map of the Holy Land (Conley 1996, 91-98; Pantin 2009b).

${ }^{40}$ This edition of Reisch's Margarita philosophica was published in 1535 (Reisch and Fine 1535), but the date of 1523 at the end of the preface indicates that it had been prepared by Fine while he was teaching at the Collège de Navarre.

${ }^{41}$ According to certain historical accounts, Fine would have been imprisoned around the years 1524-1525 because of a horoscope that would have either been unfavorable to a member of the court, Louise de Savoie (Lefranc 1893, 178; Gallois 1918), or favorable to the Constable of Bourbon (Charles III of Bourbon), an enemy of the court (Destombes 1971). The first of these two
} 
Fine remained a royal lecturer until his death in 1555 . During the 25 years he taught mathematics in the name of the King of France, which would have represented an exceptionally long career for such a position at the time, he published many other treatises, among which several reprints of the first three parts of his Protomathesis, as well as new treatises dealing with astronomy and its applications (Fine 1543a, b, 1545, 1553a, b, 1557), geometry (Euclid 1536; Fine 1544b, 1556a, b) and the theory of burning mirrors (Fine 1551b).

Thanks to his high-quality editions, geographical maps, and mathematical treatises, Fine rapidly gained an international reputation, notably in Italy and in England (Johnson 1946; Heninger 1977a, b; Feingold 1984, 59, 116, 118; Tredwell 2005, 185; Eagleton 2009; Mosley 2009; Leitão 2009; Wagner 2010; Rampling 2012; Valleriani 2013, 76-77; Axworthy 2016, 22-27; Valleriani 2017, 430). The Italian translation of the Protomathesis by Cosimo Bartoli (1503-1572), published with the translation of the De speculo ustorio by Ercole Bottrigari (1531-1612) (Fine 1587) as well as the English translation of his Canons des ephemerides by Humphrey Baker (fl. 1562-1587) (Fine 1558), testify to the international and long-lasting influence of Fine's mathematical teaching throughout the sixteenth century. His Cosmographia notably appears in the Bibliotheca selecta compiled by the Jesuit Antonio Possevino among the sources relevant to the study of astronomy (Possevino 1593, 201; Margolin 1976; Mosley 2009). His astronomical and arithmetical works were included in the programs of the Jesuit College of Messina (Sasaki 2003, 21; Gatto 2006), of the University of Pisa (Schmitt 1974, 1975) (Chap. 10), of the University of Cambridge (Johnson 1946; Feingold 1984, 39), and also very likely of the Spanish University of Valencia (Navarro Brotóns 2006)..$^{42}$ At the University of Oxford, the statutes of 1565 recommended astronomy lecturers to teach Fine's Cosmographia as a possible alternative to Sacrobosco's Sphaera (Goulding 2010, 88-89).

hypotheses is founded on a letter (written in Lyon on the $3^{\text {rd }}$ of November, 1526) by HeinrichCornelius Agrippa, who claimed that Fine had been imprisoned for having made an unfavorable horoscope to a member of the French court (in order to justify his reluctance to make prognostications to the French court while in Lyon). (Agrippa 1970, II, letter 62, book 4, 844): "Sed et nesciebam me praedariò astrologum conductum, quodque mihi, quod ars illa dictat, monendi dicendique jus relictum non esset, occurritque exemplò Orontius Parrhisiorum insignis mathematicus et astrologus, qui dum veriora, quàm poterat, vaticinaverat, iniquissima captivitate diutinè vexatus est: iamque aiebam apud me, quid, si reliqua misisses prognostica? proculdubio ex fumo in flammam te conjecisses." Yet, although it is generally admitted by historians that Fine spent some time in prison, the reason for this unfortunate event is not fully attested, as other sources suggest that it may have been because of his opposition to the Concordat (Boulay 1665-1673, 4, 965-66; Tuilier 2006a) or for having refused, as he worked on the fortifications of Milan, to submit himself to the aforementioned Constable of Bourbon, who would have had him arrested during the construction of a bridge on the Tessino (Escallier 1957, 6-7; Aked 1990). More generally, on this issue, see (Ross 1971, 386-97; Dupèbe 1999, II, 536-38).

${ }^{42}$ As indicated by Víctor Navarro Brotóns (Navarro Brotóns 2006), Jerónimo Muñoz, who studied in Valencia for his Bachelor of Arts, referred to Fine as "preceptor noster" in his Astrologicarum et geographicarum institutionum libri sex (Muñoz 2004, 68v). 


\section{Fine's Edition of Sacrobosco's Sphaera and It's Significance for His Pedagogical and Scientific Project}

Sacrobosco's Sphaera was, as indicated above, the second treatise on which Fine worked as an editor. It was first published in 1516 in Paris by Regnault Chaudière (died 1554), when Fine was about twenty years old and was teaching at the Collège de Navarre. ${ }^{43}$ As indicated by the title and the colophon, the work he performed for this edition of the Sphaera consisted in applying corrections, engraving woodblocks, and adding marginal indications. ${ }^{44}$ In addition to his epigram to the reader, he included several liminary poems at the beginning and at the end of the book, ${ }^{45}$ written by himself and by some of his colleagues or condisciples, such as the poet Hugues d'Ambert or Hugues de Colonges (fifteenth-sixteenth century), who was then addressing both Fine ${ }^{46}$ and Fine's protector Antoine Silvestre, ${ }^{47}$ and Nicolas Petit (1497-1532), ${ }^{48}$ addressing Jean Fossier or Jean des Fosses (fifteenth-sixteenth century), ${ }^{49}$ one of Fine's disciples (Dupèbe 1999, II, 526). ${ }^{50}$ The engravings provided by Fine for this edition were mostly modeled on the figures found in the editions of Sacrobosco's Sphaera published in Venice from the end of the fifteenth century onwards (Cosgrove 2007; Pantin 2010) (Chap. 9), ${ }^{51}$ though he integrated, for the representation of the motion of the sun, engravings he had produced for his

\footnotetext{
${ }^{43}$ This is indicated in the title of the epigram to the reader which prefaces his edition of Sacrobosco: (Sacrobosco and Fine 1516, sig. a1v): "Orontius Fine Briansonnianus: Ebredunensis Artium liberalium professor: Ad lectorem: Phaleuticum Epigramma."

${ }^{44}$ (Sacrobosco and Fine 1516, title page) Mundialis sphere opusculum Joannis de sacro busto: nuper vigilantissime emendatum una cum figuris accommodatissimis: cumque marginariis annotatiunculis recenter adjectis and (sig. d3v): "Explicit tractatus de sphera Johannis de sacro busco profundissimi Astronomi. Nuper vigilantissime per Magistrum Orontium Fine: emendatus: et ab eodem figuris accommodatissimis. Nec non et marginarijs annotatiunculis illustratus."

${ }^{45}$ (Sacrobosco and Fine 1516, sig. a1v): Phaleuticum Epigramma (epigram in phalecian verses), (Sacrobosco 1516, sig. a1v): Saphicum (saphic verse), (sig. d3v): Epigramma Extemporeaneum (improvised epigram); Carmen Elegum (elegiac verse), sig. d4r: Endecasillabum (hendecasyllabic verse). I would like to thank Alain Legros for the complementary indications he provided me on these verses.

${ }^{46}$ (Sacrobosco and Fine 1516, sig. d3v): "Magistri Hugonis Ambertani Eruditissimo artium doctori. Exactissimoque Astrosophie percunctatori Orontio Fine Epigramma Extemporeaneum."

${ }^{47}$ (Sacrobosco and Fine 1516, sig. d4r): "M. Hugonis ambertani celeberrimo bonarum literarum Magistro Anthonio silvestri preceptori observando. Endecasillabum."

${ }^{48}$ Nicolas Petit was a poet, rector of the Faculty of law of Poitiers and professor at the Parisian Collège de Montaigu, where Fine also taught.

${ }^{49}$ (Sacrobosco and Fine 1519, sig. d3v): "M. Nicolai Parvi Bellosanensis libri munere fugentis ad magistrum Johannem Fosserium virumundecunque doctissimum. Carmen Elegum."

${ }^{50}$ All three, and very likely also Fine himself, would have been disciples of Antoine Silvestre (Élie 1951).

${ }^{51}$ On the illustrations in the Venetian editions of Sacrobosco, see (Gingerich 1999; Cosgrove 2007; Barker and Crowther 2013; Oosterhoff 2015).
} 
edition of Peurbach's Theorica planetarum. ${ }^{52}$ This edition also contains a few tables: a table displaying the cosmic, chronic, and heliacal rising and setting of the signs $;{ }^{53}$ a table for the rising and setting of the signs in the right sphere (indicating the durations of the rising and setting of each sign and the quantities of the corresponding arcs of equinoctial) $;{ }^{54}$ a table for the latitudes of the seven climates, coupled with a table indicating the duration of the longest artificial days for these latitudes. ${ }^{55}$ The inclusion of these tables, though quite elementary, demonstrates Fine's will to add to the Sphaera complementary elements of a practical nature, ${ }^{56}$ in line with the material added by Lefèvre d'Étaples in his 1495 commentary on Sacrobosco (Sacrobosco et al. 1495; Oosterhoff 2015) (Chap. 2). This also anticipated his later contribution to the diffusion and transformation of spherical astronomy in the tradition of Sacrobosco's Sphaera in the Cosmographia. The printed marginalia mark out the different topics dealt with by Sacrobosco, the authors referred to such as Virgil (Publius Vergilius Maro, 70-19 BCE), Ovid (Publius Ovidius Naso, 43 BCEca. 18), Lucan (Marcus Annaeus Lucanus, 39-65), al-Farghānī (Abū al-'Abbās Aḥmad ibn Muḥammad ibn Kathīr al-Farghānī, ca. 805-870), as well as the distinction and hierarchical status of the various arguments provided, ${ }^{57}$ giving this edition the style and the structure of university textbooks while making the text easier to read and consult. ${ }^{58}$ The large white spaces on the exterior margins also facilitated note-taking, as shown by extant exemplaries containing substantial hand-written marginal notes. ${ }^{59}$

\footnotetext{
${ }^{52}$ The two illustrations in (Sacrobosco and Fine 1516, sig. d1v) are drawn from (Peurbach and Fine 1515, 14r, 24v). On Fine's engravings for the 1515 edition of the Theorica, see (Pantin 2012).

${ }^{53}$ (Sacrobosco and Fine 1516, sig. b4r): "Tabula ortus: et occasus cosmici et chronici 12 signorum. Ortus vero et occasus heliacus signorum per introitum solis in 12 signa sciri poterit."

${ }^{54}$ (Sacrobosco and Fine 1516, sig. c1r): "Tabula ortus et occasus signorum in sphera recta per gradus et minuta: ac per horas et minuta equinoctialis."

${ }^{55}$ (Sacrobosco and Fine 1516, sig. d1r): "Elevationes poli and Quantitates maximarum dierum."

${ }^{56}$ On the mostly practical nature of the material added to the text of Sacrobosco in the sixteenth century, see (Crowther et al. 2015; Oosterhoff 2015; Valleriani 2017).

${ }^{57}$ These are divided in ratio, objectio, solutio, confirmatio, probatio, conclusio and occasionally numbered (prima ratio; secunda ratio...).

${ }^{58}$ The use of such marginalia does not appear to have been very widespread among the various editions of Sacrobosco published in the first decades of the sixteenth century. Among those which I have consulted, those which featured comparable marginal indications were the 1478 edition printed in Venice by Adam de Rottweil (Sacrobosco 2003 [1478]) and the commentary by Pedro Sanchez Ciruelo based on Pierre d'Ailly's Quaestiones on the Sphaera, first printed in 1498 in Paris (Sacrobosco et al. 1498) - the earliest edition which I was able to consult was, however, that of 1508 (Sacrobosco et al. 1508b).

${ }^{59}$ At least one surviving copy of Fine's edition of Sacrobosco's Sphaera displays the use made of it by its early modern readers, as it contains hand-written marginal notes that offer complementary information and precisions, notably definitions of specific terms. This is the copy of the 1519 edition (Sacrobosco and Fine 1519) held at the Universitäts- und Landesbibliothek Sachsen-Anhalt and made accessible via http://digital.bibliothek.uni-halle.de/hd/urn/urn:nbn:de:gbv:3:3-41345 (Accessed June 2019). Although there is no information concerning the owner and consequently
} 
Fine's contribution to the 1521 edition of Lefèvre d'Étaples's commentary on Sacrobosco's Sphaera (Sacrobosco et al. 1521) is mainly indicated by the inclusion of the frontispiece he had drawn for his edition of Peurbach's Theorica planetarum published in 1515 (Pantin 1993; Conley 1996, 98-105) and, starting with the 1527 edition (Sacrobosco et al. 1527), through the introduction of a new frontispiece in which he represented himself resting on the ground while contemplating a bidimensional worldly sphere situated above him (Pantin 2012). He probably also added the marginal annotations, re-engraved some of the woodblocks, and changed the design of the tables and layout of the text (Pantin 2009b, 2010, 2012; Oosterhoff 2015, 2016) (Chap. 2). However, the content of the text, of the tables, and most of the illustrations are drawn from the earlier editions of Lefèvre's commentary on Sacrobosco.

Although these editorial interventions in Sacrobosco's Sphaera may be regarded as minor, notably as they are not related to the content of the text, they would nevertheless have a certain impact on the reading and the reception of the work by its readers. As Isabelle Pantin has shown in this volume (Chap. 9), such interventions in the layout, the illustrations, and the editing of the text may be held as innovations, just as the commentary or the inclusion of new textual material. This is all the more significant in the case of authors such as Fine or Peter Apian (1495-1552), who were also involved in the technical aspects of the production of the book, either as engravers, as editors, or as printers, as they could then control the production of the works in order to suit their own agendas, in particular when they themselves taught mathematics, since they could aim to satisfy certain conditions required by their teaching practice through their editorial interventions.

The fact that Fine intended this work as a university textbook is not only suggested by the layout of the text, but also by the fact that he produced it while he was a professor of the Arts Faculty, which he made explicit in the title of his address to the reader (Artium liberalium professor) and, more generally, by the established place of Sacrobosco's Sphaera among the works studied in the mathematical curriculum of the Parisian University.

At that point in Fine's career, especially after the work he had done on Peurbach's Theorica planetarum published a year before, this edition of Sacrobosco's Sphaera represented a meaningful move to confirm his competence as an editor of scientific books, since he then likely intended to maintain this activity as an auxiliary source of income while teaching mathematics at the Collège de Navarre. It would certainly enable him to gain visibility in this function, ${ }^{60}$ as Sacrobosco's Sphaera was a highly demanded work and therefore an easily marketable product, especially as it was part of the standard mathematical curriculum of the university (Crowther et al. 2015;

on the context in which he could have added these annotations, it is possible that such notes were written down in the context of a classroom. On this type of layout and on the practice of notetaking on printed textbooks in Parisian university classrooms at the beginning of the sixteenth century, see (Oosterhoff 2015, 2018, 74-75) (Chap. 9).

${ }^{60}$ As suggested by the paper of Isabelle Pantin in this volume (Chap. 9), the fact that an editor indicated his interventions, even only in the colophon, was significant. 
Oosterhoff 2015; Valleriani 2017). The teaching of Sacrobosco's theory of the sphere actually represented one of the most important parts of the mathematical program of university faculties of arts since the Late Middle Ages, ${ }^{61}$ given that it was used to introduce students to astronomy, as well as to the reading of the De caelo of Aristotle (384-322 BCE) (Valleriani 2017), offering them a general description of the structure of the cosmos and of the motions of the stars, as well as the geometrical tools required to apprehend them (Pantin 1995, 31-36; Oosterhoff 2015) (Chap. 2). The teaching of Ptolemy's Almagest, as well as the more in-depth study of planetary motions provided by the medieval Theorica and later by the new Theorica provided by Peurbach, were considered too advanced for beginners and were therefore taught at a later stage of the mathematical curriculum (Pantin 1995, 29-31; Barker 2011; Crowther et al. 2015; Oosterhoff 2015; Valleriani 2017) (Chap. 6).

For that matter, Fine's edition offered students a stand-alone version of Sacrobosco's text, devoid of any commentary, printed in an easily transportable format (in-quarto), and not bound to other astronomical treatises within large compendia, as was the case for many editions of Sacrobosco published at the end of the fifteenth century (Oosterhoff 2015). ${ }^{62}$ It would therefore have been more affordable for university students and easier to bring to class.

Hence, through this edition and the other works he edited during this period, Fine contributed to the stylistic reform of scientific and pedagogical texts instigated by Lefèvre d'Étaples and his disciples at the end of the fifteenth century and which enabled Paris to have a central role in the production of printed textbooks and scientific works (Pantin 2009a, 2013a; Oosterhoff 2015, 2016, 2018, ch. 4; Valleriani 2017). As shown by Isabelle Pantin, the explicit manner in which he indicated early on his role in the various editions he worked on (including in his edition of Sacrobosco's Sphaera), and the evolution of this practice of identification (Conley 1996; Pantin 2009b), reveals his pride and desire to assert himself as an active promoter of the mathematical culture of his time (Pantin 2010, 2013a). ${ }^{63}$

\footnotetext{
${ }^{61}$ On Sacrobosco's Sphaera and on its place in the medieval and Renaissance university curriculum, see (Thorndike 1949, 42-43; Oosterhoff 2015).

${ }^{62}$ See (Chap. 9) for this factor as a motivation for the development of the in-octavo tradition.

${ }^{63}$ It is interesting to note that, in this respect, Fine published this French paraphrase of Peurbach anonymously. His authorship of this work may be attested by the appearance of the motto "virescit vulnere virtus," which he used on all his works from the publication of his edition of the Ars arithmetica of Juan Martínez Silíceo in 1519 (Martínez Silíceo and Fine 1519), and also by the fact that this work was published again under his name postumously on several occasions. Although the motivations for the anonymous publication of this work remains an open question, one could conjecture that the reason why he published this work anonymously may be related to the fact that he wrote this paraphrase in French, which was a less conventional practice for works traditionally used for academic teaching. His attitude to this question may have changed in the later period, when he wrote and published (or intended to publish) under his name certain treatises in French (Fine 1543a, Fine 1551b, Fine 1556b), though this may be qualified by the fact that some treatises which were first written in French but left at the state of manuscript (perhaps intended to be read by the King or members of his entourage) were later published in Latin (such as Fine 1543b later published in Latin in Fine 1544b). Notwithstanding, the fact that he published a French version of
} 
In this regard, the fact of providing a new edition of Sacrobosco, especially one that was more accessible to college students, would have been, for Fine, a means to demonstrate his commitment to the pedagogical model of the university, though he later went on to criticize the pedagogical methods used in the Faculty of the Arts for the teaching of mathematics (Axworthy 2016, 30-33). For that matter, despite Fine's later project to renew the mathematical teaching provided within the Parisian academic sphere, he did remain faithful, at least in the first years of his career as a royal lecturer, to the curricular model of the university, asserting, in the preface of the Protomathesis, the importance and propaedeutic value of mathematics for the three superior faculties of the university: medicine, law, and theology (Axworthy 2016, 186-87) ${ }^{64} \mathrm{He}$ also stated in the preface of the first edition of the Cosmographia ${ }^{65}$ the necessity of astronomy for the students of medicine and theology, given its importance for the computation of calendars and for the determination of the dates of Easter and other mobile religious celebrations (Axworthy 2016, 172-74) ${ }^{66}$ and given the role of judicial astrology (which represented the practical part of the science of stars, according to Fine $)^{67}$ in the determination of the favorable days for

Peurbach's treatise on planetary theory, even anonymously in 1528 , could be a sign of his will to change the audience of traditional astronomy, though not necessarily to reach out to a less educated and socially lower class of people, but to a different class of privileged readers such as members of the French court.

${ }^{64}$ (Fine 1532, sig. AA3r): "Quod si Deus ipse, ad optatum finem dignetur aliquando perducere: videbis universam Galliam, jam fideliores amplectentem literas, caeteras nationes, non secus ac Lilium spinas, brevi tempore superare. Theologos in primis nativam sacrae scripturae consequi puritatem, tandemque fieri meliores: Philosophos sophistis succedere, et justo deinceps titulo philosophicae dignitatis laurea donari: Medicos humanis passionibus foelicius consulere, nec amplius cum tanto mortalium periculo suas venditare conjecturas: Rerum tandem humanarum judices aequiores, mitioresque succedere (quos omnium artium expedit habere cognitionem) et publicam utilitatem, potius, quàm privatam (ut tenentur) aliquando procurare: et in summa, omnes ad saniora tendere, et Christianam tandem induere pietatem." On Fine's commitment to the teaching of the masters of the University of Paris in his early years, see also (Dupèbe 1999, II, 525-26, 543).

${ }^{65}$ (Fine 1532 (Cosmographia, I.1), 102r): "Quam necessaria postmodum Apolineae sit arti, is judicare poterit, quem praesagia Hipocratis legere non pigebit: in quibus coeleste quoddam asserit esse, in quo et ipsum medicum praevidere oportet. Quod Galenus ille medicae artis restaurator in testimonium adducens, omnem substantiam corpoream animatam coelestibus signis et planetis alligari demonstrat. Adde quod viris ecclesiasticis non modo perutilis, verumetiam necessaria videtur Astronomia, idque tanto magis, quanto graviori dignitate fruuntur: ad mobilia festa, caeteraque decus et statum ecclesiae respicientia pensiculatius discutienda. Ob cuius Astronomiae neglectum, ne dicam praelatorum incuriam, a vera sacri Paschatis observatione, et evangelico ritu (horresco referens) tantum plaerunque distamus: ut pudeat hoc commune Christianorum scandalum ulterius aperire."

${ }^{66}$ On the uses of Sacrobosco's Sphaera for the domains of medicine and calendar computation, see (Cosgrove 2007; Crowther et al. 2015; Valleriani 2017) (Chap. 5); and on the tradition of computus from the early Middle Ages, see the introduction of Faith Wallis to (Bede 2004, xxxiv-lxiii; Declercq 2000, 49-95). On Sacrobosco's computus (De anni ratione) in particular, see (Moreton 1994).

${ }^{67}$ (Fine 1532 (Cosmographia), I.1, 102v): “...universam Astronomiam, veluti quamlibet aliam disciplinam, bifariam discindi, apud omnes, etiam vulgariter eruditos, in confesso est. Aut enim ipsum scire, magisque necessaria consyderat Astronomia, utpote, coelestes globos, sydera, eorum 
bloodletting and for the administration of remedies, ${ }^{68}$ to which should be added the production of medical almanacs (Chap. 5). ${ }^{69}$

It is important to note here that, for many students, astrology (both judicial and natural ${ }^{70}$ )_because of its uses in medicine, and also because of its place in Renaissance society and courtly life, as it was held (at least in principle) to guide decisions in all aspects of individual and communal human life (Azzolini 2005;

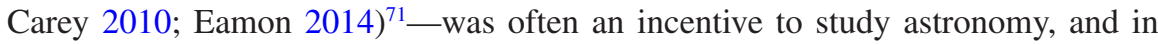
particular Sacrobosco's Sphaera, which taught how to determine the positions of the zodiacal signs from different latitudes. ${ }^{72}$ Because of its relationship to medicine, astrology actually held a privileged place among the mathematical arts in the university curriculum since its foundation. ${ }^{73}$ The fact that Fine had been trained in medicine, although he does not appear to have practiced as a physician after

motus, et passiones, ac ejuscemodi: et theorica, vereque mathematica dicitur. Vel circa contingentia versatur, qualia sunt accidentia activorum et passivorum sphaerae, ex eorundem coelestium corporum latione provenientia: et tunc practica, et a necessarioribus remotior, sive conjecturalis appellatur." As indicated here, this distinction is drawn from Ptolemy's Liber quadripartitum (Tetrabiblos). See also (Ptolemy 1533, sig. A1r): "Rerum...in quibus est pronosticabilis scientiae, stellarum perfectio, magnas et praecipuas duas esse deprehendimus. Quarum altera quae praecedit, et est fortior, est scientia solis et lunae, nec non quinque stellarum erraticarum figuras demonstrans, quas suorum motuum causa, et unius ad aliam, eorumque ad terram collatione contingere manifestum est. Altera vero, est scientia qua explanantur et mutationes et opera quae accidunt et complentur propter figuras circuitus earum naturales eis in rebus quas circundant." On Fine's division of astronomy, see (Axworthy 2016, 201-4) and on the division and hierarchization of the parts of astronomy in the Renaissance Sacrobosco tradition prior and contemporary to Fine, see (Chaps. 4 and 5).

${ }^{68} \mathrm{On}$ the Galenic theory of critical days and its reception in the Middle Ages and in the Renaissance, see (Azzolini 2005; Pennuto 2008; Cooper 2013).

${ }^{69}$ On the production of almanacs, see (Carey 2003, 2004; Eamon 2014; Kremer 2017).

${ }^{70}$ On the difference between judicial and natural astrology, see (Vanden Broecke 2003, 18-19).

${ }^{71}$ Yet, reservations were expressed since the Late Middle Ages as to whether occult influences should be admitted in addition to the light, heat, and motion of the planets (Vermij 2016), and as to the extent to which the stars influenced the events taking place in the lives of individuals (Vanden Broecke 2016) or as to its potential association with superstition (Vanden Broecke 2003, 9-12). J. Dupèbe (Dupèbe 1999, II, 530-33) mentions in this regard the critical discourse on occult influences held by Gregor Reisch, in his Margarita philosophica (which Fine edited).

${ }^{72}$ On astrology as a motivation for the study of astronomy, and of Sacrobosco's Sphaera in particular, in the sixteenth century, see (Pedersen 1978; Eamon 2014; Hübner 2014) (Chaps. 2, 3, 5, 7 and 10), but also (Chap. 9), concerning the inclusion of elements on the practice of domification in the Venetian editions of Sacrobosco.

${ }^{73}$ For this reason, astronomy and astrology were often taught in medieval universities, such as in Padua and Bologna, by professors of medicine before the creation of a distinct chairs of mathematics, which were initially designated as lectureships in astrology and/or astronomy before being related to mathematics in general (Grendler 2002, 408, 415-26). See also, on the relation between astronomy and medicine in the medieval university curriculum, (Siraisi 1981, 139-45; Siraisi 1990, 68-69, 128-29, 134-36; Vanden Broecke 2003, 12-16). 
his studies,${ }^{74}$ would have made him clearly aware of the importance of astrology for the medical art, as would his long-lasting friendship with Antoine Mizauld (1510-1578). ${ }^{75}$ Mizauld was a physician and a professor of medicine in Paris as well as an astrologer, and published several works on iatro-mathematics (Mizauld $1550,1551,1555),{ }^{76}$ some of which Fine contributed to (at least as the author of some of the liminary texts).

It would therefore be reasonable to think that Fine also viewed his editorial work on Sacrobosco's Sphaera as a contribution to the training of astrologers, to help them learn how to calculate the positions of planets in relation to the zodiacal signs and the celestial houses (Valleriani 2017), an activity in which he himself engaged as a court astrologer and which he later promoted through the publication of the Canons des ephemerides (Fine 1543a) and the De duodecim caeli domiciliis (Fine 1553a). ${ }^{77}$ As we will see, the importance of judicial astrology as a motivation to study astronomy was also set forth in the Cosmographia, when Fine discussed the general structure of the cosmos and the number of celestial spheres, claiming the necessity to reject certain cosmological models in order to safeguard the validity of judicial astrology.

\section{From the Sphaera of Sacrobosco to the Cosmographia, sive Sphaera mundi}

While in the 1516 edition of Sacrobosco's Sphaera, Fine most likely intended to address a public of students, in the Cosmographia, he addressed a slightly different readership-namely, the audience of the royal lecturers. This new public still

\footnotetext{
${ }^{74}$ As noted by Jean Dupèbe (Dupèbe 1999, II, 526-27), Jean Fossier designated Fine as such in the latter's edition of Johannes de Bassolis's commentary on the Sentences of Pierre Lombard (Bassolis 1517a, sig. ijv): "Ioannis Fosserij Matiscensis Domino Magistro Orontio Fine Delphinati, Mathematices ac Medicinae professori solertissimo" and in the fourth book (Bassolis 1517b, 3r), "Ioannis Fosserij Matiscensis in Magistrum Orontium Fine Delphinatem Astronomiae ac Medicinae professorem clarissimum."

${ }^{75}$ Fine and Mizauld's friendship is notably manifested in the poem Mizauld wrote in Fine's honor after the latter's death in the posthumous edition of his De rebus mathematicis hactenus desideratis libri IIII (Vita et tumulus Orontij, in Fine 1556a, 5r-6r). On Fine's friendship with Mizauld, see (Dupèbe 1999, II, 528-29).

${ }^{76}$ On Antoine Mizauld, his work on iatro-mathematics and the Parisian scene of medical astrology, see (Dupèbe 1999).

${ }^{77}$ These works respectively deal with the art of producing almanacs (including their astrological features) and with the division of the celestial houses and of the planetary hours necessary to the casting of horoscopes. Fine also published in 1529 an Almanach novum aimed (as indicated by the title) to help produce elections in the context of medicine, church duties, banking, and many other important functions (Almanach novum insigniora computi et kalendarii succincte complectens ad longos annos duraturum, viris ecclesiasticis, medicis, chirurgicis, trapezitis, quibusvis tandem hominum conditionibus necessarium). On the context of its publication, see (Dupèbe 1999, II, $540-41)$.
} 
included university students, but was also composed of humanists, curious notables, and members of the court, and was in principle open to anyone, especially as the teaching of the royal lecturers did not lead to any degree (Pantin 2006). This gave Fine and the other royal lecturers the flexibility to propose a teaching program that was relatively different from that which was provided at the Faculty of the Arts (when it was provided at all). In Fine's case, this reformed mathematical teaching program was communicated, as noted above, through the publication of the Protomathesis in $1532 .{ }^{78}$ It is within this work that appeared the first edition of the Cosmographia, which refers for a considerable part of its content and structure to the textual paradigm of the Tractatus de sphaera. ${ }^{79}$

The fact that Fine's Cosmographia relates to Sacrobosco's Sphaera in terms of its content, composition, and finality is suggested by its title: Cosmographia, sive sphaera mundi, a title which evolved from 1542 into Sphaera mundi, sive cosmographia (Fine $1542 \mathrm{a}, \mathrm{b}, 1551 \mathrm{a}, \mathrm{b}, 1555)$, making its focus on the theory of the sphere more obvious (Mosley 2009). ${ }^{80}$ What this title also indicates is that this teaching pertained to cosmography, ${ }^{81}$ which was, in the sixteenth century, properly developed into a

\footnotetext{
${ }^{78}$ The pedagogical aim of the Protomathesis is first suggested by the context of its publication, which coincides with the beginning of Fine's career as royal lecturer. His new function as royal lecturer is indicated in the title of the work (Orontij Finei Delphinatis, liberalium disciplinarum professoris Regii, Protomathesis). In the preface of L'Esphere du monde, which corresponds to the French translation of the Cosmographia published in 1551, Fine clearly described the pedagogical mission the King François I had assigned to him as a royal lecturer, which he fulfilled, as he writes then, through ordinary lectures and through the publication of written works. (Fine 1551b, sig. A3r): "Et fuz d'autant plus incliné audit estude, que je cogneu le feu Roy vostre pere (auquel Dieu doint repos eternel) outre le bon jugement qu'il avoit de toute chose, comme prince bien né, porter singuliere affection ausdittes mathematiques: desquelles il me ordonna finablement publique interpreteur en l'Université de Paris, ou j'ay fait mon devoir, tant par leçons ordinaires, que par oeuvres escrittes, les remettre sus, $\&$ icelles demonstrer l'espace de trent'ans \& plus." As seen above, Fine also reiterated the propaedeutic role of mathematics for the higher university faculties in the preface of the Protomathesis, manifesting his will to offer a complete mathematical course for the students and masters of the Faculty of Arts, in addition to the new public to which his teaching was open.

${ }^{79} \mathrm{See}$ also, for comparison, the place given to the teaching of the sphere in the pedagogical programs of Jacques Lefèvre d'Étaples (Chap. 2), Conrad Tockler (Chap. 5), Pedro Sanchez Ciruelo (Chap. 3), Franco Burgersdijk (Chap. 11), as well as in those of Portuguese and Spanish mathematics professors more generally (Chaps. 7 and 10).

${ }^{80}$ The association between the theory of the sphere and cosmography is also indicated by the title of the treatise of Antoine Mizauld, De mundi sphaera, seu cosmographia, libri tres, which was published in 1552 and which Fine contributed to editing. On other works that indicate in their title the connection between cosmography and the theory of the sphere, see (Oosterhoff 2015; Valleriani 2017) (Chap. 7).

${ }^{81}$ It may be noted that the Theorique des cielz, which was published four years before the Cosmographia and in which Fine gives the main elements of the general description of the universe (serving him also for the corresponding part of the Cosmographia), he explicitly identified cosmography with the theory of the sphere; (Fine 1528, 3r): "[le mouvement qui est appelle diurnel] appartient traicter en la Cosmographie, ou traicte de l'esphere mondaine: come nous avons faict, et doibt estre presuppose devant ce livre cy." See also (Fine 1528, 33v): "comme nous avons amplement declaré au traicté de la Cosmographie, ou de la Sphere du monde." Here Fine refers to
} 
discipline in its own right, bringing together metrical geography and the theory of the sphere. ${ }^{82}$ It was thus not only conceived as a practice relating to the production of the mappa mundi, or to the cartographical description of the contours of the terrestrial world (for which reason the title of cosmographer, in the Iberian peninsula, was attributed to those in charge of casting navigational charts and of constructing mathematical instruments) ${ }^{83}$ or as a synonym of geography, following the designation of Ptolemy's Geographia as Cosmographia by its fifteenth-century translator, Jacopo d'Angelo (1360-1410) (Broc 1980; Milanesi 1994; Cosgrove 2007; Besse 2009; Mosley 2009; Tessicini 2011) ${ }^{84}$ but also as relating to spherical astronomy. The shifts in meaning of the term cosmography (from maps to treatises, from applied practical knowledge to academic teaching, or from the consideration of the terrestrial globe to that of the universe in its totality) display the various orientations and also the tensions inherent to cosmographical knowledge in the sixteenth century (Cosgrove 2007) ${ }^{85}$ These show also that cosmography, as well as geography, was a knowledge in transformation, not only with regard to its content (by integrating the new geographical discoveries), but also with regards to its status, since neither geography nor cosmography was acknowledged as a proper discipline or object of teaching (distinct from natural philosophy, astronomy, or natural history) before the Renaissance (Besse 2003, 10) ${ }^{86}$ It remains that, within the sixteenth-century treatises on cosmography, the different definitions of cosmography remained connected, since, as shown by Fine's Cosmographia in particular, it was also defined as the means to describe the universe in its entirety and in its various parts, though what cosmographical treatises offered was less a visual description of the world and of its two main regions than a method or set of principles necessary to produce such a description (Besse 2009; Mosley 2009).

In this framework, the mapping of the universe in its two main parts, celestial and terrestrial, required the projection of the circles which divide the celestial sphere in

a prior teaching of cosmography or the theory of the sphere on which he would have previously worked. It is not clear to which treatise he is referring. Perhaps he had already written his Cosmographia in 1528. Indeed, as it was already printed two years before the actual publication of the Protomathesis from the date of the frontispiece of its cosmographical part (Fine 1532, 101r), it is not impossible that he had written it before 1528. But he could also be referring to his edition of Sacrobosco's Sphaera, or less likely to the discourse he has presented in the first pages of the Theorique des cielz, though this may hardly be called a treatise. I would like to thank Isabelle Pantin for her help in verifying the presence of the relevant passages in the 1528 version, which included a visit on her part to the Bibliothèque Nationale de France.

${ }^{82}$ On the development of sixteenth-century cosmography and cosmographical culture, see (Mosley 2009; Gaida 2016), as well as (Chap. 2).

${ }^{83}$ On this topic, see (Navarro Brotóns 2004; Portuondo 2009; Mosley 2009; Cattaneo 2016; Almeida 2017) (Chaps. 7 and 10).

${ }^{84}$ The earlier meanings of the term cosmographia, for instance in the works of Cassiodorus and Bernard Silvestris, are also described in (Cosgrove 2007; Mosley 2009).

${ }^{85} \mathrm{On}$ the various audiences and applications of the teaching of cosmography in the Iberian peninsula, see (Chap. 7).

${ }^{86}$ On the entry of cosmography into the university mathematical curriculum in sixteenth-century Spain, see (Chap. 7). 
spherical astronomy onto the terrestrial globe, establishing a correspondence between the systems of longitudinal and latitudinal positioning of celestial objects and terrestrial places (Broc 1980, 66-68; Milanesi 1994; Besse 2003, 36-37, 46-48; Besse 2009; Mosley 2009). Through the mathematical correspondence this establishes between the celestial sphere and the terrestrial globe, cosmography is presented as an essentially dual teaching. ${ }^{87}$ Geography is indeed assigned a comparable epistemological status to astronomy, ${ }^{88}$ leaving aside the more qualitative approach of Strabo (ca. 63 BCE-ca. 24) and Pomponius Mela (died ca. 45) in favor of the mathematical mode of description of the earthly contours followed by Ptolemy in the Geography. ${ }^{89}$ In Fine's prefaces to the 1551 edition of the Cosmographia, this double orientation of cosmography is justified by the double function of man-on one hand, called on to inhabit the earth; on the other, invited to contemplate the heavens (Besse 2009; Mosley 2009; Axworthy 2016, 154-59). ${ }^{90}$

Through the development of cosmography as a discipline, the teaching of Sacrobosco's theory of the sphere was absorbed into a larger framework. The Tractatus de sphaera provided in this regard one of the most adequate teachings of

\footnotetext{
${ }^{87}$ The two orientations of cosmography, and their correspondence with the two main parts of the cosmos, are clearly expressed by Fine in the 1542 edition of the Cosmographia; (Fine 1542b,

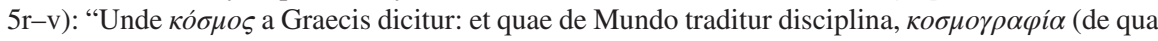
praesentis tractare est instituti) respondenter vocitatur. Est enim Cosmographia, Mundanae structurae generalis ac non injucunda descriptio: prima Astronomiae partem, atque Geographiam, hoc est, caeli terraeque rationem comprehendens."

${ }^{88}$ On the epistemological status of geography in Fine's mathematical thought, see (Besse 2009; Axworthy 2016, 329-49).

${ }^{89}$ For an overview of Ptolemy's approach to geography, see the introduction of J. Lennart Berggren and Alexander Jones to their annotated translation of the Geography (Ptolemy 2000, 3-54). On the content and the influence of Ptolemy's Geography in the Renaissance, especially on sixteenthcentury treatises on the sphere, see (Besse 2003, 29-30, 111-48; Oosterhoff 2015); in relation to Fine's cartographical work specifically, (Brioist 2009b) and, in a more general perspective, (Šālew and Burnett 2011).

${ }^{90}$ (Fine 1551a, sig. aa2r-v): "Inter admiranda naturae sive Dei miracula, duo sunt quae omnium miraculorum superare videntur admirationem: Mundus scilicet, et homo. Quorum partes insigniores sunt rursum duae: utpote, immortalis vel aeterna, et ea quae corruptioni, atque mutationi semper obnoxia est. Mundi nanque pars aeterna, est ipsum caelum, divino lumine Solis illustratum, et suis in primis ornatum corporibus, regulari et indefessa latione circunductis: quae unum atque eundem ordinem perpetuo videntur observare, utpote, quem ex Deo ab ipsa Mundi creatione sunt adepta. Pars vero corruptibilis ipsius Mundi, et quae nunquam in eodem statu permanet, est ipsa elementorum moles, intra caeli cavaturam conglobata: assidua quidem agitatione pertubata, atque alterata, omnium generatorum materia, et alimentum. Haud dissimiliter, homo ex duplici natura compositus esse videtur: aeterna videlicet, hoc est, ipsa anima Deo simili, quam nonnulli substantialem vocant homine: et mortali, utpote corporea, quae ut ex ipsis constare perhibetur elementis, sic et in eadem elementa tandem resolvitur. Homo itaque sic efformatus est, ut utranque suam originem aeternam videlicet, et corruptibilem recognoscere possit et debeat: hoc est, incolere atque gubernare terrena, et simul intelligare et admirari quae coelestia sunt. Nempe cui soli inter animantia, portio mentis ab ipso Deo, caeli et animae, ac omnium eorum quae Mundus comprehendit opifice atque rectore, concessa est." Jean-Marc Besse (Besse 2009) also shows that the duality was interpreted as a double view-point of the mathematician on the cosmos, which cosmography both connects and encompasses.
} 
the astronomical circles that divide the celestial sphere and which the cosmographer is required to project onto the terrestrial globe (Cosgrove 2007). ${ }^{91}$ Sacrobosco's Sphaera thus became the natural starting point for the mathematical analysis and treatment of the terrestrial space ${ }^{92}$ at a global and local level (Besse 2009; Brioist $2009 b) .{ }^{93}$ This relation between the theory of the sphere and geography is clearly expressed by the content and division of Fine's Cosmographia, in which the first four books are dedicated to the description of the celestial region of the cosmos (leaving aside, however, the trajectories of the moon and the five planets) and the fifth book to the description of the earth. ${ }^{94}$

The topics tackled in the Cosmographia which properly deal with spherical astronomy are in large part the same as those in Sacrobosco's Sphaera, although Fine does not explicitly acknowledge this inheritance, which reveals the traditional and omnipresent character of this textual model in sixteenth-century treatises on the sphere (Mosley 2009; Oosterhoff 2015; Valleriani 2017). Sacrobosco's name is indeed never mentioned, as Fine rather refers in general terms to previous authors, thereby acknowledging the existence of an established tradition. He does not either tacitly take up any parts of Sacrobosco's text, as was sometimes done in early modern books pertaining to the theory of the sphere (Valleriani 2017, 428). In most pre- and early-modern treatises on spherical astronomy and on cosmography, the imprint of the canonic model of Sacrobosco's Sphaera remains underlyingly present, as shown also by other cosmographies written and published before Fine's Cosmographia, such as the Cosmographiae introductio of Martin Waldseemüller (1470-1520) and Matthias Ringmann (1482-1511) (Waldseemüller and Ringmann

\footnotetext{
${ }^{91}$ As shown by (Chap. 2) through the exemplary case of Lefèvre d'Étaples's 1494 commentary on Sacrobosco, this relation also took place in a reversed order, with the integration of cosmography within the framework of the Sphaera, the addition of many elements from Ptolemy's Geographia, as well as of various tables and computation methods necessary to the cosmographical practice. On the relation between Sacrobosco's Sphaera and cosmography in the sixteenth century, see also (Oosterhoff 2015; Valleriani 2017) (Chaps. 7 and 9).

${ }^{92}$ As indicated by Pantin in this volume (Chap. 9), Peter Apian wrote in the address to the reader of his first edition of Sacrobosco's Sphaera (Sacrobosco and Apian 1526, A1v) that this edition was to be regarded as a preamble to his introduction to Ptolemy's Geographia: “...visum est mihi haud inutile fore, si ingenuis adolescentibus primum omnium Astronomiae rudimenta praelegerem, Sphaeram JANI de Sacrobusto accuratissime interpretarer. Futurum tandem existimans ut ex sphaerae circulorumque ejus attenta cognitione, spaciorum terrae coelique absoluta notitia proveniret."

${ }^{93}$ As was shown by Besse (Besse 2009), in Fine's Cosmographia, geography (mapping of the earth), chorography (regional mapping), and hydrography (marine cartography) are not distinguished from an epistemological point of view, as they are in the classifications found in contemporary cosmographical and geographical treatises.

${ }^{94}$ (Fine 1532, 101r): "Liber primus, de universa Mundi compagni, sive structura; Liber secundus, de principalioribus circulis in Mundana sphaera prudenter imaginatis; Liber tertius, de signorum et arcuum ascensionibus et descensionibus: atque de syderum ortu et eorundem occasu; Liber Quartus, de dierum et horarum tam aequalium, quàm inaequalium, et umbrarum rationibus: deque singulorum accidentibus, juxta varium sphaera situm observatis; Liber quintus, de geographicis, Chorographicis, et hydrographycis institutis."
} 
1907), the Liber cosmographicus of Peter Apian (Apian 1524), ${ }^{95}$ or the Rudimentorum cosmographiae of Johannes Honterus (1498-1549) (Honterus 1535, 1440-63).

The fact that Fine never mentions Sacrobosco's name in this context, even as an authority among others, may seem paradoxical given the importance of the Tractatus de sphaera in Fine's early career as a master of the Faculty of the Arts and as an editor of scientific books, but also given the clearly identifiable imprint of Sacrobosco's treatise on the structure of the Cosmographia, to which could be added its significance for the development of early modern cosmography more generally. The absence of any explicit mention of Sacrobosco in the Cosmographia, along with the fact that he does not (even tacitly) quote Sacrobosco's text, may be due to Fine's will to detach himself in name and in principle from what could by then be considered as "the old sphere" in order to promote his own version of "the new sphere"- to take up the distinction between the theorica vetus and the theorica nova $-{ }^{96}$ while surreptitiously basing the latter on the former. The will to revise the doctrine of the sphere devised by Sacrobosco's Sphaera transpires in particular through Fine's criticisms of the literary parts of the traditional teaching on the sphere, which is one of the distinctive marks of Sacrobosco's treatise, as will be shown later.

The fact of following the textual content and design of the Sphaera without mentioning the name of Sacrobosco is not unheard of over its period of diffusion in print. Matteo Valleriani (Valleriani 2017, 427-28) established that, among the nearly 400 different printed treatises that may be counted as belonging to the tradition of the Tractatus de sphaera between 1472 and 1697, a certain number of works relate to Sacrobosco's treatise by their structure and by their visual material without mentioning Sacrobosco's name (Chap. 1). ${ }^{97}$ Even among the works that quote Sacrobosco's text (entirely or partially), such as the Elementa sphaerae mundi sive cosmographiae in usum Scholae Mathematicae Basilensiis of Peter Ryff (1552-1629) (Ryff 1598) analyzed by Matteo Valleriani (Valleriani 2017) or the treatise on the sphere of André do Avelar (Avelar 1593), considered in this volume by Roberto de Andrade Martins (Chap. 10), there are cases of treatises that do not feature his name. Moreover, sixteenth-century cosmographies, and in particular

\footnotetext{
${ }^{95}$ On Apian's contribution to sixteenth-century cosmography, see (Gaida 2016).

${ }^{96}$ When Georg Peurbach proposed his own version of the geometrical system intended to model the motions of the planets (theorica planetarum) in the fifteenth century, in order to replace the system previously taught in the universities, he presented it explicitly as a new model (Novae theoricae planetarum) aimed at replacing this old system (Theorica planetarum antiqua). In spite of the popularity of Peurbach's new version, the old theorica continued to be printed, sometimes with the new theorica, up to the sixteenth century. On the history of the Theorica planetarum, see (Pedersen 1981). A parallel may therefore be made between this development and the fact that Sacrobosco's Sphaera continued to be printed up to the seventeenth century, alongside more modern treatises on the theory of the sphere.

${ }^{97}$ For a list of the various printed editions of Sacrobosco's Sphere, see the online database coordinated by Matteo Valleriani: https://sphaera.mpiwg-berlin.mpg.de, as well as that of Roberto de Andrade Martins: http://www.ghtc.usp.br/server/Sacrobosco/Sacrobosco-ed.htm (Accessed June 2019) and the bibliographical inventory in (Hamel 2004, 2014). Complementary information may be found in (Thorndike 1949; Gingerich 1988; Pedersen 1995; Valleriani 2017).
} 
those mentioned above, do not mention Sacrobosco's name as the main source of their doctrine of spherical astronomy either, in spite of their reappropriation of parts of the Sphaera's content, design and images.

Although Fine's Cosmographia does not explicitly relate to Sacrobosco's Sphaera and does therefore not feature any parts of Sacrobosco's text, but rather aims to offer a new teaching on the worldly sphere, ${ }^{98}$ the first edition of the Cosmographia maintains the style of a commentary on a canonic text, as would a commentary on the Sphaera, each chapter starting by enunciating a general teaching on the topic at stake and offering, in a separate section, a commentary on this teaching printed in a smaller font (Fig. 8.1). In the main part, each element of teaching is indicated by a letter in superscript, which allows us to identify the commentary in the second part, marked by the corresponding letter in the margin. This commentary-type exposition disappeared in the subsequent editions and translations of the Cosmographia, apart from the unabridged version of 1542 (Fine 1542a), where the main text is enriched with portions of the initial commentary. ${ }^{99}$ The fact that this textual disposition was intended as a form of commentary is confirmed by the subtitle on the main title-page of the Cosmographia ${ }^{100}$ and was made explicit by Cosimo Bartoli in his Italian translation of the Cosmographia (Fine 1587). ${ }^{101}$ This textual layout, which clearly confirms the pedagogical aim of this work, did not commonly appear in contemporary cosmographical treatises.

With regard to the division and ordering of its content, Fine's Cosmographia follows quite closely the structure and thematic division of the Sphaera, and this more than other early sixteenth-century cosmographical treatises, including those mentioned above, which put a greater emphasis on geography, and especially on descriptive geography and on the study of populations (Mosley 2009). Indeed, in the cosmographies of Waldseemüller/Ringmann (Waldseemüller and Ringmann 1907), Apian (Apian 1524),

\footnotetext{
${ }^{98} \mathrm{~A}$ good summary of the content of the Cosmographia is found in the preface to the 1555 edition (Fine 1555, sig. *3r-v): "Primò libro universa Mundi structura, hoc est, caelestis ac elementaris regionis descriptio, continetur. In secundo, de circulis ipsi mundanae sphaerae coaptatis (à quibus tota motus caelestis ratiocinatio, instrumentorum quoque Astronomicorum pendet origo) tractatur: De via insuper solari, quae Zodiacus vocitatur, illiùsque declinatione, et duodenario signorum numero. Tertius liber, totus est de stellarum, atque signorum Zodiaci revolutionibus, quas ascensiones atque descensiones appellant: déque illarum differentiis, pro dato sphaerae situ contingentibus. Quarto agitur de naturalibus, atque artificialibus diebus: De aequalibus insuper, et inaequalibus horis, et horum omnium tam in recta, quàm in obliqua sphaerae positione facta diversitate. Quintus et ultimus (è caelesti in terrestrem descendendo molem) Geographicis, Chorographicis, ac Hydrographicis deputatus est rebus, ac disciplinis: cuiusmodi sunt parallelorum et climatum rationes, locorum longitudines atque latitudines, viatoriae illorum distantiae, seu directae profectiones itinerum, planarum denique chartarum (sic enim Geographicas, vel Hydrographicas projectiones, in planum extensas appellant) tam universales, quàm particulares descriptiones, et his similia."

${ }^{99}$ On the successive transformations brought to the text of the Cosmographia, see (Pantin 2010, 2013a).

${ }^{100}$ (Fine 1532, 101r): "De Cosmographia, sive mundi sphaera libri V. Propriis eiusdem Orontij commentariis elucidate."

${ }^{101}$ Bartoli wrote in front of each main part the designation Testo and in front of the second part, Commento.
} 


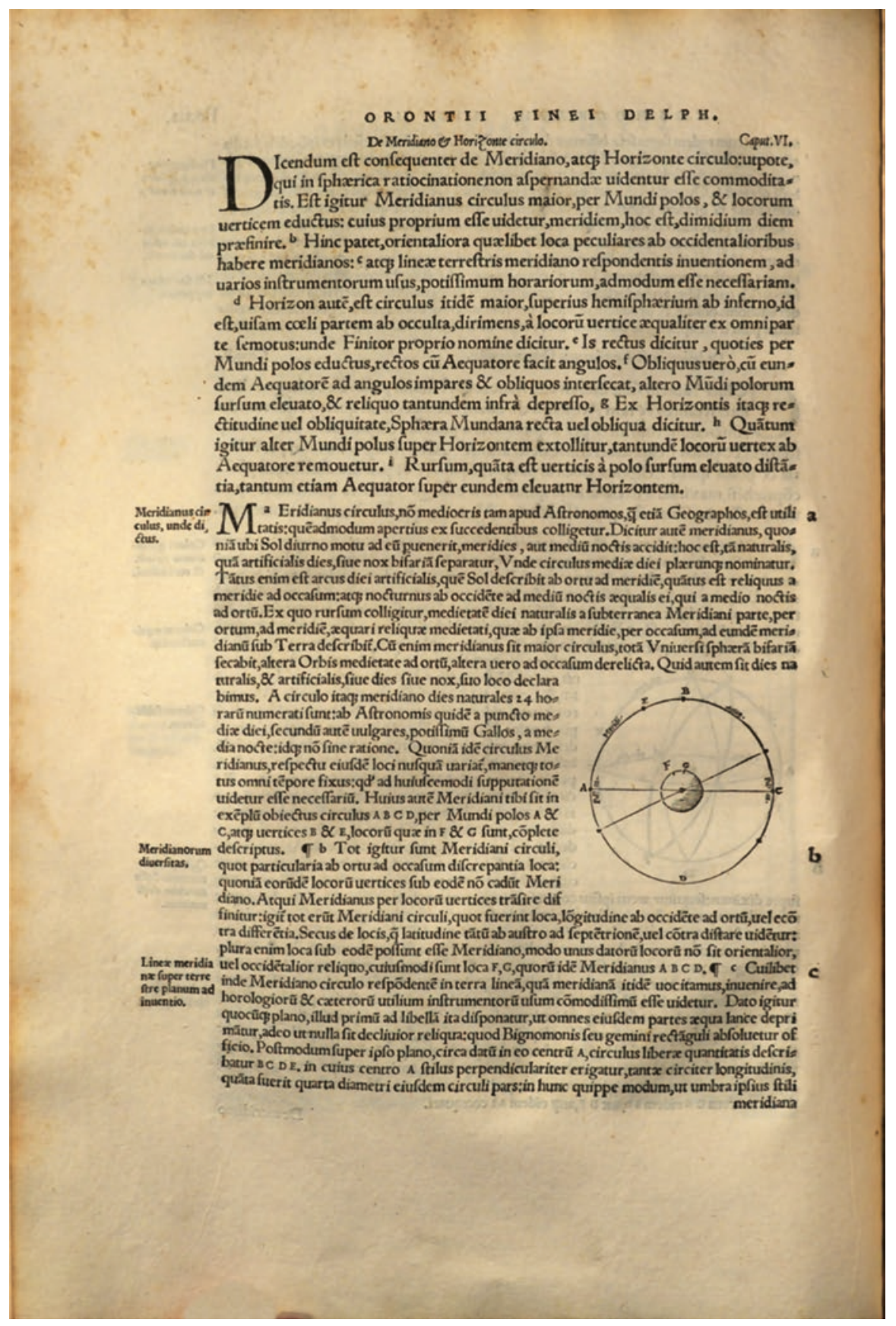

Fig. 8.1 The commentary-like layout of the Cosmographia. The main teaching is clearly separated from the commentary and referred to in its different sections by letters placed in the margins. From (Fine 1532). Augsburg, Staats- und Stadtbibliothek-2 Math 30, fol. 112v, urn:nbn:de:bvb:12-bsb11199761-8 
or Honterus (Honterus 1535), the topics dealt with by Sacrobosco in the first three chapters are treated only partially and/or superficially, for instance as a preliminary introduction to its geographical part. In comparison, the topics dealt with by Sacrobosco in these first three books are extensively dealt with in Fine's Cosmographia and in practically the same order. Admittedly, some topics which were tackled separately by Sacrobosco, and which were marked as distinct sections in previous printed editions (also in Sacrobosco and Fine 1516), were sometimes brought together in one chapter (as were the tropics, the polar circles, and the five zones); and notions (such as natural days) which, on the contrary, were not dedicated a specific exposition in Sacrobosco's text, constitute the subject of a separate chapter in Fine's work. This denotes a will, on Fine's part, to reorganize and clarify the content of the traditional teaching on the sphere and to make it more accessible to readers less familiar with it.

The main structure of the Cosmographia is also slightly different from that of the Sphaera. Although the topics considered by Sacrobosco in the first two books (on the general structure of the world and on the circles dividing the celestial sphere) are respectively dealt with in the first two books of the Cosmographia, ${ }^{102}$ the topics discussed in Sacrobosco's third book are distributed in two books (book III and IV) and extend to a part of the third book (book V), therefore occupying the last three books of Fine's treatise - that is, book III for the rising and setting of the signs, ${ }^{103}$ book IV for the motion of the sun and its influence on the duration of light and shadows at different latitudes on Earth, ${ }^{104}$ and book V for the theory of climates, which is then integrated into the geographical part of the Cosmographia. ${ }^{105}$ Moreover, certain complementary chapters pertaining to the more modern teaching of the sphere are occasionally inserted between some of the more traditional chapters and various elements of a more practical nature are added in the last four books. Yet, in spite of these differences, Fine's Cosmographia stands out among the sixteenth-century cosmography treatises by its strong focus on the theory of the sphere, ${ }^{106}$ highlighted in particular by the fact that the astronomical section of the work covers four out of

${ }^{102}$ (Fine 1532, 102r): "Liber primus, de generali ipsius Mundi compagine, sive structura" and (108r): "Liber secundus cosmographiae, sive mundi sphaerae, De principalioribus circulis in eadem sphaera prudenter imaginatis." An exception is the part on the dimensions of the earth, which is integrated to the fifth book of the Cosmographia; (Fine 1532, V.4, 149r): [in marg. Quantus universus terrestris ambitus per eundem Ptolemaeum.]

${ }^{103}$ (Fine 1532, 118v): "Liber tertius cosmographiae, sive mundi sphaerae: De signotum et arcuum ascensionibus et descensionibus: atque sydorum ortu et eorundem occasu."

${ }^{104}$ (Fine 1532, 130v): "Liber quartus cosmographiae, sive mundi sphaerae, De dierum et horarum tam aequalium, quàm inaequalium, et umbrarum ratione: deque singulorum accidentibus, juxta varium sphaerae situm observatis."

${ }^{105}$ (Fine 1532, 141v): "Liber quintus et ultimus cosmographiae, sive mundi sphaerae: De geographicis, chorographicis, et hydrographicis institutis."

${ }^{106}$ This may also be corroborated by the fact that, in the title of the 1542 and of the later editions of the Cosmographia, the teaching offered is first designated as pertaining to the theory of the sphere and is specifically assimilated to the first part of astronomy. See, for example, (Fine 1542b): De Mundi sphaera, sive Cosmographia, primàve Astronomiae parte. 
five books, ${ }^{107}$ and also by the fact that, within this part, the disposition and structure of Sacrobosco's Sphaera remains overall clearly identifiable (Mosley 2009). ${ }^{108}$

More precisely, the topics common to the first book of the Sphaera and to the first book of the Cosmographia ${ }^{109}$ are the distinction between the elementary and the heavenly regions, along with their respective divisions, ${ }^{110}$ the motions and the sphericity of the heavens, ${ }^{111}$ the immobility, sphericity, and centrality of the earth in the middle of the universe. ${ }^{12}$ It may be noted here that, in the Theorique des cielz (Fine 1528), Fine added to his exposition of Peurbach's planetary theory a preliminary exposition on the general structure of the universe, which presents the abovedescribed content. ${ }^{113}$

In the second book of the Cosmographia, Fine followed the model of the Sphaera by presenting the various astronomical circles that divide the worldly sphere ${ }^{114}$

\footnotetext{
${ }^{107}$ The four first books occupy 38 of the 53 folios of the Cosmographia.

${ }^{108}$ The commentary on the Sphaera of André do Avelar (Chap. 10) and the edition of Franco Burgersdijk (Chap. 11) are other examples of works which made substantial changes to the structure of Sacrobosco's text, but in which the original model stays clearly recognisable. Other examples of such works, including Fine's Cosmographia, are mentioned in by (Valleriani 2017) (Chap. 9).

${ }^{109}$ For the sake of conciseness, I will mainly compare the titles of the sections or chapters (in italics) and some of the corresponding marginalia (in square brackets and indicated by "in marg.") given in Fine's 1516 edition of Sacrobosco and in the Cosmographia to summarize the corresponding content.
}

${ }^{110}$ (Sacrobosco and Fine 1516, book I, sig. a2v-a3r): [in marg. Divisio sphaerae mundi elementaris Regio. Ordo elementorum. De coelorum substantia. De eorum numero]. See also (Fine 1532 (Cosmographia), I.1, 102v): "De praecipuis Mundi partibus. [in marg. Elementaris regio. Regio coelestis.]", (I.2, 102v-103v): "Quibus constet elementaris regio, ac de elementorum ordine. [in marg. Cur quatuor tantum elementa. Quatuor elementa omnium mixtorum radices. Quatuor elementa cur simplicia dicta. De elementorum ordine. De situ elementorum. Terra cur frustulatim discooperta.]" and (I.3, 103v-04v): "De coelestium orbium numero, atque positione." [in marg. Coelum quinta essentia nominatum. Coelum in octo principales orbes distributum.]

${ }^{111}$ (Sacrobosco and Fine 1516, I, sig. a2v): "Quae si forma mundi. [in marg. De motibus celorum]" and (sig. a3r): "De celi rotunditae." See also (Fine 1532, I.4, 104v-05v): "Quaenam coelestium orbium figura, atque motus qualitas" [in marg. Quod coelum sit sphaericum Prima ratio, à commoditate. Quae dicantur isoperimetrae. Secunda ratio à necessitate. Quod coelum circulariter moveatur. Motus universalis totius coeli. Motus secundus orbibus peculiaris, priori contrarius.] and (I.5, 105r-v): "De generali eorundem coelestium motuum expressione. [in marg. Primus motus quem diurnum appellamus, unde proveniat. De proprio singulorum orbium motu]."

${ }^{112}$ (Sacrobosco and Fine 1516, I, sig. a3v): "Quod terra sit rotunda;" (sig. a4r): "Quod acqua sit rotunda. Quod terra sit centrum mundi" and "De immobilitate terrae." See also (Fine 1532, I.6, 106r-07v): "De quiete, loco, et figura ipsius Terrae. [in marg. Quod terra non movetur circulariter. Terra non movetur motu recto, secundum totam. Quod terra est in medio totius Universi. Telluris et aquae superficies unica. Quod idem globus, à septentrione ad austrum sit rotundus. Quod globus ex Tellure et acqua resultans respectu universi, imperceptibilis sit quantitatis. Terra mundi centrum esse videtur.]"

${ }^{113}$ The relation between the Theorique des cielz and the Cosmographia is confirmed by the fact that these works contain the same diagrams for the spheres of the elements (Fine 1528, 2v; Fine 1532, 103r) and for the celestial spheres (Fine 1528, 3r; Fine 1532, 104r).

${ }^{114}$ (Sacrobosco and Fine 1516, II, sig. a4v): "Capitulum secundum de circulis ex quibus sphaerae materia componitur: et illa super coelesti quae per istam imaginatur componi intelligitur." See also (Fine 1532, II.1, 108r): "Liber secundus cosmographiae, sive Mundi Sphaerae, De principalioribus circulis in eadem Sphaera prudenter imaginatis." 
namely, the equinoctial or celestial equator (along with the poles of the world), ${ }^{115}$ the colures, ${ }^{116}$ the meridians and the horizons, ${ }^{117}$ the tropics, the polar circles, as well as the zodiac, the ecliptic and the various modes of division and representation of the zodiacal signs in the sphere, ${ }^{118}$ to which adds the division of the heavens into five zones. ${ }^{119}$ All these circles were considered again in the first chapter of the fifth book, through their projection onto the terrestrial globe. ${ }^{120}$

The topics dealt with by Sacrobosco in the third chapter of the Sphaera are those with which Fine dealt most extensively, as they cover books III and IV, and a part of book V. The third book, which deals with the risings and settings of the signs, allows

\footnotetext{
${ }^{115}$ (Sacrobosco and Fine 1516, II, sig. a4v): [in marg. Quid circulus equinoctialis. De duobus polis et nominibus eorum] (Fine 1532, Cosmographia, II.1, 108r): "De Aequatore circulo, et Mundi polis. [in marg. Aequator primus sphaeralium circulorum. Poli mundi. Polorum nomenclaturae]."

${ }^{116}$ (Sacrobosco and Fine 1516, II, sig. b2r): "De duobus coluris. [in marg. Quid colurus. Colurus solsticialis. Solstitium. Quid maxima solis declinatio. Colurus equinoctialis]." See also (Fine 1532, II.5, 112r): "De duobus circulis maioribus, quos coluros appellant. [in marg. Coluri qui dicantur circuli, et eorum officium. Colurus aequinoctiorum. Colurus solstitiorum. Qui nam arcus maximas Solis metiantur declinationes. Quid maximae declinationes polorum distantijs adaequantur]."

${ }^{117}$ (Sacrobosco and Fine 1516, II, sig. b2r-v): "De Meridiano et orizonte circulo. [in marg. Quid meridianus. Longitudo regionum. Quid orizon. Rectus orizon. Orizon obliquus]." See also (Fine 1532, II.6, 112v): "De Meridiano et Horizonte circulo. [in marg. Meridianus circulus, unde dictus. Meridianorum diversitas. De Horizonte circulo. Horizon rectus. Horizon obliquus. Cur sphaera recta vel obliqua dicatur]."
}

${ }^{118}$ (Sacrobosco and Fine 1516, II, sig. b1r-b2r): "De zodiaco circulo [in marg. Quid zodiacus circulus. Tria eius nomina primum. Nomina ordo et numerus signorum. Divisiones partium zodiaci. Quid linea ecliptica. Acceptiones signi]." See also (Fine 1532, II.2, 108v-09v): "De Zodiaco vel Ecliptica, atque duodecim ejusdem signis. [in marg. Mathematica Zodiaci descriptio. Zodiacus circulus cur ita nominatus. Zodiacus et Ecliptica idem. De zodiaci latitudine. Quod signa proprie sunt zodiaci circuli. De ordine ac initio signorum. De signorum partibus. Quadruplex signorum acceptio]."

${ }^{119}$ (Sacrobosco and Fine 1516, II, sig. b2v): "De quatuor circulis minoribus. [in marg. Tropicus estivalis. Tropicus hyemalis. Circulus arcticus. Circulus antarcticus. Quae zonae sint bene habitabiles et quae male.]" See also (Fine 1532, II.7, 113v-14v): "De duobus tropicis, totidemque polaribus circulis, quinque Mundi partes (quas zonas vocant) distinguentibus. [Tropici unde ita nominati. Tropicus aestivalis, sive cancri. Tropicus hyemalis, sive Capricorni. De polaribus circulis. Quid circuli polares invicem aequales sunt et paralleli. Circulus arcticus. Circulus antarcticus. Quinque zonae coelestes. De figura et magnitudine praedictarum zonarum. Quid praefatae zonae accidentali natura differant]."

${ }^{120}$ (Fine 1532, V.1, 141v): "De circuli atque parallelis, super conglobata Telluris et Aquae superficie respondenter imaginandis: eorumque parallelorum ratione, ad quemvis magnum circulum: Inter majores itaque circulos, quos in coelesti sphaera constituimus, sex primarij, utpote, Aequator, Meridianus, Horizon, ambo Coluri, et is qui per duorum quoruncumque locorum vertices transire diffinitur, super conglobata Telluris et Aquae superficie, veniunt respondenter imaginandi: Ex minoribus autem, duo Tropici, totidemque circuli polares.... Ut quemadmodum eorundem coelestium circulorum officio, syderum venamur habitudines: haud dissimiliter per eos, quos super ipso terrestri globo designamus, locorum positiones, atque distantias obtinere valeamus.... Manifestum est praeterea, compositam et Tellure et Aqua superficiem, in quinque regiones praecipuas, sive Zonas, figura, magnitudine, atque natura differentes (quemadmodum et coelum) respondenter separari.” 
Fine to present the distinction between cosmic, chronic, and heliacal risings, ${ }^{121}$ as well as the distinction between right and oblique ascensions. ${ }^{122}$ Book IV, which deals with the motion of the sun and its effect on the duration of daylight, tackles the inequality of natural days ${ }^{123}$ and the difference between artificial day and night. ${ }^{124}$

${ }^{121}$ (Sacrobosco and Fine 1516, III, sig. b3v-b4r): "Capitulum tertium de ortu et occasu signorum. De diversitate dierum et noctium et de divisione climatum. [in marg. Diffinitio ortus et occasus. Cosmicus ortus. Cosmicus occasus. Chronicus ortus. Chronicus occasus. Heliacus ortus. Heliacus occasus.]" See also (Fine 1532, III.1): "Liber tertius Cosmographiae, sive mundi Sphaerae: de signorum et arcuum ascensionibus et descensionibus: atque syderum ortu et eorundem occasu," $(118 \mathrm{v}-19 \mathrm{v})$ : "De vulgari syderum ortu ac eorundem occasu. [in marg. Generalis ortus et occasus syderum interpretatio. Ortus cosmicus. Occasus cosmicus. Ortus chronicus. Occasus chronicus. Ortus heliacus. Occasus heliacus]."

${ }^{122}$ (Sacrobosco and Fine 1516, III, sig. b4r-c1v): "De ortu et occasu signorum secundum astrologos. [in marg. De sphera recta. Oppositio signorum. Comparatio sphaerae rectae et obliquae]." See also (Fine 1532, III.2, 119v-20v): "De signorum Eclipticae, atque syderum ortu, ac eorundem occasu, qui ab Astronomis ascensio, atque descensio proprie nominantur: quae recta item vel obliqua tam ascensio, quàm descensio vocitetur. [in marg. Quid in ortu vel occasu syderum consyderat Astronomus. Quid ortus vel ascensio signi aut dati arcus Eclipticae. Descensio vel occasus signi vel dati arcus Eclipticae. Syderum ortus vel ascensio quid. Descensio vel occasus eorundem syderum. Signum rectè oriens. Signum obliquè oriens. Unde recta vel obliqua signorum ascensio. Quae signa rectius oriantur caeteris. Signum rectè occidens. Signum obliquè occidens. Quae signa rectius occidunt caeteris. De signorum vel arcuum partibus];" (III.3, 120v-23r): "Quaenam ascensionis atque descensionis accidentia in recto contingant Sphaerae situ: necnon de rectarum ascensionum supputatione. [in marg. De signis oppositis. Oppositio signorum. De habentibus sphaeram rectam. De obliqua sphaera]."

${ }^{123}$ (Sacrobosco and Fine 1516, III, sig. c1v-c2r): [Dies naturalis. De inequalitate dierum.] See also (Fine 1532, IV.1) "Liber quartus cosmographiae, sive mundi Sphaerae, De dierum et horarum tam aequalium, quàm inaequalium, et umbrarum ratione: deque singulorum accidentibus, juxta varium sphaerae situm observatis," (130v-32v): "De Die naturali. [in marg. Dies naturalis. Ex quibus dies naturalis integretur. Exemplum diei naturalis. Cur dies naturales sint adinvicem inaequales]."

${ }^{124}$ (Sacrobosco and Fine 1516, III, sig. c1v): "[De habentibus sphaeram rectam. De obliqua sphera. De diebus majoribus. De minoribus diebus. De die maxima. De minima. De diebus aequinoctialibus. De alijs diebus anni]." and (3.7-3.9): "De diversitate dierum et noctium quae sit habitantibus in diversis locis terrae; Quorum zenith est inter aequinoctialem et tropicum cancri; Quorum zenith est in tropico cancri; Quorum zenith est inter tropicum cancri et circulum arcticum; Quorum zenith est in circulo arctico. Quorum zenith est inter circulum arcticum et polum mundi. Quorum zenith est in polo arctico." See also (Fine 1532, IV.2, 132v): "De die artificiali, eiusque differentijs et calculo. [in marg. Unde orta diei atque noctis artificialis distincto. Dies artificialis. Nox artificialis. Cur in recta sphaera dies sint semper aequales noctibus. Quod in quavis obliquitate sphaerae, bis tantum in anno dies sint aequales noctibus. De reliquis diebus artificialibus in obliquo sphaerae situ cum noctibus semper inaequalibus. Causa majoris inaequalitatis dierum et noctium in obliqua sphaera. In quibus locis Eclipticae, dierum et noctium alternata contingat paritas. Dies aestivales. Dies brumales. Qui dies sine noctibus minores, et econtra. Ubi dierum et noctium diversitas maxima. Sub qua poli sublimitate dies naturalis continue lucidus, vel totus contingat obscurus. De diebus artificialibus diem exuperantibus naturalem. De iis quae dimidium annum lucidum et reliquum videntur habere tenebrosum]." and (IV.4, 138r-41r): "De utraque umbra, recta scilicet et versa, earumque differentis et calculo: unà cum Solarium altitudinum supputatione [in marg. De meridianarum umbrarum varietate. De umbris meridianis eorum qui sub Aequatore, vel inter Aequatorem et Tropicorum alterum degunt. De ijs quorum vertices sub tropicis collocantur. De ijs quorum vertex inter Tropicos et circulos polares constituitur. Ubi dies artificialis aequalis aut major 24 horis, qualis umbrarum inflectio]." 
Fig. 8.2 De caeli revolutione. The representation of the circular motion of the stars in the Venetian incunabula editions. From (Sacrobosco et al. 1488, sig. a8v:). HAB Wolfenbüttel: 16.1 Astron

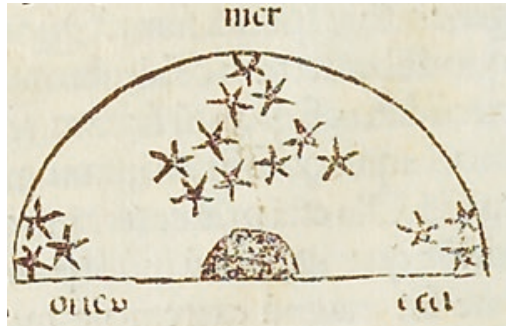

Fig. 8.3 De caeli revolutione. The representation of the circular motion of the stars in Fine's edition of the Sphaera. From (Sacrobosco and Fine 1524, sig. a3r). Courtesy of the Library of the Max Planck Institute for the History of Science, Berlin

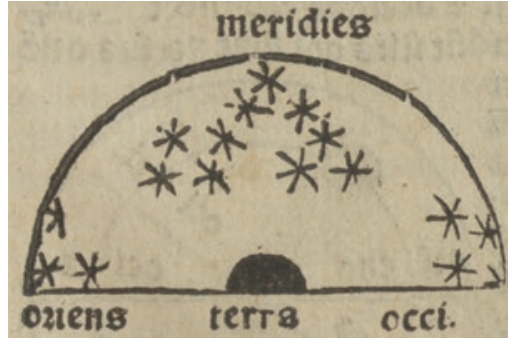

Book V, which deals with the second main division of cosmography (geography), considers the distinction of the climates. ${ }^{125}$ The remaining topics dealt with in book $\mathrm{V}$, as well as some topics considered in books II to IV, do not belong, strictly speaking, to the list of topics considered by Sacrobosco and will be presented later.

The relation between the Cosmographia and the Sphaera is also made clear by the use of illustrations similar to those found in prior editions of Sacrobosco, notably in the editions printed in Venice in the late fifteenth century and in the early sixteenth century, to which relate some of the engravings Fine produced for his own edition of the Sphaera and for the Cosmographia, though the style of the drawing is perceptibly different (Pantin 2010). ${ }^{126}$ Compare, for example, the illustrations in the first book of Sacrobosco's Sphaera in the 1488 edition-as indicated in (Chap. 9), it was the first printed edition of Sacrobosco that included the complete set of "Venetian Sacrobosco figures"- - with those in Fine's edition and in the Cosmographia for the revolution of the heavens (Figs. 8.2, 8.3 and 8.4 ). In the Cosmographia, the engravings are both richer in detail when it comes to the representation of the ter-

\footnotetext{
${ }^{125}$ (Sacrobosco and Fine 1516, III, sig. c4r-d1v): "De divisione climatum [in marg. Divisio climatum. Diffinitio climatum. Primum clima. Secundum clima. Tertium clima. Quartum clima. Quintum clima. Sextum clima. Septimum clima. Quid latitudo climatis. Quid longitudo climatis]." See also (Fine 1532, V.2, 143v-44v): "De Parallelis Climatum distinctoribus: quonam item pacto, dato lucis arcu singulorum parallelorum, polares investigentur altitudines. [in marg. De parallelis climatum distinctoribus. Climatum diffinitio. Distributio climatum. De climatum magnitudine.]" ${ }^{126}$ On the evolution of illustration practices in Renaissance astronomical treatises, including editions and commentary on Sacrobosco, see (Gingerich 1999; Pantin 2001; Cosgrove 2007; Barker and Crowther 2013; Oosterhoff 2015).
} 
Fig. 8.4 De caeli revolutione. The representation of the circular motion of the stars in the Cosmographia. From (Fine 1532). Augsburg, Staats- und Stadtbibliothek-2 Math 30, 105r, urn:nbn:de:bvb:12-bsb11199761-8
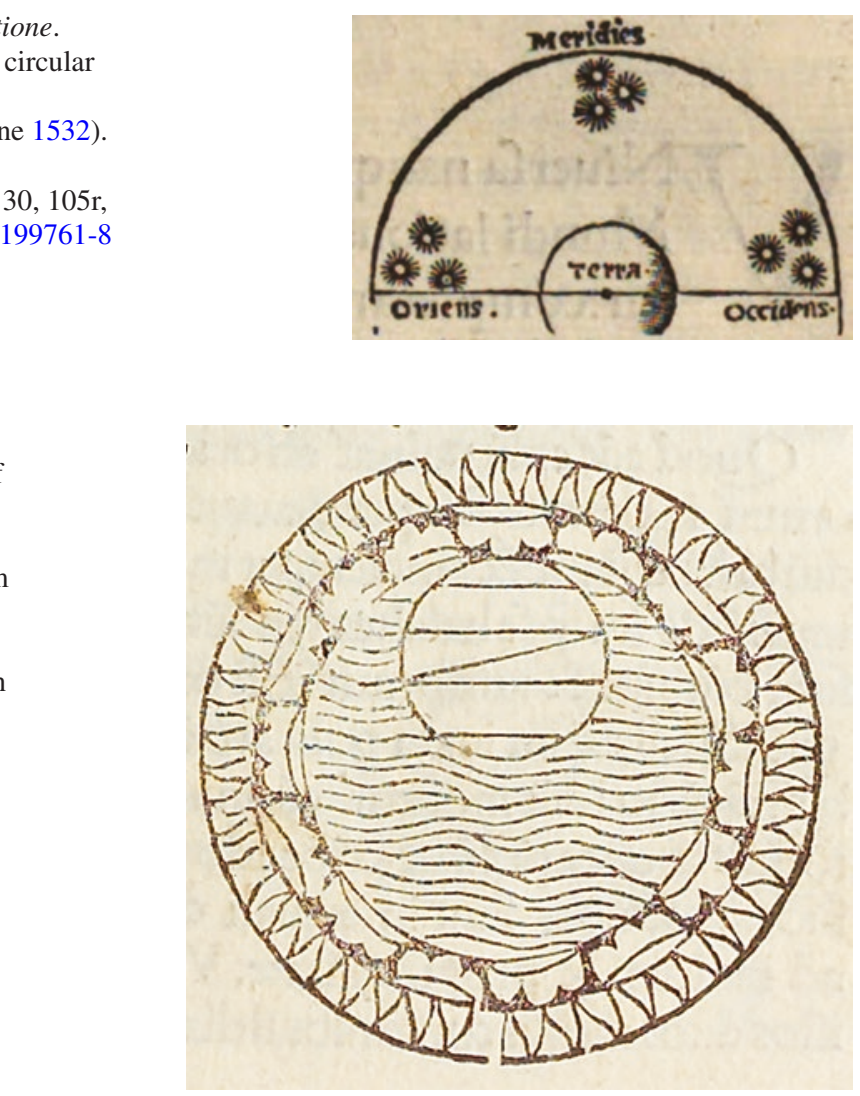

Fig. 8.5 Quae forma sit mundi. The disposition of the elementary spheres according to the Venetian incunabula editions. From (Sacrobosco et al. 1488, sig. a8r). HAB

Wolfenbüttel: 16.1 Astron

restrial globe and of mathematical instruments, ${ }^{127}$ and more abstract when representing the geometrical configuration of parts of the celestial sphere and the modes of computation of the positions of stars (Pantin 2010; Mosley 2009). ${ }^{128}$ It is interesting to note here that there is a great difference between these works in the depiction of the sphere of earth when representing the mutual disposition of the elementary spheres (Figs. 8.5, 8.6 and 8.7), as, in Fine's edition of Sacrobosco (Fig. 8.6), contrary to the Venetian edition (Fig. 8.5), the spheres of earth and of water are drawn

\footnotetext{
${ }^{127}$ This richness of detail appears indeed also in his representation of instruments, for instance in the demonstration of the difference between umbra recta and umbra versa, where the illustration includes some form of contextualization by the presence of a human figure or a landscape in the background (Fine 1532, resp. fol. 110v, 113r, 138r). On this aspect in Fine's astronomical frontispieces, see (Pantin 2009b) and, on the visual changes made to Sacrobosco's Sphaera through the integration of cosmographical elements, see (Chap. 2).

${ }^{128}$ As shown by (Chap. 9), 15 of Fine's 1532 Cosmographia were taken up in the edition of Sacrobosco published in Wittenberg in 1538.
} 
Fig. 8.6 Divisio sphaerae mundi elementaris regio. The disposition of the elementary spheres according to Fine's edition of the Sphaera. From (Sacrobosco and Fine 1524, sig. a2v). Courtesy of the Library of the Max Planck Institute for the History of Science, Berlin

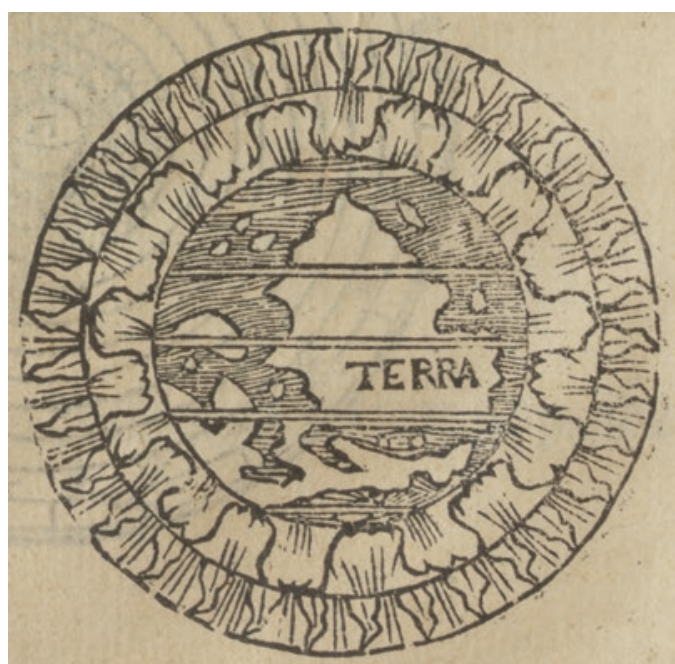

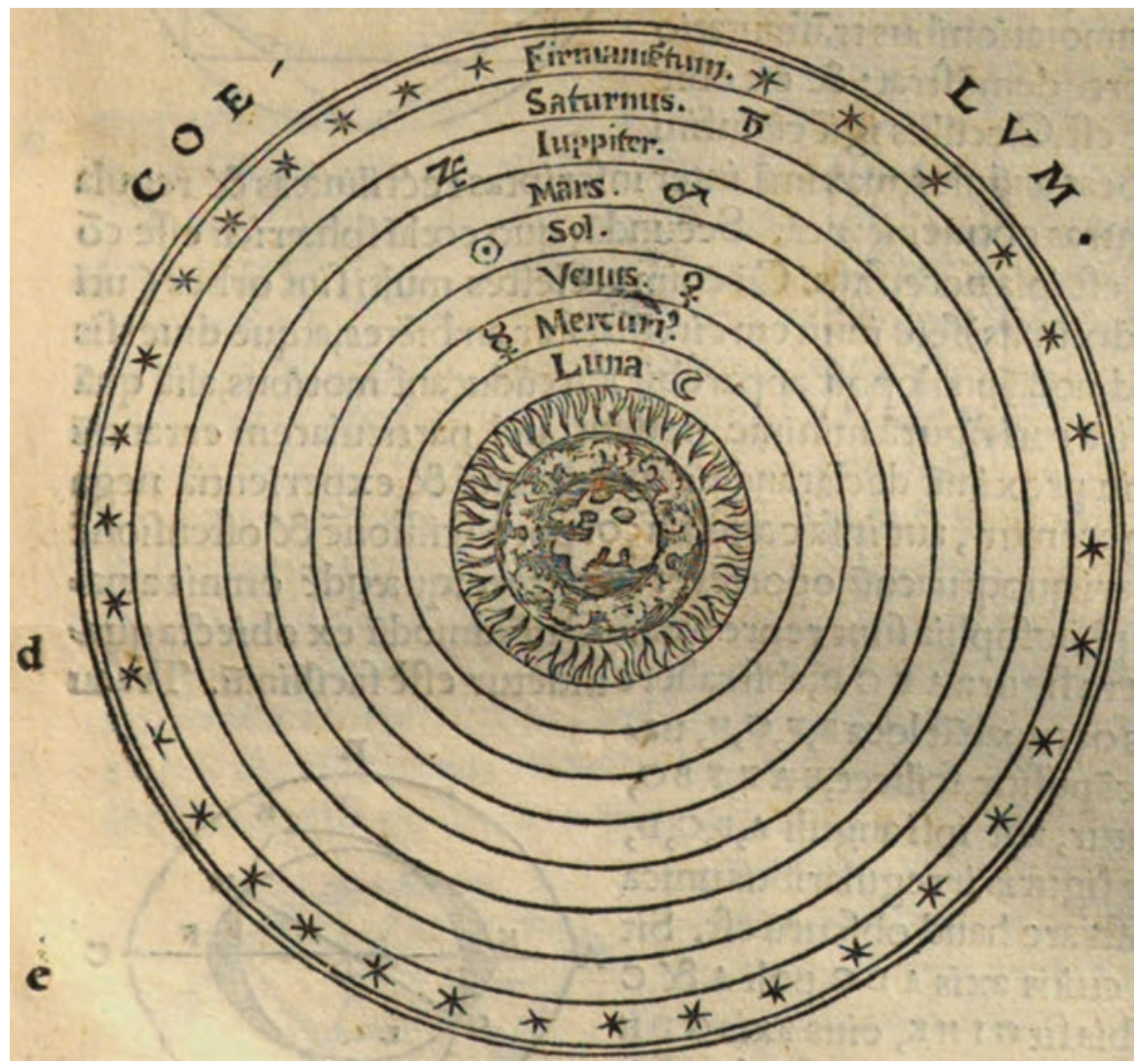

Fig. 8.7 De coelestium orbium numero, atque positione. The disposition of the elementary and celestial spheres according to the Cosmographia. From (Fine 1532). Augsburg, Staats- und Stadtbibliothek-2 Math 30, 104r, urn:nbn:de:bvb:12-bsb11199761-8 
in the form of a single orb. The relative similarity with the corresponding illustration in the Cosmographia (Fig. 8.7), which is also found in the Theorique des cielz (Fine $1528,3 r$ ), indicates that Fine then wished to introduce an updated knowledge of the relation between the spheres of earth and water. However, the representation of the nesting orbs that divide the world according to the number of planets and according to the different motions of the fixed stars is different in Fine's edition of the Sphaera (Sacrobosco and Fine 1516, sig. a2r) and the Cosmographia (Fig. 8.7), since for the former (which, on this topic, closely follows the Venetian editions of the Sphaera), there are nine spheres, as was taught by Sacrobosco, while for the latter there are only eight celestial spheres, according to what Fine taught in this context (as will be shown in the last section).

If the structure of Sacrobosco's treatise may be easily recognized behind the list of topics and thematic divisions of the Cosmographia, this treatise was still an occasion for Fine to provide an expanded and up-to-date teaching on the various topics dealt with in the Sphaera (Pantin 2010, 2013a; Mosley 2009) - in this, it was not so different from the various sixteenth-century editions of Sacrobosco that expanded the original text by collating it with complementary material (Crowther et al. 2015; Valleriani 2017; Pantin 2013b). It was also an occasion for Fine to offer a teaching on his practice of cartography, materialized by his own terrestrial or regional maps (Fine 1525, 1531b, 1536), some of which were produced before he was enrolled as a royal lecturer and which undoubtedly contributed to his recognition by the French court (Conley 1996, 115-32; Dupèbe 1999, II, 530, 541; Brioist 2009b; Pantin 2009a, 2010, 2013a).

In wanting to provide a modernized teaching of the sphere, Fine chose to change or leave aside several chapters he very likely judged obsolete or irrelevant to the learning required in this framework, or which simply repeated elements already taught in previous parts of the Protomathesis, as was the case for the preliminary definitions of the geometrical sphere by Euclid ( $3^{\text {rd }}$ century BCE) and Theodosius (ca. 160-ca. 100 BCE), which Sacrobosco included at the beginning of the first book and which Fine had presented beforehand in the geometrical part of the Geometria libri duo. ${ }^{129} \mathrm{He}$ also left aside the distinction between the division of the sphere

\footnotetext{
${ }^{129}$ (Fine 1532 (Geometria libri duo), 53v): "solidas figuras, primum sese offert Sphaera, omnium regularissima: hoc modo diffinienda. Sphaera est corpus solidum, regulare, unica superficie terminatum: in cujus medio punctum assignatur, centrum eiusdem adpellatum, à quo ad ipsam orbicularem et terminativam superficiem, omnes quae ducuntur rectae lineae sunt invicem aequales.... Imaginatur autem describi Sphaera, ex completo semicirculi circunductu: cum videlicet semicirculi diametro manente fixo, ejusdem circuli plana superficies abstractivè circunducitur, quatenus unde ferri ceperat revertatur." (Sacrobosco and Fine 1516, sig. a2r): "Sphera igitur ab Euclide sic describitur. Sphera est transitus circumferentie dimidii circuli que fixa diametro quousque ad locum suum redeat circumducitur. Id est Sphera est tale rotundum et solidum quod describitur ab arcu semicirculi circumducto. Sphaera etiam a Theodosio sic describitur. Sphaera est solidum quoddam una superficie contentum in cuius medio est punctus a quo omnes lineae ductae ad circumferentiam sunt aequales. Et ille punctus dicitur centrum sphaerae." It should be noted that, contrary to the order found in Sacrobosco, Fine first presented the definition of the sphere by Theodosius, which defines the sphere by its spatial properties, and then the definition of Euclid, which on the contrary defines the sphere by its mode of generation. Such order is also found in later commentar-
} 
according to substance (secundum substantiam) and according to accident (secundum accidens), which was probably due to the fact that such a distinction would be tacitly expounded afterwards when dealing with the composition of the heavens ${ }^{130}$ and when appealing to the distinction between right and oblique horizons. ${ }^{131}$

As in the other cosmographical treatises mentioned above, the part concerning the theory of the planets was completely left aside, with the exception of the theory of the sun, which was then integrated into the chapter on natural and artificial days. The fact that the motion of the planets is not dealt with in this context was very likely due to its belonging to a different section of the teaching of astronomy within the traditional mathematical curriculum (Barker 2011; Valleriani 2017). Fine, in the division of astronomy he presents in the preface of the first edition of his Cosmographia, implicitly points out that, although the theory of the sphere and the theory of planetary motions both belong to the same type of knowledge (mathematical or theoretical astronomy), they represent distinct subdivisions of this teaching, the theory of the sphere representing the first part and the theory of planetary motions, the second part. ${ }^{132}$ Thus, for Fine (in accordance with the common model for the teaching of astronomy in medieval and Renaissance faculties of the arts), if spherical astronomy could be taught independently from planetary theory, the teaching of planetary motions required at least a basic understanding of the theory of the sphere, as shown by his Theorique des cielz, in which he included a general description of the cosmos, which was absent from the original text of Peurbach's Theorica planetarum. ${ }^{133}$ In the Cosmographia, Fine also left aside the section dealing with eclipses presented by Sacrobosco in the fourth chapter, whose absence in

ies on Euclid's Elements, for instance, in those of François de Foix-Candale or Henry Billingsley, in which was clearly enunciated the distinction and hierarchization between essential definitions and genetic definitions of geometrical objects, adequately illustrated by the difference between Theodosius and Euclid's respective definitions of the sphere (Euclid 1566, 140r-v; Euclid 1570, $315 \mathrm{v}$ ). This distinction is also made in the medieval commentaries of Sacrobosco, for instance, in Pierre d'Ailly's Quaestiones (Sacrobosco et al. 1531, 146v), who argued that the Euclidean definition was less proper than the definition of Theodosius to define the sphere, since it defined it by one its accidental features (the motion by which it is produced) rather than by one of its essential features (its spatial properties).

${ }^{130}$ (Fine 1532 (Cosmographia), I.3, 103v-104v): "De coelestium orbium numero, atque positione."

${ }^{131}$ (Fine 1532, II.6, 112v): "De Meridiano et Horizonte circulo. [in marg. Horizon rectus. Horizon obliquus. Cur sphaera recta vel obliqua dicatur]."

${ }^{132}$ (Fine 1532, 102v): “Theoricae.... Astronomiae duplex habetur consyderatio. Aut enim primi tantum et universalis est motus: aut particularium orbium, peculiari et indefessa latione ductorum. At si primi tantummodo, et universalioris motus fiat observatio: haec universalior erit, multiplicem, cum numerum, tum coelestium corporum agitationem, signorum ascensus et descensiones, dierum et umbrarum incrementa et diminutiones, geographica omnia, et reliqua ejuscemodi ex eadem prima et regulata totius Universi circunductione, inferioribus accidentia concernens." (Fine 1542b, 5v): "Est enim Cosmographia, Mundanae structurae generalis ac non injucunda descriptio: prima Astronomiae partem."

${ }^{133}$ Peurbach's treatise starts directly with the sun's theorica; (Peurbach and Fine 1515, 2v): De Sole. "Sol habet tres orbes a se invicem omni quamque divisos atque sibi contiguos...." 
this context is less expected, as eclipses related to the theory of the motion of the sun and were necessary at the time for the calculation of longitudes, as indicated in the third chapter of book V. ${ }^{134}$

Fine also expressed strong reservations in the second book concerning the various geometrical representations or divisions of the twelve zodiacal signs which are described in the Sphaera (Sacrobosco and Fine 1516, sig. b1v-b2r), ${ }^{135}$ stating that these imaginary representations are not only fictitious and useless, but also entirely alien to the contemplation of the mathematician. ${ }^{136} \mathrm{He}$ furthermore manifested the will, in the third book, to distance himself from the literary approach adopted in the Sphaera, where ancient Roman authors (Virgil, Ovid, Lucan) are regularly quoted. As already mentioned, he criticized this approach as violating the mathematical purity of the teaching of the sphere ${ }^{137}$ and thus clearly positioned himself on this aspect against the form and style of Sacrobosco's teaching of astronomy. ${ }^{138}$ The authors he referred to (ancient and modern) in this context are indeed mostly mathematicians, astronomers, and philosophers: Aristotle, Euclid, Eratosthenes (ca. 276-ca. 195 BCE), Ptolemy, al-Farghān̄̄, ${ }^{139}$ al-Battān̄̄ (850-929), Averroës (1126-1198), Abraham ibn Ezra (1089-ca. 1167), Campanus of Novara (ca. 1220-1296), Alfonso X of Castile (1221-1284), Nicolas of Cusa (1401-1464), Georg Peurbach, Johannes Regiomontanus, Johannes Werner (1468-1522), Albert Pigghe (1490-1542), and Agostino Ricci (1512-1564). The absence of Sacrobosco's name, within this relatively long list of authorities, stands out all the more.

Besides the integration of new authorities, Fine made many more additions. He first of all quasi-systematically added examples to illustrate the meaning of the theo-

\footnotetext{
${ }^{134}$ (Fine 1532, V.3, 145v): "Cognoscitur autem ipsa longitudinalis duorum quoruncunque locorum differentia, per eiusdem Lunaris eclipsis in utroque loco factam observationem."

${ }^{135}$ The various regions encompassing the zodiacal constellations of stars would be represented either as the twelve rectangular divisions of the zodiacal belt, each measuring thirty degrees wide and twelve degrees high; or as the twelve pyramids whose bases are the aforementioned rectangular divisions of the zodiacal belt and whose vertices coincide with the centre of the universe; or as the twelve regions obtained by dividing the outer surface of the worldly sphere by six great circles passing by the beginnings of the signs; or otherwise as the twelve wedges obtained by the division of the whole body of the world by the afore-mentioned six great circles and which all extend to the axis of the zodiac.

${ }^{136}$ (Fine 1532, II.2, 109v): "Sed haec tam varia signorum imaginatio non modo fantastica, sed prorsus inutilis, et a mathematica contemplatione mihi videtur aliena. Solam enim syderum ad partes ipsius Eclipticae respondentiam, ut eorundem syderum mutua cognoscatur habitudo, motusque diversa supputetur quantitas, observare solemus."

${ }^{137}$ (Fine 1532 (Cosmographia), III.1, 119v): "Hoc demum triplici et vulgato syderum ortu et occasu, poetae frequentius uti solent: utpote, qui circuitiones tantummodo consyderant, ad discernenda videlicet anni tempora. Uti videre licet ex Virgilio, Ovidio, Lucano, et caeteris ejuscemodi. Quorum exempla dare, esset mathematicam violare puritatem."

${ }^{138}$ This may be contrasted with the opposite approach of André do Avelar, who did not only avidly quote the ancient authors cited by Sacrobosco (Lucan, Ovid, and Virgil), but also added supplementary quotations from these authors and others (Chap. 10). On the literary use of Sacrobosco's Sphaera, see (Oosterhoff 2015).

${ }^{139}$ The five latter were also referred to in the Sphaera.
} 
retical and practical teaching he provided. These examples, which are present throughout the five books of the Cosmographia, often consist of commented figures, showing, for example, the position of a star in relation to the equinoctial or the ecliptic in order to explain its mode of calculation. When a computational procedure is taught, numerical examples are used.

Fine also completed or reassessed some of the notions dealt with by Sacrobosco in the Sphaera by comparing, for example, the notions of declination and right ascension with the notions of latitude and longitude of stars and their respective relations to the celestial equator and to the ecliptic in chapter 3 of book II. ${ }^{140} \mathrm{He}$ furthermore added various chapters and subsections containing practical material (which, however, maintain an overall theoretical scope), ${ }^{141}$ pertaining, for instance, to the positioning of stars, to the measurement of the altitude of the sun, as well as to judicial astrology, ${ }^{142}$ as Jacques Lefèvre d'Étaples had done in his commentary on Sacrobosco's Sphaera (which Fine contributed to reprint in 1521) (Chap. 2). These additional elements did not necessarily bring forth new knowledge and, for some, were mainly meant to offer complementary or up-to-date information required by the practice of astronomers and cartographers on the basis of concepts enunciated in Sacrobosco's Sphaera. ${ }^{143}$ For instance, a few of the tables provided by Fine are similar to those found in Lefèvre's commentary on Sacrobosco, although the format and the compiled data (which Fine claims to have computed himself) are slightly different. ${ }^{144}$

In chapter II.4, Fine presented the means to find the declination of the ecliptic for any degree of the equinoctial. ${ }^{145} \mathrm{He}$ then also described the mode of fabrication and

\footnotetext{
${ }^{140}$ (Fine 1532 (Cosmographia), II.3, 109v): "Quidnam sit declinatio et latitudo syderum, atque de ratione declinationis Zodiaci ab Aequatore: Declinatio est arcus circuli magni, per Mundi polos, et datum astrum, vel coeli punctum educti: inter Aequatorem, et ipsum astrum, sive punctum compraehensus. Latitudo verò, est arcus magni itidem circuli, sed ex polis Eclipticae, per datum sydus, aut signatum in coelo punctum transeuntis: qui inter ipsum sydus, vel idem punctum, et Eclipticam capitur."

${ }^{141}$ Adam Mosley makes it clear that, although Fine offered various elements pertaining to practical mathematics in this context, notably instructions on how to perform certain procedures, even on how to make instruments (often expressed in the second-person singular imperative), these remain of a theoretical nature (Mosley 2009).

${ }^{142}$ On these additions, see also (Mosley 2009; Pantin 2010).

${ }^{143}$ See the title of the 1542 unabridged edition: "De Mundi Sphaera, sive Cosmographia, primáve Astronomiae parte, Libri V: Inaudita methodo ab authore renovati, proprijsque tum commentarijs et figuris, tum demonstrationibus et tabulis recens illustrati."

${ }^{144}$ Compare for instance (Fine 1532, III.3, 122v) and (Sacrobosco and Fine 1538, 17v), in the 1538 reprint of Fine's edition of Lefèvre's commentary on Sacrobosco or (Fine 1532, III.4, 126r) and (Sacrobosco and Fine 1538, 18r). Fine's tables are presented further. Richard Oosterhoff (Oosterhoff 2018, 149-150) considered that Fine wrote the Cosmographia in order to replace Lefèvre's commentary on Sacrobosco's Sphaera (Sacrobosco et al. 1495). This would confirm that Fine's main model for the introduction of numerous practical elements in his teaching of spherical astronomy (tables and computation techniques) was this commentary by Lefèvre, which, as said, he reedited in 1521. Moreover, this would confirm that, in writing the Cosmographia, Fine consciously placed his work in the tradition of Sacrobosco's Sphaera.

${ }^{145}$ (Fine 1532, II.4, 110v): "Ut maxima Solis, vel Eclipticae declinatio et reliquae singulorum punctorum eiusdem Eclypticae declinationes inveniantur."
} 
the use of the quadrant to measure the altitude of the sun and provided a table for the declination of the sun, along with the instructions on how to compute and use it. ${ }^{146}$ After dealing with the celestial circles taught in Sacrobosco's second book, he introduced, in chapters 8 and 9 of book II, circles relating to the horizontal positioning of the viewer-namely, the perpendicular and parallel circles that divide the sphere according to the horizon (verticals and circles of altitude) $)^{147}$ and the circles of hours and their role in the constitution of sundials. ${ }^{148}$ Chapter 10 , which is the last of book II, deals with the astrological division of the heavenly sphere into twelve houses, where Fine compared the modes of distinction of the celestial houses adopted respectively by Campanus and by Regiomontanus, as well as its application to the astrological chart. ${ }^{149}$

In chapter 3 of the third book, Fine introduced instructions on how to compute the ascensions of the parts of the ecliptic in the right sphere for each degree of the equator from the vernal equinox, ${ }^{150}$ along with the corresponding table. ${ }^{151}$ Similar material is given in the chapters III.4 and III.5 for the computation of the arcs of

\footnotetext{
${ }^{146}$ (Fine 1532, II.4, 110v-11v): "[in marg. Instrumenti constructio, quo maxima declinatio Solis observatur. Maxima Solis declinatio, qualiter per idem observetur instrumentum.... Ut reliquorum Eclipticae declinatio supputetur. De componenda tabula declinationis. Usus tabulae succedentis];" (111v): "Tabula declinationis solis, praesupponens maximam eius declinationem 23 gra. et $30 \mathrm{mi}$. per Authorem supputata 1530."

${ }^{147}$ (Fine 1532, II.8, 114v): "De verticalibus, atque altitudinum circulis: Praeter hos autem supra descriptos sphaerae circulos, varia reperitur in eadem sphaera aliorum circulorum imaginatio: de quibus consequenter tractare commodissimum existimamus. utpote, à quibus bona pars ipsius Astronomiae, ac universa ferè coelestium instrumentorum et theorica et practica pendere videtur. Inter quos primum sese offerunt, qui dicuntur verticales: et ij, quos altitudinum solemus appellare circulos. Sunt igitur verticales circuli, qui ex dati cuiuslibet loci vertice, in singulas Horizontis partes deducuntur: et supernum hemisphaerium in tot partes quot et Horizontem undiquaque distribuunt.... Altitudinum verò circuli sunt, qui circa locorum verticem parallelicè describuntur, et cuiuslibet verticalis circuli distribuunt, et vicissim ab eisdem verticalibus circulis, in 360 partes, sive gradus, sigillatim dividuntur: quorum primus, et omnium maximus est Horizon, minimus verò, qui propior est vertici."

${ }^{148}$ (Fine 1532, II.9, 115v): "De circulis horarum distinctoribus. Non prorsus aspernandam consequenter judicamus horarium circulorum designationem: ab ipsis enim universa, tum horarum, tum solarium horologiorum ratio potissimum deducitur."

${ }^{149}$ (Fine 1532, II.10, 116v-17v): "Quibus circulis 12 coeli partes (quas vocant domos) separentur: atque de circulo positionis appellato. De circulis tandem coelestium domiciliorum distinctoribus, variae inter Astronomos reperiuntur opiniones; Figura generalis 12 coelestium domiciliorum secundum judiciarios Astrologos." Though he recognised the benefits of the division of Regiomontanus, he recommends his readers to follow Campanus: (Fine 1532, 117v): "Si meo tamen stare velis judicio a via Campani non discedes: multo siquidem fideliora, cum probatissimus Astrologis poteris elicere judicia." On the different modes of distinction of the sphere in 12 astrological houses, see (Bezza 2014).

${ }^{150}$ (Fine 1532, III.3, 120v): "Quaenam ascensionis atque descensionis accidentia in recto contingant sphaerae situ, necnon de rectarum ascensionum supputatione;" (121v): [in marg. Canon supputationis rectarum ascensionum cuiuslibet arcus Eclipticae].

${ }^{151}$ (Fine 1532, III.3, 122v): "Tabula rectarum ascensionum singulorum arcuum Eclipticae, ab Ariete gradatim initiatorum, per Authorem supputata."
} 
ascension of the ecliptic in the oblique sphere, calculated for the latitude of Paris, ${ }^{152}$ which includes a table of the ascensional differences between the arcs of the zodiacal signs in the right and oblique spheres, ${ }^{153}$ as well as tables for the oblique ascensions of the signs for the latitudes of $48^{\circ} 40^{\prime}$ on the northern and southern hemispheres for each degree of the equator, ${ }^{154}$ as well as corresponding tables for the total ascensions of each sign for the same latitudes. ${ }^{155}$ Fine then also provided a table for the oriental and occidental latitudes of the rising and setting of the arcs of the ecliptic (and thus of the sun) for the latitude of Paris. ${ }^{156}$ In this fifth chapter of book III, he also added a part on the determination of the rising degree of the ecliptic, also called the ascendant or the horoscope, ${ }^{157}$ and of the beginnings of the remaining astrological houses, according to the methods of Campanus and of Regiomontanus. ${ }^{158}$

In the fourth book, when dealing with the inequality of natural days, Fine replaced Sacrobosco's discourse on the annual spiral motion performed by the sun along the ecliptic in the course of a year by the theory of the sun's motion found in Peurbach's Theorica planetarum. ${ }^{159}$ The aim of this teaching, as Fine put it, is to

\footnotetext{
${ }^{152}$ (Fine 1532, III.4, 123r): "De ascensionum atque descensionum accidentibus in obliquo sphaerae situ contingentibus: quonam item modo obliquae supputentur ascensiones." (124v): [in marg. De ratione supputationis obliquarum ascensionum].

${ }^{153}$ (Fine 1532, III.4, 125v): "Tabula differentiarum ascensionalium, ad elevationem poli arctici 48 gra. et 40 mi. per Authorem supputata."

${ }^{154}$ (Fine 1532, III.4, 126r): "Tabula ascensionum obliquarum, ad elevationem poli arctici 48 gra. et $40 \mathrm{mi}$. per Authorem ab Ariete gradatim supputata" and (126v): "Tabula ascensionum obliquarum, ad elevationem poli antarctici 48 gra. et $40 \mathrm{mi}$. per Authorem ab Ariete gradatim supputata."

${ }^{155}$ (Fine 1532, III.4, 127r): "Tabella obliquarum ascensionum et descensionum cujuslibet signi per sese consyderati, ad elevationem poli arctici 48 gra. et 40 mi. seorsum extractarum" and (127v): "Eadem obliquarum ascensionum atque descensionum tabella, ad eandem, sed poli antarctici sublimitatem calculata."

${ }^{156}$ (Fine 1532, III.5, 127v): "Quid sit ortus vel occasus latitudo, qualiter praeterea ad liberam quamvis obliquitatem sphaerae...," (128r): [in marg. Ortus latitudo in obliqua sphaera, qualiter supputanda]; 128v: "Tabula latitudinis ortus, ad elevationem poli arctici 48 gra. et 40 mi. [in marg. De usu tabulae latitudinis ortus]."

${ }^{157}$ (Fine 1532, III.5, 128v-129v): "Quid sit ortus vel occasus latitudo, qualiter praeterea ad liberam quamvis obliquitatem sphaerae, unà cum ascendente Eclipticae gradu supputetur: ubi de supputandis coelestium domorum initijs notanda digressio. [in marg. De supputando ascendente gradu eclipticae. De supputanda ascendentium tabula]."

${ }^{158}$ (Fine 1532, III.5, 130r): [in marg. Initia 12 domorum qualiter, secundum viam Campani, veniant supputanda. Alius modus ad idem; juxta modum Joannis Regiomontani].

${ }^{159}$ Compare, for example, the following passages: (Fine 1532, IV.1, 131r): "Ut autem universa dierum naturalium discrimina, et mediocrum ad veros dies, aut econtra, reductionem concipere facile possis: theoricam motus ipsius Solis, ad salvandam, supputandamque motus eiusdem Solis circa Mundi centrum observatam irregularitatem subtiliter excogitatam, hoc loco perstringere libet.... Imaginantur itaque prudentiores Astronomi, solarem orbem in tres adinvicem contiguos orbes separari..." See also (Peurbach and Fine 1515, 2v): De Sole. "Sol habet tres orbes a se invicem omni quamque divisos atque sibi contiguos...," (Fine 1532, 131v): "Fingunt praeterea, circa idem centrum eccentrici, circulum quendam, partem Eclipticae itidem eccentricum nominatum, cujus circunferentia per centrum Solis transire diffinitur... In hunc porro circulum eccentricum procedentium ex Mundi centro rectarum linearum, maxima est in qua centrum eccentrici...et lon-
} 
help understand the difference between natural days and show how to obtain the true motion of the sun from its mean motion and vice versa. ${ }^{160}$ In this part, he used the illustration of the sun's motion which he engraved for his Theorique des cielz (Fine 1528; Pantin 2010). ${ }^{161}$ However, this part is not a full substitution, since in the next chapter (chapter IV.2) he resorted to Sacrobosco's description of the daily parallel circles obtained from the annual spiralling of the sun from one tropic to the other to describe the differences between day and night in the right and oblique spheres (Fine 1532, 133v-34r). In this chapter, Fine taught the means by which astronomers determine the lengths of artificial days and nights for each degree of the ecliptic for any latitude, ${ }^{162}$ providing a table of the lengths of artificial days for the latitude of Paris, ${ }^{163}$ as well as the means to calculate the duration of the longest artificial day for each degree of latitude from the equator to the North Pole, along with a corresponding table. ${ }^{164}$

gior ob id vocatur longitudo, apogium sive augem eiusdem indicans eccentrici: minima vero reliqua..., quae longitudo brevior respondenter appellatur, et perigium, hoc est, punctum apogio, vel augi denotat oppositum...." See also (Peurbach and Fine 1515, 8v-9v): "Imaginamur autem in sole eccentricum circulum per lineam a centro eccentrici usque ad centrum solare euntem: super centro eccentrici regulariter motam una revolutione facta describi: qui semper est pars superficiei eclyptice orbis signorum octave sphaere. Aux solis in prima significatione sive longitudo longior est punctus circumferentie eccentrici maxime a centro mundi remoto. Et determinatur per lineam a centro mundi per centrum eccentrici utrinque ductam: quae linea augis dicitur. Oppositum augis sive longitudo propior est punctus circumferentie eccentrici maxime centro mundi propinquus et semper augi diametraliter opponitur. Longitudo media est punctus circumferentie inter augem et oppositum augis...;" and (Fine 1532, 131v): "Orbis vero medius, deferens Solem appellatus, circa proprium centrum et axem, secundum ordinem signorum (praeter diurnum, et supradictorum orbium motum) regulariter circumfertur: ita ut Sol de circumferentia proprij eccentrici 59 minuta, et 8 fere secunda partis quotidie perambulet." See also (Peurbach and Fine 1515, 7v): "Sed orbis solare corpus deferens motu proprio super suo centro secundum eccentrici regulariter secundum successionem signorum quottidie lix minutis et octo secundis fere de partibus circunferentie per centrum corpis solaris una revolutione completa descripte movetur."

${ }^{160}$ (Fine 1532, IV.1, 131r): "Ut autem universa dierum naturalium discrimina, et mediocrum ad veros dies, aut econtra, reductionem concipere facile possis: theoricam motus ipsius Solis, ad salvandam, supputandamque motus eiusdem Solis circa Mundi centrum observatam irregularitatem subtiliter excogitatam, hoc loco perstringere libet...." This section is maintained in the 1542 unabridged version (Fine 1542a, 48v-50v), where it is described as a Digressio notanda, but not in the later versions.

${ }^{161}$ Compare (Fine 1528, 16r) and (Fine 1532, 131v). As mentioned earlier, Fine also appealed, for his edition of Sacrobosco, to images drawn from his 1516 edition of the Theorica.

${ }^{162}$ (Fine 1532, IV.2, 132v): "De die artificiali, ejusdemque differentijs, et calculo;" (134v) [in marg. Qualiter supputanda dierum artificialium magnitudo, ad quamvis poli sublimitatem complemento maximae declinationis solaris minorem.... Arcum diurnum aliter supputare].

${ }^{163}$ (Fine 1532, IV.2, 135r): "Tabula maximarum dierum artificialium, ad elevationem poli arctici 48 graduum et 40 minutorum, et singulos Eclipticae gradus, per authorem fideliter supputata."

${ }^{164}$ (Fine 1532, IV.2, 135v): [in marg. Alia maximarum vel minimarum dierum supputandi ratio. De supputando maximo lucis arcu, seu continuatae lucis tempore, ad quamvis poli sublimitatem complemento maximae Solis declinatio majorem.... ]; (136r): "Tabula maximarum dierum artificialium, ab Aequatore circulo, ad polum usque arcticum, gradatum per authorem supputata." 
The third chapter of Book IV considers the distinction between the equal and the unequal hours that divide artificial days and nights according to the latitude of the viewer and shows how to calculate the length of unequal hours for the latitude of Paris, as well as how to reduce unequal hours to equal hours and vice versa. ${ }^{165}$ Fine also explained at this occasion the correspondence between the planets (and their rising in the first hour of the artificial day) and the names of the days of the week (Saturn on Saturday, the sun on Sunday, etc.), which he represented through a little table also indicating the planets ruling the first hour of the night, as well as the means to determine the planets ruling the other planetary hours for any day of the week. ${ }^{166}$

In chapter IV.4, which deals with the altitude of the sun and with the shadows produced by the sun for different parts of the world, Fine explained the distinction between umbra versa and umbra recta, and introduced the means to compute the lengths of shadows with the help of the geometrical square (quadratum geometricum) placed on the back of planispheres or astrolabes, ${ }^{167}$ which he complemented with a corresponding table indicating the lengths of shadows according to the altitude of the sun. ${ }^{168} \mathrm{He}$ also taught the means to calculate the elevation of the sun at a given place, ${ }^{169}$ along with a table indicating the altitude of the sun for the latitude of Paris at each hour of the day throughout the year. ${ }^{170}$

In book $\mathrm{V}$ of the Cosmographia, as noted above, Fine taught the principles of geography, hydrography, and chorography in the tradition of Ptolemy's Geography (Brioist 2009b) and according to the previously mentioned cosmographical projection onto the terrestrial globe of the celestial circles and zones described in the

\footnotetext{
${ }^{165}$ (Fine 1532, IV.3, 136r): "De Horis tam aequalibus quàm etiam inaequalibus." (137r-v): [in marg. Diurnae vel nocturnae et inaequalis horae quantitatem invenire.... De mutua horarum conversione. Inaequales horas, ad aequales reducere.... Aequalium ad inaequales conversio.... Ut vulgares horae convertantur in astronomicas].

${ }^{166}$ (Fine 1532, IV.3, 136v): [in marg. Planetam quamlibet horarem temporali diei, vel noctis artificialis dominantem invenire]. and Planetam dominans hora prima. Successio planetarum, pro reliquis horis à prima, tam diei quàm noctis artificialis (table).

${ }^{167}$ (Fine 1532, IV.4, 138r-v): "De utraque umbra, recta scilicet et versa, earumque differentis et calculo: unà cum Solarium altitudinum supputatione [in marg. Umbrae diffinitio. Umbra recta. Umbra versa];” (140v): “...quadratum...geometricum..., planisphaerio atque caeteris instrumentis inscribi solitum: quo duce, per alterutrius umbrae intersectionem, rerum altitudines, planicies, et profunditates, hoc est, omnem longitudinem elevatam, jacentem, vel depressam proportionaliter emetimur." See also (Fine 1551a, 43r): "Hinc tractum esse videtur quadratum illud geometricum, quod tum in quadrantibus, tum in Astrolabiorum dorso figuratur."

${ }^{168}$ (Fine 1532, IV.4, 137v): (138v-39v) [in marg. Ex Solis altitudine data utriusque umbrae perscrutari longitudinem. Idem per umbrarum absolvere tabulam...]; (139r): "Tabulae utriusque umbrae, rectae scilicet et versae, in partibus qualium umbrosum est 12: ad singulos gradus Solaris altitudinis, per Authorem exactè supputata."

${ }^{169}$ (Fine 1532, IV.4, 139v): [in marg. Eandem Solis altitudinem generaliter supputare.... Ut meridiana Solis altitudo colligatur].

${ }^{170}$ (Fine 1532, IV.4, 140r): "Tabula elevationum solis, seu locorum eiusdem in Ecliptica, qualibet hora diei artificialis, Ad poli sublimitatem 48 graduum et 40 minutorum, per Authorem fideliter supputata."
} 
second book of Sacrobosco's Sphaera. This book also includes the theory of the climates and the ancient and modern distinctions of winds. Chapter V.1 considers in particular the various circles projected onto the terrestrial globe with the addition of the 89 parallels that divide each hemisphere of the terrestrial globe horizontally at one degree intervals from the equator and which enable, by their intersection with the meridians, to determine the longitudinal and latitudinal coordinates of the various places on earth. ${ }^{171}$ For this, Fine provided a table indicating the circumference of a quadrant for each parallel in degrees of the equator and the quantity of their respective longitudinal degrees in minutes and seconds of arc. ${ }^{172}$ Chapter V.2 properly deals with the theory of the climates, presenting the twenty-four parallels that enable one to distinguish them. In this context, Fine criticized the distinction of seven climates found in Sacrobosco's Sphaera and in earlier teachings on the sphere, which he attributed to the limited knowledge of their authors concerning the boundaries of the habitable world. ${ }^{173}$ He then gave instructions on how to calculate the height of the pole from the given length of the artificial day for each degree starting from the equator ${ }^{174}$ and a table indicating the distance from the equator of each parallel delimiting the beginning and the end of a climate zone, as well as the corre-

\footnotetext{
${ }^{171}$ (Fine 1532, V.1, 141v): "Inter majores itaque circulos, quos in coelesti sphaera constituimus.... Unà cum singulis datorum quoruncumque locorum parallelis, per ipsa quidem loca liberè, gradatimve ab Aequatore distributis. Ut quemadmodum eorundem coelestium circulorum officio, syderum venamur habitudines: haud dissimiliter per eos, quos super ipso terrestri globo designamus, locorum positiones, atque distantias obtinere valeamus."

${ }^{172}$ (Fine 1532, IV.4, 143r): "Tabula demonstrans rationes aequatoris, seu magni cujusvis, ad singulos parallelos, ab eodem Aequatore, versus utrumque polorum ipsius Mundi, gradatim distributos. Primo, in partibus, qualium Aequatoris quadrans perhibetur esse 90 . Secundo, in partibus, qualium unus gradus ejusdem Aequatoris est 60."

${ }^{173}$ (Fine 1532, V.2, 143v-44v): "De parallelis Climatum distinctoribus: quonam item pacto dato lucis arcu, singulorum parallelorum polares investigentur altitudines;" (143v): "Quanquàm autem haec Climatum excogitatio à vulgaribus Geographis in septenarium redacta sit numerum: nihilominus tamen ab Aequatore versus utrunque Polum, et usque ad eo parallelos, ubi Sol ad diei naturalis quantitatem semel in anno sinè nocte luscescit, 24 sunt annumeranda;" (144r-v): [in marg. Propter quid 7 tantummodo à vulgaribus Geographis, sint ordinata climata. De peculiari climatum nomenclatura. Exemplaris 7 vulgarium climatum descriptio. Qualis vera climatum distributio. Quot sint climata, secundum veram imaginationem]. On the transformation of the theory of climates in the sixteenth century, see (Cattaneo 2009; Leitão and Almeida 2012; Almeida 2017; Valleriani 2017) (Chap. 7). It should be noted, however, that the only diagram that accompanies this chapter presents the ancient division of the climates, and not the modern division, as the later editions from 1551 on would do. Interestingly, the representation of the terrestrial globe in these earlier diagrams that present the seven climate division is more realistic (representating the seas and continents) than in the later diagram that presents the 24 climate theory, which is, on the other hand, closer in style to the more abstract diagram presenting the climates in the Venetian editions of Sacrobosco (for instance, Sacrobosco et al. 1488, BB10r).

${ }^{174}$ (Fine 1532, V.2, 144v): [in marg. Ortivam cuiuslibet eclipticae puncti latitudinem, aliter quam superius calculare.... Data Solis declinatione, et amplitudine ejus ortiva: polarem elicere sublimitatem.... Qualiter poli sublimitas investigetur, ubi dies aestivus maximus diem excedit naturalem].
} 
sponding maximum length of artificial days. ${ }^{175}$ This table also indicates, for comparison, the situation of the seven climates of the earlier tradition of the sphere (7 vulgaria climata).

In the third chapter of book V, Fine taught the geographical notions of longitude and latitude of terrestrial places, as well as the notions of longitudinal and latitudinal differences, along with their means of calculation through lunar eclipses. ${ }^{176} \mathrm{He}$ then provided a table of the longitudes and latitudes of various cities in France, Germany, the Italian peninsula, Spain, Sicily, Sardinia, Corsica, Ireland, Scotland, and England. ${ }^{177}$ Chapter V.4 teaches how to measure the distances between places and the correspondence between the distances measured in terrestrial units of lengths (in paces, miles, leagues, and stadia) and in degrees of great circles, using the method given by Ptolemy in his Geography. ${ }^{178}$ In the fifth chapter, Fine taught the means to measure the distance between two places from their respective longitudes and latitudes. ${ }^{179}$ The following chapter deals with the hydrographical distinction and classification of winds, ancient and modern, into twelve and thirty-two different winds, respectively, which Fine represented through compass roses, as well as through a small table for the ancient distinction comparing the Latin and Greek names of the twelve winds. ${ }^{180}$ In the chapter V.7, which is also the very last

\footnotetext{
${ }^{175}$ (Fine 1532, V.2, 145r): "Tabula polarium altitudinum seu distantiarum ab Aequatore singulorum parallelorum, pro maximarum dierum artificialium quantitate ab eodem Aequatore distributorum: per authorem fideliter supputata."

${ }^{176}$ (Fine 1532, V.3, 145v): "De longitudine, atque latitudine locorum: qualiter praeterea tam longitudo, quàm etiam latitudo sit investiganda;" (146r-v): [in marg. Qualiter ex eadem eclipsi Lunari duorum locotum longitudinalis elicitur differentia. Quidnam sit dati cuiuslibet loci latitudo. Latitudinis duorum locorum differentia. Data altitudine Solis meridiana unà cum eius declinatione, latitudinem loci concludere. Idem per stellas fixas quae oriuntur et occidunt respondenter absolvere. Eandem loci latitudinem, per stellas semper apparentes colligere].

${ }^{177}$ (Fine 1532, V.3, 147r-48v): "Tabula longitudinum ab occidente, atque latitudinum ab Aequatore, insigniorum locorum, civitatum et oppidorum, per saniores nostrae melioris Europae regiones constitutorum, Ab Authore recenter verificata." For the list of coordinates Fine takes up from Ptolemy, at least for his map of France, see (Gallois 1918; Dainville 1970; Broc 1983; Conley 1996, 81-110; Pelletier 2009, 13).

${ }^{178}$ (Fine 1532, V.4, 148v): "Quantum itineris respondeat uni gradui, vel ipsi toto maximo terrestri circulo: ut etiam locorum itinerariae metiri debeant profectiones;" (149r): [in marg. Quantum itineris capiat unus gradus Meridiani per similium segmentorum observatam respondentiam elicere.... Quantum uni gradui respondeat in Terra, secundum Ptolemaeum. Quantum universus terrestris ambitus per eundem Ptolemeum. Quod directa locorum itinera fieri debeant super magni circuli segmentum demonstratio].

${ }^{179}$ (Fine 1532, V.5, 149v): "Quonam pacto duorum quoruncunque locorum longitudinibus atque latitudinibus datis, eorundem locorum viatoria metienda sit elongatio;" (150r-51r): [in marg. De locis sub eodem Meridiano, et in eadem Mundi parte constitutis.... Locorum sub eodem parallelo consistentium, qualiter viatoria metienda sit elongatio.... Qualiter directum itineris intervallum, duorum locorum sub diversis Meridianis, atque parallelis constitutorum supputetur.... De locis in diversa Mundi parte ab Aequatore constitutis. Quae sub eodem Meridiano. De locis sub varijs Meridianis et parallelis inaequaliter ab Aequatore distantibus collocatis. Quando loca ipsa sub oppositis consistent parallelis. De finali arcuum milliariorum, et leucarum inventione].

${ }^{180}$ (Fine 1532, V.6, 152r): "De numero, situ, atque ordine ventorum, ad hydrographiae cognitionem potissimùm spectantium." (152r-53r): [in marg. De numero, ordine, atque positione ventorum
} 
chapter of the Cosmographia, Fine presented the cartographical procedures necessary to produce regional maps (chorography), which he illustrated through a delineation of the French borders on a coordinate grid indicating the location of Paris, as well as various projection techniques drawn from Ptolemy's Geography for the mapping of an eighth or a half of the terrestrial globe (Brioist 2009b). ${ }^{181}$

As noted by Adam Mosley, Fine's geographical doctrine in the Cosmographia does not convey the will to present the new world discoveries, as did, on the contrary, the cosmographies of Apian (Apian 1540), Waldseemüller (Waldseemüller and Ringmann 1907) or Sebastian Münster (1488-1552) (Münster and McLean 2016; Mosley 2009). ${ }^{182}$ This is all the more peculiar in light of the fact that in 1531 Fine himself cast a Nova et integra universi orbis descriptio (Fine 1531b) - in parallel to preparing the Protomathesis for publication-which offered a cartographical representation of the known world, that is, featuring the new geographical discoveries, according to a bi-cordiform projection. Generally speaking, for a treatise of cosmography which dedicates a separate book to geography and which furthermore signals in this geographical part the heritage of Ptolemy's Geography, the Cosmographia contains very little concrete information on the actual locations and contours of the various terrestrial regions, mainly offering methodological elements for the practice of cartography and a list of geographical coordinates for European cities situated in Europe. ${ }^{183}$ It therefore seems that Fine's doctrine on the topic, as is the case for the rest of the material examined here, mostly aimed to correct and complete the theory of the sphere transmitted by Sacrobosco and its tradition, teaching in a rather theoretical manner the principles and methods used by cosmographers to determine the location of a place on earth and to represent terrestrial regions or the entire terrestrial globe on a map.

In the Cosmographia, Fine therefore followed in its broad outline the structure of the teaching provided by Sacrobosco, taking up the design and style of the Sphaera while leaving aside its text, to provide an updated and enriched theory of the sphere. In doing so, he perfectly illustrated the openness and yet the stability of the design

secundum veteres naturas atque philosophos.... De numero, ordine, atque positione ventorum secundum recentiores hydrographos. Qualia ventorum iuxta navigantes hodiernos nomina. Ventorum lineamenta, qualiter in Cartis hydrographicis describenda. De succendi ventorum hydrographica].

${ }^{181}$ (Fine 1532, V.7, 154r-55r): “Qualiter tandem oblatae cujuscunque regionis, vel partis habitabilis Orbis Chorographia, ex praedictis colligenda sit: quonam item modo hemisphaerica parallelorum atque Meridianorum contextura, ad positionem locorum necessaria in plano rationabiliter extendatur;" (154r): [in marg. Chorographiae gallicae in aliarum exemplum descriptio. Chorographiae ex curvis lineis contextae figurationis exemplum. Ut hemisphaerica parallelorum atque Meridianorum delineanda sit contextura].

${ }^{182} \mathrm{On}$ the relation between the teaching of the Sphaera and the exposition of the new geographical discoveries, see (Chap. 7).

${ }^{183}$ The fact that, contrary to Apian (Apian 1540, 31v-44v) or even Lefèvre (Sacrobosco and Fine $1538,11 \mathrm{v}-13 \mathrm{r}$ ), he restricted the list of geographical coordinates to European cities was perhaps due to the fact that he wanted to provide the information that he considered most relevant to his addressed readership. 
of the Tractatus de sphaera in the sixteenth century, as described by Richard Oosterhoff and Matteo Valleriani (Oosterhoff 2015; Valleriani 2017). Indeed, Fine's treatise introduced elements of knowledge exterior to Sacrobosco's teaching and at times drawn from different disciplines, but which were traditionally related to the early modern teaching on the sphere and which thus fit appropriately with the thematic structure of the Sphaera. The knowledge Fine added to Sacrobosco's teaching of the sphere in the Cosmographia is drawn from practical astronomy (astronomical computation procedures), instrument-making, judicial astrology, metrical geography, and cartography. Hence, if this list of additional elements is compared with the list compiled by Valleriani (2017) of the different disciplines that were associated with Sacrobosco's text by various sixteenth-century editors or commentators, Fine's Cosmographia appears to be quite similar in its form and intention to later sixteenthcentury editions of Sacrobosco's treatise (Crowther et al. 2015). ${ }^{184}$

Moreover, the position of the Cosmographia within the Protomathesis may itself be conceived as the association of the traditional teaching of the sphere with disciplines and knowledge exterior to it. Indeed, within the Protomathesis, which was conceived from the start as a unified compendium (Pantin 2010), each part being required to make sense of the others, the Cosmographia holds both a central position $^{185}$ and a role of connecting link. Practical arithmetic and geometry (theoretical and practical), which precede the Cosmographia among the various parts of the Protomathesis, are both presented as necessary for cosmography, as it requires the methods of computation, the geometrical concepts and the measurement techniques and instruments provided by practical arithmetic and geometry. This is confirmed by the numerous references made to both treatises in the Cosmographia, ${ }^{186}$ as well as by the preface of the Geometria libri duo, where Fine asserts their necessity for the astronomical teaching that follows. ${ }^{187}$ This also corroborates the idea presented by Fine in the prefaces of his later editions of the Cosmographia that the

\footnotetext{
${ }^{184}$ See also, for the specific case of the Spanish and Portuguese editions and commentaries on the Sphaera, (Chaps. 7 and 10).

${ }^{185}$ Its overarching importance in the Protomathesis is also marked by the fact that it is the only one of the four treatises to present a properly elaborate frontispiece, containing an allegorical representation of the discipline with Fine in the role of the astronomer, and that, moreover, this frontispiece appears both to introduce the corresponding treatise (the Cosmographia) and to introduce the whole compendium. On this frontispiece, see (Pantin 2009b).

${ }^{186}$ (Fine 1532 (Cosmographia), I.1, 102r): "Divinam coelestis rationis doctricem Astronomiam, post Arithmeticae atque Geometriae praemissa rudimenta, consequenter adgressuri," (II.1, 108r): "Quinam sint majores, quive minores in sphaera circuli, decimo capite libri Geometriae nostrae sufficienter annotavimus;" (II.2, 109r): "quod tametsi quilibet in sphaera circulus (uti capite primo libri tertij nostrae docuimus Arithmeticae) in 12 partes invicem aequales a Mathematicis dividatur;" ibid:: "De signorum tandem in gradus sub divisione, et graduum in minuta, et deinceps minutorum in succedentia partium discrimina, praeallegato capite primo libri tertij nostrae Arithmeticae sufficienter tractavimus," etc.

${ }^{187}$ (Fine 1532 (Geometria libri duo), 50r): "Non incommodum judicavimus, studiose lector, post Arithmeticae praxim, insignora Geometriae tradere rudimenta. utpote, quae non modo succedentibus nostris geographicis vel astronomicis operibus, passim sese offerunt accommoda: verumetiam universo mathematicarum studio videntur admodum necessaria."
} 
learning and mastering of astronomy is the reason why the other parts of the quadrivium (that is, arithmetic, geometry, and music) should be studied. Moreover, the Cosmographia is set forth as the condition and therefore as the necessary introduction to the last part of the Protomathesis-that is, the De solaribus horologiis, et quadrantibus, which deals with the art of sundials. ${ }^{188}$ Within this general teaching program, the theory of the sphere is both clearly distinguished from geography and presented as the condition of the apprehension and representation of the terrestrial globe and of its regions. It comes across, furthermore, as a necessary introduction to the astrological interpretation of the celestial influences. The situation of the Cosmographia within the Protomathesis thus allows us to regard the teaching of practical arithmetic, geometry, and dialing - in addition to the teaching of geography, cartography, and astrology — as a body of knowledge added to and associated with the traditional teaching of the theory of the sphere or as a set of complementary notions relevant to its study and application in a variety of contexts (Valleriani 2017). This again allows us to relate the composition of the Cosmographia, especially in its first edition, to the early modern practice of expanding the text of Sacrobosco, as was done in its later sixteenth-century editions and commentaries (Pantin 2013b; Crowther et al. 2015; Oosterhoff 2015; Valleriani 2017); (Chap. 5).

Fine's Cosmographia, in spite of the fact that it never mentions Sacrobosco's name, was in any case associated with the tradition of Sacrobosco's theory of the sphere by later generations, as it was proposed as a possible alternative to Sacrobosco's Sphaera in certain university teaching programs, but also because some of its illustrations were taken up in later editions of the Sphaera, such as certain in-octavo editions presented by Pantin in this volume (Chap. 9).

\section{Cosmology in the Sphaera and in the Cosmographia ${ }^{189}$}

Beyond the similarities and differences between Fine's Cosmographia and Sacrobosco's Sphaera with respect to their content and thematic structure, an important point of comparison is their respective representations of the cosmos and their cosmological principles.

The Sphaera of Sacrobosco was at the time, and up to the seventeenth century, still considered a valid source to teach and learn about the general structure of the

\footnotetext{
${ }^{188}$ On this treatise, see (Eagleton 2009). It is to be noted that, although the theory and the practice of dialing could be seen, according to the order of the parts of the Protomathesis, as the final aim of Fine's mathematical program, it is never described, contrary to astronomy, as the ultimate aim to study mathematics. In the Protomathesis, it appears rather as a domain of application of the knowledge presented in the Cosmographia, or as an extension of it, since Jim Bennett (Bennett 2012) showed that dialing, in this period and context, was also considered a means to gain cosmographical knowledge.

${ }^{189}$ This section is in large part derived from the analysis developed in (Axworthy 2016, 211-38). To avoid repetitions, I will not refer again to this prior study in this section.
} 
cosmos in academic and non-academic circles (Crowther et al. 2015), even if the cosmological stances of the Sphaera were discussed and confronted with alternative theses in many of its commentaries, and this from an early time (Thorndike 1949; Oosterhoff 2015) (Chaps. 6 and 7). ${ }^{190}$ Such discussions may be found, for instance, in the Quaestiones of Pierre d'Ailly (1350-1420) (Sacrobosco et al. 1498) and in the extensive commentary by Francesco Capuano de Manfredonia (Sacrobosco et al. 1499; Shank 2009) (Chap. 4). ${ }^{191}$

These discussions were not marked in the first decades of the sixteenth century by the strong debates raised in the late sixteenth and early seventeenth century on the cosmological models devised by Nicolaus Copernicus (1473-1543), Tycho Brahe (1546-1601), Johannes Kepler (1571-1630), and Giordano Bruno (1548-1600), but nevertheless acknowledged alternative models, such as those postulating the existence of homocentric planetary spheres, in place of the epicycles and eccentric spheres of Ptolemy. ${ }^{192}$ In doing so, they contributed to opening the path to a progressive distancing from Sacrobosco's Ptolemaic universe, qualifying to a certain degree its value for the study of cosmology. This likely helped emphasize its importance for the more practical aspects of astronomy and for its applications to cartography, navigation, and judicial astrology, as shown by the great number of editions containing complementary technical information regarding such domains in the second half of the sixteenth century (Crowther et al. 2015; Oosterhoff 2015; Valleriani 2017). It nevertheless remained for certain later commentators, such as Christoph Clavius (1537-1612) and Francesco Giuntini (1523-1590), an appropriate place to discuss cosmological ideas (Sacrobosco and Clavius 1570; Sacrobosco and Giuntini 1577; Lattis 1994; Pantin 2013b).

Although Fine, through his editorial work on both Sacrobosco's Sphaera and on Peurbach's Theorica planetarum in the years 1515-1516 (Pantin 2010, 2012, 2013a), contributed to the diffusion of the Ptolemaic geocentric cosmological model, he also illustrated, through his subsequent astronomical publications, his awareness of the problems raised by the cosmological models promoted by Sacrobosco and by subsequent followers of Ptolemaic cosmology, such as Peurbach (Aiton 1987; Barker 2011; Malpangotto 2013, 2016), with respect to the principles of natural philosophy.

In 1521, Fine edited the De motu octavae sphaerae of Agostino Ricci (Ricci and Fine 1521), ${ }^{193}$ in which an argumentation is presented against the existence of star-

\footnotetext{
${ }^{190}$ See, for example, the commentaries of Robert Anglicus, Michael Scot or Cecco d'Ascoli in (Thorndike 1949).

${ }^{191}$ Capuano also produced an often reprinted commentary on Peurbach's Theorica planetarum (Peurbach et al. 1495) and which Fine used for his 1515 edition of Peurbach (Pantin 2012).

${ }^{192}$ On the medieval and early Renaissance discussions on homocentric spheres, see (Duhem 19131959, II, 133-39, 146-56, III, 246-54; Carmody 1951; Kren 1968; Goldstein 1980; Grant 1994, 563-66; Lerner 1996, I, 99-110; Barker 1999, 2011; Shank 2002; Omodeo 2014, 77-79).

${ }^{193}$ Agostino Ricci was a converted Jew, a follower of Abraham Zacut, and a Christian kabbalist. He was for that matter the brother of Paolo Ricci, a professor of philosophy at the university of Pavia and later a physician at the court of Emperor Maximilian I, who translated the kabbalistic work
} 
less spheres (such as the ninth sphere admitted by Sacrobosco) (Johnson 1946; Pantin 1995, 442; Nothaft 2017) (94 $^{194}$ and which he followed in its broad outline in the Cosmographia, but also in the other astronomical works he published after 1521, at least through the visual representation of the cosmos he proposed in this context. ${ }^{195}$ As indicated by Francis R. Johnson (Johnson 1946), the discourse of Ricci and Fine on this issue influenced Heinrich-Cornelius Agrippa (Agrippa 1531, F5v-F6r), a friend of Agostino Ricci, ${ }^{196}$ but also Robert Recorde (ca. 1512-1558) (Recorde 1556, 10, 278-79) and Christopher Marlowe (1564-1593) (Marlowe 1604). Ricci and Fine's opinion was also referred to in a critical manner by Giuntini and Clavius in their respective commentaries on Sacrobosco's Sphaera (Sacrobosco and Clavius 1570, 68-69; Sacrobosco and Giuntini 1582, 17-19).

What Fine's Cosmographia provided in this respect in the continuation of Ricci's De motu was a reassessment of the cosmological model presented in the Sphaera and in later accounts of geocentric cosmology concerning the number of celestial

Sha'are Orah by Joseph Gikatilla under the title De porta lucis (Gikatilla and Ricci 1516). This translation was the main source of Johann Reuchlin's De Arte Cabbalistica (Reuchlin 1517). On Agostino and Paolo Ricci, see (Goodrick-Clarke 2008).

${ }^{194}$ As pointed out in the preface of this edition, Fine would have been incited to edit Ricci's De motu by members of the audience to the lectures he gave around 1520 on the motions of the eighth sphere. (Ricci and Fine 1521, 1v-2r): "Quemadmodum eruditissime Dionysi, ea quibus frequenter indigemus, si data investigentur opera, minus fiunt reperibilia: ita nonnunquam (licet insperata) et rebus et temporibus ultro se offerunt accommoda. Cum enim hisce diebus librum nostri Alberti Pighij doctissimi Mathematici, de aequinoctiorum et solstitiorum inventione, item de ratione celebrationis Christiani Paschatis, et ecclesiastici Kalendarij restauratione, quibusdam interpretarer: et accidentia singula quae ex illo accessus et recessus seu trepidationis imaginato motu, a junioribus octavae Sphaerae: peculiariter deputato, in talibus (si res ita se haberet) necessario subsequerentur, niterer ostendere: incidit forte fortuna in manus nostras (opportune tamen) libellus Augustini Ricij, viri in Astronomia non mediocriter eruditi, de ipsius octavae Sphaerae motu, opus et Mathematicis, et Philosophicis deductionibus ornatum. Quem quidem libellum cum nostris ostendassem auditoribus, et in eo pleraque tam de celestium mobilium numero, quam proprijs et indefessis, ipsorum agitationibus, nostris suasionibus quadrantia offendissent: orarunt statim (praecipue Nicolaus a Pratis, nostri amantissimus, et praeter reliquos de nobis bene meritus) ut eundem libellum ipsis, et omnibus Mathematicarum cultoribus, officio artis impressorie communicarem: quod faciliter exoravere."

${ }^{195}$ Fine's diagram of the eight-sphere model is presented in his Theorique des ciels (Fine 1528 and later editions), in all his editions of the Cosmographia, including the frontispiece of the Protomathesis, which was taken up in the unabridged 1542 edition (Fine 1542a); in the frontispiece of the commentary on the Sphaera by Lefèvre d'étaples (Sacrobosco and Lefèvre 1527), and in the In eos quos de Mundi sphaera conscripsit (Fine 1553b). It is also taken up in Charles de Bovelles's Geometrie practique (Bovelles 1551, 53r), for which Fine redrew the illustrations and which he contributed to editing, as well as insure it to be securely printed, as is indicated in the preface of the first edition (dating from 1542): (Bovelles 1551, 2r): “...Orontius Regius Mathematicus.... Duo protinus ingenuè spopondit. se quidem cum primis daturum operam, ut aereis tipis invulgata, plurimis esse visui: figurarum quoque quas ibidem frequentius inscripsi, futurum ligneis in tabellis pictorem. Necnon (quod praecipuum est) adversum mendas observaturum vigiles praeli excubias."

${ }^{196}$ (Agrippa 1531, F5v): "Augustinus Ritius, mihi in Italia summa familiaritate devinctus." 
spheres. ${ }^{197}$ In discussing the order of the cosmos in the first book of the Cosmographia, Fine did not aim to present the various opinions regarding the representation and division of the universe, as did certain previous commentators of Sacrobosco, ${ }^{198}$ such as Pierre d'Ailly (Sacrobosco et al. 1498; Duhem 1916, 168-71), Prosdocimo de' Beldomandi (ca. 1380-1428) (Sacrobosco et al. 1531; Duhem 1913-1959, IV, 294-96; Markowski 1981), Francesco Capuano (Sacrobosco et al. 1508a; Shank 2009) (Chap. 4) in the fourteenth and fifteenth centuries, or Clavius at a later period (Sacrobosco and Clavius 1570), but rather to teach the version he judged to be physically true, as in the case of the mutual disposition of the spheres of water and earth, which he considered to form together a single orb instead of distinct concentric spheres, as was proposed in Sacrobosco's Sphaera in accordance with Aristotle's doctrine of the elements. ${ }^{199}$ Yet on the issue of the number of celestial spheres, in addition to asserting his personal opinion, his intention was to offer a clear rebuttal of the theses he considered false.

It must be noted that Fine, in the Cosmographia as well as in the first pages of the Theorique des cielz (though in a much more concise version), was overall in line with the cosmological model transmitted by Sacrobosco, which is ultimately drawn

\footnotetext{
${ }^{197}$ An example of such discussions in later editions of Sacrobosco is provided by the case of Franco Burgersdijk's edition of the Sphaera (Burgersdijk 1626), considered by M. Buning in this volume (Chap. 11).

${ }^{198}$ For that matter, the first book of Sacrobosco, which is the second shortest chapter of the Sphaera, was often the object of the longest commentaries, given the controversial or problematic character of many of the questions raised by the topics it covered, such as the mutual disposition and relation of the spheres of the elements, particularly of earth and water, the number of celestial spheres, the possibility of contrary motions, as well as the centrality and immobility of the earth. The fourth book also offered the occasion to discuss the status of epicycles and eccentric orbs. See, for example, how Bartolomeo Vespucci, in his annotation to Capuano's commentary to Sacrobosco first published in 1508 (Sacrobosco et al. 1508a), presented the various topics with which dealt Sacrobosco in the Sphaera, in particular those of the first and last books (Sacrobosco et al. 1531, $2 \mathrm{v}$ ): "De ordine namque coelorum, atque elementorum natura, situ, figura, motibus, et quantitate, maxima inter antiquos disceptatio fuit, Quidam totam etheream regionem unum et continuum, quidam plura et discontinua, hi octo ponunt sphaeras, illi novem, alii decem, quidam Solem immediate supra lunam in secundo loco statuerunt, quidam in quarto. Elementarem autem regionem alii ex uno, alii ex pluribus componi credebant quorum alii certum numerum statuerunt, quidam infinita dicebant, aliqui tam elementis quam ipsis corporibus coelestibus varias figuras tribuebant, diversitas autem opinantium arguit difficultatem in re, haec igitur omnia ac multa alia a nostro autore in primo capitulo brevissime declarantur. (In secundo vero), nomina ac definitiones circulorum sphaeram materialem integrantium, cui similem coelestem et illam imaginamur optime pertractat. Tertium vero diversum ortum et occasum signorum, dierum naturalium necnon artificialium varietates, ac terrae habitabilis in climata partitionem, res cognitu difficillimas nobis absolvit. (In ultimo) omnia fere quae in theoricis planetarum longo sermone pertractantur, compendiose perstringit. circa situm orbium, planetarum sphaeras integrantium, ac motum ipsorum, et de causis eclypsium, quae omnia apud antiquos maxime dubia fuerunt, cum aliqui eccentricos et epicyclos negaverint, alii concedentes plures aut pauciores posuerint, alii motum proprium sphaerarum ab occidente in orientem non crediderint, quae omnia aperte satis autor ipse quantum ad introductorium spectat nobis enodabit."

${ }^{199}$ (Fine 1532, I.6, 106r): "Estque ipsius Telluris et Aquae frustulatim circunsparsae unica continuave forinsecus superficies" and (106v): [in marg. Telluris et aquae superficies unica].
} 
in its broad outline from Aristotle's De caelo, with the integration of Christian elements. Fine indeed defended in the first book of the Cosmographia the dual opposition between elementary and celestial regions, which compose together the whole universe, the elementary region representing the corruptible part of the universe and the celestial region, its incorruptible part. ${ }^{200} \mathrm{He}$ accepted the simplicity of the elements, as well as their quadripartition and mutual disposition within the sublunary region, ${ }^{201}$ though he added to this (as was often done) their combination with the four sensible qualities (which Fine also represented as a diagram), ${ }^{202}$ as well as the Aristotelian tripartition of the region of air (Heninger 1977b 32-33, 106-07; Cosgrove 2007). ${ }^{203} \mathrm{He}$ also took up Sacrobosco's argument of divine providence as an explanation for why the sphere of earth is not entirely covered by the sphere of water, judging insufficient the physical arguments traditionally brought forth, such as the absorbent power of earth or the influence of the stars. ${ }^{204} \mathrm{He}$ admitted, more-

\footnotetext{
${ }^{200}$ (Fine 1532, I.1, 102v): "Mundum igitur appellamus, perfectam et absolutam omnium congeriem, vel ornamentum: unde a graecis кó $\sigma \mu \varsigma \varsigma$ dicitur. Divinum certe, et admirandum naturae naturantis opus: finitum tamne, licet infinito simile videatur. Cuius partes principaliores duae, et sensu, et ratione convincuntur: coelestis, et elementaris...sunt elementa, generationibus et corruptionibus continuo vacantia.... Coelestem porro machinam, nihil aliud, quam ipsum ingens coelum vocare solemus, omni prorsus alteratione privatum...." See also (Fine 1528, 2r): "tout le monde est universellement composé de deux principales parties, c'est à sçavoir de la region celeste, et de la region elementaire."

${ }^{201}$ (Fine 1532, I.2, 102v): "Elementaris regio quatuor simplicibus elementis, Igne, Aere, Aqua, Terra, et diversa ex eorundem commixtione generatorum specie resultat. Inter haec autem quatuor elementa, Ignis omnium supremum, Aerem trifariam divisum circulariter ambit, Aer Aquam, Aqua verò Terram." See also (Fine 1528, 2r-v): "Par la region elementaire nous entendons les quatre simples elemens: qui sont le Feu, l'Air, l'Eau, et la Terre: et avec ce tous les corps parfaicts ou imparfaicts, vivans ou non vivans, faicts et composez materiellement ou virtuellement, par l'alteration, corruption, mixtion, union, et vertu desdicts quatre elemens.... La terre est au mylieu de tout le monde, comme centre universel d'iceluy. Environ et par dehors ladicte terres est l'Eau.... L'air environne et circuit rondement ladicte superfice exterieure de l'Eau et de la Terre descouverte.... Le feu finablement environne rondement l'Air, tellement que lesdictz quatre elemens tendent naturellement a rotundité, et font une sphere..." It may be noted that the elements, though maintaining the same disposition, are presented in the Cosmographia in the reversed order.

${ }^{202}$ (Fine 1532, I.2, 103r): "Secundo, quoniam per Philosophum (secundo de generatione) tot sunt elementa, quot primarum qualitatum combinationes possibiles. sed quatuor tantummodo reperiuntur: utpote, caliditatis et siccitatis, quae Ignis propria est: caliditatis et humiditatis quae naturalis Aeri: frigiditatis et humiditatis competens Aquae: frigiditatis et siccitatis ipsi Terrae peculiaris." See also (Aristotle, On Generation and Corruption 330a30-330b6; Meteorologica IV.1378b10-25 and $s q)$.

${ }^{203}$ (Fine 1532, I.2, 103r): [in marg. Aeris cur tres regiones.]. See also (Fine 1528, 2v): "Lequel air es accidentalement distingué en trois interstices, regions principales...." See also (Aristotle, Meteorologica I.3, 340b).

${ }^{204}$ (Fine 1532, I.2, 103v): "De ratione tandem partium ipsius Terrae discoopertatum, nullum sufficiens argumentum, nec ex astrorum attractiva virtute, nec ex Telluris siccitate quae Aquam sorbeat, elici posse videtur: sed solius divinae bonitatis providentia, quae sic Aquas congregavit, et Aridam, hoc est, Terram apervit, ut creatura rationalis ad sui similitudinem et imaginem facta, super eam vivere posset, et cunctis Terrae Marisque frueretur nascentibus." See also (Fine 1528, 2v): "La terre est au mylieu de tout le monde, comme centre universel d'iceluy. Environ et par dehors ladicte
} 
over, that the heavens are made of ether, ${ }^{205}$ as well as their essential incorruptibility and circular motion around the earth. ${ }^{206} \mathrm{He}$ also accepted the sphericity and finiteness of the universe, taking up two of the three arguments given by Sacrobosco to prove that the sky is spherical-namely, the arguments of commodity and of necessity, leaving aside the theological argument of the similitude between the universe and the divine archetype or creator. ${ }^{207}$ Although he mentioned the argument Sacrobosco drew from al-Farghānī in favor of the sphericity of the heavens (according to which the sun would be closer when situated above us and further away when situated nearer to the horizon if the heavens were not spherical), he did not mention the theory of the refraction caused by the vapors of the atmosphere to explain why the sun actually seems closer to us near the horizon, perhaps because he was aware of the falseness of this theory (Pantin 2001). ${ }^{208}$

$\mathrm{He}$ also accepted the division of the heavenly realm into concentric contiguous spheres $^{209}$ according to the different motions that take place in it, as well as the

terre est l'Eau, redigee en moindre quantité, et plus contraincte que sa naturelle disposition ne requiert: et ce pour la decouverture des parties exterieures de la terre, necessaires à l'habitation et vie des vivans: tellement que l'Eau et lesdictes parties descouvertes de la Terre, font une mesme superfice par dehors: tendant par tout endroit comme un mesme corps a rotundité."

${ }^{205}$ (Fine 1532, I.3, 103v): "Ex supradictis relictum est, coelum ab elementis in hoc differre, quod omni corruptiva privetur alteratione, id est, uno et semper eodem modo se habeat, lumen tantummodo perfective suscipiendo: unde quinta a philosophis essentia, hoc est, alterius et perfectioris a quatuor elementis essentiae mervit appellari." See also (Fine 1528, 2v-3r): "autour et environ et environ la region ou sphere elementaire, est la celeste region, environnant et circundant orbiculairement et rondement lesdits quatre elemens, claire, luisante, et decoree de plusieurs estoilles et de plus parfaicte nature que les dessusdits elemens, dont on la nomme la quintessence."

${ }^{206}$ (Fine 1532, I.4, 105r): "Adde, quod nobiliori corpori perfectior debetur motus, qualis est circularis. Fit namque circa medium, cui sola orbium coelestium sphaerica figura convenire videtur, foreque aptissima. Motus enim qui a medio, vel ad medium Universi contingunt, ipsis quatuor elementis solummodo competere supra monstravimus. Motus igitur circularis ipsius coeli proprius esse videtur: sunt enim tot simplicia corpora, quot simplicium motuum occurunt differentiae, et econtra." See also (Fine 1528, 2v-3r) and previous note.

${ }^{207}$ (Fine 1532, I.4, 104v): [in marg. Quod coelum sit sphaericum Prima ratio, à commoditate. Secunda ratio à necessitate]. The fact of leaving aside the similitude argument presented in Sacrobosco to prove the sphericity of the heavens is in line with Fine's will to mainly provide demonstrations that depend on rational arguments (mathematical or physical). When he favors the theological argument over other types of arguments to explain the partial emergence of the earth above the oceans, it is because, as he clearly says, he judged insufficient the physical arguments set forth by his predecessors.

${ }^{208}$ (Fine 1532, I.4, 104v-05r): "Praeterea, quemadmodum dicit Alphraganus, si coelum esset angularis, vel irregularis figurae, cum Sol universum coeli ambitum semel in anno circumgyret, aliquibus anni temporibus solito major notabiliter appareret, alijs vero minor: propter necessariam laterum vicinitatem, et angulorum remotionem."

${ }^{209}$ (Fine 1532, I.3, 103v): "Coelestis porrò machina quinta à philosophis essentia nuncupata, in octo principales orbes, utraque terminativa superficie Mundo concentricos, et sibi invicem contiguos disgregatur: utpote, septem errantium syderum vel planetarum orbes, et Firmamentum omnium maximum." See also (Fine 1528, 3r): "Et tout ainsi que la region elementaire est divisee en plusieurs parties, aussi la celeste machine est separee realement en plusieurs ciels, et orbes particuliers: 
double motion of the heavens, from east to west (for the daily motion of the entire universe) and from west to east (for the particular spheres of the planets and of the firmament). ${ }^{210} \mathrm{He}$ also accepted the order of the planets taken up by Sacrobosco from Ptolemy, despite the uncertainties and debates relating to the order of the sun, Mercury, and Venus (given the quasi-equality of their period of revolution), just adding to this the numbers given by Ptolemy and al-Battāni for the revolution of the fixed stars. ${ }^{211}$ In this context, he included a table to display the physical qualities of the planets. ${ }^{212}$

If Fine assumed that the sphere of earth and the sphere of water together form a unified globe, he admitted, through arguments found in Sacrobosco's Sphaera, that the resulting globe is situated at the center of the universe, ${ }^{213}$ is deprived of motion, ${ }^{214}$

\footnotetext{
c'est à sçavoir en sept orbes deputez aux sept planetes, et le firmament dit la huitieme sphere, où sont les estoilles fixes. Et faut imaginer que ces huit orbes sont uniformes, c'est à dire d'une egale crassitude, contigus l'un à l'autre, et concentriques, c'est à dire ayans un mesme centre avec le monde universel."

${ }^{210}$ (Fine 1532, I.5, 105r-v): "Universa nanque Coeli machina, circa Terram, veluti propria et indefessa Mundi latione, ab oriente per meridiem ad occasum, regulariter circunducitur: completam revolutionem intra 24 horarum intervallum adimplendo. Singuli tamen orbes in diversis temporum spatijs, motu proprio, ab occidente ad ortum contra nituntur." See also (Fine 1528, 3r): "les ciels dessusdicts ont deux principaux mouvemens: dont l'un est commun a tous les ciels, et l'element du Feu, et la plus haute region de l'Air, tournant avec lesdicts ciels comme si ledit mouvement estoit universel, propre, et commun a tout le monde. Lequel mouvement faict sa revolution en vingt quatre heures egales, d'orient en occident, sur les deux poles du Monde, au long de l'equinoctial.... Le second mouvement, est le mouvement particulier du firmament, et des sept Planetes, qui est divers, et irregulier quant au centre du monde, et fait sa revolution en diverses espaces de temps, selon la diversité des orbes, d'Occident en Orient, au contraire du premier, sur les poles du zodiac au long et selon l'ordre des douze signes."

${ }^{211}$ (Fine 1532, I.5, 105v-06r): "stellatus enim orbis in 36,000 annis secundum Ptolemaeum, vel in 23,760 juxta mentem Albategni circulum complet, Saturnus verò in 30 annis, Juppiter in 12, Mars in duobus, Sol in 365 diebus et $1 / 4$ ferè (quae annum faciunt), Venus atque Mercurius veluti ferè Sol, Luna autem in 27 diebus et 8 circiter horis, integram circunductionem absolvit." See also (Fine 1528, 3r): "l'ordre [des huit ciels et orbes particuliers] est trouvé estre tel comme s'ensuit. Le Ciel de la Lune est prochainement environnant l'element du Feu. Au dessus du Ciel de la Lune, est celuy de Mercure. Puis le ciel de Venus, au dessus duquel est le ciel du Soleil. Puis celuy de Mars, apres lequel est le ciel de Jupiter, et finablement le ciel de Saturne, au dessus duquel est le Firmament, le plus grand de tous." As with the enumeration of the elementary spheres, the celestial spheres are presented in the Cosmographia in the reversed order.

${ }^{212}$ (Fine 1532, 104r-v): "ordo planetarum, deinde characteres, postea colores et eisdem signis attributae naturae, sigillatim annotatur."

${ }^{213}$ (Fine 1532, I.6, 106v): "Dico praeterea, quod Terra medium Universi possidet. Nam per ea quae dicta sunt, Terra, velut omnium gravissima, deorsum moveri semper est inclinata: quousque sub caeteris elementis locum possideat infimum, sed omnium locorum abjectissimus est medium Universi, hoc est, Mundi centrum: quicquid enim ab eo recedit, necessum est ascendere, quod ipsi Terrae negatum esse videtur." See also (Fine 1528, 2v): "La terre est au mylieu de tout le monde, comme centre universel d'iceluy."

${ }^{214}$ (Fine 1532, I.6, 106r): "Terra verò motum localem non habet, sed medium Universi possidet immobiliter."
} 
possesses a spherical form, ${ }^{215}$ and is of imperceptible magnitude in comparison to the universe, being therefore assimilable to a geometrical point. ${ }^{216}$

As indicated above, the two chapters in which Fine deviated the most from the cosmological model transmitted by Sacrobosco and by later geocentric cosmological accounts are chapters 3 and 5 of Book I, where he respectively dealt with the number of celestial spheres ${ }^{217}$ and with the mode of transmission of the diurnal motion (and of motion in general) from the primum mobile (or the first moved sphere) to the inferior spheres. ${ }^{218}$

In these two chapters, Fine rejected the systems that admit the existence of one or several mobile spheres deprived of stars above the sphere of the fixed stars on account of their incompatibility with the principles of natural philosophy established by Aristotle (Johnson 1946; Heninger 1977b, 38-39; Pantin 1995, 442; Cosgrove 2007; Nothaft 2017). Such cosmological models, which were by far the most popular in the Middle Ages and in the Renaissance, included therefore not only the representation of the cosmos adopted by Sacrobosco, which postulated the existence of nine concentric contiguous orbs or spheres (with one starless sphere above the Firmament as the primum mobile), but also the models that admitted ten spheres, as illustrated, for example, by the representation of the universe provided in Apian's Liber cosmographicus (Chap. 5) (with two starless spheres above the fixed stars). ${ }^{219}$ Fine took up this discourse in the unabridged version of the second edition of the Cosmographia dating from 1542 in a shorter and slightly modified version (Fine 1542a, 3r, 5r), but not in the abridged version, nor in the later editions. However, he maintained in all these versions the diagram representing the heavens as composed of only eight spheres.

The number of distinct celestial spheres or heavens was an important issue in the development of premodern cosmology, especially in the context of treatises on the Sphaera, since the attribution of a distinct encompassing sphere for each distinct celestial motion stemmed from the will to account for the appearances while offering a cosmological model that conformed to the principles of natural philosophy. In this sense, it held a comparable status to the problem of the reality of Ptolemy's epicycles and eccentric circles in the tradition of the Theorica planetarum, although

\footnotetext{
${ }^{215}$ (Fine 1532, I.6, 107r): "Hanc porro Telluris et Aquae superficiem, rotundam ex omni parte habere figuram, hoc est, quovis modo Terra vel Aqua extrinsecus consyderetur, in rotunditatem undiquaque conglobari, talibus argumentis, seu rationibus persuaderi compellimur." See also (Fine 1528, 2v): "l'Eau et lesdictes parties descouvertes de la Terre, font une mesme superfice par dehors: tendant par tout endroit comme un mesme corps a rotundité."

${ }^{216}$ (Fine 1532, I.6, 106r): "In hunc quippe modum, ut compositus ex Terra et eadem Aqua globus, respectu totius Universi, insensibilis censeatur esse quantitatis, et veluti punctum, centrum ejusdem Universi repraesentare videatur."

${ }^{217}$ (Fine 1532, I.3, 103v-04v): De coelestium orbium numero, atque positione.

${ }^{218}$ (Fine 1532, I.5, 105v-06r): De generali eorundem coelestium motuum expressione.

${ }^{219}$ See Apian's illustration of the various spheres that compose the celestial region (Apian 1533, 4r). A system of ten spheres was also adopted by Conrad Tockler (Chap. 5), as well as by André do Avelar (Chap. 10), among others.
} 
it did not raise as many difficulties as the latter. ${ }^{220}$ As will be shown later, Fine addressed both issues, although he mainly focused on starless spheres.

In this framework, the necessity to postulate the existence of one or several spheres above the Firmament, which was initially held to surmount the seven spheres of the planets and to enclose the whole universe, was due to the fact that the fixed stars (according to the observations of astronomers since Hipparchus (ca. 190 ca. $120 \mathrm{BCE}$ )) were seen to move according to two distinct motions taking place in opposite directions and that (according to Aristotelian physics) it would be impossible for one single material body, especially a body made of pure and immutable matter, to properly move according to two distinct and opposite motions. In other words, as the sphere of the fixed stars was at first attributed the diurnal motion- that is, the east-to-west motion of the entire universe in twenty-four hours, since it is the most exterior of all celestial spheres and thus the only sphere able to carry the whole universe in its motion at once-it could not also be properly and simultaneously attributed the motion of precession of the equinoxes, according to which the fixed stars appeared to move of approximately one degree from west to east every century on the poles of the ecliptic, completing their revolution in thirty-six thousand years (according to Ptolemy, on the basis of Hipparchus's discovery) (Neugebauer 1975, 54, 160, 292-97). For this reason, astronomers and natural philosophers admitted the existence of a sphere deprived of stars above the Firmament, which would be the proper cause of the diurnal motion of the universe. The eastward motion of precession of the equinoxes could therefore be properly attributed to the sphere of the fixed stars, as in the cosmological model depicted by Sacrobosco.

The later admission of a tenth sphere, and hence of an additional starless sphere above the Firmament, was based on the observation of a motion distinct from the diurnal motion and from the precession of the equinoxes in the trajectory of the fixed stars. Indeed, while the fixed stars were already seen to revolve (along with the planets) from east to west in twenty-four hours, and from west to east uniformly by one degree every century according to the precession of the equinoxes, the equinoxes (the first degrees of Aries and of Libra) were also observed to move back and forth in small circles over a period of seven thousand years, resulting in a complete revolution of the eighth sphere in forty-nine thousand years. This motion of oscillation of the equinoxes, which is described in a work entitled De motu octavae sphaerae and regarded as a Latin translation of a treatise by the Arab mathematician Thâbit ibn Qurra (Thâbit ibn Qurra 1960; Neugebauer and Thâbit ibn Qurra 1962), was commonly called by the Latin astronomers trepidation (trepidatio), or motion of access and recess (accessus et recessus) (Neugebauer 1975, 298, 598, 631-34; Nothaft 2017). While trepidation was initially admitted as a correction of the motion of precession of the equinoxes, it came to be considered in the Latin world as a motion independent of the latter, requiring it to be accounted for by a separate sphere, distinct from the ninth, to which the precession of the equinoxes had been

\footnotetext{
${ }^{220} \mathrm{On}$ the difficulties raised over the possibility of epicycles and eccentric circles in the medieval and Renaissance Latin tradition, see, for instance, (Kren 1968; Goldstein 1980; Hugonnard-Roche 1992; Grant 1994, 278-88, 303-08; Lerner 1996, 111-14; Barker 2011) (Chap. 6).
} 
previously attributed (Dobrzycki 2010 [1965]; Neugebauer 1975, 633; Grant 1994, 315-16; Nothaft 2017).221

Although the addition of a ninth and a tenth sphere, just as the admission of partial orbs, stemmed from the will on the part of astronomers to account for the apparent motions of the stars through a system that would conform to the principles of Aristotelian natural philosophy (Morelon 1999) (at least to some of them), ${ }^{222}$ certain reservations were raised with regards to the ontological status of these spheres, as the fact that they did not carry any star made it difficult to prove their physical reality, just as it was to prove the existence of epicycles and of the eccentric spheres. ${ }^{223}$ One of Sacrobosco's early commentators, Robert Anglicus, objected to the existence of a ninth sphere in so far as it contradicted the principle that nature does not do anything in vain, since (as established by Aristotle) the orb only exists in order to carry a star (Thorndike 1949, 147). In line with this objection, some philosophers and astronomers added that if these were only fictional devices aimed to account for the apparent motions of the fixed stars, as did Averroës, Nicole Oresme (ca. 1320-1382), as well as Agostino Ricci they should be banished from the astronomical representation of the cosmos, given that there are other, more simple ways to account for the motion of the fixed stars (Ricci and Fine 1521; Oresme 1968, 488-91; Grant 1994, 319; Lerner 1996, I, 201-08).

The arguments Fine set forth in his Cosmographia against the existence of starless spheres (and therefore against the systems postulating more than eight celestial spheres) are founded on Aristotelian physical principles, but also on the assertion of its incompatibility with judicial astrology. ${ }^{224}$ Following Agostino Ricci's De motu octavae sphaerae (Ricci and Fine 1521), Fine intended to show in chapter I.3 that neither the principle established by Aristotle that one simple body cannot be properly attributed two different motions ${ }^{225}$ (and which is a key-argument for dividing the heavens into different ethereal spheres), ${ }^{226}$ nor the visible motions of the stars,

\footnotetext{
${ }^{221}$ On the reception of the theory of trepidation in Renaissance France, see (Pantin 1995, 435-56).

${ }^{222}$ In these cases, mainly the circularity of celestial motions and the attribution of a particular sphere for each motion.

${ }^{223}$ On the debates concerning the ontological status of eccentric spheres and epicycles prior to Fine, see (Chaps. 5 and 6).

${ }^{224}$ As shown by Pantin (Pantin 1995, 436-37, 440), the attribution of supplementary motions to the eighth sphere, and thus of additional spheres above it, was detrimental also to the computation of calendars, as it required one to accurately determine the duration of the solar year, as well as to calculate the motions of planets, whose positions were determined in reference to the positions of the zodiacal signs.

225 (Aristotle, De caelo I.2, 269a2-9, II.8, 289b31-32; Metaphysics V.6, 1016a5-6).

${ }^{226}$ (Fine 1532 (Cosmographia, I.3), 103v): "Saniores tamen in hoc convenerunt, quod septem sunt orbes planetarum, id est, errantium syderum, utpote Saturni, Jovis, Martis, Solis, Veneris, Mercurij, et Lunae: una cum orbe stellarum fixarum, hoc est, fixam et invariatam inter sese distantiam observantium, quod Firmamentum a fixione syderum appellare solemus. Perceptum est etenim, septem errantia sydera varijs et inaequalibus circunduci motibus, a peculiari stellarum fixarum latione
} 
compel us to believe that there are more than eight celestial spheres in the heavens. ${ }^{227}$ The only additional sphere he was willing to place above the sphere of the fixed stars is the Empyrean heaven, which had been admitted by his predecessors for theological reasons, as the abode of divine and holy beings. ${ }^{228}$ The Empyrean heaven would probably have been admissible for Fine because it was generally understood as deprived of motion, and therefore would not have compelled him to postulate any other motion than those attributable to the stars and to the whole universe. $^{229}$

Appealing to the authority of Plato (ca. 427-347 BCE), of Aristotle, of Ptolemy, and of Averroës — followed, he claimed, by most mathematicians ${ }^{230}$ _Fine described the celestial models which admit more than eight material spheres as dreams or fictions, saying (through a discourse that is very close to Ricci's words) that "those who, against so many renowned authors, have imagined (for some of them) nine and (for most of them) ten spheres, violated, without being forced to it by any compelling reason, the number of solid celestial orbs." ${ }^{231}$ Moreover, Fine said (again paraphrasing Ricci) that the more recent astronomers who defended the ten-sphere

distinctis. At cum stellae non moveantur nisi ad motum orbis (secundo Coeli) necessum est ipsum coelum in tot orbes particulares separari, quot sunt diversi motus astrorum simplices. Si nanque coelum esset continuum, unico simplici motu circunvoleretur (quinto Metaphysicae) quoniam impossibile est idem corpus simplex pluribus moveri simplicibus motibus (primo Coeli)."

${ }^{227}$ (Fine 1532, 103v): "Octo igitur praecipui sunt ponendi coelestes orbes: praedictorum videlicet septem planetarum, et Firmamentum omnium aliorum maximum, tot, tamque decoris syderibus ornatum. Supra quem fixarum stellarum orbem, nec syderum claritate, nec aliqua convincente ratione, coelum aliquod mobile cogimur assignare."

${ }^{228}$ On the function and the status of the Empyrean heaven in medieval theology and cosmology, see (Grant 1994, 371-89; Bezza 2014).

${ }^{229}$ (Fine 1532, 103v): "Admittimus tamen (si universa coelorum non sufficiat machina) coelum empyreum nominatum, felicem beatorum sedem, ne videamur a Theologorum opinione dissentire: id tamen ab omnibus, etiam philosophis, quiescere dicitur."

${ }^{230}$ (Fine 1532, I.3, 103v-04r): "Octonario igitur, cum veteribus, et quidem probatissimis Caldeorum, Aegyptiorum, et Graecorum (qui circa motus astrorum philosophati sunt) erimus contenti mobilium coelorum numero. Nec plures divinus ille Plato in de Repub. Epinomides, et de Thimaeo, Aristoteles secundo Coeli, et ejus Commentator Averrois, et Ptolemaeus primo et septimo magnae constructionis possuisse videntur: imo nec universa mathematicorum schola, paucis admodum exceptis." On this issue, it is interesting to note that the historical studies written on this topic from the nineteenth century show, on the contrary, that most precopernican astronomers postulated the existence of at least nine spheres, if not ten, to account for the anomalies which were observed in the motion of the fixed stars (Duhem 1913-1959, II, 204; Grant 1994, 315-18; Lerner 1996, 205).

${ }^{231}$ (Fine 1532, I.3, 103v-04r): "quorum aliqui novem, plaeriquae decem, contra tot gravissimos authores imaginati sunt, et stabilium coelestium orbium numerum, nulla cogente ratione, violarunt." See also (Ricci and Fine 1521, 19r): "Stultum igitur per Herculem, atque temerarium esset, contra tot gravissimos tum philosophiae tum mathematicae authores novam sententiam proferre: Et statutum jam per tot temporum curricula coelorum numerum, nulla cogente ratione violare." 
system "wrongly attributed such an extravagance to Ptolemy, to King Alfonso and to Johannes Regiomontanus." 232

As Ricci had done when he invoked the authority of Averroës in order to disprove the existence of starless spheres, Fine first appealed to the physical principle of simplicity or economy, stating that, in nature, a system that is simpler or that appeals to a smaller number of causes will always be chosen over a system that is more complex and that admits a greater number of causes than required. ${ }^{233}$ In this context, the precession of the equinoxes would be accounted for through the distinction between the motion of the part and the motion of the whole. ${ }^{234}$ By admitting that the precession of the equinoxes properly belongs to the eighth sphere, Fine supposed that the diurnal motion may be assigned to the latter only in so far as it partakes, just as any other celestial spheres, in the motion proper to the whole universe.

To explain how the universal motion can be transmitted to all the celestial spheres without having to be properly attributed to the last or highest sphere (as this sphere would otherwise need to transfer the diurnal motion to the inferior spheres by dragging the sphere immediately inferior and contiguous to it in its motion, which would then transmit it to the sphere immediately inferior to it, and so on), Fine adopted the causal model defended by Ricci, and before him by Averroës in his commentary on Aristotle's De caelo, according to which the sphere of the fixed stars would move the whole world and each of its parts by transmitting to the inferior spheres the vital virtue necessary for them to start moving spontaneously, according to their individual trajectory. ${ }^{235}$ To defend this thesis, Fine appealed (as did Ricci) to the traditional

\footnotetext{
${ }^{232}$ (Fine 1532, I.3, 103v-04r): "Cujus quidem opinionis extremae, utpote, quae denarium admittit, imo verius somniat orbium coelestium numerum, sunt omnes fere juniores: qui tantae dementiae Ptolemaeum, Alphonsum regem, et Joannem Regiomontanum authores esse mentiuntur." See also (Ricci and Fine 1521, 7r): "Sexta adhuc juniorum hodie late diffusa patet opinio, universis fere hac tempestate astronomizantibus praeter caeteras probata. Cujus autorem Alphonsum regem Castellae esse mentiuntur, atque Joan. de Regio monte." For an account of trepidation and of its reception in the medieval tradition of the Alfonsine tables, see (Dobrzycki 2010 [1965]; Nothaft 2017).

${ }^{233}$ (Fine 1532, I.3, 103v-04r): "Quemadmodum in secundo nostrae Mathesis volumine, ubi particulares coelestium orbium motus tractabimus, suo loco monstrare nitemur: ubi non licere videbis (nisi prorsus orbatis philosophia) nova entia fingere, et multiplici id instrumento salvare, quod unico naturaliter et evidenter permissum est." See also (Ricci and Fine 1521, 19r): "Neminem enim, nisi forte philosophia orbatum, latere potest quantum sit a recte philosophantibus alienum, nova fingere entia: quod enim unico instrumento natura fieri licet, non construitur duplici, teste Aver. 12. Meta., et eo magis quo circa nobiliora versatus entia fueris." See also (Averroës 1562, lib. XII, co. 45, 329G): "Quòd autem sint duo motus à duobus corporibus, non indigetur. quod enim potest natura facere uno instrumento, non facit duobus."

${ }^{234}$ (Fine 1532, I.5, 106r): "Coelorum motus in duplici reperiri differentia, proxime descripsimus: reliquum est, hic declarare, undenam proveniat regularissimus ille ab ortu ad occidentem, et eidem adversus ab occidente ad ortum syderum motus. Primus itaque motus (ut re acu tangamus) totius Universi proprius esse videtur: nec quispiam orbium particularium hoc motu proprie vel seipso circunfertur, sed tantummodo veluti pars ipsius Universi." See also (Aristotle, Physics VI.10, 240b9-17).

${ }^{235}$ (Fine 1532, I.5, 106r): "Virtus itaque motiva hujus primi atque regularissimi motus, per universa diffunditur corpora: quae alio, quam hoc primo motu, propria et intrinseca latione circunferri (super alijs tamen polis et axe) nullum sequitur inconveniens, cum alius sit motus totius (sexto Physicorum) alius vero partis." See also (Averroës 1520, II, com. 42, 121v-22r, com. 71, 141r-v).
} 
comparison between the macrocosm (the universe) and the microcosm (the human being or the living being) to show that the whole body of the universe, just as the body of man or of the animal, can be said to move according to one motion, while its inner parts (the spheres, or the limbs of the living body) move according to distinct motions. ${ }^{236}$ These would nevertheless also be moved with the whole body according to its proper motion. In this framework, since the whole universe, rather than a separate sphere, is said to properly move from east to west, the eighth sphere may be considered as properly moved according to the precession of the equinoxes.

Within such a system, the attribution of the diurnal motion to the whole aggregation of the spheres, and not to one particular sphere, certainly renders obsolete the mechanical model commonly presented during the Middle Ages, notably in Sacrobosco's Sphaera, to account for the transmission of the diurnal motion to the totality of the particular spheres - that is, through the raptus exerted by the higher sphere on the sphere immediately inferior to it and thereby on the rest of the spheres successively (Lerner 1996, 179-80, 188, 195-201; Grant 1997). Nevertheless, the concept of a first moved sphere, or primum mobile, to which the diurnal motion is properly attributed and which would transmit to the other spheres the power to move according to its own motion, ${ }^{237}$ is not entirely done away with, since this model still requires a sphere that receives the vital virtue of the whole universe in the first place and transmits it to the other spheres (including the spheres of

\footnotetext{
${ }^{236}$ (Fine 1532, I.5, 106r): "Exemplum habemus de microcosmo, id est, homine: eo nanque deambulante, et velut seipso constat agitato, non repugnat manum, vel aliud quodvis membrum particulare interea moveri. Cum igitur adgregati coelestes orbes unum corpus juxta Philosophos constituant, et veluti particularia membra ipsum animal (est enim coelum animatum) spirituali ligamento videantur integrare: erit totius coeli motus unus, velut animalis, utpote, is quem ab ortu ad occasum in 24 vulgarium horarum intervallo, suam circunductionem regulariter adimplere dietim experimur. Unde cum vulgares metiantur dies, ac per eundem motum vulgus ipsum reguletur, motus hic diurnus et mundanus ab omnibus appellatur." See also (Ricci and Fine 1521, 9v-10r): “...necessario esse coelum unum numero, quod ex pluribus corporibus, quasi ex membris animal constat: est enim coelum animatum, ubi supra, igitur et unum animal erit...licet tamen isthaec animae coeli ejusque corporis unio, non sit quales perhibentur esse, quae inferiorum sunt copulae animarum, atque corporum. Est itaque diurnus motus totius coeli proprius, nec est partialum sphaerarum quaepiam quae seipsa hoc motu et proprie, sed solum veluti pars totius cietur. Nihil autem inconveniens esse videtur partialia corpora alio, quam totius, motu deferri, uti ait Commentator praeallegato loco, sicuti et manus currentis hominis eam interea ad alteram continuo partem moventis: haec enim manus absque dubio duplici latione agitabitur, altera scilicet tanquam pars totius, altera vero tanquam quippiam seipso constans: diversos enim esse motus secundum quod totius, et secundum quod partium ex sexto physicorum docemur." See also (Averroës 1562, $387 \mathrm{~K}-\mathrm{L})$.

${ }^{237}$ (Fine 1532, I.5, 106r): "Octavus tamen orbis, hoc est, Firmamentum, primum mobile (si velis) nominari poterit, non quod suo motu caeteros rapiat orbes: sed veluti principale membrum, eam motricem vim primitus accipiat, quam postmodum ad caetera videtur emittere coelestia corpora. Quemadmodum cor humanum, a quo virtus vitalis reliquis membris dispensatur, quam primum accipit, unam tamen velut pars cum toto corpore fertur: quasi motiva vis sit in toto corpore, et a corde principaliter diffundatur."
} 
the elements). ${ }^{238}$ The primum mobile, just as the heart, Fine says, is the first organ to receive the vital virtue of the living body, through which it will be transmitted to the remaining limbs or organs. Here, the primum mobile would still correspond to the highest sphere, because it is the most perfect sphere, being endowed with the most uniform motion and being the closest to the Empyrean heaven and to God (Ricci and Fine 1521, 10v; Grant 1994, 322-23; Lerner 1996, 204-05). ${ }^{239}$ Hence, Fine declares that it is "absurd and directly alien to philosophy, against nature and the order of things, to imagine new heavens on the Firmament and to dream of superfluous mobile circles without being compelled to it by reason or persuaded by experience." ${ }^{240}$

In the cosmological model then depicted by Fine, no place is left for the trepidation or the oscillation of the equinoxes observed in the trajectory of the fixed stars, which Fine, like Ricci, simply rejected as physically impossible. As he presented the modern determination of the motions of the eighth sphere, ${ }^{241}$ he declared, explicitly

${ }^{238}$ (Fine 1532, I.5, 106r): "Praeterea, elementum Ignis, una cum supremo Aeris intersticio, hoc quem diximus ab oriente ad occidentem, motu, regulari circunductione rotatur, quod indicant cometae, in eadem suprema Aeris regione plaerunque generati. Ex quo rursum liquet, ipsum motum diurnum non modo coelestibus orbibus, verumetiam elementis esse communem, id est universae Mundi structurae peculiarem."

${ }^{239}$ See also (Ricci and Fine 1521, 10v). For Ricci, who follows Averroës on this point, if the eighth sphere can be considered the source of the motion of the other spheres, it is because it is the noblest and thus the first to associate itself with the motion of the whole universe. In this framework, the proper cause of the motion of the universe is its desire to imitate and to assimilate itself, by the uniformity and eternity of its motion, to the divine mover. On the notion of primum mobile and its status in premodern astronomy, see (Granada 2004).

${ }^{240}$ (Fine 1532, I.5, 106r): "Quam absurdum igitur, et a recte philosophantibus alienum sit, contra naturam, atque rerum ordinem, nulla cogente ratione, vel experimento persuadente, novos supra Firmamentum effingere coelos, et superflua somnia mobilia, pluribus hic dissererem nisi me latius de his alibi (Deo duce) pertractaturum sperarem.” As put forth by Pantin (Pantin 1995, 441-42), this judgment was also held by Albert Pigghe concerning the ninth and tenth sphere in the De aequinoctiorum solstitiorumque inventione; (Pigghe 1520, 20r-v): "Sed nec ego coelum ullum supra firmamentum aut orbem octavum esse crediderim (de beatorum sede hic nullus sermo est) quoniam nemo quantumvis linceus supra firmamentum aliquid videre potuit, nec aliqua adhuc ratio est inventa, quae mihi id persuadere possit....Non sum tam supersticiosus Astronomus ut omnia ita se in coelo habere putem quaecunque ingeniose excogitaverunt Astronomi ad apparentias coelestium motuum salvandas.... Alioqui, etsi omnino credere libeat cuncta ita esse disposita in coelesti illa millitia, qualia ab astronomis nostris comenta sunt et excogitata, sintque vere duo illi motus diversi in octava sphaera, videlicet motus accessus et motus augium et stellarum fixarum, quorum unicuique proprium mobile assignari opporteat, non tamen effingam nonam sphaeram.... Esse itaque supra firmamentum seu octavam spheram aut decimum, aut nonum coelum, nec sensus percipit, nec ratio docet." Fine states, in the preface of his edition of Ricci's De motu, that it is while teaching Pigghe's De aequinoctiorum solstitiorumque inventione that he introduced his audience to Ricci's De motu. On Fine's relation to Pigghe, see (Dupèbe 1999, 528-29; Pantin 2009b); and on Pigghe's approach to astronomy and astrology, see (Vanden Broecke 2003, 85-91). ${ }^{241}$ (Fine 1532, I.5, 106r): "Juniorum tamen quorundam, imo fere omnium, esse videtur, ut stellatus orbis duplici motu, praeter diurnum (quem ficto tribuunt mobili) circunferatur. Primo, ab occidente ad ortum, in quibuslibet 200 annis uno fere gradu: quem motum a somniata nona sphaera pendere 
referring to Ricci's De motu (and agreeing with him on the rate of precession, following al-Battānī), ${ }^{242}$ that trepidation should not only be rejected because it contradicts the physical principle of uniformity of celestial motions, which (given the difformity of such a motion) cannot be rationally seen as going back and forth, but also because its admission would overthrow judicial astrology — that is, would call into question the validity of the astrological art and the predictions of its practitioners. ${ }^{243}$

We do not want to 'titubate' (titubare) ${ }^{244}$ any longer on this inconceivable motion (as when
we follow the opinion of other astronomers), since we declare and openly acknowledge,
driven by reason, that this opinion is the weakest, not to say the falsest of all, and was fal-
laciously imagined by the most pernicious and most ignorant disciples [of astronomy],
causing the greatest damage to human beings by overthrowing judicial astronomy. For I
know that there is nobody (who is not entirely deprived of philosophical knowledge) who
denies that this highly irregular motion of celestial bodies is repugnant to all, as Agostino
Ricci demonstrates in his small treatise. ${ }^{245}$

dijudicant. Secundo, proprio accessus et recessus artificioso motu, quem dixere titubationis, completam revolutionem in 7000 annis absolvendo. Hujus autem motus qualitatem, longum nimis ac taedosium, et huic loco dissonum esset, sigillatim exprimere: consule itaque Purbachium, vel nostrum Albertum Pighium."

${ }^{242}$ (Fine 1532, I.5, 106r): "Albategni vero diligentissimus cum philosophus tum mathematicus, stellas fixas unam circuli partem in quibuslibet 66 annis peragrare, nobis pro certo dereliquit: et quotannis moveri 54 secundis, 32 ter, 43 quar, 38 quintis, et 20 sextis. Cuius opinionis meminit idem Joannes Regiomontanus propositione 6, ejusdem septimi Epitomatis, et quasi eidem assentire, atque eundem Albategni inter alios plurimi facere videtur. Hanc quoque mentem Albategni Augustinus Ricius, vir sanequam eruditus, adeo vivacibus argumentis, gravibus authoritatibus, et firmissima observationum concordantia, nuper sustinere conatus est: ut eandem opinionem veritati propriorem, et inter reliquas magis apparentem judicare cogaris."

${ }^{243}$ On discussions concerning the epistemological status of astrology prior to Fine, see (Chaps. 3 and 4).

${ }^{244}$ Fine then plays with the double meaning of titubatio, which both refers to the motion of trepidation of the equinoxes and to the action of staggering, wavering, or simply hesitating.

${ }^{245}$ (Fine 1532, I.5, 106r): "Nolumus enim super hoc inopinabili motu (quemadmodum cum caeteris aliquando fecimus) ulterius titubare: utpote, qui opinionem hanc omnium debilissimam, ne dicam falsissimam, a pertinacissimis et indoctissimis illius sectatoribus perperam etiam intellectam, atque non sine maxima jactura mortalium judiciariam evertentem Astronomiam, cogente ratione fatemur, et recognoscimus. Neminem enim scio (ni prorsus orbatum Philosophia) qui nesciat motum illum tam irregularem cuilibet coelestium repugnare corporum: veluti praefatus Augustinus Ricius, proprio demonstrat opusculo." See also (Ricci and Fine 1521, 25v-26r): "Confutatio praememoratae juniorum opinionis. Hunc itaque in modum explicata istorum opinione, ad ejus destructionem accedendum est. Omnium enim (quod pace multorum dictum sit) falsissima esse videtur: quam primo, ex naturali philosophia sumptis rationibus, expugnabimus, postea ad mathematicas probationes reccurremus: ultimo rationibus, quibus hanc opinionem probare conantur, respondentes, totam ruere sententiam plane videbis. Motus itaque accessus, atque recessus in corpore coelesti, eo modo quo in octavo ponitur orbe, dari minime potest: tum primo, quia est motus admodum alienus, ab eo qui circularis dicitur, quem quidem proprium esse caelo omnis philosophia solet affirmare: patetque hoc primo Coeli. Dicunt enim isti juniores capita arietis, et librae imaginum tantum, hoc motu describere parvos circulos circa capita arietis, atque librae signorum, immobilium in nona sphaera existentium: capita autem haec, duo sunt indivisibilia puncta: caeterae vero partes totius firmamenti, nullo modo circulum, sed dissimiles magis, tortuosasque figuras 
This argument is far from secondary here, given that judicial astrology, as the part of astronomy whose aim is to determine the influence of celestial motions on the events of the sublunary world, was, as mentioned earlier, regarded at the time as an important part of the activity of astronomers (and of mathematicians in general) within the community; it represented, for most people, one of the main incentives to study astronomy and mathematics in general. The fact that the Cosmographia contains several sections on astrology and on the casting of horoscopes confirms that this was not, to Fine, an anecdotic part of the astronomer's activity. For that matter, Fine openly admitted the influence of celestial motions on sublunary events, considering the motion and light of stars to be the intermediaries by which the virtues of the celestial world are diffused into the sublunary world, as set forth in the chapter II.10 of the Cosmographia ${ }^{246}$ and in his works pertaining more specifically to astrology, such as the Canons des ephemerides ${ }^{247}$ and the De duodecim caeli

describunt: Ita quod nulla stellarum fixarum, quae potissimae, nobilioresque coeli partes esse dicuntur, hoc motu circulum describat mirabile, dij immortales, quidpiam videtur, eos credidisse hunc motum eo se modo habere, ut circularis nulla ratione dici possit, quum ejus orbis nulla fit pars quae circulum perscribere possit. Velle autem tam vasti corporis lationem appellare circularem, eo quod duo dumtaxat in eo puncta sub circulo volventur, dementiae potius, quam rationis esse videtur, etenim nono meta. patet denominationem fieri non debere nisi ab immediato subjecto vel forma: motus autem circularis, necnon et rectus, et si qui alij sunt motus, non a subjecto, sed a forma motuum denominari solent: circularis scilicet eo, quod mota puncta circulares formas, rectus vero, quia sic lata puncta rectilineas describere videntur: si itaque totius motus firmamenti forma conspecta fuerit, non erit circularis: talis enim a circulo quem universa, quae in subjecta sphaera sunt, puncta describere solent denominatur: quod in hoc trepidationis motu minime accidit, nisi in prefatis duobus punctis."

${ }^{246}$ (Fine 1532, II.10, 117r): "ipsa videlicet sydera alium et alium influentiarum effectum in haec inferiora jugiter imprimere, secundum quod aliam et aliam ad totum Coelum obtinent habitudinum, diversoque radiorum influxu haec eadem afficere videntur inferiora." See also (Fine 1542a, 24r): "Quemadmodùm astra propria et intrinseca latione singula Zodiaci peragrando signa, pro varia suorum radiorum in haec inferiora projectione, propriae virtutis sive naturae potestatem multis diversisque modis his rebus imprimunt inferioribus: haud dissimiliter ad primum et universalem motum, veluti partes ipsius Universi, dietim circunducta, pro diversa eorundem syderum irradiatione...horum rursum inferiorum qualitates sensibiliter immutant;" (Fine 1555, II.12, 18v): "Quemadmodùm astra propria et intrinseca latione singula Zodiaci peragrando signa, pro varia suorum radiorum in haec inferiora projectione, propriae virtutis sive naturae potestatem multis diversisque modis his rebus imprimunt inferioribus: haud dissimiliter ad primum et universalem motum, veluti partes ipsius Universi, dietim circunducta, pro diversa eorundem syderum irradiatione...horum rursum inferiorum qualitates sensibiliter immutant" and (Fine 1553a, 4r-v): "Nam quemadmodum sydera (potissimum errantia) Zodiacum ipsum gradatim perambulando, pro diversa suorum radiorum in haec inferiora projectione, proprias vires imprimere, naturalesve potestates multifariam exercere videntur. Non aliter ad universalem motum caeli (quem diurnum, sive primum appellant) absque intermissione revoluta, diversas irradiationes, tum ascendendo super horizontem, aut sub illo descendendo, tum ipsum praeterlabendo meridianum, intra diem naturalem censentur contrahere: et horum propterea inferiorum qualitates, sive naturas, pendenter immutare." On this issue, see (Mosley 2009).

${ }^{247}$ (Fine 1543a, § 17, sig. B5v-6r): "tout ainsi que le Soleil et la Lune et les cinq planetes, faisant leur revolution par leur propre mouvement sous le zodiac, causent divers effects et sensibles mutations es choses inferieures et terrestres, selon la diverse projection de leurs raiz, et diverse disposition des choses naturelles de ça bas, en peragrant de signe en signe, et selon la nature accidentale 
domiciliis. ${ }^{248}$ All this hints to the expectations of students as well as of the audience of the royal lecturers with regards to the purpose of astronomy as it had been the case for the students of the Faculty of the Arts with respect to the study of Sacrobosco's Sphaera. ${ }^{249}$

One of the main problems posed to astrologers by the admission of starless spheres was the complexity this added to the computation of the positions of planets with respect to the zodiacal signs. This matter already raised concerns in relation to the admission of the precession of the equinoxes, since the fact of attributing to the visible stars a proper motion from west to east along the poles of the ecliptic, in addition to the diurnal motion of the universe (as was taught in the Tractatus de sphaera), called into question the possibility of using the firmament as an immobile system of reference to calculate the motions of the planets and to determine their positions and conjunctions in relation to the signs of the zodiac. Therefore, astronomers posited the existence of another set of constellations on the ninth sphere, which would be the invisible images of the constellations of the eighth sphere and which served as a system of reference to determine the positions of the planets and the proper motion of the visible constellations.

As shown by discussions that were raised on this issue since antiquity, ${ }^{250}$ this practice was not only a problem in view of the invisibility of the constellations of the ninth sphere, which made it difficult to use these constellations as a system of reference in order to determine the motion of the planets and of the visible constellations, but also because these invisible stars were attributed an influence on the inferior bodies or at least an impact on the influence of the planets according to their position relatively to these invisible signs. Astrologers, therefore, had to take into account the influence of these invisible signs in their astrological predictions, which would introduce additional complications in the establishment of astrological charts. For example, certain medieval astrologers, such as Pietro d'Abano (ca. 1257-1316) in the Conciliator differentiarum philosophorum (Pietro d'Abano $1520,14 \mathrm{r}$ ), attributed an influence to both the visible signs and the invisible signs,

desdits 12 signes du zodiac: pareillement lesdits luminaires et planetes, en tournant environ et au tout de la terre par le premier et universel mouvement de tout le monde, d'orient par le mydi en occident, dedans le temps et espace de 24 heures (que nous appellons jour naturel) causent de rechef tous les jours de l'an divers et particuliers effects selon qu'ils sont en orient ou occident, et notablement eslevez ou deprimez sous la terre, et qu'ils ont plus forte ou debile irradiation sur lesdites choses de ça bas."

${ }^{248}$ (Fine 1553a, 4r): "Nam quemadmodum sydera (potissimum errantia) Zodiacum ipsum gradatim perambulando, pro diversa suorum radiorum in haec inferiora projectione, proprias vires imprimere, naturalesve potestates multifariam exercere videntur: Non aliter ad universalem motum caeli (quem diurnum, sive primum appellant) absque intermissione revoluta, diversas irradiationes, tum ascendendo super horizontem, aut sub illo descendendo, tum ipsum praeterlabendo meridianum, intra diem naturalem censentur contrahere: et horum propterea inferiorum qualitates, sive naturas, pendenter immutare."

${ }^{249} \mathrm{On}$ the relation between astrology and cosmography in the sixteenth century (as considered through the case of academic and courtly environment of Louvain), see (Vanden Broecke 2003, $113-18$ and 129-33).

${ }^{250}$ On these earlier discussions, see (Duhem 1913-1959, II, 191-92). 
and considered that the influence of the signs of the zodiac was stronger when the visible and the invisible signs were superposed (Chap. 4). ${ }^{251}$ But as the signs of the ninth sphere are invisible, it would be very difficult in practice to decide when the superposition takes place. Hence, for Fine, the fact of rejecting the existence of starless spheres (and of partially rejecting the cosmological system adopted by Sacrobosco) was not only a question of safeguarding Aristotelian cosmology, but also a question of guaranteeing the validity of the calculations and of the predictions of astrologers.

Although this argument only makes a small appearance in Fine's rebuttal of the existence of starless spheres, it would be highly significant in this context and may have even been his main incentive to reject starless spheres. ${ }^{252}$ This could very likely have been the case for Ricci himself, who was a court astrologer at Casale Monferrato and, as mentioned above, a friend of Cornelius Agrippa (Johnson 1946; GoodrickClarke 2008). Indeed, in his De motu, Ricci clearly questions the ability of the more recent astrologers to offer a solid prognostic on the basis of the nine- or ten-sphere system, denouncing thereby the damage these systems caused to the practice of judicial astrology. ${ }^{253}$ This argumentation seems to have been influenced by the Disputationes adversus astrologiam divinatricem of Giovanni Pico della Mirandola (1463-1494), who, in book VIII of this treatise, used the uncertainty concerning the numbers of the celestial spheres and the problems raised by the admission of immobile and invisible signs as additional arguments to dismiss judicial astrology. ${ }^{254}$ Ricci referred to this discourse in the above-mentioned section of his De motu

\footnotetext{
${ }^{251}$ As shown then by Duhem (Duhem 1913-1959, IV, 239-40), this conception is not original, since it was beforehand expounded by Bernard of Trilia, disciple of Albertus Magnus, in his Questions on Sacrobosco's Sphaera (Sacrobosco n.d., f. 75, col. d).

${ }^{252}$ With regards to the question of the place of astrology in the cosmological reforms of the sixteenth century, see (Westman 2011).

${ }^{253}$ (Ricci and Fine 1521, 20v-21r): “...nec contineri quicquam veritatis, nisi forte id casu quoddam acciderit in hisce praedictionibus, quae juxta signa novae vel decimae sphaerae, vel immobilia fiunt, cujusmodi sunt juniorum mobile coeli imagines omnino negligentium universa pronostica. Hincque videtur illud esse, quod tam pauca in hodiernis pronosticis comperiantur vera, cum omnes (Arabibus quibusdam exceptis) errantes stellas illuc locare nituntur, ubi imnime consistunt. Nec in locandis nituntur, ubi minime consistunt. Nec in locandis duntaxat sideribus eos errare affirmamus: sed etiam in revolutionum ascendentibus a veritate tantum discedere deprehenduntur, quantum inter quamlibet radicem atque revolutionem octava sphaera proporio motu lata fuerit, tantoque ampliorem fieri errorem, quanto a sua quaque radice, loco solis uti oportet: qui quoniam non est ubi isti imaginantur, ideo nec talis coeli pars oriri potest, qualem isti ex loco solis excerpere conantur, sed tot amplius, minusve partium oriri necesse erit, quot inter caput mobilium vereque existentium signorum, et caput eorum, quae imaginationis ope adinventa sunt, partes fuerint."

${ }^{254}$ (Pico 2005, 642-47): Cap. I: "Incertum esse numerum corporum superiorum, penes quae iuxta astrologos fati decernendi potestas est;" Cap. 2: "Si supra octavam sphaeram alia sit, falsam esse veterem astrologiam, si nulla, quam si sit, nona ruere omnino necesse est." A good synthesis of Pico's critical approach to judicial astrology, and especially to the practice of fifteenth-century Italian astrologers (though not specifically on the impact of the nine- or ten-sphere systems on judicial astrology), see (Vanden Broecke 2003, 55-80).
} 
(Ricci and Fine 1521, 18r, 21v), ${ }^{255}$ yet not in order to dismiss the validity of astrology, but rather to dismiss the systems postulating nine or ten spheres.

Yet whether or not this was the main incentive for Fine's rejection of starless spheres, this discussion was also an occasion for him to reassess the traditional representation of the cosmos in its relation to the principles of Aristotelian natural philosophy (which were followed by Sacrobosco with regard to the general structure of the cosmos and the nature of the elements) as well as of the role of the astronomer in determining the physical order of the universe.

With respect to the function of the starless spheres in the astronomer's apprehension of the celestial order, an apparent tension however emerges in Fine's discourse in the Cosmographia, since although he partly based his dismissal of starless spheres on their incompatibility with the principles of natural philosophy, he concluded chapter 5 (immediately after asserting the absurdity of trepidation) by conceding the usefulness of the astronomer's fictions to account for the irregularities of the visible motion of the stars.

So all the things which the wisest astronomers have thought up above the eight sphere were only the imagination of immobile circles, through which they were able to regulate the motion of the Firmament and of the other orbs which are inferior to it. The same judgement should be passed on the particular orbs of the errant stars - that is, the epicycles and the eccentric spheres, and their very particular motions-as well as on similar inventions. These were subtly invented for the sole purpose of saving the apparent variety of each motion and to render the quantity of their irregular motions computable by the power of geometry. ${ }^{256}$

This discourse held an important place in Fine's thought, as it first appeared in the Theorique des cielz at the beginning of the chapter on the motion of the eighth sphere (Fine 1528, 33r-v) $)^{257}$ and came up later on several occasions, notably in the

\footnotetext{
${ }^{255}$ (Ricci and Fine 1521, 21v): "Huc accedit sicut quam optime dicit Jo. Picus Mirandulanus in eo libro, quem in astronomos confecit, quod scilicet quicquid antiqui de signorum naturis tradiderint, hoc de signis veris octavae sphaerae experti sunt."

${ }^{256}$ (Fine 1532, I, 5, 106r): "Quicquid ergo prudentiores Astronomi super octavum orbem finxerunt, fuit sola immobilium circulorum imaginatio: ut per ipsos, et Firmamenti, et reliquorum inferiorum orbium motus regulare valerent. Idem quoque habendum est judicium, de particularibus errantium syderum orbibus, utpote epicyclis et eccentricis, atque tam diversis eorundem motibus, et his similibus inventis: quae solum ad salvandam evidentem singulorum motuum varietatem, et redigendam ad calculum irregulatum eorundem motuum quantitatem, ex ubertate Geometriae sunt admodum subtiliter excogitate."

${ }^{257}$ (Fine 1528, 33r): "il a esté imaginé par les modernes Astronomes un mouvement composé de trois particuliers, point le mouvement de la huitiesme sphere: dont l'un est attribué au premier mobile, ou quel est l'eclyptique fixe, et est le regulier mouvement de vingt quatre heures: l'autre est attributé à la neufiesme sphere, imaginee entre ledit premier mobile et le firmament: lequel mouvement est d'Occident en Orient, au long du zodiac fixe: Le tiers est une maniere de titubation, propre à ladicte huitiesme sphere: laquelle titubation a esté excogitee pour reformer la variété et irregularité du mouvement dessusdit, comme l'on a faict par epicycles et eccentriques aux sept planetes."
} 
second edition of the Cosmographia (unabridged version), ${ }^{258}$ but also in the 1532 edition of the Cosmographia when dealing with the sun's theorica. ${ }^{259}$ It was also put forward in an unfinished manuscript draft of a work entitled Speculum astronomicum (Fine n.d.), which was intended to present the theoretical principles, the mode of fabrication, and the use of an instrument to determine planetary positions, and which directly referred to the Cosmographia. As Fine indicated in this text, starless spheres would have the same status as Ptolemy's epicycles and eccentric spheres, ${ }^{260}$ all corresponding to abstract geometrical devices used by astronomers to account for the apparently irregular motions.

\begin{abstract}
What one generally needs to know first is that all the things which the wisest astronomers have imagined concerning the number, the figure and the various motions of the celestial orbs have only been so in order to calculate the apparent irregularity of the celestial motions. And nobody would think (aside from he who is entirely deprived of philosophical knowledge) that each of these things really exists, since they were only invented through a geometrical and purely imaginary theory so that the true motions of the stars could be obtained. Indeed, the particular orbs of the heavens, which move around the center of the world (as may be seen from the Theory of the planets) would be about twenty-six, that is, leaving aside the epicycles and small orbs situated around them, which are adapted to the diversity of the motions. We have shown sufficiently clearly in the first book of our prior Cosmographia, and we will reveal it elsewhere in a more complete treatise (if God allows it), how absurd and directly alien to philosophers it is to admit their existence. We have to concede, therefore, whether we want it or not, that the divine and incomprehensible wisdom
\end{abstract}

\footnotetext{
${ }^{258}$ (Fine 1542a, 3r): "Nec supra Firmamentum, aut claritate syderum, aut aliqua convincente ratione, Caelum aliquod mobile imaginari compellimur: ni forsitan circulos aliquot immobiles, eruditiones aut calculi gratia, nobis effinxerimus. Octonario igitur cum Platone, Aristoteles, Ptolemaeo, caeterisque probatissimis authoribus (qui circa motus astrorum philosophati sunt) mobilium orbium erimus contenti numero;" (5r): "Quàm absurdum igitur et à rectè philosophantibus alienum sit, contra naturalem rerum ordinem, nulla cogente vel ratione vel experientia, novos supra Firmamentum somniare mobiles orbes (nisi id gratia lucidioris effingatur intelligentiae) cuivis sanae cogitationis relinquimus dijudicandum. Quiquid enim super octavum orbem prudentiores excogitarunt astronomi, fuit sola circulorum ad contemplationem motus ipsius octavi orbis necessariorum imaginatio. Idem quoque velim habeas judicium, de peculiaribus errantium syderum lineamentis, circulis, aut orbibus (quibus tota referta est planetarum theorica) et his similibus inventis, ad contemplandam apparentem in motibus diversitatem, et in fideliorem aliquem calculum redigendam, ex ubertate Geometriae subtiliter admodùm excogitates."

${ }^{259}$ (Fine 1532, IV.1, 131r): "theoricam motus ipsius Solis, ad salvandam, supputandamque motus eiusdem Solis circa Mundi centrum observatam irregularitatem subtiliter excogitatam."

${ }^{260}$ This is also perhaps the case, for Fine, for the circles that divide the worldly sphere, which are defined in the second book of Sacrobosco's Sphaera as imaginary. Indeed, there is a certain ambiguity in the Cosmographia as to whether these "spheres thought up above the eighth sphere" and which "were the imagination of immobile circles" correspond, for Fine, to the starless spheresnamely to the fixed zodiac and to the primum mobile - or rather to the great circles dividing the worldly sphere according to Sacrobosco's Sphaera, such as the equinoctial and the colures. Yet in the Theorique des cielz, trepidation (and thus the starless sphere its admission led to postulate) is explicitly described as a fiction invented by astronomers to account for the irregularity of the motions of the stars and assimilated in this respect to the partial orbs; (Fine 1528, 33v): "laquelle titubation a esté excogitee pour reformer la variété et irregularité du mouvement dessusdit, comme l'on a faict par epicycles et eccentriques aux sept planets." It remains, in any case, clear that Fine also reduced, in the Cosmographia, the starless spheres to geometrical fictions, just as he did for epicycles and eccentric spheres.
} 
kept to itself the eternally admirable quality of the celestial motions, but has, in its merciful benevolence, granted to men the ability to apprehend and eventually calculate the quantity of these motions through a geometrical and abstract discourse."261

This passage was entirely crossed out in the manuscript, but was initially placed within the first proposition of the treatise and shows Fine's eagerness at this point to discuss the ontological status of the constructions necessary for astronomers to calculate and predict the apparent positions and trajectories of stars. As he explains it then, if starless spheres (as well as partial epicycles and eccentric spheres) are not physically real, they would be regarded as useful by astronomers for determining the positions and trajectories of the stars and planets, given that the human mind was not endowed by God with the ability to apprehend the true quality of the celestial order, though it was made able to access the true motions of the stars - that is, their visible position from the earth at any moment of their cycle-by means of geometrical and abstract devices.

Therefore, if, on one hand, Fine invited astronomers in the Cosmographia to dismiss starless spheres because they contradict the principles of natural philosophy and because they introduce unnecessary complexity into the practice of astrologers, he acknowledged, on the other hand (in this text as in the Cosmographia), the utility of such fictions, alongside epicycles and eccentric spheres, to account for the visible celestial motions, since the true causes and structure of these motions would remain incomprehensible and thus hidden to the human mind.

Yet from what Fine said in the Cosmographia in reference to Ricci's De motu, this would not justify the admission of starless spheres beyond the starry heaven, since he held them not only as contradictory to the principles of natural philosophy, but also as mathematically irrelevant, since they would not be necessary to account for the variety of the motions of the fixed stars. Furthermore, he considered starless spheres as certainly more problematic than partial orbs in regard to the validity of judicial astrology, given that the knowledge of the motion of the fixed stars is more important to determine the true positions of planets in relation to the zodiacal signs than the causes of their stations and retrogradations.

Hence, although the astronomer would not be able to fully access the true order of the heavens, he should, to the extent of his abilities, still attempt to determine the nature of celestial substances as much as it is possible by always choosing the hypothesis that is most simple and best conforms to the principles of natural

\footnotetext{
${ }^{261}$ (Fine n. d., 4v): "In primis itaque illud in universum est notandum: quicquid prudentiores astronomi de multiplici coelestium orbium numero, figura, et motu sunt imaginati, ad supputandam observatam coelestium motuum irregularitatem fuisse tantummodo repertum. Neque putet quispiam (in forsitam orbatus philosophia) singula re ipsa constare, quae geometrica, et pure imaginaria ratiocinatione, ut veri syderum moti obtinerentur, solum excogitata sunt. Essent enim particulares coelorum orbes, mundi centrum ambientes, (ut ex planetarum licet videre theorica) numero circiter 26; etiam praeter epyciclos, et circumpositos orbiculos, ad motuum varietatem convenientes. Quòd quàm absurdum, et à recte philosophantibus alienum existat, libro primo noster precedentis Cosmographiae, et alibi satis aperte mostravimus, et pleniori tractatu (se concedat altissimus) elucidaturi sumus. Confiteamur igitur, velimus nolimus oportet, Divinam illam et incompraehensibilem sapientiam, coelestium motuum semper admirandam sibi reservasse qualitatem: hominibus tamen, sua clementi bonitate, hanc contulisse gratiam, ut geometrico, et abstractivo discursu, praedictorum motuum quantitatem obtinere, tandemque supputare $<$ hujusce $>$ valerent."
} 
philosophy. This is why, in the Theorique des cielz, although Fine taught Peurbach's theory of planetary motions and expounded the motion of trepidation, referring in this process to separate spheres for both precession and trepidation (as Peurbach had done), he represented the heavens as divided into only eight spheres at the beginning of the treatise (Fine 1528, 3r), just as he did in the frontispiece of the 1527 edition of Lefèvre's commentary on the Sphaera and in the various editions of the Cosmographia.

What Fine then seemed to condemn in the Cosmographia and in the Speculum astronomicum is not so much the use of geometrical fictions for calculational purposes, but rather the fact of admitting them as physically real and also of appealing to them, even as calculational devices, when these are not necessary to account for the apparent motions of the heavens, especially when they have a role to play in the determination of the planets's influence in the framework of judicial astrology, as in the case of the ninth sphere.

This discussion, therefore, brings forth the vexed issue of the reality and of the function premodern astronomers attributed to partial orbs and starless spheres in the description of the celestial order, be it according to the model defended by Sacrobosco or that transmitted by Peurbach. ${ }^{262}$ Now, if, in view of the incompatibility of the Ptolemaic astronomical model with the principles of Aristotelian natural philosophy, certain astronomers and philosophers restricted these models to mere calculational devices, which would only be fit to predict the apparent positions of the stars from the earth and to cast tables of ephemerides, this cannot be straightforwardly interpreted as a sign that they did not attribute to astronomy the right and the duty to investigate and to describe the true order of the heavens to the extent that it is humanly possible. ${ }^{263}$ This is marked in particular by Ptolemy's will to maintain the circularity of celestial motions and by his physical account of partial orbs in the Planetary hypotheses (Goldstein 1967; Morelon 1999), which was known to the Latin medieval and Renaissance astronomers through derived Arabic cosmological accounts (Lerner 1996, I, 94-99) (Chap. 6). As shown in particular by Peter Barker, there are also various examples, in the Middle Ages and in the precopernican Renaissance, of astronomers attributing physical reality to partial orbs and starless spheres (Barker 2011) (Chap. 6). This may also be confirmed by the fact that, in Almagest XIII.2, Ptolemy dismissed the opinions of those who rejected certain astronomical models (notably his own) on account of their complexity by qualifying the ability of the human understanding to decide on the degree of simplicity that is appropriate to divine realities (as celestial bodies and motions were considered to be) on the basis of what is simple in the elementary world ${ }^{264}$ This discourse of Ptolemy

\footnotetext{
${ }^{262}$ This is the great question raised by P. Duhem, in $\Sigma \hat{\omega} \zeta \varepsilon \varepsilon \nu \tau \dot{\alpha} \varphi \alpha ı \cos \varepsilon \nu \alpha$ (Duhem 1908), in which he deploys an instrumentalist interpretation of precopernican astronomy.

${ }^{263}$ This has been shown by several historians of astronomy in the last decades, among which (Lloyd 1978; Jardine 1979, 1982; Westman 1980; Barker and Goldstein 1998; Morelon 1999; Barker 2011).

${ }^{264}$ (Ptolemy 1984, XIII.2, 600): "Now let no one, considering the complicated nature of our devices, judge such hypotheses to be over-elaborated. For it is not appropriate to compare human [constructions] with divine, nor to form one's beliefs about such great things on the basis of very
} 
did not intend to fully validate the physical reality of his cosmological system, but it certainly aimed to restrict attacks on its physical possibility.

For Fine as well, the fact that it is not possible for the human mind to grasp the true quality of celestial motions in no manner means that the astronomer should not, as much as possible, attempt to investigate and describe the true order of the cosmos. This is not only indicated by his assertion of the physical impossibility of starless spheres and by his will to maintain an eight-sphere system in the general structure of the heavens (even in his adaptation of Peurbach's Theorica), but is also suggested by his definition of astronomy in the preface of the 1532 edition of the Cosmographia, where astronomy (then specifically identified as theoretical or mathematical astronomy) is said to study the "celestial globes, stars, their motions, their accidents and things of the kind," 265 and more generally "the celestial body itself, the most illustrious of all bodies, which is absolutely deprived of alteration, is situated in the highest place, is the noblest and is endowed with circular motion, that is, with the first and most perfect of all motions," 266 a description which is derived from the Aristotle's De caelo and which states the physical qualities of the celestial body. Moreoever, even if Fine's rejection of starless spheres was primarily motivated by the will to safeguard astrology, this motivation never seems entirely separate from the will to determine the real position of the fixed stars in relation to the earth and the planets, since the very influence of the planets (itself considered physically real) - in other words the action operated by their light, heat, and motion (plus

dissimilar analogies. For what [could one compare] more dissimilar than the eternal and unchanging with the ever-changing, or that which can be hindered by anything with that which cannot be hindered even by itself? Rather, one should try, as far as possible, to fit the simpler hypotheses to the heavenly motions, but if this does not succeed, [one should apply hypotheses] which do fit. For provided that each of the phenomena is duly saved by the hypotheses, why should anyone think it strange that such complications can characterise the motions of the heavens when their nature is such as to afford no hindrance, but of a kind to yield and give way to the natural motions of each part, even if [the motions] are opposed to one another? Thus, quite simply, all the elements can easily pass through and be seen through all other elements, and this ease of transit applies not only to the individual circles, but to the spheres themselves and the axes of revolution. We see that in the models constructed on earth the fitting together of these [elements] to represent the different motions is laborious, and difficult to achieve in such a way that the motions do not hinder each other, while in the heavens no obstruction whatever is caused by such combinations. Rather, we should not judge 'simplicity' in heavenly things from what appears to be simple on earth, especially when the same thing is not equally simple for all even here. For if we were to judge by those criteria, nothing that occurs in the heavens would appear simple, not even the unchanging nature of the first motion, since this very quality of eternal unchangingness is for us not [merely] difficult, but completely impossible. Instead [we should judge 'simplicity'] from the unchangingness of the nature of things in the heaven and their motions. In this way all [motions] will appear simple, and more so than what is thought 'simple' on earth, since one can conceive of no labour or difficulty attached to their revolutions."

${ }^{265}$ (Fine 1532, 102v): “...consyderat Astronomia, utpote, coelestes globos, sydera, eorum motus, et passiones, ac ejuscemodi."

${ }^{266}$ (Fine 1532, 102r): "Nam subjectum Astronomiae est ipsum coeleste corpus, inter omnia corpora praestantissimum, omni prorsus alteratione privatum, supremo et nobiliori loco, motuque circulari omnium motuum priori ac perfectiori decoratum." 
occult influences, when they were admitted) on the events occurring in the elementary world — is determined by their disposition in relation to the zodiacal signs. ${ }^{267}$

The discourse presented by Fine in the first edition of the Cosmographia concerning the number of celestial spheres thus shows that, in the context of a teaching on the sphere tacitly based on Sacrobosco's Sphaera, which he approached with the intention of offering a properly up-to-date and complete teaching of its theoretical and practical aspects, he considered it important to establish the representation of the cosmos on a physically acceptable foundation, in particular as it played a crucial role for him in asserting the validity of astrology.

Rejecting in this manner the general structure of the universe and the type of celestial causality (raptus) defended by Sacrobosco, among many others, Fine's Cosmographia demonstrates again the openness of the textual design of the Tractatus de sphaera, which allowed the transformation of various part of its content, notably concerning its cosmological stances, without disturbing the general structure of its teaching on the theory of the sphere (Oosterhoff 2015; Valleriani 2017).

\section{Conclusion}

The relation between Oronce Fine's astronomical work and Sacrobosco's Sphaera, from the edition of the Sphaera in 1516 to the Cosmographia in 1532, instantiates the royal lecturer's various talents as a mathematician, a professor of mathematics, a cartographer, a maker of scientific instruments, an editor, and an engraver. Through his early contributions to the diffusion of the Sphaera in a format accessible to students, Fine demonstrated his active commitment to the mathematical curriculum of the Faculty of the Arts in his first teaching years at the Collège de Navarre. As he started to teach mathematics as a royal lecturer about fifteen years later, he offered his new audience a renovated teaching of spherical astronomy rooted in Sacrobosco's Sphaera, in which he included the practical notions necessary to its application in judicial astrology, cartography, nautical geography, and dialing. Given the strong emphasis Fine placed on practical knowledge in the Cosmographia, this work constituted an important element of his project to transform the traditional mathematical curriculum.

In its relation to the Sphaera, the Cosmographia cannot be straightforwardly considered a commentary since it does not feature Sacrobosco's text. However, it integrated many aspects of Sacrobosco's teaching in its content and format, for which Fine's treatise could be considered an appropriate alternative to the Sphaera in certain teaching programs of sixteenth-century institutions. For that matter, if Fine innovated on his 1516 edition of Sacrobosco's Sphaera with regard to the layout of the text and by the inclusion of a few tables, ${ }^{268}$ the Cosmographia offered a complete renovation of the content of the traditional teaching of spherical astronomy from which the very name of Sacrobosco is entirely absent.

\footnotetext{
${ }^{267}$ On the relation between astrology and cosmology in the sixteenth century, see also (Chap. 5).

${ }^{268} \mathrm{On}$ innovations of this type, see (Chap. 9).
} 
Within the Protomathesis, the theory of the sphere appears as a core teaching, demonstrating the necessity of arithmetic and geometry to study astronomy while providing the necessary principles for the study and practice of cartography, judicial astrology, and gnomonics. The relation of the Cosmographia to the other parts of Fine's mathematical teaching, as well as his recurrent assertion of the higher necessity of astronomy for the contemplation of the Creation and of the Creator himself, thus allowed him to present this discipline as the crowning of the traditional quadrivium, as well as the condition of its fruitfulness.

The Cosmographia was also the occasion for Fine to express his opinion on the order of the cosmos and on the relation between mathematics and natural philosophy, as was the teaching of Sacrobosco's Sphaera for several of its commentators. Showing the importance of offering a correct cosmological system in order to safeguard astrology, given its dependence on the knowledge of the true relation of the planets to the zodiacal signs, Fine also addressed the expectation of many students of the Faculty of the Arts at the time with regard to the applications of astronomy and of Sacrobosco's Sphaera, notably for the practice of medicine.

Fine's Cosmographia, which represented a means of disseminating Sacrobosco's teaching on the sphere that differed in its form and intention from proper editions and commentaries on the Sphaera, also gives us an illustration of the various manners in which the content of this thirteenth-century elementary treatise was adapted to the needs of the sixteenth-century reader and how it contributed to the transformation and to the promotion of mathematical teaching in Renaissance France. While the name of Sacrobosco did not explicitly appear in works such as Fine's Cosmographia - which in Fine's case reveals an ambiguous relation to a source he himself edited and taught during his years at the Collège de Navarre-, the Sphaera remained a clearly identifiable and stable source at the time for the study and the application of the theory of the sphere, through which it was able to maintain, in European academic and non-academic scientific culture, the status of universal reference for the introductory teaching of astronomy until the seventeenth century.

\section{References}

Agrippa von Nettesheim, Heinrich Cornelius. 1531. De incertitudine et vanitate scientiarum declamatio invectiva, qua universa illa sophorum gigantomachia plus quam Herculea impugnatur audacia: doceturque nusquam certi quicquam, perpetui, et divini, nisi in solidis eloquijs atque eminentia verbi dei latere. Köln: Melchior Novesianus.

Agrippa, Heinrich-Cornelius. 1970. Opera. Hildesheim/New York: Georg Olms.

Aiton, Eric J. 1987. Peurbach's Theoricae Novae Planetarum: A translation with commentary. Osiris 3: 4-43. https://doi.org/10.1086/368660.

Aked, Charles K. 1990. Biography of Oronce Fine. In Oronce Fine's first book of solar horology, ed. Peter I. Drinkwater. Shipston-on-Stour: Peter I. Drinkwater.

Almeida, Bruno. 2017. For the benefit of cosmography: Notes on the contributions of Pedro Nunes to astronomy. Cahiers François Viète 3: 37-60.

Apian, Peter. 1524. Cosmographicus liber Petri Apani Mathematici studiose collectus. Landshut: P. Apian. Repr. 1533. Cosmographicus liber Petri Apani Mathematici, iam denuo integritati restitutus per Gemmam Phrysium. Item eiusdem Gemmae Phrysij Libellus de Locorum describendorum ratione, et de eorum distantijs inveniendis, nunquam ante hac visus. Antwerp: Arnold Birckman; Repr. 1540. Cosmographia Petri Apiani. Antwerp: Arnold Birckman. 
Avelar, André (do). 1593. Spharae Utriusq[ue] Tabella ad Spharae huius mundi Faciliorem Enucleationem. Coimbra: Antonius Barrerius.

Averroës. 1520. Libri IIII de coelo et mundo, subnexis eius duobus illis De generatione et corrup., cum singulorum epitomis hactenus non impressis ac Aver. fidiss. Interprete. Papie: Burgofrancus.

1562. Aristotelis metaphysicorum libri XIIII cum Averrois Cordubensis in eosdem commentarijs, et epitome. Theophrasti metaphysicorum liber. Marci Antonij Zimara contradictionum solutiones, in hoc Metaphysicorum libros. Venice: Giunta.

Axworthy, Angela. 2009. The epistemological foundations of the propaedeutic status of mathematics according to the epistolary and prefatory writings of Oronce Fine. In The worlds of Oronce Fine. Mathematics, instruments and print in Renaissance France, ed. Alexander Marr, 31-51. Donington: Shaun Tyas.

- 2016. Le Mathématicien renaissant et son savoir. Le statut des mathématiques selon Oronce Fine. Paris: Classiques Garnier. https://doi.org/10.15122/isbn.978-2-406-05921-9.

Azzolini, Monica. 2005. Reading health in the stars: Politics and medical astrology in Renaissance Milan. In Horoscopes and public spheres: Essays on the history of astrology, ed. Günter Oestmann, Daniel H. Rutkin, and Kocku von Stuckrad, 183-205. Berlin/New York: Walter de Gruyter.

Baldi, Bernardino. 1998. Le Vite de' matematici, ed. Elio Nenci. Milan: Francoangeli.

Barker, Peter. 1999. Copernicus and the critics of Ptolemy. Journal for the History of Astronomy 30: 343-358. https://doi.org/10.1177/002182869903000401.

— 2011. The reality of Peurbach's orbs: Cosmological continuity in fifteenth and sixteenthcentury astronomy. In Change and continuity in early modern cosmology, ed. Patrick J. Boner, 7-32. Dordrecht: Springer. https://doi.org/10.1007/978-94-007-0037-6_2.

Barker, Peter, and Kathleen Crowther. 2013. Training the intelligent eye: Understanding illustrations in early modern astronomy texts. Isis 104: 429-470. https://doi.org/10.1086/673269.

Barker, Peter, and Bernard R. Goldstein. 1998. Realism and instrumentalism in sixteenth-century astronomy: A reappraisal. Perspectives on Science 6: 232-258.

Bassolis, Johannes (de), and Oronce Fine. 1517a. Preclarissimi sacre theologie Doctoris F. Jo. de Bassolis Minorite in Tertium sententiarum Opus, non minus utile quam ingeniosum, impensis non minimis, curasque et emendatione non mediocri, ad debite integritatis sanitatem revocatum, ac marginalibus adnotamentis, claro quoque contentorum indice recenter illustratum, opera denique, et arte impressionis mirifica elaboratum, ed. Oronce Fine. Paris: Nicolas des Prez, François Regnault, and Jean Frellon.

1517b. Opera Joannis de Bassolis doctoris subtilis Scoti (sua tempestate) fidelis discipuli, philosophi ac theologi profundissimi In quatuor Sententiarum libros (credite) aurea: quae nuperrime impensis non minimis curaque, et emendatione non mediocri, ad debitae integritatis sanitatem revocata: decoramentisque marginalibus ac indicibus adnotata: opera denique et arte impressionis mirifica dextris syderibus elaborata fuere, ed. Oronce Fine. Paris: Nicolas des Prez, François Regnault, and Jean Frellon.

Bataillon, Marcel. 1951. Les lecteurs royaux et le nouveau monde. Bibliothèque d'Humanisme et Renaissance 13: 231-240.

Bede. 2004. The Reckoning of Time. Trans. Faith Wallis. Liverpool: Liverpool University of Press. https://doi.org/10.3828/978-0-85323-693-1.

Bennett, Jim. 2012. Cosmography and the meaning of sundials. In Nature engaged. Science in practice from the Renaissance to the present, ed. Mario Biagioli and Jessica Riskin, 249-262. New York: Palgrave Macmillan. https://doi.org/10.1057/9780230338029_13.

Besse, Jean-Marc. 2003. Les Grandeurs de la Terre: Aspects du savoir géographique à la Renaissance. Lyon: ENS éditions.

Besse, Jean-Marc. 2009. Cosmography and geography in the sixteenth century: The position of Oronce fine between mathematics and history. In The worlds of Oronce fine. Mathematics, instruments and print in renaissance France, ed. Alexander Marr, 100-113. Donington: Shaun Tyas.

Bezza, Giuseppe. 2014. Representation of the skies and the astrological chart. In A companion to astrology in the Renaissance, ed. Brendan Dooley, 57-86. Leiden/Boston: Brill. 
Borrel, Jean. 1554. Opera geometrica, quorum tituli sequuntur. Lyon: T. Bertellus.

-1559. De quadratura circuli libri duo, ubi multorum quadraturae confutantur, et ab omnium impugnatione defenditur Archimedes. Ejusdem annotationum opuscula in errores Campani, Zamberti, Orontij, Peletarij, Jo. Penae interpretum Euclidis. Lyon: G. le Rouille.

Borrhaus (Cellarius), Martin. 1551. Elementale cosmographicum, quo totius et astronomiae et geographiae rudimenta, certissimis brevissimisque docentur apodixibus recens castigatum et emendatum, figurisque et annotationibus opportuniss. illustratum: adjunximus huic libro Cosmographiae introductio cum quibusdam geometriae ac astronomiae principiis ad eam rem necessariis. Paris: Guillaume Cavellat.

Boudet, Jean-Patrice. 2007. Charles V, Gervais Chrétien et les manuscrits scientifiques du collège de Maître Gervais. Médiévales (52): 15-38. https://doi.org/10.4000/medievales.1943.

Boulay, César (du). 1665-1673. Historia universitatis parisiensis. Paris: P. de Bresche and J. de Laize-de-Bresche.

Bovelles, Charles (de). 1551. Geometrie practique, composee par le noble Philosophe maistre Charles de Bovelles, \& nouvellement par luy reveue, augmentee, \& grandement enrichie. Paris: R. Chaudière.

Brioist, Pascal. 2009a. Oronce Fine's practical geometry. In The worlds of Oronce Fine. Mathematics, instruments and print in Renaissance France, ed. Alexander Marr, 52-63. Donington: Shaun Tyas.

Brioist, Jean-Jacques. 2009b. Oronce Fine and cartographical methods. In The worlds of Oronce Fine. Mathematics, instruments and print in Renaissance France, ed. Alexander Marr, 137155. Donington: Shaun Tyas.

Broc, Numa. 1980. La Géographie de la Renaissance (1420-1620). Paris: Bibliothèque nationale.

- 1983. Quelle est la plus ancienne carte 'moderne' de la France? Annales de Géographie 92: 513-530. https://doi.org/10.3406/geo.1983.20208.

Brun, Robert. 1934. Un illustrateur méconnu. Oronce Finé. Arts et métiers graphiques 41: 51-57. . 1966. Maquettes d'éditions d'Oronce Finé. In Studia bibliographica in honorem Herman de La Fontaine Verwey, ed. Sape van der Woude, 36-42. Amsterdam: M. Hertzberger.

-1969. Le Livre français illustré de la Renaissance, étude suivie du catalogue des principaux livres à figures du XVI e siècle. Paris: A. and J. Picard.

Carey, Hilary. 2003. What is the folded almanac? The form and function of a key manuscript source for astro-medical practice in later medieval England. Social History of Medicine 16: 481-509. https://doi.org/10.1093/shm/16.3.481.

- 2004. Astrological medicine and the medieval English folded Almanac. Social History of Medicine 17: 345-363. https://doi.org/10.1093/shm/17.3.345.

Carey, Hillary. 2010. Judicial astrology in theory and practice in later medieval Europe. Studies in History and Philosophy of Science Part C 41: 90-98. https://doi.org/10.1016/j. shpsc.2010.04.004.

Carmody, Francis J. 1951. Regiomontanus' notes on al-Bitruiji's Astronomy. Isis 42: 121-130. https://doi.org/10.1086/349282.

Cattaneo, Angelo. 2009. Réflexion sur les climats et les zones face à l'expansion des XVe et XVI ${ }^{\mathrm{e}}$ siècles. Le Monde des Cartes: Revue du Comité français de cartographie 199:7-17.

- 2016. European medieval and Renaissance cosmography: A story of multiple voices. Asian Review of World Histories 4: 35-81. https://doi.org/10.12773/arwh.2016.4.1.035.

Cifoletti, Giovanna. 2009. Oronce Fine's legacy in the French algebraic tradition: Peletier, Ramus and Gosselin. In The worlds of Oronce Fine. Mathematics, instruments and print in Renaissance France, ed. Alexander Marr, 114-136. Donington: Shaun Tyas.

Clagett, Marshall. 1978. Archimedes in the Middle Ages, vol. 3, part 3. Philadelphia: The American Philosophical Society.

Concasty, Marie-Louise. 1964. Commentaires de la faculté de médecine de l'université de Paris, 1516-1560. Paris: Imprimerie nationale.

Conley, Tom. 1996. The self-made map: Cartographic writing in early modern France. Minneapolis: University of Minnesota Press.

Cooper, Glenn M. 2013. Approaches to the critical days in late medieval and Renaissance thinkers. Early Science and Medicine 18: 536-565. https://doi.org/10.1163/15733823-0186P0003. 
Cosgrove, Denis E. 2007. Images of renaissance cosmography, 1450-1650. In Cartography in the European Renaissance, vol. 3, part 1, ed. David Woodward, 55-98. Chicago: The University of Chicago Press.

Crowther, Kathleen, Ashley Nicole McCray, Leila McNeill, Amy Rodgers, and Blair Stein. 2015. The book everybody read: Vernacular translations of Sacrobosco's Sphere in the sixteenth century. Journal for the History of Astronomy 46: 4-28. https://doi.org/10.1177/0021828614567419.

Dainville, François (de). 1970. How did Oronce Fine draw his large map of France? Imago Mundi 24: 49-55. https://doi.org/10.1080/03085697008592349.

Declercq, Georges. 2000. Anno Domini: The origins of the Christian Era. Turnhout: Brepols.

Destombes, Marcel. 1971. Oronce Fine et son globe céleste de 1553. In Actes du XII Congrès international d'histoire des sciences (Paris, 1968), 41-50. Paris: A. Blanchard.

Dhombres, Jean. 2006. La mise à jour des mathématiques par les professeurs royaux. In Histoire du Collège de France, ed. André Tuilier, vol. I, 377-420. Paris: Fayard.

Dobrzycki, Jerzy. 2010 [1965]. Theory of precession in medieval astronomy. Studia Copernicana 43:15-60.

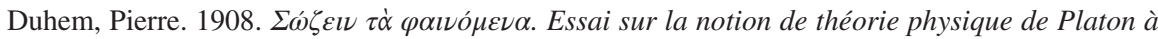
Galilée. Paris: A. Hermann.

—.1913-1959. Le Système du monde: Histoire des doctrines cosmologiques de Platon à Copernic. Paris: A. Hermann et fils.

Dupèbe, Jean. 1999. Astrologie, religion et médecine à Paris. Antoine Mizault (ca. 1512-1578). $\mathrm{PhD}$ dissertation, Université Paris-Nanterre.

Dupré, Sven. 2009. Printing practical mathematics: Oronce Fine's De speculo ustorio between paper and craft. In The worlds of Oronce Fine. Mathematics, instruments and print in Renaissance France, ed. Alexander Marr, 64-82. Donington: Shaun Tyas.

Eagleton, Catherine. 2006. Medieval sundials and manuscript sources: The transmission of information about the Navicula and the Organum Ptolemei in fifteenth-century Europe. In Transmitting knowledge: Words, images, and instruments in early modern Europe, ed. Sachiko Kusukawa and Ian Maclean, 41-71. Oxford: Oxford University Press.

. 2009. Oronce Fine's sundials: The sources and influences of De Solaribus Horologijs. In The worlds of Oronce Fine. Mathematics, instruments and print in Renaissance France, ed. Alexander Marr, 83-99. Donington: Shaun Tyas.

Eamon, William. 2014. Astrology and society. In A companion to astrology in the Renaissance, ed. Brendan Dooley, 141-191. Leiden/Boston: Brill.

Élie, Hubert. 1951. Quelques maîtres de l'université de Paris vers l'an 1500. Archives d'histoire doctrinale et littéraire du moyen âge 18: 193-243.

Escallier, Emile. 1957. Aspects d'Oronce Fine. Gap: Éditions Ophrys.

Euclid, and François de Foix-Candalle. 1566. Euclidis Megarensis mathematici clarissimi Elementa, libri XV ad germanam geometriae intelligentiam è diversis lapsibus contractis restituta... His accessit decimus sextus liber de solidorum regularium sibi invicem inscriptorum collationibus, tum etiam coeptum opusculum de Compositis regularibus solidis planè peragendum. Paris: Jean Royer.

Euclid, and Henry Billingsley. 1570. The elements of geometrie of the most ancient philosopher Euclide of Megara. London: John Daye.

Euclid, and Oronce Fine. 1536. In sex priores libros Geometricorum elementorum Euclidis Megarensis demonstrationes. Paris: Simon de Colines. Repr. 1544 and Regnaud Chaudière, 1551.

Feingold, Mordechai. 1984. The Mathematician's apprenticeship: Science, universities and society in England 1560-1640. Cambridge: Cambridge University Press.

Fine, Michel. 1522. Succincta et utilissima preservatio epideme seu febris pestilente, una cum ejusdem cura. Paris: s. n.

Fine, Oronce. 1525. Nova totius Galliae descriptio. Paris: Simon de Colines. Repr. 1538, 1546, 1553. Paris: Jérôme de Gourmont and 1557. Paris: Alain de Mathonière.

1526. Aequatorium planetarum, unico instrumento comprehensum, omnium antehac excogitatum et intellectum et usu facillimum Canones. Paris: Nicolas Savetier. Repr. 1538. Paris: Jérôme de Gourmont. 
1527. Descriptio partium et succincta utilitatum elucidatio quadrantis cujusdam universalis, ejusdem et aeque facilis cum vulgato astrolabio, sive planispherio commoditatis, Orontio Fineo Delphinate authore. Paris: Nicolas Savetier. Repr. 1534. Paris: Simon de Colines.

-1528. La Theorique des cielz, mouvemens, et termes practiques des sept planetes, nouvellement redigee en langaige francois. Avec les figures tresutiles en leurs lieux proprement inserees. Paris: Simon du Bois for Jean Pierre de Tours. Repr. La Theorique des cieux et sept planetes, avec leurs mouvemens, orbes et disposition tres-utile et necessaire, tant pour l'usage et pratique des tables Astronomiques, que pour la cognoissance de l'université de ce hault monde celeste. Paris: Guillaume Cavellat, 1557 and 1558; Paris: Denise Cavellat, 1607 and Paris: Jacques Quesnel, 1619.

- 1529. Almanach novum insigniora computi et kalendarii succincte complectens ad longos annos duraturum, viris ecclesiasticis, medicis, chirurgicis, trapezitis, quibusvis tandem hominum conditionibus necessarium, nuper ab Orontio Fineo Delphinate in commune bonum Parisiis feliciter editum anno 1529. Paris: Toussaint Denis.

- 1530. Epithoma musice instrumentalis ad omnimodam Hemispherii seu Luthine et theoricam et practicam per Orontium Fineum Delphinatem studiose collectum. Paris: Pierre Attaingnant.

- 1531a. Epistre exhortative touchant la perfection et commodite des ars liberaulx mathematiques, Composee soubz le nom et tiltre de la tresantienne et noble princesse Dame philosophie, et puis nagueres presentee au treschrestien Roy de France. Paris: Pierre Leber. Repr. 1551 and 1552. In L'Esphere du monde, proprement ditte cosmographie. Paris: Michel de Vascosan. http://hdl.handle.net/21.11103/sphaera.101206; http://hdl.handle.net/21.11103/ sphaera.101196.

- 1531b. Nova et integra universi orbis descriptio. Paris: Galliot du Pré. Repr. 1540. Basel: Chrétien Wechel.

-1532. Orontij Finei Delphinatis, liberalium disciplinarum professoris Regii, Protomathesis: Opus varium, ac scitu non minus utile quàm jucundum, nunc primùm in lucem foeliciter emissum. Paris: G. Morrhe and J. Pierre. http://hdl.handle.net/21.11103/sphaera.101190.

1535. De arithmetica practica. Libri IIII. Paris: Simon de Colines. Repr. 1542, 1544 and Paris: Michel de Vascosan, 1555.

1536. Recens et integra orbis descriptio. Paris: Jérôme de Gourmont.

1542a. Orontij Finei Delphinatis, Regii mathematicarum professoris, De mundi sphaera, sive cosmographia, primáve astronomiae parte, Libri V: Inaudita methodo ab authore renovati, proprijsque tum commentarijs et figuris, tum demonstrationibus et tabulis recens illustrati. Eiusdem Orontij, Rectarum in circuli quadrante subtensarum (quos sinus vocant) demonstratio, supputatióque facillima, nunc primùm edita: unà cum eorundem sinuum tabula, fideli admodum calculo restituta. Eiusdem Orontij, Organum universale, ex supradicta sinuum ratione contextum, quo tum Geometrici, tum omnes astronomici canones, ex quatuor sinuum proportione pendentes, mira facilitate practicantur. Paris: Simon de Colines. http://hdl.handle. net/21.11103/sphaera.101201.

1542b. Orontij Finei Delphinatis, Regii mathematicarum professoris, De mundi sphaera, sive cosmographia, primáve astronomiae parte. Libri $V$. Ab ipso authore recogniti, aucti, ac prorsus renovati: seorsùmque in studiosorum gratiam absque commentarijs recenter impressi. Paris: Simon de Colines (abridged version).

-1543a. Les canons et documents tresamples, touchant l'usage et practique des communs Almanachz, que l'on nomme Ephemerides. Repr. 1551, 1556 and 1557. Paris: Simon de Colines.

-1543b. L'Art et maniere de trouver certainement la longitude, ou difference longitudinale de tous lieux proposez sur la terre: par le cours et mouvement de la Lune, et aultrement que par les eclipses d'icelle. En tout temps que l'on vouldra. Item la composition et usaige d'ung singulier Metheoroscope geographique: Par lequel on peust facilement et soubdainement trouver ladicte difference longitudinale, et aussi latitudinale, et avec ce la vraye elongation et distance desdictz lieux proposez. Le tout nouvellement invente, descript, et composé par Oronce fine natif du Daulphine, Lecteur mathematicien du Roy nostre Sire en l'université de Paris. Paris, BNF, ms. français 1337 et 14760. 
1544a. Liber de geometria practica, sive de practicis longitudinum, planorum et solidorum, hoc est linearum, superficierum, et corporum mensionibus aliisque mechanicis, ex demonstratis Euclidis elementis corollarius, ubi et de quadrato geometrico, et virgis seu baculis mensorijs. Strasbourg: Georg Messerschmidt. Repr. 1558 and 1584, and 1556 and 1586 as Regii Mathematwn Lutetia professoris ac illustratoris, De re et praxi geometrica, Libri tres, figuris et demonstrationibus illustrati. Ubi de Quadrato geometrico, et virgis seu baculis mensoriis, necnon aliis, cùm mathematicis, tum mechanicis. Paris: Gilles Gourbin.

1544b. Orontij Finei Delphinatis, Regii mathematicarum professoris, Quadratura circuli, tandem inventa et clarissimè demonstrata. De circuli mensura, et ratione circumferentiae ad diametrum, Demonstrationes duae. De multangulorum omnium et regularium figurarum descriptiones, Liber hactenus desideratus. De invenienda longitudinis locorum differentia, aliter quàm per Lunares eclipses, etiam dato quovis tempore, Liber admodùm singularis. Planisphaerium geographicum, quo tum longitudinis atque latitudinis differentiae, tum directae locorum deprehenduntur elongationes. Paris: S. de Colines.

- 1545. Tabula proportionalis, omnibus astronomicis supputationibus indifferenter adcommodata. Paris: Simon de Colines.

. 1551a. Sphaera mundi, sive cosmographia quinque libris recèns auctis et emendatis absoluta: in qua tum prima astronomiae pars, tum geographiae, ac hydrographiae rudimenta pertractantur. Authore Orontio Finaeo Delphinate, Regio mathematicarum Lutetiae professore. Paris: Michel de Vascosan. http://hdl.handle.net/21.11103/sphaera.101206.

- 1551b. L'Esphere du monde, proprement ditte cosmographie, composee nouvellement en françois, et divisee en cinq livres, comprenans la premiere partie de l'astronomie, et les principes universels de la geographie et hydrographie. Avec une epistre, touchant la dignité, perfection et utilité des sciences mathematiques. Par Oronce Fine, natif du Daulphiné, lecteur Mathematicien du tres-chrestien Roy de France en L'université de Paris. Paris: M. de Vascosan. http://hdl.handle.net/21.11103/sphaera.101304.

- 1551c. De speculo ustorio, ignem ad propositam distantiam generante, Liber unicus, ex quo duarum linearum semper appropinquantium, et nunquam concurrentium colligitur demonstratio. Paris: Michel de Vascosan.

1553a. De duodecim caeli domiciliis, et horis inaequalibus, Libellus non aspernandus. Paris: M. de Vascosan.

1553b. In eos quos de mundi sphaera conscripsit libros, ac in planetarum theoricas, canonum astronomicarum Libri II. Paris: M. de Vascosan.

. 1553c. De astrolabio sive planisphaerio, in suam harmoniam tandem revocato. Paris: Bibliothèque Nationale de France, ms. latin 7415.

- 1555. Orontij Finaei Delphinatis, Regij mathematicarum Lutetiae professoris, De mundi sphaera, sive Cosmographia, libri V. ab ipso authore denuò castigari, et marginalibus (ut vocant) annotationibus recèns illustrati: quibus tum prima astronomiae pars, tum geographiae, ac hydrographiae rudimenta pertractantur. Paris: Michel de Vascosan. http://hdl.handle. net/21.11103/sphaera.101198.

- 1556a. De rebus mathematicis hactenus desideratis libri IIII. Paris: M. de Vascosan.

1556b. La Composition et usage du quarré geometrique. Paris: G. Gourbin.

1557. Compendiaria tractatio de fabrica et usu annuli astronomici. Paris: G. Cavellat.

1558. The rules and righte ample documentes, touchinge the use and practise of the common Almanackes, which are named Ephemerides. A briefe and shorte introduction upon the Judiciall Astrologie, for to prognosticate of thinges to come, by the helpe of the sayde Ephemerides. With a treatise added hereunto, touchinge the conjunction of the planets, in every one of the 12 signes, and of their prognostications and revolutions of yeres. Trans. H. Baker. London: T. Marshe.

1587. Opere di Orontio Fineo del Delfinato divise in cinque Parti, Aritmetica, Geometria, Cosmografia, e Orivoli, Tradotte da Cosimo Bartoli, Gentilhuomo, e Academico Fiorentino, Et gli Specchi, Tradotti dal Cavalier Ercole Bottrigaro, Gentilhuomo Bolognese, Nuovamente poste in luce. Venice: Francesco Franceschi. http://hdl.handle.net/21.11103/sphaera.101202.

- n.d. Speculum astronomicum, ab orontio Fineo Delphinate recenter aeditum, omnium ante hac excogitatorum et fabrica, et usu, vel intellectu facillimum: Quo tam medij, quàm veri, cum fixorum, tum errantium syderum motus promptissimi reperiuntur. Paris: La Sorbonne, ms. 149. 
Gaida, Margaret. 2016. Reading Cosmographia: Peter Apian's book-instrument hybrid and the rise of the mathematical amateur in the sixteenth century. Early Science and Medicine 21: 277-302.

Gallois, Lucien. 1890. De Orontio Finaeo gallico geographo. Paris: E. Leroux.

. 1918. Un géographe dauphinois: Oronce Fine et le Dauphiné sur sa carte de France de 1525. Recueil des travaux de l'institut de géographie alpine 6: 1-25. https://doi.org/10.3406/ rga.1918.4716.

1935. La grande carte de France d'Oronce Fine. Annales de Géographie 44: 337-348. https://doi.org/10.3406/geo.1935.11062.

Gatto, Romano. 2006. Christoph Clavius' Ordo Servandus in Addiscendis Disciplinis Mathematicis and the Teaching of Mathematics in Jesuit Colleges at the Beginning of the Modern Era. Science and Education 15: 235-258. https://doi.org/10.1007/s11191-004-5607-8.

Gikatilla, Joseph, and Paolo Ricci. 1516. Portae lucis: haec est porta Tetragrammaton, justi intrabunt per eam. Augsburg: Miller.

Gingerich, Owen. 1988. Sacrobosco as a textbook. Journal for the History of Astronomy 19: 269273. https://doi.org/10.1177/002182868801900404.

-1999. Sacrobosco illustrated. In Between demonstration and imagination: Essays in the history of science and philosophy presented to John D. North, ed. Lodi Nauta and Arie Johan Vanderjagt, 211-224. Leiden: Brill. https://doi.org/10.1163/9789004247505_008.

Goldstein, Bernard R. 1967. The Arabic version of Ptolemy's planetary hypotheses. Transactions of the American Philosophical Society 57: 3-55. https://doi.org/10.2307/598158.

- 1980. The status of models in Ancient and Medieval astronomy. Centaurus 24: 132-147. https://doi.org/10.1111/j.1600-0498.2008.00104.

Goodrick-Clarke, Nicholas. 2008. Planetary and angel magic in the Renaissance. In The western esoteric traditions: A historical introduction. Oxford: Oxford University Press. https://doi. org/10.1093/acprof:oso/9780195320992.003.0001.

Goulding, Robert. 2010. Defending Hypatia. Ramus, Savile, and the Renaissance rediscovery of mathematical history. Dordrecht: Springer. https://doi.org/10.1007/978-90-481-3542-4.

Granada, Miguel Angel. 2004. Aristotle, Copernicus, Bruno: Centrality, the principle of movement and the extension of the universe. Studies in History and Philosophy of Science Part A 35: 91-114. https://doi.org/10.1016/j.shpsa.2003.12.007.

Grant, Edward. 1994. Planets, stars, and orbs: The Medieval cosmos, 1200-1687. Cambridge: Cambridge University Press.

- 1997. Celestial motions in the late Middle ages. Early Science and Medicine 2: 129-148. https://doi.org/10.1163/157338297X00096.

Grendler, Paul F. 2002. The universities of the Italian Renaissance. Baltimore: Johns Hopkins University Press.

Guyot, Patrick, and Frédéric Métin. 2004. Les ouvrages de géométrie pratique au XVIe siècle. In Instruments scientifiques à travers l'histoire, ed. Elisabeth Hébert, 251-265. Paris: Ellipses.

Hamel, Jürgen. 2004. Johannes de Sacroboscos Handbuch der Astronomie (um 1230)-kommentierte Bibliographie eines Erfolgwerkes. In Wege der Erkenntnis: Festschrift für Dieter B. Herrmann zum 65. Geburtstag, ed. Dietmar Fürst and Eckehard Rothenberg, 115-170. Frankfurt am Main: Harri Deutsch.

2014. Studien zur Sphaera des Johannes de Sacrobosco. Leipzig: AVA Akademische Verlagsanstalt.

Heninger, Simeon K. 1977a. Oronce Fine and English textbooks for the mathematical sciences. In Studies in the continental background of Renaissance English literature: Essays presented to John L. Lievsay, ed. Dale B.J. Randall and George Walton Williams, 171-185. Durham N.C: Duke University Press.

— 1977b. The cosmographical glass: Renaissance diagrams of the universe. San Marino: Huntington Library.

Hillard, Denise, and Emmanuel Poulle. 1971. Oronce Finé et l'horloge planétaire de la Bibliothèque Sainte-Geneviève. Bibliothèque d'Humanisme et de Renaissance 33: 311-349.

Hillard, Denise, Jacqueline Linet, and Emmanuel Poulle. 1971. Science et astrologie au Xvé siècle: Oronce Fine et son horloge planétaire. Paris: Bibliothèque Sainte Geneviève. 
Honterus, Johannes. 1535. Rudimentorum cosmographiae. In Margarita philosophica, rationalis, moralis philosophiae principia, ed. Gregor Reisch, 1440-1463. Basel: Sebastian Henricpetri and Conrad Resch.

Hübner, Wolfgang. 2014. The culture of astrology from ancient to Renaissance. In A companion to astrology in the Renaissance, ed. Brendan Dooley, 17-58. Leiden/Boston: Brill.

Hugonnard-Roche, Henri. 1992. Problèmes méthodologiques dans l'astronomie au début du XIVe siècle. In Studies on Gersonides: A fourteenth-century Jewish Philosopher-scientist, ed. Gad Freudenthal, 55-70. Leiden/New York/Köln: Brill.

Thâbit ibn Qurra, and Francis J. Carmody. 1960. The astronomical works of Thâbit B. Qurra, ed. Francis J. Carmody. Berkeley/Los Angeles: University of California Press.

Irigoin, Jean. 2006. Les lecteurs royaux pour le grec (1530-1560). In Histoire du Collège de France, ed. André Tuilier, vol. I, 233-256. Paris: Fayard.

Jardine, Nicholas. 1979. The forging of modern realism: Clavius and Kepler against the sceptics. Studies in History and Philosophy of Science. Part A 10: 141-173. https://doi. org/10.1016/0039-3681(79)90014-1.

. 1982. The significance of the Copernican orbs. Journal for the History of Astronomy 13: 168-194. https://doi.org/10.1177/002182868201300302.

Johnson, A.F. 1928. Oronce Finé as an illustrator of books. Gutenberg-Jahrbuch 3: 107-109.

Johnson, Francis R. 1946. Marlowe's astronomy and Renaissance skepticism. English Literary History 13: 241-254.

Karrow, Robert W. 1993. Mapmakers of the sixteenth century and their maps: Bio-bibliographies of the cartographers of Abraham Ortelius, 1570: Based on Leo Bagrow's A. Ortelii Catalogus cartographorum. Chicago: The Newberry Library by Speculum Orbis Press.

Kessler-Mesguich, Sophie. 2006. L'enseignement de l'hébreu et de l'araméen par les premiers lecteurs royaux (1530-1560). In Histoire du Collège de France, ed. André Tuilier, vol. I, 257 282. Paris: Fayard.

Kish, George. 1965. The cosmographic heart: Cordiform maps of the 16th century. Imago Mundi 19: 13-21. https://doi.org/10.1080/03085696508592261.

Kremer, Richard. 2017. Incunable almanacs and practica as practical knowledge produced in trading zones. In The structures of practical knowledge, ed. Matteo Valleriani, 333-369. Dordrecht: Springer. https://doi.org/10.1007/978-3-319-45671-3_13.

Kren, Claudia. 1968. Homocentric astronomy in the Latin west. The De reprobatione ecentricorum et epiciclorum of Henry of Hesse. Isis 59: 269-281. https://doi.org/10.1086/350396.

Langlois (Lt.-Col.), Charles-Victor. 1922. Étude sur deux cartes d'Oronce Fine de 1531 et 1536. Journal de la Société des Américanistes 14: 83-97. https://doi.org/10.3406/jsa.1922.3993.

Lattis, James M. 1994. Between Copernicus and Galileo: Christoph Clavius and the collapse of ptolemaic cosmology. Chicago: University of Chicago Press.

Launoy, Jean (de). 1677. Regij Navarrae gymnasij parisiensis historia. Paris: E. Martin.

Le Huen, Nicole. 1517. Grant voyage de Jherusalem. Paris: François Regnault.

Lefranc, Abel. 1893. Histoire du Collège de France depuis ses origines jusqu'à la fin du premier empire. Paris: Hachette.

Leitão, Henrique. 2009. Pedro Nuñez against Oronce Fine: Content and context of a refutation. In The worlds of Oronce Fine. Mathematics, instruments and print in Renaissance France, ed. Alexander Marr, 156-171. Donington: Shaun Tyas.

Leitão, Henrique, and Bruno Almeida. 2012. A anotação de Pedro Nunes acerca da "largura" dos climas. In António Estácio dos Reis. Marinheiro por vocação e historiador com devoção, ed. Jorge Semedo de Matos, 123-142. Lisboa: Comissão Cultural de Marinha.

Lerner, Michel-Pierre. 1996. Le Monde des sphères: Genèse et triomphe d'un représentation cosmique. Paris: Les Belles Lettres.

Lestringant, Frank, and Monique Pelletier. 2007. Maps and descriptions of the world in sixteenthcentury France. In The history of cartography. Vol. 3: Cartography in the European Renaissance, part. 2, ed. David Woodward, 1463-1479. Chicago: The University of Chicago Press.

Lloyd, G.E.R. 1978. Saving the appearances. The Classical Quarterly 28: 202-222. https://doi. org/10.1017/S0009838800037861. 
Malpangotto, Michela. 2013. L'univers auquel s'est confronté Copernic: La sphère de Mercure dans les Theoricae novae planetarum de Georg Peurbach. Historia Mathematica 40: 262-308. https://doi.org/10.1016/j.hm.2013.03.001.

- 2016. The original motivation for Copernicus's research Albert of Brudzewo's Commentariolum super theoricas novas Georgii Purbachii. Archive for History of Exact Sciences 70: 361-411. https://doi.org/10.1007/s00407-015-0171-y.

Margolin, Jean-Claude. 1976. L'enseignement des mathématiques en France (1540-1570). Charles de Bovelles, Fine, Peletier, Ramus. In French Renaissance Studies, 1540-1570: Humanism and the encyclopedia, ed. Peter Sharratt, 109-155. Edinburg: Edinburg University Press.

Markowski, Mieczysław. 1981. Die Kosmologischen Anschauungen des Prosdocimo de' Beldomandi. In Studi sul XIV secolo in Memoria di Anneliese Maier, ed. Alfonso and Agostino Maierù, 263-273. Rome: Edizioni di Storia e Letteratura.

Marlowe, Christopher. 1604. The tragicall history of Doctor Faustus. London: Thomas Bushell.

Marr, Alexander. 2009. Introduction. In The worlds of Oronce Fine. Mathematics, instruments and print in Renaissance France, ed. Alexander Marr, 1-12. Donington: Shaun Tyas.

Martínez Silíceo (Guijarro), Juan, and Oronce Fine. 1519. Arithmetica Joannis Martini, Scilicei, in theoricen, et praxim scissa, ed. Oronce Fine. Paris: H. Estienne.

Métin, Frédéric. 2004. Le début et la fin de l'histoire: D’Oronce Fine à Samuel Marolois. In Instruments scientifiques à travers l'histoire, ed. Elisabeth Hébert, 233-250. Paris: Ellipses.

Milanesi, Marica. 1994. Geography and cosmography in Italy from the XVth to the XVIIth century. Memorie della Societa Astronomica Italiana 65: 443-468.

Mizauld, Antoine. 1550. Aesculapii et uraniae medicum simul et astronomicum ex colloquio conjugium harmoniam microcosmi cum macrocosmo, sive humani corporis cum caelo, paucis figurans, et perspicuè demonstrans. Lyon: Jean de Tournes.

-1551. Planetologia: rebus astronomicis, medicis, et philosophicis Erudite Referta: Ex qua, coelestium corporum cum humanis, et astronomiae cum medicina societas, et harmonia

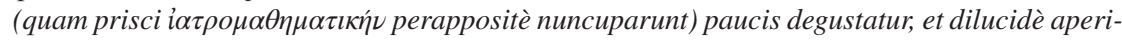
tur. Lyon: Maurice Roy and Ludovic Pesnot.

1552. De mundi sphaera, seu cosmographia, libri tres: figuris et demonstrationibus illustrati. Paris: Guillaume Cavellat.

1555. Harmonia coelestium corporum \& humanorum, dialogis undecim astronomicè et medicè per Anton. Mizaldum Monlucianum elaborata, et demonstrata. Paris: Jacques Kerver.

Morelon, Régis. 1999. Astronomie 'physique' et astronomie 'mathématique' dans l'astronomie précopernicienne. In Les Doctrines de la science de l'Antiquité à l'Age classique, ed. Roshdi Rashed and Joël Biard, 105-129. Leuven/Paris: Peeters.

Moreton, Jennifer. 1994. John of Sacrobosco and the calendar. Viator 25: 229-244. https://doi. org/10.1484/J.VIATOR.2.301215.

Mosley, Adam. 2009. Early modern cosmography: Fine's sphaera mundi in content and context. In The worlds of Oronce Fine. Mathematics, instruments and print in Renaissance France, ed. Alexander Marr, 114-136. Donington: Shaun Tyas.

Muñoz, Jerónimo. 2004. Introducción a la astronomía y la geografía, ed. and trans. Víctor Navarro Brotons. Valencia: Consell Valenciá de Cultura.

Münster, Sebastian, and Matthew McLean. 2016. The Cosmographia of Sebastian Münster: Describing the world in the Reformation. Abingdon/Oxon: Routledge.

Navarro Brotóns, Víctor. 2004. Astronomy and cosmography, 1561-1625: Different aspects of the activities of Spanish and Portuguese mathematicians and cosmographers. In The practice of mathematics in Portugal, ed. Luís Saraiva and Henrique Leitão, 225-274. Coimbra: Por ordem da Universidade.

- 2006. The cultivation of astronomy in Spanish universities in the latter half of the 16th century. In Universities and science in the early modern period, ed. Mordechai Feingold and Víctor Navarro-Brotons, 83-98. Dordrecht: Springer.

Neugebauer, Otto. 1975. A history of Ancient mathematical astronomy. Berlin/Heidelberg/New York: Springer.

Neugebauer, Otto, and Thâbit ibn Qurra. 1962. Thâbit ben Qurra On the solar year and On the motion of the eighth sphere. Proceedings of the American Philosophical Society 106: 264-299. 
Nothaft, C. Philipp E. 2017. Criticism of trepidation models and advocacy of uniform precession in medieval Latin astronomy. Archive for the History of Exact Sciences 71: 211-244. https:// doi.org/10.1007/s00407-016-0184-1.

Nuñez, Pedro. 1546. De erratis Orontij Finaei Regij Mathematicarum Lutetiae Professoris, Qui putavit inter duas datas lineas, binas medias proportionales sub continua proportione invenisse, circulum quadrasse, cubum duplicasse, multangulum quodcunque rectilineum in circulo describendi, artem tradidisse, et longitudinis locorum differentias aliter quam per eclipses lunares, etiam dato quovis tempore manifestas fecisse, Petri Nonij, Salaciensis Liber unus. Coimbra: J. Barreira et J. Álvares.

Omodeo, Pietro Daniele. 2014. Copernicus in the cultural debates of the Renaissance. Leiden/ Boston: Brill.

Oosterhoff, Richard J. 2014. Idiotae, mathematics, and artisans: The untutored mind and the discovery. Intellectual History Review 24: 301-319. https://doi.org/10.1080/17496977.2014.891 180.

2015. A Book, a pen, and the sphere: Reading Sacrobosco in the Renaissance. History of Universities 28: 1-54. https://doi.org/10.1093/acprof:oso/9780198743651.003.0001.

- 2016. Lovers in paratexts: Oronce Fine's republic of mathematics. Nuncius 31: 549-583. https://doi.org/10.17863/CAM.6419.

- 2017. "Secrets of industry" for "common men": Charles de Bovelles and early French readerships of technical print. In Translating early modern science, ed. Sietske Fransen, Niall Hodson, and Karl A.E. Enenkel, 207-229. Leiden - Boston: Brill

- 2018. Making Mathematical culture. University and print in the circle of Lefèvre d'Étaples. Oxford: Oxford University Press.

Oresme, Nicole. 1968. Le Livre du ciel et du monde. Trans. A.D. Menut and Alexander J. Denomy. Madison/Milwaukee/London: University of Wisconsin Press.

Pantin, Isabelle. 1993. Une École d'Athènes des astronomes: La représentation de l'astronome antique dans les frontispices de la Renaissance. In Images de l'Antiquité dans la littérature française: le texte et son illustration, ed. Emmanuèle Baumgartner and Laurence Harf-Lancner, 87-99. Paris: Presses de l'Ecole normale supérieure.

- 1995. La Poésie du ciel en France dans la seconde moitié du seizième siècle. Geneva: Droz.

2001. L'illustration des livres d'astronomie à la Renaissance: l'évolution d'une discipline à travers ses images. In Immagini per conoscere. Dal Rinascimento alla Rivoluzione scientifica, ed. Fabrizio Meroi and Claudio Pogliano, 3-41. Firenze: Leo Olschki.

- 2006. Teaching mathematics and astronomy in France: The Collège Royal (1550-1650). Science and Education 15: 189-207. https://doi.org/10.1007/s11191-005-1794-1.

- 2009a. Oronce Fine's role as royal lecturer. In The worlds of Oronce Fine. Mathematics, instruments and print in Renaissance France, ed. Alexander Marr, 13-30. Donington: Shaun Tyas.

- 2009b. Altior incubuit animus sub imagine mundi. L'inspiration du cosmographe d'après un gravure d'Oronce Finé. In Les Méditations cosmographiques à la Renaissance, ed. Frank Lestringant and Centre V.L. Saulnier, 69-90. Paris: Presses de l'Université Paris-Sorbonne.

. 2010. The astronomical diagrams in Oronce Finé's Protomathesis (1532): Founding a French tradition? Journal for the History of Astronomy 41: 287-310. https://doi. org/10.1177/002182861004100302.

- 2012. The first phases of the Theoricae planetarum printed tradition (1474-1535): The evolution of a genre observed through its images. Journal for the History of Astronomy 43: 3-26. https://doi.org/10.1177/002182861204300102.

- 2013a. Oronce Finé mathématicien et homme du livre: la pratique éditoriale comme moteur d'évolution. In Mise en forme des savoirs à la Renaissance: à la croisée des idées, des techniques et des publics, ed. Isabelle Pantin and Gérald Péoux, 19-40. Paris: Armand Colin.

- 2013b. Francesco Giuntini et les nouvelles célestes. In Celestial novelties on the eve of the scientific revolution: 1540-1630, ed. Dario Tessicini and Patrick Boner, 85-104. Firenze: Leo S. Olschki.

Pedersen, Olaf. 1978. Astronomy. In Science in the middle ages, ed. David C. Lindberg, 303-337. Chicago/London: The University of Chicago Press. 
Pedersen, Olaf. 1981. The origins of the Theorica planetarum. Journal for the History of Astronomy 12: $113-123$.

- 1985. In quest of Sacrobosco. Journal for the History of Astronomy 16: 175-221. https:// doi.org/10.1177/002182868501600302.

- 1995. The corpus astronomicum and the traditions of medieval Latin astronomy. Studia Copernicana 13: 57-96.

Pelletier, Monique. 2009. De Ptolémée à La Guillotière (XVe-XVIe siècle). Des cartes pour la France: Pourquoi? Comment? Paris: Comité des travaux historiques et scientifiques.

Pennuto, Concetta. 2008. The debate on critical days in Renaissance Italy. In Astro-medecine: Astrology and medecine, East and West, ed. A. Akasoy, C. Burnett, and R. Yoeli-Tlalim, 75-98. Florence: Sismel-Edizioni del Galluzzo.

Pettegree, Andrew, and Malcolm Walsby. 2012. French Books III and IV: Books published in France before 1601. Leiden/Boston: Brill.

Peurbach, Georg, and Oronce Fine. 1515. In Theoricarum novarum Textus Georgij Peurbachij cum expositione Domini Francisci Capuani de Manfredonia. Item in easdem Sylvestri de Prierio commentatio. Insuper Jacobi Fabri Stapulensis astronomicon, ed. Oronce Fine. Paris: Jean Petit.

- 1525. Theoricarum novae Planetarum, id est, septem errantium syderum, Necnon Octavi orbis, seu firmamenti, Authore Georgio Purbachio Germano, Mathematicarum disciplinarum (olim) interprete subtilissimo: Nuper summa diligentia Orontij Finei Delphinatis emendatae, Figuris item opportunissimis, et scholijs non aspernandis illustratae, longeque castigarius, quam antea, ipso curante coimpressae, ed. Oronce Fine. Paris: Regnauld Chaudière. Repr. Jean Petit, 1534.

Peurbach, Georg, and Francesco Capuano de Manfredonia. 1495. Theoricae novae planetarum. Venice: Simon Bevilaqua.

Pico della Mirandola, Giovanni. 2005. Opera omnia. Facsimile of: Basel, 1573. Hildesheim: Olms.

Pietro d'Abano. 1520. Conciliator differentiarum philosophorum et praecipue medicorum. Venice: Giunta.

Pigghe, Albert. 1520. Albertus Pighius Campensis. De aequinoctiarum solstitiorumque inventione et de ratione paschalis celebrationis, deque restitutione ecclesiastici Kalendarii. Paris.

Portuondo, Maria M. 2009. Secret science: Spanish cosmography and the new world. Chicago: University of Chicago Press.

Possevino, Antonio. 1593. Bibliotheca selecta qua agitur De ratione Studiorum. Rome: Typographia Apostolica Vaticana.

Poulle, Emmanuel. 1961. L'équatoire de Guillaume Gilliszoon de Wissekerke. Physis 3: 223-251. . 1978. Oronce Fine. In Dictionary of scientific biography, ed. Charles C. Gillispie, vol. 15, 153-157. New York: American Council of Learned Societies.

Ptolemy, Claudius. 1533. Cl. Ptolomaei Pheludiensis Alexandrini Quadripartitum. Basel: Johannes Hervagius.

1984. Ptolemy's Almagest. Trans. G.J. Toomer. London: Duckworth.

- 2000. Ptolemy's Geography: An annotated translation of the theoretical chapters. Trans. A. Jones and J. Lennart Berggren. Princeton: Princeton University Press.

Rampling, Jennifer M. 2012. John Dee and the sciences: Early modern networks of knowledge. Studies in History and Philosophie of Science. Part A 43: 432-436. https://doi.org/10.1016/j. shpsa.2011.12.001.

Ramus, Petrus. 1599. Prooemium reformandae Parisiensis academiae. In Collectaneae praefationes, epistolae, orationes, ed. Petrus Ramus and Omer Talon, 362-387. Marburg: Paul Egenolph.

Recorde, Robert. 1556. Castle of knowledge. London: Reginald Wolfe.

Regiomontanus, Johannes. 2008. Oratio Johannis de Monteregio habita Patavij in praelectione Alfragani. In Regiomontano e il rinnovamento del sapere matematico e astronomico nel quattrocento, ed. Michela Malpangotto. Bari: Cacucci Editore.

Reisch, Gregor, and Oronce Fine. 1535. Margarita philosophica, rationalis, moralis philosophiae principia. Basel: Sebastian Henricpetri and Conrad Resch.

Reuchlin, Johann. 1517. De Arte Cabbalistica libri tres. Hagenau: Thomas Anshelm.

Rey Pastor, Julio. 1934. Los Matématicos españoles des siglo XVI. Madrid: A. Medina. 
Ricci, Agostino, and Oronce Fine. 1521. In Augustini Ricij, de motu octavae Sphaerae, ed. Oronce Fine. Paris: Simon de Colines.

Rochas, Adolphe. 1856-1860. Biographie du Dauphiné. Paris: Charavay.

Ross, Richard P. 1971. Studies on Oronce Fine, 1494-1555. Doctoral dissertation, Columbia University.

— 1974. Oronce Fine's printed works: Additions to Hillard and Poulle's bibliography. Bibliothèque d'Humanisme et de Renaissance 36: 83-85.

1975. Oronce Fine's De sinibus libri II: The first printed trigonometric treatise of the French Renaissance. Isis 66: 379-386.

Ryff, Peter. 1598. Elementa sphaerae mundi sive cosmographiae in usum Scholae Mathematicae Basilensis. Basel: Johannes Schroeter.

Sacrobosco, Johannes, and Oronce Fine. 1516. Mundialis sphere opusculum Joannis de Sacrobusto, ed. Oronce Fine. Paris: Regnault Chaudière. Repr. 1519, 1524, 1527 and 1538. http://hdl.handle.net/21.11103/sphaera.100991; http://hdl.handle.net/21.11103/sphaera.100069; http://hdl. handle.net/21.11103/sphaera.100997; http://hdl.handle.net/21.11103/sphaera.100170; http:// hdl.handle.net/21.11103/sphaera.101024.

Sacrobosco, Johannes. 2003 [1478]. Sphaera mundi. Venice: Adam de Rottweil, 1478, ed. Roberto de Andrade Martins. Campinas: Universidade estadual de Campinas.

Sacrobosco, Johannes, and Peter Apian. 1526. Sphaera Iani de Sacrobusto astronomiae ac cosmographiae candidatis scitu apprime necessaria per Petrum Apianum accuratissima diligentia denuo recognita ac emendata. Ingolstadt: P. Apian. http://hdl.handle.net/21.11103/ sphaera. 100070.

Sacrobosco, Johannes, and Bernardus of Trilia (Bernard de la Treille). n.d. Fratris Bernardi de Trilia Questiones in sphaeram Joannis de Sacro Bosco. Laon: Bibliothèque municipale, ms. 171.

Sacrobosco, Johannes, and Franco Petri Burgersdijk. 1626. Sphaera Iohannis de Sacro-Bosco, decreto illustr. et potent. D. D. Ordinum Hollandiae et West-Frisiae, in usum scholarum ejusdem provinciae sic recensita, ut et Latinitas et methodus emendata sit, multaque addita, quae ad huius doctrinae illustrationem requirebantur. Leiden: Bonaventura and Abraham Elzevir. http://hdl.handle.net/21.11103/sphaera.100980.

Sacrobosco, Johannes, and Christoph Clavius. 1570. Christophorii Clavii Bambergensis, ex Societate Iesu, in Sphaeram Ioannis de Sacro Bosco, commentarius. Roma: Vittorio Eliano. http://hdl.handle.net/21.11103/sphaera.100365.

Sacrobosco, Johannes, and Francesco Giuntini. 1577. Fr. Junctini Florentini, sacrae theologiae doctoris, Commentaria in Sphaeram Ioannis de Sacro Bosco accuratissima. Lyon: Philippus Tinghius. http://hdl.handle.net/21.11103/sphaera.100921.

- 1582. La Sfera del mondo. Di M. Francesco Giuntini, Dottore Theologo: col testo di M. Giovanni Sacrobosco. Opera utile et necessaria a poeti, historiografi, naviganti, agricoltori, et ad ogni sorte di persone. Lyon: Symphorien Beraud. http://hdl.handle.net/21.11103/ sphaera.101118.

Sacrobosco, Johannes, Georg Peurbach, and Johannes Regiomontanus. 1488. Sphaerae mundi compendium foeliciter inchoat. Venice: Johannes Sanritter and Hieronymus de Sanctis. http:// hdl.handle.net/21.11103/sphaera.100822.

Sacrobosco, Johannes, Jacques Lefèvre d'Étaples, Bonet de Lattes, Euclid, and Boethius. 1495. Textus de sphera Iohannis de Sacrobosco, cum additione (quantum necessarium est) adjecta: novo commentario nuper edito ad utilitatem studentium philosophiae parisiensis academie: illustratus. Cum compositione Annuli astronomici Boneti Latensis, et Geometria Euclidis Megarensis, ed. Jacques Lefèvre d'Étaples. Paris: Wolfgang Hopyl. http://hdl.handle. net/21.11103/sphaera.101126.

Sacrobosco, Johannes, Pierre d'Ailly, and Pedro Sanchez Ciruelo. 1498. Uberrimum Sphere mundi commentum, intersertis etiam questionibus Domini Petri de Aliaco. Paris: Guy Marchant for Jean Petit. http://hdl.handle.net/21.11103/sphaera.100038.

Sacrobosco, Johannes, Cecco d'Ascoli, Francesco Capuano, and Jacques Lefèvre d'Étaples. 1499. Sphera mundi cum tribus commentis. Venice: Simon Bevilaqua. http://hdl.handle.net/21.11103/ sphaera.100021. 
Sacrobosco, Johannes, Bartolomeo Vespucci, Jacques Lefèvre d'Étaples, Francesco Capuano, Pierre d'Ailly, Robert Grosseteste, Johannes Regiomontanus, and Georg Peurbach. 1508a. Tractatus de Sacrobosco. Venice: Giuntino Giunta. http://hdl.handle.net/21.11103/sphaera.100915.

Sacrobosco, Johannes, Pierre d'Ailly, and Pedro Sanchez Ciruelo. 1508b. Uberrimum Sphere mundi commentum, intersertis etiam questionibus Domini Petri de Aliaco. Paris: Guy Marchant for Jean Petit. http://hdl.handle.net/21.11103/sphaera.100642.

Sacrobosco, Johannes, Jacques Lefèvre d'Étaples, Bonet de Lattes, Euclid, and Boethius. 1521. Textus de sphera Iohannis de Sacrobosco: Introductoria additione (quantum necessarium est) commentarioque: ad utilitatem studentium philosophiae parisiensis academie illustratus. Cum compositione annuli astronomici Boneti Latensis: Et geometria Euclidis Megarensis, ed. by Jacques Lefèvre d'Étaples. Paris: Simon de Colines. http://hdl.handle.net/21.11103/ sphaera.100995.

Sacrobosco, Johannes, Jacques Lefèvre d'Étaples, Bonet de Lattes, Euclid, and Boethius. 1527. Textus de sphera Iohannis de Sacrobosco: Introductoria additione (quantum necessarium est) commentarioque, ad utilitatem studentium philosophiae parisiensis academiae illustratus. Cum compositione annuli astronomici Boneti Latensis: Et geometria Euclidis Megarensis, ed. by Jacques Lefèvre d'Étaples. Paris: Simon de Colines. http://hdl.handle.net/21.11103/ sphaera.100998.

Sacrobosco, Johannes, Luca Gaurico, Bartolomeo Vespucci, Prosdocimo de' Beldomandi, Francesco Capuano de Manfredonia, Jacques Lefèvre d'Étaples, Pierre d'Ailly, Robert Grosseteste, Gerard of Cremona, Johannes Regiomontanus, Michael Scot, Campanus of Novara, Georg Peurbach, and al-Bitruji. 1531. Sphaerae tractatus. Venice: Lucantonio Giunta. http://hdl.handle.net/21.11103/sphaera.100999.

Šālew, Șûr, and Charles Burnett, eds. 2011. Ptolemy's geography in the Renaissance. London: Warburg Institute.

Sasaki, Chikara. 2003. Descartes's mathematical thought. Dordrecht: Springer. https://doi. org/10.1007/978-94-017-1225-5.

Schmitt, Charles B. 1974. The university of Pisa in the Renaissance. History of Education: Journal of the History of Education Society 3: 3-17. https://doi.org/10.1080/0046760740030101.

1975. Philosophy and science in sixteenth-century universities: Some preliminary comments. In The cultural context of Medieval learning, ed. John E. Murdoch and Edith D. Sylla, 485-537. Dordrecht/Boston: D. Reidel.

Shank, Michael. 2002. Regiomontanus on Ptolemy, physical orbs, and astronomical Fictionalism: Goldsteinian themes in the Defense of Theon against George of Trebizond. Perspectives on Science 10: 179-207. https://doi.org/10.1162/106361402321147522.

- 2009. Setting up Copernicus's Astronomy and natural philosophy in Giambattista Capuano da Manfredonia's Expositio on the Sphere. Early Science and Medicine 14: 290-315. https://doi.org/10.1163/157338209X425597.

Siraisi, Nancy. 1981. Taddeo Alderotti and his pupils: Two generations of Italian medical learning. Princeton: Princeton University Press.

1990. Medieval and early Renaissance medicine: An introduction to knowledge and practice. Chicago: University of Chicago Press.

Tessicini, Dario. 2011. Definitions of 'cosmography' and 'geography' in the wake of fifteenth- and sixteenth-century translations and editions of Ptolemy's Geography. In Ptolemy's Geography in the Renaissance, ed. Șûr Šālew and Charles Burnett, 31-50. London: Warburg Institute.

Thévet, André. 1584. Les vrais pourtraits et vies des hommes illustres grecz, latins et payens recueilliz de leurs tableaux, livres, médalles antiques et modernes. Paris: Veuve de J. Kerver and Guillaume Chaudière.

Thomé de Maisonneufve, Paul. 1922. Oronce Finé et sa famille. Bulletin de la Société d'Études Historiques, Scientifiques et Littéraires des Hautes-Alpes 33: 175-179.

_. 1924. Un Manuscrit briançonnais à enluminures du XVe siècle: Le matutinaire des frères Fine. Notes sur la famille d'Oronce Fine. Grenoble: Allier.

Thorndike, Lynn. 1941. A history of magic and experimental science. Vol. 5. New York: Columbia University Press.

Press. 
Tredwell, Katherine A. 2005. The exact sciences in Lutheran Germany and Tudor England. Doctoral dissertation, University of Oklahoma.

Tuilier, André. 2006a. L'entrée en fonction des premiers lecteurs royaux. In Histoire du Collège de France, ed. André Tuilier, vol. I, 145-163. Paris: Fayard.

2006b. Ce que signifie l'enseignement des mathématiques en 1530. In Histoire du Collège de France, ed. André Tuilier, vol. I, 369-376. Paris: Fayard.

Turner, Anthony. 2009. Dropped out of sight: Oronce Fine and the water-clock in the sixteenth and seventeenth centuries. In The worlds of Oronce Fine. Mathematics, instruments and print in Renaissance France, ed. Alexander Marr, 191-212. Donington: Shaun Tyas.

Valleriani, Matteo. 2013. Metallurgy, ballistics and epistemic instruments. The Nova scientia of Nicolò Tartaglia. A new edition. Berlin: Edition Open Access.

- 2017. The tracts on the Sphere. Knowledge restructured over a network. In The structures of practical knowledge, ed. Matteo Valleriani, 421-473. Dordrecht: Springer.

Vanden Broecke, Steven. 2003. The limits of influence: Pico, Louvain, and the crisis of Renaissance astrology. Leiden: Brill.

- 2016. From cosmic governance to governmentality: Shaping sublunary order in seventeenth-century French critiques of astrology. In Unifying heaven and earth: Essays in the history of early modern cosmology, ed. Miguel Ángel Granada, Patrick J. Boner, and Dario Tessicini, 317-342. Barcelona: Universitat de Barcelona.

Vermij, Rienk. 2016. Seventeenth-century Dutch natural philosophers on celestial influence. In Unifying heaven and earth: Essays in the history of early modern cosmology, ed. Miguel Ángel Granada, Patrick J. Boner, and Dario Tessicini, 291-315. Barcelona: Universitat de Barcelona.

Wagner, Roy. 2010. The geometry of the unknown: Bombelli's algebra linearia. In Philosophical aspects of symbolic reasoning in early modern mathematics, ed. Albrecht Heeffer and Maarten van Dyck, 229-269. London: College Publications.

Waldseemüller, Martin and Matthias Ringmann. 1907. Cosmographiae Introductio, (St. Die: Nicolas Lud, 1507); facs. The Cosmographiae introductio of Martin Waldseemüller in facsimile: followed by The Four Voyages of Amerigo Vespucci, with their translation into English; to which are added Waldseemïller's two world maps of 1507, ed. Charles Herbermann. New York: United States Catholic Historical Society.

Westman, Robert. 1980. The astronomer's role in the sixteenth century: A preliminary study. History of Science 18: 105-147. https://doi.org/10.1177/007327538001800202.

- 2011. The Copernican question: Prognostication, skepticism, and celestial order. Berkeley: University of California Press.

Wickerheimer, Ernest. 1979. Dictionnaire biographique des médecins en France au Moyen Âge. Genève: Droz.

William (Gilliszoon) of Wissekerke. 1538. In proprium planetarium aequatorium, omnium antehac excogitatorum et intellectum et usu facillimum Canones. Paris: J. de Gourmont.

Open Access This chapter is licensed under the terms of the Creative Commons Attribution 4.0 International License (http://creativecommons.org/licenses/by/4.0/), which permits use, sharing, adaptation, distribution and reproduction in any medium or format, as long as you give appropriate credit to the original author(s) and the source, provide a link to the Creative Commons license and indicate if changes were made.

The images or other third party material in this chapter are included in the chapter's Creative Commons license, unless indicated otherwise in a credit line to the material. If material is not included in the chapter's Creative Commons license and your intended use is not permitted by statutory regulation or exceeds the permitted use, you will need to obtain permission directly from the copyright holder.

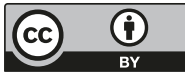




\title{
Chapter 9 \\ Borrowers and Innovators in the History of Printing Sacrobosco: The Case of the In-Octavo Tradition
}

\author{
Isabelle Pantin
}

\begin{abstract}
The Sacrobosco editions constitute a textual tradition wherein innovation owed to the interaction of two types of actors: borrowers, responsible for chains of related editions, and innovators, who wrote relatively original commentaries. This can be observed in the "in-octavo tradition," a series of editions printed in several European towns, which began with Apianus's 1526 Sphaera and endured until the seventeenth century. Different kinds of innovation were produced in it (concerning the layout, the illustration, and different kinds of textual additions). This successful attempt at standardization produced a kind of manual that always retained an essential part of its original features while remaining capable of evolution. This evolution was due to close cooperation between the publishers and mathematicians, and to the fact that the former, with a few exceptions, kept control over the process, and combined innovation with the artful practice of reusing borrowed material.
\end{abstract}

\section{Introduction}

The advent of print culture greatly facilitated the building of textual traditions. The great number of manuscripts of Johannes de Sacrobosco's (died ca. 1256) Sphaera were copied in codices containing variable sets of texts-with or without illustrations, with or without different kinds of commentary, and with numerous variants on the original text itself. Many of these manuscripts were copied from earlier ones, so it is possible to reconstruct certain lines of transmission, but a stemma would be impossible to achieve. Confronted with "legions" of manuscripts, Lynn Thorndike contented himself with collating twenty significant manuscripts and inventorying the principal commentaries (Thorndike 1949). With the printed editions, in contrast, it is possible to make a census of all those still in existence and to study their

\footnotetext{
I. Pantin $(\bowtie)$

Ecole Normale Supérieure - PSL Research University, Paris, France

e-mail: isabelle.pantin@ens.fr
} 
interrelations. ${ }^{1}$ Very few of them were completely unrelated to the others, as their authors, editors, and publishers were more or less aware of the other editions available on the market. Thus, the entire body of Sacrobosco editions, with its different branches - some of which eventually became trunks of their own ${ }^{2}$ - can be studied as a textual tradition. In this frame, we can observe more precisely how innovations occurred. I thus intend to focus on the interaction between two types of actors that contributed to the transmission of the Sacrobosco tradition: borrowers, responsible for long chains of related (if not identical) editions, and innovators, who chose to write commentaries that were, up to a certain point, original, and as a consequence signed their contributions personally.

\section{The Dialectic of Tradition and Innovation: The In-Octavo Editions}

In the case of the Sacrobosco editions, borrowers and innovators worked together in close collaboration. This is probably linked to the fact that booksellers were, as a rule, particularly involved in the publication of the treatises of the sphere, and that they understood the art of combining innovations with well-tried materials as crucial to commercial success. These booksellers had to respond to the specific demands of the teachers of mathematics (as well as to the vaguer demands of a larger clientele), as they depended on these teachers for achieving the mathematical part of the work; but they kept much more control over the whole process than in the case of more sophisticated scientific works. In some instances (Oronce Finé (1494-1555), Peter Apian (1495-1552)), the mathematicians were also competent in book design, book printing, and even book selling, which contributed to blurring the distinction between the roles.

Quite often, the more innovative writers of commentaries tended to bury the original text under a considerable amount of new data and arguments, or even to depart from the original pattern, so that their claims for full authorship prevailed over their linkage to the tradition. That was the case with Oronce Finé (Chap. 8), Francesco Maurolico (1494-1575), ${ }^{3}$ and many others, notably the authors of oversized treatises intended as summae of cosmological knowledge rather than simple

\footnotetext{
${ }^{1}$ For a census of the printed editions of treatises of Johannes de Sacrobosco's Tractatus de sphaera, see the Database produced by the project The Sphere. Knowledge System Evolution and the Shared Scientific Identity of Europe: https://sphaera.mpiwg-berlin.mpg.de/database. Accessed June 2019. See also (Valleriani 2017).

${ }^{2}$ From the beginning of the printed tradition of the Sphaera, some editors and commentators (for instance Jacques Lefevre d'Étaples and Oronce Finé in France) took this manual as a basis for developing topics that had been perfunctorily treated by Sacrobosco, notably cosmography and mapping (Chaps. 2 and 8). Ultimately, that lead to the publication of books detached from the Sacrobosco tradition, entitled Cosmographiae.

${ }^{3}$ Maurolico's Cosmographia, published in Venice in 1543, was an adaption of the Sphaera in the form of a dialogue. There are very few studies on this part of Maurolico's work, only brief remarks in (Clagett 1974; Moscheo 1998; Rosen 1957). On the notion of adaption, see the introduction to this volume.
} 
textbooks, which deeply transformed the field around 1570. These works were elaborated mostly for the use of teachers of astronomy, but they also originated from the desire to assert the mastery of Catholic mathematicians over the field of cosmology, which was then dominated by Lutherans. ${ }^{4}$ Erasmus Oswald Schreckenfuchs (1511-1579), who published his commentary in 1569 (Schreckenfuchs 1569), ${ }^{5}$ taught at the Catholic University of Freiburg im Breisgau and dedicated his work to Jacobus Curtius, Canon of the Cathedral of Constance, a patron and benefactor of the university; Christophorus Clavius (1538-1612), as is well known, published his Sphaera (first edition 1570) (Clavius 1570) to provide a summa of the orthodox cosmological doctrine for the use of Jesuit colleges. ${ }^{6}$

However, we can observe at least one long series of editions in which borrowing, copying, and imitating carried as much weight as innovating. This series, which I shall call the "in-octavo tradition," began with Apianus's 1526 edition and endured until the middle of the seventeenth century, though it dwindled down in the last decades of the sixteenth century due to the emergence of successful competing models of treatises on the Sphaera. Francesco Giuntini (1523-1590) was its last significant contributor, that is if we set aside the 1626 edition by Franco Burgersdijk (1590-1635), which revived the "in-octavo tradition" in extremis (Chap. 11). But Giuntini soon abandoned it to write two more original treatises on the Sphaera under his own name. This is a strong indicator that the tradition could not integrate highly idiosyncratic projects.

I shall describe the development of the "in-octavo tradition" both through time and space (since several printing centers in Europe were involved), and try to analyze the different kinds of innovation that were produced in it. These innovations concerned the commentary, the illustration, and the layout and editing (including the formulation of titles). It is often tough to determine whom exactly they ought to be attributed to, but the following inquest should at least improve our understanding of the type of actors involved, and of their principal aims and motives.

\section{The Predecessors: The Venetian Incunabula and the Leipzig Editions}

The Sphaera was probably first printed in Venice in 1472 or earlier (Sacrobosco ca. 1472a); ${ }^{7}$ the first dated edition appeared in Ferrara in 1472 (Sacrobosco 1472b). These first editions were without commentaries and had no printed diagrams, but

\footnotetext{
${ }^{4}$ On the rivalry between Catholic and Lutheran mathematicians, see (Pantin, 1999).

${ }^{5}$ Schreckenfuchs was also the author of a huge commentary on Peuerbach's Theoricae planetarum with innovative diagrams. See (Mosley 2004).

${ }^{6}$ On the original version of Clavius's commentary and on its successive revisions, see (Lattis 1994).

${ }^{7}$ This Venetian edition is undated, but a manuscript note in the Library of Congress copy shows that it was published before $8^{\text {th }}$ of May 1472. It could be anterior to the Ferrara 1472 edition, which is revised and has a more elaborate layout (with the use of subtitles).
} 
some blank spaces (two in the Venice edition, three in the Ferrara edition) allowed the insertion of manuscript drawings. Other editions followed, and from 1478 onwards, some printed figures were added. ${ }^{8}$ The complete set of the 'Venetian Sacrobosco diagrams' first appeared in the revised edition printed by Johannes Santritter (before 1460-after 1498) in 1488. This Santritter 1488 edition originated a tradition. It was copied by other Venetian printers and book-sellers, notably Ottaviano Scoto (ca. 1444-ca. 1499) and Melchior Sessa (active 1505-1555). ${ }^{9}$

The Venetian editions, from the 1488 Santritter edition onwards, contained significant corrections to the original text and at least four important additions: a description of the armillary sphere, a preliminary treatise of geometry, an excursus on the constellations at the end of chapter II, and a large note concerning domification (the construction of the figura caelestis for the horoscopes) in chapter III. The books were small quartos, ${ }^{10}$ of which the Sphaera occupied around forty pages, followed by two other texts: Johannes Regiomontanus's (1436-1476) Disputationes contra Cremonensia deliramenta and Georg von Peuerbach's (1423-1461) Theoricae novae planetarum. ${ }^{11}$ The long-line layout was dark and dense, and the white spaces quasi-inexistent. Some detached subtitles and, above all, numerous images helped the readers to find their way through the text. These images were small and purely descriptive (lettered geometrical diagrams were avoided). Some of them derived from a long manuscript tradition.

Indeed, a significant minority of the manuscripts of the Sphaera had been illustrated, ${ }^{12}$ and a kind of iconographical tradition had even been established as early are the second half of the thirteenth century. The diagrams were always related to the same parts of the text, that is, mainly to the first and fourth chapters, and to a lesser extent the third chapter. Some of them had very ancient sources and had been transmitted through the manuscript traditions of late Antiquity texts, notably Calcidius's In Timaeum (fourth cent.) and Macrobius's In somnium Scipionis

\footnotetext{
${ }^{8}$ In 1478, Franciscus Renner from Heilbronn and Adam Burkardt from Rottweil printed in Venice two different editions with three diagrams (the elementary and celestial spheres; the climes; the solar and lunar eclipses). In 1482, still in Venice, Erhard Ratdolt published a new edition that added a fourth figure (an armillary sphere). In 1485, Ratdolt released another edition with twenty-two small new diagrams and some improvements to the existing diagrams.

${ }^{9}$ The Santritter edition was used as a model for the editions printed in Venice by [Bonetus Locatellus] for Octavianus Scotus, $4^{\text {th }}$ of October 1490, for Melchior Sessa, $3^{\text {rd }}$ of December 1501 and $3^{\text {rd }}$ of December 1513, and by Jacobus Pentius for Sessa, $24^{\text {th }}$ of December 1519.

${ }^{10}$ The dimension of the small quarto page is about $180 \times 140 \mathrm{~mm}(145 \times 115 \mathrm{~mm}$ for the printed text).

${ }^{11}$ Regiomontanus's and Peuerbach's texts do not begin on the recto of the first folio of a quire, which indicates that they were not meant to be sold or bound separately.

${ }^{12}$ Only seven of the twenty manuscripts described by Thorndike (see Footnote 1 ) are with diagrams and only five of these seven have what could be considered as a 'complete set.'
} 
(first quarter of the fifth cent.), of which the earliest surviving manuscripts are from the ninth century. ${ }^{13}$

In the following list, we have underlined the diagrams for which prototypes can be traced back to the thirteenth and fourteenth centuries (or even earlier). Of course, for each type of diagram, there existed a quantity of variants. Further research on the fifteenth century manuscripts of the Sphaera would be necessary to identify the sources of the diagrams in the first illustrated editions of the Sphaera. This list is the brief census of the diagrams that illustrated the text of Sacrobosco in the Venetian incunabula, from the Santritter 1488 edition onwards (Table 9.1).

Even before the turn of the century, other types of treatises on the Sphaera appeared in which Sacrobosco's text was accompanied by commentaries, sometimes collected in massive in-folio volumes (Sacrobosco 1495b, 1498, 1499a, b). Other diagrams were conceived for these publications, often more purely geometrical than in the series above described, and new elements were added, notably samples of astronomical tables. At the same time, however, the idea of providing the students with handy textbooks was carried forward. This intention was most apparent in a series of tracts printed in Leipzig starting in 1486 (Sacrobosco 1486, ca. 1487, [1489], and so on). The volumes were small quartos, and they contained no other text than the Sphaera, except for some of these editions which included a commentary by Wenceslaus Faber from Budweis (died in 1518) (Sacrobosco [ca. 1495a], 1499a, b, 1500, 1501a, b, 1503a, 1505, 1508). The Sphaera commented by Conrad Tockler (1470-1530) (Chap. 5) was published by the same printer in Leipzig, in the same format and with the same figures (Sacrobosco 1503b, 1509).

The layout of the Leipzig quartos was quite different from that of the Venetian incunabula. Large interlinear spacing facilitated note-taking. The text was divided by pilcrows, but there were no detached subtitles (other than the titles of see Chapter II, III and IV of Tractatus de Sphaera by Sacrobosco). The diagrams (which were revised and augmented around 1494) illustrated almost the same topics as those of the Venetian editions, but they were different in style; they were often best suited to give the reader a simple but concrete understanding of the basic cosmological phenomena. For instance, the revised iconography provided what is probably the first attempt, in any version of the Sphaera, to include a map in the diagram of the terrestrial zones (Asia, Africa, and Europa are crudely delineated in the northern habitable zone). Besides, some diagrams had no counterparts in the Venetian editions, like a series of seven diagrams in the third chapter that showed the variation of the horizon (and its consequences) for people living at different latitudes (Fig. 9.3) (Table 9.5).

\footnotetext{
${ }^{13}$ Late Ancient diagrams concern the concentric spheres of the world (see Chapter I of Tractatus de Sphaera by Sacrobosco), the terrestrial and celestial zones, the climes (see Chapter II of Tractatus de Sphaera by Sacrobosco), the figura retrogradationis (showing how the movement of the planet on its epicycle produces, as observed from the earth, cycles of direct motion, station, and retrograde motion), and the lunar and solar eclipses (see Chapter IV of Tractatus de Sphaera by Sacrobosco). On this iconographic tradition, see notably (Obrist 2004; Müller 2008).
} 
Table 9.1 The diagrams in the Venetian editions from 1488. (NB: The diagrams that had ancient models are underlined)

Preliminaries

1. Armillary sphere: 1 large diagram

2. Geometry: 24 small diagrams

Chapter I

3. The elemental and celestial spheres: 1 large diagram that shows the four elemental spheres (earth and water are separated, the former being completely surrounded by the latter), the seven orbs of the planets, the sphere of the fixed stars, and the ninth invisible sphere, divided into the twelve zodiac signs. ${ }^{\mathrm{a}}$

4. Sphaera recta/sphaera obliqua: 2 diagrams showing a circle and two diagonals (in the first diagram, the equator and the perpendicular right horizon, in the second, the equator and the oblique horizon).

5. The four elemental spheres or orbs: 1 diagram. This time, the earth is shown as a small eccentric sphere, which, at its top, emerges from the surrounding orb of water into the orb of air.

6. De cali revolutione: 1 diagram. The diurnal revolution of heaven is symbolized by a semi-circle (with the earth at its center), within which fixed stars are shown in three supposedly successive positions: at the oriental horizon (oriens), at the meridian (mer), and at the occidental horizon (occi).

7. De cali rotunditate: 1 diagram. A circle and three regular polygons inscribed in it (triangle, square, and pentagon) to show that the sphere is "the most capacious" of all shapes and the best suited to enclose all natural things, and that, if the world were not round, "it would follow that some place would be vacant and some body without a place" (Thorndike 1949, 120).

8. Effects of refraction: 2 diagrams. The first one is synthetic to the point of being illegible. It shows, first, the false hypothesis of a flat sky (in which case the stars would be nearer at the zenith), and, second, the reason why the stars look bigger at the horizon than at the zenith: the interposition of vapors that disperse the visual rays. In order to illustrate this phenomenon, the second diagram shows a piece of money immersed in water, and how it is enlarged.

9. Quod terra sit rotunda: 2 diagrams. In the first one, the earth is surrounded by the circles of the moon and of the sun. These planets are in opposite positions, so that the moon must be eclipsed. That illustrates (not quite clearly) the fact that, as the earth is round, oriental people see lunar eclipses at an earlier hour than occidental people. The second diagram (Fig. 9.1) shows the earth surrounded by the circle of the fixed stars. Four men are walking around the upper hemisphere, from north (sept) to south (mer), and lines drawn from their position at the surface of the earth to stars at different positions on the outer circles symbolize the fact that southern observers do not see the same stars as northern observers.

10. Quod aqua sit rotunda: 1 diagram. The visual ray (Radius visualis) from an observer on a ship at the top of the mast reaches without obstacle a signal on the seacoast (Signum littoris), while the visual ray from an observer on the deck is intercepted by the bulge of the water.

Chapter II

11. The equinoctial: 1 diagram. A circle that represents the world, the axis of the world, and the equator.

12. De zodiaco circulo: 1 diagram. A circle that represents the world, the axis of the world, and the zodiac divided in twelve signs. The equator is not drawn, and the inclination of the zodiac with respect to the axis of the world is not correct. 
Table 9.1 (continued)

13. Zodiacal signs: 2 diagrams illustrate two significations of "sign." The first one is a pyramid, of which the basis is the corresponding portion of the zodiac (in the eighth sphere), and the apex is at the center of the world. The second one is a crescent-shaped portion of the eighth sphere, of which the points are at the poles and the larger part is the corresponding portion of the zodiac.

14. De duobus coluris: 1 diagram. In a circle that represents the world, the axis of the world, and both colures (equinoctial and solsticial).

15. De meridiano et horizonte: 1 diagram.

16. Celestial zones and circles: 1 diagram. In a circle that represents the world, the equator, the tropics, the polar circles, the zodiac, the axes of the equator and of the zodiac.

17. Terrestrial zones: 1 diagram. The Arctic and Antarctic zones and the zone between the tropics are marked Inhabitabilis. The two zones between the tropics and the polar circles are marked habitabilis. In the lower habitable zone (in the northern hemisphere) a landscape is drawn.

Chapter III

18. Ortus/occasus cosmicus, chronicus, heliacus: 1 diagram. The circle of the sun (with the sun in two different positions, oriental and occidental), surrounded by a circle that represents the zodiac: on its oriental part, below and above the radiating sun, several stars are represented. Without reading the text, it is not easy to guess that this is a visual definition of the cosmic, acronychal, and heliacal rising and setting of the stars.

19. What is necessary to understand the astronomical rising and setting: 1 diagram. How the equator, the zodiac, the right horizon, and the oblique horizon mutually intersect.

20. Dies naturalis: 1 diagram. A circle that represents the zodiac surrounds the earth and the circle of the sun. The symbol of Aries is marked on the right, and the position of the sun is slightly below. That corresponds probably to the definition of the natural day: "the revolution of the equinoctial with as much as the sun covers meanwhile by its own movement against the firmament" (Thorndike 1949, 132).

21. The circles of natural days: 1 diagram. A great circle of the world, the axis of the world, the polar circles, the tropics, the zodiac, and a crude representation of the spiral movement of the sun caused by the combination of its diurnal and annual motions.

22. The great circles of the sphere: 1 diagram.

23. The 12 celestial houses: 3 diagrams corresponding to three different ways of drawing an astrological chart. They illustrate the addition on the methods of domification.

24. The shadows at the equator: 1 diagram. A hemisphere, delimitated by the line of the horizon, and a semi-circle that represents the zodiac, below it, the circle of the sun, with the sun at three different positions: at the zenith, at noon, when the sun is in either equinoctial point (according to the text), when the sun is in the northern signs, and when it is in the southern signs (again according to the text). These three suns cast the shadows of a tower surrounded by ramparts: the shadow is "perpendicular" in the first case, southern in the second one (umbra austr), and northern (umbra bore) in the third.

25. Terrestrial zones and climates: 2 diagrams. One large diagram: a circle that represents the world, with the equator, the tropics, the polar circles, the zodiac, and the axis of the equator marked. In the northern hemisphere (north is below) the seven Ptolemean climes are drawn. One smaller diagram: the great circle that passes through the poles and the equinoctial points, the equator, lines drawn from the pole to the equinoctial points, and the seven climes: the geometrical significance of this diagram is not explained in the text. 
Table 9.1 (continued)

\section{Chapter IV}

26. Circles of the sun: 1 small diagram shows the eccentric deferent of the sun (and the sun on it), a larger circle that represents a great circle of the sphere (probably the ecliptic), and the centers of both circles.

27. Moon's circles, caput \& cauda draconis: 1 small diagram. A larger circle that represents a great circle of the sphere, probably the ecliptic, surrounds the eccentric deferent of the moon with its epicycle, and the equant circle, which has a different center than the deferent. The equant and the deferent intersect at two points, called the "head" and the "tail" of the Dragon.

28. The stationary, direct and retrograde motions (figura retrogradationis): 1 small diagram. A larger circle that represents a great circle of the sphere, probably the ecliptic, surrounds the eccentric deferent of any planet (the sun and the moon excepted) with its epicycle, the equant circle, and the three centers of these circles. Tangents to the epicycle are drawn from the center of the world: that shows why a terrestrial observer sees a succession of stationary, direct, and retrograde motions as the planet rotates on its epicycle.

29. The lunar eclipse: 1 diagram. The traditional diagram shows simply the disposition of the three globes (Sun, Earth, and Moon) and the production of the umbra cone. Here, the eclipse is represented in a broader frame: the ecliptic circle (with stars), the horizon, the deferent of the sun, the deferent and the equant of the moon are drawn. The sun is at the nadir, the moon at the zenith (and at one node of the Dragon), and a landscape is visible on the large earth.

30. The solar eclipse: 1 diagram shows the deferent circle of the sun, the horizon, and the earth, moon, and sun in alignment. The earth, represented with terrestrial and maritime landscapes, is so large that two men are seen, silhouetted against the sky near the eastern and western horizon. A tangent to the earth passing through the border of the umbra cone of the moon marks the limit outside of which the eclipse is completely invisible.

${ }^{a}$ Concerning the diagram that shows the spheres of the elements and the celestial orbs, there is a discrepancy between the diagram, which corresponds to the original text of Sacrobosco (according to which the sphere is divided into nine celestial spheres), and the revised text of the Santritter edition and its followers that lists ten celestial spheres (Chap. 5).

Fig. 9.1 Quod Terra sit rotunda (Table 9.1, n 9). From (Sacrobosco 1488). Deutsches Museum, München/Public Domain Mark

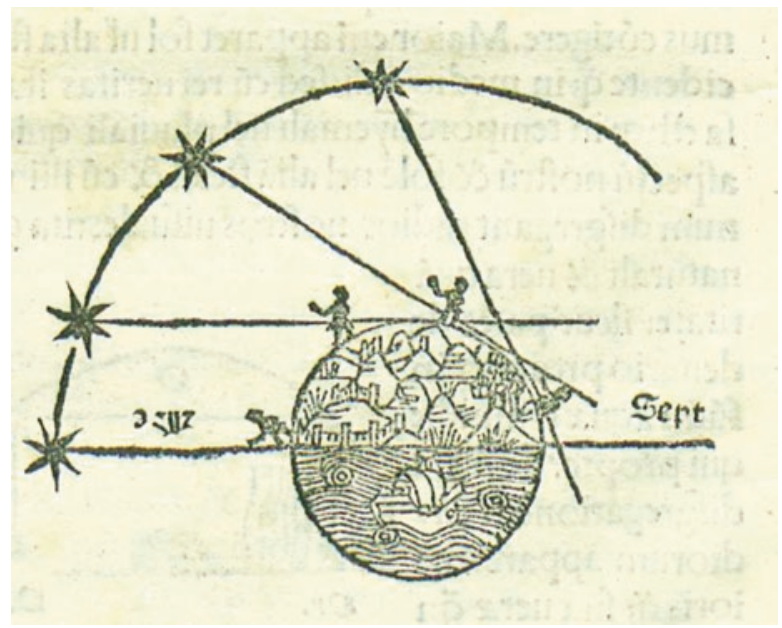




\section{The Founder of the Tradition: Petrus Apianus (1526)}

The new orientation towards pedagogical clarity, cosmographical realism, and interest in a more practical understanding of astronomy was accentuated in the edition printed by Petrus Apianus in Ingolstadt in 1526 (Sacrobosco 1526), which founded the in-octavo tradition. Apianus was then still at the beginning of his career. He had recently moved to Ingolstadt from Landshut where he had already published at least one world map, astrological practica, a book on a new kind of sundial (Apianus 1524a), and what was to become (after its revision by Gemma Frisius (1508-1555)) a best-seller, the Cosmographicus liber (1524), a manual based on Ptolemy's (second century) geographical knowledge that also contained abundant up-to-date information about land surveying, map projections, instrument making, and navigation (Apianus 1524b). ${ }^{14}$ Moreover, Apianus's bias towards practicality showed itself in the way the book was printed: it was lavishly illustrated and contained volvelles (wheel charts) (Vanden Broecke 2000, 130-50). This kind of paper instrument, already used in the Middle Ages, had been introduced in printed books by Regiomontanus, followed by other mathematicians, instrument makers, and designers of astronomical books like Lazarus Behaim and Johann Stoeffler (1452-1531) (Regiomontanus (1472-1474?); Stoeffler 1514; Gingerich 1993, 63-74; Bennett 1998, 195-222; Rhodes and Sawday 2001; Kremer 2011; Schmidt 2011; Stijnman and Upper 2014).

This background must be kept in mind to better understand the new orientation around practicality given to the Sacrobosco printed tradition by Apianus's edition, which at first sight is a much less innovative book than the Cosmographicus liber. Indeed, Apianus refers to this earlier work in the Ad lectorem of his 1526 Sphaera. He adds that this new edition of the Sphaera has been conceived "because of the numerous correspondences that exist between geography and astronomy." 15 Indeed, if young students acquired a precise knowledge of the sphere and its circles via Sacrobosco, they would understand thoroughly the measures of Earth and heaven. ${ }^{16}$

The Apianus edition contained only the text of the Sphaera, slightly revised, without additions, notes, or commentary, and exhibited thorough editorial work. The layout was airier, using some paragraphs with first-line indents and blank interlinear spaces at the end of the chapters and of the sections in chapters. These chapters and sections had titles and subtitles printed in capital letters, and their set, more complete than in the Venetian incunabula (Table 9.2), better helped the reader in moving through the succession of topics in the text, and in grasping the logical organization of the treatise.

\footnotetext{
${ }^{14}$ On Apianus, see (Röttel 1995).

${ }^{15}$ (Sacrobosco 1526, A1v):"...cum Geographia plurimum comercii habeat cum Astronomia...."

${ }^{16}$ (Sacrobosco 1526, A1v):"...visum est mihi haud inutile fore, si ingenuis adolescentibus primum omnium Astronomiae rudimenta praelegerem, Sphaeram IANI de Sacrobusto accuratissime interpretarer. Futurum tandem existimans ut ex sphaerae circulorumque ejus attenta cognitione, spaciorum terrae coelique absoluta notitia proveniret."
} 
Table 9.2 Titles and subtitles in the Venetian editions from 1488 and in the edition of Apianus (1526)

\begin{tabular}{|c|c|}
\hline Venetian editions & $\begin{array}{l}\text { Apianus edition (1526) (NB: new subtitles are } \\
\text { underlined) }\end{array}$ \\
\hline Divisio secundum accidens sphaerae & $\begin{array}{l}\text { Prooemium auctoris } \\
\text { Diffinitio sphaerae. Cap. } 1 \\
\end{array}$ \\
\hline Quae forma sit mundi & $\begin{array}{l}\text { Quae forma sit mundi } \\
\text { De coeli revolutione } \\
\text { De coeli rotunditate } \\
\text { Quod Terra sit rotunda } \\
\text { Quod aqua sit rotunda } \\
\text { Quod Terra sit centrum mundi } \\
\text { De immobilitate Terrae } \\
\text { De quantitate absoluta Terrae } \\
\end{array}$ \\
\hline $\begin{array}{l}\text { De circulis ex quibus sphaera materialis } \\
\text { componitur: et illa supercaelestis quae per } \\
\text { istam imaginatur componi intelligitur. } \\
\text { Capitulum secundum } \\
\text { De zodiaco circulo } \\
\text { De duobus coluris } \\
\text { De meridiano et horizonte } \\
\text { De quatuor circulis minoribus } \\
\text { *De caracteribus sphaerae decimae vel nonae } \\
\text { et stellationibus octavae } \\
\text { *Quae signa quibus circulis dividantur } \\
\text { * Sequuntur figurae septentrionales } \\
\text { *Figurae Australes }\end{array}$ & $\begin{array}{l}\text { Capitulum secundum De circulis ex quibus } \\
\text { sphaera materialis componitur: et illa } \\
\text { supercaelestis (quae per istam imaginatur) } \\
\text { componi intelligitur } \\
\text { De zodiaco circulo } \\
\text { De duobus coluris } \\
\text { De meridiano et horizonte } \\
\text { De quatuor circulis minoribus } \\
\text { De quinque zonis }\end{array}$ \\
\hline $\begin{array}{l}\text { De ortu et occasu signorum et diversitate } \\
\text { dierum et noctium et de diversitate climatum. } \\
\text { Capitulum tertium } \\
\text { De ortu et occasu signorum secundum } \\
\text { astrologos } \\
\text { De diversitate dierum et noctium quae sit } \\
\text { habitantibus in diversis locis terrae }\end{array}$ & $\begin{array}{l}\text { Capitulum tertium De ortu et occasu signorum, } \\
\text { de diversitate dierum et noctium, et de } \\
\text { diversitate climatum } \\
\text { De ortu et occasu signorum secundum } \\
\text { astrologos } \\
\text { De diversitate dierum et noctium quae sit } \\
\text { habitantibus in diversis locis terrae } \\
\text { Quorum zenith est inter aequinoctium et } \\
\text { tropicum Cancri } \\
\text { Quorum zenith est in tropico Cancri }\end{array}$ \\
\hline $\begin{array}{l}\text { Quorum zenith est inter tropicum cancri et } \\
\text { circulum arcticum } \\
\text { Quorum zenith est in circulo arctico } \\
\text { Quorum zenith est inter circulum arcticum et } \\
\text { polum mundi } \\
\text { Quorum zenith est in polo arctico } \\
\text { De divisione climatum }\end{array}$ & $\begin{array}{l}\text { Quorum zenith est inter tropicum cancri et } \\
\text { circulum arcticum } \\
\text { Quorum zenith est in circulo arctico } \\
\text { Quorum zenith est inter circulum arcticum et } \\
\text { polum mundi } \\
\text { Quorum zenith est in polo arctico } \\
\text { De divisione climatum }\end{array}$ \\
\hline $\begin{array}{l}\text { De circulis et motibus planetarum et de causis } \\
\text { eclipsium solis et lunae. Capitulum quartum }\end{array}$ & $\begin{array}{l}\text { Capitulum quartum De circulis et motibus } \\
\text { planetarum, et de causis eclypsium Solis et } \\
\text { Lunae } \\
\text { De statione, directione et retrogradatione } \\
\text { De eclypsi Lunae }\end{array}$ \\
\hline
\end{tabular}

${ }^{a}$ The subtitles marked with an asterisk correspond to a long addition on the visible constellations of the eighth sphere and their correspondence with those of the ninth and tenth spheres.

${ }^{b}$ The first two subtitles «Quorum zenith est» are in the flow of the text. 
Fig. 9.2 Quod Terra sit rotunda. From (Sacrobosco 1526, A6r). State Library Regensburg--999/ Philos.1325, urn:nbn:de:bvb:12bsb11110162-1

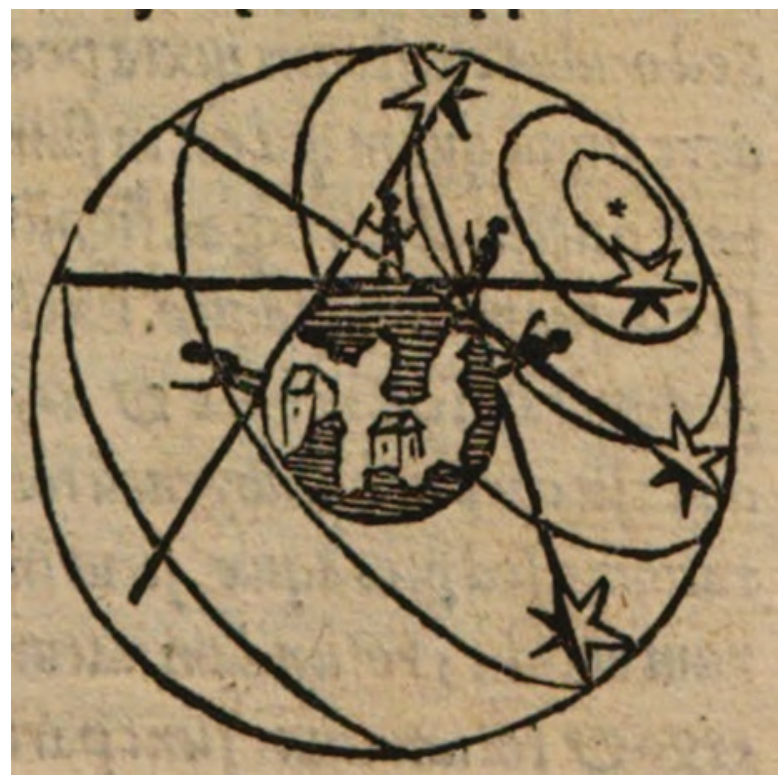

However, the main improvement lay in the illustration. The diagrams of the Apianus edition bore an evident link of continuity to those of its Venetian and Leipzig predecessors in that they concerned the same topics, but they had all been redrawn. Several of these new diagrams were inspired by diagrams already present in the Venetian (Fig. 9.2) as well as the Leipzig editions (Table 9.5), but Apianus had found new visual solutions whenever the models at his disposal lacked clarity or relevance, or when they perpetuated out-of-date representations. An improved mastery of three-dimensional images provided better readability.

For instance, his figure of the elementary and celestial spheres (Table 9.1, No. 3) showed ten celestial spheres (instead of nine) according to the standard opinion of the astronomers at the beginning of the sixteenth century: it corresponded to the model adopted in the Alphonsine Tables and explained in Peuerbach's Theoricae novae planetarum (of which Apianus was to publish an edition in 1528). Thus, in Apianus's edition, the figure was more up to date than the text, which remained true to the original version and listed only nine celestial spheres. ${ }^{17}$ Furthermore, in this diagram, like in that of the four elements (Table 9.1, No. 5), the sphere of earth was no longer included into the sphere of water, for earth and water formed one single

\footnotetext{
${ }^{17}$ The discrepancy in Apianus's work is the reverse of that in the Venetian editions, which modernized the text and kept the traditional figures.
} 
sphere, according to the new representation of the terraqueous globe. ${ }^{18}$ Such a representation was then still quite rare among Sphaera editions, for the printers reused the same woodcuts from edition to edition. It had first appeared in the edition supervised by Oronce Finé and printed in Paris by Vincent Quignon (active 1514-1557) for Regnault Chaudière (active 1509-1554) in 1516. ${ }^{19}$

More generally, the images were better distributed throughout all parts of the text (Table 9.5), and Apianus managed to replace diagrams that were not intelligible without the aid of the text with figures that made sense by themselves. To begin with, instead of the ambiguous diagram showing "The revolution of heaven" (Table 9.1, No. 6), there appeared the image of a celestial globe, the horizon of which separated the diurnal from the nocturnal sky (Sacrobosco 1526, A4v).

Indeed, Apianus created a coherent visual language with which his reader could become familiar, as the diagrams often constituted series. For instance, in chapter III, the figure of the "circles of natural days" (Table 9.1, No. 21) is followed by a series of eight diagrams that show what happens to the respective length of night and day (and to related phenomena) around the year under different latitudes (that is, different horizons). ${ }^{20}$

The figure of the "circles of natural days" (Apianus 1526, C1r), which inaugurates the series, shows the sphere of the sun, a small Earth at its center, the oblique track of the ecliptic, and the tight quasi-parallel (in fact spiral) circles that symbolize the path of the sun, day after day, as it follows the diurnal revolution of the heavens while progressing along the ecliptic of its own proper motion.

The next diagram (Apianus 1526, C1r) shows that in the "right sphere," that is at the equator, the horizon passes through the poles of the world and always divides the "circles of the days" into equal parts, so that nights are equal to days, whatever the position of the sun. The ecliptic and the earth are no longer visible, but we recognize the sphere and the band of solar spiral circles ("circles of the days"). These circles, drawn like lines, are vertically positioned, perpendicular to the line of the horizon (dividing night and day). Three of them are more heavily marked: the middle one (the path of the sun at the equinox that corresponds to the axis of the horizon) and those at both extremities (the solar path at the summer and winter solstices).

\footnotetext{
${ }^{18}$ The change concerning the representation of the spheres of water and earth was a consequence of the navigation of Amerigo Vespucci along the east coast of Brazil in 1501, which proved that the southern hemisphere was not immersed in water. Joachim Vadianus was probably the first to infer that the earth constituted one single sphere with the water, from which it "partly emerged," doing so in a letter to Rudolf Agricola that was published for the first time in Wien in 1515. See (Randles 1980, 44-48; Grant 1994, 635-37).

${ }^{19}$ In the (Chaudière 1516) edition (and in the 1519, 1524, and 1527 re-editions), the terraqueous globe is represented in the diagram of the four elements (a2v), but not in the diagram of the elementary and celestial spheres (a2r). In the Sphaera printed in Wien in 1518 by Johann Singriener for Lucas Alantsee, the terraqueous globe, with a map drawn on it, figures in the diagram of the elementary and celestial spheres (a3r, a6v).

${ }^{20}$ This part of chapter 3, entitled "on the variation of phenomena according to latitude," is not illustrated in the Venetian editions; in the Leipzig editions, it is illustrated with seven diagrams, which have only remote links to Apianus's diagrams (Fig. 9.3).
} 


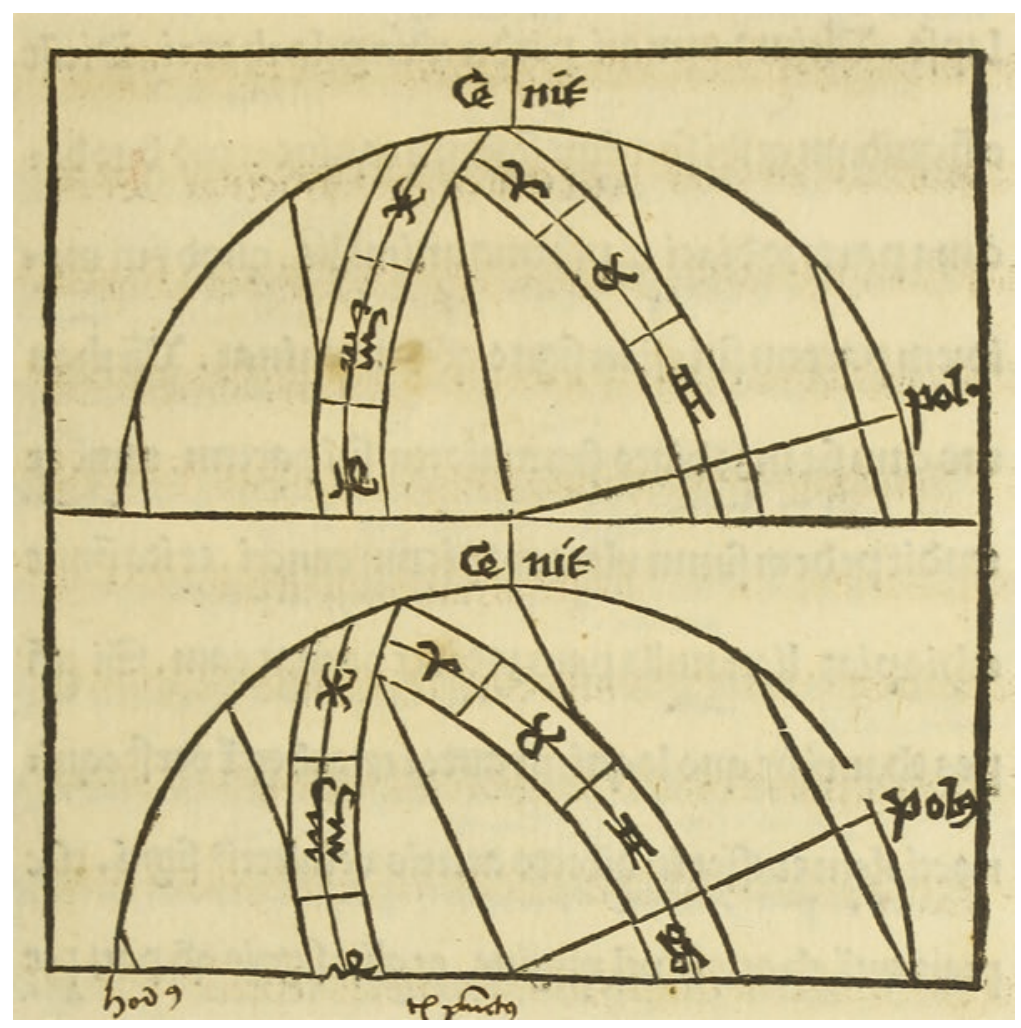

Fig. 9.3 Opusculum spericum cum figuris optimis et novis. When the zenith is between the Equator and the Tropic of Cancer (first diagram), and on the Tropic of Cancer (second diagram). From (Sacrobosco 1494). Courtesy of the John Carter Brown Library

At the right and left extremities of the horizon line, small stars symbolize the north and south poles: the plan of the horizon coincides with that of the axis of the world. The band of the "circles of the days" is divided by twelve lines (portions of meridians), parallel to the horizon and equally spaced. They are numbered and symbolize the perfect equality of all diurnal and nocturnal hours, whatever the season, in the right sphere (sphaera recta).

In the seven next diagrams, the basic elements are the same, but the respective positions of the horizon (with its axis), the axis of the world, and the "circles of the days" vary, as the text describes what happens to people "whose zenith is" at different latitudes (Fig. 9.4). Thanks to the consistency of the visual language, the principle of the variation of the duration of day and night (and of the direction and length of shadows) is easier to grasp. Apianus's effort towards transforming the traditional Sphaera into a modern manual capable of transmitting useful and applicable cosmological knowledge ended there, but this effort was to be pursued by followers and imitators. 
tcm, $\sigma$ reliqua dcprimitur fub horizonte fubito, $v$ boc est quod dicit Alphraganus qibioccidütrepcnte $\int \mathrm{ex}$ fig $=$

' na, $\sigma$ reliqua ex oriütur cü toto equinoctialt. Cum aüt eclyptica fit horizonillorum, erit tropicus Cancri totus $f u=$ prahorizonta, ev totus tropi $=$ cus Capricornifub horizonte, o fic Sole exiftente in primo puncto Cancri,crit illis una di. - esz4. horarü, $\odot$ quafi inftás pronocte, quia in inftantt sol tranfit horizonta, $\sigma$ fatiom $e=$ mergit, $v$ ille cŏtactusest pronocte. Ecöuerfocontingit illis solc exiftente in primo purcto Capricorni . Est . $n$. tunc illis una nox z4. horarü, $v$ quafi inftans pro dic.

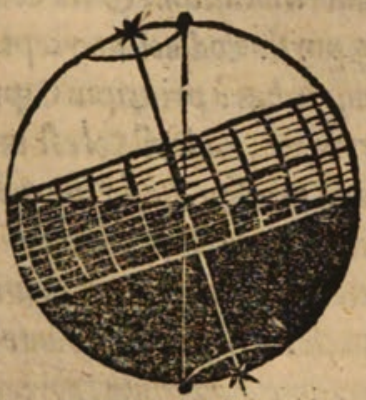

QVORVM ZENITHEST INTER CIR: culum arcticum $\sigma$ polum mundt.

- Illis aüt quorum zenth eft inter circulum arcticü $\sigma$ po= lum müdiarcticum, cōtingitg gorizon illorü inter fecat zoduacum in duobus püttrs equidiftantibus à principio

- Cancrl, $\sigma$ in reuolutiöe fir mamét contingitqilla por tio zodiaciintercepta, femp relinquitur fupraborizon $=$ tem.Vndepatetq quàm diu Sol est in illa portioe inter=

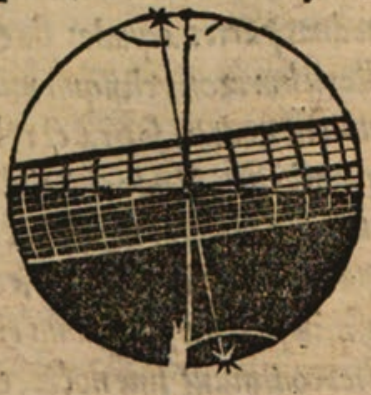

D cepta

Fig. 9.4 When the zenith is on the Arctic Circle (first diagram), and between the Arctic Circle and the North Pole (second diagram). From (Sacrobosco. 1526, D1r). State Library Regensburg--999/ Philos.1325, urn:nbn:de:bvb:12-bsb11110162-1 


\section{The Model Perfected: The Wittenberg Editions}

Apianus's Sphaera was never exactly copied, but the model it provided was soon imitated and improved. The University of Wittenberg, founded in 1502, was then at a critical juncture in its reformation process. The disorders provoked by radical reformers like Thomas Müntzer (ca. 1489-1525) and the Zwickau Prophets, notably the 1525 Peasant War, had convinced Martin Luther (1483-1546) and Philipp Melanchthon (1497-1560) of the necessity of founding a strong educational system in order to spread the teaching of moral philosophy, physics, the arts of language, and mathematical disciplines (Kusukawa 1995). The elaboration of new programs at Wittenberg and the publication of manuals, meant to be circulated in Germany and even throughout Europe, were the focus of this scheme. ${ }^{21}$

The publication of a new edition of the Sphaera took place in a still more particular context. Melanchthon, who was the professor of Greek at Wittenberg, was a strong advocate of mathematics. He thought it provided key knowledge for reading ancient texts, history, and geography. He furthermore grew more and more convinced that the attentive study of celestial signs was a Christian duty, as it helped to pursue a better understanding of God's providential governance. He expressed this conviction in a well-argued apology of astronomy and astrology addressed to Simon Grynaeus (1493-1541) and appended as a preface to the new edition of Sacrobosco prepared for the beginning of the 1531-1532 academic year (Sacrobosco 1531). ${ }^{22}$ This letter to Grynaeus was written in August 1531 while Melanchthon was observing the return of Halley's comet, which made a deep impression on him (Kusukawa 1995, 124-34).

This momentous preface was instrumental in the success of the book, ${ }^{23}$ whose other attractive features were borrowed from the Apianus edition. The Wittenberg editor imitated Apianus's airy layout, his clear subtitles, and his use of paragraphs. He even added several new paragraphs and introduced many interlinear blank spaces. ${ }^{24} \mathrm{He}$ suppressed a few diagrams ${ }^{25}$ and copied the rest of them, either closely

\footnotetext{
${ }^{21}$ On the amazing transformation of the modest town of Wittenberg into one of the largest book production centers in Germany, thanks to the publication of religious pamphlets, in the first place, but also of educational manuals, see (Pettegree 2010, 91-106).

${ }^{22}$ On Melanchthon's vision of astrology, see notably (Caroti 1986; Müller-Jahncke 1998).

${ }^{23}$ On the success of Melanchthon's letter, see (Pantin 1987).

${ }^{24}$ The description of the colures (see Chapter II of Tractatus de Sphaera by Sacrobosco) in the Apianus edition (B2v), for instance, does not use a paragraph to separate the general description from what concerns each colure; it uses two asterisks instead (“...** Colurus igitur distinguens solsticia..."). The Wittenberg 1531 edition (C3v) adds a paragraph and an interlinear blank, and it also keeps the asterisks (probably because their meaning was no longer understood). A second example: the beginning of the section on the natural days ("Ex praedictis etiam patet quod dies naturales. Est enim dies naturalis...") is only marked by an intralinear blank (before "Ex praedictis") in the Apianus edition (B8v). In the Wittenberg edition (D3v), a new paragraph, made more visible by an interlinear blank, begins at "Est enim dies." As a consequence of this airier layout, the text of the Wittenberg 1531 edition is printed on forty-three folios (instead of thirty-one in the Apianus edition).

${ }^{25}$ The diagrams on the effect of refraction, supposed to enlarge the image of the stars near the horizon, were suppressed.
} 
(in almost all cases) or more freely, to improve their clarity. ${ }^{26}$ In only one case, he followed another model. ${ }^{27}$

But the important thing was that the Wittenberg edition set a dynamic process in motion. The printers of the Sphaera had always worked for the universities that provided their first market. But in this case, the association and the cooperation were still closer. The regular reprinting of the Wittenberg Sphaera over decades shows that the printers had a monopoly on the production of textbooks for the University of Wittenberg and for other Lutheran universities, and that they were supposed to adapt this production to any change in the syllabus, with the aid and under the supervision of the professors. That was probably a good business model, and the large quantity of books produced year after year allowed the 'Wittenberg Sacrobosco' to be widely known and influential, even outside Germany: already in 1532, the Venetian bookseller Melchior Sessa copied the Wittenberg edition instead of reproducing one of the versions of the Sphaera that had been regularly printed in Venice since 1472 (Sacrobosco 1532). ${ }^{28}$ Moreover, the low commercial risk and the easy access to teachers of mathematics created the favorable conditions for a smooth evolution. Moderate additions were progressively introduced, and two significant revisions took place before 1545 .

In the 1531 edition, the additions were limited to four mnemonic Latin verses on the cosmic, acronychal, and heliacal risings and settings (Mane vehit supra terram tibi cosmicus ortus...), and to an extract of Regiomontanus's Epitome (III, 21 ) on "the double cause of the inequality of natural days" (Dies naturales duplici causa inaequales esse) (Sacrobosco 1531, F2r-F3r). The 1534 and 1536 Wittenberg editions (Sacrobosco 1534a, 1536) followed the 1531 edition line to line, but the next edition, in 1538, was carefully revised, with important changes in the layout and the subtitles, the addition of several notes, ${ }^{29}$ and even some corrections to the text. Furthermore, at the end of the book, an extract from Alfraganus (Sacrobosco 1538, G6v-G8r) ${ }^{30}$ followed the one from Regiomontanus. However,

\footnotetext{
${ }^{26}$ Examples of improved diagrams include two figures of the terrestrial zones in Apianus's edition: the first one is a crude geometrical diagram; in the second one, a kind of map covers all the space between the polar circles. In the Wittenberg 1531 edition, there is only one larger and more precise geometrical diagram, with the name of the zones inscribed.

${ }^{27}$ The image of the lathe that illustrates the definition of the sphere (Sacrobosco 1531, B1v) is closer to the diagram introduced by Jacques Lefevre d'Étaples in Parisian treatises on the Sphaera (Chap. 2).

${ }^{28}$ For a general view of the development of the in-octavo tradition, see the next sections.

${ }^{29}$ For instance: (Sacrobosco 1538, B1v): a note on Euclid's definition, which is quoted in Greek and translated; (D4v): a marginal note on 'CHRONICUS:' "Pro Chronico legendum [in Greek:] akronuchos...," with a quotation in Greek from Proclus's commentary on Hesiod; (F2v): a marginal note on the evaluation of the width of the first climate: "Unui gradui latitudinis, tribuuntur hoc loco 56. Milliaria et duae tertiae unius. Est enim hic locus omnino fere ex Alfragano desumptus."

${ }^{30}$ The text "De ortu et occasu Planetarum, et occultationibus eorum de sub radiis solis. Diff. xxiv" is taken from the edition printed in Nuremberg in 1537, with Regiomontanus's Oratio habita Patavii in praelectione Alfragani and a preface by Melanchthon: Rudimenta astronomica Alfragani. Item Albategni...de motu stellarum.
} 
the more obvious additions concerned the diagrams, notably with the introduction of four volvelles. ${ }^{31}$ This imitation of the device used in Apianus's 1524 Cosmographia signaled the moderate but significant tendency towards practicality (at least as far as pedagogical methods were concerned) that was to characterize the Wittenberg treatises on the Sphaera. The volvelles were all the more useful as pedagogical tools in that their movable parts, printed on a folded sheet at the end of the volume, had to be cut out and assembled by the reader. Besides, they were true paper instruments, meant to complement certain demonstrations or to show some of the elementary procedures of astronomical calculation. For instance, the second volvelle bears this caption:

Instrument by which the roundness of Earth according to latitude [that is, from south to north] is proven, and by which all that the author says in the third chapter about the natural days is very easily understood. ${ }^{32}$

The underlying diagram (Fig. 9.7) shows a graduated circle (a meridian), the axis of the world, the southern star Canopus, "Helice" (that is Ursa Major), and the quasiparallel circles (more exactly, spiral) that describe the daily motion of the sun as it progresses along the zodiac, from one tropic to the other. These circles are divided into equal portions by twelve numbered arcs (which are portions of meridians). The lines of the climes above the arctic circle are also drawn. The movable part of the volvelle is a half-disk, bearing the words "HORIZON" and "NULLA DIES SINE LINEA" ("Not a day without writing a line"), a proverb taken from Pliny (23-79) (Natural history, XXXV, 84), which is an admonition against laziness. This halfdisk is meant to recover the part of the hemisphere under the horizon; a kind of paper alidade, showing the zenith, is attached to it (Fig. 9.8).

The next edition, in 1540, strictly followed the 1538 edition, with only one (probably accidental) change: the letter of Melanchthon was dated August 1540 (Sacrobosco 1540, A8v). ${ }^{33}$ Then, in 1543, a new revision occurred leading to significant additions: in Chapter III of Tractatus de Sphaera by Sacrobosco, an "Annotatio" on the three causes of the inequalities of natural days (with a new diagram) (Sacrobosco 1543b, E2r), two more marginal notes on the climes (Sacrobosco $1543 \mathrm{~b}, \mathrm{~F} 4 \mathrm{v}, \mathrm{F} 5 \mathrm{r}$ ), and a "Table of the maximal lengths of the natural days in every latitude between the arctic circle and the pole." ${ }^{34}$ Aside from this, the extract from Alfraganus at the end of the book was replaced by a brief treatise on the "Poetical

\footnotetext{
${ }^{31}$ On the probable author of the revision of the 1538 Wittenberg edition, Georg Joachim Rheticus, and on the changes to the illustration and the subtitles, see infra.

${ }^{32}$ (Sacrobosco 1538, B8r): "Instrumentum quo et rotunditas terrae secondum latitudinem probatur, et facillime omnia ea., quae autor in tertio capite de diebus artificialibus tradit dijudicantur."

${ }^{33}$ The change to the date of the preface was probably a mistake that originated in the printer's shop (because of the habit of making the date of the preface match with that of the printing). In the next Wittenberg editions (1543, 1545a, and so on) the initial date (1531) was restored. However, the error was transmitted to Paris and Antwerp editions (Table 9.3).

${ }^{34}$ (Sacrobosco 1543b, F1v-F2r): "Tabula maximorum dierum naturalium ad singulas elevationes poli habitantium a circulo arctico usque ad polum arcticum."
} 
risings of the stars" (De ortu poetico), which provided all the information needed to inventory and to interpret the astronomical passages in classical texts. The De ortu poetico was accompanied by two astronomical tables printed on two folded sheets (Sacrobosco 1543b, G3v-I7v). ${ }^{35}$

Thus, thanks to the Wittenberg editions, the series of small treatises that derived from the edition of Apianus fully became a tradition: the transmission of the model, always clearly recognizable, was kept alive by its ability to evolve, unjeopardized by changes and additions.

\section{The Development of the In-Octavo Tradition}

The success of the Wittenberg Sphaera launched a long-lasting movement. During the rest of the century, about seventy editions following the same model, more or less improved and with different sets of additions, were printed in several European towns. It will be clearest to present the progress and ramification of this tradition in tabular form (Table 9.3).

In the first column, the editions that were used as models are listed, for they introduced major innovations that were adopted by later editions. Each of these editions is identified by the initial letter of the town where it was printed, followed by a number. For instance, "W3" (for "Wittenberg 3") means the third model of edition (with a particular set of texts and of diagrams) that was published in Wittenberg. The relationship between this model and its predecessors is briefly indicated in underlined notes. If the model-edition in question was reproduced in the same town without significant changes, the dates of the editions are given

\footnotetext{
${ }^{35}$ The tables are referred to in G7v ("Huc pertinet Tabula continens ingressum Solis in XII signa Zodiaci") and G8r ("Huc referatur Tabula quae habet gradus eclipticae cum quibus stellae insigniores olim oriebantur et occidebant"). They have disappeared from most copies.
} 
below (and the names of the booksellers if they were different from the editors of the preceding editions).

In the second column, the editions that copied a model are described according to the same principles. They are placed in front of the model they copied, and the variants they could introduce are briefly indicated in underlined notes. The editions that showed significant variants but were not copied, or that transmitted limited variants but not a whole model (notably Paris 2-5 and Cologne 2), are in this second column.

In the third column, publications are mentioned that were linked to the Sacrobosco editions, but were outside the "in-octavo tradition" proper.

Table 9.3 The in-octavo tradition $1526-1601^{\text {a }}$

\begin{tabular}{|c|c|c|}
\hline $\begin{array}{l}\text { Innovative editions used as models } \\
\text { (Main variants and additions are } \\
\text { underlined) }\end{array}$ & $\begin{array}{l}\text { Following editions } \\
\text { (Main variants are underlined) }\end{array}$ & $\begin{array}{l}\text { Sideways } \\
\text { publications }\end{array}$ \\
\hline \multicolumn{3}{|l|}{$\begin{array}{l}\text { Ingolstadt } 1 \text { [I1] 1526. Sphaera } \\
\text { Iani de Sacrobusto, ed. Petrus } \\
\text { Apianus: P. Apianus. }\end{array}$} \\
\hline $\begin{array}{l}\text { Wittenberg } 1 \text { [W1] 1531. Liber } \\
\text { Johannis de Sacro Busto de } \\
\text { sphera. Addita est praefatio...: } \\
\text { Joseph Klug. } \\
\text { = I1 revised + Melanchthon's } \\
\text { preface } \\
\text { extract from Regiomontanus. } \\
\text { New iconography (see above and } \\
\text { Table 9.6). } \\
\text { 1534a; } 1536 .\end{array}$ & $\begin{array}{l}\text { Venice } 1 \text { [V1] 1532: M. Sessa; 1534b; } \\
\text { 1537a, b: F. Bindoni; 1541; } \\
\text { 1541: M. Sessa; 1545c; 1553a: } \\
\text { F. Bindoni. } \\
\text { = W1. } \\
\text { Venice } 2 \text { [V2] 1548: Sphaera... } \underline{\text { Addita }} \\
\text { sunt quaedam ad explanationem eorum } \\
\text { quae in Sphaera dicuntur facentia: } \\
\text { M. Sessa; 1550a; 1552; 1554; 1557a; } \\
\text { 1561a; 1564c: F. Rampazeto; } \\
\text { 1572a: Sessa; 1577a; 1580; 1587; } \\
\text { 1594; 1601a. } \\
\text { =W1, but Melanchthon's preface is } \\
\text { replaced by a short treatise of } \\
\text { elementary geometry (with diagrams). }\end{array}$ & \\
\hline
\end{tabular}


Table 9.3 (continued)

\begin{tabular}{|c|c|c|}
\hline $\begin{array}{l}\text { Innovative editions used as models } \\
\text { (Main variants and additions are } \\
\text { underlined) }\end{array}$ & $\begin{array}{l}\text { Following editions } \\
\text { (Main variants are underlined) }\end{array}$ & $\begin{array}{l}\text { Sideways } \\
\text { publications }\end{array}$ \\
\hline $\begin{array}{l}\text { Wittenberg } 2 \text { [W2] 1538. Joannis } \\
\text { de Sacro Busto Libellus de } \\
\text { Sphaera. Ejusdem autoris libellus, } \\
\text { cujus titulus est Computus...Cum } \\
\text { praefatione... et novis quibusdam } \\
\text { typis, qui ortus indicant: J. Klug. } \\
\text { =W1 revised and augmented, } \\
\underline{\text { with new diagrams (and four }} \\
\text { volvelles) } \pm \text { extract from } \\
\text { Alfarganus + Sacrobosco, De anni } \\
\underline{\text { ratione. }} \\
1540 \text { (=W2, but the date of the } \\
\text { preface has been accidentally } \\
\text { modified: "August } 1540 " \text { instead } \\
\text { of "August } 1531 \text { "). }\end{array}$ & 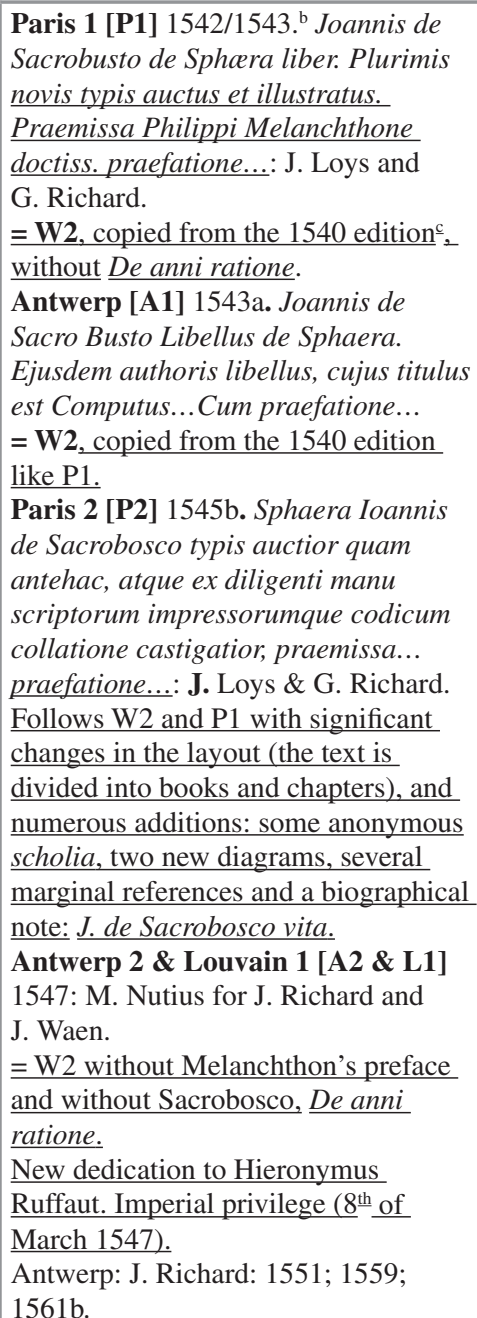 & $\begin{array}{l}\text { 1546. La Sphere, } \\
\text { transl. Martin de } \\
\text { Perer: J. Loys. }\end{array}$ \\
\hline
\end{tabular}


Table 9.3 (continued)

\begin{tabular}{|c|c|c|}
\hline $\begin{array}{l}\text { Innovative editions used as models } \\
\text { (Main variants and additions are } \\
\text { underlined) }\end{array}$ & $\begin{array}{l}\text { Following editions } \\
\text { (Main variants are underlined) }\end{array}$ & $\begin{array}{l}\text { Sideways } \\
\text { publications }\end{array}$ \\
\hline $\begin{array}{l}\text { Wittenberg } 3 \text { [W3] } 1543 \mathrm{~b} . \\
\text { Joannis de Sacro Busto Libellus } \\
\text { de Sphaera. Accessit ejusdem } \\
\text { autoris Computus ecclesiasticus et } \\
\text { alia quaedam in studiosorum } \\
\text { gratiam edita: P. Seitz. } \\
\text { W2 revised and augmented, with } \\
\text { one new diagram + De ortu } \\
\text { poetico. } \\
\text { 1545a: V. Creutzer; 1549: } \\
\text { J. Krafft; 1550b; 1553b; 1558; } \\
\text { 1561d; 1563; 1568; 1574a: } \\
\text { P. Seitz; 1578a: heirs of P. Seitz; } \\
\text { 1601b: Z. Schurer and J. Krafft. }\end{array}$ & 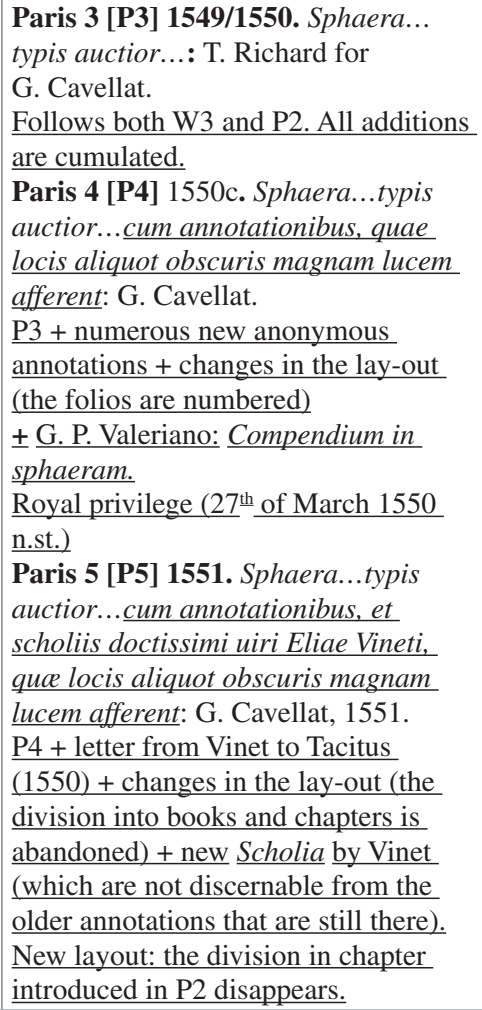 & \\
\hline
\end{tabular}


Table 9.3 (continued)

\begin{tabular}{|c|c|c|}
\hline $\begin{array}{l}\text { Innovative editions used as models } \\
\text { (Main variants and additions are } \\
\text { underlined) }\end{array}$ & $\begin{array}{l}\text { Following editions } \\
\text { (Main variants are underlined) }\end{array}$ & $\begin{array}{l}\text { Sideways } \\
\text { publications }\end{array}$ \\
\hline 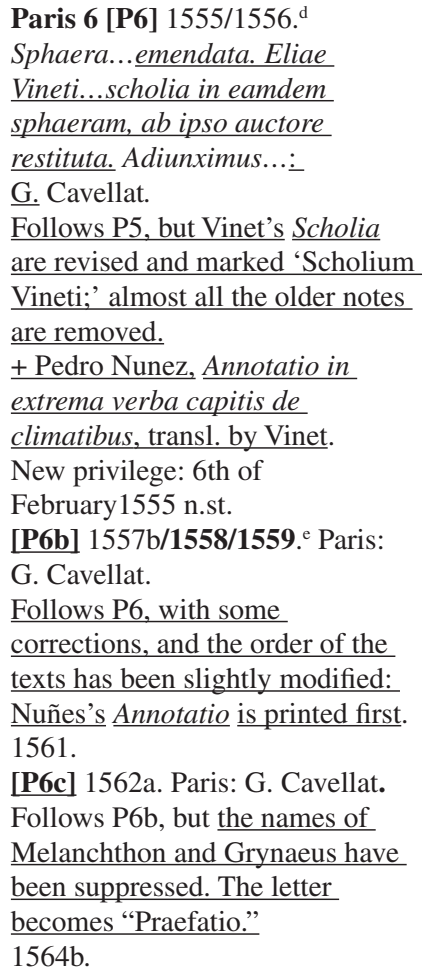 & 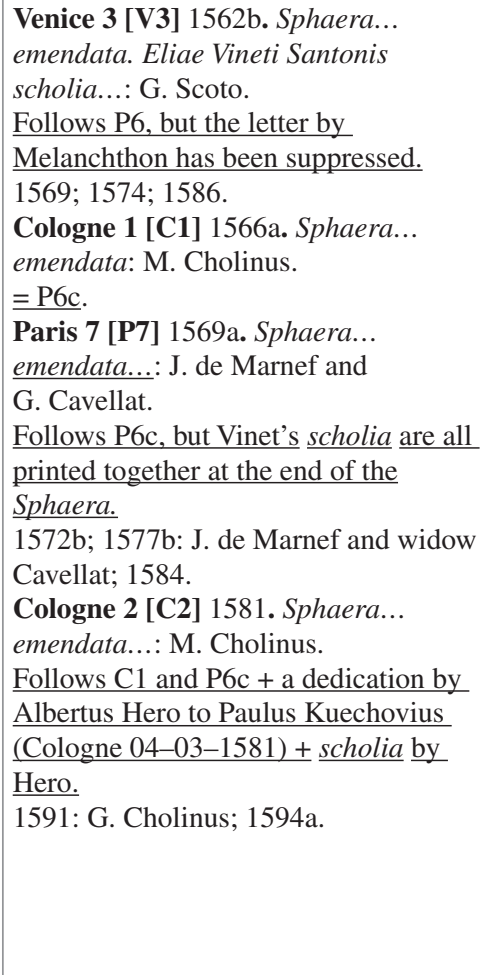 & $\begin{array}{l}\text { 1570. La sphère, } \\
\text { transl. Guillaume } \\
\text { des Bordes with } \\
\text { some of Vinet's } \\
\text { Scholia. } \\
\text { Paris: J. de Marnef } \\
\text { and G. Cavellat. } \\
\text { 1576; } 1584 .\end{array}$ \\
\hline $\begin{array}{l}\text { Lyons } 1 \text { [Ly1] 1564a/1567. }{ }^{\mathrm{f}} \\
\text { Sphaera...emendata. Cum } \\
\text { additionibus in margine, \& indice } \\
\text { rerum \& locorum memorabilium. } \\
\text { \& familiarissimis scholijs, } \text { nunc } \\
\text { recenter compertis, \& collectis à } \\
\text { Francisco Iunctino: } \text { S. Barbier for } \\
\text { the heirs of J. Giunta. } \\
\text { P6 without } \text { De ortu poetico. } \\
+ \text { Dedication by Giuntini to Thomas } \\
\text { de Guadagne (Lyons, } 15.06 .1564)+ \\
\text { a large commentary by Giuntini } \\
\text { (with some new diagrams) }+ \text { new } \\
\text { appendices }+ \text { an Index. } \\
\text { Privilege: } 10^{\text {th }} \text { of January } 1564 \text { n.st. }\end{array}$ & 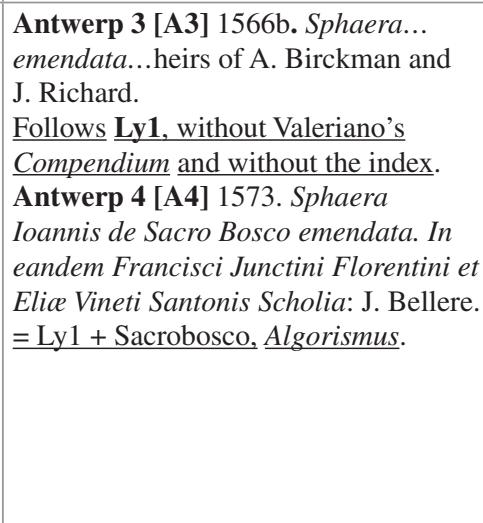 & \\
\hline & $\begin{array}{l}\text { Antwerp } 5 \text { [A5] 1582. Sphaera... } \\
\text { emendata. In eandem...Iunctini... } \\
\text { Vineti...et Alberti Heronis scholia: } \\
\text { J. and P. Bellere. } \\
\text { = A4 + Hero's scholia from C2. }\end{array}$ & \\
\hline
\end{tabular}


Table 9.3 (continued)

\begin{tabular}{l|l|l}
\hline $\begin{array}{l}\text { Innovative editions used as models } \\
\text { (Main variants and additions are } \\
\text { underlined) }\end{array}$ & $\begin{array}{l}\text { Following editions } \\
\text { (Main variants are underlined) }\end{array}$ & $\begin{array}{l}\text { Sideways } \\
\text { publications }\end{array}$ \\
\hline & $\begin{array}{l}\text { Lyons 2 [Ly2] 1578b. Sphaera... } \\
\text { emendata a Fr. Iunctino Theologo..., } \\
\text { qui etiam in capite libri adjunxit } \\
\text { Principia Geometrica...In calce libri } \\
\text { habes Scholia Eliae Vineti: F. Tinghi. } \\
\text { With Vinet's Scholia printed as in }\end{array}$ & $\begin{array}{l}\text { Giuntini, } \\
\text { Francesco. } \\
1577-1578 . \\
\text { Commentaria in } \\
\text { Sphaeram Joannis } \\
\text { de Sacrobosco. } \\
\text { Pyons: F. Tinghi, } \\
\text { 2 vols. Giuntini, Principia geometrica. }\end{array}$ \\
\hline $\begin{array}{l}\text { Cologne 3 [C3] 1601c. Sphaera... } \\
\text { emendata...: G. Cholinus. }\end{array}$ & No other text. & \\
$\begin{array}{l}\text { Follows C2 }+ \text { some notes taken } \\
\text { from Clavius's commentary }+\end{array}$ & & \\
$\begin{array}{l}\text { some anonymous comments }+ \text { a } \\
\text { poem by Thomas Abel. physician }\end{array}$ & & \\
$\begin{array}{l}\text { and professor of mathematics, } \\
\text { perhaps the editor of the volume. }\end{array}$ & & \\
\hline
\end{tabular}

an this table, only true editions are listed. In some towns, particularly in Paris, the practice of reissuing earlier editions with a new date on the title was quite common. As the products of this practice ("separate issues" in English, "émissions" in French) had strictly no impact on tradition, they are not taken into account to prevent skewing the statistics. Editions posterior to 1601 are not listed here.

${ }^{\mathrm{b}} 1542$ is the date at the colophon; 1543 is the date on the title page.

${ }^{\mathrm{C}}$ The 1540 Wittenberg edition copies line for line W2, with one exception: all marginal notes are inserted into the text, and the preface is dated 1540 (instead of 1531).

${ }^{\mathrm{d}} 1555$ on the "achevé d'imprimer;" 1556 on the title-page.

${ }^{\mathrm{e}} 1557$. Two reissues with the date modified: $1558,1559$.

${ }^{\mathrm{f}} 1564$. Reissue with the date modified: 1567.

This tabular presentation shows that the development of the tradition was not chronologically linear. For instance, the tracts published in Venice by the Sessa firm until 1601 (V1 and V2) reproduced (with nonessential variants) a model conceived in Wittenberg in 1531 (W1); whereas in the same town, the Scoto firm published, from 1569 to 1586, a Sphaera (V3) that followed a 1556 Parisian model (P6).

It also shows that the rhythm of the innovations was rather rapid up to 1556, at which point it slowed down, and that the initiative of the innovations passed from town to town.

Thirdly, the analysis of these progressively introduced changes suggests that it would be quite misleading to make a sharp distinction between innovations and borrowed material: in the in-octavo tradition, the innovation process was largely a braiding process in which old and new materials, either produced inside the tradition or borrowed from outside, were closely interlocked. All these indications will be examined further, as they bring us back to the initial question: what kinds of actors were mostly responsible for the changes? 


\section{Publishers Versus Mathematicians}

My point is that the evolution of the in-octavo tradition was the result of close cooperation between the publishers and the mathematicians, but also that the former, with a few exceptions, kept control over the process, which accounts for the longevity of this tradition.

\subsection{The Shift from Town to Town}

As we have seen, in the in-octavo tradition, the power to innovate passed from town to town. Almost each time, the existence of close cooperation between mathematicians and publishers figures as an important factor. At first (between 1531 and 1543), the most creative publishers were in Wittenberg; afterward in Paris. Between 1564 and 1582, the main feature of the editorial landscape was a kind of rivalry between Lyons and Antwerp, while Cologne also entered the game.

In the cases of Wittenberg and Paris, the main causes of the shifts are apparent. Apianus, the founder of the tradition, was simultaneously a printer and a mathematician, but he did not work in association with a university, and his interest in astronomical textbooks (the Sphaera in 1526 and Peuerbach's Theoricae novae in 1528) soon dwindled, as he embarked on a career at the imperial court. Then, around 1530, the reform of the university of Wittenberg experienced a significant turning point, as we have seen. Melanchthon supervised an editorial program that produced several innovative textbooks, notably in astronomy, written or edited by the professors and printed at the university print shop. The Wittenberg innovations, which did so much to give the in-octavo tradition its identity, were thus an exception in that their principal initiator was neither a mathematician nor a bookseller, but the reformer of the university syllabuses. However, when his efforts in this field had borne fruit, Melanchthon turned his attention to other priorities, such as the reform of the teaching of philosophy (the first version of his Initia doctrinae physicae was to appear in 1549). Moreover, the Wittenberg mathematicians, notably Kaspar Peucer (1525-1602), went on to publish alternative models of astronomical textbooks (Peucer 1550), and the publication of successive editions of the Sphaera, which remained in use, became simple routine work.

Paris had become one of the main centers of the European book trade during the first decades of the sixteenth century. It had benefited from the importance of its university and from the decline of Venice, which had been the center of the book world in the fifteenth century, but was now handicapped by a succession of political and economic crises. Major proponents of mathematical humanism were then teaching in Paris, notably Jacques Lefèvre d'Étaples (ca. 1450-1536) (Chap. 2) and his disciples, and in the next generation Oronce Finé (Chap. 8). These scholars were convinced of the necessity of spreading their ideas through the publication of innovative books, and could rely on their relationship with different interconnected milieus to do so: the Art Faculty and the Parisian col- 
leges, the humanists engaged in pedagogical reform, the courtly circles that supported the foundation of the Collège royal, and prestigious printers able to assert themselves in the European market, namely Henri I Estienne (active 1502-1520) and Simon de Colines (active 1520-1546). Then, towards the end of the 1540s, less distinguished booksellers decided to widen the range of mathematical books offered on the market in order to attract new customers: Jean Loys, Guillaume Richard, and above all Guillaume Cavellat. ${ }^{36}$ Their first targets were students, and they eagerly copied the pocket-sized textbook published in Wittenberg. They could furthermore count upon the cooperation of teachers who were willing to revise the annotation while preparing their own lectures: from 1545 to 1556, five editions of the Sphaera (P2 to P6) were published in Paris with significant additions and changes.

The move to Lyons (Ly1) was short-lived and probably mainly due to the initiative of the astrologer Francesco Giuntini, who wished, as we shall see, to affirm his mastery of all astronomical knowledge, starting with the Sphaera. At first, the inoctavo tradition probably appealed to him as an easy way to enter the field. But he abandoned it as soon as he saw that it offered too narrow a framework and did not permit him to expand his ambitions.

Antwerp was a "commercial megapolis" (Pettegree 2010, 250), and each time a kind of book proved successful, Antwerp booksellers often tried to enter its market. Until 1561, Jean Richard had on several occasions published two variants of the Wittenberg editions (A1 and A2). In 1566, in association with the heirs of Arnold I Birckmann (died 1542), he published, with some suppressions, a copy of Ly1 (A3). Then, in 1573, another Antwerp bookseller, Jean Bellere (1526-1595), issued a new edition (A4) that combined A3 and the Paris 1556 edition (P6). Finally, in 1582 (A5), the same Bellere still added Albertus Hero's (1549-1589) notes that had been printed in Cologne the preceding year $(\mathrm{C} 2)$. This practice of combining borrowed material, which needed little mathematical expertise, can barely be called innovation. In any case, these attempts were not successful, as the in-octavo tradition was already declining.

The Cholinus firm in Cologne resorted to similar practices: it first followed a Parisian model (C1); then it freshened it up by adding some modest scholia written by Albertus Hero (C2). The masterpiece was achieved by Goswin Cholinus (active 1588-1610) in 1601 (C3): he published a new version of the Sphaera emendata that looked like a patchwork of diverse material, for an anonymous mathematician ${ }^{37}$ had added to Elie Vinet's (1509-1587) and Hero's scholia several extracts from Clavius's commentary, some new notes (under the heading "Commentarius"), and even one scholium of Giuntini, one extract from Peuerbach's Theoricae, and two new (but not original) diagrams.

\footnotetext{
${ }^{36}$ On Cavellat's career, see (Pantin and Renouard 1986).

${ }^{37}$ This anonymous editor of the Cholinus edition was perhaps Thomas Abel, a physician and professor of mathematics, who wrote a poem "De hoc libro sphaerico emendato," printed between Hero's 1581 dedication and the beginning of the Sphaera.
} 


\subsection{Editorial Policies and Clustered Publications}

For printers and booksellers, the publication of the Sphaera was as a rule part of a larger editorial program that included printing several mathematical and cosmological textbooks. Thus, as we have seen, Peter Apian began by editing a Cosmographicus liber in 1524, even before he settled as a printer in Ingolstadt. In 1529, he published a modified version of the Cosmographiae introductio of Mathias Ringmann (1482-1511) and Joannes Waldseemüller (ca. 1470-ca. 1521) (Ringmann and Waldseemüller 1529). He published the Sphaera in 1526, then Peuerbach's Theoricae novae planetarum in 1528, according to the same editorial principles (Peuerbach 1528). The printers of the university of Wittenberg imitated first Apianus's Sphaera (1531), then Apianus's Theoricae novae (1535); both editions were copied by Melchior Sessa the elder in Venice, in 1532 (the Sphaera) and 1534 (the Theoricae).

In 1538, the Wittenberg editors adopted the coupling of the Sphaera and Sacrobosco's De anni ratione, alias Computus ecclesiasticus, which was largely imitated by printers outside Germany, either in one volume or two separate editions. Other works, partly complementary to the Sphaera, partly redundant with it, were published in parallel by the same firms, such as Hartmann Beyer's (1516-1577) Quaestiones novae in sphaeram, an adaption of the Sphaera, first printed in Frankfurt (1549), then reproduced in Wittenberg (1550) and in Paris (1551) (Beyer 1549, 1550, 1551). From around 1550 on, as we have seen, the Wittenberg publishers continued to print regularly the 1543 model of the Sphaera, but they minimized the impact of obsolescence by printing, in parallel, the works of the actual professors in mathematics, Kaspar Peucer and Sebastianus Theodoricus (Sebastian Dietrich) (died in 1574) (Theodoricus 1563, 1564). ${ }^{38}$

The Parisian bookseller Guillaume Cavellat, active from 1549 to 1575 , had in his catalogue a remarkable set of mathematical and astronomical textbooks (Pantin and Renouard 1986; Pantin 1988). He seems to have been keen to find new titles in this field. He was also responsible for important changes in the Sacrobosco in-octavo tradition, notably the adjunction of Pierio Valeriano's (1477-1558) Compendium in Sphaeram. Numerous similar examples - too many to enumerate-show that the publication of the Sphaera has to be evaluated in the context of booksellers's editorial policies.

\subsection{Anonymity Versus Signature}

Until the first publications of Elie Vinet's Scholia (Paris, 1551, P5), the changes and additions to the text and the illustration were always anonymous, with the noticeable exception of Apianus's founding work. For instance, there were some scholia in W2 and $\mathrm{W} 3$, and P1, P2, P3, and P4 added new ones, but their authors did not sign their names.

\footnotetext{
${ }^{38}$ Theodoricus's adaptions of the Sphaera were reprinted in Wittenberg in 1567, 1570, 1573, 1578, and 1583.
} 
The case of the Wittenberg editions is interesting. They were published under the authority of Melanchthon, who wrote the preface, but certainly did not supervise the editorial work. For W2 (1538) and W3 (1543), this work may probably-at least partially-be ascribed to Georg Joachim Rheticus (1514-1574), then titular of the chair of lesser mathematics in Wittenberg, before and after his momentous stay with Nicolaus Copernicus (1473-1543) in Frombork. ${ }^{39}$ In any case, Melanchthon remained the inspiration for the evolution of the Wittenberg treatises on the Sphaera. The addition, in W3, of the small anonymous treatise De ortu poetico, which gives technical explanations on heliacal, acronycal, and cosmical risings and settings followed by a number of poetical quotations with commentary, corresponded exactly to Melanchthon's conception of what ought to be the lectio poetarum (Ben-Tov 2009). Thus, in Wittenberg, the anonymity of the editors and commentators responded to a conscious policy: all publications displayed the pedagogical views of the university, under the authority of Melanchthon. However, the adaptions later published in Wittenberg by Kaspar Peucer and Sebastianus Theodoricus (Sebastian Dietrich) bore the name of their authors.

Indeed, in the second part of the century there came a change. As a probable result of a more competitive situation, the publishers now obviously recognized that signatures added value to their editions. A signature, often strengthened by a dedication, ${ }^{40}$ highlighted the novelty of an edition and could warrant the request for a privilege. In March 1550, Guillaume Cavellat obtained a royal privilege for the printing of the Sphaera, which expired in March 1555. In France, as a rule, it was impossible to obtain a second privilege for the same work without demonstrating that the edition had been significantly improved, as the criterion of newness had been, since the origins of the system, essential in the granting of privileges (Armstrong 1990, 92-99). ${ }^{41}$ Cavellat successfully applied for a privilege for the Sphaera Joan. De Sacro Bosco emendata cum scholiis Eliae Vineti. ${ }^{42}$ The heirs of Giacomo Giunta (1487-1546) in Lyons also obtained a royal privilege for the

\footnotetext{
${ }^{39}$ The 1538 edition (W2) adds an edition of the De anni ratione, with a preface by Melanchthon addressed to A.P. Gasser. This preface states that the editorial work for the De anni ratione was done by Caspar Borner, but that the idea for the addition was Rheticus's. The intervention of Rheticus in W2 is thus documented. In a letter to Paul Eber (1 March 1562), Rheticus affirmed that he had "prepared the Sphaera and Computus for the press" in 1550 and complained of having been miserly paid (then, the W3 model was firmly installed in Wittenberg and the supervisor's work was routine). From the summer of 1542 on, Rheticus no longer taught in Wittenberg, but before that date the supervision of the printing of mathematical textbooks had been part of his job (Rosen 1970, 1974).

${ }^{40}$ Vinet wrote a dedication to Johannes Tacitus (P4), and Francesco Giuntini one to Thomas de Guadagne (L1). Even Albertus Hero wrote a dedication to Paulus Kuechovius (C2), though the few scholia he added to those of his predecessors were quite small indeed.

${ }^{41} \mathrm{~A}$ great change occurred in the French book-privilege system in February 1566, when the ordinance of Moulins (art. 78) stipulated that it was henceforth mandatory to publish under royal privilege. However, this still concerned "nouveaux livres." See (Saugrain 1744, 357-58).

${ }^{42}$ This privilege was first used in P6 (1555/1556). It is worth noting that Vinet's scholia had first been printed by Cavellat in 1551 (P5) under the first privilege. But P6 was emendata and added, for the first time, Pedro Nuñes's Annotatio in extrema verba capitis de climatibus translated by Vinet.
} 
treatise of the sphere "corrigé et augmenté par maistre François Junctini professeur en Mathematique." ${ }^{3}$

When no author was available, a bookseller could write the dedication himself and obtain a privilege. That was the case with Jan Waen (active 1545-ca. 1565), who dedicated to Hieronymus Ruffaut (died 1563), abbot of Saint-Vaast in Arras, a reprint of W2 (and A1), but without Melanchthon's preface, under an imperial privilege (A2 \& L1, 1547). ${ }^{44}$ Thus, the decision for signature or for anonymity responded to editorial policies and commercial strategies. It was for the bookseller to decide which signatures were worth displaying. On the title page of the Cologne 1601 edition (C3), there is only one new name (in addition to those of Sacrobosco, Vinet, Hero, ${ }^{45}$ Pierio Valeriano, and Pedro Nunez): that of Clavius. The Cholinus were the printers of the Jesuits in Cologne and used their emblem as their mark. The names of Giuntini and Peuerbach appear inside the volume, but not that of the author of the new "commentarii," who probably also supervised the organization of the new textual patchwork - unless we identify him as Thomas Abel, who discreetly signed his name under a poem at the end of the introductory part of the book.

\subsection{The Large Range of Innovations and the Importance of the mise en texte}

Innovation in the in-octavo tradition concerned a large range of elements. The additions, substitutions, and corrections in the scholia were viewed as fundamentalthat is why the names of Elie Vinet, Francesco Giuntini, and even the modest Albertus Hero were displayed on the title-pages. So were the improvements in the illustration (as we shall see below).

The text itself was frequently submitted to revision. The corrections were superficial and only meant to improve the clarity of the style. At first, they were mainly due to the fact that nobody held the original author in particular respect. But, with the Parisian editions, a 'humanist turn' progressively occurred. The title of the 1545 edition printed by Jean Loys (P2) already boasted that the text was "more correct, thanks to the diligent collation of manuscript and printed exemplars" (ex diligenti manuscriptorum impressorumque codicum collatione castigatior), and this evolution lead to the production in 1555/1556 of a Sphaera emendata (P6) that enjoyed great success: until the end of the century, all the new editions (and their imitations) retained this phrase at the beginning of their titles.

\footnotetext{
${ }^{43}$ Privilege of Ly1.

${ }^{44}$ Imperial privileges could be granted to "republication as well as new publication, although in most cases even republication was claimed to be an improved and enlarged version of the first edition" (Maclean 2012, 140). On imperial privileges and their use in the Netherlands, see (Gompel 2011, 61-64). There, as in France, in the first part of the sixteenth century, book-privileges were mainly meant to protect the commercial interests of the beneficiaries; afterwards, they became mainly instruments of censorship.

${ }^{45}$ Vinet's and Hero's dedications are printed at the beginning of the volume, in addition to Melanchthon's letter, now an anonymous preface.
} 
Indeed, the titles played a role in the innovation process: there never was a new model of edition without a new title - in turn faithfully copied in the imitations of this model. The new titles always advertised the innovations: the scholia and the improvement in the text, as we have seen, ${ }^{46}$ but also the changes in the illustration ${ }^{47}$ and other additions: "addita est praefatio...Philippi Mel. ad Simonem Grynaeum" (W1), later "Cum praefatione..." (W2) and "Praemissa praefatione..." (P1); "with a small treatise of the same author entitled the Comput" ("Ejusdem autoris libellus, cujus titulus est Computus...," W2); "and other materials printed to please the students" ("et alia quaedam in studiosorum gratiam edita," W3). On V2's title-page appear the words: "with some additions that help to explain what is told in the Sphaera" ("Addita sunt quaedam ad explanationem eorum quae in Sphaera dicuntur facentia"), which means that the preface of Melanchthon has been replaced by a short treatise of elementary geometry. The addition, in P4, of Valeriano's Compendium in Sphaeram is also advertised, as is that of Pedro Nunez's Annotatio in P6. Even the new marginalia and the index introduced in the 1564 Giuntini edition (Ly1) are signaled: "Cum annotationibus in margine, et indice rerum et locorum memorabilium."

This highlighting of the index and the marginalia shows that what the French historians of the book analyze as the elements of the "mise en texte" and "mise en livre" (Martin and Vezin 1990; Martin 2000) was viewed as an integral part of the innovation process. For instance, the Apianus and the Wittenberg editions had no running titles, and their pages were unnumbered. Guillaume Cavellat, in 1550 (P4), was the first to number the folios and add running titles.

As we have seen, the editors of the in-octavo editions, from the beginning, improved the clarity of the divisions of the text, using more subtitles, interlinear blanks, and other typographical devices. In this respect, W1 had already made progress in comparison to $\mathrm{I} 1$. Then W2 changed the wording of the subtitles (some of them became short summaries) and introduced a hierarchy between them to mark more clearly the logical structure of the text. For instance, in the last part of Chap. 2 (Table 9.4).

Table 9.4 The subtitles of the last part of chap. I in W1 and W2

\begin{tabular}{l|l}
\hline W1 & W2 \\
\hline QUOD TERRA SIT ROTUNDA & DE TERRA \\
QUOD AQUA SIT ROTUNDA & I Terram cum aqua globum constituere \\
\hline QUOD TERRA SIT CENTRUM MUNDI & $\begin{array}{l}\text { II Terram esse centrum mundi, hoc est, in medio } \\
\text { universi sitam et velut punctum respectu } \\
\text { DE IMMOBILITATE TERRAE }\end{array}$ \\
\hline DE QUANTITATE ABSOLUTA esse, immobilemque consistere.
\end{tabular}

\footnotetext{
${ }^{46}$ The anonymous scholia of P3 were mentioned in the title too: "with notes that throw much light on somewhat obscure passages" ("cum annotationibus, quae locis aliquot obscuris magnam lucem afferunt").

${ }^{47} \mathrm{~W} 2$ : "with new figures that explain the risings [of the zodiacal signs]" ("et novis quibusdam typis, qui ortus indicant"), echoed in P1 by "with the addition and illustration of numerous new figures" ("Plurimis novis typis auctus et illustratus").
} 
From 1545 (P2) on, the Parisian editions adopted an important innovation: the four chapters became four books, each divided into numbered chapters. However, this tendency to modernize the Sphaera was checked by the humanist turn operated by Elie Vinet. In 1551 (P5), the Sphaera returned to the original division into four chapters.

\subsection{The Illustration: Scientific and Commercial Issues}

From 1526 to 1538 , the principal innovations concerned the illustration (Tables 9.5 and 9.6). Apianus and the anonymous editor or editors of Wittenberg did all the work, and the result was deemed so satisfactory that their successors simply copied their set of diagrams. Only Franco Burgersdijk, in 1626, was to undertake a complete reworking of the illustration (Chap. 11).

The creation of the complete set of diagrams that illustrated the in-octavo Sphaeras from 1538 to 1620 was progressive. Its authors borrowed from their predecessors (the Venetian incunabula, the Leipzig quartos, and above all the Apianus edition), but also from books outside this strict tradition. Thus, the editor of W2 (1538) borrowed fifteen diagrams from Oronce Finé's Protomathesis, published in Paris in 1532. As a result, some figures of a type that had previously been excluded from the tradition were introduced into it: four true geometrical diagrams meant to explain the ascensions of the signs (in Chapter III of Tractatus de Sphaera by Sacrobosco). However, as we have seen, the more striking innovation of W2 was the arrival of four volvelles, of which the different parts were printed on folded sheets bound at the end of the volume - the reader had simply to cut the parts and assemble them.

If we set aside a few additions that were not retained for long in the tradition, the iconography of the in-octavo editions was thus conceived between 1526 and 1538, with a strong dynamic of innovation. It was the main contribution of the German mathematicians to this tradition, and their work in that field was so well received by the public that a certain commercial logic cemented this contribution's place in future publication. The typical set of diagrams and volvelles of the in-octavo tradition was such a success that to modify it was out of the question. It could even be used as an identifying trademark.

The main reason why iconographical innovation ceased at an early stage in the in-octavo tradition was thus probably commercial. Such immobility could have represented a detrimental shortcoming, as it was indicative of a lack of serious mathematical work on the text: the invention of new diagrams was bound to happen as soon as mathematicians worked on a text and made commentary. However, this did not happen in this case, thanks to the particular character of Sacrobosco's short introduction to cosmology, whose large and enduring success was due to its completeness, the clarity of its style, but also its avoidance of all mathematical complexities. The Sphaera was more descriptive-even narrative-than demonstrative. As Thorndike has observed, it achieved a happy compromise between the literary tradition, derived notably from Macrobius's Commentarii in somnium Scipionis, and a then (in 1220) recent and more scientific approach to cosmology, permitted by the first translations of Arabic astronomers. Rival manuals composed at around the 
Table 9.5 The diagrams from the Venetian incunabula to the Apianus edition ${ }^{\mathrm{a}}$

\begin{tabular}{|c|c|c|c|}
\hline $\begin{array}{l}\text { Venetian incunabula } \\
\text { V }\end{array}$ & $\begin{array}{l}\text { Leipzig } 1486 \\
\text { Le1 }\end{array}$ & $\begin{array}{l}\text { Leipzig } 1494-\& \\
\text { Faber von Budweis } \\
(1495-) \text { Le2 }\end{array}$ & $\begin{array}{l}\text { Apianus } 1526 \\
\text { I1 }\end{array}$ \\
\hline \multicolumn{4}{|l|}{ Preliminaries } \\
\hline Armillary sphere: 1 & 1 different & 1 different & 1 different (title) \\
\hline $\begin{array}{l}\text { Geometry: } 24 \\
\text { diagrams }\end{array}$ & 0 & 2 (copied from V?) & 0 \\
\hline Chap. 1 & Chap. 1 & Chap. 1 & Chap. 1 \\
\hline Diffinitiones 0 & 1 new & 0 & 3 new \\
\hline $\begin{array}{l}4 \text { elementary and } 9 \\
\text { celestial spheres: } 1\end{array}$ & $\begin{array}{l}1 \text { different (1 } \\
\text { elementary and } 9 \\
\text { celestial spheres) }\end{array}$ & $\begin{array}{l}\text { 1, between } \mathrm{V} \text { and Le1 } \\
\text { (1 elementary, } 9 \\
\text { celestial spheres) }\end{array}$ & $\begin{array}{l}1 \text { new (terraqueous } \\
\text { globe, air, fire, and } 10 \\
\text { celestial spheres) }\end{array}$ \\
\hline $\begin{array}{l}\text { Sphaera recta/obliqua: } \\
1\end{array}$ & 1 new & $=$ Le1, but simplified & 2 new \\
\hline Elemental spheres: 1 & 1 new & 1 different from Le1 & 1 new \\
\hline De caeli revolutione: 1 & 1 similar to $\mathrm{V}$ & 2 new & 1 new \\
\hline De caeli rotunditate: 1 & 3 new & 3 similar to Le1 & 4 new \\
\hline Effects of refraction: 2 & 0 & 0 & 2 (linked to V) \\
\hline $\begin{array}{l}\text { Quod terra sit } \\
\text { rotunda: } 2 \text { (Fig. 9.1) }\end{array}$ & 2 new & $\begin{array}{l}\text { 2: } 1 \text { similar to V; } 1 \\
\text { similar to Le1 }\end{array}$ & $\begin{array}{l}2 \text { new (linked to V) } \\
\text { (Fig. 9.2) }\end{array}$ \\
\hline $\begin{array}{l}\text { Quod aqua sit } \\
\text { rotunda: } 1\end{array}$ & 1 new & 1 similar to $\mathrm{V}$ & 1 new \\
\hline $\begin{array}{l}\text { Quod terra sit centrum } \\
\text { mundi: } 0\end{array}$ & 1 new & $\begin{array}{l}1 \text { similar to Le1 } \\
\text { (clearer) }\end{array}$ & 1 new \\
\hline $\begin{array}{l}\text { De immobilitate } \\
\text { terrae: } 0\end{array}$ & 0 & 0 & 0 \\
\hline $\begin{array}{l}\text { De quantitate terrae: } \\
0 .\end{array}$ & 0 & 0 & 0 \\
\hline Chap. 2 & Chap. 2 & Chap. 2 & Chap. 2 \\
\hline 0 & Celestial circles & 1 new & 0 \\
\hline The equinoctial: 1 & 0 & 0 & 1 new (linked to $\mathrm{V}$ ) \\
\hline De zodiaco circulo: 1 & 0 & 0 & 1 new (linked to $\mathrm{V})$ \\
\hline Zodiacal signs: 2 & 4 (2 similar, 2 new) & 4 similar to Le1 & 4 new (linked to Le1/2) \\
\hline De duobus coluris: 1 & 0 & 0 & 1 new \\
\hline $\begin{array}{l}\text { Meridian and horizon: } \\
1\end{array}$ & 2 new & 2 similar to Le1 & 1 new \\
\hline $\begin{array}{l}\text { Celest. zones \& } \\
\text { circles: } 1\end{array}$ & 0 & 0 & 0 \\
\hline $\begin{array}{l}\text { Terrestrial zones (with } \\
\text { landscape): } 1\end{array}$ & 1 new & 1 new (with a map) & $\begin{array}{l}2 \text { new (1 with landscape } \\
\text { and map) }\end{array}$ \\
\hline Chap. 3 & Chap. 3 & Chap. 3 & Chap. 3 \\
\hline $\begin{array}{l}\text { Poetical risings and } \\
\text { settings: } 1\end{array}$ & 2 new & 2 similar to Le1 & 1 new (unclear) \\
\hline $\begin{array}{l}\text { The circles to measure } \\
\text { astronomical risings: } 1\end{array}$ & 2 new & 2 similar to Le1 & 2 new \\
\hline Natural day: 1 & 0 & 0 & 0 \\
\hline
\end{tabular}


Table 9.5 (continued)

\begin{tabular}{|c|c|c|c|}
\hline $\begin{array}{l}\text { Venetian incunabula } \\
\text { V }\end{array}$ & $\begin{array}{l}\text { Leipzig } 1486 \\
\text { Le1 }\end{array}$ & $\begin{array}{l}\text { Leipzig } 1494-\& \\
\text { Faber von Budweis } \\
(1495-) \text { Le2 }\end{array}$ & $\begin{array}{l}\text { Apianus } 1526 \\
\text { I1 }\end{array}$ \\
\hline $\begin{array}{l}\text { Circles of natural } \\
\text { days: } 1\end{array}$ & 1 new & 1 much clearer & $1(=\underline{\mathrm{L} 2}$ reduced $)$ \\
\hline $\begin{array}{l}\text { Circles of the sphere: } \\
1\end{array}$ & 0 & 0 & 0 \\
\hline 12 celestial houses: 3 & 0 & 0 & 0 \\
\hline $\begin{array}{l}\text { Shadows at the } \\
\text { equator: } 1\end{array}$ & $\begin{array}{l}7 \text { new (diversitas } \\
\text { dierum) }\end{array}$ & $\begin{array}{l}7 \text { similar to Le1 but } \\
\text { clearer (Fig. 9.3) }\end{array}$ & $\begin{array}{l}8 \text { new (diversitas } \\
\text { dierum) (Fig. 9.4) }\end{array}$ \\
\hline $\begin{array}{l}\text { Terrestrial zones and } \\
\text { climes: } 2\end{array}$ & 1 new & 1 new, with a map & $\begin{array}{l}2 \text { new (only climes, } 1 \\
\text { linked to V) (Figs. } 9.5 \\
\text { and 9.6) }\end{array}$ \\
\hline Chap. 4 & Chap. 4 & Chap. 4 & Chap. 4 \\
\hline Circles of the Sun: 1 & 1 new & 1 similar to Le1 & 2 new \\
\hline $\begin{array}{l}\text { Moon's circles, caput } \\
\& \text { cauda draconis: } 1\end{array}$ & 1 new & 1 similar to Le1 & 2 new \\
\hline $\begin{array}{l}\text { Circles of other } \\
\text { planets } 0\end{array}$ & 0 & 0 & 1 new \\
\hline $\begin{array}{l}\text { Station, } \\
\text { retrogradation: } 1\end{array}$ & 1 new & 1 similar to Le1 & 1 new \\
\hline The lunar eclipse (1) & 2 new & 2 similar to Le1 & 2 new (+1: phases) \\
\hline The solar eclipse (1) & 2 new & $\begin{array}{l}2 \text { similar to Le1 (with } \\
\text { variants) }\end{array}$ & 1 new \\
\hline
\end{tabular}

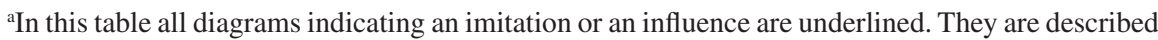
with "similar to" if the imitation is obvious or with "linked to" if the imitation is less complete

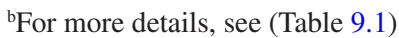

same time, such as those of Robert Grosseteste and John Peckham, were far less successful, although they were more up-to-date, probably because they were too dryly technical and mathematical and less elegantly written, and because they suppressed the quotations of classical poets (Thorndike 1949, 21). Indeed, technicity was not banned altogether, as it subsisted in largely diffused commentaries very soon to be associated with Sacrobosco's Sphaera, like the one attributed to Michael Scot that was composed in the first half of the thirteenth century.

Thus, from the beginning up to the Renaissance, the successful formula was the association of a short, clear, and elegant treatise with commentaries that could afford further information. In the in-octavo tradition, as soon as the Sphaera was provided with a set of clear, precise, pedagogical, and (if possible) self-explanatory diagrams, the effort turned elsewhere. The editors made improvements of a different kind. They wrote pedagogical or erudite notes-notably to rectify some blunders owing to Sacrobosco's lack of humanist training, and to explain the meaning of a few Greek words. ${ }^{48}$ And they also resorted to additions: the addition of a few modest

\footnotetext{
${ }^{48}$ The Paris editors were particularly keen on this point. For instance, the Wittenberg 1538 editor (W2) already tells, in a sober marginal note (D4v), that in Sacrobosco's text "chronicus ortus" means "achronichos," referring to Proclus's commentary on Hesiod, whereas the 1545 Paris editor
} 
Table 9.6 From the Apianus edition to the Wittenberg editions ${ }^{\mathrm{a}}$

\begin{tabular}{|c|c|c|c|}
\hline Topics & $\begin{array}{l}\text { I1: Ingolstadt } \\
\mathbf{1 5 2 6} \\
\text { Cf Table } 9.5 \text {. }\end{array}$ & $\begin{array}{l}\text { W1: Wittenberg 1531-1536 } \\
\text { Crudely copied in V1 } \\
\text { (Venice, 1532-1541, 1553), } \\
\text { and, with some additions, } \\
\text { in V2 (1548-1601) }\end{array}$ & $\begin{array}{l}\text { W2: Wittenberg, } \\
\text { 1538-1540 } \\
\text { P1-P2: Paris 1542/1543, } \\
\text { 1545 } \\
\text { A1-L1: Antwerp and } \\
\text { Louvain, 1547; Antwerp } \\
\text { 1551, 1559, 1561b } \\
\text { With one more } \\
\text { diagram: W3: } \\
\text { Wittenberg 1543 } \\
\text { Copied with a few } \\
\text { eventual additions in: } \\
\text { P3-P7: Paris 1549- } \\
\text { seventeenth cent. } \\
\text { V3: Venice 1562b-1586 } \\
\text { Ly1-2: Lyons, 1564a, } \\
\text { 1578b } \\
\text { A2-A4: Antwerp } \\
\text { 1566b-1582 } \\
\text { C1-C3: Cologne } \\
\text { 1566a-1601c }\end{array}$ \\
\hline
\end{tabular}

\section{Preliminaries}

\begin{tabular}{|c|c|c|c|}
\hline Armillary sphere & 1new (title) & 1 copied from I1 (title) & Id. \\
\hline $\begin{array}{l}\text { Geometrical } \\
\text { diagrams }\end{array}$ & 0 & 0 & Id. \\
\hline Chap. 1 & Chap. 1 & Chap. 1 & Chap. 1 \\
\hline Diffinitiones & 3 new & 2 inspired by I1 & Id. +2 new \\
\hline $\begin{array}{l}\text { Elementary and } \\
\text { celestial spheres }\end{array}$ & $\begin{array}{l}1 \text { new: } \\
\text { Elements, } 10 \\
\text { celestial } \\
\text { spheres }\end{array}$ & 1 copied from I1 & Id. \\
\hline $\begin{array}{l}\text { Sphaera recta / } \\
\text { obliqua }\end{array}$ & 2 new & 2 copied from I1 & Id. \\
\hline Elemental spheres & 1 new & 0 & 0 \\
\hline De caeli revolutione & 1 new & 0 & $\begin{array}{l}1 \text { new }+2 \text { copied from } \\
\text { Finé }\end{array}$ \\
\hline De caeli rotunditate & 4 new & 4 copied from I1 & $\begin{array}{l}\text { Id. }+1 \text { inspired by } \mathrm{V}+1 \\
\text { inspired by Le } 2\end{array}$ \\
\hline Effects of refraction & 2 & 0 & $\begin{array}{l}2 \text { copied from I1 } \pm 1 \\
\text { copied from Finé }\end{array}$ \\
\hline $\begin{array}{l}\text { Quod terra sit } \\
\text { rotunda }\end{array}$ & 2 (Fig. 9.2) & 2 copied from I1 & $\begin{array}{l}2 \text { new (= volvelles)(Figs. } \\
9.7 \text { and } 9.8 \text { ) }\end{array}$ \\
\hline $\begin{array}{l}\text { Quod aqua sit } \\
\text { rotunda }\end{array}$ & 1 new & 1 copied from I1 & Id. \\
\hline $\begin{array}{l}\text { Quod terra sit } \\
\text { centrum mundi }\end{array}$ & 1 new & 1 copied from I1 & Id. \pm 1 copied from Finé \\
\hline
\end{tabular}


Table 9.6 (continued)

\begin{tabular}{|c|c|c|c|}
\hline $\begin{array}{l}\text { De immobilitate } \\
\text { terrae }\end{array}$ & 0 & 0 & 0 \\
\hline De quantitate terrae & 0 & 0 & 2 new \\
\hline Chap. 2 & Chap. 2 & Chap. 2 & Chap. 2 \\
\hline Armillary sphere & 0 & 1 (= title) & Id. \\
\hline The equinoctial & 1 new & 0 & 1 copied from Finé \\
\hline \multirow[t]{2}{*}{ De zodiaco circulo } & \multirow[t]{2}{*}{1 new } & \multirow[t]{2}{*}{0} & 1 new $=$ volvelle \\
\hline & & & +1 copied from Finé \\
\hline Zodiacal signs & 4 & 4 copied from I1 & Id. + 1 copied from Finé \\
\hline De duobus coluris & 1 new & 1 copied from I1 & Id. \\
\hline $\begin{array}{l}\text { De meridiano et } \\
\text { horizonte }\end{array}$ & 1 new & 1 copied from I1 & Id. \\
\hline $\begin{array}{l}\text { Terrestrial zones } \\
\text { (with landscape) }\end{array}$ & $\begin{array}{l}2 \text { new (1 with } \\
\text { landscape and } \\
\text { map) }\end{array}$ & 1 new & $\begin{array}{l}\text { Id. }+1 \text { copied from Finé: } \\
\text { terrestrial globe and } \\
\underline{\text { celestial circles }}\end{array}$ \\
\hline Chap. 3 & Chap. 3 & Chap. 3 & Chap. 3 \\
\hline Poetical risings & 1 new (unclear) & 1 copied from I1 & 1 new = volvelle \\
\hline $\begin{array}{l}\text { Circles to measure } \\
\text { astronomical risings }\end{array}$ & 2 new & 2 copied from I1 & Id. \\
\hline De ascensionibus & 0 & 0 & 4 copied from Finé \\
\hline Dies naturalis & 0 & 0 & 1 copied from Finé \\
\hline $\begin{array}{l}\text { Circles of natural } \\
\text { days }\end{array}$ & 1 & 1 copied from I1 & Id. \\
\hline $\begin{array}{l}\text { De diversitate } \\
\text { dierum...in diversis } \\
\text { locis terrae }\end{array}$ & 8 new (Fig. 9.4) & 8 copied from I1 & Id. \\
\hline $\begin{array}{l}\text { Terrestrial zones } \\
\text { and climes }\end{array}$ & $\begin{array}{l}2 \text { new (climes) } \\
\text { (Fig. 9.5) }\end{array}$ & 1 copied from I1 & $\begin{array}{l}1 \text { (with map) copied from } \\
\text { Finé. (Fig. 9.6) }\end{array}$ \\
\hline Chap. 4 & Chap. 4 & Chap. 4 & Chap. 4 \\
\hline $\begin{array}{l}\text { Circles of the } \\
\text { Moon, nodes of the } \\
\text { dragon }\end{array}$ & 4 new & 4 copied from I1 & Id. \\
\hline $\begin{array}{l}\text { Circles of other } \\
\text { planets }\end{array}$ & 1 new & 1 copied from I1 & Id. \\
\hline $\begin{array}{l}\text { De statione, } \\
\text { directione...: }\end{array}$ & 1 & 1 copied from I1 & Id. \\
\hline The lunar eclipse & 3 new & 3 copied from I1 & Id. \\
\hline The solar eclipse & 1 new & 1 copied from I1 & Id. \\
\hline
\end{tabular}

an this table as in (Table 9.5) the diagrams copied from other editions (or inspired by them) are underlined. The new diagrams in $\mathrm{W} 2$ are in bold

${ }^{\text {bP2 }}$ (Paris, 1545b) adds two crude and completely redundant diagrams. The first one (in a note on Euclid's definition of the sphere) remains in the Paris editions until P5 (1551), the second one (on the solar eclipse) until P6 (1555/1556) 
Fig. 9.5 De divisione climatum. From (Sacrobosco 1526, D2v). State Library Regensburg--999/ Philos.1325, urn:nbn:de:bvb:12bsb11110162-1

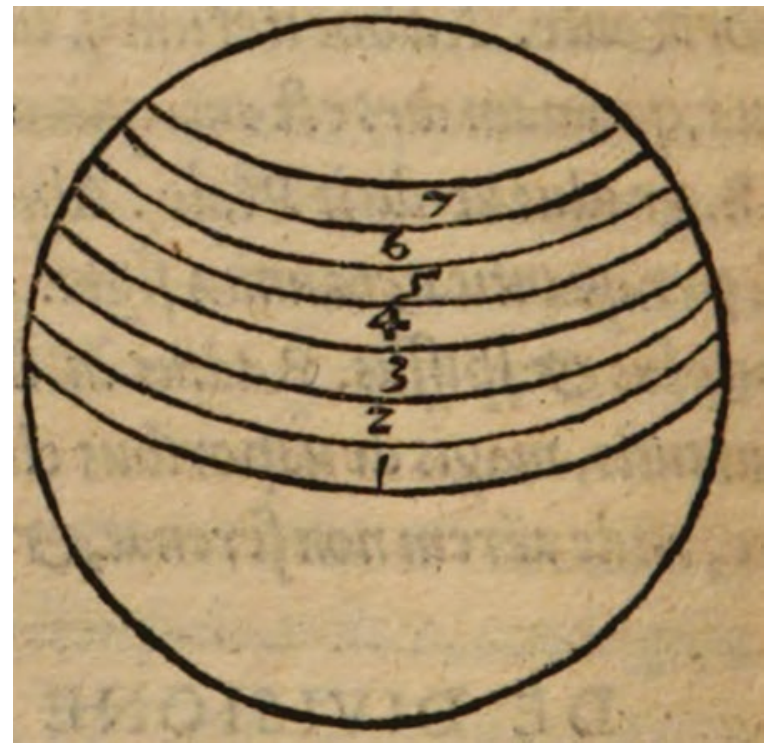

tables inside the commentary, ${ }^{49}$ and above all the addition of other texts to complement the Sphaera. ${ }^{50}$

\section{The Limits of the Tradition: The Case of Francesco Giuntini}

This cumulative process had its limits. The control of the publishers over the evolution of this tradition fostered innovation to a certain degree; but it could also hinder it. The iconography, as we have seen, consisted of a fixed set of diagrams; the additions were welcome, but only if they could fit into the handy format of the in-octavo textbook; the original contributions of skilled commentators were sought-after, provided that they let the model remain recognizable. The ideal new edition in the inoctavo tradition was an improved item that continued on the lines of previous

(P2) expands on this topic in a long note ("Corrupta scriptura..." D5r). Then Elie Vinet, in 1551 (P5), writes a new version of the note with more erudite details (34r). The 1550 Paris editor (P4) adds some notes on difficult words, like "Archetypus" (B7r) and "Diaphanum" (B8r).

${ }^{49} \mathrm{In} \mathrm{W} 3$, the table of the longest natural days for all degrees of latitude between the arctic circle and the pole appeared (Sacrobosco. 1543b, F1v-F2r), and in P2 a table of the climes (Sacrobosco. $1545 \mathrm{~b}, \mathrm{~F} 3 \mathrm{v})$. The first massive addition of tables occurred thanks to Giuntini, but never to appear again in further editions (see infra).

${ }^{50}$ For a general view of additions, see (Table 9.3). 


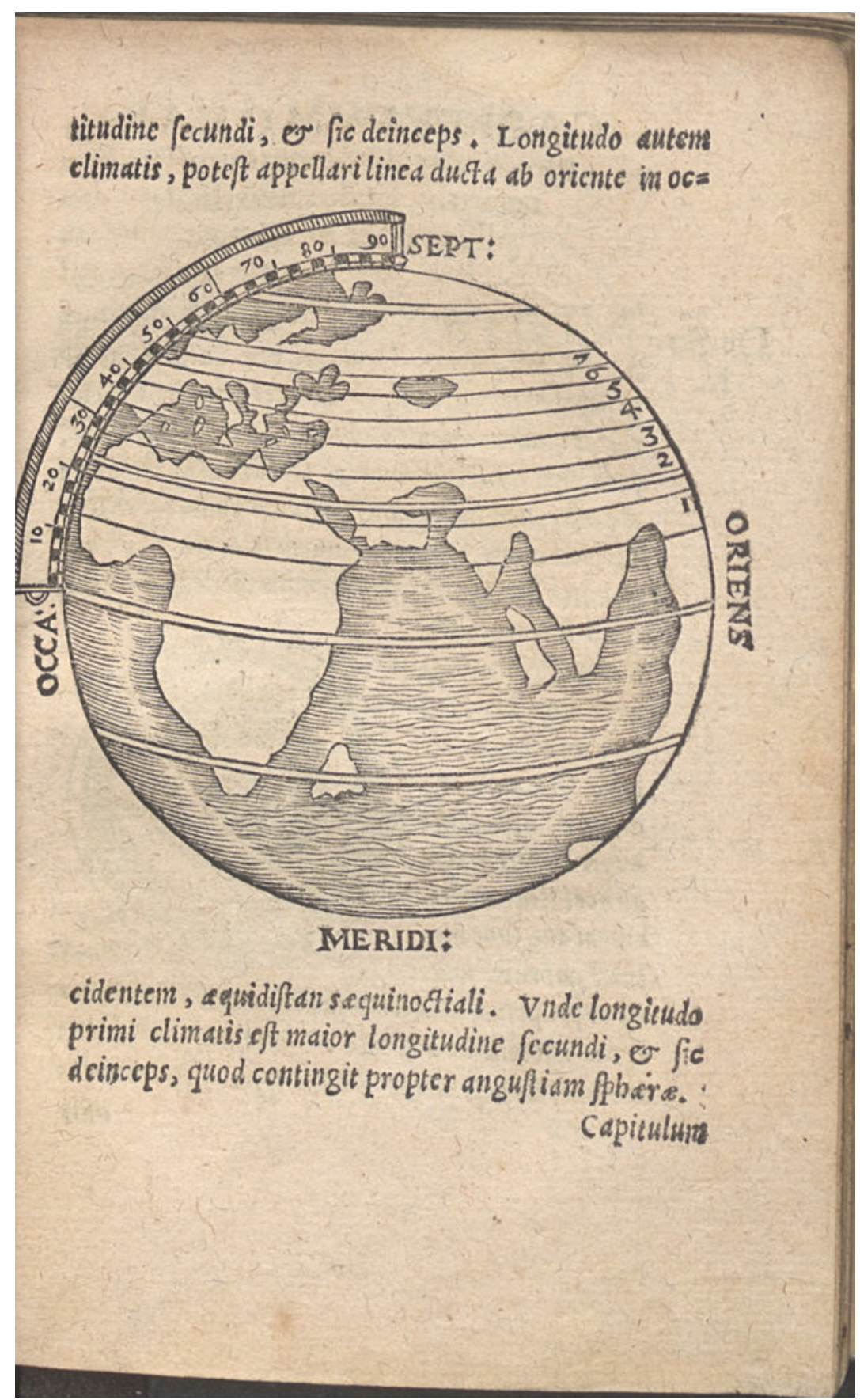

Fig. 9.6 De divisione climatum. From (Sacrobosco 1538, F4r). Bavarian State Library MunichAstr.u. 154, urn:nbn:de:bvb:12-bsb00020992-1 


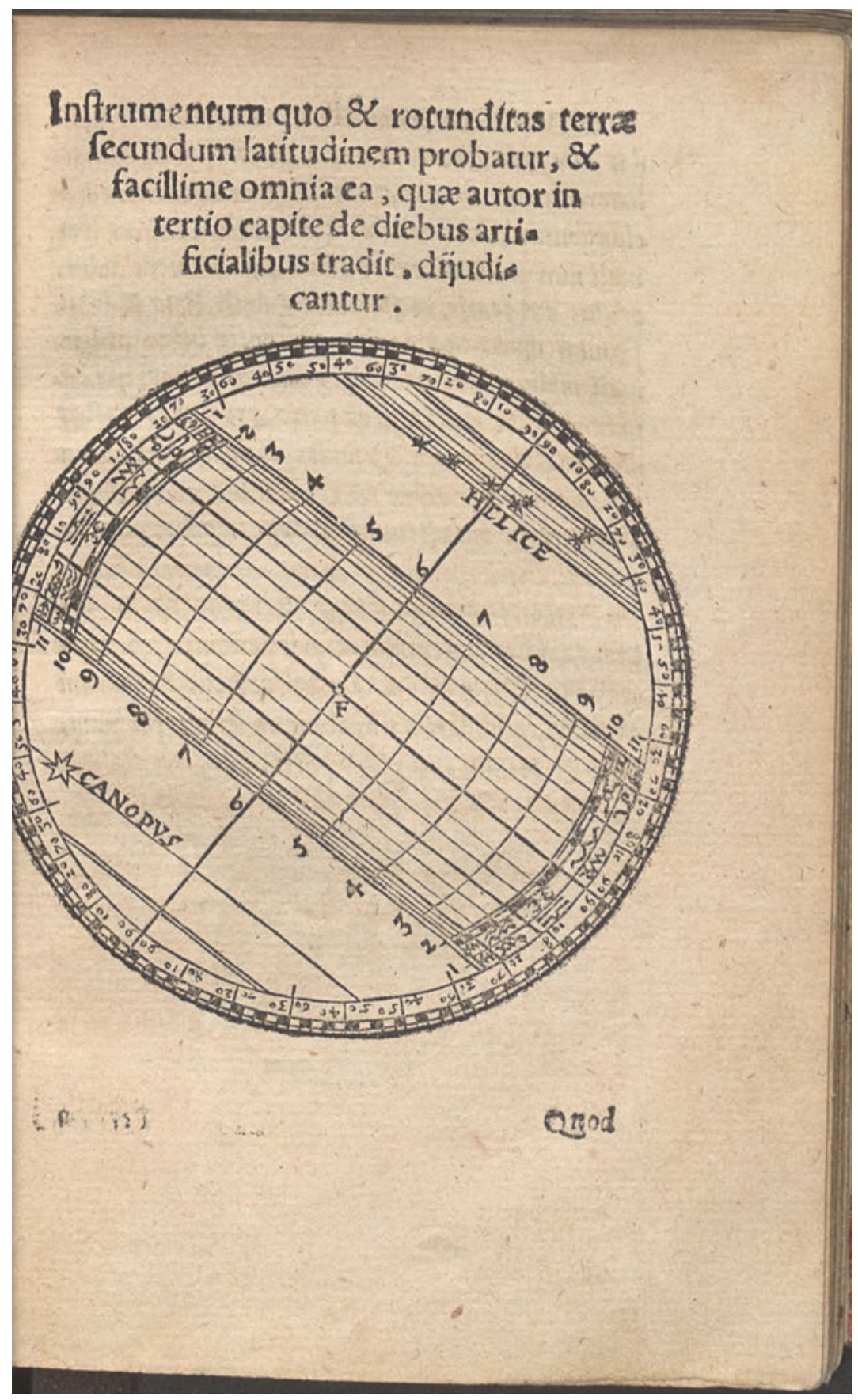

Fig. 9.7 Unmounted volvelle. From (Sacrobosco 1538, B8r). Bavarian State Library MunichAstr.u. 154, urn:nbn:de:bvb:12-bsb00020992-1 


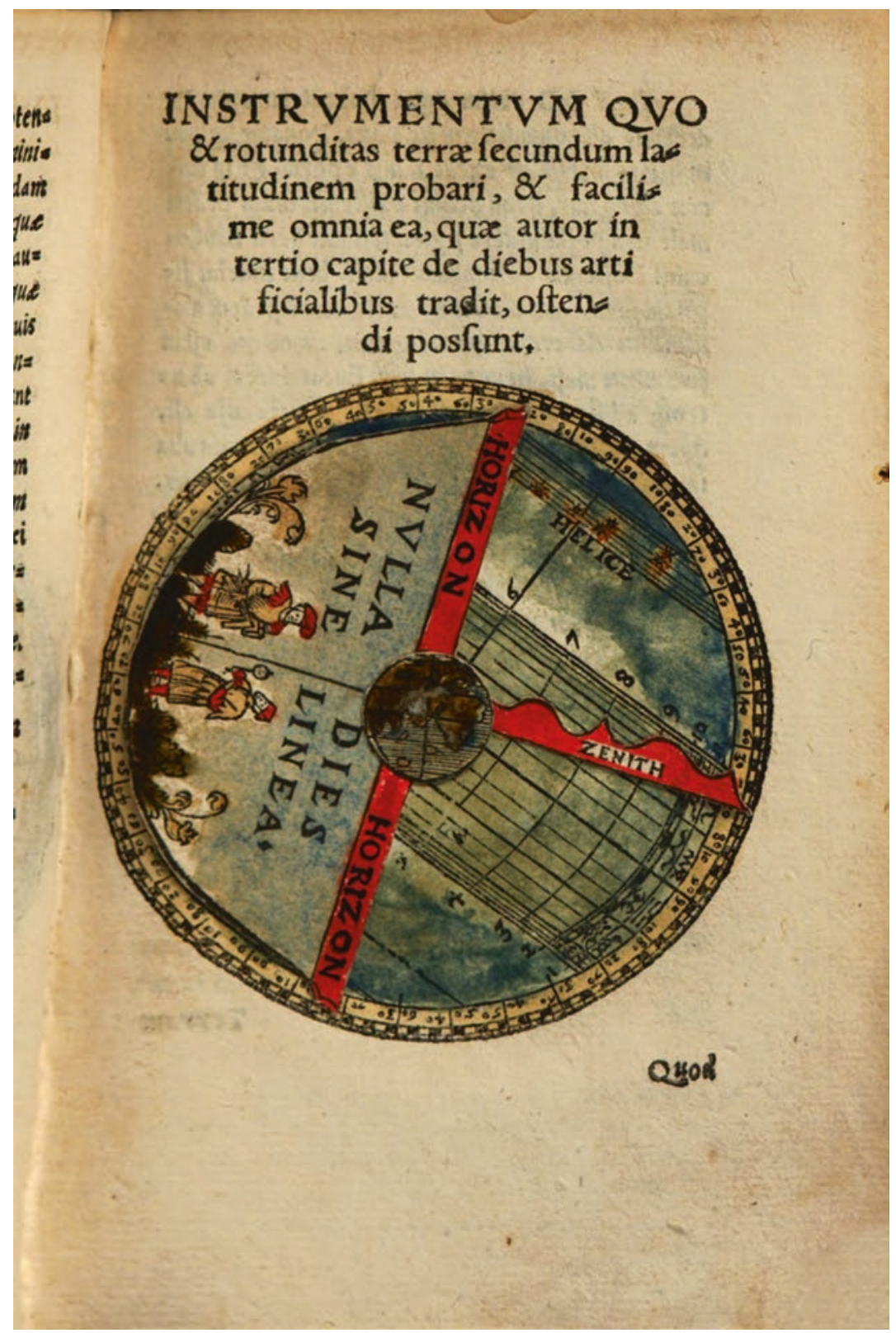

Fig. 9.8 Mounted volvelle. From (Sacrobosco 1543b, B8r). Staats- und Stadtbibliothek Augsburg—Math 745, urn:nbn:de:bvb:12-bsb11267683-6 
editions. The case of Francesco Giuntini shows that more ambitious projects were bound to leave this framework.

Francesco Giuntini, a Florentine by birth, had been a Carmelite priest and a doctor of theology. His assiduous practice of astrology and, above all, his Protestant sympathies led him into trouble. In 1561, he went to Lyons as a religious exile, publicly renounced his heresy, and entered a new career as a mathematician and astrologer with the support of the Italian colony in Lyons. After a time, he won the patronage of royal officers and even began to aim higher. ${ }^{51}$ His first commentary on Sacrobosco was published in 1564, when he was still at the beginning of this successful second career (Sacrobosco 1564a). It fit into the framework of the in-octavo tradition, which likely appeared to him a good medium to widen his fame outside the Lyons circles. The presence of Melanchthon's preface in praise of astrology (which had to be printed without the name of its author) probably appealed to him as well (Sacrobosco 1564a, 3r-7v).

In the dedication of the work to Thomas de Gadagne (ca. 1539-1594), lord of Bellegarde, Giuntini states that Filippo Tinghi (died 1580), a Florentine printer and bookseller settled in Lyons, has asked him to emendate the Sphaera and add some "very brief notes" ("brevissimis notis") to explain the difficult passages, a demand which he has eagerly answered out of his zeal for promoting such a universally useful science as astronomy (Sacrobosco 1564a, 2r-v). Indeed, the "very brief notes" were to consist of innumerable marginalia, abundant scholia (even lengthier than Vinet's, and printed in bigger type), and long technical appendices, which concerned the method of determining the polar altitude at any location in the northern hemisphere, ${ }^{52}$ the method of determining longitudes, ${ }^{53}$ the method of determining the duration of natural days at different latitudes,${ }^{54}$ and instructions for the calendar (Sacrobosco 1564a, 143-46). The Giuntini edition thus brought into the in-octavo tradition a noticeable amount of material borrowed from other types of treatises on the Sphaera - adaptions or huge commentaries in which the original text was buried. Whereas the standard in-octavo model included only two modest tables, as we have seen, Giuntini added a series of tables (none of them original), which transformed the original textbook into an introduction to astronomical practice and calculation..$^{55}$

\footnotetext{
${ }^{51}$ On Giuntini's career, see (Ernst 2001; Pantin 2013).

${ }^{52}$ (Sacrobosco 1564a, 117-27): "Quomodo altitudo poli Aquilonaris et aequatoris sit investiganda."

${ }^{53}$ (Sacrobosco 1564a, 128-29): "Quomodo Astrologi invenerunt locorum longitudines."

${ }^{54}$ (Sacrobosco 1564a, 136-42): "De quantitate diei et noctis, ortu et occasu Solis."

${ }^{55}$ The tendency to transform the original textbook into an introduction to astronomical practice and calculation, already present in Lefevre's and Finé's work on the Sphaera (Chaps. 2 and 8), had been reinforced in many adaptions and 'hypercommentaries' of Sacrobosco, notably those of (Schreckenfuchs 1569) and (Clavius 1570).
} 
A table of the measures of the earth (perimeter, diameter etc.) in different units of measurement (leagues, miles, etc.). ${ }^{56}$

A table to compare the measures of the obliquity of the ecliptic by Ptolemy, Albategnius, etc. until Johannes Werner. (Sacrobosco 1564a, 41-42)

A table of the cosmic and chronic risings and settings of the twelve zodiacal signs. (59)

Two tables of the astronomical risings and settings of the zodiacal signs under the right sphere, measured in arcs of the equator, and in hours and minutes. (66-67)

A table of the astronomical risings and settings of the zodiacal signs under the oblique sphere, measured in arcs of the equator and calculated for each of the eight climes. (70-71)

For the determination of latitudes (first appendix), a table of the true position (verus locus) of the sun at midday for each day of the year according to the Prutenic Tables ${ }^{57}$ (119-20), a table of the equation of the $\operatorname{sun}^{58}$ (123), and a table of the declination of the sun. (125)

A table of the longitudes and latitudes of the principal towns of the world (130-36)

For the determination of the length of natural days, a table of the semi-diurnal arcs and of the latitudes of the sun at midday under different latitudes. (139-42)

Two calendar tables. $(243,246)$

Giuntini was not satisfied with this first work on the Sphaera and he planned more ambitious publications, both to attract the attention of more important patrons and to advance the project he took most to heart: asserting the complete legitimacy of astrology as an integral part of the science of the stars, and as the science of Providence, perfectly compatible with the Catholic faith, even under the new Tridentine rules. ${ }^{59}$ In 1573, he dedicated to Catherine de'Medici (1519-1589), the queen mother, the first version of his Speculum astrologiae (Lyons: Filippo Tinghi), which contained a series of astrological treatises and new astronomical tables (Tabulae resolutae). Then he published a two-volume commentary on the Sphaera in 1577-1578, which rivaled that of Clavius, though it was far less methodical and much more digressive (Giuntini 1577-1578) ${ }^{60}$ Its most exceptional feature was the space it devoted to astrological and theological questions. The content of the former commentary was immersed into this new one, which still retained the typical diagrams conceived in Wittenberg (mixed with new ones), and even the in-octavo format, but, all the same, no longer belonged to the tradition founded by Apianus. The

\footnotetext{
${ }^{56}$ (Sacrobosco 1564a, 30): "Tabula quantitatis terrae secundum Ptolemaeum et experientiam."

${ }^{57}$ On Giuntini's reliance on Erasmus Reinhold's “Copernican tables," though he had otherwise no Copernican sympathies, see (Omodeo 2014, 136-39; Proverbio 1997).

${ }^{58}$ The equation of the sun (aequatio Solis) is the arc of the ecliptic between the true position (verus locus) of the sun, determined by a line issued from the center of the world and passing through the center of the body of the planet, and its mean position (medius motus) determined by a line issued from the center of the world and parallel to a line issued from the center of the eccentric deferent of the Sun and passing through the center of the body of the planet. All these notions are part of the knowledge taught in the Theoricae planetarum.

${ }^{59}$ Although the Council of Trent had hardened the control of the practice of astrology, Giuntini felt confident that he could promote this practice by using the same arguments as those developed by Melanchthon. On Giuntini's astrology, see (Thorndike 1941, 129-33; Pantin 2013).

${ }^{60}$ One volume of Giuntini's work is dated 1577 , the other one 1578 , but both were issued together. This commentary was reprinted in 1583 as part as the second in-folio volume of the much enlarged new version of the Speculum astrologiae (Lyons: Filippo Tinghi).
} 
same year (1578), Filippo Tinghi published a new edition of the Sphaera emendata (Ly2). The scholia added in 1564 had been removed from it, replaced by a short treatise of elementary geometry. Giuntini's commentary and the in-octavo tradition had parted company for good.

\section{Conclusion}

In this paper, I focused on a kind of collective authorship, which was responsible for the development of a long-running tradition that developed from 1526 until the seventeenth century. I chose the privileged example of the in-octavo tradition to provide an interesting point of view on the means, the ways, and even the rhythm of innovation in the Sacrobosco field. This tradition was a successful attempt at standardization, producing a kind of manual that was able to retain, for over half a century, an essential core of original features even as it continued to evolve. This success proves the efficiency of a commercial model. The never-relenting interest in this particular model of Sphaera among a succession of booksellers in several European countries was certainly a motor for innovation: it would not have been possible to perpetually reprint the same book without drying up the market. It was necessary to innovate, at least to a certain extent, to gain enough new customers. But on the other hand, the constraints of the tradition, the obligation to retain the model, and the weight of trade imperatives imposed a limit on innovation, which, at the end, made decline inescapable. Between Giuntini's intervention and Burgersdijk's late attempt at reviving the tradition in 1626 (Chap. 11), no significant innovation occurred: the Wittenberg 1538 (W2) and the Paris 1555/1556 (P6) models were still printed, either in a repetitive manner (in Paris and Venice), or with different attempts at refreshment (in Antwerp and Cologne). In the second part of the sixteenth century, the concurrence of numerous new types of tracts on the Sphaera had marginalized the type studied in this paper.

In spite of the importance of the German mathematicians who conceived a remarkable set of cosmological pedagogical diagrams (following Melanchthon's educational plan), and in spite of the patient work of annotation achieved by a succession of professors (notably Elie Vinet), the actors who did most to support first the dynamic of the tradition, then its longevity, were probably the printers and booksellers: they did not write commentaries, but in many cases ${ }^{61}$ they acted as intermediaries between the authors and the public, and they managed to keep control over the process. Innovation, as they conceived it, was a braiding process: it was often achieved through the artful combination of diverse borrowed material. In this way and in this specific instance, the printers and booksellers were largely responsible for blurring the distinction between borrowers and innovators.

\footnotetext{
${ }^{61}$ Not in all cases printers acted as intermediaries: as we have seen, in Wittenberg, the printers followed the instructions of the university.
} 


\section{References}

\section{Editions of Sacrobosco's Sphere Anterior to the In-Octavo Tradition}

Sacrobosco. ca. 1472a. Tractatum de spera. Venice: Florentius de Argentina. http://hdl.handle. net/21.11103/sphaera.100685.

. 1472b. Spaera mondi, ed. Pietro Buono Avogaro. Ferrara: Andreas Belfortis. http://hdl. handle.net/21.11103/sphaera.101122.

—. 1478a. Spera mundi. Venice: Franciscus Renner from Heilbronn. http://hdl.handle. net/21.11103/sphaera.100686.

—. 1478b. Spera. Venice: Adam Burkardt from Rottweil. http://hdl.handle.net/21.11103/ sphaera.100687.

- 1482. Sphericum opusculum. Venice: Erhard Ratdolt. http://hdl.handle.net/21.11103/ sphaera.100692.

—. 1485. Sphericum opusculum. Venice: Erhard Ratdolt. http://hdl.handle.net/21.11103/ sphaera.101123.

-1486. Spericum opusculum. Leipzig: Drucker des Capotius.

_. ca. 1487. Spericum opusculum. Leipzig: Martin Landsberg. http://hdl.handle.net/21.11103/ sphaera.101126.

- 1488. Spaerae mundi compendium. Venice: Johannes Santritter. http://hdl.handle. net/21.11103/sphaera.100822.

_. 1489. Spericum opusculum. Leipzig: Conrad Kachelofen. http://hdl.handle.net/21.11103/ sphaera.100266.

. 1490. Sphaera mundi. Venice: Bonetus Locatellus for Octavianus Scotus. http://hdl.handle.net/21.11103/sphaera.101124.

- 1494. Opusculum spericum cum figuris optimis et novis. Leipzig: Martin Landsberg. http://hdl.handle.net/21.11103/sphaera.100271.

- ca. 1495a. Opusculum spericum cum notabili commento, comm. Wenceslas Faber von Budweis. Leipzig: Martin Landsberg. http://hdl.handle.net/21.11103/sphaera.100886.

- $1495 \mathrm{~b}$ n.st. Textus de Sphera, comm. Jacques Lefèvre d'Etaples. Paris: Wolfgang Hopyl. http://hdl.handle.net/21.11103/sphaera.101126.

- 1498. Uberrimum sphere mundi comentum, comm. Pierre d'Ailly and Pedro Sanchez Ciruelo. Paris: Jean Petit. http://hdl.handle.net/21.11103/sphaera.100038.

- 1499a. Opusculum spericum cum notabili commento. Leipzig: Wolfgang Stöckel. http:// hdl.handle.net/21.11103/sphaera.100888.

1499b. Sphaera mundi, comm. Cecco d'Ascoli, Franciscus Capuanus de Manfredonia, Jacques Lefèvre d'Etaples, with Peuerbach, Theoricae novae planetarum, comm. Franciscus Capuanus. Venice: Simone Bevilaqua. http://hdl.handle.net/21.11103/sphaera.100265.

-1500. Opus sphericum... figuris et notabili commento illustratum, comm. Wenceslas Faber von Budweis. Cologne: Heinrich Quentell. http://hdl.handle.net/21.11103/sphaera.100891.

—.1501a. Opus sphericum... figuris et perutili commento illustratum, comm. Wenceslas Faber von Budweis. Cologne: Heinrich Quentell. http://hdl.handle.net/21.11103/sphaera.100023.

—. 1501b. Sphaera mundi. Venice: Melchior Sessa. http://hdl.handle.net/21.11103/ sphaera.100892.

-1503a. Opus sphericum... figuris verissime exculptis et interpretatione familiari...illustratum, comm. Wenceslas Faber von Budweis. Cologne: Heinrich Quentell. http://hdl.handle. net/21.11103/sphaera. 100024 .

1503b. Textus Spere materialis...cum lectura Magistri Conradi Norici, comm. Conrad Tockler. Leipzig: Martin Landsberg. http://hdl.handle.net/21.11103/sphaera.100931.

- 1505. Opus sphericum...figuris verissime exculptis et interpretatione familiari...illustratum, comm. Wenceslas Faber von Budweis. Cologne: Heinrich Quentell. http://hdl.handle. net/21.11103/sphaera. 100028 . 
1508. Opus sphericum...figuris verissime exculptis et interpretatione familiari...illustratum, comm. Wenceslas Faber von Budweis. Cologne: Heirs of Heinrich Quentell. http://hdl. handle.net/21.11103/sphaera.100183.

- 1509. Textus Spere materialis...cum lectura Magistri Conradi Norici, comm. Conrad Tockler. Leipzig: Martin Landsberg. http://hdl.handle.net/21.11103/sphaera.101042.

- 1513. Sphaera mundi. Venice: Melchior Sessa. http://hdl.handle.net/21.11103/ sphaera.101023.

- 1516. Mundialis sphere opusculum. Paris: Vincent Quignon for Regnault Chaudière. http://hdl.handle.net/21.11103/sphaera.100991.

- 1518. Opusculum de sphaera. Wien: Johann Singriener for Lucas Alantsee. http://hdl. handle.net/21.11103/sphaera.100883.

- 1519. Sphaera mundi. Venice: Jacobus Pentius for Melchior Sessa. http://hdl.handle. net/21.11103/sphaera.100992.

\section{Editions in the In-Octavo Tradition (1526-1601)}

1526 [I1]. Sphaera...per Petrum Apianum accuratissima diligentia denuo recognita ac emendata. Ingolstadt: Petrus Apianus. http://hdl.handle.net/21.11103/sphaera.100070.

- 1531 [W1]. Liber de sphaera. Addita est praefatio in eundem librum Phlippi Melanchthonis ad Simonem Gryneum. Wittenberg: Joseph Klug. http://hdl.handle.net/21.11103/ sphaera.100138.

- 1532 [V1]. Liber de sphaera. Venise: G.A. Nicolini da Sabio for Melchior Sessa. http:// hdl.handle.net/21.11103/sphaera.100118.

- 1534a. Liber de sphera. Wittenberg: Joseph Klug. http://hdl.handle.net/21.11103/ sphaera.100085.

. 1534b. Liber de sphaera. Venice: G.A. Nicolini da Sabbio for Melchior Sessa. http://hdl. handle.net/21.11103/sphaera.100179.

- 1536. Liber de sphaera. Wittenberg: Joseph Klug. http://hdl.handle.net/21.11103/ sphaera.101008.

. 1537a. Liber de sphaera. Venice: Maffeo Pasini and Francesco Bindoni. http://hdl.handle. net/21.11103/sphaera.101059.

- 1537b. Liber de sphaera. Venice: Giovanni Antonio Nicolini da Sabbio for Melchior Sessa. http://hdl.handle.net/21.11103/sphaera.101060. . 1538 [W2]. Libellus de sphaera. Wittenberg: Joseph Klug. http://hd1.handle.net/21.11103/
sphaera.101106.

. 1540. Libellus de sphaera. Wittenberg: Joseph Klug. http://hdl.handle.net/21.11103/ sphaera.101025.

- 1541a. Liber...de sphaera. Addita est praefation in eundem librum Philippi Mel.

Ad Simonem Grineum. Venice: Francesco Bindoni and Maffeo Pasini. http://hdl.handle. net/21.11103/sphaera.100140.

- 1541 b. Liber...de sphaera. Addita est praefatio in eundem librum Philippi Mel. Ad Simonem Grineum. Venice: Giovanni Antonio Nicolini da Sabbio for Melchior Sessa. http:// hdl.handle.net/21.11103/sphaera.100144.

—. 1542/1543 [P1]. De sphaera liber. Plurimis novis typis auctus. Paris: Jean Loys. http:// hdl.handle.net/21.11103/sphaera.101027.

_. 1543a [A1]. Libellus de sphaera. Antwerp: Jean Richard. http://hdl.handle.net/21.11103/ sphaera.100180.
_. 1543b [W3]. Libellus de sphaera. Wittenberg: Peter Seitz. http://hdl.handle.net/21.11103/ sphaera. 101029.
—. 1545a. Libellus de sphaera. Wittenberg: Veit Kreutzer. http://hdl.handle.net/21.11103/ sphaera.100818.

. 1545b [P2]. Sphaera typis auctior, quam antehac, atque ex diligenti manu scriptorum impressorumque codicum collatione castigatior. Paris: Jean Loys and Guillaume Richard. http://hdl.handle.net/21.11103/sphaera.101054. 
1545c. Liber de sphaera. Venice: Giovanni Antonio Nicolini da Sabbio for Melchior Sessa. http://hdl.handle.net/21.11103/sphaera.100145.

. 1546. La Sphere...traduicte de latin en langue francoyse, transl. Martin de Perer. Paris: Jean Loys. http://hdl.handle.net/21.11103/sphaera.101030.

—. 1547 [A2 \& L1]. Sphaera. Antwerp and Louvain: Martinus Nutius for Jean Richard and Jan Waen. http://hdl.handle.net/21.11103/sphaera.100917 [A2]. http://hdl.handle. net/21.11103/sphaera.100125 [L1].

. 1548 [V2]. Liber de sphaera. Addita sunt quaedam ad explanationem eorum, quae in sphaera dicuntur facientia. Venice: Pietro Nicolini da Sabbio for Melchior Sessa. http://hdl. handle.net/21.11103/sphaera.101031.

—. 1549a. Libellus de sphaera. Wittenberg: Veit Kreutzer. http://hdl.handle.net/21.11103/ sphaera.100136.

- 1549b [P3]. Sphaera typis auctior, quam antehac...atque ex diligenti manu...castigatior. Paris: Thomas Richard and Guillaume Cavellat. http://hdl.handle.net/21.11103/ sphaera.100137.

- 1550a. Sphaera. Addita sunt quaedam...Venice: Pietro Nicolini da Sabbio for Melchior Sessa. http://hdl.handle.net/21.11103/sphaera.100163.

1550b. Libellus de sphaera. Wittenberg: Johann Krafft. http://hdl.handle.net/21.11103/ sphaera.100157.

. 1550c [P4]. Sphaera typis auctior, quam antehac...cum annotationibus. Paris: Guillaume Cavellat. http://hdl.handle.net/21.11103/sphaera.100952.

—. 1551a. Sphaera. Antwerp: Jean Richard. http://hdl.handle.net/21.11103/sphaera.100161.

. 1551b. Sphaera typis auctior, quam antehac...cum annotationibus, et scholiis...

Eliae Vineti, comm. Elie Vinet. Paris: Guillaume Cavellat. http://hdl.handle.net/21.11103/ sphaera.100181.

- 1552. Sphaera. Addita sunt quaedam...Venice: Cornelio Nicolini da Sabbio for Melchior Sessa. http://hdl.handle.net/21.11103/sphaera.101045.

_. 1553a. Liber de sphaera. Venice: Francesco Bindoni. http://hdl.handle.net/21.11103/ sphaera.100193.

—. 1553b. Libellus de sphaera. Wittenberg: Johann Krafft. http://hdl.handle.net/21.11103/ sphaera.101102.

- 1554. Sphaera. Addita sunt quaedam.... Venice: Francesco Rampazetto for Melchior Sessa. http://hdl.handle.net/21.11103/sphaera.100164.

—. 1555/1556 [P6]. Sphaera emendata. Eliae Vineti Santonis scholia...ab ipso autore restituta, comm. Elie Vinet. Paris: Guillaume Cavellat. http://hdl.handle.net/21.11103/ sphaera.100198.

- 1557a. Sphaera. Addita sunt quaedam.... Venice: heirs of Giovanni Padovani for Melchior Sessa. http://hdl.handle.net/21.11103/sphaera.101048.

_ 1557b [P6b]. Sphaera emendata, comm. Elie Vinet. Paris: Guillaume Cavellat. http:// hdl.handle.net/21.11103/sphaera.100207. Reissues in 1558: http://hdl.handle.net/21.11103/ sphaera.100210, and in 1559. http://hdl.handle.net/21.11103/sphaera.100819.

. 1558. Libellus de sphaera. Wittenberg: Johann Krafft. http://hdl.handle.net/21.11103/ sphaera.101049.

- 1559. Sphaera. Antwerp: Jean Richard. http://hdl.handle.net/21.11103/sphaera.101107.

. 1561a. Sphaera. Addita sunt quaedam.... Venice: heirs of Melchior Sessa. http://hdl.handle.net/21.11103/sphaera.101066.

—. 1561b. Sphaera. Antwerp: Jean Richard. http://hdl.handle.net/21.11103/sphaera.101058.

. 1561c. Sphaera emendata, comm. Elie Vinet. Paris: Guillaume Cavellat. http://hdl.handle. net/21.11103/sphaera.100211.

—. 1561d. Libellus de sphaera. Wittenberg: Johann Krafft. http://hdl.handle.net/21.11103/ sphaera.101109.

—. 1562a [P6c]. Sphaera emendata, comm. Elie Vinet. Paris: Cavellat. http://hdl.handle. net/21.11103/sphaera.101067.

- $1562 \mathrm{~b}$ [V3]. Sphaera emendata...ex postrema impressione Lutetiae, comm. Elie Vinet. Venice: Girolamo Scoto. http://hdl.handle.net/21.11103/sphaera.101094. 
1563. Libellus de sphaera. Wittenberg: Johann Krafft. http://hdl.handle.net/21.11103/ sphaera.101070.

- 1564a [Ly1]. Sphaera...emendata cum additionibus in margine...nunc recenter compertis et collectis a Francisco Junctino Florentino sacrae theologiae doctore, comm. Elie Vinet and Francesco Giuntini. Lyons: Symphorien Barbier for Filippo Tinghi and the heirs of Giunta. http://hdl.handle.net/21.11103/sphaera.101071. Reissue with the date 1567. http://hdl.handle. net/21.11103/sphaera.101111.

_ 1564b. Sphaera emendata, comm. Elie Vinet. Paris: Guillaume Cavellat. http://hdl.handle. net/21.11103/sphaera.100110.

—. 1564c. Sphaera. Addita sunt quaedam.... Venice: Francesco Rampazetto. http://hdl.handle.net/21.11103/sphaera.100165.

—. 1566a [C1]. Sphaera emendata, comm. Elie Vinet. Cologne: Maternus Cholinus. http:// hdl.handle.net/21.11103/sphaera.101076.

- 1566b [A3]. Sphaera emendata cum additionibus in margine, comm. Elie Vinet and Francesco Giuntini. Antwerp: Jean Richard and the heirs of Arnold Birckmann. http://hdl. handle.net/21.11103/sphaera.101114. http://hdl.handle.net/21.11103/sphaera.101115.

- 1568. Libellus de sphaera. Wittenberg: Johann Krafft. http://hdl.handle.net/21.11103/ sphaera.101112.

—. 1569a [P7]. Sphaera emendata, comm. Elie Vinet. Paris: Guillaume Cavellat and Jérôme de Marnef. http://hdl.handle.net/21.11103/sphaera.100240.

- 1569b. Sphaera emendata...ex postrema impressione Lutetiae, comm. Elie Vinet. Venice: Girolamo Scoto. http://hdl.handle.net/21.11103/sphaera.101040.

—. 1572a. Sphaera. Addita sunt quaedam.... Venice: heirs of Melchior Sessa. http://hdl.handle.net/21.11103/sphaera.101086.

- 1572b. Sphaera emendata, comm. Elie Vinet. Paris: Guillaume Cavellat and Jérôme de Marnef. http://hdl.handle.net/21.11103/sphaera.100268.

- 1573 [A4]. Sphaera emendata, comm. Elie Vinet and Francesco Giuntini. Antwerp: Gilles van der Rade for Jean Bellere. http://hdl.handle.net/21.11103/sphaera.100460.

— 1574a. Libellus de sphaera. Wittenberg: Peter Seitz. http://hdl.handle.net/21.11103/ sphaera.101056.

- 1574b. Sphaera emendata...ex postrema impressione Lutetiae, comm. Elie Vinet. Venice: heirs of Girolamo Scoto. http://hdl.handle.net/21.11103/sphaera.100309.

- 1577a. Sphaera. Addita sunt quaedam.... Venice: heirs of Melchior Sessa. http://hdl.handle.net/21.11103/sphaera.100478.

- 1577b. Sphaera emendata, comm. Elie Vinet. Paris: widow of Guillaume Cavellat and Jérôme de Marnef. http://hdl.handle.net/21.11103/sphaera.100269.

—. 1578a. Libellus de sphaera. Wittenberg: heirs of Peter Seitz. http://hdl.handle. net/21.11103/sphaera.101116.

- 1578b [Ly2]. Sphaera emendata a Fr. Junctino...qui etiam in capite libri adjunxit Principia geometrica, comm. Elie Vinet and Francesco Giuntini. Lyons: Filippo Tinghi. http:// hdl.handle.net/21.11103/sphaera.100311.

- 1580. Sphaera. Addita sunt quaedam.... Venice: heirs of Melchior Sessa. http://hdl.handle.net/21.11103/sphaera.100299.

- 1581. Sphaera emendata, comm. Elie Vinet and Albertus Hero. Cologne: Maternus Cholinus. http://hdl.handle.net/21.11103/sphaera.100655.

- 1582 [A5]. Sphaera emendata, comm. Elie Vinet, Francesco Giuntini and Albertus Hero. Antwerp: Pierre Bellere. http://hdl.handle.net/21.11103/sphaera.100898.

- 1584. Sphaera emendata, comm. Elie Vinet. Paris: widow of Guillaume Cavellat and Jérôme de Marnef. http://hdl.handle.net/21.11103/sphaera.100324.

- 1586. Sphaera emendata...ex postrema impressione Lutetiae, comm. Elie Vinet. Venice: heirs of Girolamo Scoto. http://hdl.handle.net/21.11103/sphaera.100325.

- 1587. Sphaera. Addita sunt quaedam.... Venice: heirs of Melchior Sessa. http://hdl.handle.net/21.11103/sphaera.100300.

- 1591. Sphaera emendata, comm. Elie Vinet and Albertus Hero. Cologne: Goswin

Cholinus. http://hdl.handle.net/21.11103/sphaera.100326. 
1594a. Sphaera emendata, comm. Elie Vinet and Albertus Hero. Cologne: Goswin Cholinus. http://hdl.handle.net/21.11103/sphaera.100656.

_ 1594b. Sphaera. Addita sunt quaedam.... Venice: heirs of Melchior Sessa. http://hdl.handle.net/21.11103/sphaera.100301.

. 1601a. Sphaera. Addita sunt quaedam.... Venice: heirs of Melchior Sessa. http://hdl.handle.net/21.11103/sphaera.100302.

1601b. Libellus de sphaera. Wittenberg: Johann Krafft for Zacharias Schurer. http://hdl. handle.net/21.11103/sphaera.100646.

. 1601c [C3]. Sphaera emendata, aucta, et illustrata...nunc accessere R.P. Christoph. Clavii breves commentarii, comm. Elie Vinet, Albertus Hero and Christoph Clavius, ed. Thomas Abel [?]. Cologne: Goswin Cholinus. http://hdl.handle.net/21.11103/sphaera.100327.

\section{Large Commentaries on the Sphere}

Clavius, Christopher. 1570. In Sphaeram Ioannis de Sacro Bosco commentarius. Rome: Vittorio Eliano. http://hdl.handle.net/21.11103/sphaera.100365.

Giuntini, Francesco. 1577-1578. Commentaria in Sphaeram Joannis de Sacrobosco, 2 vols. Lyons: Jean de Tournes for Filippo Tinghi, 1577-1578. http://hdl.handle.net/21.11103/ sphaera.100921; http://hdl.handle.net/21.11103:sphaera.100393.

Idem. 1583. Speculum astrologiae, ed. Giuntini, Francesco, vol. II. Lyons: Filippo Tinghi. http:// hdl.handle.net/21.11103/sphaera.101101.

Schreckenfuchs, Erasmus. 1569. Commentaria in sphaeram. Basel: Henricpetri. http://hdl.handle. net/21.11103/sphaera.101080.

\section{'Adaptions' of the Sphere and Other Cosmological and Astronomical Books}

Apianus, Petrus. 1524a. Cosmographicus liber. Landshut: Johann Weissenburger for Petrus Apianus.

- 1524b. Ein Kunstlich Instrument oder Sonnen Ur. Landshut: Johann Weissenburger for Petrus Apianus.

Beham, Lazarus. 1476. Buch von der Astronomie. Cologne: Nicolaus Götz.

Beyer, Hartmann. 1549. Quaestiones novae in sphaeram. Frankfurt: Peter Braubach. http://hdl. handle.net/21.11103/sphaera.100645.

. 1550. Quaestiones novae in sphaeram. Wittenberg: Heirs of Peter I Seitz. http://hdl.handle.net/21.11103/sphaera.101121.

. 1551. Quaestiones novae in sphaeram. Paris: Guillaume Cavellat. http://hdl.handle. net/21.11103/sphaera.101038.

Dietrich, Sebastian, see Theodoricus.

Maurolico, Francesco. 1543. Cosmographia in tres dialogos distincta. Venice: heirs of Luca Antonio Giunta. http://hdl.handle.net/10.3931/e-rara-2055.

Peucer, Kaspar. 1550. De dimensione terrae, et fontibus doctrinae longitudinis et latitudinis locorum. Wittenberg: heirs of Peter I Seitz.

- 1551. Elementa doctrinae de circulis coelestibus, et primo motu. Wittenberg: Johann Krafft. http://hdl.handle.net/21.11103/sphaera.100251.

Peuerbach, Johannes. 1528. Novae theoricae planetarum, ed. Petrus Apianus. Ingolstadt: Petrus Apianus.

Regiomontanus, Johannes. [1472-1474?]. Kalender. Nüremberg: Johannes Regiomontanus.

Ringmann, Mathias, and Joannes Waldseemüller. 1529. Cosmographiae introductio cum quibusdam Geometriae ac Astronomiae principiis ad eam rem necessariis. Ingolstadt: Petrus Apianus.

Stoeffler, Johann. 1514. Tabulae astronomicae. Tubingen: Thomas Anshelm.

Theodoricus, Sebastianus (Sebastian Dietrich). 1563. Breve, perspicuum et facile compendium logisticae astronomicae. Wittenberg: Hans Lufft. 
(Sebastian Dietrich). 1564. Novae quaestiones sphaerae, hoc est, de circulis coelestibus, et primo mobile. Wittenberg: Johann Krafft. http://hdl.handle.net/21.11103/sphaera.101072.

\section{Secondary Literature}

Armstrong, Elizabeth. 1990. Before copyright. The French book-privilege system 1498-1526. Cambridge: Cambridge University Press.

Bennett, James A. 1998. Practical geometry and operative knowledge. Configurations 6 (2): 195-222.

Ben-Tov, Asaph. 2009. Lutheran humanists and Greek antiquity. Melanchthonian scholarship between universal history and pedagogy. Leiden: Brill.

Caroti, Stefano. 1986. Melanchthon's astrology. In Astrologi hallucinati, ed. Paola Zambelli, 115121. Berlin: De Gruyter.

Clagett, Marshall. 1974. The works of Francesco Maurolico. Physis 16: 148-198.

Ernst, Germana. 2001. Giuntini, Francesco. In Dizionario biografico degli Italiani, vol. 57, 104 108. Rome: Treccani.

Gingerich, Owen. 1993. Astronomical instruments with moving parts. In Making instruments count. Essays on historical scientific instrument, ed. R.J.W. Anderson, J.A. Bennett, and W.F. Ryan, 63-74. Aldershot: Variorum.

van Gompel, Stef. 2011. Formalities in copyright law. An analysis of their history, rationales, and possible future. New York: Wolters Kluwer.

Grant, Edward. 1994. Planets, stars, and orbs: The Medieval cosmos, 1200-1687. Cambridge: Cambridge University Press.

Kremer, Richard. 2011. Experimenting with paper instruments in fifteenth- and sixteenth-century astronomy: Computing syzygies with isotemporal lines and salt dishes. Journal for the History of Astronomy 42: 223-258.

Kusukawa, Sachiko. 1995. The transformation of natural philosophy. The case of Philip Melanchthon. Cambridge: Cambridge University Press.

Lattis, James. 1994. Between Copernicus and Galileo. Christopher Clavius and the collapse of Ptolemaic cosmology. Chicago: The University of Chicago Press.

Maclean, Jan. 2012. Scholarship, commerce, religion. The learned book in the age of confessions, 1560-1630. Cambridge, MA: Harvard University Press.

Martin, Henri-Jean. 2000. Mise en page et mise en texte du livre français. La naissance du livre moderne (XIV ${ }^{e}-X V I I^{e}$ siècles). Paris: Cercle de la Librairie.

Martin, Henri-Jean, and Jean Vezin. 1990. Mise en page et mise en texte du livre manuscrit. Paris: Promodis.

Moscheo, Rosario. 1998. L'insegnamento delle matematiche nell'antico Studium Messinese: Francesco Maurolico. Annali di Storia delle Università italiane 2: 123-145.

Mosley, Adam. 2004. Tycho Brahe, Erasmus Oswald Schreckenfuchs and the mysterious planetary motion machine. In Instruments of mystery, ed. Patrick Boner, 14-26. Cambridge: Cambridge Whipple Museum of the History of Science.

Müller, Kathrin. 2008. Visuelle Weltaneignung. Astronomische und kosmologische Diagramme in Handschriften des Mittelalters. Göttingen: Vandenhoeck \& Ruprecht.

Müller-Jahncke, Wolf-Dieter. 1998. Melanchthon und die Astrologie: Theoretisches und Mantisches. In Melanchthon und die Naturwissenschaften seiner Zeit, ed. Günther Frank and Stefan Rhein, 105-136. Sigmaringen: Thorbecke.

Obrist, Barbara. 2004. La cosmologie médiévale. I. Les fondements antiques. Florence: Sismel.

Omodeo, Pietro Daniel. 2014. Copernicus in the cultural debates of the Renaissance. Leiden: Brill.

Pantin, Isabelle. 1987. La lettre de Melanchthon à Simon Grynaeus: les avatars d'une défense de l'astrologie. In Divination et controverse religieuse au XVI siècle, 85-101. Paris: Cahiers V.L Saulnier.

- 1988. Les problèmes spécifiques de l'édition des livres scientifiques à la Renaissance: l'exemple de Guillaume Cavellat. In Le Livre dans l'Europe de la Renaissance, ed. Pierre Aquilon et al., 240-252. Paris: Promodis. 
1999. New philosophy and old prejudices: Aspects of the reception of copernicanism in a divided Europe. Studies in History and Philosophy of Science. Part A 30-32: 237-262.

- 2013. Francesco Giuntini et les nouveautés célestes. In Celestial novelties, science and politics on the eve of the scientific revolution, ed. Patrick Boner and Dario Tessicini, 85-104. Florence: Olschki.

Pantin, Isabelle, and Philippe Renouard. 1986. Imprimeurs et libraires parisiens du XVI ${ }^{e}$ siècle: Cavellat - Marnef et Cavellat. Paris: Bibliothèque nationale.

Pettegree, Andrew. 2010. The book in the Renaissance. New Haven: Yale University Press.

Proverbio, Edoardo. 1997. Francesco Giuntini e l'utilizzo delle tavole copernicane in Italia nel XVI secolo. In La diffusione del copernicanesimo in Italia, 1543-1610, ed. Massimo Bucciantini and Maurizio Torrini, 37-55. Florence: Olschki.

Randles, W.G.L. 1980. De la terre plate au globe terrestre. Une mutation épistémologique rapide 1480-1520. Paris: Armand Colin.

Rhodes, Neil, and Jonathan Sawday. 2001. Paperworlds: Imagining the Renaissance computer. In The Renaissance computer: Knowledge technology in the first age of print, 1-17. London: Routledge.

Rosen, Edward. 1957. Maurolico's Attitude toward Copernicus. Proceedings of the American Philosophical Society 101 (2): 177-194.

. 1970. Rheticus' earliest extant letter to Paul Eber. Isis 61: 384.

1974. Rheticus as editor of Sacrobosco. In For Dirk Struik, ed. R.S. Cohen et al., 245-248. Dordrecht: Reidel.

Röttel, Karl, ed. 1995. Peter Apian. Astronomie, Kosmographie und Mathematik am Beginn der Neuzeit. Buxheim-Eichstätt: Polygon-Verlag.

Saugrain, Claude-Marin. 1744. Code de la librairie...avec les anciennes ordonnances. Paris: Communauté des libraires.

Schmidt, Suzanne Karr. 2011. Printed instruments. In Prints and the pursuit of knowledge in early modern Europe, ed. Suzan Dackerman, 267-315. New Haven: Yale University.

Stijnman, Ad, and Elizabeth Upper. 2014. Color prints before Erhard Ratdolt. Engraved paper instruments in Lazarus Beham's Buch von der Astronomie. Gutenberg-Jahrbuch 89: 86-105.

Thorndike, Lynn. 1941. A history of magic and experimental sciences. Vol. VI. New York: Columbia University Press. Press.

Valleriani, Matteo. 2017. The tracts on the Sphere. Knowledge restructured over a network. In The structures of practical knowledge, ed. Matteo Valleriani, 421-473. Dordrecht: Springer.

Vanden Broecke, Steven. 2000. The use of visual media in Renaissance cosmography: The cosmography of Peter Apian and Gemma Frisius. Paedagogica Historica 36: 130-150.

Open Access This chapter is licensed under the terms of the Creative Commons Attribution 4.0 International License (http://creativecommons.org/licenses/by/4.0/), which permits use, sharing, adaptation, distribution and reproduction in any medium or format, as long as you give appropriate credit to the original author(s) and the source, provide a link to the Creative Commons license and indicate if changes were made.

The images or other third party material in this chapter are included in the chapter's Creative Commons license, unless indicated otherwise in a credit line to the material. If material is not included in the chapter's Creative Commons license and your intended use is not permitted by statutory regulation or exceeds the permitted use, you will need to obtain permission directly from the copyright holder.

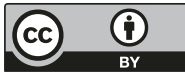




\title{
Chapter 10
}

\section{André do Avelar and the Teaching of Sacrobosco's Sphaera at the University of Coimbra}

\author{
Roberto de Andrade Martins
}

\begin{abstract}
André do Avelar was the mathematics professor of University of Coimbra from 1592 to 1616. During his lifetime he published two astronomical works: a popular vernacular book called Reportorio dos tempos (1585) and Sphaerae vtrivsque tabella (1593). Avelar's Sphaera, composed for use at the university, was the only Latin version of Sacrobosco's work ever published in Portugal. Avelar's book was inspired by Sacrobosco's work and followed it closely, but it might be regarded as a new work, because he changed the wording and the order of presentation of the topics, added new information and several tables. After his retirement, Avelar was accused of Jewish beliefs and practices, and was condemned by the Inquisition in 1620 , dying in prison. This paper analyzes Avelar's life, his work at the University of Coimbra, the content and role of his Sphaera, his career, and his trial by the Inquisition.
\end{abstract}

\section{Introduction ${ }^{1}$}

All over Europe, the Tractatus de sphaera by Johannes de Sacrobosco (died ca. 1256) remained the most widely known astronomical textbook for centuries. Four versions of Sacrobosco's Sphaera were published in Portugal in the sixteenth century. Three of them were in Portuguese, and only one in Latin (do Avelar 1593) (Fig. 10.1).

The title page of the Latin version contains some biographical information about the author, André do Avelar (1546-ca. 1623): born in Lisbon (Olysipo, in Latin), he was a Master of Arts and Philosophy (to be exact, in theology), and at the time of

\footnotetext{
${ }^{1}$ The author is grateful for the support provided by the Brazilian National Council for Scientific and Technological Development (CNPq). The author is also grateful to Charlie Zaharoff for his careful revision of the paper.

R. de Andrade Martins ( $\square$ )

FESB, Bragança Paulista, Brazil

UNIFESP, São Paulo, Brazil

GHTC-USP, São Paulo, Brazil

e-mail: roberto.andrade.martins@gmail.com
} 
Fig. 10.1 Title page of André do Avelar's commentary on the Sphaera. From (do Avelar 1593, fol. 1). Courtesy of the Biblioteca Universidad de Sevilla

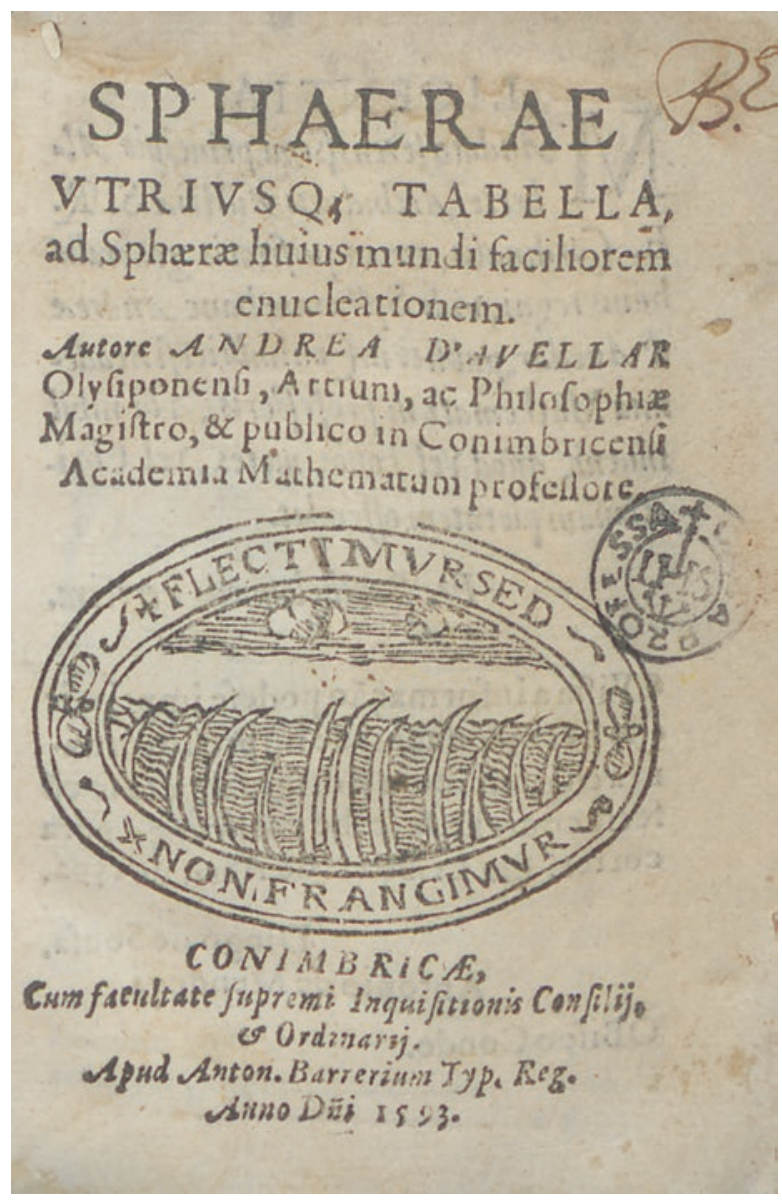

the book's publication he was a professor of mathematics at the University of Coimbra. As one can see on the title page, the work was published with the permission of the Inquisition. The elliptical emblem contains the expression "Flectimur sed non frangimur" (we are bent, but not broken), meant to exhibit a proud and defiant attitude in the face of adversity. Here, on the very first page of the book, we find the main topics to be addressed in the following paper: a Latin commentary on the Sphaera; its author's biography; the teaching of the Sphaera at the University of Coimbra; and the involvement of the author in the Inquisition.

\section{Pedro Nuñes and the Sphaera at the University of Coimbra}

The first Portuguese university was created in Lisbon in 1290 (Rodrigues 2006). During the fourteenth century it moved to Coimbra, then back to Lisbon, back again to Coimbra, and once more to Lisbon (1377), where it remained until 1537, when it 
was permanently relocated to Coimbra by King João III (1502-1557). Only after this final move was the university endowed with its earliest chair of mathematics, which was first occupied by Pedro Nuñes (1502-1578) in 1544 (da Fonseca 2001; da Fonseca 2004).

The Society of Jesus was officially approved by Pope Paul III (1468-1549) in 1540. In the same year, two Jesuits arrived in Portugal to begin their religious and educational work. Their first school in Portugal was the Colégio de Jesus in Coimbra, founded in 1542. The Colégio do Espírito Santo began its activities in Évora in 1551, and it officially became the second Portuguese university in 1559 (Dias et al. 2012, 117). No other university was created in Portugal until the twentieth century.

Pedro Nuñes studied medicine at the universities of Salamanca and Lisbon, obtaining his title in 1525. During his medical studies he became deeply involved with mathematics and astronomy, and in Portugal he obtained the position of "Royal Cosmographer" in 1529 (da Fonseca 2004). From 1531 onwards, he was the tutor of two of the younger brothers of King João III: Luís, Duke of Beja (1506-1555), and Fernando, Duke of Guarda (1507-1534). Later on, he also taught the prince and future king Dom Sebastião (1554-1578). Some noblemen also benefited from Nuñes's teachings during this period, including Dom João de Castro (1500-1548), who became famous for his navigations and was later viceroy of Portuguese India.

In 1537, Nuñes published his first book, containing a Portuguese translation of the Sphaera with commentary as well as a partial translation of Georg Peuerbach's (1423-1461) Theorica planetarum and other tracts (Nuñes 1537). It was dedicated by his author to Prince Luís. This was not the first Portugese translation of Sacrobosco; another one, by an anonymous translator, had been published twice before 1520 (Bensaude 1912; de Albuquerque 1965) (Chap. 7).

It is clear that Nuñes's translation was not intended to be nor ultimately used as an academic textbook, because the statutes of the university prescribed the exclusive use of Latin as the official idiom for teaching (Leite 1963, 314). The language and content of Pedro Nuñes's first book show that his envisioned audience included people associated with navigation (pilots and cosmographers). That is what the author himself stated in the preface of his book:

Having seen that the treatise on the Sphaera and the theory of the Sun and the Moon, and also the first book on the Geography of Ptolemy, contain those principles that must belong to any person who wants to know something about Cosmography, I translated them into our language so that those who do not know Latin would not be deprived of them. (Nuñes 1537, 5)

Nuñes had taught philosophy at Lisbon University (1531-1533), and became its initial professor of mathematics after it was moved to Coimbra (da Fonseca 2001; da Fonseca 2004). He certainly used Sacrobosco and Peuerbach as the basis of his astronomical teaching. Another of his books was possibly produced for the use of his students: Astronomici introdvctorii de spaera epitome (Nuñes 1940, vol. 1, 244-67). It is a very short version (twelve pages) of the first three books of the Sphaera. There is only one known copy of this book and it lacks the title page; for that reason, its place of publication, publisher, and date are uncertain. Some historians (including Joaquim Bensaúde) claim that it was written before the translation of the Sphaera; others (such as Rodolfo Guimarães) suppose that it was composed 
later (Nuñes 1940, vol. 1, 329-33). It is doubtful that it could be of any use outside the academic environment. Hence, I think that it was composed for use at the university, probably after 1544. This book was published only once in the sixteenth century and was not reproduced in Nuñes's Opera (printed in 1566, 1573, and 1592), although that work contained his comments on Peuerbach's Theorica planetarum.

In 1547, Nuñes was appointed as the first "cosmógrafo-mor" (high cosmographer) of the Portuguese kingdom, holding that position until his death in 1578 (da Mota 1976, 54). The duties of the high cosmographer during this period are not well known. The oldest official regulations about the cosmógrafo-mor were established in 1559, but they are unknown; only the directives of 1592 survived. Those were established under Spanish rule, and might have been widely different from their predecessors.

Pedro Nuñes taught mathematics only from 1544 to 1557 , with frequent calls by the king to Lisbon. In 1557, he took a leave and moved to Lisbon for 4 years, possibly because of the needs of his position as high cosmographer. He retired from the university in 1562, shortly after his return to Coimbra (da Fonseca 2004). It is odd that his chair was not assigned to any other professor for three decades. Mathematics had been a relevant part of the Liberal Arts curriculum in all European universities since the Middle Ages, and it was also required for the study of medicine because of its astrological components. It is known that there were temporary teachers of mathematics in some periods after Nuñes's retirement; but the chair remained vacant until 1592.

\section{Mathematics at the Colégio das Artes of Coimbra}

The extended absence of a mathematics professor at the University of Coimbra can be explained, however, by the fact that this discipline was taught at another institution. In 1542, King Dom João III also founded the Real Colégio das Artes e Humanidades (Royal School of Arts and Humanities), a preparatory school in Coimbra, which was attached to the university. Its aim was providing the prerequisite studies for the main university courses. It was created as a general college for grammar, rhetoric, poetry, logic, philosophy, mathematics, Greek, and Hebraic. Its faculty numbered sixteen, one of them a professor of mathematics (Teixeira 1899, 4-5).

Its activities began in 1547 under the direction of André de Gouveia (1497-1548), who had formerly been the dean of the University of Paris. André de Gouveia brought from France several outstanding teachers and the school soon gained prominence (Hopkins 2016, 165). One of the foreign teachers brought by Gouveia to Coimbra was Élie Vinet (1509-1587), who became a friend of Pedro Nuñes and helped to disseminate his works abroad. In 1555, Dom João III decided to hand the direction of the Colégio das Artes to the Company of Jesus (Dias et al. 2012, 118). 
Several archival documents of the 1550s refer to the professor of mathematics (Teixeira 1899, 282, 305, 403, 407), although there is no information about who occupied the chair. The directive of the Colégio das Artes was contained in the 1559 statutes of the University of Coimbra, which ascertained that the students of arts should have lessons on arithmetic, geometry and perspective during the third term of the second year, and during the third term of the third year they should read the Sphaera (Leite 1963, 317-18). Perhaps the subjects that were lectured on were not so different from the curriculum taught at other Jesuit schools. Jerónimo Nadal (1507-1580) wrote the statutes of the Jesuit School of Mesine and included the following mathematical topics in the study of philosophy: some books of Euclid (died 285 BCE), practical arithmetic, the Sphaera or the cosmography of Oronce Fine (1494-1555), the astrolabe of Johannes Stoeffler (1452-1531), and the astronomy of Georg von Peuerbach (1423-1461). In 1552, Nadal proposed a general plan of study for all Jesuit schools, including a more complete program of mathematics, adding to the previous list the study of the theory of music and perspective; all the students of philosophy should study mathematics for 3 years (Fuentes 2012, 136-37). Baltasar Torres (1518-1561), the first professor of mathematics at the Collegio Romano, wrote two poposals for the teaching of mathematics at the Jesuit schools that were similar to those of Nadal (Fuentes 2012, 139). It is unlikely, however, that the teaching of mathematics at the Colégio das Artes was so complete. Nadal himself visited the school of Coimbra and complained in his report that only the students in their second and third years received lectures on mathematics, which lasted only half an hour each day (Fuentes 2012, 141).

Christophorus Clavius (1538-1612), one of the most famous mathematicians of late sixteenth century, studied at the Colégio das Artes. When he was 16 years old, he entered the Society of Jesus in Rome, and the next year he was sent to Coimbra, where he remained as a student from 1556 to 1560 . It is unlikely that he was ever a student of Pedro Nuñes, and we do not know who could have been his mathematics professor at the Jesuit college, so he was probably a self-taught mathematician (Lattis 1994, 14-15; Baldini 1998, 214). In 1561, he went back to Rome, and in 1563, he began teaching mathematics at the Collegio Romano.

Sometimes the philosophy teachers of the Colégio das Artes provided their students with the necessary mathematical and astronomical knowledge by introducing the study of the Sphaerae in their courses on natural philosophy, between the lessons on Aristotle's (384-322 BCE) Physica and the study of his De Coelo (Baldini 1998, 205). Some manuscripts of such mixed lectures are extant, the earliest one from 1570, written by the Jesuit "Ioannis Gomesii Bracharensis," that is, João Gomes of Braga — an otherwise unknown philosophy teacher at Coimbra. A similar manuscript by another Jesuit priest, Luís de Cerqueira (ca. 1552-1614), who taught philosophy at Coimbra from 1581 to 1585 , is also preserved, as are analogous manuscripts by three Jesuits teaching at Évora in the decade of 1580 (Baldini 1998, 235).

Philosophy, not mathematics, was the main focus of the professors of the Colégio das Artes. From 1592 to 1606, they published the eight volumes of the famous Cursus Conimbricensis, containing the best commentaries on Aristotle produced at that time. These underwent several editions and were used throughout Europe (Casalini 2017). 
It seems that the first Portuguese Jesuit mathematician was João Delgado (1553-1612). He joined the Jesuit order in 1574 and 2 years later was sent to Rome to study at the Collegio Romano, where he learned mathematics under Clavius. He remained there for 9 years and returned to Portugal in 1585 (Leitão 2008, 46). He intended to go to Brazil as a missionary, ${ }^{2}$ but for unknown reasons he remained in Coimbra, where he taught mathematics from 1586 to 1589 . The manuscripts of his lessons corresponding to 1586/7 and 1587/9 have been preserved (Baldini 1998, 229). From that time onwards, the influence of Clavius in Portugal was remarkable (Carolino 2006).

In 1590, Delgado began to teach mathematics at the Colégio de Santo Antão in Lisbon. This Jesuit school had begun its activities in 1553 and it was initially dedicated to the teaching of Latin, Greek, rhetoric, ethics, and religion. Mathematics was taught there occasionally, but at the end of 1573, the cardinal Dom Henrique asked the Jesuits to include in their curriculum the study of subjects related to navigation. The agreement was only fulfilled many years later, under the Spanish domain. João Delgado became the first mathematics teacher of Santo Antão, starting in 1590 with the aula da esfera (lessons on the sphere) (Leitão 2008). He was sometimes substituted by another priest, Francisco da Costa (1567-1604). Several manuscripts of Delgado's courses have been preserved, some of them on astronomy (especially Sacrobosco and Peuerbach), but also including astrology (Silva and Ferreira 2008, 103-08). The manuscripts of Francisco da Costa that have been preserved show that he lectured on geography and hydrography - that is, the science of navigation (Silva and Ferreira 2008, 113-20). The mathematician Christoph Grienberger (1564-1636), who had also studied under Clavius, also taught at the Colégio de Santo Antão in the period 1599-1602, returning afterwards to Rome. Hence, from 1590 onwards, the Jesuit Colégio de Santo Antão in Lisbon became an outstanding center for the study of mathematics, and especially astronomy (Leitão 2008).

\section{André Do Avelar's Reportorio dos tempos}

After the disappearance or death of King Sebastian I (1554-1578) during the battle of Alcácer Quibir, his great-uncle, Cardinal Henry (1512-1580), assumed the throne. His death led to a succession crisis, and the Portuguese crown was seized by the Spanish king Phelippe II (1527-1598). He was called Phelippe I in Portugal, where he was king from 1581 to his death. During his reign, the University of Coimbra received new statutes.

They were signed by the king in 1591, with immediate effect. This decree declared as vacant the mathematics chair and established the modus operandi for the election of a new professor (called "lente," or reader). The new statutes of the

\footnotetext{
${ }^{2}$ Jesuit priests sent to distant places as missionaries were required to study mathematics (astronomy, geography, cartography etc.). For more information, see (Baldini 1998, 196-203).
} 
university required that candidates for the chair of mathematics should read two lessons, one about Euclid and the other on the theory of the planets (Universidade de Coimbra 1593, fol. 77r).

There was only one candidate for the job: André do Avelar. In January 1592, he was examined and presented his lectures, and the selection commission decided to bestow him the chair of mathematics, because there was no other candidate ("opositor," that is, opponent) and because he was "one of the greatest men in this science" (Almeida 1967, 47-48). The university Dean ("Reitor"), who played a part in the decision, was Dom Fernão Martins Mascarenhas (1548-1628); he later became the General Inquisitor of Portugal in 1616 (Martins 2011).

Who was André do Avelar at this time? The documentation of his selection only states his name (penned as "Andre dauellar"), that he was poor (so that the university would have to pay his taxes) and a "foreigner" (probably meaning that he was not from Coimbra). Also, the selecting commission knew that he was knowledgeable in mathematics (de Almeida 1967, 47-48).

Very little is known about his life previous to his entrance into the University of Coimbra. ${ }^{3}$ Most of the available biographical information about him comes from the documents of the Inquisition. ${ }^{4}$ He was born in Lisbon in 1546 to a family of converted Jews ("cristãos-novos," or New Christians). His father was called Galás do Avelar, and his mother was Violante Fernandes. He had four brothers and three sisters. He studied in Salamanca and Valladolid, obtaining the degree of Master of Arts; he also studied theology. He married Luiza de Faria, and they had six children, three sons, and three daughters (Baião 1919, 134-35).

We have no information about his way of living before he became professor of the University of Coimbra, and at that time he was 45 years old. There is, however, a relevant event in this period: in 1585, he published his first book (Fig. 10.2), called Reportorio dos tempos - an untranslatable title; it means something along the lines of a repertory or collection of information concerning time.

This is a peculiar work, belonging to a category of books on astronomy, calendars, and astrology, which became common in Spain and Portugal from the late fifteenth to the early seventeenth century (da Costa 2007, 75-79). They usually received the names Chronographia or Reportorio dos tempos (or Reportorio de los tiempos, in Spanish). They were different from the almanacs found all over Europe in several respects. They were large books (sometimes with a few hundred pages), not cheap and disposable items; they were intended to function as general nontechnical treatises of permanent significance. They were always written in vernacular in order to reach a wide public. The oldest example was Andrés de Li's Reportorio de los tiempos, published in Zaragoza in 1495. This small work was printed several times in Spain and in Portugal, where it was translated and improved by Valentim

\footnotetext{
${ }^{3}$ There is only one publication describing Avelar's life (de Almeida 1967) and, although it transcribes relevant documents, it is very sketchy and does not deal with Avelar's religious involvement and the Inquisition process.

${ }^{4}$ Avelar presented his biographical information to the Inquisition on March 23, 1620 (Braga 18921902, vol. 2, 603-04; Baião 1919, 134-35).
} 
Fig. 10.2 Title page of André do Avelar's first book, Reportorio dos Tempos. Notice that it contains an emblem very similar to the one that was published in his Sphaera, in 1593. From (da Costa 2007)

Fernandes (died ca. 1518). It inspired successively larger works with similar titles and content, the most famous being Jerónimo de Chaves's (1523-1574) Chronographia o reportorio de los tiempos. The last known works of this type were composed in Portugal by Manuel de Figueiredo (1568-1630) and in Spain by Rodrigo Zamorano (1542-1620).

This highly popular class of works represents a nice example of a blend combining various approaches and interests (Cardoso and Martins 2018). Its chronological part included information required by priests to calculate the religious calendar and the correlation between the hours of each weekday and the planets, according to astrologers; it described the division of day and night in natural and artificial hours; the heavenly spheres, and the astrological influence of each planet; the Zodiac was described both from the point of view of its influence on the sublunary world and 
regarding the details of the sun's motion along the ecliptic, and the duration of the days and nights. This kind of work included a fairly detailed description of the universe and its parts, of the heavenly circles and their terrestrial counterparts, introducing the zones and climes. The religious calendar, with the names of Catholic saints connected to each day, was combined with recommendations concerning what should be done or avoided in each lunar phase, for each month. A considerable part of the book was devoted to astrological medicine, explaining the four humors and temperaments, and the astronomical choice of treatments according to the temperament and the configuration of the heavens. Eclipses were described both as purely astronomical phenomena, providing tables of their occurrences, and as astrological causes of storms, wars, and other calamities. The treatises dealt with the influence of the moon on the weather and on crops, and they sometimes presented information concerning navigation and tides.

The encyclopedic character of works of this kind shows that it was not aimed at a particular public with a specific interest_-indeed, any person of that time could profit from reading some part of the book. This circumstance probably explains the wide circulation and popularity of those works.

André do Avelar's Reportorio dos tempos was not an exception; it was typical for that kind of literature. As with many other works of this type, it drew heavily from earlier Reportorios without citing them. However, the author also consulted many other calendrical, astronomical, and astrological works, besides books on geography and navigation, to update and improve his own composition. In the successive editions of his book, Avelar always added new information. The first edition (do Avelar 1585) had 297 pages, from the title page to the end of the work; the fourth edition (do Avelar 1602) had 575 pages, with a slighter larger mean number of characters per page. Hence, the fourth edition was about twice the size of the first one.

Avelar's Reportorio dos tempos was described by some authors as a mere Portuguese translation of a similar Spanish book called Chronographia, o, Reportorio delos tiempos, el mas copioso y preciso que hasta agora ha salido a luz, by Jerónimo or Hieronymo de Chaves. This was the most successful book of its kind. It was first published in 1548 and was reprinted twelve times in the sixteenth century, seven times as a posthumous publication. There are, of course, many similarities in content between Avelar's book and Chaves's work, as was the case with analogous publications of the time. The charge of plagiarism was dismissed, however, by a careful comparison between the two works done by Adalgisa Botelho da Costa (da Costa 2007, 81-143).

The full title of Avelar's book contained a misleading advertisement: the most copious that has hitherto been brought to light ("o mais copioso que ate agora sahio a luz"). As a matter of fact, it was smaller than Chaves's Reportorio.

The first edition of the book was dedicated to Dom Manoel de Castelbranco, or Castello Branco (1560-1614), Second Earl of Villa Nova de Portimão (Avelar 1585, fol. IIr). Several members of this family, including Manoel, participated in the Battle of Alcácer Quibir (1578) when the King of Portugal Sebastião I (1554-ca. 1578) was killed or disappeared. Manoel was then 17 years old and was captured by the moors. Afterwards he was released and returned to Portugal. His father, Dom João, and his grandfather, Dom Martinho, died in this battle (Bayão 1737, 706). 
Why did Avelar dedicate his book to this young earl? The inscription found on the book does not elucidate this. It only mentions that the Castelbranco family had "many titles of honor and greatness." We may presume that Avelar knew Dom Manoel personally, because it was not acceptable to dedicate a work to a person without his or her permission. It is also likely that the subject of the book had some significance to the earl. A single source describes Dom Manoel de Castelbranco as a "distinguished mathematician" (Encyclopedia e Diccionario Internacional 1933, vol. 4, 2264) and Diogo Barbosa Machado stated that "he applied himself exceedingly to the study of mathematical disciplines" (Machado 1741-1759, vol. 3, 217-18). ${ }^{5}$ Was he a private student of André do Avelar? Was Avelar his astrologer? Any further interpretation of their relationship would be mere guesswork.

The context of the composition and publication of Avelar's Reportorio dos tempos is not evident. In his preface, he tells a tale about Diogenes the Cynic (ca. 412-323 BCE) to justify why he wrote the book:

There was a time when it was said that King Philip of Macedon would come with his army against the city of Corinth. All the dwellers of that city, in a hurry, became busy with all the things that were necessary for its defense. Some refurbished arms, others carried stones, some mended old walls, others strengthened towers and places to fight. But Diogenes, seeing the hustle and care of that people, and having nothing to do because nobody gave him any occupation, put his cloak over his arms and, in a hurry, began to roll his tub up and down the Craneum mount. ${ }^{6}$ One of his friends asked him why he was doing this, and he answered: I also move and roll my tub, so that among all those who are busy and hurried, I do not remain the only idle one, having nothing to do. I [André do Avelar] say this because facing this multitude of writers and books that every day come to light, I should not be the only one who does not do his part, as Diogenes intended with his tub. Farewell. (Avelar 1585 , fol. IIv)

This story about Diogenes was not invented by André do Avelar; it was reported by Lucian of Samosata (ca. 125-180), in his work "The way to write history," where the anecdote is introduced to provide Lucian's own support for writing that work (Lucian 1905, 110). Of course, this is not an adequate justification for writing and publishing a book; it could only be an excuse for some useless occupation. Why did Avelar present Diogenes as his prototype? Did he see himself as a philosopher? Was he really as idle as Diogenes, having no job and nothing to do? No, we know that he was married and had already one daughter (Tomásia) to take care of (Carvalho 1990, 333). Perhaps the true motive for writing the book was an attempt to get some money. And the book was successful indeed, as it underwent four editions (do Avelar 1585, 1590, 1594, 1602). ${ }^{7}$

\footnotetext{
${ }^{5}$ The Jesuit priest António de Castello Branco, who imparted lessons on the Sphaera at Évora in the decade of 1580 (Baldini 1998, 235) was not his relative.

${ }^{6}$ Avelar wrongly understood the Craneum as a mount. It was a gymnasium, that is, a place for physical exercise.

${ }^{7}$ The website of the University of Coimbra described and made available for download a book published in 1590, with the title: "Reportorio dos tempos muito curioso acrescentado e emendado de nouo...conforme a noua constituição do sanctíssimo Papa Sixto quinto que tirou os abusos," attributing it to André do Avelar. The book was published in Coimbra by António de Barreyra, the
} 
A large part of the book was concerned with astrology. Judicial astrology, that is, the prediction of future events in the life of a single person, had been condemned by the Roman Church because it was understood as conflicting with human free will (Chap. 3). Avelar was well aware of that, and at the beginning of the book he added a proem, which stated: "understanding that everything that be said of the properties of the signs and planets will not remove the freedom of man, nor win over free will, nor bring necessity to human activities; and the whole [content of the book] is subject to correction in obedience to the sacred motherly Roman Church" (do Avelar 1585 , fol. IIv).

As stated before, Avelar's Reportorio dos tempos is not a mere translation of the similar work published by Jerónymo de Chaves. It seems to have drawn information from a variety of sources, and this leads us to a relevant question: How did Avelar have access to the books he needed, since he and his family were not rich? There were no public libraries in Portugal at that time. The university library had moved to Coimbra. In Lisbon, where Avelar lived, there were only libraries belonging to wealthy families, rich professionals (such as physicians), and those of religious institutions. Therefore, we may assume that he had access to some of these. From the dedications of his books, we may guess that he had access to the libraries of noblemen.

The second edition of the Reportorio dos tempos, published in 1590, was dedicated to Dom Álvaro de Lencastre (1540-1626), third Duke of Aveiro. At the begining of Avelar's inscription to the Duke of Aveiro, there is a relevant piece of biographical information:

Last year (when I bade farewell to your excellency to read on the chair of mathematics at the University of Coimbra by order of his Majesty) I promised to your excellency that any of my works that was first brought to light would be put under your protection and support. However, I had a different intent, that of [dedicating to you] the books on the Sphaera and its use, that I have [ready] to print at the said University. Nevertheless, in the mean time, as I should not be idle to the curiosity of the mathematical studies [não me soffrendo estar occioso a curiosidade do studo Mathematico], and, on the other hand, desiring to show to your excellency a first gesture [towards fulfilling] this offer and promise, I made in this recast of the treatise on the times [tractado dos tempos] a particular [addition] on the prognostic of the changes of the air, with some principles related both to natural philosophy and to rural astrology, and some brief but compendious rules for sowing, the culture of trees, and the breeding of animals. Besides those reasons, I was impelled [to dedicate this book to you] by seeing that your highness is so fond of the countryside and of its care. (do Avelar 1590 , fol. IIv)

printer of the University of Coimbra. This book, however, is not an edition of Avelar's Reportorio dos tempos. It is a different work compiled by the printer. Notice that the title page of the 1590 Lisbon edition of Avelar's Reportorio dos tempos stated that the printer had received the royal privilege for ten years. Therefore, no one else could publish it during this period. The Coimbra edition contains no declaration of privilege, and the prologue to the reader implies that the printer had produced a compilation taken from different works to compose the book. 
The same dedication is reproduced in the third edition of the Reportorio dos tempos (do Avelar 1594, fol. IIr). The fourth edition is also offered to the Duke of Aveiro, but it contains a different inscription (do Avelar 1602, fol. A2v).

Hence, André do Avelar was already teaching mathematics at the University of Coimbra in 1589 (and maybe before that year), although he only became a regular professor ("lente") in 1592. The above citation also shows that in 1590 Avelar had already written his Sphaera, probably intending to use it at the university, since it was ready to be printed there.

The citation also exhibits a friendly relationship between Avelar and the Duke, once more suggesting that he was on good terms with some noblemen and could probably profit from their favors and access to their libraries. That a dedication to Dom Álvaro de Lencastre appeared in the three editions from 1590 to 1602 (and the last one was not a reproduction of the first) proves that the relationship between them was enduring. It is possible that he also received patronage from the Duke of Aveiro during that period.

Around 1600, Avelar was better known for his Reportorio dos tempos than for his Sphaera.

\section{5 "Flectimur Sed Non Frangimur"}

The first three editions of the Reportorio dos tempos and the only edition of Avelar's Sphaera have in the title page a peculiar emblem (Fig. 10.3). The same woodcut was used in the three editions of the "Reportorio." The woodcut used for the Sphaera (Fig. 10.1) was a bad copy of the Lisbon original.

Venâncio Deslandes (Deslandes 1888, 127) described the emblem and suggested that it was a representation of the four elements. He wrongly transcribed the phrase appearing on the emblem as "non frangimur sed flectimur." (Fig. 10.4).

The emblem of reeds in the water, being bent but not broken, with the motto "Flectimur non frangimur" (we are bent but not broken) or "Flectimur non frangimur unde" (we are bent but not broken by the waves) had been used since the fourteenth century by two Italian families, Colonna and Acquaviva (Gelli 1916, 286-87). In the fifteenth century, the Pope Alexander VI, born Rodrigo de Borja (1431-1503), banished from Rome the Cardinal Giovanni Colonna (1456-1508) and other members of the family, who took refuge in Naples and Sicily. They then assumed the emblem again (Fig. 10.4), and this was meant as a warning: although the Colonna family was bent by pontifical persecution, the Pope should not consider them dead and buried; they were still alive and powerful, and hoped sooner or later to grow even stronger than before and get pay back (Gelli 1916, 287; Palliser 1870, 73-74). Both the emblem and its history were well known in the sixteenth century and were included in the work "Symbolorum \& emblematum" of Joachim Camerarius (1500-1574) under number "95" (Camerarius 1590, fol. 97r). 


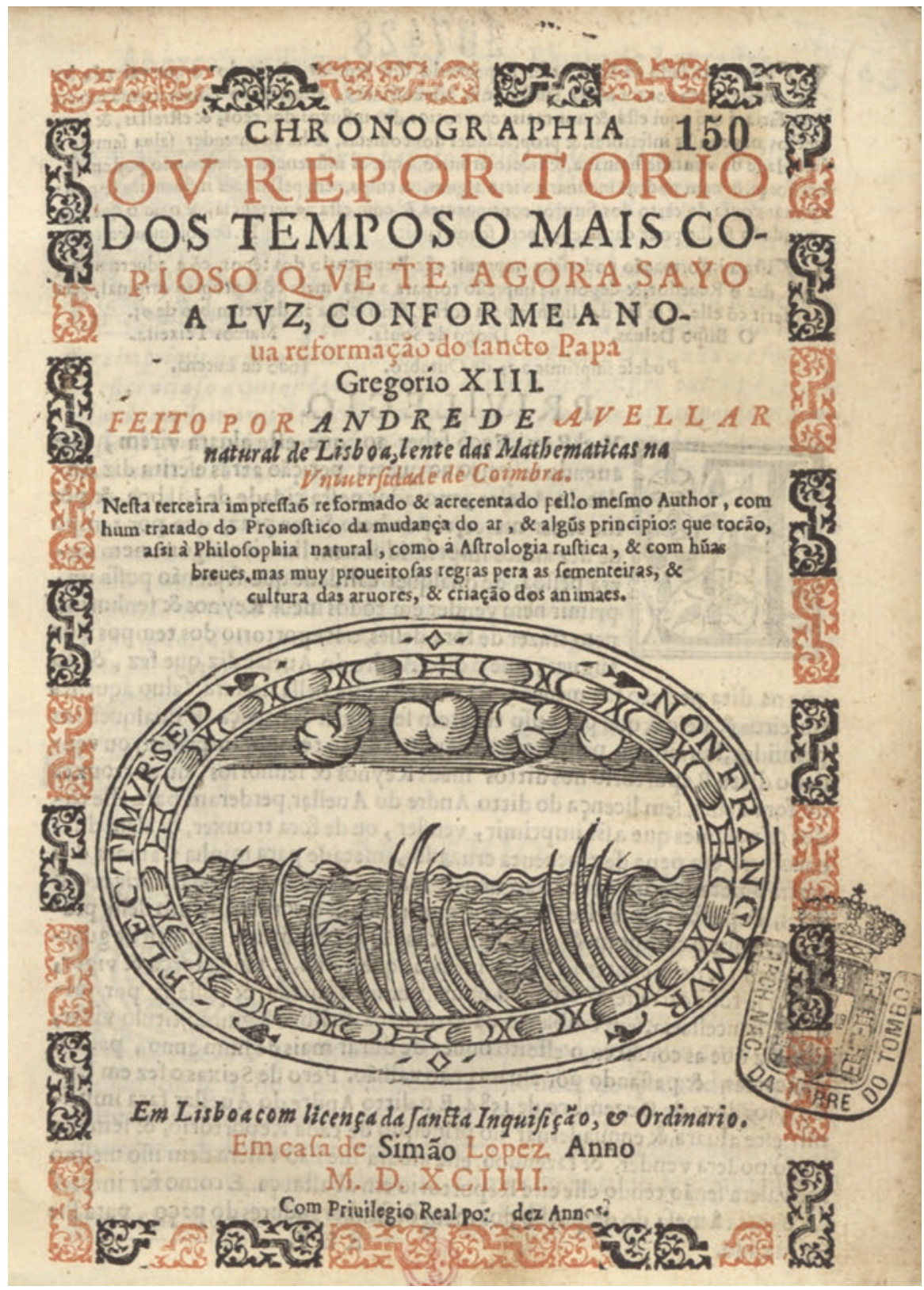

Fig. 10.3 Title page of the third edition of André do Avelar's Reportorio dos tempos. From (do Avelar 1546). Courtesy of the National Library of Portugal 


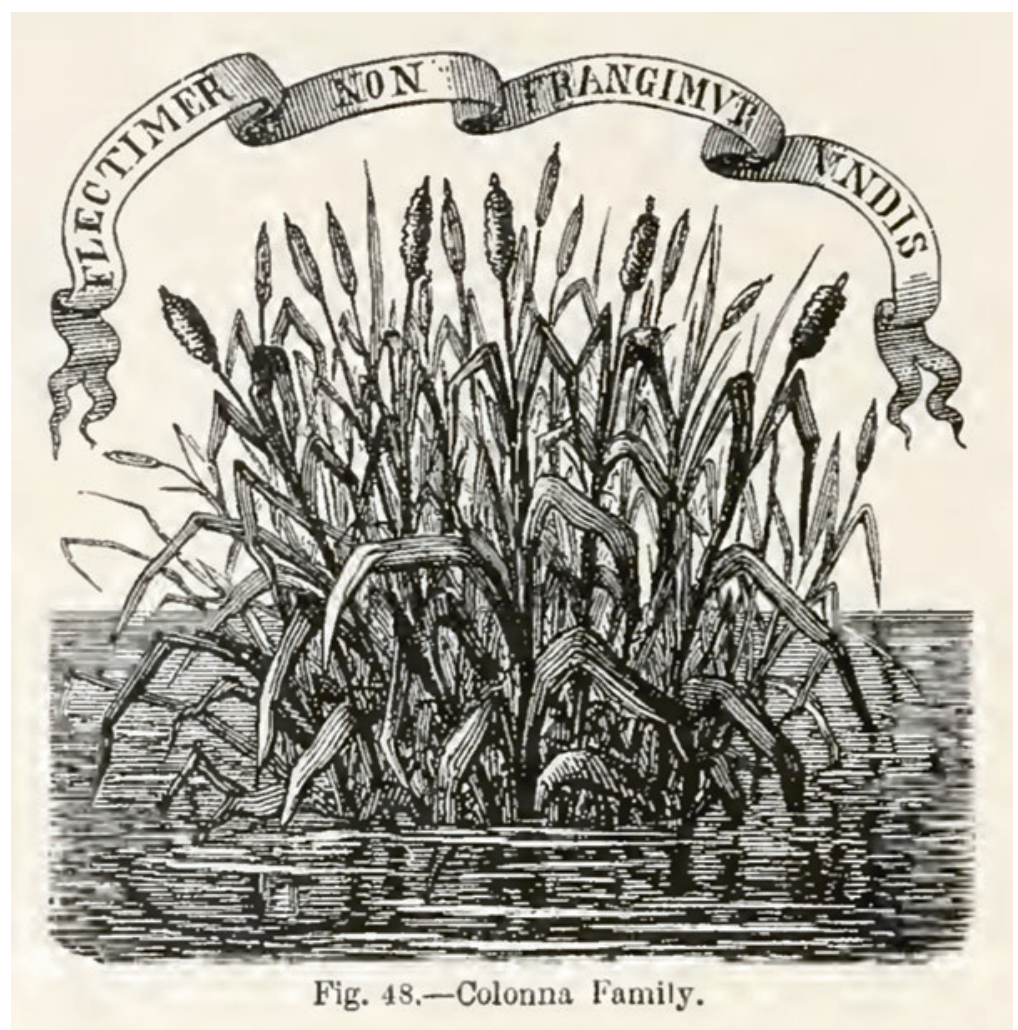

Fig. 10.4 The emblem of the Colonna family, with the motto "Flectimur non frangimur undis." According to Mrs. Bury Palliser, the emblem was created by Jacopo Sannazaro (1458-1530). From (Palliser 1870, 74). Public Domain Mark

Why did Avelar incorporate this emblem in his books? Had he suffered some personal persecution? Did he hope to rise from a defeated, humble condition to a higher one? Lack of knowledge about his personal history prevents us from giving any well-founded answer. However, one may conjecture that the emblem was related to his family situation: they were of Jewish origin, and there was a social stigma oppressing this class. As is well known, all Jews had been expelled from Spain in 1492, and from Portugal in 1497. Any Jew willing to remain in Portugal after that time was compelled to become a Christian. The pejorative name "New Christian" was applied to those Jewish converts and to their posterity. Perhaps Avelar yearned for a time when the New Christians would rise once more to their deserved social status or would be allowed to become Jews again. 


\section{Avelar's Sphaera}

The only edition of Avelar's Sphaera was published in 1593, the year after he became the official reader of mathematics at the University of Coimbra. The title of the book is highly peculiar: Sphaerae vtrivsq[ue] tabella, ad sphaerae huius mundi faciliorem enucleationem, meaning "Tablet of both spheres, for easier explanation of the sphere of this world." Here, "tabella" does not mean "table," but a little board or tablet. In the aforesaid title, it meant a summary or abridgment. The word appeared with the same meaning, for example, in the title of one of the books of Louis de Blois (1506-1566): Tabella spiritualis alias sacellum animae fidelis nuncupata: continens brevem institutionem vitae Christianae (de Blois 1583). However, Avelar's book cannot be interpreted as a summary of Sacrobosco's work, because it is indeed larger than the medieval treatise. It could be understood as a short version of the Sphaera only when compared to the large commentaries that had become usual by the end of the sixteenth century.

The phrase "both spheres" (sphaerae utriusque) used in this book was unusual. The only astronomical work I have found with a title that might have inspired Avelar was De mundi et sphaerae: ac utriusque partium declaratione cum planetis et variis signis historiatis by Gaius Iulius Hyginus (ca. 64-17 BCE), which was printed several times in the sixteenth century.

Avelar's Sphaera was dedicated to Dom Ferdinando (or Fernão) Martins Mascarenhas, the Dean (Reitor) of the University of Coimbra and adviser of King Phelippe who became General Inquisitor two decades later. After the dedication, the author addressed the students of mathematics that comprised his intended public. After that, we find several poems dedicated to the readers and to the author of the book by the priest António Velloso of Braga; by Pedro Mendes, professor of Latin and Greek; and by Dom Jorge de Castro (do Avelar 1593, fol. IIr-VIr). Unfortunately, it was impossible to find information about them.

Avelar's Sphaera does not cite the name of Sacrobosco at any point, although he closely follows the medieval text. Of course, every reader knew that the book was a new version of Sacrobosco's, therefore Avelar could not have held the expectation of being regarded as the original author of the ideas contained in the book.

Many of the commentaries on the Sphaera contained Sacrobosco's full original text, set in a clearly distinct typography and intermixed with elucidations. That was the style followed, for instance, by Pedro de Espinosa, ${ }^{9}$ a professor of the University of Salamanca, who published a Latin commentary on Sacrobosco that underwent two editions $(1535,1550)$, a commentary that might have been read by Avelar when he was a student (de Espinosa 1550). The famous and massive commentary produced by Christophorus Clavius (Lattis 1994) also followed the same structure. Avelar, however, did not follow the example of those predecessors. It is simply

\footnotetext{
${ }^{8}$ This following section is an expanded and corrected version of (Martins 2003b).

${ }^{9}$ The name "Pedro de Espinosa" was rather common in Spain in the early sixteenth century. There is no reliable information about the dates of birth and death of the author of this commentary on Sacrobosco (Díaz Díaz 1987, v. 3, 68-69; Delgado 1983).
} 
impossible to identify, by any typographical hint, where he was simply transcribing Sacrobosco's text and where he was presenting his own contribution. Indeed, the style of Avelar's book is that of a paraphrase of Sacrobosco's Sphaera.

Sacrobosco started his first chapter with definitions of the geometric sphere by Euclid and Theodosius (347-395). Avelar referred initially to the "material sphere," that is, the armillary sphere, the instrument used to explain the structure of the universe. Immediately afterwards, however, Avelar applied Theodosius's definition to that sphere and introduced the concepts of axis and pole exactly as Sacrobosco had done. In the citations shown below, the corresponding parts are underlined.

\begin{tabular}{|c|c|}
\hline Avelar & Sacrobosco \\
\hline $\begin{array}{l}\text { Sphaera materialis est instrumentum quoddam } \\
\text { rotundum, compositum ex variis circulis, quibus } \\
\text { coelorum motus, totiusque mundis situs, } \\
\text { commodissime explicantur, in cuius medio } \\
\text { punctum est, à quo omnes lineae rectae ad } \\
\text { circunferentias circulorum ductae sunt aequales: } \\
\text { \& illud punctum dicitur centrum sphaerae, linea } \\
\text { vero recta transiens per centrum, applicans } \\
\text { extremitates suas ex utraque parte ad } \\
\text { circunferentiam circa quam sphaera voluitur } \\
\text { dicitur axis sphaerae: duo vero puncta axem } \\
\text { terminantia, dicuntur poli mundi. (do Avelar } \\
1593, \text { fol. } 1 \mathrm{r}-\mathrm{v} \text { ) }\end{array}$ & $\begin{array}{l}\text { Sphaera etiam a Theodosio sic describitur: } \\
\text { sphaera est solidum quoddam una superficie } \\
\text { contentum, in cuius medio punctus est, a } \\
\text { quo omnes lineae ductae ad circumferentiam } \\
\text { sunt aequales: \& ille punctus dicitur } \\
\text { centrum sphaerae. Linea vero recta, } \\
\text { transiens per centrum sphaerae, applicans } \\
\text { extremitates suas ad circumferentiam ex } \\
\text { utraque parte, circa quam sphaera voluitur, } \\
\text { dicitur axis sphaerae. Duo vero puncta axem } \\
\text { terminantia dicuntur poli sphaerae. (Vinet } \\
\text { 1561, fol. 9v) }\end{array}$ \\
\hline
\end{tabular}

The underlined parts show that Avelar, for the most part, just copied Sacrobosco's text without substantial changes. Differences concerning the order of the words, punctuation, and even changes to some terms are not noteworthy, since similar differences appeared in different printed editions of Sacrobosco's own text.

After the definition of the sphere, Avelar presented the main circles of the heavenly sphere, a subject that appeared only at the second part of Sacrobosco's text. The explanation of the greater and smaller circles is slightly different.

\begin{tabular}{|c|c|}
\hline Avelar & Sacrobosco \\
\hline $\begin{array}{l}\text { De circulis sphaera materialis. Cap. II } \\
\text { Sphaera autem materialis componitur ex decem } \\
\text { circulis, quarum haec sunt nomina scilicet } \\
\text { aequinoctialis, zodiacus, colurus solstitiorum, colurus } \\
\text { aequinoctiorum, meridianus, horizon, tropicus Cancri, } \\
\text { tropicus Capricorni, circulus Arcticus, circulus } \\
\text { Antarcticus. Horum vero circulorum, quidam sunt } \\
\text { maiores, quidam minores: priores sex maiores } \\
\text { dicuntur, seu maximi: posteriores quatuor minores } \\
\text { appellantur, sive non maximi. Maior circulus in } \\
\text { sphaera is dicitur, qui idem centrum cum sphaera } \\
\text { obtinet: ipsamquae, in duo hemisphaeria dividit: } \\
\text { minor vero circulus est ille, qui diversum centrum a } \\
\text { sphaera centro possidet, ipsa sed in duo segmenta } \\
\text { inaequalia partitur. (do Avelar } 1593 \text {, fol. } 2 \mathrm{r}-\mathrm{v} \text { ) }\end{array}$ & $\begin{array}{l}\text { Capitulum secundum. De circulis, ex } \\
\text { quibus sphaera materialis componitur: } \\
\text { \& illa supercoelestis, quae per istam } \\
\text { imaginatur, componi intelligitur } \\
\text { Horum autem circulorum quidam sunt } \\
\text { maiores, quidam minores, ut sensui } \\
\text { patet. Maior autem circulus in sphaera } \\
\text { dicitur, qui descriptus in superficie } \\
\underline{\text { sphaerae super eius centrum, dividit }} \\
\text { sphaeram in duo aequalia. Minor vero, } \\
\text { qui descriptus in superficie sphaerae, } \\
\text { eam non dividit in duo aequalia sed in } \\
\text { portiones inaequales. (Vinet } 1561, \\
\text { fol. 20v) }\end{array}$ \\
\hline
\end{tabular}


André do Avelar did not follow the text of Sacrobosco and did not treat it as a sacred or immutable astronomical revelation. The original Sphaera was, of course, his point of departure, but he felt free to produce his own work. In this respect, his approach was uncommon, although there had been several precedents, including Galileo Galilei's (1564-1642) unpublished textbook on the Sphaera (Galilei 1656; Martins and Cardoso 2008; Martins and Cardoso 2017).

Avelar's book was divided into four parts like Sacrobosco's work, and it included essentially the same content, but with an inversion of the order of the first and second parts. The first part of Avelar's Sphaera, "On the material sphere and the circles of which it is composed," containing twelve chapters and one table and occupying nine numbered leaves, presented the main circles of the celestial sphere and their terrestrial counterparts. The sequence and content are almost identical to the second part of Sacrobosco's Sphaera, with some slight differences. For instance, Avelar used $23^{\circ} 30^{\prime}$ for the obliquity of the ecliptic, a better estimate, at that time, than Sacrobosco's value of $23^{\circ} 33^{\prime}$.

The second part, called "On the sphere of the world, or natural [sphere], and its parts," was divided into eighteenth chapters and one table, filling forty-five numbered leaves. It is similar to the first part of Sacrobosco's book, but some parts were put into a different order. For instance, Avelar discussed the size of the earth before presenting the celestial structure (ether, motions, and form of the heavens). He mentions the theory of trepidation and the need for ten heavenly orbs, instead of the nine mentioned by Sacrobosco, following, at this point, the proposal that had been introduced by King Alphonso X, el Sabio (1221-1284). Besides this change, Avelar added some quantitative data and some tables. One of them provides the declination of the sun throughout the year, essential information for the determination of latitudes. There are other relevant differences. Avelar introduced several mentions of the Astronomica of Marcus Manilius (fl. $1^{\text {st }}$ century), a book that was seldom cited in commentaries on Sacrobosco's Sphaera. The outlook of Manilius's work was mainly astrological, and references to his contribution betray Avelar's deep involvement with astrology. Accordingly, in the second part of his Sphaera he presented some astrological information about the signs and established relationships between the four elements, the four humors, the seasons, and the four ages of mankind. This part of the book also mentions new information that became available because of the Iberian navigations, such as knowledge of the Southern Cross (Fig. 10.5), dark nebulae, the Magellanic Clouds, and a new evaluation of the size of the earth.

The third part of Avelar's Sphaera, containing fourteen chapters and several tables encompassing thirty-nine leaves, closely follows the structure and the content of Sacrobosco's third chapter. It deals with the rising and setting of the stars and constellations, the yearly motion of the sun, the diversity of duration of days and nights, and the climates. Avelar added to this part some quantitative tables, one of them showing the degrees of the equinoctial corresponding to each of the zodiacal signs, both in the case of the right sphere and the oblique sphere and, in particular, for the latitude of Lisbon. In his discussion of the climates, Avelar stated that Claudius Ptolemy (died 160) had described twenty-one parallel circles and seven climates, but the recent authors had introduced twenty-three climates and fourtynine parallel circles. He provides a table with the data for those climates and the 


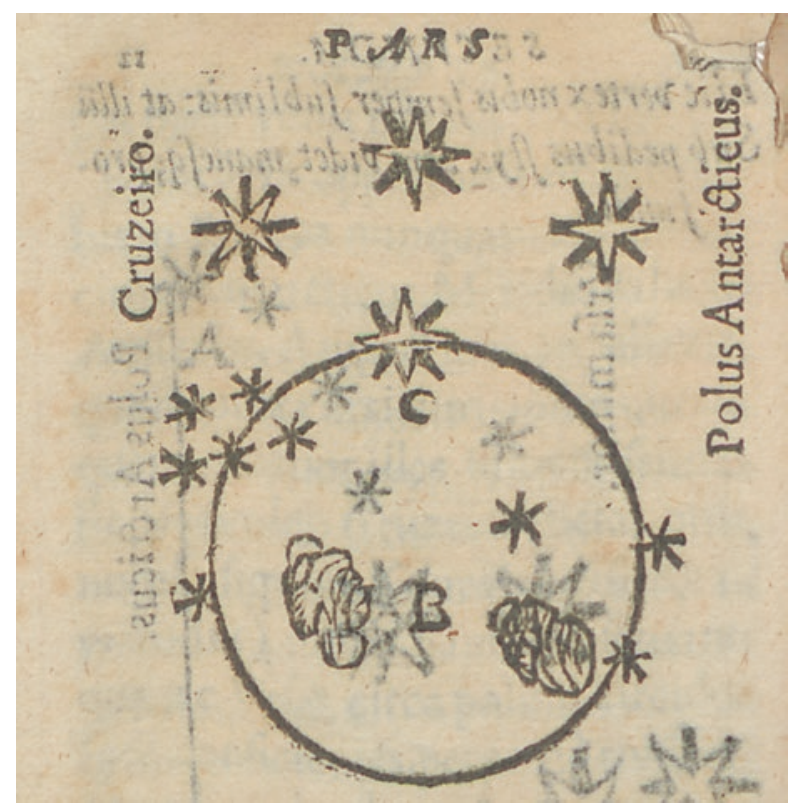

Fig. 10.5 Representation of the Southern Cross ("Cruzeiro") and the Magellanic Clouds, according to Avelar. From (do Avelar 1593, fol. 12v). Courtesy of the Biblioteca Universidad de Sevilla

variation of daylight length during the year. Following Sacrobosco, Avelar presents copious literary citations from Publius Vergilius Maro (70-19 BCE), Publius Ovidius Naso (43 BCE-18), and Marcus Annaeus Lucanus (39-65).

The fourth and last part of Avelar's Sphaera is quite short: six chapters and a few tables, encompassing eleven leaves. Like Sacrobosco's fourth chapter, it deals with the motions of the sun and the moon, of the planets, and of the eclipses. Avelar provided a more detailed theory than Sacrobosco, mentioning the contributions of Alphonso $\mathrm{X}$ and presenting data relative to the motion of the moon.

\section{The Sources of Avelar's Sphaera}

André do Avelar certainly consulted other works besides Sacrobosco's to write his Sphaera. It is difficult, however, to find out which sources he used. Part of this difficulty is due to Avelar himself, who did not have an inclination to name his authorities. It is possible to notice this tendency in his Reportorio dos tempos: Chaves had provided a number of references in his Chronographia o reportorio de los tiempos, but Avelar did not reproduce this information, even in the cases where he was clearly translating Chaves's book (da Costa 2007, 91-93). Note that in the late sixteenth century, several authors of academic books provided specific references to authors, the title of their works, and their relevant parts or chapters. Sometimes those references appeared inside the text, but there was an increasing use of marginal notes, the 
antecedent of our footnotes. One may find a profuse employment of this kind of resource in the Comentarii Conimbricensis, the commentaries about Aristotle's works produced by the Jesuit teachers of Coimbra (Casalini 2017).

In his Sphaera, Avelar usually only reproduces the meager information contained in Sacrobosco's work: vague allusions to Aristotle, Ptolemy, Alfarganus (805-870), and other authors, without any hint as to which books the stated ideas are drawn from. He did, however, mention a few other authorities. One of them was king Alphonso X (1221-1284) (do Avelar 1593, fol. 26v, 96v), who was never cited by Sacrobosco, since the Sphaera was written earlier. Because of the importance of Alphonso X as a reformer of medieval astronomy, he was cited in many of the commentaries on the Sphaera. It was natural, therefore, that Avelar should include this authority in his book.

Another author cited by Avelar but not by Sacrobosco was Marcus Manilius, who is explicitly referred to in four distinct passages (do Avelar 1593, fol. 10v, 21r, 30r, 34r). The sixteenth century commentaries on the Sphaera seldom cited Manilius.

Since Avelar's book was composed for use at the University of Coimbra, it could completely avoid subjects related to navigation such as the tables of declination of the sun, used for ascertaining the latitude. This was an expected subject in the teaching of the cosmógrafo-mor or at the aula da esfera, but not at the universities. However, he did include such information, as well as data provided by navigators. He did not point out, however, which sources he used to describe the Southern Cross and the Magellanic Clouds (do Avelar 1593, fol. 11v-12v). At another point, he remarks on the visible signs of Earth's roundness and the new measurement of the geographical degree, amounting to 17.5 leagues, as determined by the "navigators of Spain" (do Avelar 1593, fol. 16r-17v). ${ }^{10} \mathrm{He}$ also referred to "more recent" authors who had expanded Ptolemy's division of the earth from seven to twenty-three climes (do Avelar 1593, fol. 88v), but nowhere did he present the source of this information.

Although Avelar was a successor of Pedro Nuñes at the mathematics chair of the University of Coimbra, he never cited his writings (Leitão 2002, 27). In contrast, the many editions of Élie Vinet's Sphaera Joannis de Sacro Bosco Emendata contained Nuñes's analysis of the climes (Valleriani 2017); and the Portuguese mathematician was also cited in other commentaries, such as Clavius, where his name appeared in nine different places (Knobloch 1999, 347).

\section{Literary Citations}

Sacrobosco's Sphaera contained a significant number of poetic quotes from Virgil, Ovid, and Lucan. One of the reasons for the introduction of those classical citations was the need to elucidate the literary works themselves: many passages of those

\footnotetext{
${ }^{10}$ At this time, Portugal was part of Spain, under Phelippe I.
} 
Latin authors could not be understood without an adequate knowledge of astronomy (Martins 2003a).

Avelar's Sphaera kept seventeen of the twenty-one original poetic references. He dismissed only three from the Georgica of Virgil and one from Lucan's Pharsalia. It is quite clear, however, that he did cherish those literary quotations. Indeed, in several cases he presented a larger number of verses than Sacrobosco did. For instance, when he quoted Ovid's Metamorphoses, Avelar reproduced seven verses (do Avelar 1593, fol. 54r); in most of the editions of Sacrobosco's work we find only four verses. He also added to his work three quotations from Ovid and one from Lucan (do Avelar 1593, fol. 30r, 36v, 56v, 78v) that were not used by Sacrobosco. The several quotations of Manilius presented by Avelar were also probably introduced for aesthetic reasons.

Avelar also incorporated in his Sphaera five additional literary quotes that have no counterpart in Sacrobosco's work. Only one of them was identified by Avelar himself (do Avelar 1593, fol. 35v): a citation of In sphaeram Archimedis, from Claudius Claudianus (ca. 370-404). Sacrobosco did not include any quotation from Claudianus in his Sphaera, but he did so in his De anni ratione, or Computus ecclesiasticus (de Sacrobosco 1550, fol. L 4r). ${ }^{11}$

What do those additions tell us about Avelar and his sources? At first sight, they suggest that the author was familiar with Latin poetry and that this allowed him to add several quotations to those that Sacrobosco had used in his Sphaera. There is, however, another explanation. Maybe Avelar just made use of some commented editions of the Sphaera where those passages can be found. Indeed, several of the extracts used by Avelar can be found in the very popular Sphaera Joannis de Sacro Bosco emendata, edited by Élie Vinet (1509-1587). Observe that Élie Vinet was professor of the Colégio das Artes in Coimbra from 1547 to 1549 . He was a friend of Pedro Nuñes and helped to make some contributions of the Portuguese mathematician known in Europe, introducing them in his own edition of the Sphaera.

Some specific instances will be examined in the following section. The seven lines of Ovid's Metamorphoses transcribed by Avelar were contained in Vinet's edition (Vinet 1561, fol. 87r). There we can also find one of Avelar's citations from Ovid that does not appear in Sacrobosco's work (do Avelar 1593, fol. 56v; Vinet 1561, fol. 72v) and the additional quotation from Lucan (Avelar 1593, fol. 78v; Vinet 1561, fol. 33r). Two of the four citations of authors who were not identified by Avelar were also contained in Vinet's Sphaera (do Avelar 1593, fol. 26r, 57r; Vinet 1561, fol. 20r, 61v).

Hence, we see that Avelar did not require considerable erudition to insert the additional poetic quotations of his Sphaera. Some of those literary addenda were not taken from Vinet's work, but they might have been copied from some other commentary on Sacrobosco's Sphaera.

\footnotetext{
${ }^{11}$ Unlike Sacrobosco's Sphaera, his treatise on the calendar called Computus ecclesiasticus or De anni ratione has been scarcely studied by historians of science. Some information about that work and its genre can be found in papers published by Lynn Thorndike (1954) and Jennifer Moreton (1994).
} 
The quotation of Claudianus had been published by Francesco Giuntini (1523-1590) in his commentary on the Sphaera (Giuntini 1578, 347). Clavius's commentary also contains the Claudianus's verses that were used by Avelar (Knobloch 1999, 9). The same quotation also appeared in the first edition of Clavius's commentary (Clavius 1570, 24).

One particular literary addition by Avelar should be emphasized: it was part of a poem by Philip Melanchthon (1497-1560) on the rising and setting of the stars: "Mane vehit supra terram tibi Cosmicus ortus Sidera, sed Phoebi lumine tecta latent. Mane dat Heliacus quaedam subvecta videre Astra, sed Achronicus nocte videnda trahit" (Avelar 1593, vol. 26r; Melanchthon 1579, fol. Q5v). Melanchthon was an outstanding intellectual leader of the Lutheran Reformation and an author prohibited by the Index librorum prohibitorum since 1559 (Lenard 2006, 55-56) (Chap. 9).

Notice that before the publication of the Index, many commentaries on Sacrobosco's Sphaera contained as a preface a piece written by Melanchthon in 1531 in praise of astronomy (Gingerich 1988). That was also the case of the early editions of Élie Vinet's Sphaera (the 1552 edition of Elie Vinet's Sphaera, for instance, contained Melanchthon's preface.)

After the proscription of Melanchthon's works by the Inquisition in 1559, the editions of the Sphaera containing his preface were partially censured in Catholic countries. In several cases, only Melanchthon's name was effaced, cut or crossed over while the preface was kept. In some later Italian editions, the preface was kept but as an anonymous text (Gingerich 1988, 269).

Philipp Melanchthon's epigram quoted by Avelar had been included, without any allusion to its author, at the end of the fourth chapter of Sacrobosco's Sphaera in the first edition printed in Wittenberg, which also included Melanchthon's preface (Sacrobosco 1531, fol. F IIr). It was reproduced in successive publications of the book in several cities, usually at the same point (although its subject had nothing to do with the fourth chapter of the Sphaera) and without any declared authorship (see, for instance, de Sacrobosco 1547, fol. E [V]r; de Sacrobosco 1550, fol. G2r). ${ }^{12}$ Sometimes it was moved to the third chapter, where its theme would fit more naturally (de Sacrobosco 1545, fol. D [V]r).

Philipp Melanchthon's verses were also published in some editions of the Sphaera Ioannis de Sacro Bosco emendata that contained Francesco Giuntini's comments (de Sacrobosco 1564, 116; de Sacrobosco 1573, 88) at the end of the fourth chapter of the Sphaera, as in the first Wittenberg edition. It was later included in Francesco Giuntini's long commentary on the Sphaera that was part of his Speculum astrologiae (Giuntini 1581-1583, vol. 2, 767). ${ }^{13}$ In the later work, Giuntini moved the quotation to the third chapter of the Sphaera, where its content is more appropriate.

Most of the editors and authors who reproduced this epigram were probably unaware of its authorship; and it was not explicitly disapproved by the Inquisition,

\footnotetext{
${ }^{12}$ I am grateful to Matteo Valleriani for pointing out those occurrences of Melanchton's citation.

${ }^{13}$ I am grateful to Elio Nenci for pointing out this occurrence of Melanchthon's quotation.
} 
although all of Melanchthon's works had been condemned. Indeed, although Giuntini's Speculum astrologiae had been heavily censured, as witnessed by a copy that belonged to a Jesuit institution-that now can be found at the Library of the University of Sevilla (A Res. 03/3/13-14) — the epigram was not crossed out by the person who "corrected" that book, although several lines on the same page and on the following one were scored out (Fig. 10.6). It is possible that Avelar copied Melanchthon's verses without knowing their authorship.

\section{Manilius's Astronomica and the Sphaera}

Marcus Manilius's Astronomica is the earliest surviving classical astrological work. It is a lengthy Latin poem, written between the year 10 and 20 under the reign of Augustus and/or Tiberius (Goold 1977, xii; Folk 2009, 4). It is likely that part of the work was lost. In its present form, it contains five books. The first one presents a general description of the universe, the celestial circles, stars, constellations, the Milky Way, planets, and comets. The subject of the second book is the Zodiac, its movement relative to the earth, its signs and their influence upon the human body. The third one teaches how to draw a horoscope and describes the lots, the ascendant, and the influence of the stars on man. The fourth book presents the decans of the Zodiac and contains an astrological geography, providing a description of the heavenly influences upon places and people. The last book explains the variable influence of the planets according to their position and motion, describing the influence of constellations that do not belong to the Zodiac.

Sacrobosco did not quote and was probably unaware of Manilius's work, since the Astronomica and his author were never explicitly cited by extant Roman authors and it was barely known during the Middle Ages. Manilius's poem was retrieved from obscurity in the early fifteenth century by Poggio Bracciolini (1380-1459), who obtained a copy of a manuscript version; it was published for the first time around 1473 by Johannes Regiomontanus (1436-1476) in Nuremberg (Folk 2009, 2). In 1474, it was also published in Bologna, and 10 years later it was commented on by Lorenzo Buonincontro (1410-ca.1500). It was reprinted several times in the fifteenth and sixteenth centuries, becoming a quite popular book. The first critical edition was published in 1579 by Joseph Justus Scaliger (1540-1609).

The Astronomica was therefore available to Avelar when he wrote his Sphaera, both directly and through indirect sources, as will be described. Let us first present four passages of that work quoted by Avelar.

Avelar's first quotation of Manilius appeared at the place where he described the axis of the universe (Avelar 1593, fol. 10v). These are the corresponding lines of the Astronomica (I.279-282) in a recent edition (Manilius 1977, 26):

Aera per gelidum tenuis deducitur axis libratumque regit diverso cardine mundum; sidereus circa medium quem volvitur orbis aetheriosque rotat cursus, immotus.... 


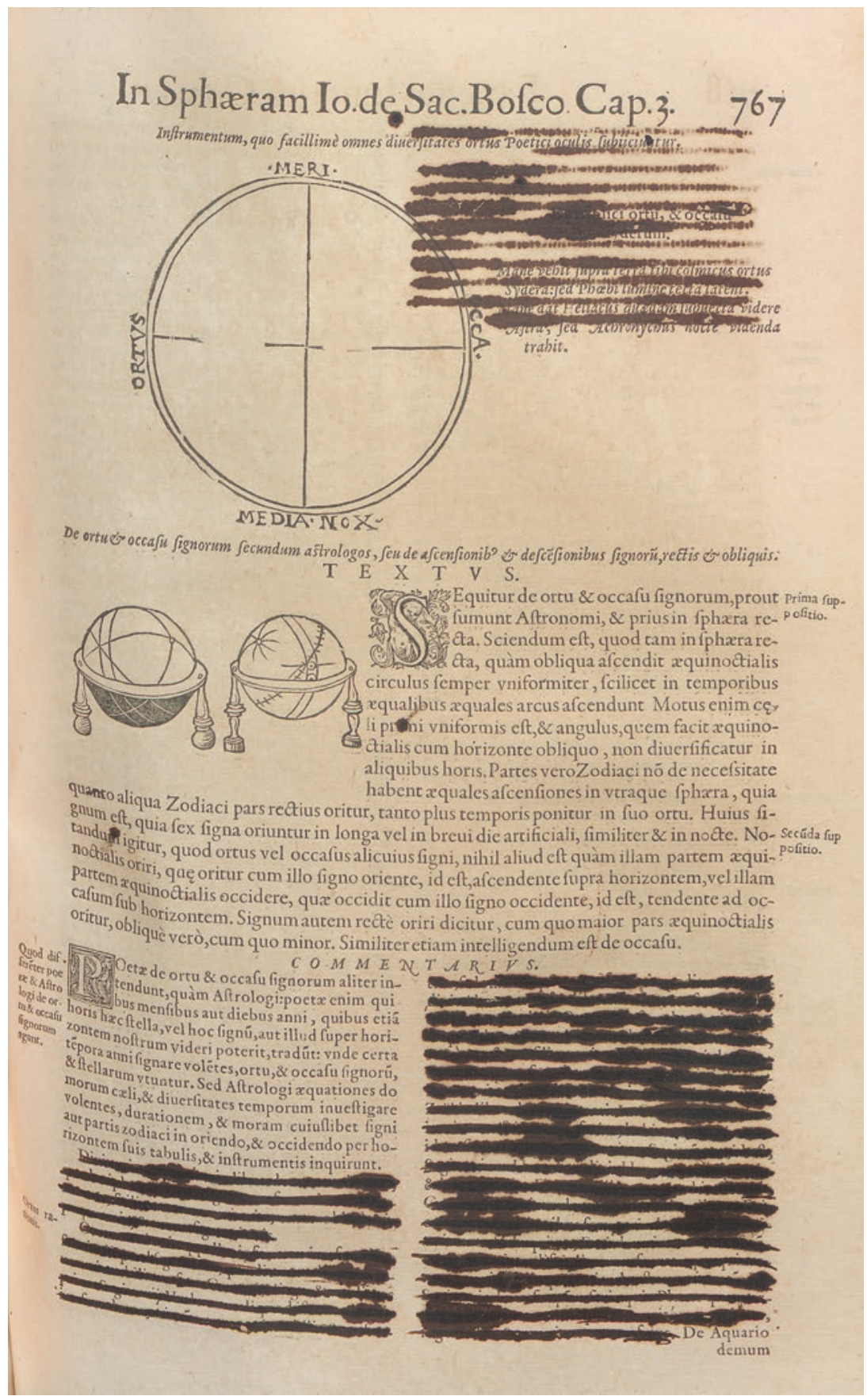

Fig. 10.6 One censured page of the copy of Giuntini's Speculum astrologiae kept at the Library of the University of Sevilla. From (Giuntini 1581-1583). Courtesy of the Biblioteca Universidad de Sevilla 
The verses were translated by George P. Goold as follows: “... an insubstantial axis runs down through the wintry air and controls the universe, keeping it pivoted at opposite poles: it forms the middle about which the starry sphere revolves and wheels its heavenly flight, but is itself without motion..." (Manilius 1977, 27).

Avelar's transcription of this passage is slightly different, not only because of the chosen orthography and punctuation, but also for more significant dissimilarities (see words in italic):

Aera per gelidum tenuis deducitur axis,

Libratumque gerit diverso cardine mundum.

Sydereus, medium circa quem, volvitur orbis,

Aeternosque rotat cursus, immotum.... (do Avelar 1593, fol. 10v)

Avelar's second (and longest) quotation of the Astronomica appeared in his discussion of the position of the earth in the middle of the universe (do Avelar 1593, fol. 21r-v). These are the verses he cited (Astronomica I.194-206):

Nec vero admiranda tibi natura videri pendentis terrae debet, cum pendeat ipse mundus et in nullo ponat vestigia fundo, quod patet ex ipso motu cursuque volantis, cum suspensus eat Phoebus currusque reflectat huc illuc agilis, et servet in aethere metas, cum luna et stellae volitent per inania mundi, terra quoque aerias leges imitata pependit. est igitur tellus mediam sortita cavernam aeris, e toto pariter sublata profundo, nec patulas distenta plagas, sed condita in orbem undique surgentem pariter pariterque cadentem. haec est naturae facie:.... (Manilius 1977, 18-20)

Goold's translation of that citation is the following:

But the principle of the Earth's suspension should cause you no surprise. The firmament itself hangs thus and does not rest on any base, as is clear from the actual movement of its swift career; the Sun moves unsupported, as it wheels its chariot nimbly now this way and now that, keeping to its turning points in heaven; and the Moon and the stars wing their way through empty regions of the sky: therefore the Earth, too, in obedience to celestial laws, has hung suspended. Thus it is that Earth has been allotted a hollow space in mid-air, equidistant from every quarter of heaven's depths, not spread into flat plains but fashioned into a sphere which rises and falls equally at every point. This is the shape of nature;.... (Manilius 1977, 19-21)

Avelar's transcription of this extract is also slightly different from the modern edition (see words in italic):

$\mathrm{Nec}$ vero admiranda tibi natura videri

Pendentis terrae debet, cum pendeat ipse

Mundus, et in nullo ponat vestigia fundo:

Quod patet ex ipso motu, cursuque volantis,

Cum suspensus eat Phoebus, cursuque reflectat

Huc, illuc, agiles et servet in aethere metas

Cum luna et stellae volitent per inania mundi,

Terra quoque aereas leges imitata pependit.

Est igitur tellus mediam sortita cavernam 
Aeris, e toto pariter sublata profundo:

Nec patulas distenta plagas, sed condita in orbem,

Undique surgentem pariter, pariterque cadentem:

Haec est naturae facies.... (do Avelar 1593, fol. 21r-v)

The third quotation of the Astronomica in Avelar's Sphaera appeared at a point where he describes the Milky Way (do Avelar 1593, fol. 30r), a subject that was not included in Sacrobosco's original work. This is a modern version of the verses he cited (Astronomica I.699-703):

trisque secat medios gyros et signa ferentem partibus e binis, quotiens praeciditur ipse. nec quaerendus erit: visus incurrit in ipsos sponte sua seque ipse docet cogitque notari. namque in caeruleo candens nitet orbita mundo.... (Manilius 1977, 60)

It was translated by Goold as follows:

At two points it cuts the three middle circles and the circle which carries the signs and is as often cleft itself. One need not search to find it: of its own accord it strikes the eyes; it tells of itself unasked, and compels attention. It shines like a glowing path in the dark-blue of the heavens,.... (Manilius 1977, 61).

In the case of the third quotation, Avelar's transcription is also somewhat different from the modern edition (see words in italic):

Tresque secat medios gyros, et signa ferentem

Partibus e binis, quoties praeciditur ipse,

Nec quaerendus erit, visus incurrit in ipsos

Sponte sua, seque ipse docet, cogitque notari:

Namque in caeruleo candens nitet orbita mundo.... (do Avelar 1593, fol. 30r)

Avelar's fourth and last quotation of the same work, containing a single line, appeared at his description of the equinoxes (do Avelar 1593, fol. 34r): "Libra Ariesque parem reddunt noctemque diemque" (Manilius 1977, 180), which may be translated as: "Libra and Aries make equal night and day" (Manilius 1977, 181) (Chap. 2).

Manilius had sometimes been cited by astronomical authors of the late fifteenth and sixteenth centuries, before Avelar's work. Jacques Lefèvre d'Étaples (ca. 1450-1536), in his commentary on Sacrobosco's Sphaera, had a short quotation of Manilius's Astronomica that partially corresponds to Avelar's first citation: "Aera per gelidum tenuis deducitur axis / Sidereus: medium circa quem volvitur orbis" (de Sacrobosco 1499, fol. m IIr). Later editions of Jacques Lefèvre's commentary contain the same two lines (de Sacrobosco 1508, fol. 57r; de Sacrobosco 1527, fol. 4v; de Sacrobosco 1531, fol. 128r; de Sacrobosco 1538, fol. 4v). Notice, however, that Avelar's quotation contained four lines: "Aera per gelidum tenuis deducitur axis, / Libratumque gerit diverso cardine mundum. / Sydereus, medium circa quem, volvitur orbis, / Aeternosque rotat cursus immotum" (do Avelar 1593, fol. 10v). It is quite odd that Jacques Lefèvre's quotation did not include the second verse (only the first and third ones); and hence that work could not be the source of Avelar's corresponding citation. 
One of the authors who cited Manilius a number of times was Luca Gaurico (1475-1558), at several places in his 1531 edition of the Sphaera ${ }^{14}$ At the beginning of the book, in his "Oratio de laudibus astrologiae," Gaurico mentioned Manilius's name and quoted his Astronomica several times (de Sacrobosco 1531, fol. a IIr; a IIIv; a IIIIv). However, none of those quotations match Avelar's citations. At another part of the book, containing the commentaries of Prosdocimo de Beldomandis (ca. 1370/1380-1428) and of Bartolomeo Vespucci (fl. 1500) on Sacrobosco's Sphaera, we find a long quotation of the Astronomica that contains Avelar's second citation (de Sacrobosco 1531, fol. 15r). Gaurico's unconventional quotation skipped some of the verses and changed the order of other ones, without warning his readers of those changes (he reproduced Astronomica I.194-204, 211-13, 215-17, 228-29, 230-31, and 235). Avelar's corresponding extract (Astronomica I.194-206) included two verses that were not transcribed by Gaurico. Hence, this was not the source of Avelar's second quotation of Manilius.

Hartmann Beyer (1516-1577), in his Quaestiones novae in libellum de sphaera Ioannis de Sacro Busto, quoted a single verse by Manilius that was also reproduced by Avelar: "Libra Ariesque parem reddunt noctemque diemque" (Beyer 1549, fol. 26v).

Cornelius Valerius (1512-1578), in his Sphaera, quoted some verses from Manilius's Astronomica to illuminate the relation between the signs of the Zodiac and the parts of the human body (Valerius 1564, fol. 10r) and when describing the main winds (ibid., fol. 18r). Those verses of the Astronomica were not quoted by Avelar.

Theodor Graminaeus (ca. 1530-ca. 1593), in his commentary on Sacrobosco's Sphaera, cited Manilius's Astronomica three times (Graminaeus 1567, 72, 91, 116). None of his quotations correspond to those used by Avelar.

Francisco Sánchez de las Brozas (1523-1600) published a Latin Sphaera where he presented two quotations of the Astronomica (Brozas 1579, fol. 3v; fol. 23v). They were different from those published by Avelar.

Those occurrences show that, before Avelar, several astronomical authors did quote Manilius; but none of those works could have been the source of the quotations found in Avelar's Sphaera. Of course, Avelar could have drawn his citations from one of the several editions of the Astronomica; but there is a better explanation: he probably copied the quotations from Clavius.

It was quite unexpected to find out that the author who supplied Avelar's citations of Manilius was Christophorus Clavius, since the Jesuit mathematician was not interested in astrology. The 1999 reprint of the 1611 edition of Clavius's commentary on Sacrobosco's Sphaera, edited by Eberhard Knobloch, contains a very useful addition: an index of cited authors and works (Knobloch 1999, 341-50). That index points to five quotations of Marcus Manilius's Astronomica (Knobloch 1999, 9, 107, 126, 134, 185-86). Avelar's four citations of Manilius are contained therein. He did not include in his Sphaera Clavius's fourth citation, which describes the

\footnotetext{
${ }^{14}$ I am grateful to Angela Axworthy for calling my attention to this occurrence.
} 
constellations of the Zodiac. The same five citations had already appeared in the first edition of Clavius's commentary (Clavius 1570, 25, 249-50, 284, 295, 377), with a single difference: the first one is incomplete in this edition (only two verses are quoted, exactly as in Jacques Lefèvre d'Étaples's commentary on Sacrobosco's Sphaera). The second edition, however, contained the four verses that appeared in Avelar's Sphaera (Clavius 1581, 18). Although I did not check the other editions, it is probable that they also contained the same quotations.

It is likely that Avelar copied his citations of Manilius from Clavius's commentary, since all the quotations he used were contained there. I could find no other work published before Avelar's book that contained all those citations except, of course, the editions of Manilius's poem. Had Avelar consulted the Astronomica itself, he would probably have choosen some quotations different from those published by Clavius.

Of course, Clavius's commentary on Sacrobosco's Sphaera contained references to many additional authors. Besides Manilius, there were eleven other authors quoted by Clavius five or more times: Alfarganus (al-Farghān̄̄), Aristotle, Lucan, Pedro Nuñes, Ovid, Proclus (412-485), Ptolemy, Regiomontanus, Erasmus Reinhold (1511-1553), Averroes (ibn Rushd), (1126-1198) and Virgil. Only three of them were also mentioned by Avelar: Lucan, Ovid, and Virgil, who had been quoted by Sacrobosco himself. If Avelar did take his quotations from Clavius's book, then it seems that he made a careful selection of the citations he wanted to include in his own book. Perhaps the choice was made just for aesthetic reasons, or maybe he added the quotations from Manilius's Astronomica to his Sphaera because of his own deep involvement with astrology.

\section{Avelar's Manuscripts}

The only book published by André do Avelar for his teaching activities at the University of Coimbra was his Sphaera. It is not altogether clear why he decided to write that book. For his classes, he could have used any of the several editions and commentaries on Sacrobosco's Sphaera that were available at that time. The most popular ones were the Sphaera Ioannis de Sacrobosco Emendata produced by Élie Vinet and the massive In Sphaeram Ioannis de Sacro Bosco Commentarius by Christophorus Clavius. ${ }^{15}$ Perhaps he wanted to make a name for himself.

\footnotetext{
${ }^{15}$ There were thirty-three editions of Vinet's compilation, published from 1551 to 1620 in several countries, and 18 editions of Clavius's commentary between 1570 and 1618. See my survey of editions of Sacrobosco's Sphaera: http://www.ghtc.usp.br/server/Sacrobosco/Sacrobosco-ed.htm. Accessed June 2019. For the list of treatises that contain the tract of Sacrobosco respectively authored by Christophorus Clavius, see http://hdl.handle.net/21.11103/sphaera.100732 and for the list of treatises respectively authored by Elie Vinet, see http://hdl.handle.net/21.11103/ sphaera.100903.
} 
It seems that Avelar enjoyed writing scholarly treatises, some of them directly linked to his teaching activities at the University of Coimbra. Several of his manuscripts have been conserved (Fiolhais and Martins 2016, 714-15), and it is likely that he wrote a larger number of them. There are eight known manuscripts and digital copies of two of them are available on the Internet:

1. "Lectio[n]es Mathematicae," dated 1595, Biblioteca Nacional de Lisboa, FG. Cód. 1894.

2. "In Theoricas Septem Planetarum Purbachii et Octavae Spherae eiusdem Apostillae recte expplicatae ad Preceptore meo Andrea d'Auellar,' Biblioteca do Escorial-Ms. RBME \&-IV-9.

3. "Tratado do Uso da Esfera," Biblioteca Municipal do Porto-Ms. 249

4. "Galatas de Curiosidades Matemáticas," Arquivo Nacional Torre do Tombo, Lisboa-Manuscritos da Livraria, nr. 681. ${ }^{16}$

5. "Geographia Theorica \& Practica," Biblioteca Nacional de Lisboa-Ms. Cod. $2138 .{ }^{17}$

6. "Juizo que tirou em Coimbra Andre do Avelar Cathedratico da Cadeira de Mathemattica sobre os effeitos do Cometa que apareceo no anno de 1607," Biblioteca da Ajuda, Lisboa-Ms. 51-V-11.

7. "Discurso Astronomico \& Astrologico do Cometa que apareceo por novembro de 1619 em Coimbra," Biblioteca da Ajuda, Lisboa, Ms. 46-VIII-16.

José Pereira Osório cited another manuscript (Biblioteca Municipal do Porto, Ms. 669) that he did not describe, in which Avelar referred to Copernicus's astronomical theory, rejecting it (Osório 1986, 120).

Those manuscripts display the intense scientific production of André do Avelar. Item (1), in Latin, contains notes of Avelar's Coimbra lectures in the years 1594 and 1595. Item (2), also in Latin, contains notes made by a student concerning Avelar's teaching of Peuerbach's Theorica Planetarum. Item (5), in Latin, is a large manuscript containing notes on geography and astronomy, probably also included in Avelar's teaching activities at the university. The other tracts, in Portuguese, could not be intended for use at the University of Coimbra. ${ }^{18}$

A detailed study of all available manuscripts produced by André do Avelar is a desideratum. It will greatly broaden our perception of this Portuguese author.

\footnotetext{
${ }^{16} \mathrm{http}: / /$ digitarq.arquivos.pt/details?id=4461821 Accessed June 2019.

${ }^{17}$ http://purl.pt/24925 Accessed June 2019.

${ }^{18}$ Although item (4) is usually attributed to André de Avelar, it is unlikely that he wrote it. The description of the manuscript on the website of the Torre do Tombo Archive states that the word "Galatas" in the manuscript title was a pseudonym of Avelar. However, I was unable to find any other source referring to this pseudonym; and at the end of the prologue of that manuscript, one finds the name "Frei Joseph de Jesus Maria Olisiponense [from Lisbon] Galatas." Hence, instead of Avelar, the author of the manuscript could have been that priest. On the other hand, although Diogo Barbosa Machado, in his Bibliotheca Lusitana, mentioned several authors called "José de Jesus Maria" (Machado 1741-1759, vol. 2, 863-65), none of them could be the author of that work.
} 


\section{Avelar's Career at the University of Coimbra}

Besides his teaching and research activities, Avelar became involved in several other occupations at the University of Coimbra. It seems that he had financial difficulties. The annual wage of a mathematics professor was 80,000 reis, according to the statutes of the university (de Almeida 1967, 48). One year after being admitted to the university, however, he asked for a supplementary yearly payment of 20,000 reis to help support his children. The king accepted his request and ordered the dean to pay this additional amount (de Almeida 1967, 49, 51). In 1593, Avelar sold to the university an astrolabe made of wood and a large world map in color for 2700 reis; two years later he sold another map for 3400 reis (de Almeida 1967, 50, 52). The astrolabe and maps were used in his classes and are directly related to his manuscript on practical and theoretical geography.

The statutes of the University of Coimbra had determined that there should be a proof reader for the books produced by its staff. In addition to this post, the proof reader would also become the keeper of the university's library, receiving for this work 30,000 reis each year (Universidade de Coimbra 1593, fol. 69r). In 1595, Avelar attempted to become the director of the library and corrector of the books published by the university, but his request was denied on dubious grounds: the university, it was claimed, had no library at that time (de Almeida 1967, 39, 53). It is likely, however, that the official document describing the decision meant to say that there was no place to keep the books. There is reliable information that the university did have a library. In 1536, before moving to Coimbra, it had 151 volumes, all of them attached to chains to avoid being stolen (do Amaral 2014, 20). After the transfer of the university to Coimbra, access to the books was made public to any person who wished to consult them (do Amaral 2014, 33). Around 1600, it already had 739 volumes, and many others were ordered by the university. The writer Pedro de Mariz (ca. 1550-1615) was afterwards chosen to organize the books, and in 1598 Avelar replaced him (de Carvalho 1990, 169). In the same year, Avelar was also granted the position of keeper of the notary's office, adding 12,000 reis to his annual income (de Almeida 1967, 40, 55; Braga 1892-1902, vol. 2, 245). In 1598, because of this additional job, Avelar produced the first catalog of the archive of the university (Brandão 1927).

Avelar's wife Luiza de Faria died around 1600. The six children of the couple were born in the following years: Tomásia 1581; Mariana 1591; Ana 1592; Luiz 1593; Pedro 1596; and Violante 1596 (de Carvalho 1990, 333). In 1600, five of them were under ten. Avelar, however, turned his widowhood to his own advantage. During his youth he had studied theology in Salamanca or Valladolid. Now, after the demise of his wife, he took religious vows and became a Catholic priest (Machado 1965-1967, vol. 1, 137-38; vol. 4, 15-16). After that, he applied for a position at the See of Coimbra.

The annual income of the See of Coimbra was 45,000 cruzados (Botelho 1873, 30 ). Around 1600, the cruzado (a gold coin with a weight corresponding to $3.55 \mathrm{~g}$ ) was equivalent to about 400 reis (Fernandes 1856, 124; Lima 2005, 171). Hence, the 
income of the See of Coimbra was $18,000,000$ reis. Part of this huge revenue was divided between the priests connected to the See.

There were thirty-five canons attached to the See, and some were appointed by the university. One of them, who should be a Master of Arts, was "tercenário," that is, he received one third of the full annual payment of an ordinary canon (Botelho 1873, 30). Miguel Vaz Pinto, the university professor who formerly held this position, died in 1601, and three candidates applied to replace him. One of them was André de Avelar, who was elected on account of his age and capacities (de Almeida 1967, 56). However, there were some doubts whether he should ultimately assume this position, because he was the descendant of Jews. The King consulted the Pope, who in 1603 authorized the appointment (de Carvalho 1990, 184; de Almeida 1967, 55; Braga 1892-1902, vol. 2, 492-93). It seems that this additional income solved his financial problems.

In 1612, after teaching for twenty years at the university, Avelar (now 66 years old) had the right to retire and receive two thirds of his wages (de Almeida 1967, 59). However, two months later he was reappointed to the chair of mathematics for an additional interval of four years, receiving during that time the full corresponding wages (de Almeida 1967, 60-61). He was employed again not only because of his good services and the satisfaction of his students, but because there was nobody who could replace him at that time (de Carvalho 1990, 211).

Notice that the benefits successively obtained by Avelar at the University of Coimbra suggest that he was on good terms both with the successive deans and with his colleagues.

In his old age Avelar had reached a privileged status. His poverty belonged to the remote past. He had published a popular book (Reportorio dos tempos) and another one not so successful, his Sphaera. He was a respected university professor and was still producing an abundance of manuscripts on mathematics, astronomy, and astrology. He had beneficial relationships with some noblemen who probably helped to boost his career. There was, however, a dark cloud lingering over him. His last years were to become a nightmare.

\section{Inquisition in Portugal}

The first aim of the Catholic Council of Trent, held between 1545 and 1563, was the development of strategies for fighting the growing influence of Martin Luther (1483-1546). In Portugal, Protestantism did exist (Bodian 2002) but never became popular. The rising inquisitorial wave found another target there: crypto-Judaism among the "New Christians," the descendants of the Jews who King Dom Manoel (1469-1521) had compelled to become Christians in 1497 (Roth 1959, 27-29). The recently converted Jews and their offspring became a separate social class that was not fully accepted by the "Old Christians," even after more than one century. There was a general suspicion that the "New Christians" or "people of the Hebrew nation" were Christians only outwardly, but kept the old practices of Judaism privately. A Jew who practiced Judaism could not become a target of the Inquisition, because it 
was an internal institution of the Catholic Church; but a converted Jew who practiced the religion of his ancestors was classified as a heretic and could be prosecuted. So, in the second half of the sixteenth century, the hidden practice of Judaism turned out to be the main concern of the Portuguese Inquisition.

This was a peculiarity of Portugal. In Spain, after an early preoccupation with Judaizers, the Inquisition turned its attention to sexual offences (bigamy and "sexual deviation"), blasphemy, and specific heretical propositions. Between 1540 and 1700 , only $10 \%$ of the Spanish inquisitorial processes involved Judaizers. In Portugal, before 1770 , over $80 \%$ of the Inquisition trials dealt with people accused as Judaizers (Schwartz 2008, 95; Salomon 1998, 132). Among the forty thousand known inquisitorial processes held in continental Portugal, there were about seven thousand denunciations regarding witchcraft, but only about one thousand cases were prosecuted, and punishment was usually soft, as compared to northern Europe (Schwartz 2008, 97).

Around 1600, the Portuguese Inquisition was engaged in the suppression of crypto-Judaism, spreading a culture of religious and racial discrimination towards the New Christians. Other reasons might also have been relevant at that time for such persecution (Schwartz 2008, 105).

The situation became particularly strained in the early seventeenth century. After a few years of negotiation, a group of New Christians obtained from King Philippe III of Spain (1578-1621) (known as Philippe II in Portugal) the publication of a General Pardon in January 1605 signed by the Pope, which abolished all past religious faults and allowed them to leave the country with their property intact. In exchange for this bill, the New Christians promised to pay the enormous sum of $1,800,000$ crusados, corresponding to over 6000 kilograms of pure gold. Because of this decree, on January 16, 1605, the Portuguese tribunals liberated 410 prisoners after imposing only a formal penance (Roth 1959, 40). There was an immediate public reaction against the royal act of mercy. In Coimbra, students attacked and killed some New Christians, setting their houses on fire (Curto 1997, 188; Braga 1892-1902, vol. 2, 493). Unfortunately, the New Christians could not pay the promised amount, and the pardon was revoked in 1610. There were new attempts to negotiate with the king, but they were not successful, and the situation of the New Christians deteriorated during that decade (Schwartz 2008, 116).

\section{Avelar's Involvement with Jewish Religion}

Shortly after the General Pardon episode, an outstanding professor of law at the University of Coimbra, António Homem (1564-1624), began to organize a secret Judaic brotherhood. ${ }^{19}$ António Homem was the heir of a long Jewish family tradition.

\footnotetext{
${ }^{19}$ Some historians of the past denied the existence of this brotherhood and stated that the Inquisition had falsely accused him. There is no doubt, however, that it was real. Those interested in this subject should consult the most careful research ever produced about António Homem and the Fellowship of St. Diogo, written by (de Carvalho 1990).
} 
His great-great-grand father lived and died as a Jew. Some of his relatives had been sentenced as Judaizers by the Inquisition: his great-grandfather, his grandmother, and two of his uncles. His father had kept the Judaic religious tradition and taught it to all his children, without the knowledge of his wife, who was an Old Christian of noble lineage (de Carvalho 1990, i).

Up to 1607, António Homem kept his Judaic practices private. He knew several other New Christians who were also Judaizers or sympathetic to those practices. $\mathrm{He}$ probably thought that strong cooperation and organization were needed both to support and develop their religious faith and to defend themselves (de Carvalho 1990, 32). In September of that year, he organized at his own home a celebration of Yom Kippur, to which he invited several friends, including André do Avelar. Avelar started collaborating directly with Homem, using his astronomical knowledge to determine the right day for Judaic ceremonies (de Carvalho 1990, 37).

Avelar had been initiated in the Jewish faith at the age of sixteen by his maternal aunt, Brites Lopes (Braga 1892-1902, vol. 2, 603). However, his wife Luiza de Faria was an Old Christian, and he kept his belief to himself until her death. Only a few years later, after the General Pardon, did he disclose his faith to his children, who also became crypto-Jews (de Carvalho 1990, 169).

Under the leadership of António Homem, the growing clandestine Jewish community became the "Confraria de São Diogo" (Fellowship of St. Diogo), a name that was supposedly Christian, but was actually a tribute to a Judaic martyr, the Franciscan Friar Diogo da Assumpção (1571-1603), who spontaneously converted to Judaism in 1599. He tried to escape from Portugal to a country where he could become a Jew, but he was denounced and arrested by the Inquisition. Friar Diogo tried to convince the Inquisitors that he was right and that the Christian religion was false, and maintained this attitude for years during his imprisonment. He was finally convicted for the crimes of heresy and apostasy and was burned alive on the $3^{\text {rd }}$ of August, 1603, without showing a sign of regret (Teixeira 1895, 217-64; Curto 1997, 181-88).

The underground Jewish activities of the Fellowship of St. Diogo were kept secret for a few years, and during this period Avelar suffered no harassment. The situation changed around 1620 for two reasons: official inspections of the University of Coimbra by the order of the King and the pursuits of the Inquisition.

The first royal inspection of the university in the seventeenth century was prompted by rumors of frauds and bad behavior amongst the students, professors, and other personnel of the institution (Baião 1919, 104). In 1615, the King appointed Dom Martim Affonso de Mexia (ca. 1570-1623), Bishop of Leiria (afterwards of Lamego), as "visitador e reformador" (visitor and reformer) of the university (Braga 1892-1902, vol. 2, 500). The Bishop spent several months hearing all types of allegations. António Homem was accused of bribery in the election of professors, and of protecting and favoring New Christians (Braga 1892-1902, vol. 2, 497). There was also a more serious charge. In May 1616, one of the canons of the Coimbra Cathedral named Alvaro Soares Pereira wrote a letter to an Inquisitor in Coimbra, denouncing António Homem for the sin of sodomy, pointing out the names of people who could be interrogated to confirm the accusation. He also identified one of the young lovers of António Homem: Jorge Mexia, nephew of the Bishop 
(de Carvalho 1990, 54-65). At that time, any homosexual activity was regarded as a crime and could be severely punished both by the civil authorities and by the Inquisition (de Azevedo 1921, 141).

The Inquisitor who received the letter was Francisco de Brito de Menezes (ca. 1570-1631), a fierce enemy of António Homem with whom he had fought over a vacant canon at the Coimbra Cathedral in 1610. António Homem was chosen, although he was a New Christian and notwithstanding the support the defeated professor received from members of the Inquisition (Braga 1892-1902, vol. 2, 499). Now, Francisco de Menezes had a nice opportunity for revenge, but nothing happened, possibly for two reasons: first, António Homem was a friend and legal adviser of the Bishop Dom Martin Affonso Mexia (de Carvalho 1990, 64); second, it was not advisable to expose the nephew of the "university visitor" and Bishop.

After a brief investigation, António Homem was formally charged in November 1616 for only corruption and bribery. Although he defended himself, he was found guilty and had to pay a fine of 100,000 reis, more than the annual remuneration received by Avelar (de Carvalho 1990, 69; Braga 1892-1902, vol. 2, 506-11). António Homem's punishment was light compared to that of other people. Another professor of law, Manuel Rodrigues Navarro, was found guilty of usury, corruption, and sodomy. In June 1616, he was expelled from the university in perpetuum and his name was struck off the university records. Afterwards, he was sentenced to deportation and the loss of his property. He went to Italy, where he lectured in the universities of Bologna and Naples (de Carvalho 1990, 70, 392). Many other professors received serious or light punishments.

Nothing happened to André do Avelar during the visitation of Dom Martim Affonso de Mexia, but all New Christians were regarded as highly suspicious after that time (Braga 1892-1902, vol. 2, 500). Besides that, the mood of intrigue and denunciations stimulated by the visitor would soon produce new difficulties.

\section{Astrology and the Jewish Messiah}

In the sixteenth century, the people who were more deeply interested in astrology and who understood its technical details were physicians (and other people involved with health issues, such as surgeons) and, of course, astrologers (sometimes called "mathematicians"). In old documents Avelar is not described as an astrologer, and he did not study medicine. However, there was a strong tradition in the teaching of astrology at the University of Salamanca, where he was a student. That might have been the origin of his deep association with this subject, as shown in his Reportorio.

During his involvement with the fraternity of Saint Diogo, Avelar made use of his extensive knowledge about the calendar and astronomy to choose an adequate time for the Jewish ceremonies performed by the group. We may conjecture that he was also interested in the astrological prediction of the coming of the Jewish Messiah, since this was a central interest of crypto-Jews and particularly of António Homem's group. There had already been several outstanding attempts to use astrology as an instrument for predicting the coming of the Messiah in the preceding centuries. 
At least since the tenth century, there had been Jews in the Iberian Peninsula who described their hope for the coming of the Messiah (Montenegro 2017, 23). Messianic belief involved both the idea of a religious-spiritual redemption and national and political independence (Sáenz-Badillos 1999, 178). The Jews used several methods for predicting the coming of the Messiah. The most common and earliest one was the interpretation of the Book of Daniel, alone or together with other Biblical texts. In the tenth century, Sa'adiah ben Yosef Gaon (882/892-942) interpreted the prophecies of Daniel as indicating that the coming of the Messiah would occur abruptly. His advent would be accompanied by many disgraces to the enemies of Israel: fire, stones, violent deaths, etc. The Jews would gather in Jerusalem and there would follow idyllic times of peace and happiness, without diseases or sorrows (Sáenz-Badillos 1999, 189).

Another method made use of comparisons between the different periods when the Jews were kept in exile, in Egypt and in Babylon. The third one was an analysis of the Torah using special numerical techniques for the interpretation of letters and words, such as gematria and Kabbala. Astrology was another independent method (Silver 1927, 243-59).

Although many early Jew authorities denied the validity of astrology in late Antiquity, taking inspiration from the Greeks and Romans, it became a highly significant belief. Its impact increased in the Middle Ages, due to the influence of Islam (Silver 1927, 255-56).

Two medieval Jewish authors who attempted to predict the coming of the Messiah by means of astrological calculations were Solomon Ibn Gabirol (ca. 1021-1058) and Abraham Bar Hiyya (ca. 1065-ca. 1140) (Ruderman 2001, 26; Sela 2010, 9). Gabirol was probably the first Jewish astronomer to attempt to predict the "end of days" using astrological techniques (Goldstein 2001, 42). Using astrological methods developed by Abū Ma'shar (787-886) and especially by Māshāaallāh ibn Atharī (762-ca. 815), those Jewish astrologers attempted to explain past historical events and to predict future ones by astral causes (Rodríguez-Arribas 2011, 14). Māshāaallāh's Book of Eclipses contained an astrological theory of world history and associated the great conjunctions of Jupiter and Saturn to the coming of great prophets and seers (Goldstein 1996, 14). Both Gabirol and Bar Hiyya linked the Saturn-Jupiter conjunctions in the sign of Pisces to the advent of the Messiah, because a historical conjunction of the same type was associated with the exodus of the Jews from Egypt. Actually, the detailed analysis of the astrological situation concerning the exodus was much more detailed and intricate (Rodríguez-Arribas 2005, 146-48). According to Bar Hiyya's calculations, the new deliverance of the Jews could happen in 1358 (the last of twelve great conjunctions) or in the years corresponding to the largest conjunction, 1448 or 1468 (Sáenz-Badillos 1999, 190; Sela 2010, 9-11).

Many Jewish authors denied the possibility of predicting the arrival of the Messiah by astrological calculation, saying only prophets could anticipate it. Two examples of scholars with this attitude are Saadia Gaon (882-942) and Abraham ben Meir ibn Ezra (1092-ca.1167) (Rodríguez-Arribas 2011, 14, 17). Ibn Ezra accepted historical astrology and the relevance of the conjunctions of Jupiter and 
Saturn (Goldstein 1996, 14), but criticized its use for predicting the coming of the Messiah (Rodríguez-Arribas 2005, 149-53).

One important Spanish kabbalist was rabbi Moshe ben Shem-Tov (ca. 1240-1305), known as Moses de León, who is regarded as the composer or compiler of the Zohar. Messianism is an important subject of that work, and the coming of the Messiah is described as the way to redeem mankind from evil, bringing harmony to the world. The coming of the Messiah would be accompanied by the death of the Pope and great wars, followed by the reconstruction of Jerusalem (Montenegro 2017, 33).

In the following centuries, the religious relevance of the Saturn-Jupiter conjunctions was discussed by other Jewish astrologers such as Levi ben Gershon, or Gerson (1288-1344), who studied the event of 1345 (Goldstein 1996, 18-19). He agreed with the prevailing Jewish view that the Messiah would come in 1355 or 1358 . Christian authorities were also anticipating some dangerous religious upheaval. The cardinal Pierre d'Ailly (1351-1420) associated the coming of the Antichrist with a Saturn-Jupiter conjunction (Goldstein 1996, 19).

In the fifteenth century, the famous Portuguese-born Jewish philosopher Isaac ben Judah Abravanel or Abarbanel (1437-1508) used the same method employed by Bar Hiyya. The first conjunction of Saturn and Jupiter in Pisces had occurred in the Jewish year 2365, three years before the birth of Moses and eighty-three years before the exodus; the new conjunction, in the year 5224 (1464), might announce the birth of the Jewish Messiah (Cohen-Skalli 2006, 196-97). The redemption of the Jews would occur a few decades after that time, between 1503 and 1571, perhaps in 1531 (Lawee 2001, 18). There would be terrible wars involving the Jews, the Christians, and the Muslims; the Messiah would defeat their enemies and the Jews would return to Jerusalem (Rodrigues 2010, 98).

In the transition from the fifteenth to the sixteenth century, the Jewish astrologers Bonet de Lattes (1450-1514) and Abraham ben Samuel Zacut (1452-ca. 1515) ${ }^{20}$ (Chap. 3) also made messianic predictions (Ruderman 1992, 308). Zacut made use of the calculation of eclipses and planetary conjunctions and predicted that the salvation of Israel would begin in 1503 or 1504 (Goldstein 1998, 182). In the early sixteenth century, the expectation was so strong that in 1521 an inquiry was sent from Rome to Jerusalem asking whether the signs of the approaching Messiah had not already appeared there (Silver 1927, 149).

Possibly because of the failure of those astrological forecasts, during the sixteenth and seventeenth centuries most of the Messianic predictions were made using biblical interpretation and gematria, not astrology (Silver 1927, 116-43, 183-92). Moses de Léon, the author of the Zohar, suggested a handful of dates: 1300, 1306, $1324,1334,1340,1608$, and 1648. In the seventeenth century, several Kabbalists and non-Kabbalists accepted the year 1648 as the date of Redemption (Silver 1927, 151); others, however, predicted different years, such as 1713 or 1725 (Patai 1988, 56). In 1648, the last date predicted by the Zohar, Shabbatai Zevi (1626-1676), a

\footnotetext{
${ }^{20}$ Samuel Zacut or Zacuto, born in Spain, was a highly influential astronomer and astrologer. His astronomical tables were used by Portuguese navigators (Goldstein 1998).
} 
Jew born in Smyrna, became convinced that he was the Messiah and produced a strong commotion (Merrill 1973, 161; Patai 1988, xlv). That famous episode, however, happened after Avelar's passing.

Did Avelar get involved in astrological predictions concerning the Messiah? His published works display no clear hint about this subject. Luís Miguel Carolino and Carlos Ziller Camenietzki studied the two known manuscripts left by Avelar containing astrological predictions (Carolino and Camenietzki 2006). Both manuscripts described the effects of comets that appeared respectively in 1607 and 1618. Comets, in astrology, are usually a warning of bad occurrences, and Avelar's analysis of those comets was no exception. The 1607 event, according to Avelar, would produce the following effects:

.... king will almost die of a sudden death, and princes and nobles of the highest rank will die. A war will be waged in a nearby land, or rather many wars will occur in many places, and there will be the destruction of cities, shipwrecks, and great dangers and raids by pirates at sea, and their fleets will spread fear and do great ill at seaports. There will be great changes in religion and political affairs. There will be different and unexpected journeys and embassy missions. (Carolino and Camenietzki 2006, 38)

Predictions of the "end of days" usually described wars and the violent deaths of key persons, together with political changes, before the dawn of the new age brought by the Messiah. Therefore, Avelar's description of the effects of the 1607 comet was compatible with this scenario. However, although Avelar did mention great political and religious changes, there was no direct allusion in those manuscripts to the coming of the Jewish Messiah. ${ }^{21}$ If Avelar made any astrological prediction about this subject, it was probably kept secret.

Luiz de Avelar, son of André do Avelar, published a short dialogue on the 1618 comet (do Avelar 1619). He mentioned the usual injurious effects of comets, but he did not suggest any influence of that celestial occurrence on religious affairs.

\section{Avelar and the Inquisition. First Proceedings}

Meanwhile, the Coimbra Inquisition was busy receiving denunciations, arresting, interrogating, and judging hundreds of suspects. The first known allusion to André do Avelar in a process of the Inquisition arose in 1612. A prisoner called Antonio Gomes accused Avelar and three other canons of the Coimbra See who were New Christians of practicing Judaism (Antonio Dias da Cunha, Chrispim da Costa and Fernão Dias). The second mention, much more serious, appeared early in 1619 in the process of Miguel Gomes, called "o Manco" (the lame one). In his deposition we find the first description of the Brotherhood consecrated to Friar Diogo, in which Gomes identified some of its members, including himself. He mentioned António

\footnotetext{
${ }^{21}$ Luís Miguel Carolino, private communication, $22^{\text {nd }}$ of June 2018. Carolino conjectures that Avelar would be very careful in his public prognostics because of his position as professor at the University of Coimbra and his status as a New Christian.
} 
Homem, André do Avelar, Diogo Lopes da Rosa, António Dias de Almeida, Diogo Lopes de Sequeira, António Corrêa, Luiz de Sá, André Vaz Cabaço, Manuel Gomes Tasquinha, Francisco da Costa, Pêro Cabral, Francisco de Aguiar, Miguel da Fonseca, Fernão Dias da Silva, José Coutinho, and António de Oliveira (Braga 1892-1902, vol. 2, 511-12). In the following months, other members of the Brotherhood were successively arrested and interrogated.

By coincidence, in 1619, Francisco de Brito de Menezes, the opponent of António Homem, had a new opportunity to take vengeance: he was appointed the new visitor and reformer of the University of Coimbra as well as substitute dean, or intervenor (Braga 1892-1902, vol. 2, 516). Francisco de Menezes began his work in May 1619. He summoned students and professors at random and questioned them about the cases of immorality and corruption they knew. In a few weeks he had already obtained several depositions against António Homem, who was accused of bribery, corruption, and homosexuality (de Carvalho 1990, 82-85).

In October 1619, the promotor of the Coimbra Inquisition requested the arrest of António Homem and the confiscation of his estate, since there were three separate reliable testimonies against him by relatives; he was a New Christian and it was known that he had other relatives that had been convicted as Judaizers; and he had also been accused of moral offenses with male boys. He was arrested on Sunday, the $24^{\text {th }}$ of November, and three weeks later was transferred to the Lisbon headquarters of the Inquisition (de Carvalho 1990, 90-93; Braga 1892-1902, vol. 2, 555; Baião 1919, 105). He would never be set free.

André do Avelar knew that he was also going to be arrested, but it was impossible to escape. Although his name had already been mentioned by several members of the Fellowship that had been seized previously, the formal charge against André do Avelar was made on the $1^{\text {st }}$ of March, 1620, by the canon Crispim da Costa, who stated that once, when they were leaving the Coimbra See, they had confessed to each other that they followed the Jewish faith (Baião 1919, 134; de Carvalho 1990, 98). Avelar was arrested by the Inquisition on the $20^{\text {th }}$ of March. He was seventyfour years old at that time. The next day, he asked to be heard and made a detailed confession. He stated that he had also disclosed his Jewish belief to other Judaizers and named António Homem, Miguel Gomes, Henrique de Aredes, Francisco de Almeida, Francisco Gomes, and others (Baião 1919, 134; de Carvalho 1990, 99; Braga 1892-1902, vol. 2, 602-03). The process of André do Avelar was unbelievably fast. A few days later, on the $29^{\text {th }}$ of March, his sentence was read and he was ordered to abjure his mistakes. After doing so, he was "imprisioned" in Coimbra on the next day, though this meant in effect his release from detainment (Baião 1919, 135-36; Braga 1892-1902, vol. 2, 604).22

It is difficult to understand the unusually gentle and speedy treatment received by Avelar on this occasion, but Avelar was not the only one to receive such mild treatment. Crispim da Costa, who had denounced him and António Homem, and Miguel

\footnotetext{
${ }^{22}$ In the case of mild offenses, the sentence of incarceration ad arbitrium was interpreted as a temporary obligation to live in one's own town, during a given number of months (de Azevedo 1921, 145).
} 
da Fonseca, who had also denounced António Homem, were also allowed to abjure on the same day (29 ${ }^{\text {th }}$ of March 1620) and were afterwards released (de Azevedo 1921, 174). Maybe, at that time, the main interest of the Inquisition was obtaining additional evidence to convict António Homem.

\section{Avelar and the Inquisition. Second Proceedings}

Avelar only remained free until the next year. There were successive arrests of members of the Fellowship and the mathematics professor was now accused of being one of the heads of the group (Baião 1919, 136). On the $11^{\text {th }}$ of February 1621, his son Pedro Homem de Faria (twenty-five years old) was arrested by the Inquisition at Lisbon. He had enlisted to serve in India and it was suspected that he was running away to avoid prosecution (de Carvalho 1990, 112). He was questioned but denied any involvement with Judaic practices and made no denunciation. The other son, Luiz de Avelar (twenty-eight years old), who was a Master in Arts, was arrested on the $10^{\text {th }}$ of September (de Carvalho 1990, 115). He soon admitted his own guilt and accused his father, brother, and four sisters.

Three of André do Avelar's daughters were nuns at the Monastery of Santa Ana in Coimbra: Ana de Faria (twenty-eight years old), Mariana do Deserto (thirty), and Violante de Faria (twenty-five). They were all arrested by the Inquisition on the $17^{\text {th }}$ of October 1621, in the morning. Soon afterwards, their sister Tomásia de Faria (fourty years old), who was married and had six children, was arrested at her home; the same happened to André do Avelar (de Carvalho 1990, 118). The whole family was now in prison. The youngest of the daughters, Violante de Faria, immediately confessed (de Carvalho 1990, 281), stating that she became a Judaizer under the influence of her father. She also disclosed the existence of a larger group of cryptoJews at the Monastery of Santa Ana; they were arrested a few days later.

After being seized, André do Avelar first requested some time "to ponder his faults" because he was very disturbed by his arrest. One week later, on the $25^{\text {th }}$ of October, he was heard and said that everything he had confessed in the previous year was false, and that he had never accepted the Judaic faith (Carvalho 1990, 119). Of course, given the weight of the accusations against him, this attitude could not be accepted by the Inquisitors (Baião 1919, 136). Two weeks later, on the $8^{\text {th }}$ of November, he asked for an audience with the Inquisitor and declared that he was guilty and that his former statement was untrue. He knew that his sons had been arrested before him, but he may not have known that his daughters were also in prison; he possibly thought that he had been denounced by them and that he should disclose that the whole family followed the Judaic faith. He told the Inquisitor that he had withheld some information because of his love for his children, and declared that sometime after the General Pardon he had told them that he accepted the Law of Moses and instructed them accordingly (Baião 1919, 136-37). A few days later, two other daughters, Mariana do Deserto and Ana de Faria, made their confessions, blaming the father for their apostasy. They also confirmed the Jewish cult meetings at the Monastery (de Carvalho 1990, 121). 
A few weeks later, on the $28^{\text {th }}$ of November, there was an Auto de Fé in Coimbra where 174 people were sentenced, including three of André do Avelar's children: Ana de Faria, Tomásia de Faria, and Luiz de Faria. They had confessed, their faults were not severe, and they were condemned to prison and penitential dress ad arbitrium (de Carvalho 1990, 123-24). As a matter of fact, they were "detained" in Coimbra. Ana de Faria, like the other nuns who were pronounced guilty, could not return to the monastery, and the family estate had been confiscated by the Inquisition. She was entrusted to a widow and afterwards to her mother's relatives (de Carvalho 1990, 277).

Up to the beginning of 1623, André do Avelar did not confess to his active participation in the Fellowship of St. Diogo. Evoking his old age, Avelar alleged that his memory was worn out and that he did not remember the things they asked to describe (Baião 1919, 137-38; Braga 1892-1902, vol. 2, 605). He only admitted his prominent role in that Brotherhood on the $21^{\text {st }}$ of February, naming António Homem as its High Priest (de Carvalho 1990, 131-32). He accused over twenty other people and made a detailed description of the ceremonies of the Fellowship, and of his own role in those meetings (Baião 1919, 139; Braga 1892-1902, vol. 2, 605-07).

However, his new confession was deemed incomplete. On the $20^{\text {th }}$ of May 1623 , he was admonished and then taken to the torture chamber, where he was stripped of his clothes and tied up (Baião 1919, 139). However, before the beginning of the torment, he asked to be heard and incriminated Father Diogo da Mata and his mother, but he had nothing else to add. On the same day, his sentence was decided: he should be kept for life in the penitential prison of the Inquisition in Lisbon to avoid his contact with other "people of his nation," as he could corrupt them (de Carvalho 1990, 134-35).

Avelar, his two daughters Mariana do Deserto and Violante de Faria, and 136 other people were sentenced in the Auto de Fé that occurred in Coimbra on the $18^{\text {th }}$ of June 1623 (de Carvalho 1990, 137). The two nuns were condemned to prison and penitential dress ad arbitrium, as were her other sisters (de Carvalho 1990, 285). ${ }^{23}$ Avelar was condemned to perpetual imprisonment without remission, with the use of penitential dress with the insignia of fire (de Carvalho 1990, 137), meaning that his faults were so severe that he deserved to be burned, but he repented and was acquitted.

On the $20^{\text {th }}$ of June 1623 André do Avelar was transferred from Coimbra to the Inquisition prison in Lisbon. At that time, he was 76 or 77 years old. There is no additional information about him after this day. It is likely that he died there, after a few years (de Carvalho 1990, 285).

António Homem, as the leader of the crypto-Jews of Coimbra, could have informed the Inquisition about everyone involved in his Fellowship. He made, however, a firm decision: he never confessed anything, he never accused anybody, he always denied every charge against him, and declared that he was innocent and a good Christian. He maintained this consistent attitude over more than three years,

\footnotetext{
${ }^{23}$ António Baião wrongly stated that he was sent to the Inquisition prison in Lisbon (Baião 1919, 147).
} 
but the evidence against him was overwhelming. He was finally sentenced by the Inquisition, excommunicated, and "released to the secular arm." At the last moment, before being burned at the stake, António Homem made a public declaration of Christian faith and chose to die as a Catholic. He was garroted, and his body was burned on the $5^{\text {th }}$ of May, 1624 (de Carvalho 1990, 142-47).

The younger son of André do Avelar, Pedro Homem de Faria, did not cooperate with the Inquisition. He refused to admit any fault. In March 1624, three years after being arrested, he continued to deny his guilt, although several witnesses had presented depositions against him, including his relatives (de Carvalho 1990, 127). On the $3^{\text {rd }}$ of May, Pedro Homem was informed that he would be handed over to the secular arm, that is, he would be burned alive. The next day, on the eve of his execution, he asked to be heard and confessed. His life was spared. In the same Auto da $F e ́$ in which António Homem died (Sunday, $5^{\text {th }}$ of May 1624), Pedro Homem abjured, received absolution, and was sentenced to perpetual imprisonment and penitential dress with the insignia of fire, without remission, and penal servitude in the King's galleys for five years, without payment. On the $17^{\text {th }}$ of May, he embarked, with other convicted prisoners, on the ship "Madalena" (de Carvalho 1990, 142-44, 280, 288-89; Baião 1919, 153-54).

\section{Concluding Remarks}

André do Avelar's Sphaerae vtrivsque tabella, ad sphaerae huius mundi faciliorem enucleationem (1593) was the only Latin version of Sacrobosco's Sphaera published in Portugal. It was written to be used by the students of the University of Coimbra, unlike Pedro Nuñes's Portuguese translation of the Sphaera. The composition of Avelar's Sphaera was similar to that of his Reportorio dos tempos in several respects. In both cases he took a successful, previously existing book and rewrote it, abandoning some parts, following a different arrangement, and adding new information without identifying his sources. Although the contents of the Reportorio and the Sphaera are quite different, Avelar introduced in his version of Sacrobosco's work some information useful for navigators and also some astrological knowledge. The creation of both works required access to a variety of books that were possibly consulted by Avelar at the private libraries of the noblemen to whom he dedicated the Reportorio dos tempos. Avelar's Sphaera, on the other hand, was dedicated to Dom Fernão Martins Mascarenhas, the dean of the university, who ironically became the General Inquisitor at the time when the mathematician was arrested and condemned.

It seems that Avelar's Jewish ancestry was not a hindrance to his professional work at the University of Coimbra up to his retirement, because he obtained several new appointments that helped to complement his income, including the duty of a canon at the Coimbra cathedral. He led an exterior life of a Catholic, but he was really a Jew, to most effects, suffering the prejudices of the Portuguese against the New Christians and following the Law of Moses in secrecy. This situation was con- 
ceivably the motivation for his emblem with the motto "Flectimur sed non frangimur." However, he was finally bent and broken by the Inquisition.

The known association between Avelar's astronomical knowledge and the activities of the Fellowship of St. Diogo consisted in the need to settle the adequate time for Jewish ceremonies. There is, however, another conceivable link between Avelar's religious faith and his interest in astronomy and astrology. There was a general trend of Messianic thought among the Portuguese crypto-Jews in the sixteenth and seventeenth centuries, and it was even thought that the Messiah could be born among the New Christians at that time. António Homem was one of those believers who were preparing for the coming of the Messiah and who, in turn, would save the Jews from the oppression of Christians. We do not know whether Avelar personally tried to predict the time of the Messiah's appearance by astrology, but it would be meaningful to search for that connection.

\section{References}

Baião, António. 1919. Episódios Dramáticos da Inquisição Portuguesa. Volume I. Homens de Letras e de Sciência por Ela Condenados. Porto: Renascença Portuguesa.

Baldini, Ugo. 1998. As Assistências ibéricas da Companhia de Jesus e a actividade científica nas missões asiáticas (1578-1640). Alguns aspectos culturais e institucionais. Trans. Bernardino Fernandes. Revista Portuguesa de Filosofia 54 (2): 195-246.

Bayão, José Pereira. 1737. Portugal Cuidadoso e Lastimado com a Vida e Perda do Senhor Rey Dom Sebastiaõ, o Desejado de Saudosa Memoria. Lisboa Occidental: Officina de Antonio de Sousa da Sylva.

Bensaude, Joaquim. 1912. L'Astronomie Nautique au Portugal a l'Epoque de Grandes Découvertes. Bern: Akademische Buchhandlung von Max Drechsel.

Beyer, Hartmann. 1549. Quaestiones novae in libellum de sphaera Ioannis de Sacro Busto. Frankfurt: ex officina Petri Brubachii. http://hdl.handle.net/21.11103/sphaera.100645; http:// hdl.handle.net/21.11103/sphaera.100644.

Bodian, Miriam. 2002. In the cross-currents of the reformation: Crypto-Jewish martyrs of the inquisition 1570-1670. Past \& Present 176: 66-104.

Botelho, Bernardo de Brito. 1873. Historia Breve de Coimbra: sua Fundaçam, Armas, Igrejas, Collegios, Conventos, e Universidade. 2nd ed. Lisboa: Imprensa Nacional.

Braga, Teophilo. 1892-1902. Historia da universidade de Coimbra nas suas relações com a instrucção publica portugueza. Lisboa: Academia Real das Sciencias.

Brandão, Mário. 1927. Contribuições para a história da Universidade de Coimbra: A livraria do P. Francisco Suarez. Biblos 3 (4-5): 325-349.

Brozas, Francisco Sánchez de las. 1579. Sphaera Mundi, ex variis autoribus concinnata. Salmanticae: ex officina Ildefonsi a Terranoua.

Camerarius, Joachim. 1590. Symbolorum \& Emblematum ex Re Herbaria Desumtorum Centuria Una. Noribergae: Hofmann.

Cardoso, Walmir Thomazi, and Roberto de Andrade Martins. 2018. Iberian approaches to astronomy during the sixteenth century. Mediterranean Archaeology and Archaeometry 18 (4): 265-271.

Carolino, Luís Miguel. 2006. João Delgado SJ e a ‘Quaestio de Certitudine Mathematicarum’ em inícios do século XVII. Revista Brasileira de História da Matemática 6 (11): 17-49. 
Carolino, Luís Miguel, and Carlos Ziller Camenietzki. 2006. Tokens of the future: Comets, astrology and politics in early modern Portugal. Cronos. Cuadernos Valencianos de. Historia de la Medicina y de la Ciencia 9: 33-58.

Casalini, Cristiano. 2017. Aristotle in Coimbra: The cursus conimbricensis and the education at the college of arts. Trans. Luana Salvarani. London: Routledge

Clavius, Christoph. 1570. In Sphaeram Ioannis de Sacro Bosco Commentarivs. Romae: apud Victorium Helianum. http://hdl.handle.net/21.11103/sphaera.100365.

- 1581. In Sphaeram Joannis de Sacro Bosco Commentarius. Roma: ex officina Dominici Basae. http://doi.org/21.11103/sphaera.101117.

Cohen-Skalli, Cedric. 2006. Authorship in the age of early jewish print: Isaac Abravanel's Ma'aynei ha-Yeshu'a and the first printed edition in Ferrara 1551. In Tradition, heterodoxy and religious culture: Judaism and Christianity in the early modern period, ed. Chanita Goodblatt and Howard Theodore Kreisel, 185-201. Beer-Sheva: Ben-Gurion University of the Negev.

Curto, Diogo Ramada. 1997. The stranger within in the time of Quijote. Portuguese Studies 13: 180-197.

da Costa, Adalgisa Botelho. 2007. O "Reportorio dos Tempos" de André do Avelar e a Astrologia em Portugal no século XVI. Rio de Janeiro: Booklink.

da Fonseca, Fernando Taveira. 2001. Pedro Nuñes na Universidade. II - Coimbra. Revista Portuguesa de História 35: 297-333.

- 2004. Pedro Nuñes na Universidade. I - Lisboa. In Estudos em Homenagem a Luis António de Oliveira Ramos, ed. Francisco Ribeiro da Silva et al., vol. 1, 537-544. Porto: Faculdade de Letras da Universidade do Porto.

da Mota, Avelino Teixeira. 1976. Some notes on the organization of hydrographical services in Portugal before the beginning of the nineteenth century. Imago Mundi 28: 51-60.

de Albuquerque, Luís Mendonça. 1965. Os Guias Náuticos de Munique e de Évora. Lisboa: Junta de Investigações do Ultramar.

de Almeida, Manoel Lopes. 1967. Apontamentos para a Biografia de André de Avellar: Professor de Matemática na Universidade. Revista da Faculdade de Ciências da Universidade de Coimbra 29: 31-72.

de Azevedo, João Lucio. 1921. Historia dos Christãos Novos Portugueses. Lisboa: Livraria Clássica Editora.

de Blois, Louis. 1583. Tabella Spiritualis aliâs Sacellum Animae fidelis Nuncupata. Continens brevem Institutionem vitae Christianae. Pataviae: Matthaeus Nenninger.

Carvalho, João Manuel Almeida Saraiva de. 1990. The fellowship of St. Diogo: New christian judaisers in Coimbra in the early 17th century. PhD diss. University of Leeds.

de Espinosa, Pedro. 1550. Sphera Ioannis de Sacro Busto. Cum Commentariis Petri a Spinosa Artium Magistri, Celeberrimiq[ue] Praeceptoris Salmanticensis Gymnasij, Aeditis. Salmanticae: Ioannes Iunta. http://hdl.handle.net/21.11103/sphaera.100199.

de Sacrobosco, Johannes. 1499. Sphaera mundi cum tribus commentis. Venezia: per Simonem Papiensem dictum Biuilaquam. http://hdl.handle.net/21.11103/sphaera.100021.

- 1508. Nota eorum quae in hoc libro continentur. Venezia: Iuncta de Iunctis. http://hdl. handle.net/21.11103/sphaera.100915.

— 1527. Textus de sphaera Ioannis de Sacrobosco. Paris: Simonem Colinaeum. http://hdl. handle.net/21.11103/sphaera.100998.

- 1531. Liber Iohannis de Sacro Busto, de sphaera. Addita est praefatio in eundem librum Philippi Mel. ad Simonem Gryneum. Wittenberg: Josephum Clug. http://hdl.handle. net/21.11103/sphaera.100138.

—. 1538. Textus de sphaera Ioannis de Sacrobosco. Paris: Simonem Colinaeum. http://hdl. handle.net/21.11103/sphaera.101011.

- 1545. Sphaera Ioannis de Sacrobosco typis avctior. Paris: apud Guilielmum Richardum. http://hdl.handle.net/21.11103/sphaera.101054.

- 1547. Sphaera Iohannis de Sacrobosco. Antuerpiae: Iohannem Richardum. http://hdl. handle.net/21.11103/sphaera.100917; http://hdl.handle.net/21.11103/sphaera.100143. 
1550. Ioannis de Sacro Busto Libellus de sphaera: Accessit Eiusdem Autoris Computus Ecclesiasticus. Wittenberg: Iohannem Cratonem. http://hdl.handle.net/21.11103/ sphaera.100157.

- 1564. Sphaera Ioannis de Sacro Bosco emendata. Lugduni [Lyon]: apud Haeredes Iacobi Iunctae. http://hdl.handle.net/21.11103/sphaera.101071.

- 1573. Sphaera Ioannis de Sacro-Bosco, emendata. Antuerpiae: apud Ioannem Bellerum. http://hdl.handle.net/21.11103/sphaera.100460.

Delgado, Vicente Muñoz. 1983. Pedro de Espinosa (+1536) y la Lógica en Salamanca hasta 1550. Anuario Filosofico 16: 119-208.

Deslandes, Venancio Augusto. 1888. Documentos para a Historia da Typographia Portugueza nos Seculos XVI e XVII. Lisboa: Imprensa Nacional.

Dias, Nuno, Elza Amaral, and José M. Cobos. 2012. Influência dos Jesuítas no Ensino em Portugal. Llull 35 (75): 111-128.

Díaz Díaz, Gonzalo. 1987. Hombres y Documentos de la Filosofía Española. Madrid: Consejo Superior de Investigaciones Cientificas.

do Amaral, António Eugénio Coelho Maia. 2014. Os Livros em sua Ordem: para a História da Biblioteca Geral da Universidade (antes de 1513-2013). Coimbra: Imprensa da Universidade de Coimbra.

do Avelar, André. 1546. Chronographia ou reportório dos tempos o mais copioso que te agora sayo a luz conforme a noua reformação do santo Papa Gregorio XIII. Lisboa: Simão Lopez.

-1585. Reportorio dos tempos. O Mais Copioso que Ate Agora Sahio a Luz, Conforme à Noua Reformação do Sancto Padre Greg. XIII. Anno 1582. Lisboa: Manoel de Lyra.

1590. Reportorio dos Tempos. O Mais Copioso que Ate Agora Saio a Luz Conforme a Noua Reformação do Sancto Papa Gregorio XIII. Nesta segunda impressam reformado \& acrescentado pelo mesmo author. Lisboa: Manoel de Lyra.

- 1593. Sphaerae Utriusq[ue] Tabella ad Sphaerae huius Mundi Faciliorem Enucleationem. Autore Andrea d'Avellar Olysiponensi, Artium, ac Philosophiae magistro, \& publico in Conimbricensi Academia Mathematum professore. Conimbricae: Antonius Barrerius. http:// hdl.handle.net/21.11103/sphaera.100534.

- 1594. Chronographia ou Reportorio dos Tempos. O Mais Copioso que te Agora Sayo a Luz Conforme a Noua Reformação do sancto Papa Gregorio XIII. Nesta terceira impressã reformado \& acrecentado pello mesmo author. Lisboa: em casa de Simão Lopez.

-1602. Chronographia ou Reportorio dos Tempos. O Mais Copioso que te Agora Sayo a Luz. Conforme a Noua Reformação do Santo Papa Gregorio XIII. Nesta quarta impressam reformado \& acrescentado pelo mesmo author. Lisboa: Iorge Rodriguez.

do Avelar, Luís. 1619. Nox attica. Hoc est Dialogvs de Impressione Metheorologica, et Cometa Anni Domini 1618. Coimbra: Nicolau Carvalho.

Encyclopedia e Diccionario Internacional. 1933. Organizado e redigido com a collaboração de distinctos homens de sciencia e de lettras brasileiros e portuguezes. Rio de Janeiro: W. M. Jackson.

Fernandes, Manuel Bernardo Lopes. 1856. Memoria das Moedas Correntes em Portugal, desde o Tempo dos Romanos, até o Anno de 1856. Lisboa: Academia Real das Sciencias.

Fiolhais, Carlos, and Décio Martins. 2016. Reportório da Ciência Matemática em Portugal entre 1582 e 1623: André de Avelar em Coimbra e os Jesuítas da Aula da Esfera em Lisboa. In Concilio de Trento: innovar en la tradición: historia, teología y proyección, ed. José Eduardo Franco et al., 711-718. Alcalá de Henares: Universidad de Alcalá.

Folk, Katharina. 2009. Manilius and his intellectual background. Oxford: Oxford University Press.

Fuentes, Jesus Luis Paradinas. 2012. Las Matemáticas en la Ratio Studiorum de los Jesuitas. Llull 35 (75): 129-162.

Galilei, Galileo. 1656. In Trattato Della Sfera Ovvero Cosmografia, ed. Urbano d'Aviso. Roma: N. A. Tinassi.

Gelli, Jacopo. 1916. Divise, Motti e Imprese di Famiglie e Personaggi Italiani. Milano: Ulrico Hoepli. 
Gingerich, Owen. 1988. Sacrobosco as a textbook. Journal for the History of Astronomy 19 (4): 269-273.

Giuntini, Francesco. 1578. Commentaria in Sphaeram Ioannis de Sacro Bosco Accuratissima. Lugduni: Philippum Tinghius. http://hdl.handle.net/21.11103/sphaera.100393.

_. 1581-1583. Speculum astrologiae. 2 vols. Lugduni [Lyon]: Simphorianum Beraud. http:// hdl.handle.net/21.11103/sphaera.101207.

Goldstein, Bernard R. 1996. Astronomy and astrology in the works of Abraham ibn Ezra. Arabic Sciences and Philosophy 6 (1): 9-21.

-1998. Abraham Zacut and the medieval hebrew astronomical tradition. Journal of the History of Astronomy 29 (2): 177-186.

. 2001. Astronomy and the jewish community in early islam. Aleph 1: 17-57.

Goold, George P. 1977. Introduction. In Astronomica, ed. Marcus Manilius, xi-cxxiii. Cambridge, MA: Harvard University Press.

Graminaeus, Theodor. 1567. Uberior enarratio eorum, quae a Joanne de Sacro Bosco proponuntur: ita ut adjecta difficilioribus locis commentarii vicem supplere possit. Coloniae: apud Maternum Cholinum.

Hopkins, Marjorie Irene. 2016. Humanism as civic project: The Collège de Guyenne 1533-1583. Ph.D. Dissertation. University of Guelph.

Knobloch, Eberhard, comp. 1999. Christoph Clavius. In Sphaeram Ioannis de Sacro Bosco Commentarius. Olms-Weidmann: Hildesheim.

Lattis, James M. 1994. Between Copernicus and Galileo: Christoph Clavius and the collapse of ptolemaic cosmology. Chicago: The University of Chicago Press.

Lawee, Eric. 2001. The messianism of Isaac Abarbanel, father of the [jewish] messianic movements of the sixteenth and seventeenth centuries. In Millenarianism and Messianism in early modern European culture, ed. M. Goldish and R.H. Popkin, 1-39. Dordrecht: Springer.

Leitão, Henrique. 2002. Introdução. In Pedro Nuñes (1502-1578): novas terras, novos mares e o que mays he: novo ceo e novas estrelas, ed. Henrique Leitão and Lígia de Azevedo Martins, 15-28. Biblioteca Nacional: Lisboa.

-2008. A Ciência na Aula da Esfera no Colégio de Santo Antão: 1590-1759. Lisboa: Comissariado Geral das Comemorações do V Centenário de S. Francisco Xavier.

Leite, Serafim. 1963. Estatutos da Universidade de Coimbra (1559). Coimbra: Universidade de Coimbra.

Lenard, Max. 2006. On the origin, development and demise of the Index Librorum Prohibitorum. Journal of Access Services 3 (4): 51-63.

Lucian. 1905. The works of Lucian of Samosata. Trans. Henry Watson Fowler, and Francis George Fowler. Oxford: The Clarendon Press.

Lima, Fernando Carlos G. de Cerqueira. 2005. Uma análise crítica da literatura sobre a oferta e a circulação de moeda metálica no Brasil nos séculos XVI e XVII. Estudos Econômicos 35 (1): 169-201.

Machado, Diogo Barbosa. 1965-1967. Bibliotheca Lusitana Histórica, Crítica e Cronológica. Coimbra: Atlântida.

Manilius, Marcus. 1977. Astronomica, ed. and trans. George P. Goold. Cambridge, MA: Harvard University Press.

Martins, Roberto de Andrade. 2003a. Las Fuentes Literarias del Tratado de la esfera de Sacrobosco. In Epistemología e Historia de la Ciencia. Selección de Trabajos de las XIII Jornadas, ed. Víctor Rodríguez and Luis Salvatico, 307-314. Córdoba: Universidad Nacional de Córdoba.

_ 2003b. O Tratado da Esfera de André do Avelar (1593). Paper presented at the $9^{\circ}$ Seminário Nacional de História da Ciência e da Tecnologia and $2^{\circ}$ Congresso Luso-Brasileiro de História da Ciência e da Tecnologia, Rio de Janeiro, October 08-10, 2003. http://www.ghtc.usp.br/ server/pdf/ram-Sacro-Avellar.pdf. Accessed June 2019

Martins, Maria Teresa Payan. 2011. O Índice Inquisitorial de 1624 à Luz de Novos Documentos. Cultura. Revista de História e Teoria das Ideias 28: 67-87. 
Martins, Roberto de Andrade, and Walmir Thomazi Cardoso. 2008. O Trattato della sfera ovvero cosmografia de Galileo Galilei e algumas cosmografias e tratados da esfera do século XVI. Episteme 13 (27): 15-38.

- 2017. Galileo's Trattato della Sfera ovvero Cosmografia and its sources. Philosophia Scientae 21: 131-147.

Melanchthon, Philipp Petrus Vincentius. 1579. In Epigrammatum Libri Sex, ed. Petrus Vincentius, 1579. Wittenberg: Haeredes Iohannis Cratonis.

Merrill, Eugene H. 1973. Sabbatai Zvi and Jewish Messianism. Journal of the Evangelical Theological Society 16 (3): 159-165.

Montenegro, Enrique Cantera. 2017. La esperanza mesiánica en el judaísmo hispano medieval. Estudios de Historia de España 8: 11-57.

Moreton, Jennifer. 1994. John of Sacrobosco and the calendar. Viator 25: 229-244.

Nuñes, Pedro. 1537. Tratado da Sphera com a Theorica do Sol \& da Lua. E ho Primeiro Liuro da Geographia de Claudio Ptolomeo Alexãdrino. Lixboa: per Germão Galharde. http://hdl. handle.net/21.11103/sphaera.101010.

- 1940. Obras. Vol. 1. Lisboa: Academia das Ciências de Lisboa.

Osório, José Pereira. 1986. Sobre a história e desenvolvimento da astronomia em Portugal. In História e desenvolvimento da ciência em Portugal. I colóquio-até ao século XX, ed. José Pinto Peixoto, vol. 1, 111-142. Lisboa: Academia das Ciências de Lisboa.

Palliser, Bury. 1870. Historic devices, badges, and war-cries. London: Sampson Low, Son \& Marston.

Patai, Raphael. 1988. The messiah texts. Jewish legends of three thousand years. Detroit: Wayne State University Press.

Reportorio dos Tempos Muito Curioso. Acrescentado e Emendado de Nouo Conforme a Noua Constituição do Sanctíssimo Papa Sixto Quinto que Tirou os Abusos. 1590. Coimbra: António de Barreira impressor da Universidade

Rodrigues, Manuel Augusto. 2006. Notas sobre a Universidade de Coimbra desde as origens (1290) até à fixação definitiva em Coimbra (1537). In Estudos em homenagem ao Professor Doutor José Marques, vol. 3, 111-128. Porto: Faculdade de Letras da Universidade do Porto. 4 vols.

2010. O judeu português Isaac Abravanel no espaço ibérico e europeu. Revista de Historia das Ideias 31: 77-115.

Rodríguez-Arribas, Josefina. 2005. Historical horoscopes of Israel. In Horoscopes and public Sphaeras: Essays on the history of astrology, ed. Günther Oestmann, H. Darrel Rutkin, and Kocku von Stuckrad, 145-164. Berlin: Walter de Gruyter.

- 2011. The terminology of historical astrology according to Abraham Bar Hiyya and Abraham Ibn Ezra. Aleph. Historical Studies in Science \& Judaism 11: 10-54.

Roth, Cecil. 1959. A history of the Marranos. New York: Meridian Books.

Ruderman, David B. 1992. Hope against hope: Jewish and christian messianic expectations in the late middle ages. In Essential papers on Jewish culture in renaissance and Baroque Italy, ed. David Ruderman, 299-323. New York: New York University Press.

- 2001. Jewish thought and scientific discovery in early modern Europe. Detroit: Wayne State University Press.

Sáenz-Badillos, Ángel. 1999. Milenarismo y Cábala entre los judíos hispanos. In Milenarismos y milenaristas en la Europa Medieval, 177-202. Nájera: Instituto de Estudios Riojanos.

Salomon, Herman Prins. 1998. Crypto-judaism or inquisitorial deception? The Jewish Quarterly Review 89 (1/2): 131-154.

Schwartz, Stuart B. 2008. All can be saved: Religious tolerance and salvation in the Iberian Atlantic world. New Haven: Yale University Press.

Sela, Shlomo. 2010. Abraham Ibn Ezra, the book of the world: A parallel hebrew-english critical edition of the two versions of the text. Leiden: Brill. 
Silva, Ana Cristina, Ferreira, Teresa Duarte. 2008. Catálogo. In Sphaera Mundi: A ciência na Aula da Esfera. Manuscritos científicos do Colégio de Santo Antão nas colecç̧ões da BNP, ed. Henrique Leitão, 99-247. Lisboa: Biblioteca Nacional de Portugal.

Silver, Abba Hillel. 1927. A history of messianic speculation in Israel. From the first to the seventeenth century. New York: Macmillan.

Teixeira, Antonio José. 1895. Antonio Homem e a Inquisição. Coimbra: Imprensa da Universidade. 1899. Documentos para a Historia dos Jesuitas em Portugal. Coimbra: Imprensa da Universidade.

Thorndike, Lynn. 1954. Computus. Speculum 29 (2): 223-238.

Universidade de Coimbra. 1593. Estatutos da Vniuersidade de Coimbra. Confirmados por el rey Dom Phelippe primeiro deste nome, nosso Senhor em o anno de 1591. Comibra [sic]: por Antonio de Barreira.

Valerius, Cornelius. 1564. De Sphaera, Et Primis Astronomiae Rvdimentis, Libellvs vtilissimvs. Antverpiae: Silvius.

Valleriani, Matteo. 2017. The tracts on the Sphere. Knowledge restructured over a network. In The structures of practical knowledge, ed. Matteo Valleriani, 421-473. Dordrecht: Springer.

Vinet, Élie. 1561. Sphaera Joannis de Sacro Bosco Emendata. Lutetiae: apud Gulielmum Cavellat. http://hdl.handle.net/21.11103/sphaera.100211.

Open Access This chapter is licensed under the terms of the Creative Commons Attribution 4.0 International License (http://creativecommons.org/licenses/by/4.0/), which permits use, sharing, adaptation, distribution and reproduction in any medium or format, as long as you give appropriate credit to the original author(s) and the source, provide a link to the Creative Commons license and indicate if changes were made.

The images or other third party material in this chapter are included in the chapter's Creative Commons license, unless indicated otherwise in a credit line to the material. If material is not included in the chapter's Creative Commons license and your intended use is not permitted by statutory regulation or exceeds the permitted use, you will need to obtain permission directly from the copyright holder.

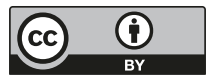




\title{
Chapter 11 \\ Fashioning Cosmology: Franco \\ Burgersdijk as the Author of the Dutch \\ Tractatus de sphaera
}

\author{
Marius Buning
}

\begin{abstract}
In 1625, the highest authorities in the province of Holland prescribed the use of De sphaera in all the regional Latin schools. For the occasion, they decided that a new edition of the famous text by Johannes de Sacrobosco was needed, primarily to purify the textbook of its "barbaric" Latin. The task of editing the text was assigned to Leiden professor Franco Burgersdijk. In what follows, I situate Burgersdijk's 1626 edition of De sphaera in the broader context of Leiden Aristotelianism, discussing the relationship between religion, educational practices, and astronomy in the first decades of Dutch independence. Teasing out some of the differences with the other contemporary manuals circulating on the market, I argue that Burgersdijk's version of Sacrobosco's textbook must be seen as an attempt to make the Dutch less dependent on Catholic literature and modes of knowledge production.
\end{abstract}

\section{Life and Work}

Burgersdijk was a farmer's son, born in 1590 in De Lier, Delfland, not far from The Hague, where the Dutch authorities had declared their independence from landlord Philip II (1527-1598) and the Spanish Habsburg Empire in $1581 .{ }^{1}$ According to his first biographer, the young Burgersdijk attended the Latin school at Amersfoort (1604-1606) and the Delft Gymnasium (1606-1610), where he first became familiar with the art of logic and rhetoric. Like many farmer's sons, he then attended the University of Leiden to study theology. He was thoroughly immersed in the art of disputation and undertook private lessons with the famous scholastic adversary of

\footnotetext{
${ }^{1}$ I am referring to the Plakkaat van Verlatinghe (1581), the unofficial declaration of independence. On the history of the Dutch Republic, see for instance (Israel 1995). On Burgersdijk, see (Dibon 1954, 90-119; van Meurs 1625, 340-42; Bos and Krop 1993; Molhuysen et al. 1927, 229-31).
}

\author{
M. Buning $(\bowtie)$ \\ Freie Universität Berlin, Berlin, Germany \\ e-mail: marius.buning@fu-berlin.de
}


René Descartes (1596-1650), Gisbertus Voetius (1589-1676), who was at the time still the vice-principal of the Staten Collegie (a boarding school for students of theology established by the States of Holland, the highest provincial authorities). By the time he finished his education, around 1614, Burgersdijk was conversant in Latin and Greek, in Roman History, and in the salient details of the Protestant faith. The next step in his education was undertaking a grand tour, in the course of which he found himself for some time in the Academy of Saumur. There, he worked with the Scottish philosopher Mark Duncan (ca. 1570-1640) and the strict Calvinist theologian Franciscus Gomarus (1563-1641), who had fled to the Huguenot University in 1611 to escape his Dutch Arminian opponents. And it was in Saumur, in 1614, that Burgersdijk would first attain to a professorship in philosophy.

Burgersdijk's academic career cannot be understood without some degree of insight into the religious troubles that flared up in the period right after the young Dutch Republic had agreed on an armistice with the Spanish enemy. The ink on the treaty, concluded in 1609, was not yet dry when the followers of the Leiden theology professor Jacobus Arminius (1560-1609) requested the States of Holland to call for a church synod in order to decide on a number of sensitive religious issues in the series of heated debates between Arminius and Gomarus (contingent on their respective leaders, followers of both theologians were also called Gomarists or Arminians). The issue at stake in the debates, which later took a violent turn, was the correct interpretation of the Holy Scriptures; whereas the Arminians reckoned with the possibility of a very moderate form of free will, the Gomarists insisted on a strict interpretation of Calvin's notion of double predestination and denied man any form of influence on his future salvation. ${ }^{2}$

The ecclesiastical conflict had been deeply intermingled with Dutch internal power politics from the start. Whereas the Gomarists favored a form of state religion-having the Calvinist Basel in mind as an ideal-the Arminians were generally more liberal in their views on the relationship between the church and the state. ${ }^{3}$ The disagreements lingered on for years, suddenly escalating in 1618, when the central authorities of the federal Dutch state, the States-General, agreed to summon an international synod despite the objections of the mighty province of Holland, run mostly by regents who supported the Arminian faction. The States of Holland reacted by raising a military force to restore order, which brought them in direct conflict with Stadtholder Prince Maurice of Orange (1567-1625). In what has been identified as nothing less than "a coup," Maurice set off on a military campaign and quickly took power of the entire country. ${ }^{4}$ The political skirmishes concluded dramatically with the beheading of the Land's Advocate of Holland, Johan van

\footnotetext{
${ }^{2}$ Arminians were willing to pretend a certain ignorance on the issue, and to speak of God's 'stationary' or 'permitting' will (voluntas remissa, pace Perkins and others). The Arminians were strongly influenced by the Spanish scholastics on this point, and notably by Suarez and Molina (Dekker 1993, 115, 188).

${ }^{3}$ Speaking in general terms, one could say that the Arminians consisted of people from the regent class, whereas the Gomarists were found in greater numbers among the common people (Prak 2005, 31).

${ }^{4}$ For more details, see (Israel 1995, 426-57).
} 
Oldenbarnevelt (1547-1619), on the Inner Court in The Hague. The religious bickering was settled with the international Synod of Dort, which had its last meeting on the $9^{\text {th }}$ of May 1619.5 The Synod of Dort finally ruled in favor of the Gomarists and some two hundred Arminian preachers were dismissed from office (de Nijs and Beukers 2002, 311). ${ }^{6}$

Arminianism was rooted out at all levels in the Republic, including at the universities. With numerous positions opening up in the "purified" University of Leiden, Burgersdijk immediately saw his chance to return to Holland. The university initially offered him an extraordinarius professorship in logic, which he accepted on the $25^{\text {th }}$ of March 1620, obtaining the title of Magister philosophiae on the $31^{\text {st }}$ of March 1620, during a promotion ceremony led by the famous astronomer and mathematician Willebrord Snellius (1580-1626). In November 1620, ethics was added to Burgersdijk's teaching duties, and on the $9^{\text {th }}$ of February 1621, Burgersdijk was promoted to ordinarius professor. In 1623, he finally completed his theological education by defending a disputation entitled "The Clarity of the Bible and Its Interpretation" (Krop 2014, 2).

Meanwhile, Burgersdijk had maintained an ongoing interest in natural philosophy. In two series of disputations, the first held in 1623 and the second in 1627, his students had dealt with the Aristotelian knowledge corpus on natural knowledge. It brought him into direct conflict with the Leiden Professor Jacchaeus, his former teacher, who bitterly complained at the Leiden Senate that Burgersdijk was overstepping the boundaries of his discipline (Dibon 1954, 97). Jacchaeus had held the chair of natural philosophy since 1617 and remained active in that capacity until his death in $1628 .^{7}$ Soon after the chair had become vacant, on the $9^{\text {th }}$ of May 1628 , Burgersdijk exchanged it with his chair in ethics. It was under these circumstances that

...Burgersdijk devoted two manuals [to physics]. The Idea is conceived as a "guide" to be used in disputations, presenting the subject matter in definitions and short theses. By referring only to "new" authorities such as Jacopo Zabarella, Benedict Pereira, Franciscus Toletus, and the commentators of Coimbra, Burgersdijk stated as his goal to open the debate on the "text of Aristotle." In the more extensive Collegium, the same doctrinal tradition is elaborated in a synthetic order. (Krop 2014, 3) ${ }^{8}$

\footnotetext{
${ }^{5}$ The first meeting of the Synod of Dort had been on the $13^{\text {th }}$ of November 1618.

${ }^{6}$ The Synod of Dort confirmed the authority of the Belgic Confession and the Heidelberg Catechism, and drew up ninety-three new canonical rules. Furthermore, the Synod decided upon several other issues, such as the production of a Bible translation into the vernacular funded by the States-General (which eventually resulted in the 1637 Statenbijbel).

${ }^{7}$ The Scot Gilbert Jack (Lat. Jacchaeus) had first held the chairs for logic and ethics at the University of Leiden $(1605,1607)$, before publishing his lnstitutiones physicae in 1614, which has been identified as "the first work of any note on physics to issue from Leiden's faculty" (Ruestow 1973, 14). Jacchaeus was made a full professor of natural philosophy in 1617. On Jack, see (Smolenaars 2004). He "taught a reformed Aristotelianism which also made use of recent scholarship, including Zabarella, Suarez, and the Coimbra commentators" (Mijers 2017, 91). Burgersdijk would do the same. He had also taken over the teaching duties of Jacchaeus, when the latter was suspended for 3 months on the suspicion of Arminian sympathies in 1619, in the wake of the Synod of Dort.

${ }^{8}$ On Burgersdijk's Physics, see also (Dibon 1954, 90-119; Ruestow 1973, 5-33). An overview of Burgersdijk's publications can be found in (Bos and Krop 1993, 167).
} 
Although Burgersdijk did recognize the birth of new stars (Ruestow 1973, 30) and that heavens act on the terrestrial world by occult qualities, not just by light and motion (Vermij 2016, 293; Vermij 2002, 132), the ensemble of his natural philosophy has nevertheless been characterized as "the Aristotelian principles in an extreme and simplistic (and distorted) rendering...presented largely in the guise of first matter and substantial form" (Ruestow 1973, 22). Indeed, it was not for his natural philosophy that he would be remembered when he died on the $19^{\text {th }}$ of February 1635, eleven days after the end of his last term as Rector Magnificus of Leiden University. ${ }^{9}$

Instead, the Leiden Professor became known for his compendium on logic, the Institvtionvm logicarvm libri duo (Leiden, Commelius, 1626), which, "[a]lthough abhorred by students[,]...lingered in the curriculum of the British universities well into the eighteenth century" (Krop 2014, 1). ${ }^{10}$ Like his other manuals, the Institutionum was characterized by a strong inclination towards order and method. ${ }^{11}$ Although an Aristotelian in heart and soul, Burgersdijk deplored the messy presentation in the work of the Stagerite. On the other hand, he believed that in the work of humanists such as Valla, Agricola, and Ramus, where method did prevail, content had fallen behind. It was thus best to follow the example of Bartholomaeus Keckermann (1672-1609) by adopting the method of Ramus and the material of Aristotle. Burgersdijk claimed that, by doing so, he followed in the footsteps of his former mentor in Saumur, Mark Duncan. ${ }^{12}$

Aside from his works on logic and natural philosophy, Burgersdijk wrote a number of compendia on moral and political thought, again heavily inspired by Aristotle. If one was to summarize his academic career in one sentence, one could say that Burgersdijk was perhaps not a very original thinker, but a dedicated educator who brought stability to Leiden University in the wake of the Synod of Dort. It is indeed in this light that we must also read Burgersdijk's 1626 edition of Sacrobosco's textbook on the Sphaera - a booklet produced under the direct order of the Dutch political authorities.

\footnotetext{
${ }^{9}$ Burgersdijk was the rector of Leiden University in 1629, 1630, and 1634.

${ }^{10}$ On the influence of Burgersdijk in England, see also (Feingold 1993). On the status of Philosophy course at Leiden University (Sassen 1959; Dibon 1954, 71-76). Like De sphaera, the Institutionum was commissioned by the States of Holland in the framework of the 1625 School Order, which was intended to provide unity in the Dutch educational program.

${ }^{11}$ On "order" in the Philosphiae naturalis, see (Dibon 1954, 95). On the general emphasis on "method" at the time, see (Gilbert 1963).

${ }^{12}$ On the influence of Duncan on Burgersdijk, see (Prost 1907, 42-44). On the Scottish influence on Dutch universities, see (Mijers 2017). On Leiden University more generally, see (Otterspeer 2000; Ruestow 1973; Wiesenfeldt 2002).
} 


\section{The Schoolorde (1625)}

In the hive-off of the Spanish Habsburg Empire, the Northern Netherlands became a kind of federal republic, in which seven semi-independent provinces were each represented with one vote in the Assembly of the States-General seated in The Hague. The provinces, of which Holland was by far the most powerful, were in turn managed by a provincial assembly led by an individual Stadtholder (whose office was a strange remnant from the Habsburg period, resembling a cross between a prince and a president). In reality, the Stadtholder of Holland observed the Stadholdership of the majority of other provinces.

In addition, there were many other interest groups in the political domain, including the different trading companies and various congregations within the Dutch Reformed Church, which met at irregular intervals in provincial synods. It was at one of these provincial synods that the call for a reform of the Dutch educational system could first be heard. During the South Holland Synod held in Rotterdam in 1581 , members of the congregation expressed their explicit concern about the lack of properly schooled ministers. The radical break with the Catholic Habsburg landlord in their eyes called for immediate joint action by the Republican authorities to ensure the establishment of a single Dutch reformed identity. Though similar sentiments could be heard at various other provincial synods between 1583 and 1618, the political leadership did not take any action. ${ }^{13}$ The issue of religious education was taken up again at the international Synod of Dort, where various ecclesiastical representatives insisted that the States-General should be urged to bring "unity in the education of the Youth, in particular in the rules of Grammar, Dialectics and Rhetoric." ${ }^{14}$ An official request to the States-General was indeed submitted on the $18^{\text {th }}$ of May 1619; yet again it did not prompt any action. The congregation continued to complain about the matter at various synods, and in 1622, a commission was even appointed "to study the school order made in the Pfaltz, in Gelderland, in Groningen and elsewhere" in order to come up with a proposal to reform the educational system. ${ }^{15}$ Eventually, it all had little effect.

Simultaneously, complaints about the inadequate level of secondary education could be heard at Leiden University, where the professors claimed that students were not well prepared to follow even the most basic university courses in Latin. They attributed this shortcoming to the fragmentation of pre-university school programs and argued that school pupils would benefit from having a more standardized

\footnotetext{
${ }^{13}$ Kuiper provides a list with no less than sixteen instances of complaint (Kuiper 1958, 39-40).

14 “...eenparigheyt gehouden werde in de onderwijsinghe van de Jeught, voor al in de regelen van de Grammatica, Dialectica en Retorica." Kerkelijk Placaetboek van N. Wilkens (1722), I, p. 127 sq. As cited in (Kuiper 1958, 40). All translations of the source material are by the author unless otherwise stated.

${ }^{15}$ (Kuiper 1958, 40): “...visiteren ende confereren de schoolordeninghe, die gemaect syn in de CHURFORSTELICHE PFALTZ, in GELDERLAND, in GROENINGEN ende elders om daeruyt een project te maecken." The commission was formed during the South Holland synod of Gorinchem in July 1622.
} 
regimen of studies. ${ }^{16}$ After various failed efforts, the Senate of the University, in 1624, impressed upon the Assembly of the States of Holland the necessity of concrete measures. Clearly aware of the earlier efforts in the various synods, a plan was handed in that would (1) guarantee the quality of the secondary educational program and (2) ensure that the youth could move from city to city without having to use new books at every location (Kuiper 1958, 48-51). Should new measures not be implemented, the Senate warned, it was "to be feared that the young adolescents will degenerate again ad barbariam." 17

The States of Holland gave a full and sympathetic consideration to the complaints of the University, asking the Curators to draft a program that could be implemented in the Latin Schools in the province. On the $4^{\text {th }}$ of February 1625, the Curators organized a meeting with some deputies of the University Senate and of the Holland Synodes in order to come up with a proposal. The deputies of the University Senate were Antonius Walaeus (1573-1638), Antonius Thysius the Elder (1565-1640), Gerhard Johannes Vossius (1577-1649), Petrus Cunaeus (1586-1638), Daniel Heinsius (1580-1655), and Burgersdijk, who was thus closely involved in the making of the order from the very start. Indeed, no less than three members of the senatorial committee managed to put their own books on the obligatory reading list; it seems not to have bothered the commission nominated on the $22^{\text {nd }}$ of July 1625 to study the proposals made by the University. ${ }^{18}$ The draft program was approved and on the $1^{\text {st }}$ of October 1625, the States of Holland enacted the School Order (Schoolorde) that would remain in force until the early nineteenth century.

\section{Print and Privilege}

The School Order meticulously prescribed the use of specific books on specific hours, laying out an intense program for school-aged children (ca. twelve to eighteen years old) from Monday morning through to Saturday afternoon. Willem Frijhoff has provided such an eloquent and concise overview of this program that it deserves to be quoted here in full:

When the child had completed the writing classes, he entered the sixth (lowest) class, where he learned declensions and conjugations and parts of speech (the Rudimenta), and practiced reading Erasmus's dialogues. Subject matter for the fifth class included the letters of Cicero and the Disticha of Cato, as well as Erasmus's book of etiquette. The fourth class brought more Cicero, some Terence, and — as first exercises in prosody—Ovid's Tristia and Virgil's

\footnotetext{
${ }^{16}$ Kuiper convincingly identifies examination methods based on memorization as one of the main "culprits" in this entire problematic (Kuiper 1958, 45).

${ }^{17}$ (Kuiper 1958, 49): “...staet te vreesen, dat de jonge jeugt wederom soude mogen ad barbariem vervallen."

${ }^{18}$ The committee appointed by the States of Holland consisted of representatives from Dordrecht, Haarlem, Alkmaar, Amsterdam, and Hoorn (all cities with famed Latin Schools).
} 
Bucolica. From that point on the pupil also delved seriously into Greek. The focus of the second class was on rhetoric, explained with the aid of Vossius's handbook, and more Cicero, who was now studied in great detail. The program of the highest class included the logic of the Leiden professor Franco Burgersdijk, as well as Horace and Homer, and again the inescapable Cicero. The top group of the highest class was initiated into the world of the quadrivium (music, arithmetic, geometry, and astronomy), with lessons in ethics, the arithmetic of Gemma Frisius, and the Sphaera of Johannes de Sacrobosco. (Frijhoff and Spies $2004,245)^{19}$

With the existence of a fixed catalogue with books that had to be printed on a regular basis, there was a group of printers in the Republic who were attracted by the prospect of making financial gains. One way to increase their profit margin was by securing a so-called "printing privilege" from the local authorities. A printing privilege provided the exclusive rights for a limited time (generally around 8 years) to print a book for the Dutch market. ${ }^{20}$ Regularly issued for the printing of catechisms and schoolbooks written in Dutch, the Republican authorities did not issue many printing privileges for the production of works in Latin. In 1581, for example, the schoolmaster Cornelius Schonaeus (1540-1611) had tried in vain to obtain a privilege for a Latin grammar book, which would prevent instruction "from any other grammar book in the province of Holland." ${ }^{21}$ His request was denied, and the States of Holland opted to give a reward instead. The same year, the famous printer Christophe Plantin (ca.1520-1589) made another attempt to obtain a printing privilege for a grammar book by Cornelius Valerius (1512-1578), a former professor of Latin at the famed Collegium Trilingue in Leuven (Molhuysen 1913, 18 (27 $7^{\text {th }}$ of April 1581). Although supported by the Leiden University Senate, Plantin's attempt to claim the exclusive rights to the Latin grammar book were similarly unsuccessful. The book by Valerius, first published in 1567, would indeed never be printed in the Republic, but in Antwerp, in 1583, under the earlier privilege that had been issued to Plantin by the Spanish Habsburg authorities in 1566 for a set of books once written by the Leuven Professor for the instruction of the youth:

Grammaticarum institutionum libri quatuor.

Tabula summam artis Rhetorica complectens etc.

\footnotetext{
${ }^{19}$ The short overview by Frijhoff is obviously far from complete; a full transcription of the Order can be found in (Kuiper 1958, 5-25).

${ }^{20}$ Printing privileges were mainly issued by the (inter)provincial authorities in the Dutch Republic, not by the cities. In addition to sanctions against copying, they often contained a clause that prohibited the import of printed materials from abroad. The first printing privileges issued independently by the Dutch authorities date from the 1580s; they were issued for books as well as for other printed materials, such as globes and copper engravings. On the history of printing privileges in the Dutch Republic, see (Hoftijzer 1993; Schriks 2015; Buning 2019; Orenstein 2006).

${ }^{21}$ (Kuiper 1958, 39-40): "van dat geene andere grammatica binnen Holland geleert soude mogen worden,"18th of March 1581. Schonaeus was the rector of the Latin School in Haarlem; the book was commissioned by the States of Holland, being part of the first political interference in the Dutch educational program by Prince William of Orange, who consulted a commission that included high-level scholars such as Douza, Lipsius, and Donellus. Schonaeus eventually obtained fifty guilders instead of a printing privilege.
} 
Tabulae totius Dialectices etc.

De sphaera \& primis astronomia rudimentis libellus.

Physicae, sue de natua philosophia institutio etc. ${ }^{22}$

In the wake of the Council of Trent (1545-1563), the Spanish Habsburg authorities had clearly chosen to privilege a strong and uniform teaching program in preparation for the Faculty of the Arts. The School Order, as we shall see, was in many ways an attempt to keep up with the educational program as it was implemented in Leuven and elsewhere.

In contrast to what happened in Leuven, however, the Dutch authorities chose not to issue any printing privilege for the books produced in the framework of the School Order. The magistrate of Leiden had initially pushed in the States of Holland for a privilege on "the first Edition of the Books of the School Order, revised and addressed by the Deputies of the Senate of the University, in Leyden, so that the first Copies may be printed perfectly." 23 Yet most members of the Assembly abhorred the idea of a Leiden privilege and it was soon decided that printing the books in the School Order "should remain free" to all. ${ }^{24}$ Nonetheless, Burgersdijk initially managed somehow to obtain a printing privilege for his compendium on logic (the Institvtionvm logicarvm), which inevitably led to problems when he presented the finished book in the Assembly on the $23^{\text {rd }}$ of September 1625. At that point, the authorities decided "that the privilege will not have force, and [instead] to honor him [=Burgersdijk] with a hundred and fifty guilders for his trouble and Dedication." 25 After strong objections by the author, the States reconsidered its decision one week

\footnotetext{
${ }^{22}$ The example comes from (Valerius 1583, A-IV) but can be found in any of the books listed here. See also (Imhof 2014, 702-03). De sphaera by Valerius, for that matter, again followed closely the order used by Sacrobosco.

${ }^{23}$ (Koninklijke Bibliotheek, KW 402 A 31, 607): “...om den eersten Druk van de Boeken van de Schoolordre, by de Gedeputeerden van den Senaat van de Universiteyt gerevideert ende geaddresseert, te moogen doen doen binnen Leyden, op dat de eerste Exemplaren perfect moogen werden gedrukt...," $20^{\text {th }}$ of December 1625. The source material as well as translations of the "Resolutions concerning the Dutch School Order" can be found online at (Bently and Kretschmer 2017). Note that a couple of months later, the Leiden authorities again probed "whether one had to grant the Professors (who corrected the Books) a privilege for some years to have the Books printed at Leyden, so that these would be printed well and correctly for the first journey" (of men de Professoren (de Boeken gecorrigeert hebbende) soude moogen toestaan Octroy voor eenige jaaren, om de Boeken tot Leyden te doen drukken, op dat se wel en correct souden moogen worden gedrukt voor de eerste reyse). Koninklijke Bibliotheek, KW 402 A 31, 663 ( $8^{\text {th }}$ of April 1626). The Provincial Assembly again decided against it.

${ }^{24}$ (Koninklijke Bibliotheek, KW 402 A 31, 607): “...het selve moeten aan alle de Leeden vry gelaaten werden," $20^{\text {th }}$ of December 1625. Translation and transcription available online at (Bently and Kretschmer 2017). It is remarkable that all of the first editions were nevertheless printed in Leiden, and that also later on, Leiden printers kept a privileged position in practice.

${ }^{25}$ (Koninklijke Bibliotheek, KW 402 A 31, 751): “...dat het Octroy van geen kragt en sal weesen, ende dat men hem voor de moeyte en Dedicatie vereeren sal met honderd vyftig guldens," $23^{\text {rd }}-24^{\text {th }}$ of September 1626. Translation and transcription available online at (Bently and Kretschmer 2017).
} 
later, agreeing "that the aforesaid Privilege will serve him from now on for another year in order to get rid of his Copies at a price deemed appropriate by the Delegates States." ${ }^{26}$ Burgersdijk was forbidden, however, to print any additional copies mentioning the existence of a printing privilege.$^{27}$ It was, indeed, without any privilege that Bonaventura Elzevir (1583-1652) and Abraham Elzevir (1592-1652), the printers to the University of Leiden, ${ }^{28}$ one year later marketed the octavo edition of:

Sphaera Johannis de Sacrobosco, Decreto Illustr. \& Potent. DD. Ordinum Hollandiae \& West-Frisiae, in usum scholarum ejusdem provinciae, sic recensita, ut \& Latinitas, \& methodus emendata sit, multaque addita, quae ad huius doctrinae illustrationem requirebantur. Operam \& studio Franconis Burgersdicii. Lugduni Batavorum, Ex Officina Bonaventurae \& Abrahami Elzevir. Academiae Typogr. 1626 (Burgersdijk and de Sacrobosco 1626).

The professors involved in the editing and production of schoolbooks that had become mandatory under the School Order would eventually obtain a total of 2000 guilders for their collective efforts. ${ }^{29}$ Alas, we do not know the exact share of this that Burgersdijk received. What we do know, based on a declaration signed by Burgersdijk upon finishing his project, is that the 1626 edition of De sphaera had a first print run of 600 exemplars, which were sent to twenty different cities in the province of Holland; the biggest school had to purchase ninety-six exemplars and the smallest school six (Kuiper 1958, 86). ${ }^{30}$ Apparently, the Hoorn school master Jacobus Hovius managed somehow to get the schoolbooks for his students for free (Abels 2002, 409), but the rest of books were sold for exactly one stuiver and thirteen penningen per book. ${ }^{31}$ Considering the large numbers of books that were sent to the schools, we may assume that the books were used by students individually in class and passed on from year to year (i.e. they remained in the school).

\footnotetext{
${ }^{26}$ (Koninklijke Bibliotheek, KW 402 A 31, 758): “...om middelertydt syn exemplaren quyt te maaken, ten pryse als de HH. Gecomm. Raden sullen goedvinden ende geen meer moogen doen drucken," $1^{\text {st }}$ of October 1626. Translation and transcription available online at (Bently and Kretschmer 2017).

${ }^{27}$ That printers did not always adhere to the state regulations can be deduced from the fact that, in 1645, an abridged version of Burgersdijk's Logic was still printed with an indication of the 1626 privilege issued by the States General (Burgersdijk 1645). The original printing privilege had by then long lost its legal validity. On the value and meaning of these expired printing privileges, see (Buning, 2019).

${ }^{28}$ On the Elzeviers, see (Willems 1880; Dongelmans et al. 2001).

${ }^{29}$ (Koninklijke Bibliotheek, KW 402 A 31, 780-81), 19 $9^{\text {th }}$ of November 1626. Available online at (Bently and Kretschmer 2017).

${ }^{30}$ The total printing cost of the project was 4604 guilders and fourteen stuivers. Although we lack the exact numbers, the size of the Latin school student body was considerable in the seventeenth century Dutch Republic. It has been reported that, at some point, 2200 students attended a Latin school in Amsterdam (Fortgens 1958, 31). In that light, 600 copies of De sphaera was not necessarily such a large number.

${ }^{31}$ A guilder was worth twenty stuivers; one stuiver equaled sixteen penningen.
} 


\section{Situating De sphaera}

To fully appreciate the status of De sphaera in the educational program of the School Order, it is necessary to say a few words more about the educational system in the Dutch Republic. That system was divided into several phases. The youth first learned to read and write, as well as the fundamentals of the Heidelberger catechism, in so-called "Dutch Schools" (Nederduytsche scholen), or occasionally in "French Schools" (Franse scholen), where they were taught a few words of French and where usually some more attention was given to mathematics and geography. ${ }^{32}$ Youngsters attended these schools (with a lot of variation) between the age of five and twelve, after which most of them dropped out to take up a trade or a craft. Only some continued to follow courses on specific topics in private or evening schools, and only a select group of boys would continue to attend a Latin school that prepared them for university education. ${ }^{33}$ Only at the Latin schools was education carried out in groups, in contrast to the other school types, where teaching was done on an individual basis.

The Latin schools were subdivided into six classes, of which the highest class (class 1) was sometimes split into two divisions. For most pupils, the lowest division was the normal terminus of their education. But sometimes a select group of pupils formed a second division in which more attention was given to topics that were part of the curriculum at the University Faculty of the Arts. It was exclusively in these upper divisions that fragments of De sphaera were read. ${ }^{34}$ In fact, the School Order had been quite precise about when to read the textbook by Sacrobosco, namely on any day except Wednesday and Saturday:

In the highest division, when such a division exists in accordance with local circumstances and tradition, the beginnings of higher philosophy will be taught. And to this end will be taught: The Physics by Magirus, the Ethics by Walleus, the Arithmetic of Gemma Frisius, and the Sphaera by Sacobosco, with as much improvement of the Latin as possible. Furthermore, for the General History of Rome and the Outside World, Plorus and Justinus. Moreover, from Mela or Dodonaeus, and from 6 or 7 of the most important maps of Ortelius, the situation of the known parts of the world. ${ }^{35}$

\footnotetext{
${ }^{32}$ There were many variations and even crossovers possible between French and Dutch Schools. Some major cities also had Grote Scholen, a remainder of the Middle Ages, which combined primary and secondary education. The Grote Scholen were paid for by the urban governments, however, and thus the influence of the Church was limited. This paragraph is based on (Booy 1980, 23-50).

${ }^{33}$ For the history of the Latin schools see (Bot 1965; Fortgens 1958; Bastiaanse and Evers 1986; Bastiaanse et al. 1985; Emmius 1951; Witsenburg and Van der Noordaa 1988).

${ }^{34}$ Such classes seem to have flourished mainly in cities where at some point either an Athenaeum Illustre (Deventer 1630, Amsterdam 1632, Breda 1646, Rotterdam 1681) or a university would be founded (Leiden 1575, Franeker 1585, Groningen 1614, Utrecht 1636, Hardewijk 1648, Nijmegen 1655).

${ }^{35}$ (Kuiper 1958, 20): "In superiori ordine, ubi is pro loci conditione admitti solet, initia solidioris Philosophiae traduntur. Atque hic docebitur Physica Magiri, Ethica Wallaei, Arithmetica Gemmae Frisii, Sphaerica Sacrobosci, Latinitate ubi poterit emendata. Item propter Universatem Historiam Romanam et Externam Florus et Justinus. Item ex Mela aut Dodonaeo, et sex septem tabulis praecipuis Ortelii, docebitur situs nobilium partium orbis terrarium."
} 
The authors of the Order envisioned a comprehensive program, in which the pupils in the highest class would gain a broad overview of geography, astronomy, ethics, and natural philosophy. The next section will explore in which ways the Dutch were influenced by earlier initiatives of the Jesuits in this respect.

\section{Burgersdijk's Edition of De sphaera}

The 1625 School Order had not been the first attempt to organize the educational system in the independent Northern Netherlands. The province of Friesland had introduced a first School Order in 1588, and similar directives are known in Zeeland (1590) (Cau et al. 1664, 2:column 2207-08) and Gouda (1593) (Abels 2002, 409). Moreover, there were many urban regulations regarding the Latin Schools (an inventory of all Latin schools of the Republic in 1650 shows that ninety-two towns had a Latin school (Frijhoff and Spies 2004, 245)). These policy measures were a local affair, but also played an important role within an international framework of continuous ideological warfare. Accordingly, the Holland School Order of 1625 should be seen as a concrete response to Jesuit efforts to streamline the educational program, including the 1566 Leuven initiative mentioned earlier, or the Ratio Studiorum of $1599 .{ }^{36}$ The Curators of Leiden University emphasized this aspect in their 1624 guidance letter to the Senate, where they unambiguously stated that the School Order was needed:

Just as similar orders unifying the class schedules have been implemented with enormous success by the Enemies of our Religion in the schools of the Jesuits, who, much to our disadvantage and prejudice, have managed that way to direct and prepare their youth much better for the further understanding of the higher disciplines, which are afterwards studied in the universities. ${ }^{37}$

The Holland School Order was thus part of a broader process to gain control over the educational system in an attempt to establish the Dutch Republic as a Calvinist state. Other elements in that process included the appointment of school masters who, from 1619 onwards, were obliged to sign a confession that they supported the

\footnotetext{
${ }^{36}$ I am not elaborating here on the various efforts made in the Catholic world to gain control over the educational system. For an excellent analysis on the impact of the Ratio Studiorum, with a focus on mathematics and France, see (Romano 1999).

${ }^{37}$ (Kuiper 1958, 49-50): "Gelyck deselffde eenparige ordre van lessen met sonderlinge goet succes werdt gepractiseert by de Vyanden onser Religie in alle scholen der Jesuyten, die, tot onse groote affbreucke ende naerdeel, hare jeucht inde so eerste beginselen met dusdanige eenparige ordre veel beter aenleyden ende bequaem maecken tot het vordre begryp van hoogere disciplinen, die daernaer in de Universiteyten werden geleert." In 1624, the Curators had still pushed for a "national" Order, but due to practical considerations the Senate later decided to first realize a provincial order in the hope that other provinces would follow the example set by Holland.
} 
Canons of Dort (Kuiper 1958, 51) as well as the ban on Catholic teaching to counter the spread of "popery superstitions" (States of Holland 1589)..$^{38}$

Amidst these various power games to claim hegemony in the religious sphere, one also finds a reference to De sphaera by Sacrobosco-a teaching book, originally written around 1230, that had served for several centuries to instruct the youth of the Western Latin world in the first principles of astronomy. ${ }^{39}$ Especially with the breaking apart of the Christian world in sixteenth-century Europe, several editions of De sphaera had come to compete fiercely with one another. The Lutheran reformer Philipp Melanchthon (1497-1560), for instance, had used the text of Sacrobosco to formulate a panegyric on astronomy that "taught about Providence" (Kusukawa 1995, 129) (Chap. 10), whereas the Jesuit mathematician Christopher Clavius (1538-1612) used De sphaera from 1570 onwards as book of loci containing the Summa of his cosmological insights. It was particularly in the paratext and the commentaries that De sphaera concealed particular worldviews. The 1626 edition by Burgersdijk was no exception in that respect.

Burgersdijk's version of De sphaera was preceded by a short preface (see Appendix). There, the author explained that the representatives in the States of Holland had made it his assignment to purify the text by Sacrobosco from its "barbaric" (barbariem) Latin, making the textbook perspicuous and easy to understand. The Leiden professor clearly stated that his edition of De sphaera had been chiefly inspired by the "highly learned" (doctissimus) work of Christophorus Clavius, to which he had added some of Peuerbach's Theorica novae planetarum (actually, Clavius had done the same). In contrast to his Jesuit counterpart, however, Burgersdijk did not include any excursions on mathematical demonstrations, since this would go beyond the understanding of his readers. His aim was primarily to provide an effective textbook "from which adolescents could learn the first principles of Astronomy, later to be studied more fully and accurately in the Academy." 40

The unconcealed reference to a famous Jesuit mathematician in a book by a Calvinist Aristotelian in the Dutch Republic is, at first sight, remarkable. First published in 1570, Clavius's work had been privileged by Pope Pius V (1504-1572) "to the common benefit of all the scholarly community as well as his Jesuit comrades (sociorum)," and it had become a standard work in Jesuit defense against the Copernican worldview (Clavius and de Sacrobosco 1570, A1v). ${ }^{41}$ Clavius had com-

\footnotetext{
${ }^{38}$ The placard against printing seditious religious literature, first issued by the States of Holland on $20^{\text {th }}$ of December 1581, was later renewed in various forms and variations. As an introduction to censorship in the Republic, see (Weekhout 1998).

${ }^{39}$ For a first introduction to (the commentary tradition on) De sphaera, see (Hamel 2014; Pedersen 1985; Thorndike 1949; Valleriani 2017).

${ }^{40}$ (Burgersdijk and de Sacrobosco 1626, sig. a1-a2v): "ut ex eam adolescentes prima Astronomiae principia deliberarent, quam in Academiam deinde discerent plenius accuratiusque." See Appendix. 41 "ad communem omnium studiosorum vtilitatem suis sociorumque...." Note that the printer Victorius Helianus (Vittorio Eliano) obtained a highly interesting privilege for a set of books to promote the Jesuit production of knowledge. Eliano was a converted Jew, who specialized as a censor of Hebrew texts (Casetti 1993).
} 
plemented each fragment of the text by Sacrobosco with an extensive commentary, which had resulted in a hefty book with an index on chapters, persons, and topics (the first edition had consisted of no less than 506 folio pages). The Jesuit Father then continued to update his book in the seventeen subsequent editions that followed in the years 1581-1611, which represented something of a highpoint in the early modern commentary tradition on De sphaera. ${ }^{42}$ Yet another important strand in that tradition were the annotations by French humanist Élie Vinet (1509-1587), first published in 1556, and later reprinted on almost a yearly basis. ${ }^{43}$ Over time, Vinet's commentary was complemented by other commentaries, and it was often printed together with additional compendia; yet it remained the basis for the proper understanding of Sacrobosco's text in the sixteenth and seventeenth centuries. As an illustration, a 1573 edition published by the Antwerp printer Jean Bellère (1526-1595) included, in addition to a version of De sphaera annotated by Vinet and Franciscus Junctinus (Francesco Giuntini, 1523-1590), Sacrobosco's Computus ecclesiaticus as well as his Alogarismus, a compendium to De sphaera by Ioannes Pierius Valerianus (Pierio Valeriano, 1477-1558), and the commentary by Pedro Nuñes (1502-1578) on the climate zones (Sacrobosco et al. 1573). The idea to print De sphaera together with the Computus ecclesiasticus had first come from Melanchton and Georg Joachim Rheticus (1514-1574), whose so-called Wittenberg editions might be identified as a third strand in the early modern commentary tradition on Sacrobosco's text (Rosen 1974, 245; Westman 1975) (Chap. 9). ${ }^{44}$ Indeed, just as interesting as Burgersdijk's open reference to Clavius in the Leiden edition is his omission of any references to other editions of De sphaera that circulated on the market at the time.

In comparison to those other editions, the version put out by the printers of Leiden University was rather short. After 120 pages of text on the sphere followed a simple table of contents without any index on name or topic. The aim was to deliver a book without curlicues. To that end, Sacrobosco's non-humanist Latin had to be "improved" (emendata) as well. ${ }^{45}$ Burgersdijk faithfully followed the original order, yet rewrote De sphaera in such a rigorous manner that some scholars have come to argue that it essentially resulted in a new text (Hamel 2014, 44). It suffices to compare the opening words in the original with the retranslation to illustrate the radicalism of Burgersdijk's editing methods:

\footnotetext{
${ }^{42}$ Carefully revised reprints of the work appeared in Rome (1581 and 1585), Venice (1591), Lyon (1592, 1593 and 1594), Venice (1596 and 1601), Rome (1606), San Crispino (1608), and finally in Mains (1611-1612).

${ }^{43}$ The commentary by Vinet was mainly printed in Paris but also in other cities, including Lyon, Koln, Venice, and Antwerp (Valleriani 2017). Database accessible through: https://sphaera.mpiwgberlin.mpg.de/. Accessed June 2019.

${ }^{44}$ I would like to thank Matteo Valleriani for pointing out that there was a long tradition of combining the Computus and De sphaera together in manuscript form; the idea to do so in print marked essentially a return to an older tradition.

${ }^{45}$ Citation taken from the School Order, see (Kuiper 1958).
} 
Sphaera igitur ab Euclide sic describitur: Spaera est transitus circunferentiae dimidii circuli quae (fixa diametra) eousque circunducitur, qousque ad locum suum redeat. id est: Shaera est tale rotundum \& solidum, quod describitur ab arcu semicirculi circunducto. (de Sacrobosco et al. 1574, 6)

Except for some minor issues of orthography, all of the earlier editions had made use of exactly the same wording. Instead, Burgersdijk rendered this little fragment into:

Sphaera, defieniente Euclide, est figura, quae, converso circa diametrum quiescentem semicirulo, \& in eundem rursus locum restituto, à quo coeperat moveri, continetur. lib. II. d. 14 hoc est, Spheara est rotundum, quod semicirculo circumducto describitur. (Burgersdijk and de Sacrobosco 1626, 6) ${ }^{46}$

The brief example gives an impression of how Burgersdijk went about rewriting the original Latin without, however, essentially changing the original design of the text. ${ }^{47}$

This is not to say that Burgersdijk did not make numerous subtle changes. In doing so, he was-as he had indicated in the preface-primarily inspired by Clavius's extensive commentaries, merging them integrally, albeit in a highly abbreviated form, with the original text by Sacrobosco. His "method" (methodo) becomes immediately apparent when comparing his text to the earlier versions of his Jesuit counterpart. ${ }^{48}$ To illustrate, Clavius had made an extensive twenty-two-page "commentary" (commentarius) in his 1570 edition on Sacrobosco's chapter on the size of the earth, listing various alternative opinions and calculations, beginning from Aristotle (384-322 BCE) and Alfarganus (al-Farghani) (ca. 805-870) and extending to more recent authors like Jean François Fernel (1497-1558) (Clavius and de Sacrobosco 1570, 265-67). ${ }^{49}$ In other commentaries, such as those by Vinet and Giuntini, these numbers could not be found. Yet Burgersdijk listed the exact same numbers as Clavius in a throwaway sentence (Burgersdijk and de Sacrobosco 1626, 27-28), omitting a direct reference to his source, or to any tables and mathematical demonstrations that could be found in the work of his Jesuit predecessor.

In many ways, Burgersdijk's text reads as a highly condensed abridgement of Clavius's masterpiece. The Leiden Aristotelian proceeded freely in summarizing his predecessor's insights, occasionally merging together different comments that had been presented separately (such as Clavius's expositions on the composition and on centrality of the earth). ${ }^{50}$ Every now and then, Burgersdijk incorporated information

\footnotetext{
${ }^{46}$ The reference to book 11 in Euclid could be found in the editions annotated by Vinet, but not in the works of Clavius; although Burgersdijk could have taken this reference from anywhere, it seems likely that he was aware of the reference in Vinet's works.

${ }^{47}$ It should be noted that Burgersdijk did divide the four sections of the original text into four actual parts (partes), each with individual chapters, instead of using four chapters with unnumbered subheadings, as had been customary. Yet he did not change the order of the text.

${ }^{48}$ The use of methodo comes from Burgersdijk's letter to the reader (Burgersdijk and de Sacrobosco 1626, sig. a2). See Appendix.

${ }^{49}$ The entire chapter De ambitu terrae by Clavius on the size of the earth runs from page 250 to 272. Like many other commentaries, it was copied into later editions.

${ }^{50}$ Chapter VII in Burgersdijk (Burgersdijk and de Sacrobosco 1626, 23-25) provided a summary of (Clavius and de Sacrobosco 1570, 151-74) and (Clavius and de Sacrobosco 1570, 175-244).
} 
from other textbooks as well. ${ }^{51}$ But at all times he meticulously followed the argumentation and sequential layout of his Jesuit example. Clavius, for example, had divided the original chapter in Sacrobosco on the meridian and the horizon into two different chapters, each with its own commentary. ${ }^{52}$ Burgersdijk did exactly the same, whereas such a division cannot be found in any edition based on the comments by Vinet and Giuntini. ${ }^{53}$ Following the Jesuit's lead, Burgersdijk also wrote about the various movements in the eighth, ninth, and tenth spheres. There was no doubt that this motion "had been unknown to Aristotle" and his predecessors but confirmed by recent astronomical observations (Chaps. 5 and 8). ${ }^{54}$ And yet the "earth was immobile" at the center of the universe (Burgersdijk and de Sacrobosco $1626,26) .{ }^{55}$ In this respect too, Burgersdijk closely followed Clavius, defending geocentrism at a time when Galileo Galilei's (1564-1642) discoveries were commonly known and Copernican cosmology widely discussed. ${ }^{56}$

The question then, perhaps, is why the Dutch authorities considered the text by Clavius particularly appropriate to shape the minds of young Dutch youth. ${ }^{57}$ James Lattis has listed in this connection a number of points characterizing what he called Clavius's “Orthodox Cosmology" (Lattis 1994, 65-85). These points include, among others, (1) the reconciliation of the Ptolemaic planetary system with Aristotelian physics, (2) the consensus on the overall size of the cosmos, and

\footnotetext{
${ }^{51}$ Burgersdijk listed, for example, exact numbers for the cycles of the planets (Burgersdijk and de Sacrobosco 1626, 13), whereas these had only been indicated by approximation in Clavius (Clavius and de Sacrobosco 1570, 97; Clavius and de Sacrobosco 1611, 30). One possible source is (Simi 1555,70 ), yet the same numbers can be found in other handbooks as well.

${ }^{52}$ Clavius's separate treatment of the meridians had become necessary to include the enormous amount of new information that had become available in the wake of the European voyages of discovery. The chapters on the meridian and the horizon start at pp. 338 and 361, respectively. The influence of new voyages returned in various contexts. Vinet, too, had argued for example that the disagreement on the inhabitability of the tropics was "held by experience" (habetur ab experientia), identifying Columbus's 1491 journey as the major transition point (Bellère 1573, 43). Burgersdijk did exactly the same, highlighting how recent experience had shown that various parts of the world were indeed inhabitable (Burgersdijk and de Sacrobosco 1626, 51).

${ }^{53}$ Burgersdijk's division of Sacrobosco's original chapter on the meridian and the horizon conveys by comparing Burgersdijk's chapter V (Burgersdijk and de Sacrobosco 1626, 41-46) and chapter VI (Burgersdijk and de Sacrobosco 1626, 42-47) with, for instance, (Sacrobosco, Vinet, and Giuntini 1573, 35).

${ }^{54}$ (Burgersdijk and de Sacrobosco 1626, 12): "Hic motus Aristoteli, aliisque ante Aristotelem Philosophis \& Astrologis, fuit incognitus." Burgersdijk also used the example of Timocharis here, just as Clavius had done (Clavius and de Sacrobosco 1570, 81).

55 "Terram est immobilem." Compare with (Clavius and de Sacrobosco 1611, 106).

${ }^{56}$ On the comets of 1577 and 1618 and the so-called "decline of the Aristotelian worldview" see also (Van Nouhuys 1998). It may be worth noting that, after visiting the astronomer in the Tuscan countryside, the Elzeviers also published Galileo's Discorsi in 1638; a year before they reprinted Burgersdijk's Sphaera (see below in text).

${ }^{57}$ It remains an open question where Burgersdijk got the idea to integrate the text of Clavius with the original text of Sacrobosco. In 1601 and in 1610, a mixture of Vinet and Clavius had been printed in Cologne by the Jesuit Hofbuchdrucker Peter Cholinus (J. de Sacrobosco et al. 1610). Yet Clavius's remarks in that edition had been limited to only to a few short remarks, primarily at the beginning of each of the four main parts. Burgersdijk's notes were much more precise.
} 
(3) the acceptance of the order of planetary spheres according to Ptolemy (ca. 100-ca. 160). ${ }^{58}$ On all of these issues, Burgersdijk clearly followed his Jesuit paragon, using the same examples and the same style of argument, also when speaking for instance of the existence of an immobile empyrean heaven beyond the moving spheres as "a seat of the blessed" (Burgersdijk and de Sacrobosco 1626, 14). As Lattis has argued, this quantitative world picture, where the afterlife had a distinct place, was vital for maintaining a Christian vision of the cosmos (Lattis 1994, 82). ${ }^{59}$ It must have been precisely this aspect that made Clavius's orthodox views so appealing to the Leiden Neo-Aristotelians and their allies.

Yet, in some places, Burgersdijk remained selective in his rendering of Clavius's comments. He copied only the bits and pieces that he considered relevant and strategically eliminated certain specifics. Whereas Clavius, for example, had spoken of the empyrean heaven as a "a happy seat and home of the angels and the blessed," 60 the Leiden professor simply spoke of a "a seat of the blessed." ${ }^{11}$ Hence, in line with his Protestant faith, he placed less emphasis on the existence of angels. And Burgersdijk omitted other, perhaps more important aspects too. He did not mention, for instance, Clavius's ideas of the existence of an eleventh sphere, introduced by the Jesuit author in his reworks from 1593 onwards, to accommodate Copernican precession theory (Lattis 1994, 171; Grant 1994, 318). ${ }^{62}$ The reason for clinging on to earlier ideas on the topic of ten moving spheres was probably not that Burgersdijk lacked access to Clavius's later editions, ${ }^{63}$ but his unwillingness to reject Alfonsine trepidation theory in favor of a model based on Copernican mathematics. ${ }^{64}$

\footnotetext{
${ }^{58}$ The order of planetary spheres is the moon, Mercurius, Venus; then, the Sun, Mars, Jupiter, Saturn, the eight and the ninth sphere, and the primum mobile, beyond which there was only an empyrean heaven. On rival cosmologies, see (Lattis 1994, 73-77; 86-106) (Chap. 5).

${ }^{59}$ On the various opinions regarding the existence of an empyrean heaven, see (Grant 1994, 270-89).

${ }^{60}$ (Clavius and de Sacrobosco 1570, 62; Clavius and de Sacrobosco 1611, 24): "felicem angelorum beatorum sedem ac patriam."

${ }^{61}$ (Burgersdijk and de Sacrobosco 1626, 14): "sedes beatorum."

${ }^{62}$ Clavius added a moving sphere, following the ideas of Giovani Antonio Magini. Adopting "the adapted Copernican scheme for the motions of the fixed stars" probably resulted from his work on the calendar reform (Lattis 1994, 173). Burgersdijk sticks to ten moving spheres; see note 58.

${ }^{63}$ It is extremely difficult to pin down with certainty which edition of Clavius's work Burgersdijk might have used, yet a number of editions can be reasonably excluded; Burgersdijk mentioned Pope Gregory XIII's calendar reform of 1582 (Burgersdijk and de Sacrobosco 1626, 40) using the same terminology and order as in (Clavius and de Sacrobosco 1611, 147). Obviously, the remark on the calendar reform had been absent in editions earlier than 1582. See also (Clavius and de Sacrobosco 1570, 331). Perhaps, a future comparative analysis of the imagery in the various editions can provide an answer to the question of which version Burgersdijk used as a model (the 1585 Rome edition of Clavius was, for instance, very different in terms of imagery and it is hard to imagine that this edition served as an example).

${ }^{64}$ Although he did not mention it specifically, Burgersdijk may have objected to the existence of an eleventh sphere on the basis of theological grounds. It is impossible to track down a unique source for Burgersdijk's ideas on this matter. Calvin had rejected the notion of a tenth sphere and remained silent on the existence of a ninth sphere (Kaiser 1988, 83). Perhaps, Burgersdijk was rather inspired in this regard by Coimbra Jesuits (Grant 1994, 321) (Chap. 10), whom he cites approvingly in
} 
For Burgersdijk, scriptural revelation remained the basis for acquiring knowledge of heavenly motions. It was perhaps for similar reasons that Burgersdijk refrained from mentioning the existence of the telescope, whereas Clavius in his 1611 edition (the final edition completed just before his death) had indicated that the recent discoveries made with an "oblong tube" (tubi...oblongi) required astronomers to rethink how the celestial orbs could be arranged in order to save the phenomena (Clavius and de Sacrobosco 1611, 75). Omitting such particulars, which had the potential to shake up worldviews, allowed Burgersdijk to embrace Clavius's cosmology without thereby endorsing Clavius's “ontologically loaded" physical mathematics (Chap. 6). ${ }^{65}$

Whereas Burgersdijk's edition of De sphaera was primarily inspired by Clavius in terms of content, it included elements from the 1573 Antwerp edition published by Bellère in terms of imagery (which in turn had been based on the so-called 1538 Wittenberg edition) (Chap. 8). The illustrations to the text were interlaced at similar locations. ${ }^{66}$ The volvelle in Burgersdijk, for instance, came at the end of chapter one of the third part (on the rise of zodiacal signs), just as in the Antwerp edition; the tool was not to be found in Clavius (Sacrobosco et al. 1573, 48; Burgersdijk and de Sacrobosco 1626, 56). ${ }^{67}$ The design for the illustration of the five climate zones (Burgersdijk and de Sacrobosco 1626, 51) was clearly imitative of the Antwerp edition (Sacrobosco, Vinet, and Giuntini 1573, 43), whereas the layout was entirely different in the edition prepared by Clavius (Clavius and de Sacrobosco 1611, 187). ${ }^{68}$ A set of images in the chapter on "natural and civil day" (Burgersdijk and de Sacrobosco 1626, 62-89) was again inspired by Bellère, and absent in Clavius. Yet elsewhere, Burgersdijk freely copied visual elements from Clavius's work as well. For instance, an illustration supporting the notion of the roundness of the earth (Burgersdijk and de Sacrobosco 1626, 19) was bluntly plagiarized from Clavius (Clavius and de Sacrobosco 1611, 20; Clavius and de Sacrobosco 1570, 143) and absent in Bellère. The table on different climates around the world (Burgersdijk and de Sacrobosco 1626, 88-95), the only table in Burgersdijk's work, was directly copied from Clavius (Clavius and de Sacrobosco 1570, 480-90; Clavius and de Sacrobosco 1611, 288-89) and was not to be found in that form in Bellère either.

other works as well, or by the work of Jean Bodin, who was widely read in the Republic, and who argued explicitly against the eleventh sphere in his Universae Naturae Theatrum, making extensive references to theological interpretations of the crystalline sphere (Bodin 1596 in (Stimson 1917, 211-12).

${ }^{65}$ I would like to thank Peter Barker for his comments and suggestions on the issue of Burgersdijk's approach concerning Clavius's cosmology. On Burgersdijk's gradual change of view over time with regard to new cosmologies, primarily reflected in his Collegium physicum (1632), see (Vermij 2002, 132-33). The change did not reflect in his booklet on De sphaera.

${ }^{66}$ On illustrations of De sphaera, see (Crowther and Barker 2013; Gingerich 1999; Hamel 2014, 23-49).

${ }^{67}$ Moving parts were first introduced by Joseph Klug in the Wittenberg edition of 1538 (Gingerich 1999, 215). Alas, we do not know who made the engravings, or who was responsible for the editorial decisions concerning illustrations in Leiden.

${ }^{68}$ The exact same illustration can be found in other Antwerp editions published by Bellère as well. For example, in (Appianus 1584, 11). 
In short, Burgersdijk freely proceeded to mix and match illustrations as it best suited him to support and clarify his ideas.

All the same, Burgersdijk's edition made use of considerably less imagery than any of the previous editions. There were, for instance, no additional illustrations for geometrical explanations, like in Clavius's editions, nor was there any place for ornamental imagery. Instead, the thirty-six images in Burgersdijk's edition were newly engraved, in the course of which well-known images got a touch of the Dutch. Two warriors depicted under a sphere were, for example, decked out with a hat typical of Dutch traditional clothing (Figs. 11.1, 11.2 and 11.3) ${ }^{69}$ Elsewhere, a building was made to resemble a Dutch church (Figs. 11.4 and 11.5). ${ }^{70}$ Thus, the work of Sacrobosco was not just adapted to the Dutch market but fashioned to strengthen the sense of Dutch distinctness as well.

The text of De sphaera was never translated into Dutch (i.e. nor Burgersdijk's version, nor any other version). This is somewhat remarkable for a Latin school book, and for the fact that other works by Burgersdijk did appear in translation. ${ }^{71}$ Yet for those who were interested in learning something about astronomy, there were numerous alternatives on the market. Of particular importance was, for instance, the work of Adriaan Metius (1581-1635), who taught in Dutch at the University of Franeker on various topics that were of interest to navigators, engineers, and surveyors. ${ }^{72}$ His 1614 bestseller Institutiones astronomicae et Geographicae (Metius 1614) — despite its title entirely written in Dutch—was a practical textbook on cosmography connecting the theory of the sphere with geography and cartography; it clearly included elements of Sacrobosco, but went much further than his predecessor by including elements of arithmetic and geometry. ${ }^{73}$ And there were other booklets available too, such as the practical guide to the use of globes issued by the

\footnotetext{
${ }^{69}$ On this illustration, see also (Crowther and Barker 2013, 453).

${ }^{70}$ On this illustration, see also (Gingerich 1999, 217-19; Hamel 2014, 39). Notice also the topgallant sail, only present in the Dutch edition.

${ }^{71}$ The other works by Burgersdijk (Institutio physica, 1648; Idea philosophiae naturalis, 1648; Logica practica, 1648, Institutio metaphysica, 1649) were translated by Allardus Lodewijk Kok, who translated Vossius's textbook Elementa rhetorica (Amsterdam, 1648) as well.

${ }^{72}$ The Frisian example was followed in Leiden with the establishment of the Duytsche Mathematique, a mathematical school associated to the University where teaching was carried out in Dutch. For more background, see (Dijksterhuis 2017; Dijkstra 2012).

${ }^{73}$ In a way, one could compare the work of the Franeker mathematician with that of Clavius, except that Metius followed a somewhat different order than Clavius had done in his Sacrobosco. He also introduced new information that had become available due to the voyages of discovery (Chap. 8). On the mixing of the Sphaera with cosmography, see also (Chap. 9) and (Valleriani 2017, 438). An interesting detail in this connection is that Metius used a slogan from Ovid, prominently present in Clavius 1570 panegyric on mathematics, as "his" inscription in various alba amicora (Balck 1618; van Wijckel 1635). Felices animae, quibus haec cognoscere primum, Inque domos superas scandere, cura fuit ("Ah happy souls, who first took thought to know I these things and scale the heavenly mansions!" (Ovid 1989, 23). Metius therewith aligned himself with the conviction that astronomy is extremely useful and even necessary to all aspects of life. On this issue, see also (Omodeo 2017).
} 


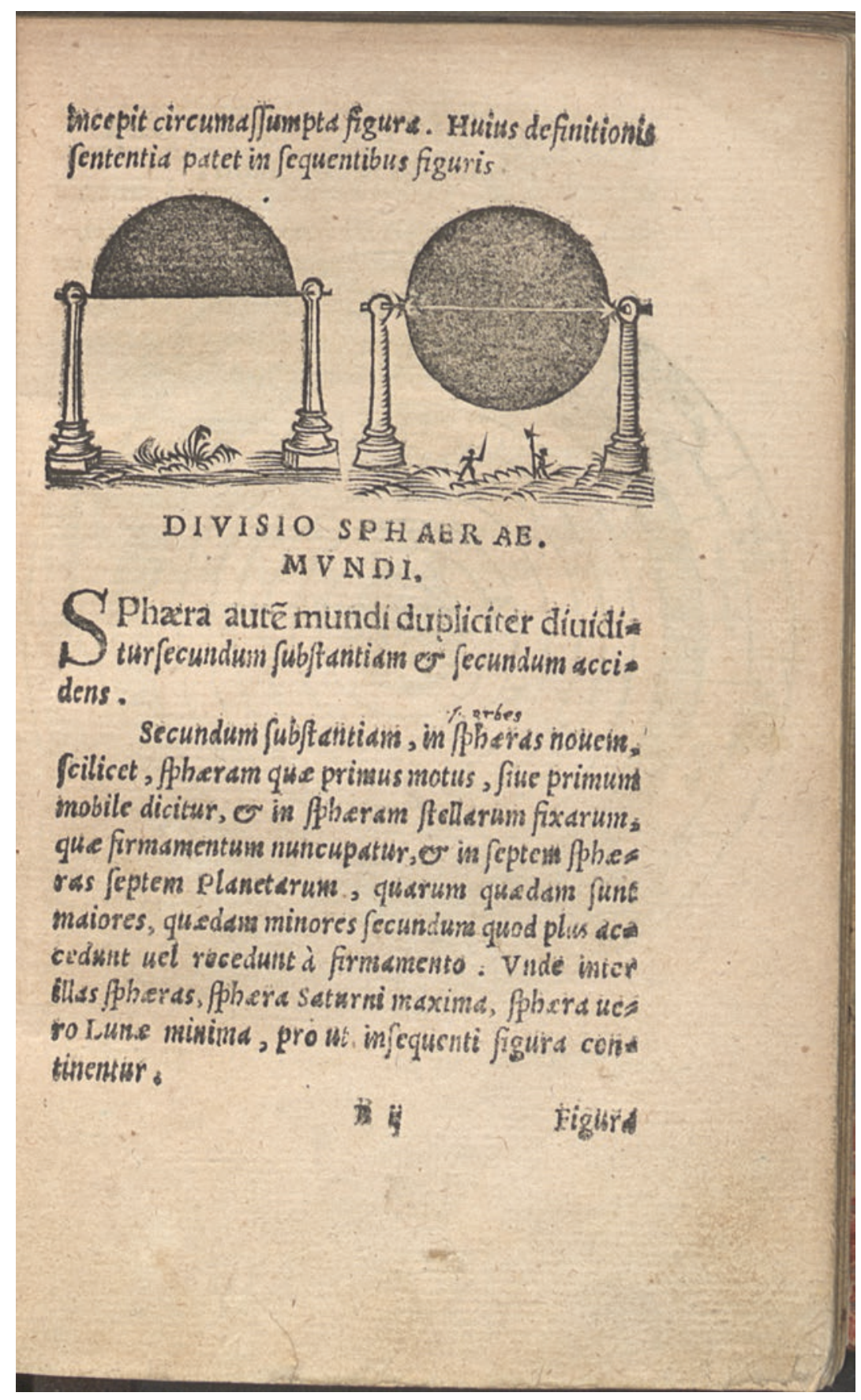

Fig. 11.1 Warriors under a sphere in the Wittenberg edition of 1538. From (de Sacrobosco and Melanchthon 1538, B3r). Bayerische Staatsbibliothek München, Astr.u. 154, urn:nbn:de:bvb:12-bsb00020992-1 
DE SAC. BOS. CA P. I. 3 circunductus femicirculus in idem rur fus redit, vnde copit circun fcribi figura illa. Huitus definitionis fententia ex Jubiectis picturis patere pot est. Quam autem ponit auctor, corruperant Gracormm Euclides interpretes. Si enim linea in latus fluens defcribit tant ùm /uperfinciem, circunferentia femictrculi curcumacta, defcribet fuperficiem globifolùm, non globum folidum.

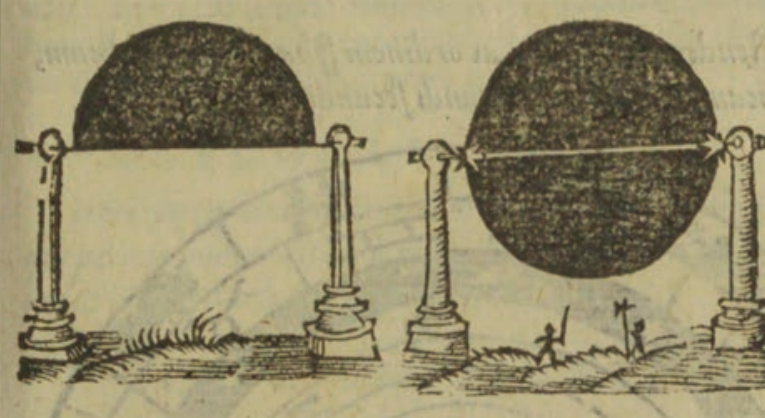

\section{DIVISIO S PHAERAE}

\section{V N D I.}

Shæra autem mundi dupliciter diuiditur, fecundum fubftantiam, \& fecundum accidens. Secundum fubftantiam in fphæras nouem.

\section{SCHOLION VINETI.}

In pheras nouem.) Recentiores Aftrologi decimam Spheram addidersut, propter tertium in octaua ppera animaducrfum motum, quem dixerunt motum trepidationis, of motum accefjus E receffus: de quo Purbachims in Theoricis.

Scilicet fpher exòd none mobile dicitur:am nonam, qux primus motus, fiue primú fint orbes mentum nun:\& in $f_{p} h x r a m$ ftellarum fixarum, qux firma celeftes. mentum nuncupatur: \& in feptem fphæras feptem plane- Firmamëa 2 tarum, $t \mathrm{tm}$.

Fig. 11.2 The same warriors in the Sphaera emendata issued by the Heirs of Birckmann (Antwerp 1566). From (de Sacrobosco et al. 1566, a2r) 


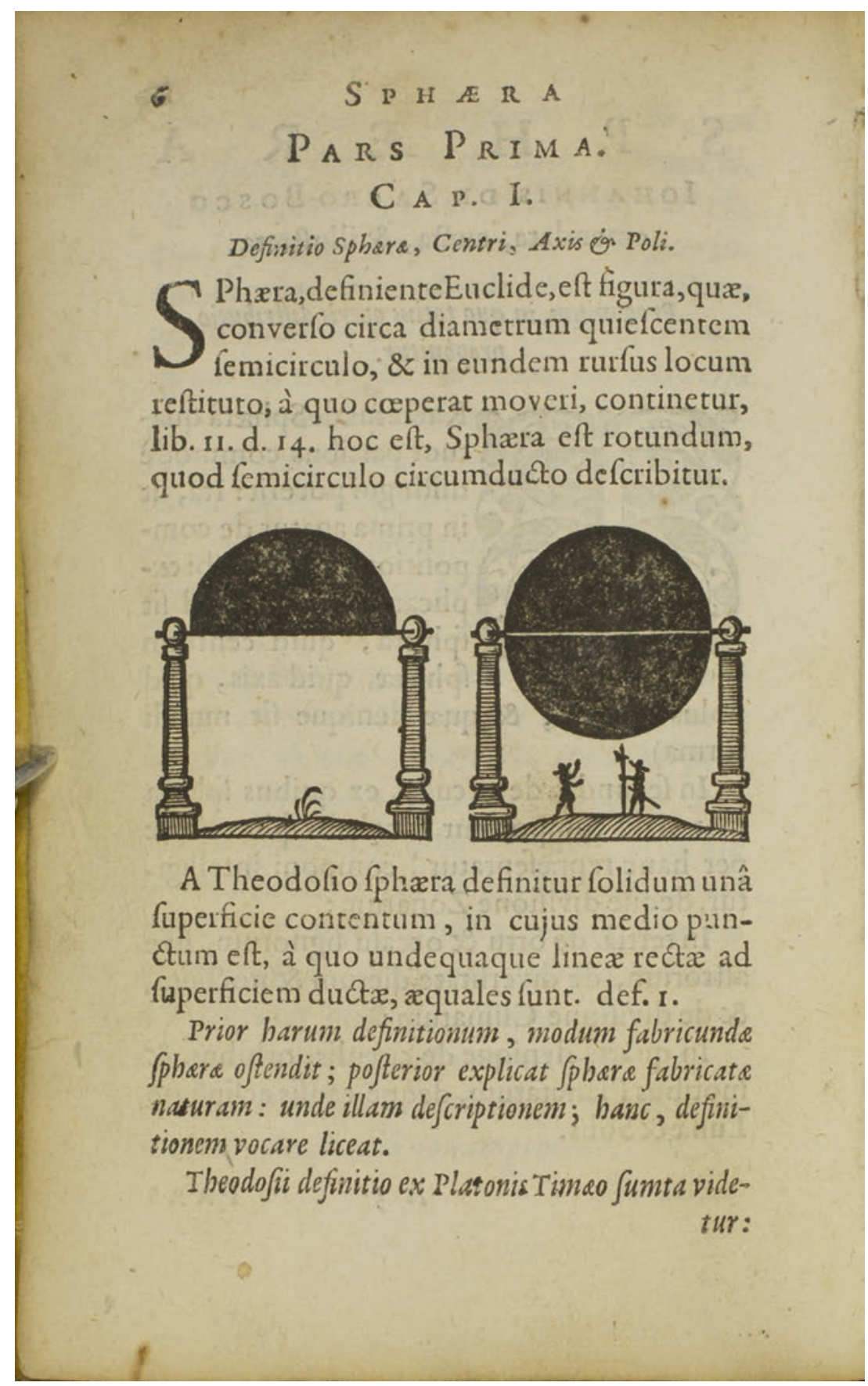

Fig. 11.3 The re-engraved image in the Leiden edition of 1626. From (Burgersdijk and de Sacrobosco 1626, 6). Courtesy of the History of Science Collections, University of Oklahoma Libraries 


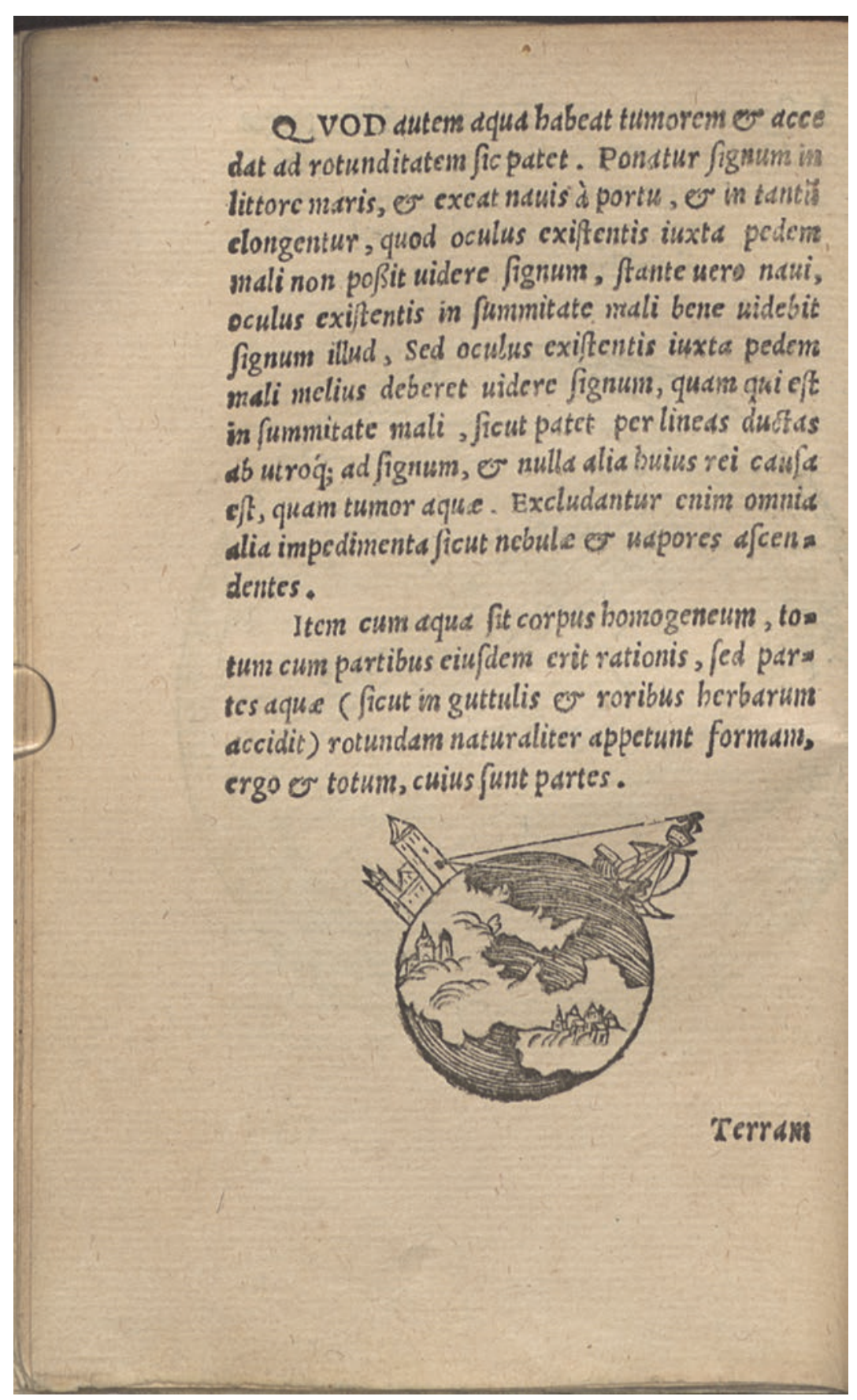

Fig. 11.4 Curvature of the ocean in the Wittenberg edition of 1538. From (de Sacrobosco and Melanchthon 1538, Cv). Bayerische Staatsbibliothek München, Astr.u. 154, urn:nbn:de:bvb:12-bsb00020992-1 
22

\section{$S P$ H AE R A}

habere centrum, quod habet convexa fuperficies terre. Atque id hinc poteft effe manifeltum. Cum navis è portu folvens longiufcule provecta eft, ii, qui in navi juxta calcem mali funt, $\mathrm{fi}_{\mathrm{i}}$ gnum aliquod in littore pofitum, puta turriom, aut pharum, videre non poterunt; quod tamen ab eo confpicietur facillime, qui fummum malum confcenderit. Cum itaq; rationi confentaneum videatur, ut fignum datum non difficilius, vel etiam facilius juxta mali calcem, quam in illius fuprema paree, videri poffit (minus enim à figno diftat, ut in fubjecta figura videre eft) fequitur, nullam caufam hujus rei reddi poffe,pręter aqux tumoré. Nam omnibus aliis impedimentis fublatis, ut funt nebulæ, vapores, \&c. hoc tamen contingit, quod diximus.

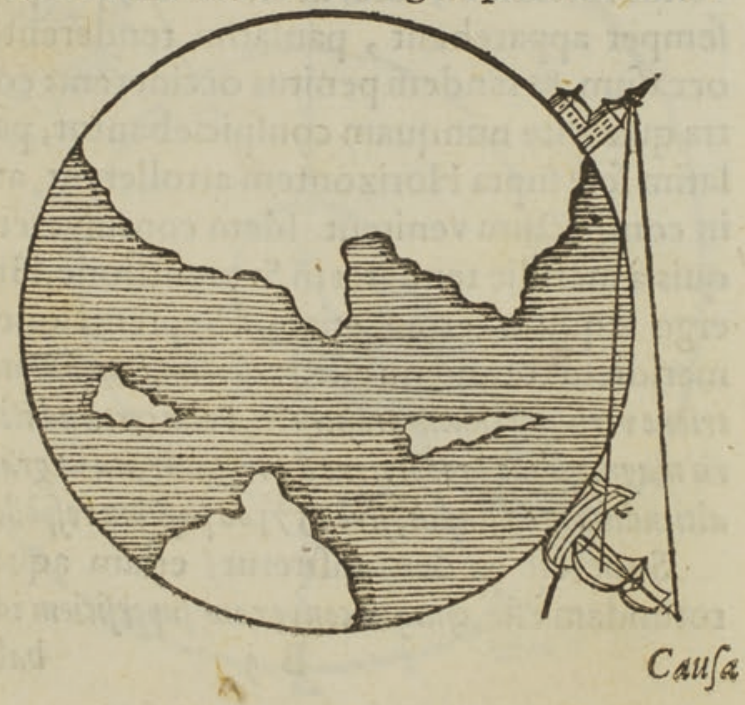

Fig. 11.5 Curvature of the ocean as re-engraved in the 1626 Leiden edition. From (Burgersdijk and de Sacrobosco 1626, 2). Courtesy of the History of Science Collections, University of Oklahoma Libraries 
famed publisher Willem Janszoon Blaeu (1571-1638), who placed the astronomy of Ptolemy and Nicolaus Copernicus (1473-1543) on an equal footing (Tweevovdigh onderwiis van de hemelsche en aerdsche globen was printed in Dutch in 1634, $1638,1647,1666$, and in Latin in 1634, 1652, 1657, 1668, and 1690, under the title Institvtio astronomica).

Despite the existence of alternatives, Sacrobosco's Sphaera could still to be found on Dutch school desks long after Copernican astronomy had changed into an established worldview. In conformity with the School Order, the medieval textbook was, for example, still prescribed in the 1692 statutes of the municipal school in The Hague, where the highest class was to be schooled in "the Logic by Burgersdijk, the Sphaera by Sacrobosco, Florus, The Greek History by Heridianus, Vergilius, Horatius, Juvenalis, etc." ${ }^{\prime \prime}$ Although the statutes did not specify exactly which version of De sphaera the youngsters were supposed to use, it could have very well still have been Burgersdijk's edition; reprints of his 1626 Sphaera followed in 1639, 1647 and 1656 (Burgersdijk and de Sacrobosco 1639, 1647, 1656). We still grope in the dark as regards the timing of these reprints. Perhaps the establishment of new schools in the Generality Lands played a role (compare in this connection the publication dates with the program for the Latin School in "s-Hertogenbosch below). Perhaps the Latin schools merely needed new books every 10 years because of wear and tear. In any case, an initial comparison between the 1626 and the 1647 edition has not brought to light any significant changes.

Even if the 1625 School Order was legally valid in the various towns of the province of Holland, schoolmasters apparently had considerable freedom when implementing the specifics of the program. Thus, we do not know exactly how intensively De sphaera by Sacrobosco was studied in the different Latin schools, just as we are in the dark on whether the textbook was still used at university. The Leiden Orientalist and mathematician Jacob Golius (1596-1667), for example, taught a course elementa Astronomica exponit in September 1662 and in February 1663, but it remains unclear what books he used to this end (Molhuysen 1918, 174*, 176*). Other evidence on the use of De sphaera by students in the Dutch Republic has not yet turned up. ${ }^{75}$

The School Order would eventually not be implemented outside of the province of Holland, except partly in the city of 's-Hertogenbosch in Brabant, where, after the takeover by the Republican army, the authorities wanted to erect a new Latin

\footnotetext{
${ }^{74}$ (Kuiper 1958, 199): "Hyer sal geleert werden Logica Burgersdijck, Sphaera Johannis de Sacrobosco, Florus, Historia Graeca Herodiani, Virgilius, Horatius, Juvenalis etc."

${ }^{75}$ All the same, it is clear that the book was widely read. Christophorus Wittichius, for instance, literally copied a section on the vacuum in a dissertation on outer limits of the universe; (Wittichius 1653, 168-69): "Si caelum non esset...non essent figura orbiculari." Compare (Burgersdijk and de Sacrobosco 1626, 16-17). The dissertation by Wittichius was compiled in a book that would make him famous for bringing together the philosophy of René Descartes and the theology of the Gisbertus Voetius, a dogmatist neo-scholastic from the Gomarist faction.
} 
school to replace a Jesuit school with an excellent reputation. ${ }^{76}$ In the program for the new school, drafted in 1639, the original segment on Sacrobosco in the Holland School Order was replaced by some other mandatory measures. Nonetheless, the students had to follow a course over two or three years, reading De sphaera by Sacrobosco and the Logic by Burgersdijk, the Physics (Physiologiae Peripateticae libri sex) by Johannes Magirus (ca. 1560-1596), the Enchiridion Metaphysicum (1621) by Caspar Bartholin the Elder (1585-1629), The Compendivm Ethicae Aristotelice ad normam veritatis christiance revocatum by Antonius Walaeus, Justinus, Florus, and Sulpicius complemented with Johannes Sleidanus (1506-1556). ${ }^{77}$ Except for the classics, these were all well-known and determinedly Protestant writers who also appeared on the Holland School Order with the intent to counterbalance the Jesuit influence on the educational system.

\section{Conclusions}

Burgersdijk's neo-Aristotelianism was closely related to the rise of the ContraRemonstrant movement within the Dutch Reformed Church. Against that background, reflected in and articulated during the Synod of Dort and in Holland's School Order of 1625, the agenda of the last editor of De sphaera becomes clear: to produce a "clean" copy of a textbook that had proved its use for instruction, adapted to the needs of the young Protestant youth. In staunch competition with the Jesuits, Burgersdijk made an attempt to make the Dutch less dependent on Catholic literature and modes of knowledge production. Yet in reality, his neoLatin retranslation of the Sphaera effortlessly integrated many of the insights of the work by the Jesuit mathematician Christophorus Clavius. Indeed, Leiden neoAristotelianism was not substantially incompatible with Jesuit principles on all fronts. The outcome was that Dutch school pupils were still instilled with a geocentric worldview at a time when the heliocentric model had already become widely available.

\footnotetext{
${ }^{76}$ Even if it was not directly copied, the Holland Order did have an influence on the other provinces (Kuiper 1958, 161-73). I did not find any additional evidence for the use of De sphaera in (Bastiaanse, Bots, and Evers 1985; Bastiaanse and Evers 1986; Booy 1980).

${ }^{77}$ On the implementation of the school program in 's-Hertogenbosch, see (Kuiper 1958, 161-63). The direct influence of Holland School Order was clearly present (Kuiper 1958, 163): "Cum hos authores Scholarum Hollandicarum publicus ordo, quem hic noster, quam maxime potest, proxime imitatur, etiam praescripserit." Note that the original segment on geographical knowledge had disappeared.
} 


\section{Appendix}

Letter to the reader from (Burgersdijk and de Sacrobosco 1626, sig. a2-a2v).

Benevolo Lectori.

Cum illust. \& Potentes D D. Ordines Holandiae \& VVest-Frisiae decrevissent, ut iidem linguarum \& artium autores in omnibus scholis Hollandicis praelegerentur, inter caeteros libros Sphaeram Ion. de Sacro-Bosco censuerunt juventuti proponendam, ut ex eam adolescentes prima Astronomiae principia deliberarent, quam in Academiam deinde discerent plenius accuratiusque. Verum enim vero, cum hic autor no tam bonus esset, quam celebris, iidem Ordines nobis mandavarunt, ut eum inter multos alios libros scholis destinatos recenseremus, Latinatem que emendaremus. Cuirei, cum mihi obtigisset, ut admoverem manum, deprehendi statim, abstergeri non posse barbariem ab hoc autore, nisi totus, non in aliam linguam, sed in alium sermonem converteretur. Itaque sententiam Iohannis, quantum fieri potuit, meis verbis extuli, methodo etiam leviter emendata. Neque tamen hoc egi, ut sermone uterer elaborato, \& comto sed simplici \& facili, ac tantum non barbaro. Addidi praeterea multa ex aliis autoribus, praecipue ex Christophoro Clavio, qui $[\mathrm{a} 2 \mathrm{v}]$ doctissimis commentariis hunc nostrum illustravit, eaq; passim suis locis inserui, \& quo facilius à praeceptis autoris distinguerentur, alio charactere edenda curavi. Ad finem pauca quaedam adjeci de Theoricis Planetarum ex Georgio Purbachio, ut universae Astonomiae compendium, hoc libello contineretur. Neque tamen necessarium puto, haec omnia pueris inculcare (quaedam enim talia sunt, ut puerorum captum superent) sed praeceptorum judicio permittemdum censui, ut hinc petant, quae discipulorum suorum captui judicabunt esse accommodata. Unum etiam aut alterum Lucani testimonium, à Ioanne citatum, praeterii; quia Jospehus Scaliger in Prolegomenis in Manilium, Lucanum ipsum in iis locis erravisse, accuratè demonstravit. Nihil in toto hoc opere, benigne Lector, mihi vendico, praeter laborem \& studium; aliorum enim vestigiis institisse me, libenter profiteor. Neque laudem hinc capto aut gloriam. Hoc unum mihi laboris erit satis amplum praemium, si intellexero, studium meum tibi non improbari. Vale.

\section{References}

Abels, P.H.A.M. 2002. Duizend jaar Gouda: een stadsgeschiedenis. Hilversum: Verloren.

Appianus, Petrus. 1584. Cosmographia, siue descriptio vniuersi Orbis, Petri Apiani \& Gemmae Frisij, Mathematicorum insignium, iam demùm integritati suae restituta. adiecti sunt alij, tum Gemmae Frisij, tum aliorum auctorum eius argumenti tractatus ac libelli varij. Antwerp: Jean Bellère.

Balck, Everhardus. 1618. Album amicorum. Steinfurt/Franeker/Leiden [e.a.]: Koninklijke Bibliotheek: 75 A 2 / 1.

Bastiaanse, R.M., and Meindert Evers. 1986. Ontwikkelingen binnen het onderwijs aan de Gelderse Latijnse Scholen in de $17 \mathrm{e}$ en 18e eeuw. Bijdragen en mededelingen Vereniging Gelre 77: 68-91. 
Bastiaanse, René, Hans Bots, and Meindert Evers. 1985. Tot meesten nut ende dienst van de jeught: een onderzoek naar zeventien Gelderse Latijnse scholen, ca. 1580-1815. Zutphen: Walburg.

Bently, Lionel, and Martin Kretschmer. 2017. Resolutions concerning the Dutch school order, The Hague (1625-1626). Primary sources on copyright (1450-1900). www.copyrighthistory.org. Accessed June 2019.

Bos, Egbert P., and H.A. Krop, eds. 1993. Franco Burgersdijk (1590-1635): Neo-Aristotelianism in Leiden. Amsterdam: Rodopi.

Bot, Petrus Nicolaas Maria. 1965. Humanisme en onderwijs in Nederland. Utrecht: Spectrum.

Buning, Marius. 2019. Privileging the common good. The moral economy of printing privileges in the seventeenth-century Dutch Republic. In Buying and selling: The business of books in early modern Europe, ed. Shanti Grahelli, 88-108. Leiden: Brill.

Burgersdijk, Franco. 1645. Franconis BurgersdicI Institutionum logicarum synopsis, sive Rudimenta logica. In quibus pracipuce definitiones, divisiones, \& regulae, ad artem logicam pertinentes, per quastiones \& responsiones, breviter \& dilucide proponuntur; in usum scholarum Hollandicarum. Leiden: Abraham Commelinus.

Burgersdijk, Franco, and Johannes de Sacrobosco. 1626. Sphaera Iohannis de Sacro-Bosco, decreto illustr. Et potent. D.D. Ordinum Hollandiae et West-Frisiae, in usum scholarum ejusdem provinciae sic recensita, ut \& Latinitas \& methodus emendata sit, multaque addita, quae ad huius doctrinae illustrationem requirebantur. Leiden: Bonaventura \& Abraham Elzevir. http://hdl.handle.net/21.11103/sphaera.101041.

- 1639. Sphaera Iohannis de Sacro-Bosco, decreto illustr. et potent. D.D. Ordinum Hollandiae et West-Frisiae, in usum scholarum ejusdem provinciae sic recensita, ut \& Latinitas \& methodus emendata sit, multaque addita, quae ad huius doctrinae illustrationem requirebantur. Leiden: Bonaventura \& Abraham Elzevir. http://hdl.handle.net/21.11103/sphaera.100589.

-1647. Sphaera Iohannis de Sacro-Bosco, decreto illustr. et potent. D.D. Ordinum Hollandiae et West-Frisiae, in usum scholarum ejusdem provinciae sic recensita, ut \& Latinitas \& methodus emendata sit, multaque addita, quae ad huius doctrinae illustrationem requirebantur. Leiden: Bonaventura \& Abraham Elzevir. http://hdl.handle.net/21.11103/sphaera.100590.

- 1656. Sphaera Iohannis de Sacro-Bosco, decreto illustr. et potent. D.D. Ordinum Hollandiae et West-Frisiae, in usum scholarum ejusdem provinciae sic recensita, ut \& Latinitas \& methodus emendata sit, multaque addita, quae ad huius doctrinae illustrationem requirebantur. Leiden: Johannes Elzevir.

Casetti, Carla. 1993. Eliano, Vittorio. In Dizionario biografico degli italiani. Roma: Istituto della Enciclopedia italiana. http://www.treccani.it/enciclopedia/vittorio-eliano_(DizionarioBiografico)/. Accessed June 2019.

Cau, Cornelis, Simon van Leeuwen, Jacobus Scheltus, Paulus Scheltus, Isaac Scheltus, Didericus Lulius, and Joannes van der Linden (eds.). 1664. Groot placaet-boeck, vervattende de placaten, ordonnantien ende edicten van de doorluchtige, hoogh mog. heeren Staten Generael der Vereenighde Nederlanden ende vande ed. groot-mog. heeren Staten van Hollandt en WestVrieslandt, mitsgaders vande ed. mog. heeren Staten van Zeelandt: waer by noch ghevoeght zijn eenige placaten vande voorgaende graven ende princen de selver landen, voor soo veel de selve als noch in gebruyck zijn. Vol. 2. 9 vols. The Hague: weduwe ende erfgenamen van wylen Hillebrandt Jacobsz van Wouw [etc.].

Clavius, Christoph, and Joannes de Sacrobosco. 1570. Sphaeram Ioannis de Sacro Bosco commentarivs. Rome: Vittorio Eliano. http://hdl.handle.net/21.11103/sphaera.100365.

Clavius, Christoph, and Johannes de Sacrobosco. 1611. Christophori Clavii Bambergensis e Societate Iesu Operum mathematicorum V tomis distributa. Moguntiae [Mainz]: Hierat, Anton I. http://hdl.handle.net/21.11103/sphaera.100383.

Crowther, Kathleen M., and Peter Barker. 2013. Training the intelligent eye: Understanding illustrations in early modern astronomy texts. Isis 104 (3): 429-470. http://hdl.handle. net/10.1086/673269.

de Booy, Engelina Petronella. 1980. Kweekhoven der wijsheid: basis- en vervolgonderwijs in de steden van de provincie Utrecht van 1580 tot het begin der 19e eeuw. Zutphen: Walburg. 
Nijs, Thimo de, and Eelco Beukers. 2002. Geschiedenis van Holland. Vol. 2. 3 vols. Hilversum: Verloren.

Sacrobosco, Johannes de and Philipp Melanchthon. 1538. Ioannis de Sacro Busto libellus, De sphaera: Eiusdem autoris libellus, cuius titulus est Computus, eruditissimam anni \& mensium descriptionem continens. Cum praefatione Philippi Melanth. \& novis quibusdam typis, qui ortus indicant. Wittenberg: Joseph Klug. http://hdl.handle.net/21.11103/sphaera.101106.

Sacrobosco, Johannes de, Élie Vinet, Francesco Giuntini, and Pedro Nuñes. 1566. Sphaera Ioannis de Sacro Bosco emendata. Cum additionibus in margine, et Indice rerum et locorum memorabilium, et familiarissimis scholijs, nunc recenter compertis, et collectis à Francesco Iunctino Florentino sacrae Theologia Doctore. Interserta etiam sunt Eliae Vineti Santonis egregia Scholia in eandem Sphaeram. Adiunximus eiusdem auctoris Computum Ecclesiasticum. Et Petri Nonii Salaciensis demonstrationem eorum, quae in extremo capite de climatibus Sacroboscius scribit de inaequali climatum latitudine, eodem Vineto interprete. Antwerp: Heirs of Arnold Birckmann. http://hdl.handle.net/21.11103/sphaera.101115.

de Sacrobosco, Joannes, Elie Vinet, Pedro Nunes, and Pierio Valeriano. 1574. Sphaera Ioannis de Sacro Bosco emendata. Venice: Heirs of Girolamo Scotto. http://hdl.handle.net/21.11103/ sphaera.100309.

Sacrobosco, Joannes de, Christophorus Clavius, Élie Vinet, Albertus Hero, Francesco Giuntini, Pedro Nunes, and Pierio Valeriano. 1610. Sphaera Ioannis a Sacrobosco emendata, aucta et illustrata. Eliae Vineti Santonis, \& Francisci Iunctini Florentini scholia in eandem Sphaeram restituta. Quibus praeter Alberti Heronis scholia nunc accessere R. P. Christoph. Clavij breves commentarij. Adiunximus huic libro compendium in Sphaeram per Pierium Valerianum Bellunensem: et Petri Nonii Salaciensis Demonstrationem eorum, quae in extremo capite de climatibus Sacroboscus scribit de inaequali climatum latitudine, eodem Vineto interprete. Cologne: Peter Cholinus. http://hdl.handle.net/21.11103/sphaera.100357.

Dekker, E. 1993. Rijker dan Midas: vrijheid, genade en predestinatie in de theologie van Jacobus Arminius (1559-1609). Zoetermeer: Boekencentrum.

Dibon, Paul Auguste Georges. 1954. La philosophie Néerlandaise au siècle d'or. Amsterdam: Elsevier.

Dijksterhuis, Fokko. Jan. 2017. Duytsche Mathematique and the building of a new society: Pursuits of mathematics in the seventeenth-century Dutch Republic. In Mathematical practitioners and the transformation of natural knowledge in early modern Europe, ed. Lesley B. Cormack, Steven A. Walton, and John A. Schuster, 167-181. Cham: Springer. https://doi. org/10.1007/978-3-319-49430-2_9.

Dijkstra, Arjen. 2012. Between academics and idiots: A cultural history of mathematics in the Dutch province of Friesland (1600-1700). Ph.D. Leeuwarden: University of Twente.

Dongelmans, Berry P.M., Paul Gerardus Hoftijzer, and Otto Stephanus Lankhorst. 2001. Boekverkopers van Europa: het 17de-eeuwse Nederlandse uitgevershuis Elsevier. Zutphen: Walburg.

Emmius, Ubbo. 1951. Programma bij de aanvaarding van het rectoraat der Latijnse School (thans Praedinius-Gymnasium) te Groningen in 1594. Trans. Antoon Gerard Roos. Groningen: Wolters.

Feingold, Mordechai. 1993. The ultimate pedagogue: Franco petri Burgersdijk and the English speaking academic learning. In Franco Burgersdijk (1590-1635). Neo-Aristotelian in Leiden, ed. Egbert P. Bos and H.A. Krop, 151-165. Amsterdam: Rodopi.

Fortgens, H.W. 1958. Schola latina, uit het verleden van ons voorbereidend hoger onderwijs, door Dr. H.W. Fortgens. Zwolle: Tjeenk Willink.

Frijhoff, Willem, and Marijke Spies. 2004. Dutch culture in a European perspective: 1650, HardWon Unity. Assen: Van Gorcum.

Gilbert, Neal Ward. 1963. Renaissance concepts of method. New York: Columbia University Press.

Gingerich, Owen. 1999. Sacrobosco illustrated. In Between demonstration and imagination, ed. Lodi Nauta and A.J. Vanderjagt, 211-224. Leiden: Brill. 
Grant, Edward. 1994. Planets, stars, and orbs: The medieval cosmos, 1200-1687. Cambridge: Cambridge University Press.

Hamel, Jürgen. 2014. Studien zur Sphaera des Johannes de Sacrobosco. Leipzig: AVA.

Hoftijzer, Paul. 1993. Nederlandse boekverkopersprivileges in de $17 \mathrm{e}$ en $18 \mathrm{e}$ eeuw. Jaarboek Nederlands Genootschap Van Bibliofielen 1: 49-62.

Imhof, Dirk. 2014. Jan Moretus and the continuation of the Plantin press: A bibliography of the works published and printed by Jan Moretus I in Antwerp (1589-1610). Vol. 2. 2 vols. Leiden: Brill.

Israel, Jonathan Irvine. 1995. The Dutch Republic. Its rise, greatness, and fall, 1477-1806. Oxford: Clarendon.

Kaiser, Christopher B. 1988. Calvin's understanding of Aristotelian natural philosophy: Its extent and possible origin. In Calviniana: Ideas and influence of Jean Calvin, Sixteenth century essays \& studies Vol. 10, ed. Robert V. Schnucker, 77-93. Kirksville: Sixteenth Century Journal Publishers.

Krop, Henri. 2014. Burgersdijk, Franco. In Encyclopedia of renaissance philosophy, ed. Marco Sgarbi, 1-6. Cham: Springer. https://doi.org/10.1007/978-3-319-02848-4_271-1.

Kuiper, E.J. 1958. De Hollandse 'Schoolordre' van 1625: een studie over het onderwijs op de Latijnse scholen in Nederland in de 17de en 18de eeuw. Groningen: Wolters.

Kusukawa, Sachiko. 1995. The transformation of natural philosophy: The case of Philip Melanchthon. Cambridge: Cambridge University Press.

Lattis, James M. 1994. Between Copernicus and Galileo: Christoph Clavius and the collapse of Ptolemaic cosmology. Chicago: University of Chicago Press.

Metius, Adriaan Adriaansz. 1614. Institutiones Astronomicae et Geographicae. Fondamentale ende grondelijcke onderwysinge van de Sterrekonst, ende beschryvinghe der Aerden, door het ghebruyck van de Hemelsche ende Aerdtsche Globen. Amsterdam: Willem Jansz. Blaeu.

Mijers, Esther. 2017. Addicted to Puritanism: Philosophical and theological relations between Scotland and the United Provinces in the first half of the seventeenth century. History of Universities 29 (2): 69-96.

Molhuysen, Philip Christiaan, (ed.). 1913-1924. Bronnen tot de geschiedenis der Leidsche Universiteit. 1574-[1811]. Vol. 1. 7 vols. Rijks Geschiedkundige Publicatiën 20. The Hague: M. Nijhoff.

, (ed.). 1918. Bronnen tot de geschiedenis der Leidsche Universiteit. 1574-[1811]. Vol. 3. 7 vols. Rijks Geschiedkundige Publicatiën 20. The Hague: M. Nijhoff.

Molhuysen, Philip Christiaan, Petrus Johannes Blok, Laurentius Knappert, and Friedrich Karl Heinrich Kossmann. 1927. Nieuw Nederlandsch biografisch woordenboek. Vol. 7, 10. Leiden: Sijthoff.

Omodeo, Pietro D. 2017. Utilitas astronomiae in the renaissance: The rhetoric and epistemology of astronomy. In The structures of practical knowledge, ed. Matteo Valleriani, 307-331. Dordrecht: Springer. https://doi.org/10.1007/978-3-319-45671-3_12.

Orenstein, Nadine. 2006. Sleeping caps, city views and state funerals: Privileges for prints in the Dutch Republic 1580-1650. In In his milieu: Essays on netherlandish art in memory of John Michael Montias, ed. Amy Golahny, Mia M. Mochizuki, and Lisa Vergara, 313-346. Amsterdam: Amsterdam University Press.

Otterspeer, Willem. 2000. Het bolwerk van de vrijheid: De Leidse Universiteit, 1575-1672. Amsterdam: Bakker.

Ovid. 1989. Fasti. Cambridge, MA: Harvard University Press.

Pedersen, Olaf. 1985. In quest of Sacrobosco. Journal for the History of Astronomy 16 (3): 175221. https://doi.org/10.1177/002182868501600302.

Prak, Maarten Roy. 2005. The Dutch Republic in the seventeenth century: The golden age. Trans. Diane L. Webb. Cambridge: Cambridge University Press 
Prost, Joseph. 1907. La philosophie à l'Académie protestante de Saumur (1606-1685). Paris: H. Paulin. http://gallica.bnf.fr/ark:/12148/bpt6k55160737. Accessed June 2019.

Romano, Antonella. 1999. La contre-réforme mathématique. Constitution et diffusion d'un culture mathématique jésuite à la Renaissance (1540-1640). Rome: Bibliothèque des Ecoles françaises d'Athènes et Rome.

Rosen, Edward. 1974. Rheticus as editor of the Sacrobosco. In For Dirk Struik: Scientific, historical and political essays in honour of Dirk J. Struik, ed. Robert S. Cohen, J.J. Stachel, and Marx W. Wartofsky, 245-248. Berlin: Springer.

Ruestow, Edward Grant. 1973. Physics at seventeenth and eighteenth-century Leiden: Philosophy and the new science in the university. The Hague: Nijhoff.

Sacrobosco, Joannes, Élie Vinet, and Francesco Giuntini. 1573. Sphaera Ioannis de Sacro Bosco emendata. Cum additionibus in margine, et Indice rerum et locorum memorabilium, et familiarissimis scholijs, nunc recenter compertis, et collectis à Francesco Iunctino Florentino sacrae Theologia Doctore. Interserta etiam sunt Eliae Vineti Santonis egregia Scholia in eandem Sphaeram. Adiunximus eiusdem auctoris Computum Ecclesiasticum. Et Petri Nonii Salaciensis demonstrationem eorum, quae in extremo capite de climatibus Sacroboscius scribit de inaequali climatum latitudine, eodem Vineto interprete. Antwerp: Heirs of Arnold Birckmann. http://hdl. handle.net/21.11103/sphaera.101115.

Sassen, Ferd. 1959. Geschiedenis van de wijsbegeerte in Nederland tot het einde der negentiende eeuw. http://www.dbnl.org/tekst/sass011gesc01_01/. Accessed June 2019.

Schriks, C. F. J. 2015. The history of copyright in the Netherlands in the 16th-19th century: The book as legal entity and provincial and national legislation; state's copyright in the Netherlands in the 17th-21st century; public access in the Trias Politica and the right of copy and copyright. Zutphen: Walburg.

Simi, Nicolò. 1555. Theoricae planetarum in compendium redactae, et pluribus figuris auctae. Basel: Johannes Oporinus. https://doi.org/10.3931/e-rara-16422.

Smolenaars, Marja. 2004. Jack [Jacchaeus], Gilbert (Bap. 1577, d. 1628), philosopher and physician. In Oxford dictionary of national biography. http://www.oxforddnb.com/view/10.1093/ ref:odnb/9780198614128.001.0001/odnb-9780198614128-e-14512. Accessed June 2019

States of Holland. 1589. Placcaet inhoudende Verbot van te Drucken, ofte te stroyen, eenighe seditieuse boucken. Delft: Aelbrecht Hendricksz.

Stimson, Dorothy. 1917. The gradual acceptance of the Copernican theory of the universe. New Hampshire: Hanover. http://archive.org/details/gradualacceptanc00stimrich. Accessed June 2019.

Thorndike, Lynn. 1949. The Sphere of Sacrobosco and its commentators. Vol. 2. Chicago: University of Chicago Press.

Valerius, Cornelius. 1583. Grammaticarvm Institvtionvm liber IIII. Antverp: Plantin.

Valleriani, Matteo. 2017. The tracts on the Sphere: Knowledge restructured over a network. In The structures of practical knowledge, ed. Matteo Valleriani, 421-473. Dordrecht: Springer. https:// doi.org/10.1007/978-3-319-45671-3_16.

van Meurs, Johannes. 1625. Athenae Batavae. Sive, de vrbe Leidensi et academià, virisque claris; qui utramque ingenio suo, atque scriptis illustrarunt: libri dvo. Leiden: Andreas Cloucquius and Elsevirs.

Van Nouhuys, Tabitta. 1998. The ages of two-faced Janus: The comets of 1577 and 1618 and the decline of the Aristotelian world view in the Netherlands. Leiden: Brill.

van Wijckel, Hans. 1635. Album Amicorum. Franeker/Groningen/Leiden: Koninklijke Bibliotheek: $79 \mathrm{~J} 52$.

Vermij, Rienk. 2002. The Calvinist Copernicans: The reception of the new astronomy in the Dutch Republic, 1575-1750. Amsterdam: KNAW.

- 2016. Seventeenth-century Dutch natural philosophers on celestial influence. In Unifying heaven and earth essays in the history of early modern cosmology, ed. Miguel á Granada, Dario Tessicini, and Patrick J. Boner, 291-316. Universitat de Barcelona: Barcelona. 
Weekhout, Ingrid Marlies. 1998. Boekencensuur in de Noordelijke Nederlanden: De vrijheid van drukpers in de zeventiende eeuw. Den Haag: SDU.

Westman, Robert S. 1975. The Melanchthon circle, Rheticus, and the Wittenberg interpretation of the Copernican theory. Isis 66 (2): 165-193.

Wiesenfeldt, Gerhard. 2002. Leerer Raum in Minervas Haus: Experimentelle Naturlehre an der Universität Leiden, 1675-1715. Amsterdam/ Berlijn: Edita KNAW/Verlag für Geschichte der Naturwissenschaften und der Technik.

Willems, Alphonse. 1880. Les Elzevier: histoire et annales typographiques. Bruxelles: G.-A. van Trigt.

Witsenburg, K., and H.M. Van der Noordaa, eds. 1988. Catalogus van 125 Nederlandse Latijnse scholen. Almelo: Stichting Stadsherstel.

Wittichius, Christophorus. 1653. Dissertationes duae. Amsterdam: Abraham Elzevir.

Open Access This chapter is licensed under the terms of the Creative Commons Attribution 4.0 International License (http://creativecommons.org/licenses/by/4.0/), which permits use, sharing, adaptation, distribution and reproduction in any medium or format, as long as you give appropriate credit to the original author(s) and the source, provide a link to the Creative Commons license and indicate if changes were made.

The images or other third party material in this chapter are included in the chapter's Creative Commons license, unless indicated otherwise in a credit line to the material. If material is not included in the chapter's Creative Commons license and your intended use is not permitted by statutory regulation or exceeds the permitted use, you will need to obtain permission directly from the copyright holder. 


\section{Index}

A

Abel, Thomas, 287, 289, 292

Abū Ma'shar, Ja far ibn Muḥammad ibn 'Umar al-Balkhī, 76, 178, 346

Achillini, Alessandro, 145, 155

Agricola, Rudolf, 276, 362

Agrippa, Heinrich-Cornelius, 193, 229, 244

Alantsee, Lucas, 276

al-Battānī, Muhammad ibn Jābir, $217,233,241$

al-Bițūjīi, Nūr al-Dīn, 142, 143

Alexander VI, Pope, 324

Alexeyevich, Peter, 41

al-Fārāb̄i, Abū Nașr Muḥammad, 125

al-Farghānī, Aḥmad ibn Muḥammad ibn Kathīr, 68, 71, 97, 167, 195, 217, 232, 339,372

Alfonso X, King of Castile, 176, 217

al-Ma’mūn, Abū al-'abbās 'abd Allāh, 141

al-Manșūr, Abū Ja far 'Abd Allāh, 126

Alphonse, King of Spain, 33

Alphonso X el Sabio, 329, 330

al-Qabīsīi, Abū al-Ṣaqr 'Abd al-'Azīz ibn 'Utmān, 68

al-Rāzī, Abū Bakr Muḥammad ibn Zakaryyā', 126

al-Shaybānī, abū al-Ḥasan 'Alī ibn Ab̄̄ al-Rijāl, 76

al-Sijzì, Abū Saīe Ahmad ibn Muḥammad, 141

al-Ṭūsī, Nașīr al-Dīn, 141

al-Urḍīi, Mu’ayyad al-Dīn, 141

Alvaro de Lencastre, Dom, 323, 324

al-Zarqāâì, Abū Isḥāk Ibrāhīm ibn Yahyā, 176

Amerbach, Johann, 39
Andrade Martins, Roberto de, 179, 186, 205 , 313-353

Anglicus, Bartolomeus, 175

Anglicus, Robertus, 68, 170, 228, 236

Apian, Peter, 39, 196, 204, 205, 266, 290

Aquin, Thomas of, 60, 65, 101, 106, 107, 144,178

Aristotle, 66, 118, 237, 246, 373

Arminius, Jacobus, 360

Assumpçao, Diogo da, 344

Augustine, St., 17, 99, 118, 119

Auvergne, William, 144

Avelar, André do, 205, 209, 217, 234, 313-353

Avelar, Galás do, 319

Axworthy, Angela, 40, 44, 63, 142, 144, 185-250

\section{B}

Bacon, Francis, 65

Bacon, Roger, 76, 116, 143

Baker, Humphrey, 193

bar Hiiyya ha-Nasi, Abraham, 346, 347

Barker, Peter, 26, 32, 33, 43, 59, 119, 137-156, 174, 190, 191, 194, 197, 212, $216,228,235,248,375,376$

Bartholin the Elder, Caspar, 383

Bartoli, Cosimo, 189, 193, 206

Behaim, Martin, 167

Beldomandi, Prodoscimo, 96, 104, 144, 230, 338

Bellanti, Lucio, 75, 78, 82

Bellère, Jean, 289, 371, 373, 375

ben Ezra, Abraham, 346

ben Gershon, Levi, 347

ben Jehuda ibn Gabirol, Solomon, 346 
ben Judah Abravanel, Isaac, 347

ben Yosef Gaon, Sa' adiah, 346

Bevilacqua, Simone, 126

Beyer, Hartmann, 290, 338

Billingsley, Henry, 216

Birckmann, Arnold, 289, 378

Blaeu, Willem Janszoon, 382

Blois, Luis de, 327

Bodin, Jean, 375

Boethius, Anicius Manlius Severinus, 15, 29-31, 60, 81, 117, 118, 133

Bonati, Guido, 76

Borrel, Jean, 186

Bottrigari, Ercole, 193

Bovelles, Charles de, 28, 29, 42, 49, 229

Bracciolini, Poggio, 334

Bradwardine, Thomas, 59

Brahe, Tycho, 165, 228

Branco, Castello, 321, 322

Brandis, Marcus, 139

Brannon, James, 186

Broner, Caspar, 291, 383

Brozas, Francisco Sánchez de las, 338

Brudzewo, Albert of, 138, 143, 145, 146,155

Bruni, Giordano, 228

Buning, Marius, 186, 230, 359-384

Buonincontro, Lorenzo, 334

Burgersdijk, Franco, 16, 19, 43, 201, 209, 230, 267, 294, 305, 359-384

Burkardt, Adam, 268

C

Camerarius, Joachim, 324

Capuano da Manfredonia, Francesco, 7, 16, $17,19,26,66,91-108,126,145,176$, $189,228,230$

Cardano, Girolamo, 75, 180

Cavellat, Guillaume, 13, 289-291, 293

Cerqueira, Luís de, 317

Charles V, King of Spain, 28, 176, 177, 192, 229

Chaudière, Regnault, 194, 276

Chaves, Alonso de, 173

Chaves, Jerónimo de, 16, 173-176, 320

Cholinus, Goswin, 289, 292, 373

Cholinus, Peter, 289, 292, 373

Chrysoloras, Manuel, 35

Ciruelo, Pedro, 16, 19, 42, 45, 53-82, 145, 178, 187, 195, 201

Citron, Nana, 111-133

Claudanius, Claudius, 138, 140, 146, 329, 332
Clavius, Christophorus, 19, 156, 228-230, 267, 287, 289, 292, 303, 304, $317,318,327,331,333$, $338-376,383$

Clichtove, Josse, 28, 29, 42

Cnidos, Eudoxus of, 140

Colines, Simon de, 26, 40, 289

Colonna, Cardinal Giovanni, 324, 326

Columbus, Christophorus, 61, 167, 373

Copernicus, Nicolaus, 138, 141, 143, 155, 156, 165, 166, 178-180, 228, 291, 340, 382

Cortes, Martin, 175-177

Costa, Francisco da, 318-321, 330, 348, 349

Crowther, Kathleen M., 20, 26, 32, 33, 58, 63, 82, 137, 144, 161-180, 186, 189-191, 194-198, 212, 215, 226-228, 375, 376

Cunaeus, Petrus, 364

Curtius, Jacobus, 267

Cusa, Nicholas of, 29, 30, 63, 217, 344, 350

D

d'Abano, Pietro, 98, 104-108, 243

d'Ailly, Pierre, 6, 7, 54, 59, 61, 65, 68, 69, 95, $96,98,144,167,195,214,228,230$, 347

d'Ambert, Hugues, 194

d'Angelo, Jacopo, 35, 202

d'Ascoli, Cecco, 26, 68, 96-98, 126, 178,228

Danes, Pierre, 187

Delgado, Joao, 318

Descartes, René, 156, 360, 382

Dias, Bartholomeu, 163

Diaz, Juan Cedillo, 166

Dietrich, Sebastian, 290, 291

Diogenes the Cynic, 322

Donatus, Aelius, 139

Duhem, Pierre, 32, 248

Duncan, Marc, 360, 362

E

Eber, Pail, 291

Eguía, Miguel de, 63

Elzevir, Abraham, 367

Elzevir, Bonaventura, 367

Encinas, Fernando de, 59

Eratosthenes, 97, 217

Espinosa, Pedro de, 327

Estienne the Elder, Henri, 26, 289 
Euclid, 29, 32, 42, 43, 115, 117, 155, 188, 193, 215-217, 280, 298, 317, 319, 328, 372

F

Faleiro, Francisco, 16, 168-172, 174, 175

Fernandes, Valentim, 168, 320

Fernandes, Violante, 319

Fernando, Duke of Guarda, 315

Fernao Martins Mascarenhas, Dom, $319,327,352$

Fernel, Jean François, 372

Ficinus, Marsilius, 31, 113, 114

Figueiredo, Manuel de, 320

Fine, François, 192

Fine, Michel, 192

Fine, Oronce, 16, 26, 29, 40, 46, 47, 185-251, 266, 276, 288, 294, 317

Florus, Annaeus, 382

Foix-Candale, François de, 216

Fossier, Jean, 194, 200

Frisius, Gemma, 273, 365, 368

\section{G}

Galilei, Galileo, 144, 329, 373

Gaon, Saadia, 346

Gasser, Achilles Pirminius, 291

Gaurico, Luca, 338

George, Duke of Saxony, 112, 113, 119, 131

Gerard of Cremona, 21, 138, 144

Gikatilla, Joseph, 229

Girout, Charlotte, 186

Giunta, Giuntino, 7, 43

Giunta, Jacob, 286

Giunta, Lucantonio, 7, 12, 95

Giuntini, Francesco, 13, 228, 229, 267, 286, 287, 289, 292, 293, 299-305, 333-335, 371-373, 375

Glarean, Henricus, 39

Glogów, John of, 16, 17, 137-156

Gomarus, Franciscus, 360

Gomes, Joao, 317

Gouveia, André de, 316

Graminaeus, Theodor, 338

Gregory XIII, Pope, 374

Grienberger, Christoph, 318

Grietan, Jean, 29

Grosseteste, Robert, 7, 26, 95, 97, 98, 101, $102,116,125,296$

Grynaeus, Simon, 279, 286

Guadagne, Thomas de, 286, 291

Guidacerius, Agathius, 187

\section{H}

Haller, Jan, 139

Heinsius, Daniel, 364

Henrique of Portugal, Infante, 163

Henry, Cardinal, 318

Henry of Hesse, 144

Hero, Albertus, 13, 286, 289, 292

Hero of Alexandria, 114

Hipparchus, 235

Hippocrates, 175

Homem, António, 343-345, 349-353

Honterus, Johannes, 205, 208

Horst, Thomas, 167, 168, 186

Hummelberg, Michael, 39

Hyginus, Gaius Iulius, 327

I

Iamblichus Chalcidensis, 116

Ibn al-Haytham, Abu 'Alī al-Ḥasan, 60

Ibn Rushd, Abū al-Walīd Muḥammad, 63, 100, 138, 142-145, 156, 176, 236-240, 339

Ibn Sīnā, Abū 'Alī al-Ḥusayn ibn 'Abd Allāh, $125,128,170,176$

Isidore of Seville, 105, 170

Iustinus, Marcus Iunianus, 368, 383

$\mathbf{J}$

Joao de Castro, Dom, 315, 327

João I, King of Portugal, 163

João II, King of Portugal, 166

João III, King of Portugal, 163, 314-316

John of Jandun, 144

John the Baptist, 177

Josephus, Flavius, 68

Jugge, Richard, 13

K

Keckermann, Bartholomaeus, 362

Kepler, Johannes, 228

Klug, Joseph, 283, 284, 375

Knoblauch, Johann, 139

Kok, Allardus Lodewijk, 376

Kräutli, Florian, 21

Kuechovius, Paulus, 286, 291

L

Landsberg, Martin, 14, 123, 127

Lanuza Navarro, Tayra M.C., 53-82, 164

Lattes, Bonet de, 33, 347 
Lax, Gaspar, 59

Lefevre d'Étaples, Jacques, 7, 13, 16, 17, 25, $59,60,63,71,81,96,97,126,187$, 195-197, 201, 204, 218, 229, 266, 280, 288, 337, 339

Leon, Mosche de, 347

Leopold of Austria, 122, 124

Li, Andrés de, 319

Loys, Jean, 284, 289, 292

Lucanus, Marcus Annaeus, 195, 330

Lucretius, Titus, 176

Luís of Portugal, Duke of Beja, 315

Lull, Ramon, 29

Luther, Martin, 279, 342

\section{M}

Macrobius, Ambrosius Theodosius, $87,268,294$

Maestlin, Michael, 43-45

Magini, Giovani Antonio, 374

Magirus, Johannes, 368, 383

Magnus, Albertus, 76, 101, 176, 244

Manilius, Marcus, 329, 331, 334-339

Manoel, Dom, 321, 322, 342

Mariz, Pedro de, 341

Marlowe, Christopher, 229

Martim Affonso de Mexia, Dom, 344, 345

Martin, Henri-Jean, 293

Māshā’ Allāh, ibn Atharī al-Bașrī, 346

Maurice, Prince of Orange, 360

Maurolico, Francesco, 266

Maximilian I, Holy Roman Emperor, 41, 167, 168, 228

Medina, Pedro, 176

Melanchthon, Philipp, 13, 19, 279-281, 288, 291, 293, 304, 333, 370, 377, 380

Mela, Pomponius, 203

Mendes, Pedro, 327

Menezes, Francisco de Brito de, 345, 349

Metius, Adriaan, 376

Mizauld, Antoine, 186, 200, 201

Morvilliers, Nicolas Masson de, 161

Muñoz, Jerónimo. 165, 174, 179, 180, 193

Müntzer, Thomas, 279

Münzer, Hieronymus, 166-168

Muris, Johannes de, 112, 118, 119

\section{$\mathbf{N}$}

Nadal, Jerónimo, 317

Navarro, Manuel Rodrigues, 345

Nemorarius, Jordanus, 60

Nenci, Elio, 91-108
Nifo, Agostino, 75, 145, 155

Novara, Campanus of, 12, 29, 60, 170, 217

Nuñes, Pedro, 11, 13, 171-174, 180, 186, 291, 314-317, 331-332, 339, 371

O

Oldenbarnevelt, Johan van, 361

Oliva, Fernán Pérez, 59

Oosterhoff, Richard, 17, 25-46, 60, 63, 186-189, 192, 194-197, 201, 203, 204, $212,217,218,226-228,250$

Oresme, Nicole, 11, 236

Ovidius Naso, Publius, 195, 330, 331, 376

$\mathbf{P}$

Pantin, Isabelle, 12, 13, 16, 26, 40, 59, 63, 75, 186-192, 195-202, 204, 206, 212, 213, 215, 218, 221, 226-229, 232, 234, 236, 240, 265-305

Paul III, Pope, 315

Peckham, John, 60, 112, 115, 116, 120, 124, 132, 133, 296

Pereira, Alvaro Soares, 344

Pérez de Mesa, Diego, 179, 180

Peter of Spain, 139

Petit, Nicolas, 194

Peucer, Kaspar, 288-291

Peuerbach, Georg, 6, 17, 32, 68, 91, 93, 94, $96,97,112,119,120,122,124$, 131-133, 137, 138, 140-142, 144-149, $155,156,171,174,189,195,209,216$, 249, 267, 268, 275, 288, 289, 292, $315-318,370$

Peutinger, Conrad, 167, 168

Phares, Simon de, 67-71, 74, 81

Philip II, King of Spain, 179, 318, 359

Philippe III, King of Spain, 343

Piccolomini, Alessandro, 7

Pico della Mirandola, Giovanni, 71, 74, 75, $82,99,244$

Pigghe, Albert, 75, 217, 240

Pius V, Pope, 370

Plantin, Christophe, 365

Plato, 28-31, 41, 42, 166, 237

Pliny the Elder, 176, 281

Polo, Marco, 168

Pontano, Giovanni, 75

Proclus, 280, 296, 339

Pseudo-Dionysius, 30

Ptolemy, Claudius, 2, 28, 35, 37, 45, 60, 66, $68,75,76,97,98,119,120,122,126$, $131,138,140-143,146,149-151,165$, 
171, 190, 197, 199, 202-204, 217 , 222, 224, 225, 228, 233-235, 237 , 238, 246, 248, 273, 304, 315, 329, $331,339,374,382$

Pythagoras, 116, 118

Q

Quiccheberg, Samuel, 41

Quignon, Vincent, 276

\section{$\mathbf{R}$}

Ramus, Petrus, 187, 188, 362

Ratdolt, Erhard, 32, 69, 122, 268

Recorde, Robert, 229

Regiomontanus, Johannes, 7, 32-34, 68, 80-82, 97, 112, 120, 126, 133, 141, 144, 165, 176, 191, 217, 219, 220, 238, $241,268,273,280,283$, 334,339

Reinhold, Erasmus, 304, 339

Reisch, Gregor, 189, 190, 192, 199

Renner, Franciscus, 268

Reuchlin, Johann, 229

Rhenanus, Beatus, 39

Rheticus, Georg Joachim, 281, 291, 371

Ricci, Agostino, 189, 192, 217, 228, 229 , 236-241, 244, 245, 247

Ricci, Paolo, 228, 229

Richard, Guillaume, 284, 289

Ringmann, Mathias, 35, 39-41, 45-47, 204, 206, 225, 290

Rotterdam, Erasmus of, 35, 363, 368

Rudolf II, Prince, 41

Ruffaut, Hieronymus, 284, 292

Russiliano, Tiberio, 75

\section{S}

Sacrobosco, Johannes de, 14-20, 25-28, 31-37, 39-40, 42-44, 46-47, 67-82, 91-108, 111-112, 115, 120-126, 132-133, 137-156, 161-181, 186-251, 265-305, 313-353, 359, 362, 365-368, $370-383$

Salaya, Juan de, 58

Samos, Aristarchus of, 180

Samosata, Lucian of, 322

Sander, Christoph, 19

Sannazaro, Jacopo, 326

Santayana y Spinosa, Rodrigo Saenz de, 177-179, 181

Santritter, Johannes, 268, 269, 272
Sapidus, Johann, 39

Scaliger, Joseph Justus, 334, 384

Schonaeus, Cornelius, 365

Schöner, Johannes, 112, 123, 127

Schreckenfuchs, Erasmus Oswald, 267, 303

Scot, Michael, 21, 92, 96, 98, 228, 296

Scoto, Ottaviano, 95, 121, 268

Sebastio I, King of Portugal, 315, 318, 321,338

Seneca, Lucius Annaeus, 167

Sessa, Melchior, 268, 280, 283, 287, 290

Severus, Sulpicius, 383

Silíceo, Juan Martínez, 59, 192, 197

Silvestre, Antoine, 192, 194

Singh, Sawai Jai, 142

Singriener, Johann, 276

Sleidanus, Johannes, 383

Snellius, Willebrord, 361

Stapulensis, Faber, 156, 176

Stöckel, Wolfgang, 139

Strabon, 37, 203

$\mathbf{T}$

Tacitus, Johannes, 285, 291

Thābit ibn Qurra, Abū al-Ḥasan ibn Zahrūn al-Ḥarrānī, 68, 120, 121, 235

Theodosius of Bithynia, 97, 172, 328

Thysius the Elder, Antonius, 364

Tinghi, Filippo, 287, 303, 304, 320

Tockler, Conrad, 124-146, 201, 234, 269

Torres, Baltasar, 317

Torres, Diego de, 58

Toussain, Jacques, 187

$\mathbf{U}$

Ungler, Florian, 139

V

Vadianus, Joachim, 276

Valeriano, Pierio, 13, 285, 286, 290-293, 371

Valerius, Cornelius, 338, 365, 366

Valleriani, Matteo, 14-35, 39, 67, 104, 129-146, 156, 161, 173, 185, 186, 205, $226,265,313,333,359,371$

Valles, Francisco, 180

Vasurto, Rodrigo, 58, 59

Vatable, Francois, 187

Velloso, António, 327

Verdun, Bernard of, 144

Vergilius Maro, Publius, 174, 195, 330

Versoris, Johannes, 139 
Vespucci, Amerigo, 26, 276

Vespucci, Bartolomeo, 7, 13, 96, 230, 338

Villa Dei, Alexander de, 139

Vinet, Élie, 11, 13, 14, 43, 173, 289, 290, 292, 293, 296, 305, 316, 331-333, 339, 371

Voetius, Gisbertus, 360, 382

Vossius, Gerhard Johannes, 364-365, 376

W

Waen, Johannes, 284, 292

Walaeus, Antonius, 364, 383

Waldseemüller, Joannes, 290
Waldseemüller, Martin, 39, 204, 206, 225

Wallingford, Richard of, 143

Welser, Margarete, 168

Werner, Johannes, 217, 304

Wissekerke, William Gilliszoon of, 192

Wittichius, Christophorus, 382

$\mathbf{Z}$

Zacut, Abraham, 58, 60, 228

Zamorano, Rodrigo, 320

Zevi, Shabbatai, 347

Zúñiga, Diego de, 165 